\title{
FAUNA OF \\ THE ALEUTIAN ISLANDS AND ALASKA PENINSULA
}

WITH NOTES ON INVERTEBRATES AND FISHES COLLECTED IN THE ALEUTIANS,

1936-38

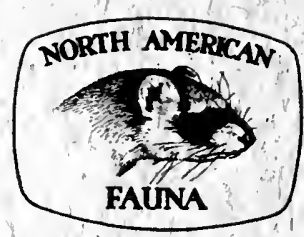

NUMBER 61

UNITED STATES

DEPARTMENT OF THE INTERIOR

FISH AND WILDLIFE SERVICE 
ain सith?

Richard H. Backus

August, 1988 


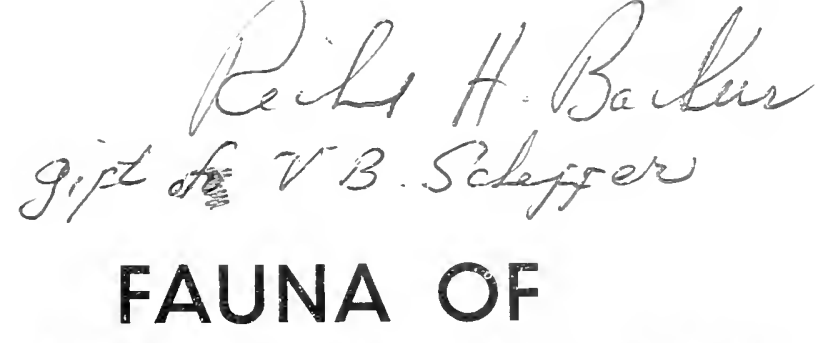

\title{
THE ALEUTIAN ISLANDS AND ALASKA PENINSULA
}

\author{
By Olaus J. Murie, Biologist
}

\author{
INVERTEBRATES AND FISHES \\ COLLECTED IN THE ALEUTIANS, \\ 1936-38
}

By Victor B. Scheffer. Biologist
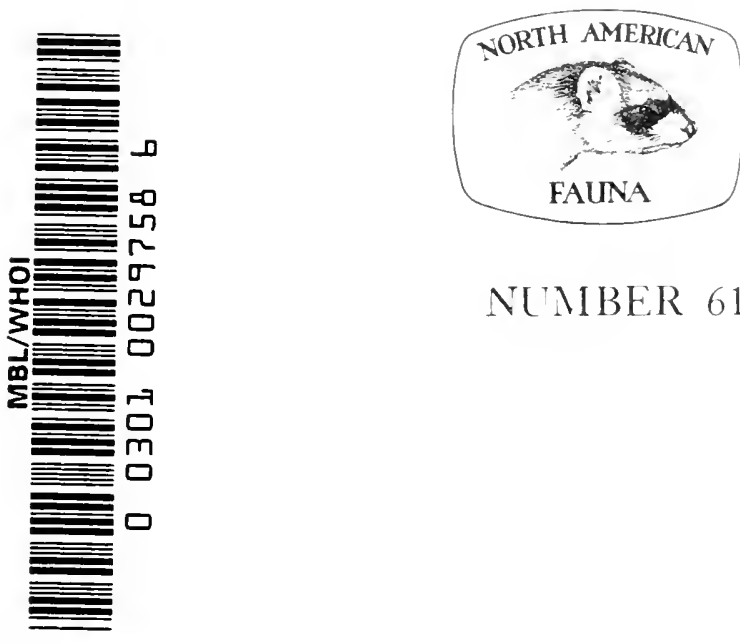

NLMBER 61 


\title{
UNITED STATES DEPARTMENT OF THE INTERIOR
}

\author{
Fred A. Seaton, Secretary
}

FISH AND WILDLIFE SERVICE

Arnie J. Suomela, Commissioner

PIBIISHED BY I'. S. FISH AYU WILDLIFE SERVICE • WASIINGTON 1959 PRINTED AT I. S. GOVERMENT PHINTING OFFICE, WASHINGTON

For sale by the Superintendent of Documents, U. S. Government Printing Office, Wa-hington 25, D. C. Price $\$ 1.23$ cents. 


\section{CONTENTS}

\section{FAUNA OF THE ALEUTIAN ISLANDS AND ALASKA PENINSULA, by Olaus.J. Murie}

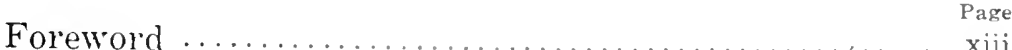

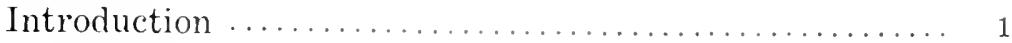

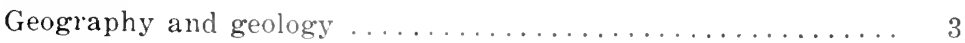

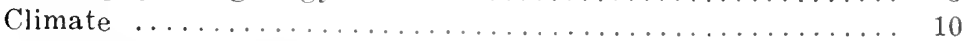

Environment and biotic distribution ............... 11

Geographic and geologic influences .............. 12

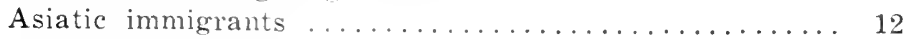

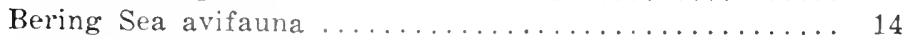

Fauna of wider northern distribution ............ 15

Southern and southeastern birds .............. 16

Environmental influence ..................... 17

Ecological classification ..................... 18

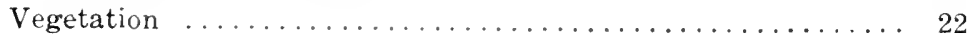

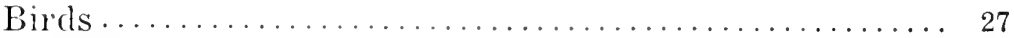

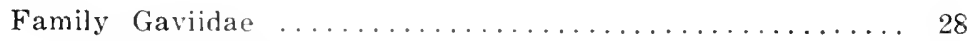

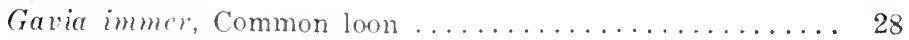

Gavia adamsii, Yellow-billed loon ............... 29

Gavia aretica, Aretic loon ................... 29

Gavia stellata, Red-throated loon .............. 31

Family Podicipedidae ...................... 32

Podiceps grisegena, Red-necked grebe ............ 32

Podiceps auritus, Horned grebe ................. 33

Family Diomedeidae ...................... 34

Diomedea nigripes, Black-footed albatross ........... 34

Diomedea albatrus. Short-tailed albatross .......... 36

Diomedea immutabilis, Laysan albatross ........... 39

Family Procellariidae ..................... 41

Puffinus tenuirostris, Slender-billed shearwater ........ 41

Puffinus griseus, Sooty shearwater .............. 44

Pterodioma inexpectata, Scaled petrel ............. 44

Pterodroma conkii, Cook's petrel ............... 45

Fulmarus glariatis, Fulmar ................ 45

Family Hydrobatidae ...................... 48

Occanodroma furcata, Fork-tailed petrel .......... 48

Oceanodroma leucorhoa, Leach's petrel ............. 51

Family Phalacrocoracidae ..................... 52

Phalucrocorix auritus, Double-crested cormorant ........ 52

Phalacrocorax pelagicus, Pelagic cormorant ........... 55

Phalacrocora. wile, Red-faced cormorant .......... 57

Family Ardeidae . . . . . . . . . . . . . . . . . . 59

Ardea horodias, Great blue heron .............. 59 
Family Anatidae ............................ 59

Olor columbianus, Whistling swan .............. 59

Olor buccinator, Trumpeter swan .............. 61

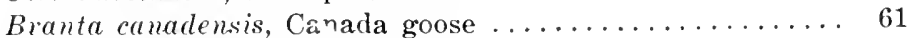

Branta nigricans, Black brant ............... 67

Philacte canagica, Emperor goose .............. 69

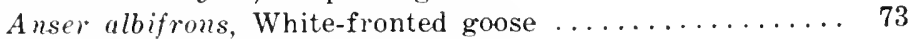

Chen hyperborea, Snow goose ............... 74

Anas platyshynchos, Mallard ................ 74

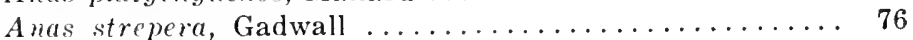

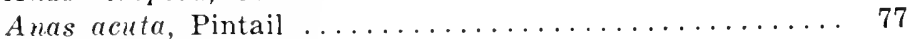

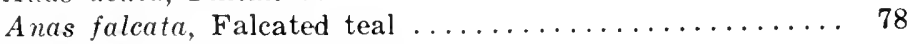

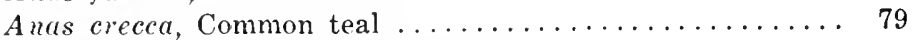

Anas carolinensis, Green-winged tea] ............ 80

Mareca penclope, European widgeon ............ 82

Mareca americana, American widgeon ........... 82

Spatula clypeata, Shoveler ................ 83

Aythya americana, Redhead ................. 83

Aythya valisineria, Canvasback ................ 84

Ayth ga marila, Greater scaup ................ 84

Aythyc affnis, Lesser scaup ................. 86

Aythya fuligula, Tufted duck ................ 86

Buccphala clangula, Common goldeneye ............ 86

Bucephala islandica, Barrow's goldeneye .......... 87

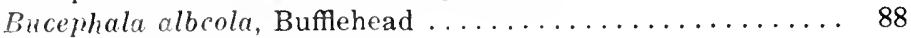

Clangula hyemalis, Oldsquaw ............... 89

Histrionicus histrionicus, Harlequin duck .......... 90

Polysticta stelleri, Steller's eider .............. 92

Somateria mollissima, Common eider ............. 94

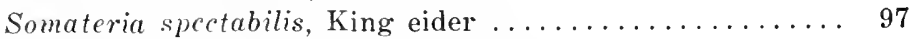

Lampronetta fischeri, Spectacled eider ............ 98

Melanitta deglandi, White-winged scoter .......... 99

Melanitta perspicillata, Surf scoter ............ 101

Oidemia nigra, Common scoter ............... 102

Mcrgus merganser, Common merganser ........... 104

Mergus scrrator, Red-breasted merganser .......... 105

Family Accipitridae ..................... 106

Accipiter gentilis, Goshawk ............... 106

Accipiter striatus, Sharp-shinned hawk .......... 107

Buteo lagopus, Rough-legged hawk ............ 107

Aquila chrysaëtos, Golden eagle ............... 109

Haliaeetus albicille, Gray sea eagle ............ 110

Haliaeetus leucoccphalus, Bald eagle ............. 111

Haliaeetus pelagicus, Steller's sea eagle ........... 117

Circus cyaneus, Marsh hawk ................ 117

Pandion halicetes, Osprey ................. 118

Family Falconidae ....................... 118

Falco misticolus, Gyrfalcon ............... 118

Falco peregrimus, Peregrine falcon ............ 119

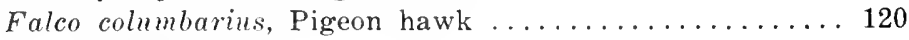

Falco sparverius, Sparrow hawk .............. 121

Family Tetraonidae ........................ 121

Canachites canadensis, Spruce grouse ............. 121 
Page

Lagopus lagopus, Willow ptarmigan ............... 122

Lagopus mutus, Rock ptarmigan ................ 123

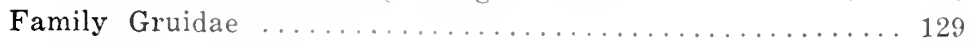

Grus canadensis, Sandhill crane ................. 129

Family Rallidae ........................... 130

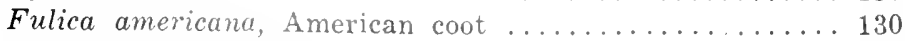

Family Haematopodidae ....................... 130

Haematopus bachmani, Black oystercatcher ........... 130

Family Charadriidae ......................... 132

Charadrius dubius, Little ringed plover ............. 132

Charadrius semipalmatus, Semipalmated plover ......... 132

Pluvialis dominica, American golden plover ........... 133

Squatarola squatarola, Black-bellied plover ........... 134

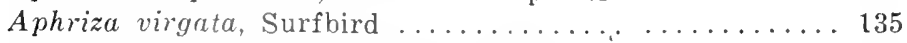

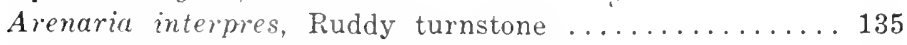

Arenaria melanocephalı, Black turnstone .......... 136

Family Scolopacidae ....................... 137

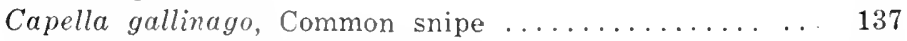

Numenius phaeopus, Whimbrel ................ 138

Numenius tahiticnsis, Bristle-thighed curlew ......... 138

Actitis macularia, Spotted sandpiper ............... 138

Tringa glareola, Wood sandpiper ............... 139

Heteroscelus incrumu, Wandering tattler ............ 139

Totanus melanoleucus, Greater yellowlegs ........... 140

Totanus flavipes, Lesser yellowlegs ............... 141

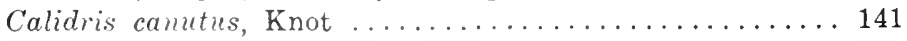

Erolia ptilocnemis, Rock sandpiper .............. 141

Erolia acuminata, Sharp-tailed sandpiper ........... 146

Erolia melanotos, Pectoral sandpiper ............. 146

Erolia bairdii, Baird's sandpiper .............. 147

Erolia mimutilla, Least sandpiper ................ 147

Erolia alpina, Dunlin ................... 150

Limnodromus griseus, Short-billed dowitcher .......... 150

Ereunetes pusillus, Semipalnated sandpiper .......... 152

Erewnetes mauri, Western sandpiper ............ 152

Limosa fedoa, Marbled godwit ................ 153

Limosa lapponica, Bar-tailed godwit ............... 153

Limosa hremastica, Hudsonian godwit ............. 154

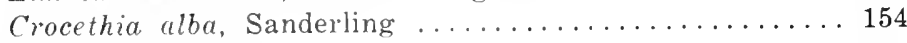

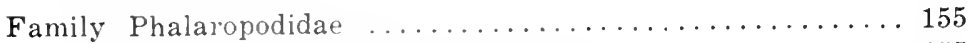

Phalaropus fulicarius, Red phalarope ............. 155

Lobipes lobatus, Northern phalarope ............ 156

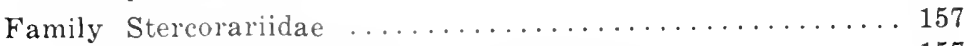

Stercorarius pomarinus, Pomarine jaeger ........... 157

Stercorarius parasiticus, Parasitic jaeger . . . . . . . . . . 159

Stercorarius longicaudus, Long-tailed jaeger ........... 161

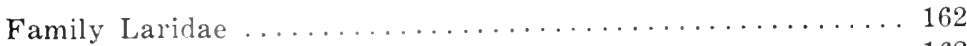

Larus hyperboreus, Glaucous gull .............. 162

Lams glaucescens, Glaucous-winged gull ............ 165

Larus schistisagus, Slaty-backed gull .............. 171

Larus argentatus, Herring gull ................ 171

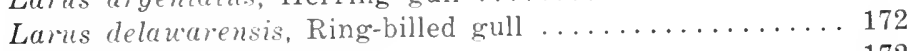

Larus canus, Mew gull ................... 172 
Lames philadelphia, Bonaparte's gull ........... 174

Larus ridibundus, Black-headed gull ............ 175

Rissa tridactyla, Black-legged kittiwake .......... 175

Rissa brevirostris, Red-legged kittiwake .......... 176

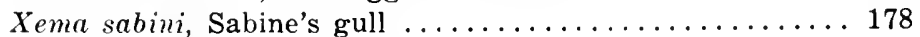

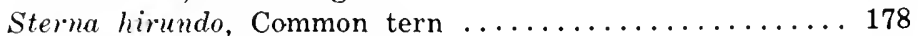

Sterna paradisaea, Arctic tern ................ 179

Sterna aleutica, Aleutian tern ............... 180

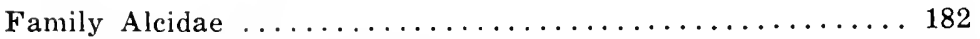

Uria aalge, Common murre .................. 182

Uria lomvia, Thick-billed murre ............. 182

Cepphus columba, Pigeon guillemot ............ 186

Brachyramphus marmoratum, Marbled murrelet ........ 187

Brachyramphus brevirostre, Kittlitz's murrelet ....... 188

Synthliboramphus antiquum, Ancient murrelet ........ 189

Ptychoramphus aleutica, Cassin's auklet ............ 191

Cyclorhynchus psittacula, Parakeet auklet ......... 193

Aethia cristatella, Crested auklet ................ 194

Aethia pusilla, Least auklet .................. 197

Acthia pygmaea, Whiskered auklet ............. 200

Cerorhinca monocerata, Rhinoceros auklet .......... 202

Fratercula corniculata, Horned puffin ............ 202

Lunda cirrhata, Tufted puffin ................ 204

Family Cuculidae ........................ 205

Cuculus saturatıs, Oriental cuckoo ............. 205

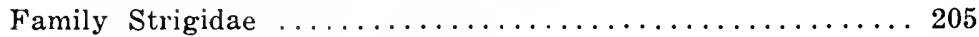

Bubo virginianus, Horned owl ............... 205

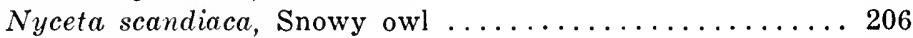

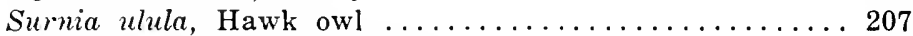

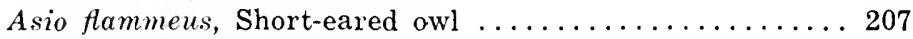

Aegolius funereus, Boreal owl ................. 209

Family Trochilidae ........................ 210

Selasphorus rufus, Rufous hummingbird ......... 210

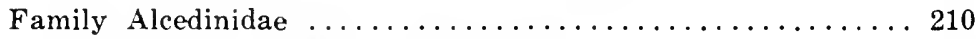

Megaceryle alcyon, Belted kingfisher ........... 210

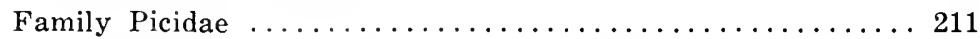

Dendrocopos pubescens, Downy woodpecker ......... 211

Picoïdes arcticus, Black-backed three-toed woodpecker .... 211

Picoïdes tridactylus, Northern three-toed woodpecker .... 212

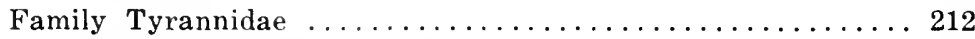

Sayornis saya, Say's phoebe ................ 212

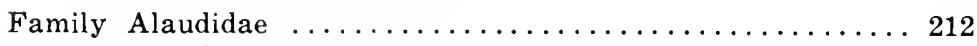

Eremophila alpestris, Horned lark ............ 212

Family Hirundinidae ...................... 212

Tachycineta thalassina, Violet-green swallow ......... 212

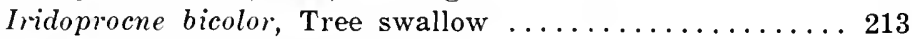

Riparia riparia, Bank swallow ................ 213

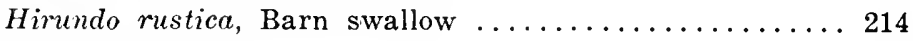

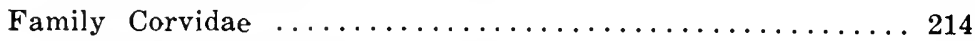

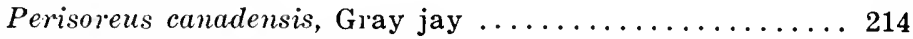

Pica pica, Black-billed magpie ................ 215 
Corvus corax, Common raven ................. 216

Corvus caurims, Northwestern crow ............ 217

Nucifraga columbiana, Clark's nutcracker ............. 217

Family Paridae ........................ 217

Parus atricapillus, Black-capped chickadee ........... 217

Parus hudsonicus, Boreal chickadee ............. 218

Family Certhiidae .............................. 219

Certhia familiaris, Brown creeper ................ 219

Family Cinclidae ........................... 220

Cinclus mexicanus, Dipper ................... 220

Family Troglodytidae . . . . . . . . . . . . . . . . . . . . . 221

Troglodytes troglodytes, Winter wren ............. 221

Family Turdidae ......................... 225

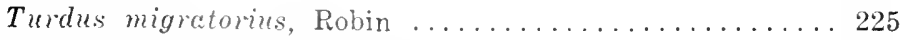

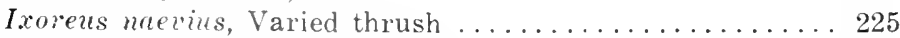

Hylocichla guttata, Hermit thrush ............. 226

Hylocichla ustulate, Swainson's thrush ............. 228

Hylocichla minima, Gray-cheeked thrush .......... 228

Luscinia calliope, Siberian ruby throat ........... 228

Family Sylviidae ........................... 229

Phylloscopus borcalis, Arctic warbler ............. 229

Regulus satrupa, Golden-crowned kinglet ............ 229

Regulus calendula, Ruby-crowned kinglet ............ 229

Family Motacillidae ...................... 230

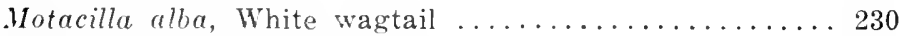

Motacille flack, Yellow wagtail ................. 230

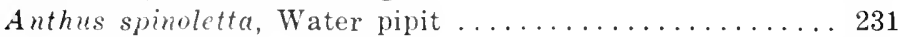

Anthus cervinus, Red-throated pipit .............. 233

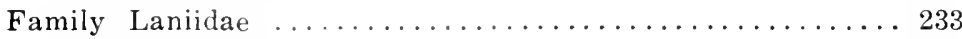

Lanius excubitor, Northern shrike .............. 233

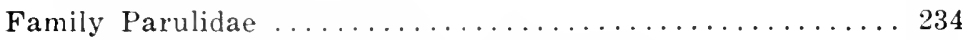

Vermivora celate, Orange-crowned warbler ......... 234

Dendroica petechia, Yellow warbler .............. 234

Dendroicu coronata, Myrtle warbler .............. 235

Dendroica striata, Blackpoll warbler ............. 235

Seiurus noveboracensis, Northern water thrush ........ 236

Wilsonia pussila, Wilson's warbler ............... 236

Family Icteridae . . . . . . . . . . . . . . . . 236

Euphagus carolinus, Pusty blackbird ............ 236

Family Fringillidae ...................... 237

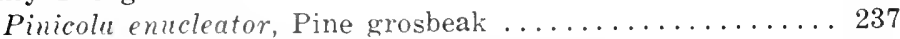

Leucosticte tephrocotis, Gray-crowned rosy finch ........ 237

Acanthis hornemanni, Hoary redpoll . ........... 240

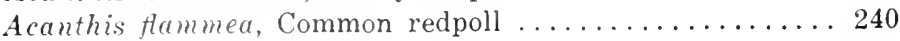

Spinus pinus, Pine siskin ................... 242

Loxia curvirostra, Red crossbill .............. 242

Loxia leucoptera, White-winged crossbill ........... 242

Passerculus sandwichensis, Savannah sparrow ........ 243

Junco hyemellis, Slate-colored junco ............. 246

Junco oregunus, Oregon junco ................ 246

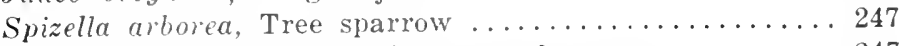

Zonotrichia leucophrys, White-crowned sparrow ........ 247

Zonotrichia atricapilla, Golden-crowned sparrow ........ 248 
Page

Passerella iliaca, Fox sparrow ............... 249

Mclospiza lincolnii, Lincoln's sparrow .............. 254

Melospiza melodia, Song sparrow .............. 254

Calcarius lapponicus, Lapland longspur ........... 257

Plectrophenax nivalis, Snow bunting ............ 258

Plectrophenax hyperboreus, McKay's bunting .......... 260

Emberiza rustica, Rustic bunting .............. 260

Mammals .................................. 262

Family Soricidae ............................. 262

Sorex cinereus, Cinereous shrew ................. 262

Sorex tundrensis, Tundra saddle-backed shrew ........ 263

Sorex hydrodromus, Unalaska saddle-backed shrew ..... 263

Sorex obscurus, Dusky shrew ................... 265

Microsorex hoyi, Pigmy shrew ................. 266

Family Vespertilionidae ........................ 266

Myotis lucifugus, Little brown bat ...............266

Family Ursidae .............................. 266

Euarctos americamus, Black bear ................ 266

Ursus arctos, Brown bear .................... 267

Thalarctos maritimus, Polar bear ................. 274

Family Procyonidae ......................... 274

Procyon lotor, Raccoon ....................... 274

Family Mustelidae ............................ 275

Martes americana, Marten ..................... 275

Mustela erminea, Weasel ...................... 275

Mustela rixosa, Least weasel . . . . . . . . . . . . . 276

Mustela vision, Mink ...................... 276

Gulo luscus, Wolverine ...................... 277

Lutra canadensis, Otter ...................... 278

Enhydra lutris, Sea otter ................... 278

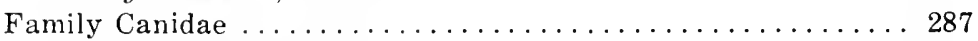

Vulpes fulva, Red fox ..................... 287

Alopex lagopus, Blue fox .................... 292

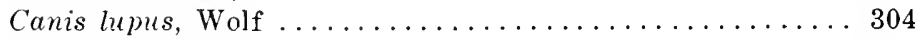

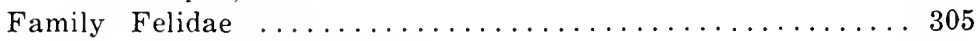

Lynx canadensis, Canada lynx ................... 305

Family Otariidae ................................... 305

Eumetopias jubata, Steller sea lion ................ 305

Callorhinus ursinus, Northern fur seal .............. 306

Family Phocidae .............................. 307

Phoca vitulina, Harbor seal ..................... 307

Pusa hispida, Ringed seal ..................... 309

Pagophilus grocnlandicus, Harp seal . .............. 309

Histriophoca fasciata, Ribbon seal ................ 310

Erignathus barbatus, Bearded seal ............... 310

Family Odobenidae ............................ 311

Odobemus rosmarus, Walrus ................. 311

Family Sciuridae ........................... 314

Marmota caligate, Hoary marmot ............... 314

Citellus parryii, Ground squirrel $\ldots \ldots \ldots \ldots \ldots \ldots \ldots 314$

Citellus kodiacensis, Ground squirrel $\ldots \ldots \ldots \ldots \ldots \ldots 316$

Tamiasciurus hudsonicus, Red squirred ............ 316 
Family Castoridae

Castor canadensis. Beaver .................... 317

Family Cricetidae ........................ 317

Synaptomys boratis, Lemming mouse ............. 317

Lemmus trimucronatus, Lemming ............... 318

Dicrostonyx aroenlandicus, Collared kmming . . . . . . . 318

Clethrionomys rutilus, Rert-backed mouse ............ 320

Microtus ofconomus, Headow mouse ............... 320

Microtus ponsyluanicus. Meadow mouse ............324

Ondutra zibethicus, Muskrat .................. 324

Family Muridae .......................... 324

Mus musculus, House mouse ................. 324

Rattus norvegicus, House rat ................ 325

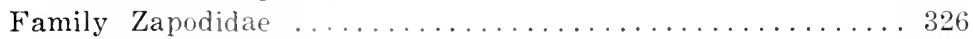

Zapus huedsonius, Jumping mouse ............. 326

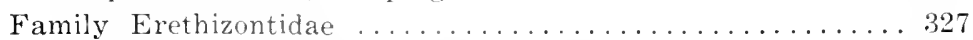

Evethizon dorsatum, American porcupine .......... 327

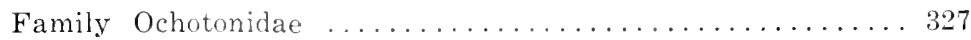

Ochotona collaris, Collared pika .............. 327

Family Leporidae ....................... 327

Lepus americams, Varying hare ............. 327

Lepus othus, Arctic hare ................ . 328

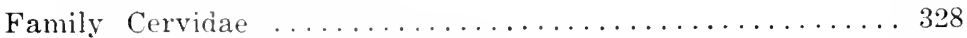

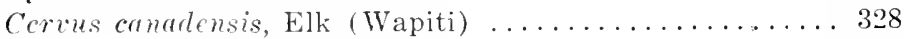

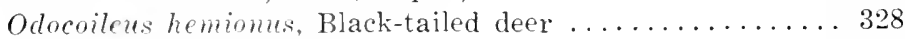

Alces alces, Moose ....................... 329

Rangifer arcticus, Barren ground caribou .......... 329

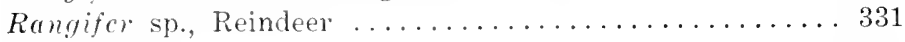

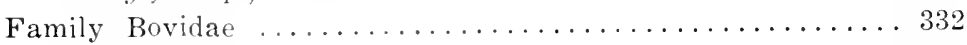

Ovis dalli, Dall sheep (White sheep) ............. 332

Family Hydrodamalidae ...................... 332

Hydrodamalis gigas, Steller sea cow ............ 332

Family Balaenidae ....................... 333

Eubalaena sicboldi, Pacific right whale ............ 333

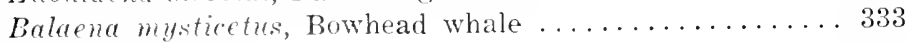

Family Eschrichtidae ...................... 334

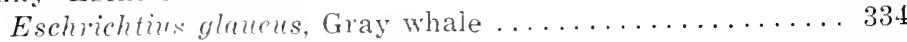

Family Balaenopteridae ..................... 334

Balacnoptera physulus, Finback whale ............. 334

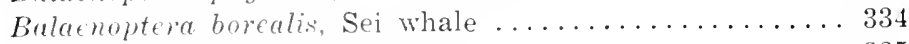

Sibbaldus musalus, Blue whale ............... 335

Megaptera notreangliae. Humpback whale .......... 335

Family Physeteridae ........................ 335

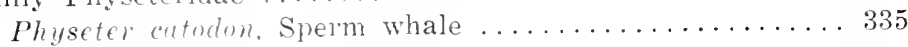

Family Delphinidae . . . . . . . . . . . . . . . 335

Giampus rectipinna, Pacific killer whale .......... 335

Globicephula seammonii, Pacific blackfish .......... 337

Lissodelphis horealis, Right-whale porpoise ......... 337

Lagenorhynchus obliquidons, Pacific striped porpoise ..... 337

Phocencu comerina, Pacific harbor porpoise ......... 337

Phocotnoides dalli, Dall porpoise ................ 338

Family Monodontidae ...................... 338

Delphinapterus leucas, White whale (Beluga) ........ 338 
Familv riphiidae ....................... 339

1 eradius bairdii, Baild beaked whale .............. 339

Mesoplodon stejnegeri, Stejneger beaked whale ........ 339

Ziphius cavirostris, Cuvier beaked whale .......... 339

References................................ 340

\section{ILLUSTRATIONS}

Figure

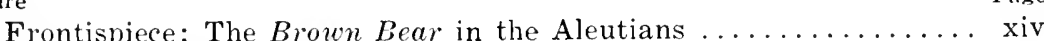

1. Aleutian Islands ............................ 4

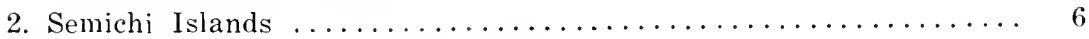

3. Sketch elevation of Agattu Island $\ldots \ldots \ldots \ldots \ldots \ldots \ldots \ldots \ldots \ldots \ldots \ldots$

4. Sketch elevation of Buldir Island ................... 6

5. Sketch elevation of several Aleutian Islands .............. 6

6. Sketch elevation of three Aleutian Islands $\ldots \ldots \ldots \ldots \ldots \ldots \ldots \ldots$

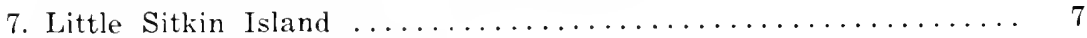

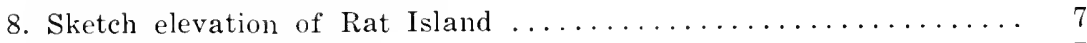

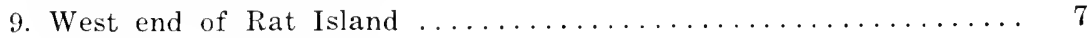

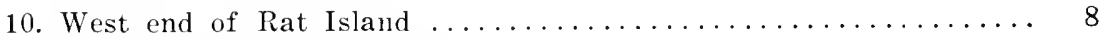

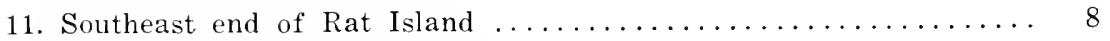

12. Sketch elevation of Semisopochnoi Island ............... 8

13. Sketch elevation of West Unalaga Island ................. 8

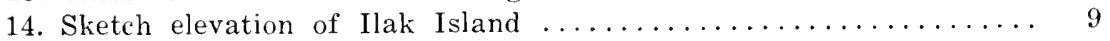

15. Sketch elevation of Kavalga Island .................... 9

16. Sadatanak I.land ........................... 9

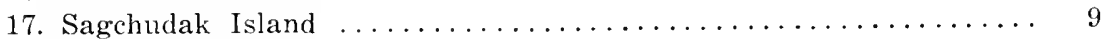

18. Sketch elevation of Bobrof Island $\ldots \ldots \ldots \ldots \ldots \ldots \ldots \ldots \ldots \ldots \ldots$

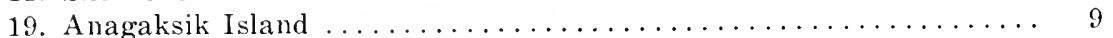

20. Sketch elevations of Kasatochi Island and Koniuji Island . . . . . . . 9

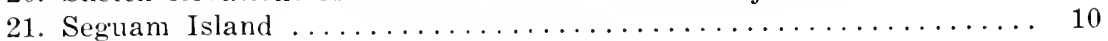

22. Sketch elevation of Ananiuliak Island . . . . . . . . . . . . . 10

23. Mounds on Kavalga Island ........................ 26

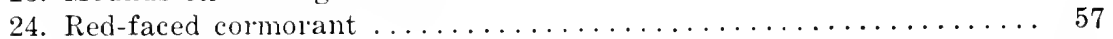

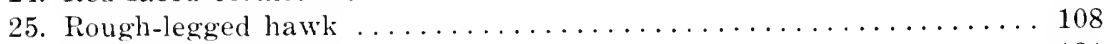

26. Black oystercatcher ........................... 131

27. Aleutian rock sandpiper . . . . . . . . . . . . . . . . . . 143

28. Least sandpiper . . . . . . . . . . . . . . . . . . . . . . . 148

29. Least sandpipers . . . . . . . . . . . . . . . . . . . . . . . 149

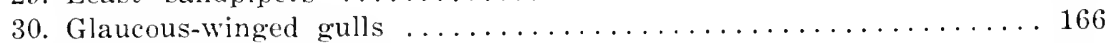

31. Black-legged kittiwakes $\ldots \ldots \ldots \ldots \ldots \ldots \ldots \ldots \ldots \ldots \ldots \ldots \ldots$

32. Colony of Pallas's thick-billed mulres on Bogoslof Island . . . . . 184

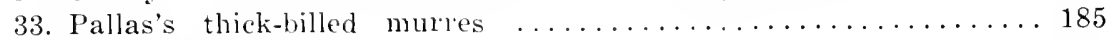

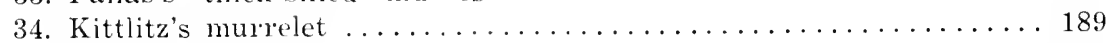

35. Ancient murelet ............................ 190

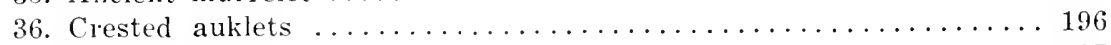

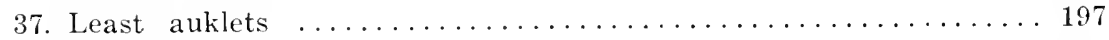

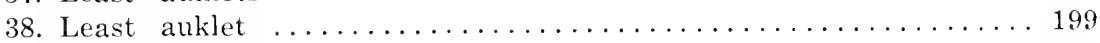

39. Horned puffins ............................ 203

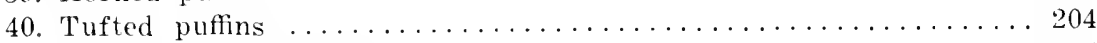

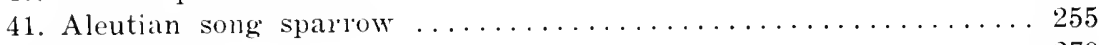

42. Sea otter ............................... 279

43. Blue fox $\ldots \ldots \ldots \ldots \ldots \ldots \ldots \ldots \ldots \ldots \ldots \ldots \ldots \ldots \ldots \ldots$ 
Introduction...................... Page

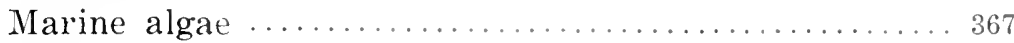

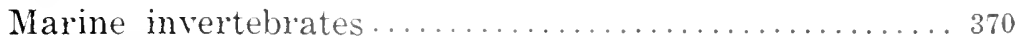

Sponges .................................. 370

Coelenterates ................................ 370

Hydroids . . . . . . . . . . . . . . . . . . . . . . 370

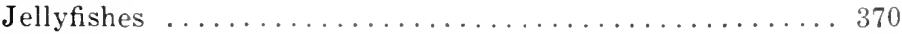

Flatworms ............................... 371

Roundworms ............................. 371

Nemertean worms ............................ 371

Brachiopods ................................ 371

Annelid worms ............................... 371

Echinoderms ................................. 372

Brittle stars . . . . . . . . . . . . . . . . . . . . 372

Starfishes ... . . . . . . . . . . . . . . . . . . . . . . 372

Sea urchins . . . . . . . . . . . . . . . . . . . . . . . . 373

Sea cucumbers ............................ 375

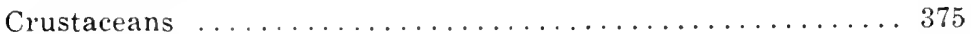

Copepods ....................................... 375

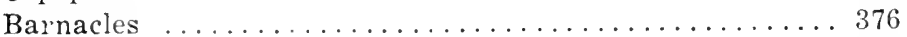

Amphipods ...................................... 377

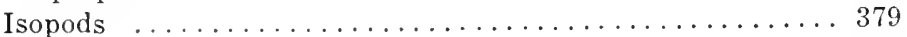

Shrimps ................................. 379

Hermit crabs . . . . . . . . . . . . . . . . . . . . 379

Anomuran crabs ............................... 381

Other crabs ................................... 381

Mollusks .................................... 381

Bivalves ................................ 381

Snails and sea slugs ........................ 383

Chitons ................................... 385

Devilfishes .............................. 386

Fresh-water invertebrates . ..................... 387

Crustaceans ................................... 391

Cladocerans ..................................... 391

Copepods ...................................... 391

Ostracods ........................................ 391

Mollusks ................................. 391

Land invertebrates............................. 392

Mollusks ................................... 392

Beetles .................................... 392

Bird lice . . . . . . . . . . . . . . . . . . . . . . . . 393

Diptera .................................... 393

Spider's . . . . . . . . . . . . . . . . . . . . . . . . . 393

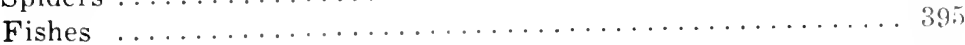

Literature cited ................................ 406 


\section{ILLUSTRATIONS}

Fingure Page

1. Fucus, a brown seaweed ............................ 368

2. Calcareous algae of the Lithothamnion group ............. 368

3. The 5-rayed starfish Asterias amurensis ............... 373

4. Twenty-layed starfish, Pycnopodia helianthoides ............ 374

5. Green sea urchin Strongylocentrotus drobachiensis ........... 375

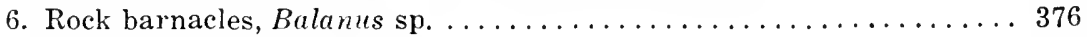

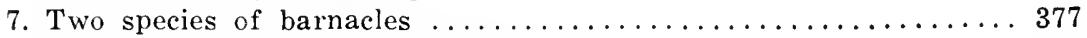

8. Parasitic amphipod Paracyamus boopis ................ 378

9. Common crab, Cancer magister .................. 380

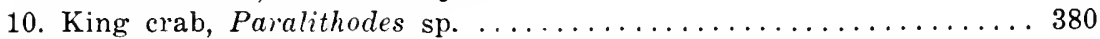

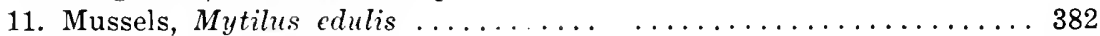

12. Limpets, Acmaea sp. .......................... 384

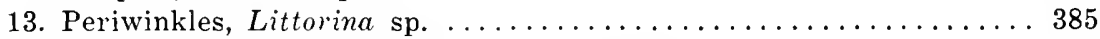

14. Fresh-water pool, type 1 (small and clear) ............... 387

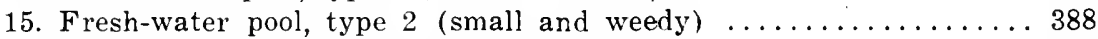

16. Fresh-water pool, type 3 (large and barren) $\ldots \ldots \ldots \ldots \ldots \ldots 389$

17. Alaska cod, Gadus macrocephalus ..................... 396

18. Red sculpin, Hemilepidotus hemilepidotus ............... 397

19. Irish lord, Hemilepidotus jordani .................. 398

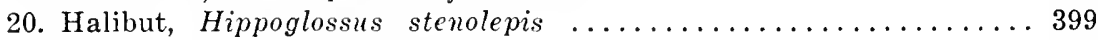

21. Pogie, Lebius superciliosus ..................... 400

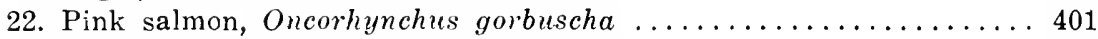

23. Native boy netting sockeye salmon .................. 402

24. Red or sockeye salmon, Oncorhynchus nerka ............. 402

25. Atka mackerel, Pleurogrammus monopterygius ............ 403

26. Silver hake, Tneragra chalcogramma ................. 404 


\section{Foreword}

This report is based on a biological survey of most of the Aleutian Islands and the Alaska Peninsula in 1936 and 1937. The report was largely prepared soon after the survey, but for various reasons it has not been practical to publish it until now. Even in manuscript form, this material has been consulted frequently, and it is issued now in the North American Fauna series so as to make more accessible information on one of North America's most significant biogeographic regions.

While the report was being readied for publication, the fifth edition of the Check-List of North American Bircls appeared (American Ornithologists' Union 1957). Throughout the report, scientific and common names of birds have been made to conform to the new Check-List, but generally references to "the A. O. U. Check-List," without specification, are to the fourth (1931) edition. Scientific names of mammals have been made to conform in general to the List of North American Recent Mammals (Niller and Kellogg 1955) ; common names of mammals for the most part follow Hall (1957). The Pinnipeds conform to the nomenclature of Scheffer (1958).

No attempt has been made to include references to all recent publications on the Aleutian and Alaskan fauna; references inclucled are those from which data were obtained for this report.

O. J. MURIE

May 19.59 


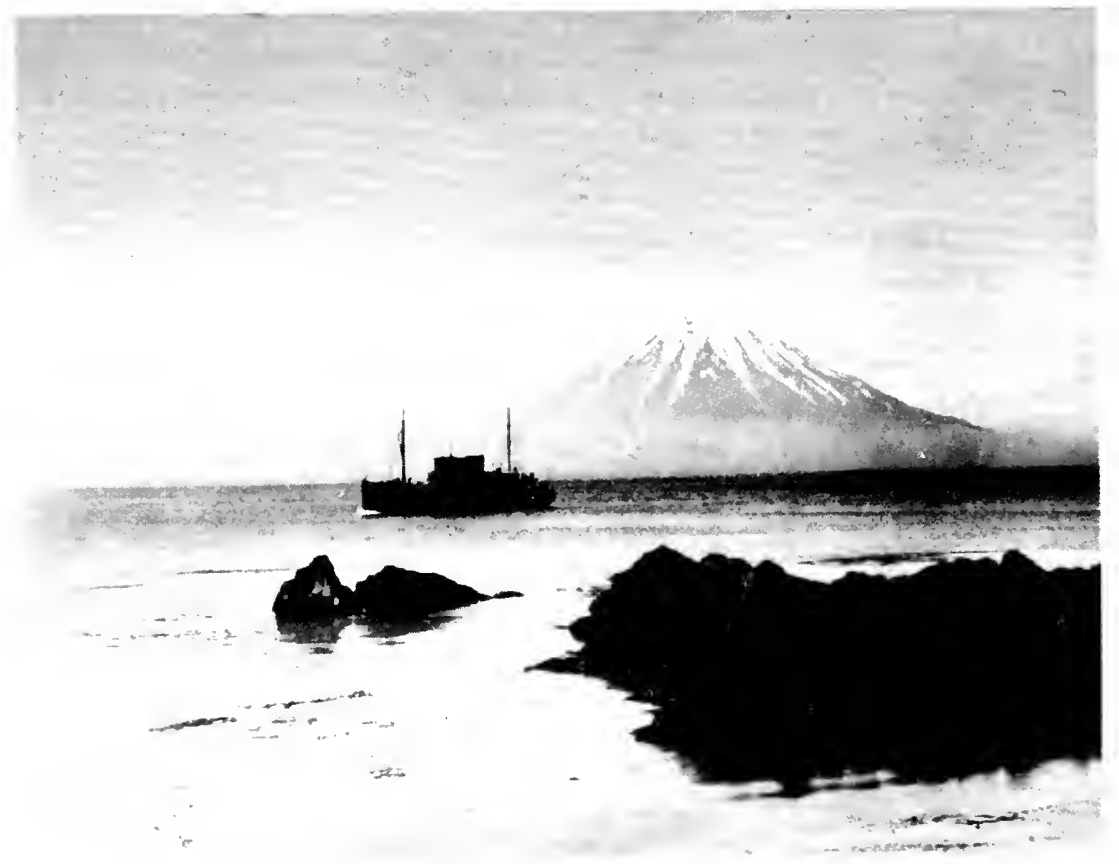

The Brown Bear in the Aleutians. Carlisle Island rising above the fog. 


\section{FAUNA OF THE ALEUTIAN ISLANDS AND ALASKA PENINSULA}

By Olaus J. Murie, Biologist

\section{Introduction}

The Aleutian Islands, treeless, fog-bound, and volcanic, extend westward from the tip of the Alaska Peninsula for about 1,100 miles to Attu, which is less than 600 miles from the Kamchatka Peninsula of Asia. The Aleutian Islands Wildlife Reservation, now a National Wildlife Refuge, was established on this chain in 1913. This reservation embraces the islands of the Aleutian chain between the North Pacific Ocean and the Bering Sea. These islands were set apart as a preserve and breeding ground for native birds, for the propagation of reindeer and fur-bearing animals, and for the encouragement and development of fisheries.

In 1920, the United States Bureau of Biological Survey ${ }^{1}$ was given the responsibility of enforcement of the Alaska fur laws and administration of the blue-fox industry in the Aleutians. As time went on, it became apparent that proper supervision of this important wildlife refuge would necessitate an extensive inventory of the resources of these islands.

In 1936, assisted by Cecil S. Williams of the Bureau of Biological Survey, I was assigned to make the necessary investigations. The motorship Broun Bear was placed at our disposal, and H. Douglas Gray and Homer Jewell, both of the Alaska Game Commission, joined us at Juneau. A second season was required for the work, and, in 1937, Victor B. Scheffer, John H. Steenis, H. Douglas Gray, and I made up the scientific party. During these two seasons we visited every Aleutian island of any size, as well as many islands south of the Alaska Peninsula and several points on the Peninsula, including Bristol Bay and the Nelson Island region of the Bering Sea coast. In 1938, Scheffer returned

\footnotetext{
1 Now a part of the U. S. Fish and Wildlife Service.
} 
with the Brown Bear for another season's work. He made limited studies of the lesser forms of animal life that inhabit the subarctic waters of the North Pacific Ocean and the Bering Sea and those that occupy the shores and slopes of the islands.

Our work, and the work of Scheffer, expanded upon information obtained by biologists who visited the area late in the 19th century and early in the 20th century. In 1902, W. H. Osgood, for the Bureau of Biological Survey, conducted an expedition to the base of the Alaska Peninsula. Results of his field work were published as "A Biological Reconnaissance of the Base of the Alaska Peninsula" (North American Fauna Series No. 24: 1904). In 1911, Alexander Wetmore and A. C. Bent investigated the wester'n end of the Alaska Peninsula and some of the Aleutian Islands (Wetmore's field report was never published). In the summer of 1925 , assisted by Fur Warden Donald H. Stevenson, I was assigned to field work at the western end of the Alaska Peninsula. Additional investigator's who visited the Aleutians include Lucien M. Turner and William H. Dall (in the 19th century), and Ira N. Gabrielson (in the 20th century).

In the present report, references are made to all individuals who are known to have contributed to the knowledge of the fauna of the Aleutian Islands. These individual contributions total into a considerable volume of data that have been of inestimable help in evaluating the Aleutian fauna. In view of this assemblage of data, and for a better understanding of the fauna of this part of Alaska, the present report embraces all of the Alaska Peninsula and the Aleutian Islands.

In compiling the material presented here, and in gathering the field data, I am indebted to my colleagues in the field on all three expeditions-1925, 1936, and 1937. These colleagues, already mentioned-Stevenson, Williams, Scheffer, Steenis, Gray, and Jewell-are men whose zeal for research and loyalty to the joint undertaking must ensure success of an expedition. John Sellevold, veteran seaman and captain of the Brown Bear, went beyond the requirements of his duty to help us in many ways.

John W. Aldrich and Allen J. Duvall, both of the U. S. Fish and Wildlife Service, have been especially helpful with advice and assistance in working with specimens. Herbert Friedmann, of the National Museum, has also helped considerably, and Ira N. Gabrielson, who has made many trips to the Aleutian district, has been especially generous with his field notes. Many others, both in Washington and in the field, assisted in many ways.

Also, I must pay tribute to those original inhabitants of tne 
Aleutians, the Aleuts, who as a race have suffered many vicissitudes through earlier contacts with white men. Those with whom we associated were eager to help with information. It is with special affection that I recall the friendly cooperation of Mike Hodikoff, Chief of Attu viliage, who was ready to do anything to further the work of our experlitions and to add to our knowledge. He, with his village, was captured by Japanese invasion forces during World War II ; there is no knowledge of his fate.

\section{GEOGRAPHY AND GEOLOGY}

The Alaska Peninsula and Aleutian Islands (see fig. 1) form a great arc that swings across the northern seas for about 1,500 miles, almost to Siberia. The Aleutian chain alone is about 1,100 miles long. This ar'c, together with the Commander Islands, forms a barrier that separates the Bering Sea from the North Pacific Ocean. The Alaska Peninsula extends southwestward from about latitude $59^{\circ} \mathrm{N}$., and Amatignak Island, the southermmost of the Aleutians, lies nearly as far south as latitude $51^{\circ} \mathrm{N}$.- the same latitude as the north end of Vancouver Island.

The north shore of the Alaska Peninsula shelves off gradually into the shallow water's of Bering Sea, forming a low coastal plain with a comparatively even coastline. However, farther inland the land rises to the rugged volcanic Aleutian Range, which runs the length of the Peninsula, and, on the south side, breaks off into the deeper water of the North Pacific. Accordingly, the south shore is irregular and rugged with bays and headlands and offshore rocks and is fringed by offshore islands-notably the Korliak-Afognak, Semidi, Shumagin, and Sanak Island groups, as well as a number of smaller ones.

The eastern Aleutians retain some of the characteristics of the Alaska Peninsula. This is most pronomeed on Unimak Island, which has a low coastal plain, lagoons, and rugged interior mountains that extend southward to the Pacific Ocean. In fact, Unimak Island is separated from the Peninsula by only a naprow strait.

Numerous eruptions have been recorded since the discovery of these islands, and the Aleutian chain proper consists of over 70 named islands, some small, other's large; Unimak is about 70 miles long. The chain is irregular and is bordered on the north and south sides by deep oceanic troughs. In other words, the south border of the shallow Bering Sea bottom, which is virtually a continental shelf, veers off northwestward so as to leave deep waters north of the Aleutian chain. As Stephen R. Capps (1984, p. 143) has stated, 


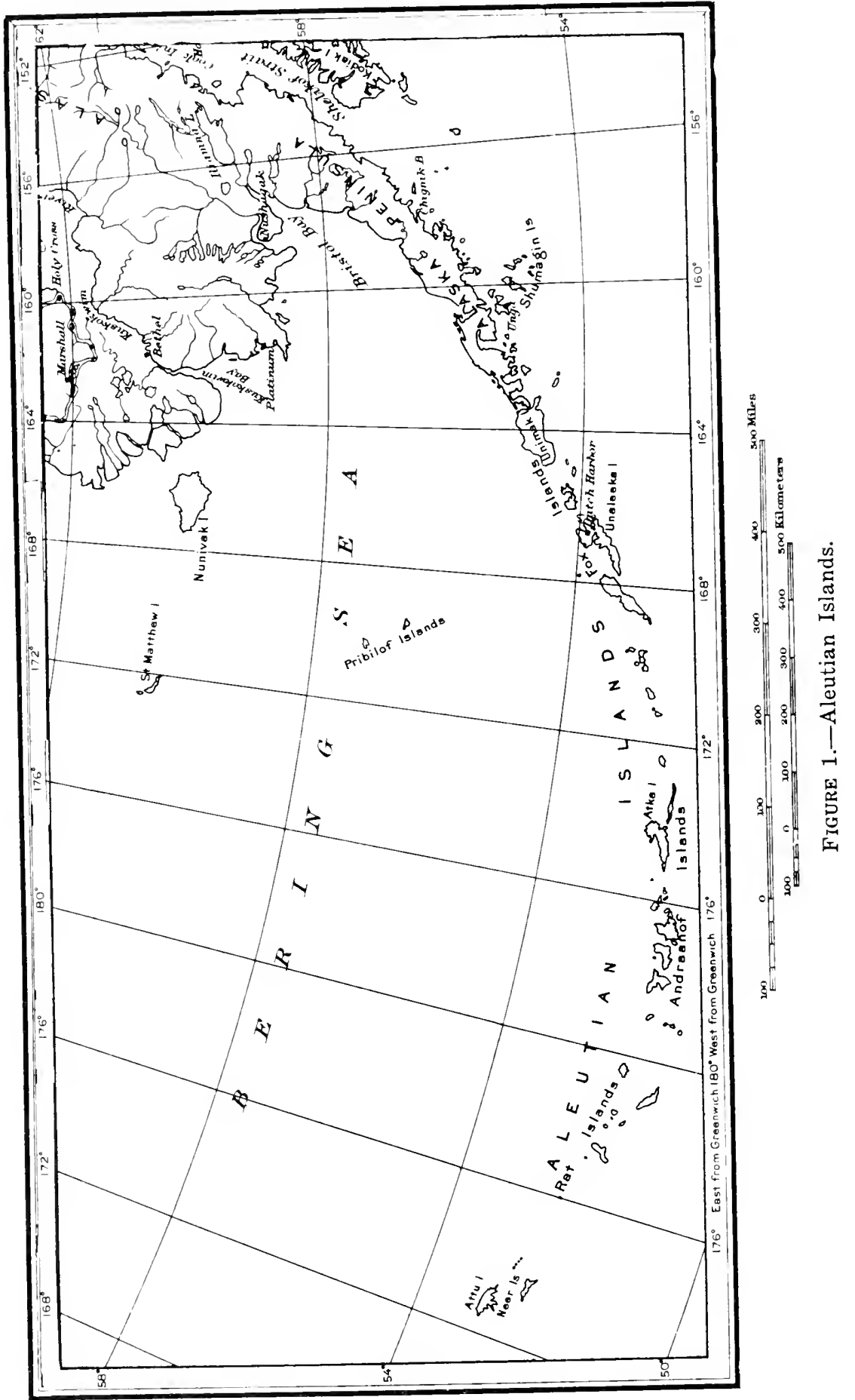


A line of soundings taken by the fathometer on the Gannet in 1932, extending along an irregular course from a point north of Amukta Pass to Attu Island, at varying distances from the intervening islands, shows that north of the islands the 1,000 fathom line lies close to the island festoon and that at a distance of 50 miles or more from them there is a remarkably smooth-floored depression at a depth of 2,000 to 2,200 fathoms. The shape of this depression between the islands and the continental mass, which includes much of Bering Sea, is not known, but it is significant that the island arc rises as a sharp ridge separating deeps of 2,000 fathoms or more both to the north and south.

The volcanic nature of this region is well known. Capps (1934, p. 142) says,

Throughout the Alaska Peninsula the volcanoes have broken out through older sedimentary or igneous rocks, by which they are now flanked. In the Aleutian Islands there are few if any exposures of the basement rocks, and the islands are largely constructional, having been built up to and above sea level by the accumulation of lavas and volcanic fragmental material ejected from below.

Many volcanoes along this remarkable arc are still in an active state. The eruption of Katmai Volcano, on the Alaska Peninsula, in 1912 was one of the great volcanic spectacles of modern times (see Griggs 1922). The activities of Bogoslof Island and Mount Shishaldin on Unimak Island are well known, and in 1930 there was an eruption on Gareloi Island. On our visit there in 1937 we examined some of the small craters, from which were issuing steam and other gases, and we noted many lava bombs on the lower slopes. We found several typical hot thermal springs that were rimmed with algae. On Kagamil Island, noisy steam jets issued from a rocky bluff, and rumblings could be heard under the boulder beach. After our return from the expedition of 1937, we learned that there had been an eruption on Yunaskia Island while we had been exploring other areas. Many of the mountains have plumes of steam issuing from the top. Mount Cleveland, on Chuginadak Island, erupted in 1944, and Okmok and Umnak Islands erupted in 1945.

As would be expected, most of the islands are mountainous. There are a few relatively flat islands, such as Amchitka, Agattu, and Semichi. However, there is a low mountain range along one side of Agattu, and there is a small mountain at one end of Alaid Island, in the Semichis. Most of the larger islands have lakes and streams, and several, such as Amchitka, Agattu, and the Semichis, are dotted with lakes. In keeping with their volcanic origin, some of these islands have notable lava beds that furnish nesting crevices for petrels and auklets, as on Amukta and Gareloi. Other islands, notably Ogliuga and part of Kavalga, 
have been covered with volcanic ash in recent times.' The shorelines are irregular, with offshore islets, rocks, and undersurface reefs, and there are boulder beaches, sandy beaches, and abrupt cliffs in great variety.

The accompanying field sketches, (see figs. 2-22) showing a few of the islands in profile, suggest the variety of configuration.

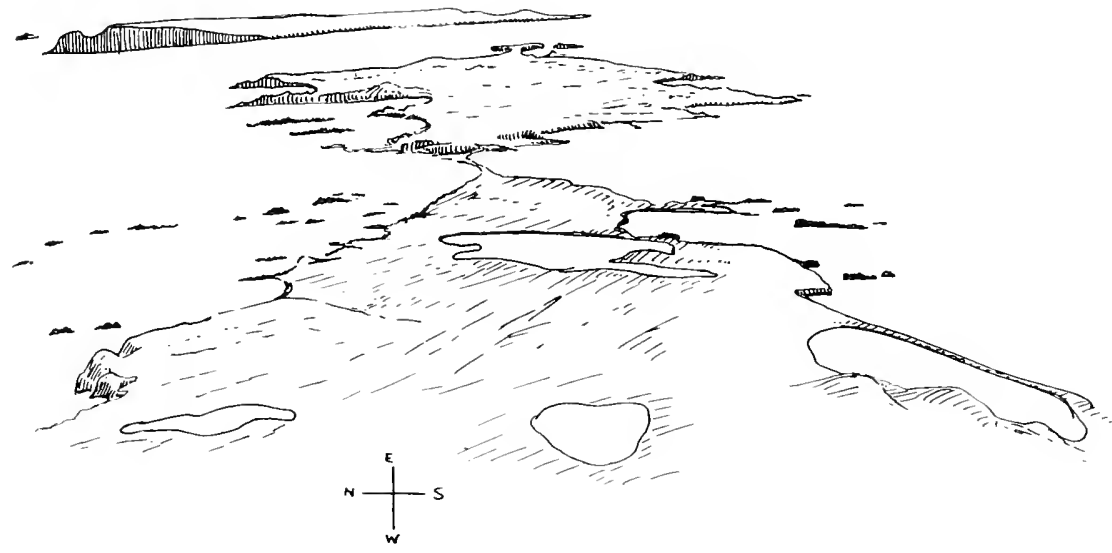

FIgure 2.--Semichi Islands from mountain on Alaid Island (June 1937). Note that a narrow spit connects Alaid, in foreground, with the middle island; Shemya, the easternmost, is in the distance.

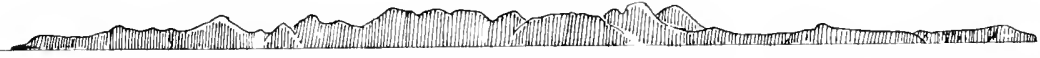

Figure 3.-Sketch elevation of Agattu Island, seen from west end of Alaid Island, looking southwesterly.

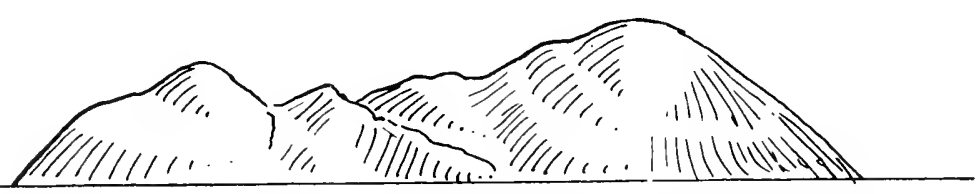

FIGURE 4.-Sketch elevation of Buldir Island, looking southeast.
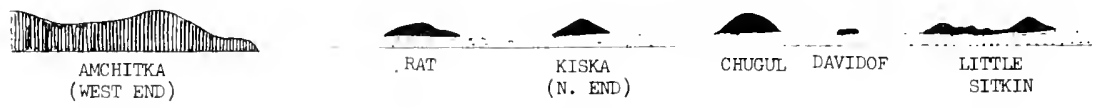

FIGURE 5.- Sketch elevation of several Aleutian Islands, looking west. 

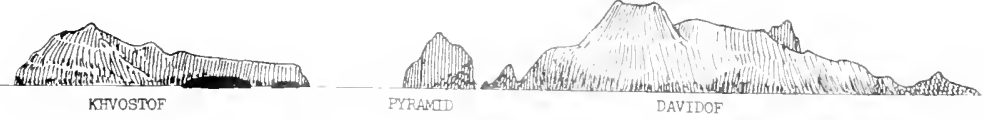

Figure 6.-Sketch elevation of three Aleutian Islands from Gunner Cove on Rat Island, looking northerly.

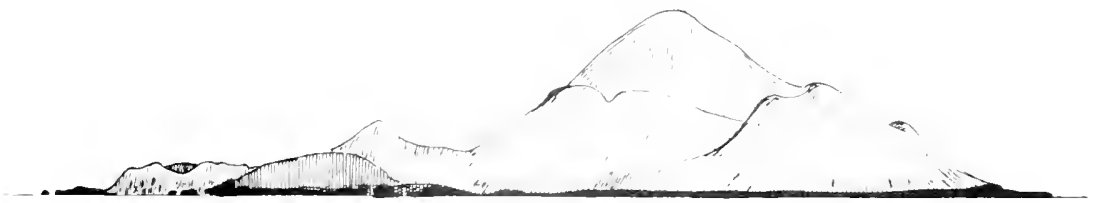

Figure 7.-Little Sitkin Island from Gunner Cove on Rat Island, looking northeasterly.

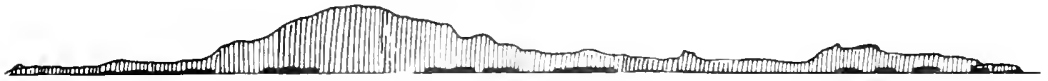

FIGURE 8.-Sketch elevation of Rat Island from southeast end of Khvostof Island, looking southerly.

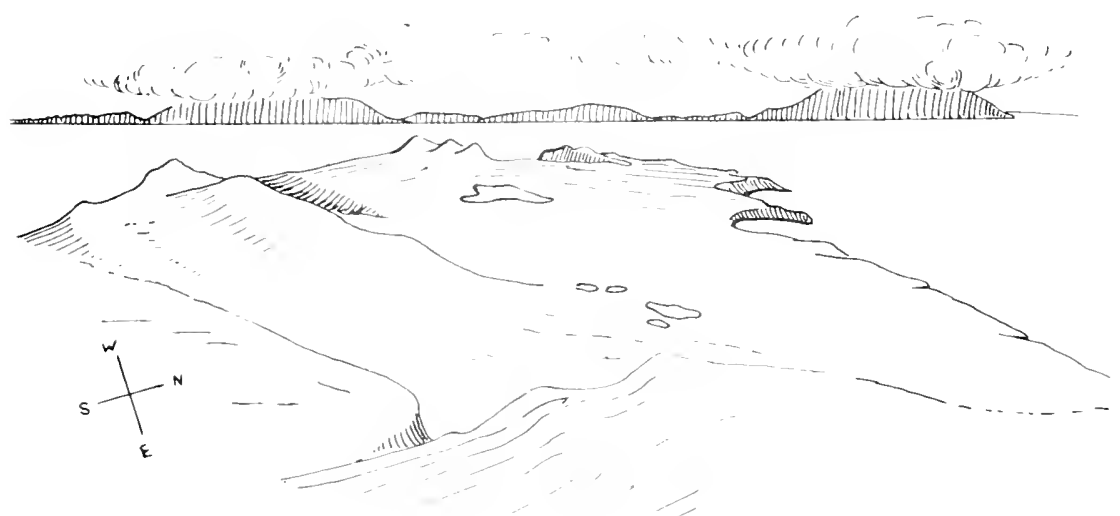

Figure 9.-West end of Rat Island (July 1937). Kiska Island in distance. 


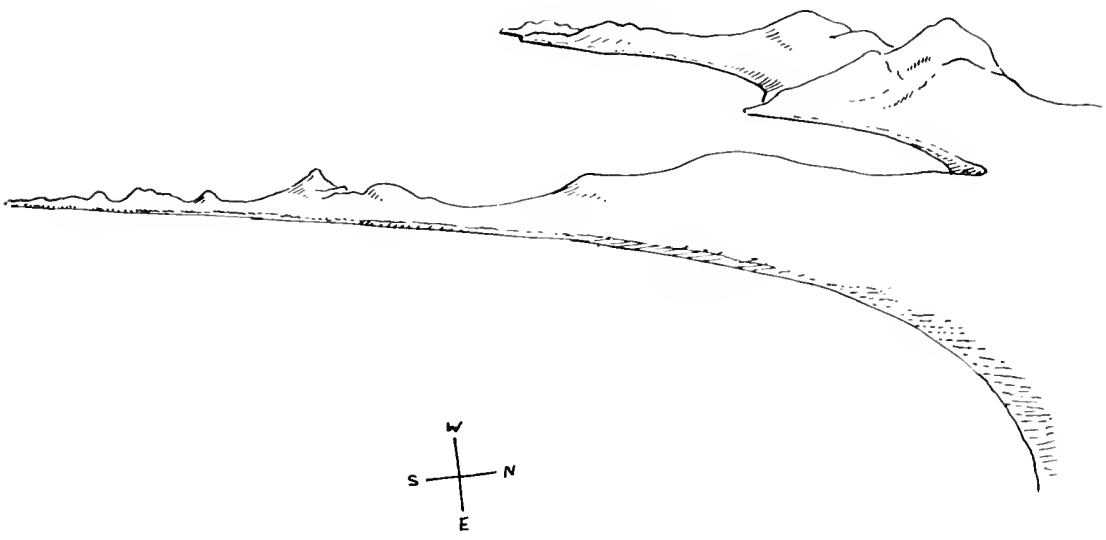

Figure 10.-West end of Rat Island (July 1937) from beach on south shore.

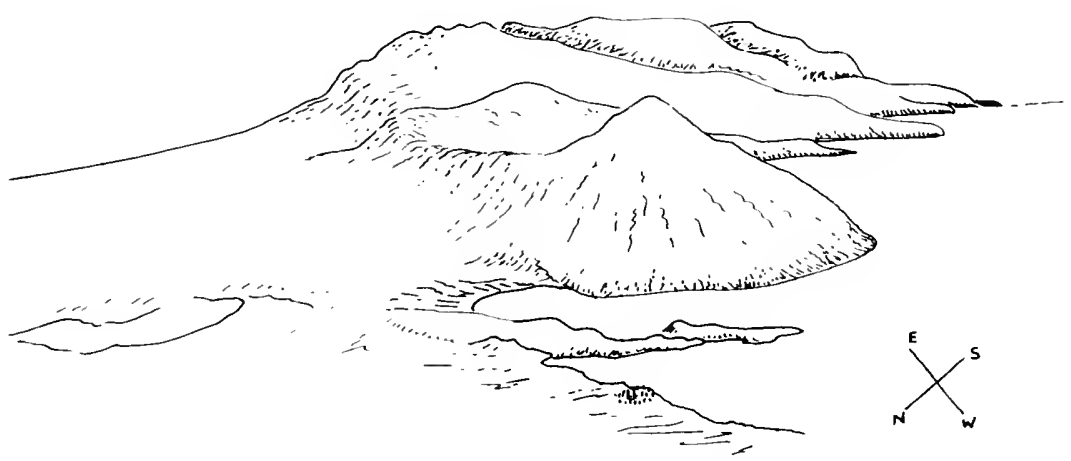

Figure 11.-Southeast end of Rat Island (June 1937).

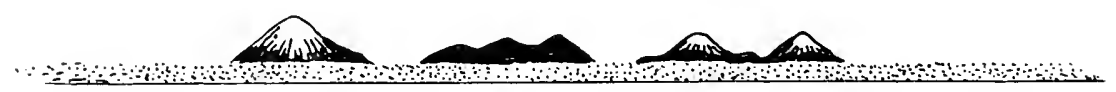

FIGURE 12.-Sketch elevation of Semisopochnoi Island seen from west end of Amchitka, looking northeasterly. Low fog bank on horizon.

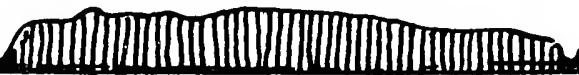

FIgURE 13.--Sketch elevation of West Unalaga Island, looking westward. 


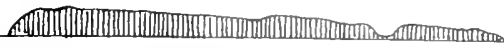

FIGURE 14.--Sketch elevation of Ilak Island, looking southerly.

FIGURE 15.-Sketch elevation of Kavalga Island from West Unalga Island, looking easterly.

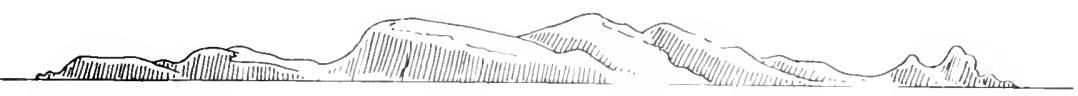

FIGURE 16.- Sadatanak Island looking easterly.

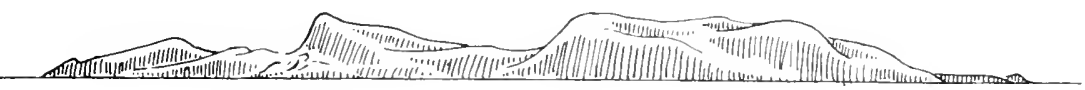

FIGURE 17.-Sagchudak Island looking easterly.

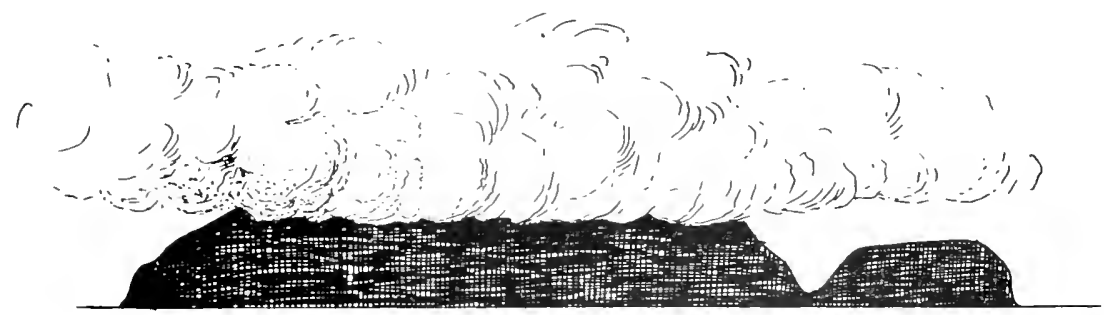

FIGURE 18.- Sketch elevation of Bobrof Island, looking southwesterly.

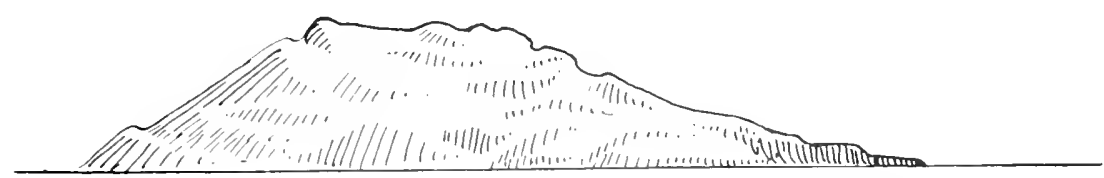

FIGURE 19.-Anagaksik Island, looking southeasterly.

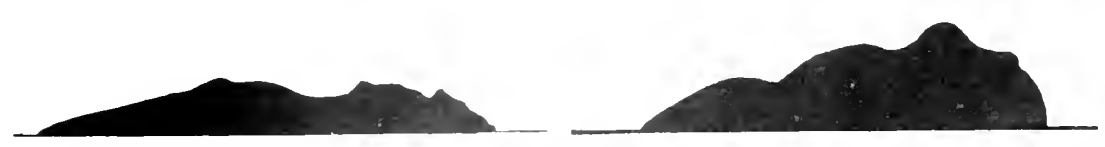

Figure 20.-Sketch elevations of Kasatochi Island and Koniuji Island, looking west. 


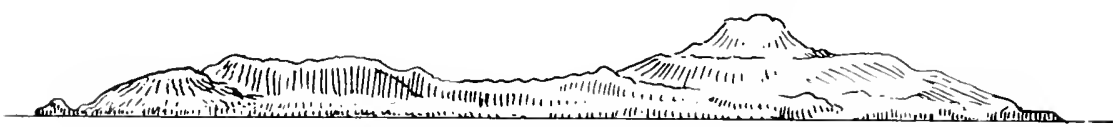

FIGURE 21.-Seguam Island, looking south-southwest.

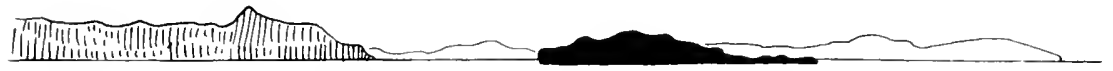

FIGURE 22.--Sketch elevation of Ananiuliak Island, looking southerly. Umnak Island in background.

\section{CLIMATE}

The Aleutian Islands and Alaska Peninsula are south of the severe low winter temperatures of interior and northern Alaska, and the surrounding waters are generally free of sea ice. To characterize winter conditions briefly: temperatures go well below freezing, fresh-water ponds freeze over at times, and snow sometimes piles knee deep. But the snow is likely to be wet and slushy, and there will be some bare ground. At higher elevations, huwever, snow is heavier, and the higher mountains are snowcapped in winter.

A few temperature records from Turner (1886), with notes on clear days, are of interest:

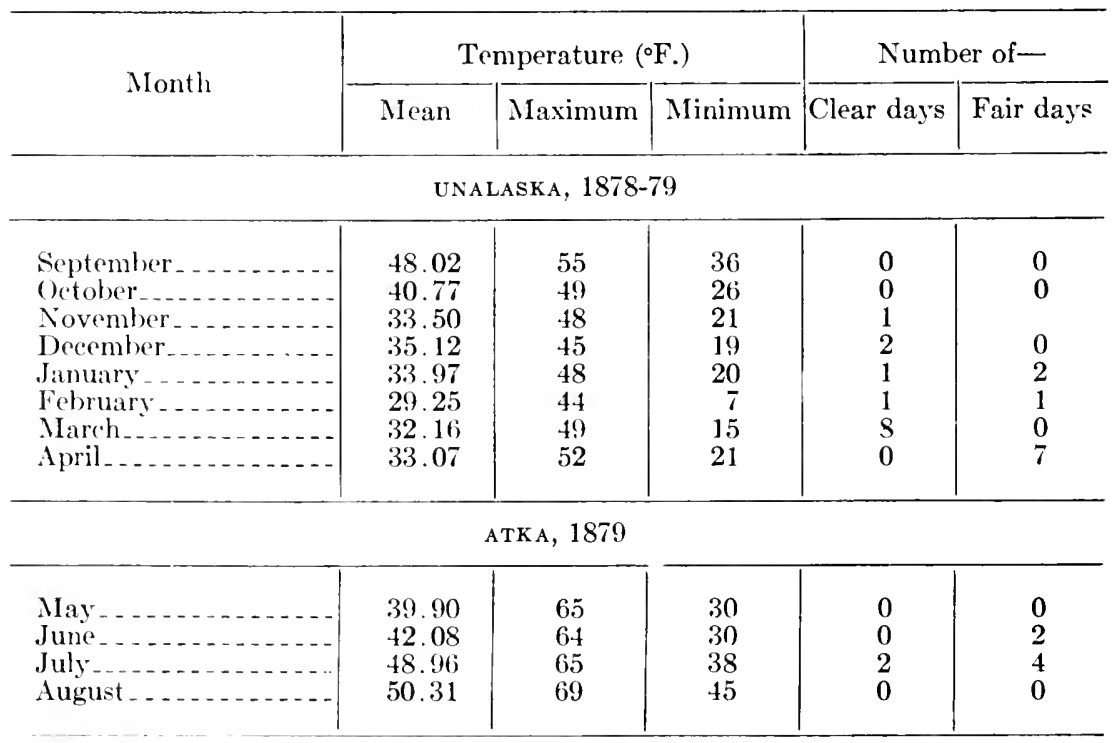


ATTL, $1 \$ S 0-\$ 1$

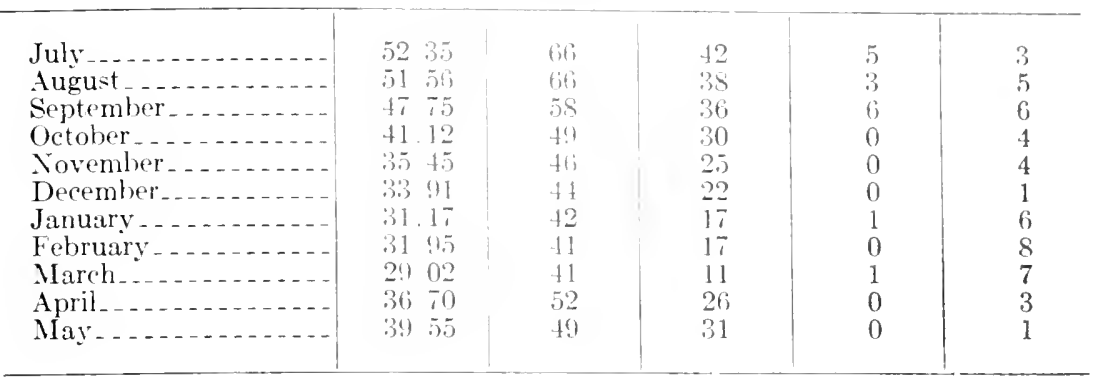

Sutton and Wilson (1916) observed birds on Attu Island from February 20 to March 18, 1945. They report,

The air temperatures at sea level did not vary much from freezing as a rule. During the daylight hours it sank somewhat below $32^{\circ} \mathrm{F}$. on 20 of the 27 days, climbed as high as 38 during the day on March 4, sank as low as 15 during the night on liarch 15 , and averaged $31^{\circ}$. On March 18 the greatest temperature variation $\left(15\right.$ to $\left.31^{\circ}\right)$, as well as the lowest temperature, was recorded. The general aspect was wintry: the sky overcast, the wind raw, the sea turbulent. Highlands and lowlands alike were covered with snow. Along the shore, tufts of rank grass and coal'se stalks of wild parsnip protruded from the drifts, and boulders, turfy mounds and narrow giay beaches were always bare. Elsewhere, save for an occasional cliff or exposed slope, everything was white.

A striking feature of the Aleutian climate is the prevalence of foggy or cloudy weather, the abundance of rain in summer, and the frequent violent winds that arise suddenly and unexpectedly. On western Alaska Peninsula, in 1925, we built a windbreak of alder brush to protect our tent, and, on the beach, light gravel occasionally would be blown into our faces. Briefly, then, one might say that although the temperature is mildneither very low in winter nor very high in summer-there is a minimum of sunshine and a maximum of fog, rain, and storm.

\section{ENVIRONMENT AND BIOTIC DISTRIBUTION}

The Alaska Peninsula and Aleutian Islands, stretching as a land bridge between two continents, present a most interesting distribution of plant and animal life. There are, of course, a number of physical facts that bear on the distribution of animals and plants-inchuling the location of the area with relation to that of other significant areas, the geologic history, the physiographic conformation of the land, the ocean currents, and the temperature, humidity, and other climatic influences. 


\section{GEOGRAPHIC AND GEOLOGIC INFLUENCES}

The Aleutian district lies within the Boreal region, and it may be identified as the southern fringe of this great circumpolar area throughout which life has so much in common. It is significant that the Alaska Peninsula and Aleutian Islands lie, in a sense, almost isolated from the mainland of Alaska and extend westward a tremendous distance toward Kamchatka, thus, in some respects, serving as a "bridge" between Asia and North America. It is also significant that they are near the other intercontinental bridge at Bering Strait, which is recognized as having an important influence on our biota.

The Aleutian Islands and Alaska Peninsula are of comparatively recent geologic origin. Volcanic activity is still prevalent, and changes in the surface of the land are still taking place. For this reason, and for reasons mentioned later, the area has a new and changing environment that has not yet been fully occupied by flora or fauna to the extent of its potential capacity. Thus, the area presents an opportunity to see immigration still taking place and to note the changes imposed on the newcomers by an unusual environment.

As the following sections show, the Aleutian biota is drawing its members from several directions. As would be expected, some have come directly from Asia; some have come from the north on the Alaskan side; others have come from the southeast along the Pacific coast; and still others are part of the fauna that appears to have developed in the Bering Sea region-an area roughly bounded by Siberia, mainland Alaska, and the Aleutian Islands. Many others are drawn from biotic populations that at present are so widely distributed in the Palaearctic region that it is impossible to judge the direction from which they entered the Aleutian area. Following, are some of these groups that have contributed to the Aleutian biota:

\section{ASIATIC IMMIGRANTS}

\section{BIRDS}

SCIENTIFIC NAME COMMON NAME

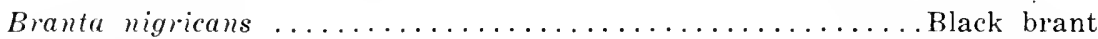

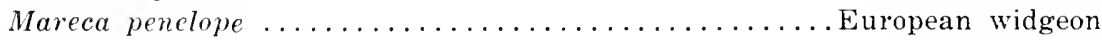

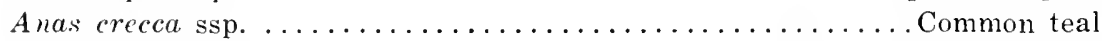

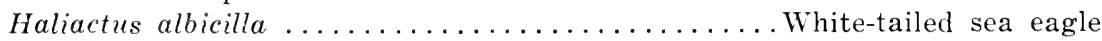
Haliaetus prlagicus ......................... Steller's sea eagle

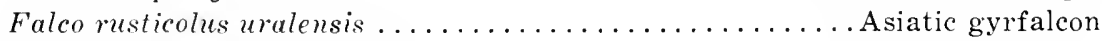
Charadrius dubius curonicus ..................tittle ringed plover 
Charadrius semipalmatus Semipalmated plover Pluvialis dominica fulva American golden plover Arenaria interpres interpres .................. Ruddy turnstone

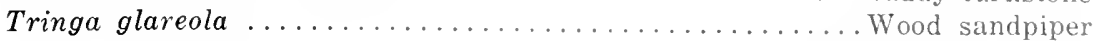

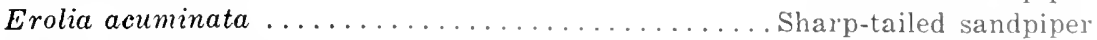

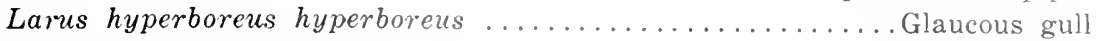

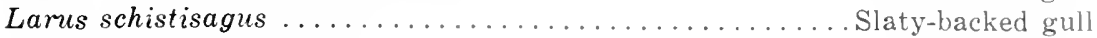

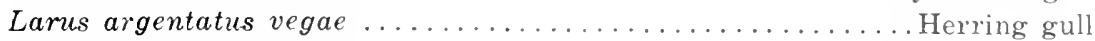

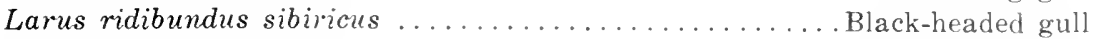

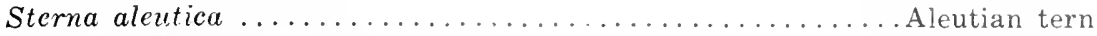

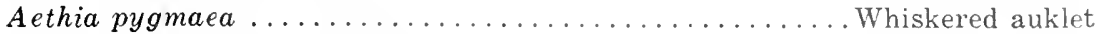

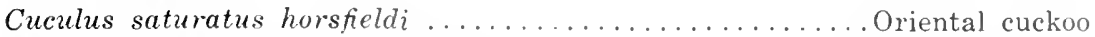

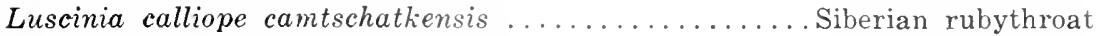
Troglodytes troglodytes ssp. (in part) ..............Winter wrens

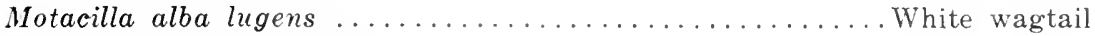
Emberiza rustica latifascia ................................. bunting

MAMMALS

SCIENTIFIC NAME

COMMON NAME

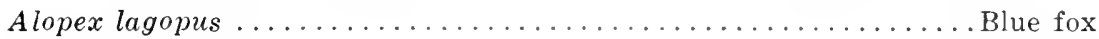

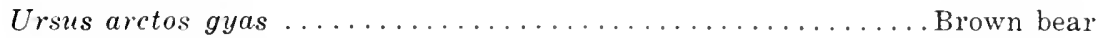

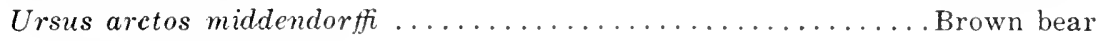

Some of these are only occasional visitors, such as the two eagles mentioned, and Larus schistisagus (slaty-backed gull), Larus ridibundus sibiricus (black-headed gull), Cuculus saturatus horsfieldi (oriental cockoo), and some others. Some have become established in the Aleutians, such as Anas crecca (common teal), Aethia pygmaea (whiskered auklet), and Sterna aleutica (Aleutian tern), and Alopex lagopus (blue fox). Others have reached the Alaskan coast in general, including the Aleutian district, but not necessarily by the Aleutian route, such as Falco musticolus uralensis (Asiatic grrfalcon), Plurialis dominica fulva (American golden plover), and the big brown bears. Some, such as Charadrius semipalmatus (semipalmated plover) and Branta nigricans (black brant), have extended eastward considerably beyond the Alaskan Peninsula but show greater affinity with Asiatic populations than with those farther east in North America. In the case of the winter wrens, Troglodytes troglodytes, the origin appears to have been from Asia and from the southeast. Of course, the bears came by the more remote northern route. Plants, too, have begun the long traverse over from Asia. In the case of plants which occur widely on both sides of Bering Strait, and which have become established all the way through the Aleutian chain, it is difficult to know the direction from which their immigration took place. There are some plants that, according to Hultén's distribution maps (1937a), have obtained 
a foothold in the western Aleutians but have not been observed to the east, even though some of them also occur on the Alaskan mainland. Concerning the plant distribution, Hultén (1937a, p. 44) stated,

If Commander Islands and westernmost Alaska Penin. are included, as in this flora, 92 America species reach that area, but 47 of them do not go further westward than to Umnak. 49 species reach the Aleutians from the west but not other parts of southern Alaska. 40 of them do not reach further eastwards than to the westernmost group of the Aleutians.

Some of the prominent Asiatic forms that we observed in the westernmost Aleutians are Cirsium kamtschaticum, Veratrum album oxysepalum, Cacalia ariculata, and Sorbus sambucifolia. These are confined to the Near Islands, though some are thought to have reached as far east as Buldir.

Hulten says further, "The flora of the middle Aleutians is very depauperated, probably due to the relatively short time elapsed since the glacial period, when most of their plants were exterminated."

Only the more obvious Asiatic elements are mentioned here. Other animal and plant forms probably originated in Siberia at a more remote time.

\section{BERING SEA AVIFAUNA}

The following birds represent a group largely confined to the coastal parts of Bering Sea, although some of them range farther north or south. They appear to be characteristic of all shores of the Bering Sea, instead of the Siberian side exclusively.

\section{SCIENTIFIC NAME}

COMMON NAME

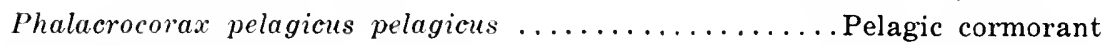

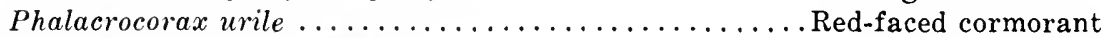

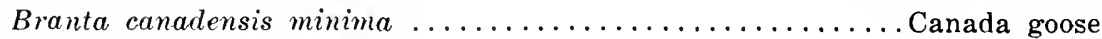

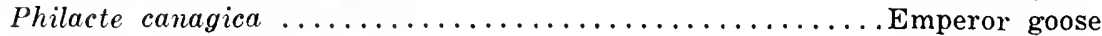

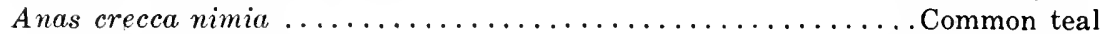

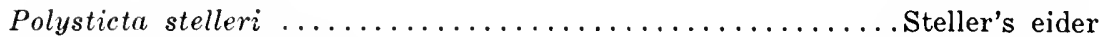

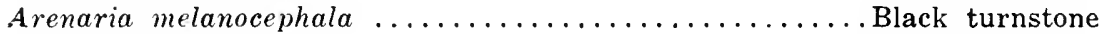

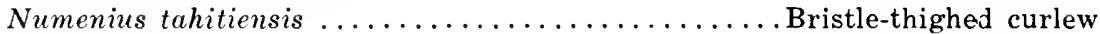
Erolia ptilocnemis $\mathrm{ssp} . \ldots \ldots \ldots \ldots \ldots \ldots \ldots \ldots \ldots \ldots \ldots$. $\ldots \ldots \ldots \ldots$ sandpiper

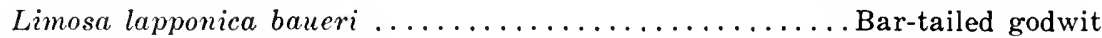

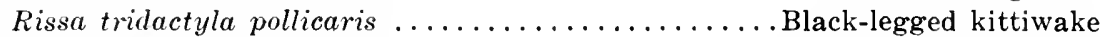

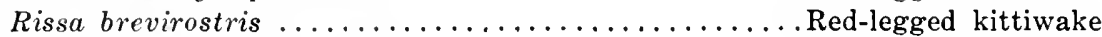

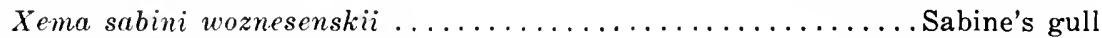

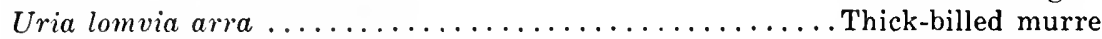

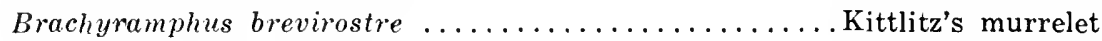

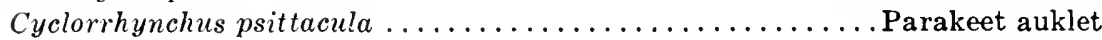
Aethia cristatella .Crested auklet 
Aethia pusilla

Fratercula coniculata

Least auklet

Phylloscopus borealis kennicotti

Horned puffin

Motacilla flava tschutschensis

Arctic warbler

Plectrophenax hyperboreus

Yellow wagtail

McKay's bunting

\section{FAUNA OF WIDER NORTHERN DISTRIBUTION}

\section{BIRDS}

SCIENTIFIC NAME COMMON NAME

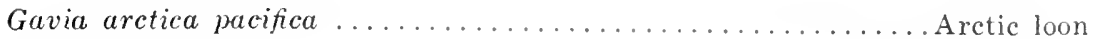

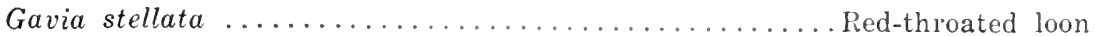

Olor columbiamus .......................Whistling swan

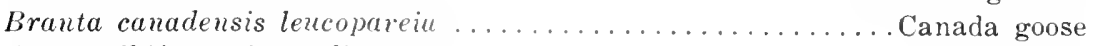

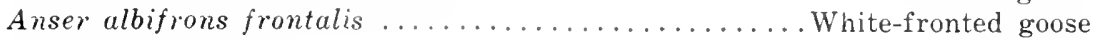

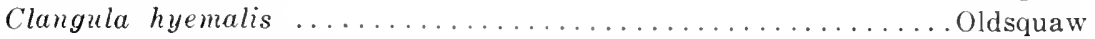

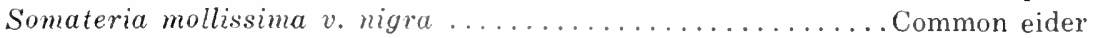

Buteo lagopus s.johannis ................... Rough-legged hawk

Falco rusticolus obsoleteus .......................... Gyrfalcon

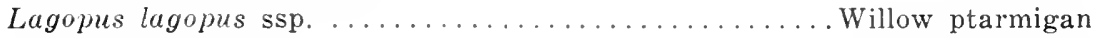

Lagopus mutus ssp. ......................... Rock ptarmigan

Erolia alpina pacifica ........................... Dunlin

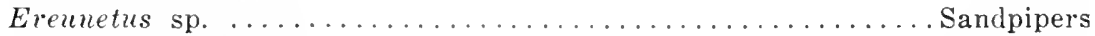

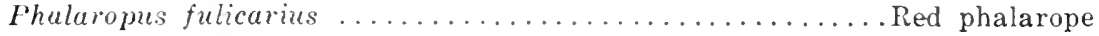

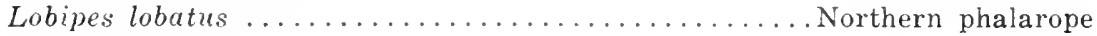

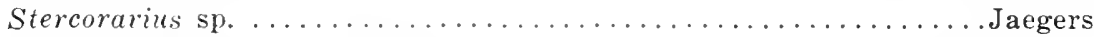

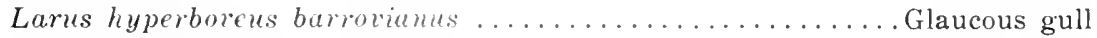

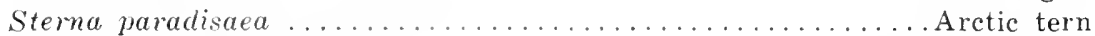

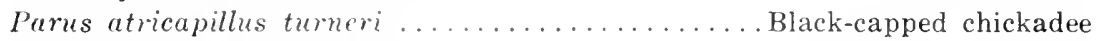

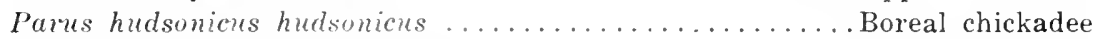

Turdus migratorius migratorius ................... American robin

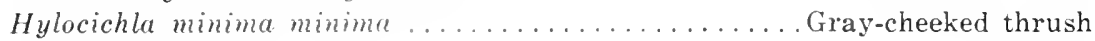

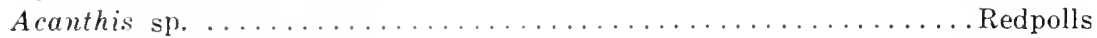

Junco hycmalis hyemalis ................... Slate-colored junco

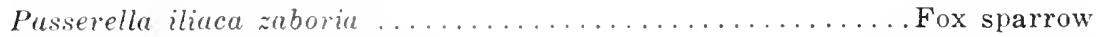

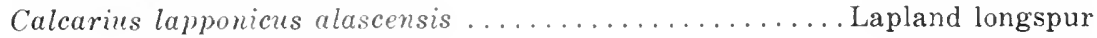

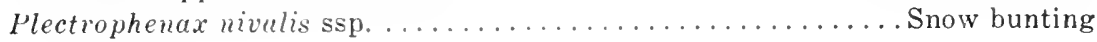

\section{MAMMALS}

SCIENTIFIC NAME

COMMON NAME

Sorex tundrensis .................... Tundra saddle-backed shrew

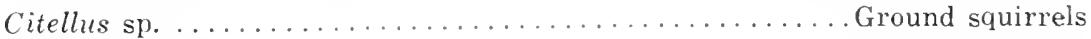

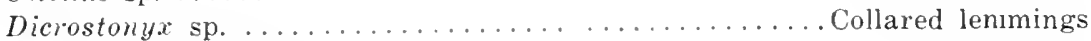

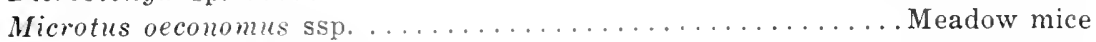

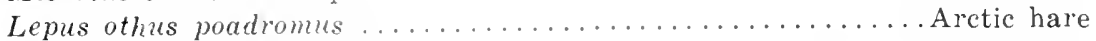

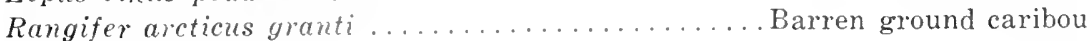

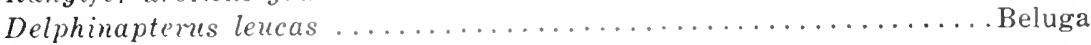

These are some of the more northern birds and mammals whose distribution with relation to the Alaska Peninsula is such that 
they probably immigrated southward or southwestward to the Aleutian district. There are, of course, a great many others of northerly distribution whose general range is such that the route of the population movement is uncertain. In the group here listed it will be seen that the Aleutian district has drawn heavily from the fauna that characterizes the northern portion of the continent from northern Alaska across to Hudson Bay. Lemmings, Arctic hares, the jaegers, Sabine's gull, and others, came straight down the Bering Sea coastal strip.

It will be noted that not all of the birds just listed actually nest in the Aleutian district.

\section{SOUTHERN AND SOUTHEASTERN AVIFAUNA}

\section{SCIENTIFIC NAME COMMON NAME}

Phalacrocorax auritus cincinatus ........... Double-crested cormorant

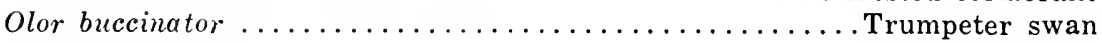

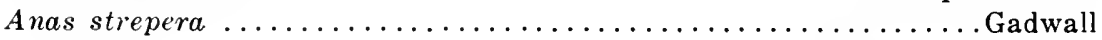

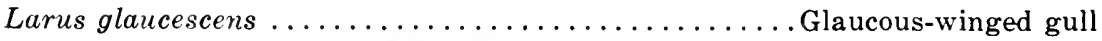

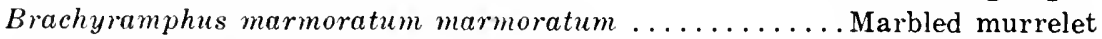

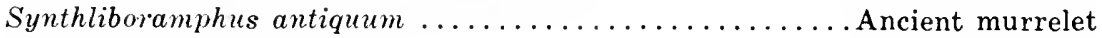

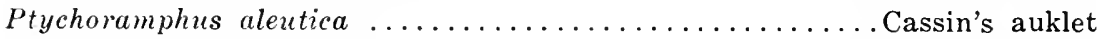

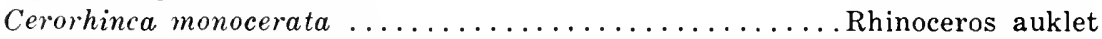

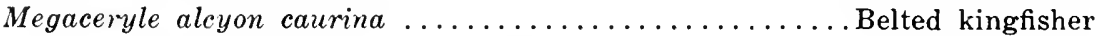
Troglodytes troglodytes ssp. (in part) ...............Winter wren

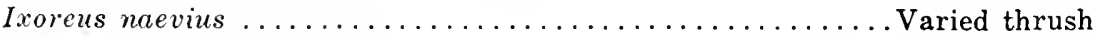

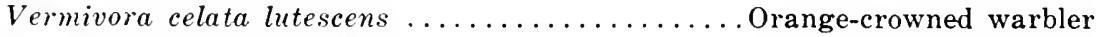
Pinicola enucleator flammula ................... Pine grosbeak Leucosticte tephrocotis ssp. ..............Gray-crowned rosy finch

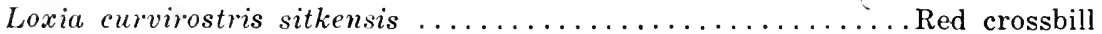

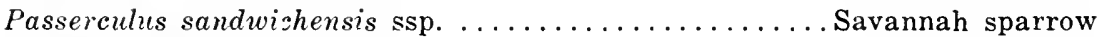

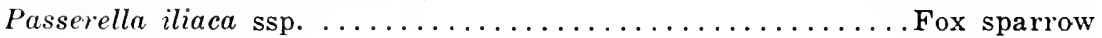

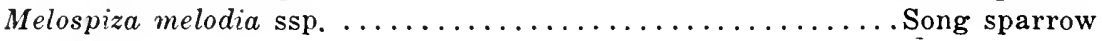

Some of these listings give us a clear demonstration of the route of influx into the Aleutian district, by way of closely related subspecies in a series extending along the coastal strip of southern and southeastern Alaska. Such examples are the song sparrows, fox sparrows, and winter wrens in particular. The fox sparrows present an interesting distributional picture. It is the dark coastal unalaschcensis group that has worked along the coast and fully occupied the suitable habitats as far as the eastern Aleutians. But the bright-colored eastern type has come down from the northeast and, at the base of Alaska Peninsula, this type has made contact with the coastal forms.

Naturally, there could be error in the interpretation of faunal immigration just cited, because complexities may have intervened 
since the territory in question was "opened for settlement"; however, the conclusions submitted are based on strong probability at least.

It will be seen that the coastal mountain masses of southern Alaska and the Alaska Range form a barrier. Although this is not an absolute barrier, presumably it is enough of an obstacle that the way of least resistance would be north and west along the coast for some species. Similarly, there is an easy avenue southward along the open Bering Sea coast for tundra-loving forms. And the Aleutian chain, reaching out close to Siberia, is an inviting route.

\section{ENVIRONMENTAL INFLUENCE}

There are some striking environmental influences operative in the Aleutian district. We know, of course, that humid regions tend to produce dark pigmentation, and this fact holds true for this area. The rosy finches reach their darker hues in the Aleutian area, with the darkest in the Pribilofs. The fox sparrows show the same tendency, exceeded in dark tones only by the populations of the excessively humid Pacific rain-forest zone that extends from the coast and islands of southeastern Alaska, southward to the northwest coast of the United States. Except for the aberrant yellow types in the middle Aleutians, the darkest rock ptarmigans are found in the Aleutian area, especially on Attu and the Commanders. Here, parasitic jaegers are, and the Arctic foxes are, almost entirely in the dark-color phase. In primitive times, silver foxes were unusually plentiful somewhere in this district, judging by the cargoes of the first Russian traders. The lemmings, Dicrostonyx, of Unalaska and Umnak do not acquire a white pelage in winter.

This is also a region of giantism. Note the huge size of the song sparrows, Savannah sparrows, and rosy finches, which, as genera, reach their greatest size in the Aleutians and Commander Islands. Here, the Aleutian winter wrens, as a group, have developed unusually long bills. Here, too, we may include the Alaska brown bear, which achieves its greatest size on the Alaska Peninsula, Unimak Island, and Kodiak Island.

Marine biologists have found that in many instances the invertebrate subspecies in the northern Pacific waters, and even farther north, are strikingly larger than forms of the same species farther to the south. This invites interesting speculation. As pointed out later, the Aleutian waters are unusually rich in plankton, and there is an abundant and varied marine inverte- 
brate fauna. An exceptionally nutritious marine food source should influence the vigor and size of the terrestrial vertebrates of that region.

The song sparrow's habitat in the Aleutians is the beach, and it is probable that its food is largely of marine origin-the small beach crustaceans, for example. Some other land birds, such as winter wrens and pipits, feed to some extent on the beach. The blue foxes feed chiefly on marine life.

The case of the Alaska brown bears is not so clear, though for a part of the summer they comb the beaches and live extensively on salmon, which are nourished in the sea. One wonders, also, if a certain type of food may, with other factors, help to encourage melanism (as in the jaeger), or darker shades of color, as in some of the other birds. It is generally accepted that a humid habitat produces dark coloration. It is not certain that this tendency, as well as melanism, is encouraged by rich food.

This is, of course, pure speculation, yet the significance of a food chain from the sea to the higher vertebrates on the adjacent land may be worthy of earnest study. There are many birds that have not responded to environmental influence. The Aleutian song sparrow has not developed dark pigmentation to an unusual degree. The northern form of the fork-tailed petrel, though averaging larger in the Aleutians, apparently is paler than those in southeastern Alaska. Also, it must be considered that the interior Alaska and Yukon caribou, as well as the Alaskan moose, which have no direct connection with the sea, are the largest on this continent. But these examples suggest that there is something in the environment-favorable food, humidity, or other stimuli-that tends to produce dark pigmentation and large size. This is an important challenge to future investigation and understanding.

\section{ECOLOGICAL CLASSIFICATION}

$\mathrm{By}$ the usual standards of life-zone allocation, the Alaska Peninsula and Aleutian Islands would fall chiefly in the Arctic Zone. A part of the Kodiak-Afognak Island group supports tree growth, and forests encroach on the base of Alaska Peninsula to the vicinity of Mount Katmai. Therefore, these locations would mark the limit of the Hudsonian Zone. However, we find the life-zone classification here to be far from simple. There are probably a number of physiographic and oceanic reasons for this situation.

There are serious difficulties in the interpretation of life zones in the Aleutians that should be considered. The lack of trees 
presumably would indicate some form of Arctic or Alpine Life Zone. So far as latitude is concerned, the southernmost island of the Aleutian chain, Amatignak, lies not far north of $51^{\circ} \mathrm{N}$., which is the latitude of heavily timbered, coastal British Columbia in the vicinity of Vancouver Island; however, the treeless Aleutians lie hundreds of miles south of the tree limit in the Brooks Range of interior Alaska. Some of the lowest temperatures in Alaska are recorded from the timbered interior, while the temperatures in the Aleutians are uniformly higher in winter, and the adjacent seas are not frozen over. From the standpoint of vegetation growth, summer temperatures are probably of greater significance than winter temperatures, and probably do not show so great a variation. Certainly the temperatures average much lower and have a lower maximum in summer than temperatures found in the forested continental areas.

Wind is another factor that generally accompanies treelessness at high altitudes and latitudes. There is a treeless coastal strip bordering the Bering Sea, with few interruptions, from Alaska Peninsula to Bering Strait, continuing around to the treeless Arctic coast. This coastal area is characterized by strong winds, as contrasted with the comparative stillness of the interior. We know the effect of wind on tree growth at timberline in mountains. In the Aleutians, I found many instances where the wind had scoured out the soil, exposing the roots of such groundhugging plants as crowberry and dwarf willow. If wind is one of the factors that establish the edge of forests, it is operative to an unusual degree in the Aleutians.

Forest growth is another important factor to be considered in the Aleutian district. Attention is invited to the series of publications on Alaskan flora by Robert F. Griggs (see bibliography) - particularly his 1934 report on the edge of the forest, in which he has assembled numerous data to show that the edge of the forest has been advancing in Alaska. This was particularly evident on Kodiak Island and in the Katmai region, where Dr. Griggs worked intensively. According to Griggs' studies, we may reason that, since the last glaciation, climate or a combination of other factors has been gradually improving the area toward suitability for forest growth. The forest, however, has not been able to migrate fast enough to keep pace with favorable climatic conditions and has not reached its potential limit.

Where, then, is the limit of the potential climax forest growth? At the end of the Alaska Peninsula? Farther west? On Merriam's life zone map, the Hudsonian Zone is shown extending the 
length of Alaska Peninsula. Spruce trees that were planted on Unalaska Island grew, but did not spread. It may be significant that tall willows, alders, and tall salmonberry have extended westward as far as Unimak Island in heavy thicket form. Here, salmonberry thickets are similar to those seen in southeastern Alaska. These facts may be indicative of a territory ripe for a forest. And such an advance line, based on climatic limitations rather than on the present position of the forest edge, may be considered to be the boundary of the Hudsonian Life Zone. The biome concept, to rely strictly on the climax end product, would have the same difficulty here, and published maps of the Tundra Biome and the Tundra-Coniferous Forest Ecotone for this area would simply substitute these terms for Arctic and Hudsonian Zones. There is the same potential boundary difficulty.

Granted that in the Boreal Zone, at least, tree growth is directly affected by the climatic factors usually associated with the life-zone concept, to what extent is the rest of the biota affected by the same influences? To what extent is it influenced by the mere presence of trees? It is reasonable to believe that the woody plants that comprise the understory of the Alaskan forest are, to a large extent, dependent on association with trees. Some forms, such as blueberries, often extend from open country into scattered forest. But there is a plant association that coincides with forest growth.

Similarly, there is a fauna that has become specialized for forest habitat-woodpeckers, certain grouse, certain warblers, jays, squirrels, black bear, and many others. These appear to be limited by the mere presence of trees. There is good reason to believe that wapiti and other deer would have a much more northern distribution if it were not for the physical barrier of deep snow in winter. On the other hand, the red-backed mouse, the hermit thrush, and the chickadee have inhabited the length of Alaska Peninsula. It is possible to assume that these mobile woodland forms simply would not wait for the slow-moving forest and thus have adapted themselves to more-open habitats than is normal for the species. Also, this would imply a lessspecialized response to habitat than some of the other forest species, as well as a greater sensitivity to direct climatic stimuli. Birds and mammals are more or less adaptive and vary between wide extremes in tolerance of adverse elements in their environment. However, there is a strong tendency for the majority of any population to be associated with the distribution of certain major vegetation types. 
One cannot escape the conviction that if we grant a certain degree of climatic influence on distribution of vegetation to cause it to fall into broad life zones, many of the birds and mammals that have become adapted to vegetation types will also tend to fall into these same life zones. These birds and mammals may be affected to a lesser extent by the life-zone climatic influences than by the indirect effects of these influences-the vegetation type of the habitat.

It should be kept in mind that, in boreal regions, biotic units are not so clearly defined as in desert or semidesert areas. Griggs (1934c), writing on Arctic regetation, says,

In short every feature of Arctic vegetation, the anomalies in the geographical distribution of arctic species, the occurrence of many species in all sorts of habitats, and their apparent indifference to the diverse conditions thereof, the lack of definiteness to the composition of the plant cover in any particular habitat, the physical instability of the ground itself, the general ruderal character of arctic vegetation, the large number of our weeds which are native to the arctic-all these testify to an instability in arctic vegetation very different from the relatively stable plant formations of the temperate zone.

He states further that-

First, combined with the demonstrated active migration of the Alaskan forest into the arctic, it gives definite support to the supposition that vegetation there has not yet recovered from the glacial period but is still in process of active readjustment.

This statement is applicable to the fauna as well, especially in the Aleutian district. Native rodents have only begun to encroach on the Aleutian Islands. Saramnah sparrows have gone only part way. Song sparrows have reached Attu, but fox sparrows have gone only as far as Unimak. Foxes had started to enter the Aleutian chain from Alaska, as well as from Siberia, before man intentionally affected their distribution.

Minute organisms that thrive unusually well in the cold waters of the northern seas have set up a food chain that developed a rich marine biota. This accounts for the presence of the fish, pinnipeds, whales, and sea otters that once inhabited these water's so abundantly. Given such a good supply of food, with an abundance of ideal cliffs and lava beds and boulder beaches for nesting sites, it is logical that the present swarming seabird colonies have assembled in the Aleutians.

There is much of the Arctic element in the Aleutians. Indeed, the Arctic and Alpine merge on these islands. The mountain-loving rosy finches and the Arctic snow bunting nest practically sicle by side, close to sea level. Alpine regetation types 
are not far above the level of the sea. But if we apply the term "Arctic" here, it must denote the "Low Arctic."

The Aleutian district is unique. For animal life, it combines favorable climatic factors and unusual food resources. It is a focal point to which animal life has been coming from north and south, and east and west, and it is a melting pot for faunal elements from two continents that have not yet reached equilibrium. It is necessary to keep in mind the fluid nature of the Aleutian biota in arriving at any system of zonal delineation.

From a purely descriptive standpoint, the fauna of the Aleutian district stands apart, and it may well merit distinction as the "Aleutian Fauna." There may be good reason to consider it as a unit of a more comprehensive Bering Sea fauna.

\section{VEGETATION}

In 1937, Eric Hultén published (in Stockholm, Sweden) "Flora of the Aleutian Islands and Westernmost Alaska Peninsula with notes on the flora of Commander Islands." The same author has also published "Flora of Alaska and Yukon," in 10 parts, issued from 1941 to 1950 . This work covers the botany of the Aleutian district so thoroughly that no detailed account of the vegetation need be attempted here, except for mention of some prominent plant associations and their distribution.

The first consideration is the distribution of forests. The spruce-forest edge is found midway on Kodiak Island and in the general vicinity of Becharof Lake on Alaska Peninsula. We find elements of the flora, as well as some of the birds, converging on the base of Alaska Peninsula from two directions. From the east, the Sitka spruce (Picea sitchensis) of southern Alaska has made its way to Kodiak Island at the base of Alaska Peninsula, out to the region abcut Becharof Lake, and now it constitutes the principal forest growth in this area. The status of the white spruce (Picca glauca) is less certain, but this interiorAlaska tree has come down from the north to at least as far as Bristol Bay, near Nushagak, and it may be considered to have barely leached the border of Alaska Peninsula, inland from the coast. The birch (Betula kenaica) is associated with the coniferous growth in all this forested area.

With the exception of this meager forest, in all lowland portions of Alaska Peninsula and Unimak Isiand, and to some extent as far west as Unalaska, tall vegetation is in the form of shrub thickets-dwarf birch (Betula nana exilis), willow, and alder. Alder (Alnus crispa sinuata) is particularly prevalent and forms 
heavy thickets. Hultén described a new form (Alnus crispa laciniata) from Kodiak Island, and mentions Alnus incana as occurring in the Katmai clistrict. Shrubby salmonberry (Rubus spectabilis) is found in suitable places along the Alaska Peninsula, and in the eastern Aleutians it is found as far as Unalaska Island.

Beyond Unalaska, the regetation is of the low type; the willows are of the dwarf species, close to the ground, and we find no appreciable high-shrub growth until at the very end, on Attu Island. Attu Island possesses moderate shrubby and tall plantslargely those with Siberian affinities. Hultén (1937a) states:

In the westernmost Aleutians, on Attu I., are found fragments of a high-grown vegetation similar to that growing in the upper subalpine belt on the open spots between the Alnus shrubs in Kamtchatka and along the Kamtchatka west coast. It is largely built up of Asiatic elements, which occur only on the westernmost islands, such as Cirsium kamtschaticum, Veratrum oxysepalum, Cacalia auriculata, Senecio palustris, and Sorbus sambucifolia, but it also includes elements occurring all over our area, such as Geranium erianthum, Streptopus amplexifolius, Calamagrostis Langsdorffi and others.

Some plant communities may be distinguished readily. Throughout all the coastal areas of southwestern Alaska the sandy beaches are bordered with a rank growth of wild rye. In the Aleutian district, other members of the Elymus arenarius, or wild rye, association are Senecio pseudoarnican, (a groundsel), Lathyrus maritimus (beach pea), Honckenya peploides, and Mertensia maritima (sea bluebell). Within this association we found the low-to-ground Honckenya peploides generally pushing out nearest the water. In many places the leafy, bulky Senecio pseudoarnica formed vigorous patches that virtually left no room for other plants. The Aleuts used the tall, coarse beach rye, Elymus arenarius, for weaving the exquisite "Attu" baskets.

Near the beach, but clinging to rocky sites, is Potentilla villosa, a herbaceous cinquefoil, which is associated with other plants. It is separate from the wild rye, or Elymus, association, though it is close to the tide, because its habitat is rock, not sand.

Behind this beach-line association, on a somewhat drier area farther from the tide, was another zone of miscellaneous grasses, with some other plants. Here, we noted a dense stand of Poa, (blue grass), Calamagrostis (brown top), Bromus (brome), and other grasses that we did not observe closely; however, we noted the demarcation between outer beach Elymus association and the adjacent inner zone of other grasses.

The dividing line was not always located by a given distance 
from the beach. I recall a striking instance where a sloping bank arose from the beach to a height of about 30 feet. Elymus, exposed to the sands of the sea, clung to the open face of this slope to the crest. At the exact point where the ground levelled off toward the interior, the other, more inland, grass formation began with a dense growth. The plants of this inner group bordering the Elymus association are by no means confined to the vicinity of the beach; instead, they become diffused among other plants farther inland.

Farther in the interior, and at higher elevations, we find what Hulten refers to as a "mosaic" of Alpine heath and meadow. Meadow formations have an abundance of Carex (sedge), together with many other species, though sedges occur elsewhere as well. In these meadows are found Artemisia unalaschensis (a herbaceous sage), Epilobium angustifolium (fireweed), Calamagrostis landsdorffi (a brown top), Geranium erianthum (geranium), Anaphalis margaritacea (pearly everlasting), Aconitum kamtschaticum (aconite), Polygonum viviparum (viviparous knotweed), Trientalis (star flower), Bromus alcuticus (brome), Castilleja unalaschensis (paint brush), Arnica chamissonis (arnica), and Aster percgrinus (aster). Such a meadow association, as defined by Hultén, is more characteristic of the eastern Aleutians. Prominent patches of the characteristic cotton grass, Eriophorum, and Ranunculus (bitterroot), were found in many wet areas. Here and there, were found Geum (avens), Caltha (marsh marigold), Habenaria (rein orchis), Lupinus (lupine), Geranium (geranium), and a botanical list too long to enumerate.

In the more exposed situations above the meadows, scattered in accordance with the character of the terrain, are the heaths. Here, are lichens, mosses, crowberry (Empetrum nigrum), and cranberry, (Vaccinium uliginosum). Numerous other plants are distributed rather indiscriminately. The showy anemone (Anemone narcissiflora), so prominent when in bloom, is very common.

Mention should be made of Heracleum lanatum (cow parsnip) and Coelopleurum gmelini (seacoast angelica). These robust plants grow throughout the Aleutian district, apparently where soil is rich. They are particularly conspicuous, together with other plants, on old Aleut village sites where the soil has been enriched by refuse from human habitation. Such village sites, seen at a distance, were recognizable by the deep-green, heavy vegetation.

On some occasions we would note a particularly green high 
mountain slope where we would find a colony of auklets nesting among rock crevices. We came to the tentative conclusion that vegetation grew more luxuriantly on the site of such bird colonies as a result of fertilization by bird guano and waste food. This vegetation was not necessarily of the same species as those growing on the Aleut village sites; however, the reasons for its presence in the two instances may have been related.

We did not have opportunity to study in detail the recovery of vegetation on islands recently corered by volcanic ash, as Griggs (1936) has done at Katmai and at Kodiak. However, little flat Ogliuga lsland would furnish such an opportunity. In 1930, there was an eruption on Gareloi, and the ash from the eruption covered Ogliuga. At the time of our visits in 1936 and 1937, regetation was just beginning to recover. Tall vigorous clumps of coarse sedges, Carer, and some Juncus, had pushed up through the ash here and there. These clumps had caught some of the drifting ash driven by the wind, had pushed up higher to clear the ash, and in turn had caught more wind-driven ash, until mounds had been created which were similar to sand dunes.

In the north are found the so-called bird mounds, whose origin has caused much speculation. One theory is that birds such as gulls and jaegers, repeatedly alighting on a small prominence, fertilize the spot, thus causing exuberant vegetative growth-a process that continues until a tall mound is formed.

On nearby Kavalga Island, I found that a part of the area nearest to Ogliuga evidently also had been in the path of an ash fall from a volcanic eruption, probably not so heavy a fall as that which covered Ogliuga.

Some typical "bird mounds" on Kavalga were carefully dissected, with the result shown in the accompanying diagram. In figure 23 , parts a and b, two such mounds show (by dark spots) the wearing away, or undercutting, by wind erosion. Also, note the wind erosion on the side in the diagrammatic section of another mound, as shown in part $c$.

Part $c$ shows, in cross section, the layers of materials in one of these bird mounds. Note that the first layer under the vegetation consists of lava sand, or ash. Beneath the first layer are the alternating layers, in increasing width toward the center, of black soil and rotted moss. This was, of course, a fairly crude field examination, with no opportunity for more precise analysis of materials. But the drifting volcanic ash on nearby Ogliuga, piling up in mounds around the pioneering clumps of vegetation, suggested a process that may also have operated on Kavalga 

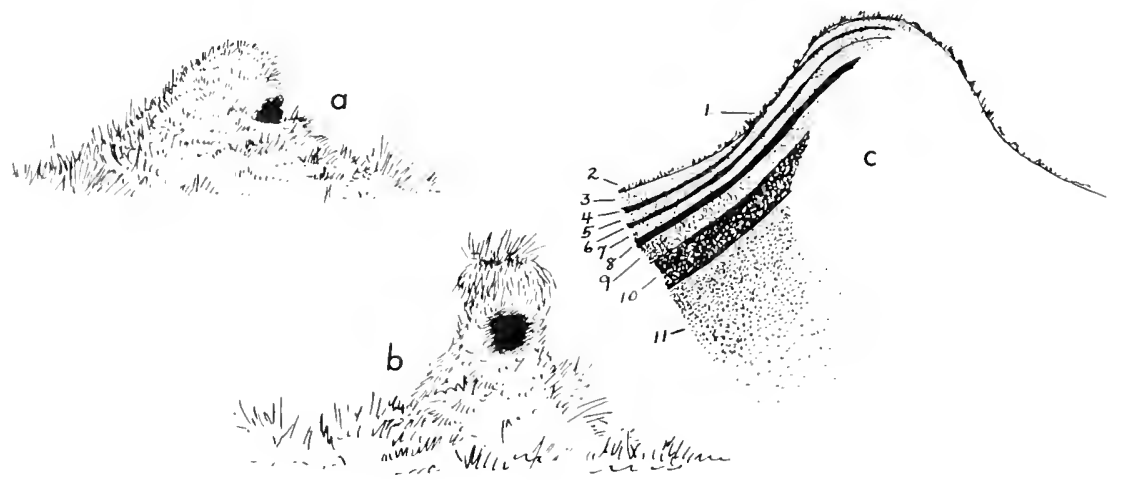

Figure 23.-Mounds on Kavalga Island (July 1937). $a$ and $b$, undisturbed mounds. $c$, cross-section of a mound: 1, wind erosion to black soil; 2, vegetation on surface; 3 , lava sand 21/4 inches; 4 , black earth $3 / 4$ inch; 5 , rotted moss $1 \frac{1}{1} 4$ inches; 6 , black earth $1 / 4$ inch; 7 , rotted moss 2 inches; 8 , black earth 1 inch; 9 , rotted moss $2 \frac{1}{2}$ inches; 10 , black earth $4 \frac{1}{2}$ inches; 11 , rotted moss 12 inches plus.

to initiate the formation of the so-called bird mounds. Possibly, the creation by the wind of these miniature dunes, together with the perching of birds thereon, are both involved in the formation of these mounds.

Wind erosion is very severe on some exposures. In places, the wind had eroded the soil in troughs, undermining the vegetative turf to form a crude type of terracing. The woody roots of crowberry had been exposed and were already supporting a thin coating of lichens. With such constant wind action, one wonders how the vegetation became established in the first place. As shown in part $c$, wind erosion apparently had affected only the outer layer.

Marine vegetation is well represented by the kelp beds, which consist of a considerable variety of seaweeds that are prevalent throughout the Aleutian district. The kelp is, of course, the habitat of numerous marine organisms, and during the summer it furnishes a favorite habitat for the sea otter. These kelp beds disappear in the winter.

The oceanic climate of this region, the high humidity and precipitation, and the prevalence of strong winds have combined to shape the vegetative complex that we find in the Aleutian district. In turn, this complex, together with climatic conditions, topography, and the rich marine fauna, has influenced the composition of the indigenous fauna. 


\section{Birds}

An effort was made to ascertain the Aleut names for birds and mammals. There are difficulties in such an undertaking, because one must be certain that both investigator and native informant are talking about the same bird. To make sure of this, a description of the bird and its calls and habits was supplemented with a colored illustration by Allan Brooks, which was obtained from the National Geographic Nagazine, and in numerous instances actual specimens were used for identification. In spite of all these precautions, it was necessary to guard against confusion in the minds of the natives because not all of them know their birds perfectly. This is particularly true of the more eastern communities, which are farthest removed from a primitive way of life. The most accurate information was obtained from the Attu people living at the extreme western end of the island chain.

There also is difficulty both in accurately hearing names spoken by natives, and in uriting them adequately. Not being familiar with the technique of the ethnologist, I have used the English alphabet to represent the sounds of Aleut words as closely as possible. The endings of Alent words, or syllables, are also a problem, because they are very soft, often somewhere between $h$ and $c h$, and sometimes have a soft $r$ sound included. Final $c h$, as used here, is the same as in the German Buch. $R$ is guttural, glided over, and sometimes is accompanied by an $h$ to emphasize this quality. I, as in "it." $E$, as in "let," unless marked long. $A$, as in "Ah."

There are at least three Aleut dialects, which are indicated here as Attu, Atka, and Unalaska. When available, names from Alaska Peninsula, recorded by Wetmore or other's, are included. Stejneger's names from the Commander Islands are also given (most of these names are Russian, but some are Aleut). Jochelson has listed a few names, but usually he did not designate the dialect ol the exact species. Some of his names cannot be identified; however, only names that are generally accepted are used here. A few names in Russian and Chukchi, from the mainland of Siberia, are also given. 
Without doubt, the Aleut language will disappear, and it is worthwhile to record the names that these people applied to the species in their native fauna. Too often, the professional ethnologist obtains only the obvious and generalized terms applied to a fauna; however, primitive societies clearly distinguish various species, almost as precisely as the scientist.

\section{Family GAVIIDAE}

\section{Gavia immer: Common Loon}

Attu: Kall-goó-gich

Atka: Kri-guch

Qigux (Jochelson)

The common loon, often observed on salt water in winter and in migration, usually is found nesting in interior lakes and ponds rather than in coastal marshes, but it also breeds throughout the Aleutian district. In this connection it is interesting to note that it does not occur in the Pribilofs.

Bones of this loon have been identified from Kodiak Island and from Little Kiska (Friedmann, 1935, 1937). A specimen was taken by Bretherton on Kodiak (1896), and the bird was reported by Chapman at Seldovia (June 30, 1903). Dall (1873) reports a "Colymbus torquatus" at Simeonof Island, in the Shumagins, on September 2, 1873, and further reports (1874) that it breeds on Kiska and is abundant on Amchitka. On July 23,1925 , I noted a pair of common loons, probably nesting, on a pond near Izembek Bay, near the west end of Alaska Peninsula.

In 1936, our party saw one of these birds (probably a migrant) on May 11, near Ushagat Island of the Barren Islands group, and on May 23, in Nushagak Bay, we saw six or more. The greatest number of these loons was found on Adak Island, though we also saw them on Amchitka, Kanaga, and Kiska. In 1937, at least 3 pairs were found on Agattu, and on June 17 of that year we found at least 2 pairs on Semichi Islands, each with 2 small downy young. In this instance, when we disturbed the adults, a glaucouswinged gull swooped down and carried off one of the young.

Dall reported that the common loon does not winter in the Aleutians, and Mike Hodikoff, chief of Attu Village, stated that it arrives at Attu Island in April and departs in October. However, during the years 1940 and 1946, Gabrielson found these loons on various islands as far west as Atka in midwinter, and in early spring and summer they were "common" or "plentiful" in numerous localities throughout the entire Aleutian district. 
Also, Cahn (1947) found this loon "not uncommon in winter in Captains and Makushin Bays" of Unalaska Island, and he noted it also in Hiuliuk Bay; the latest date was March 3.

\section{Gavia adamsii: Yellow-billed Loon}

Russian, Commander Islands: Bolschoj gayara (Stejneger)

Russian, latitudes of Yana: Gagara

Chukchi: Uvanketsjouku (Palmén)

\section{Bolschaja yagara (Pleske)}

It is extremely rare in this clistrict. Herbert Friedmann (1934, 1935,1937 ) has recorded bones of the yellow-billed loon from middens on Kodiak Island, on Amaknak (near Unalaska), and on Little Kiska Island in the western Aleutians. A specimen was collected at Kodiak by Bischoff in 1868, and Fisher obtained an aduit male in 1881.

We did not observe this species on our expeditions, blit the rhief of Attu seemed to recognize pictures of the bird and said it occurs in his home area occasionally. Stejneger $(1885,1887)$ considered it to ve a rare winter visitor in the Commander Islands, where he obtained one specimen and saw another. The bird he obtained was found on glare ice. unable to rise: evidently, it had mistaken the ice for water.

According to published accounts, this loon migrates along the Alaskan coast, from southeastern Alaska, west and north through Bering Strait. Presumably, the fall migration is the reverse of this. Several specimens are recorded from the Pribilofs (in May and August) as transients. In the spring of 1924, I obtained a specimen from an Eskimo at Hooper Bay and was informed that these loons pass that point in migration. It is likely, however, that the yellow-billed loon migration is not confined to the Alaskan coastline. In the autumn of 1924, several natives along the Koyukuk River in interior Alaska assured me that the yellowbilled loon passes through there in migration, though it does not nest there. They seemed well acquainted with the species as it was described to them, having particularly noted the light-colored bill. Therefore, the yellow-billed loon, nesting in the far north, is widely scattered in migration and occurs as a transient in the Aleutian, Commander, and Pribilof Islands.

\section{Gavia arctica: Arctic Loon Gavia arctica pacifica}

Russian: Gagara

We could obtain no Aleut name for this species. The Russsian name for loon in the general sense seems to have been adopted 
by the Aleuts, so that we find Bretherton (1896) and Turner reporting different forms of this word as the Aleut name for loon in general, and Nelson applying it to the red-throated loon.

The Arctic loon is widely distributed, nesting commonly on parts of the coastal plains of Bering Sea and the Arctic Ocean, as well as in many inland localities. It is quite common on the eastern portion of Alaska Peninsula, but it becomes exceedingly rare to the westward, as the following records show.

Bretherton and Bent report them nesting on Kodiak Island, and Cahalane (1943) found them to be common in the KodiakAfognak group in 1941. Friedmann (1935) records bones at various levels in archeological diggings on Kodiak, this indicating a regular occurrence over a long period.

Writing of his observations on the Alaska Peninsula in 1940, Cahalane (1944) says,

We found this species common on the Naknek River September 3, and at Brooks Lake September $9 \ldots$ On the western shore of Shelikof Strait, I recorded loons as "common" between Amalik and Katmai Bays, October 4, and "abundant" on the following day in Amalik and Kinak Bays and Geographic Harbor.

He also observed them off Cape Nushagak, October 7, but he adds, "They were absent from the interior of the Alaska Peninsula, even where suitable habitats existed."

These observations were made chicfly in the migration period, when Arctic loons are strikingly abundant along the Alaskan coast. On May 18, 1937, as we were approaching Valdez, Pacific loons were scattered widely over the water of the fjord. We counted at least 75 at one time. One loose flock contained 50 loons.

In 1940, Gabrielson observed 30 or more pairs, as well as scattered individuals, on Kvichak River, July 23, and he noted 2 of these birds at the upper end of Iliamna Lake on July 24. On July 7, 1946, he noted a loon at Port Moller.

Jaques (1930) found them to be common near Port Moller, June 1-23, 1928. On May 29, 1936, I noted at least eight pairs, apparently preparing to nest, among the ponds bordering the lower reaches of Ugashik River, but they are scarce at the west end of the peninsula.

Farther west, these loons are less numerous. Among the Aleutians proper, we did not identify a single Arctic loon during two seasons of extensive field work and a third season of hasty reconnaissance. The chief of Attu Village did not recognize pictures of the bird and declared that no such bird occurs there. Donald H. Stevenson, former warden in the Aleutian Islands National Wildlife Refuge, reported them as "not common." His only spe- 
cific record is the mention of two birds that he saw at Unalaska Harbor, October 15, 1920, which he thought were of this species.

Austin H. Clark (1910) mentions only one bird, which was seen on a lake on Agattu Island in 1906.

Turner, however, reported this loon, under the name of Urinator pacificus, as a common breeding bird in the Near Islands (1885), and, later (1886), he specifically reported one at Attu in the winter of 1880-81 and said that they nested commonly on Semichi Islands. Using the name Urinator arcticus, he said that this species was to be found among the Aleutians at any time of year, and he mentions seeing one at Amchitka Island in June.

These reports of Turner are rather surprising, and certainly they are not in accord with more recent findings. We had abundant opportunity to examine Agattu, Semichi, and Amchitka Islands, which were specifically mentioned by Turner, and though we found the common loon and red-throated loon, we did not see an Arctic loon. Stejneger did not record it for the Commander Islands, and it has not been recorded for the Pribilofs.

Gavia arctica viridigularis is known to be an occasional Old World straggler from Siberia to Alaska, and it has been recorded on the Pribilofs. Turner recorded two forms for the Aleutians, therefore it might be expected that viridigularis has occurred among those islands. However, in view of the confusion that has existed over the identity of the American forms of this loon, and because of its complete absence from the Aleutians, in recent year's at least, a reported occurrence should be well authenticated before being accepted.

\section{Gavia stellata: Red-throated Loon}

Attu: Ka-ka-dra-cha or Ka-da-dra-ka

Atka: Ka-kach

Russian, Commander Islands: Gargara (Stejneger)

Russian, latitude of Yana: Gagara (Birula); Malaja gagara (Birula)

Chukchi: Jouku (PaImen)

As previously mentioned, the Russian word "gagara" is used by natives in various parts of coastal western Alaska. This, and the Aleut names, are imitations of the call of this loon.

The red-throated loon is the most abundant and widespread loon in the North, especially on coastal areas, and it occurs on both shores of Bering Sea. On the basal portion of Alaska Peninsula it appears to be less abundant. Neither Gabrielson nor Cahalane reported seeing it there, although they observed the 
Pacific loon. We did not observe them there on our expeditions. Osgood (1904) records a pair on Chulitna River, August 12, 1902, and he observed a few other's "at comparatively long intervals" on the Chulitna and Kakhtul Rivers; however, he adds that "they were far exceeded in number's by the Pacific loon." McKay had collected specimens at Nushagak, and Friedmann has recorded the bird from Kodiak Island.

At the western end of Alaska Peninsula, however, red-throated loons were abundant. They were noted in some numbers on Izembek Bay in 1925. Turner (1886) found them to be abundant in the Aleutians and records them nesting on Atka, Semichi, and Agattu. We found these loons to be plentiful on Semichi, Agattu, and Amchitka, and we noted them on Sanak, Adak, Tanaga, Kiska, and Attu. Gabrielson records them on Attu, Amchitka, and Izembek Bay. Friedmann and Cahn also recorded the bird from Unalaska. They are present on all islands that bear suitable nesting ponds, and many of these red-throated loons spend the winter in the Aleutians.

Stejneger and Hartert report this loon as "abundant" and breeding "frequently" in the Commander Islands. Clark also noted a pair on Bering Island in 1906.

\section{Family PODICIPEDIDAE}

\section{Podiceps grisegena: Red-necked Grebe Podiceps grisegena holböllii}

Friedmann (1935) records a bone, as well as several skins, from Kodiak Island. Cahalane (1943) recorded these birds as numerous in Uyak Bay and recorded a few in Kupreanof Strait. He also observed 2 birds on Brooks Lake, in the Katmai region, on September 9, and he observed 4 or 5 on the lower Naknek River on September 28. He stated, "On Shelikof Strait, the species was abundant between Katmai and Kinak Bays on October 4 and 5, and off Cape Nukshak on the 7th."

On May 29, 1936, we found one of these birds in a pond, apparently nesting, near lower Ugashik River, and another was swimming in the river.

A little farther west, in ponds near Port Moller, Jaques (1930), reports several, June 4 and 20, 1928, and Gianini (1917) observed several at Stepovak Bay in June 1916.

On April 28, 1925, I obtained a specimen at False Pass, at the extreme tip of Alaska Peninsula, and on July 21, 1925, I found an adult with two young in a pond near Moffet Cove, at 
the east end of Izembek Bay, thus positively establishing the species as a nesting bird that far west. The bird was heard calling in the evenings.

In 1942, Gabrielson observed this grebe at Cold Bay, and on October 20, 1943, he obtained a specimen at Kodiak and obtained two more in September and October 1946.

There are a number of records for Unalaska. Turner mentions two specimens from there. There is a specimen in the Natioial Museum that was taken by Dall at Unalaska, December 14, 1871, and Donald H. Stevenson informed me that this grebe occurred on the salt water at Unalaska, chiefly in the fall. Laing (1925) also reports it at Unalaska and at Atka.

More recently, Cahn (1947) reported this grebe as not uncommon at Atka in November, December, and January.

There are a few records of the red-necked grebe west of Unalaska, though we have no positive data on nesting. Taber (1946) observed a flock of about 50 at Adak Island on November 25 and observed another large group December 16-this group disappeared by December 25. These sightings were on the salt water of Bering Sea. On June 18, 1936, we observed a pair as they arose from the salt water near the northeast shore of Seguam Island. We have no record of its occurrence west of Adak, but Stejneger (1885) described it as a rare straggler in the Commander Islands, where he obtained a specimen. Hartert also (1920) consiclered it a straggler in the Commander Islands, where he obtained three specimens.

\section{Podiceps auritus: Horned Grebe}

This little grebe is found sparingly in the Aleutian district, and there is no evidence that it nests there. Friedmann (1935) found osseous remains in a collection of bones from Kodiak Island and lists nine specimens taken there, most of which were taken in the winter months. On October 1, 1940, Cahalane (1943) recorded several grebes in Viekoda and Terror Bays, Kodiak Island. Referring to the Katmai region of the Alaska Peninsula, he reports one horned grebe on Brooks Lake, September 9, 1940; he found them scarce west of the Aleutian Range. On the east side, however, he found them abundant and observed "great numbers" in early October along the Shelikof Strait coast of Katmai National IIonument, as well as in most of the inlets from Katmai to Kinak Bay. Osgood (1904) recorded several small grebes, assumed to be this species, at Becharof Lake, October 
6-7, 1902, and Mckay obtained a specimen at Nushagak, June 21, 1881.

Gabrielson noted two specimens at King Cove, March 25, 1942. He obtained a specimen at Kodiak in October 1944 and obtained three more in 1946.

On our expeditions we saw no horned grebes in the Aleutian Islands, but we observed several at Port Chatham, Kenai Peninsula, on May 6, 1936, and observed two at Ushagat Island, of the Barren Islands group, 5 days later.

However, there are a few records for the Aleutian chain. Laing (1925) saw about a dozen horned grebes at Unalaska, presumably in early spring judging from his itinerary. Bailey (1925) records two specimens taken by Hendee at Unalaska, September 21, 1922. Cahn (1947) reports on this bird at Unalaska: "Secn sparingly in any of the bays during December and January, always solitary and rather shy. December 2, 1943, and February 21, 1946 are the extreme dates of record." Turner (1886) reports seeing a grebe at Attu that he suspected was auritus, but states that he did not observe it in the Aleutians in the summer, "and at no time to the westward of Unalaska Island." However, on July 1, 1946, Gabrielson noted one horned grebe on Amukta. Taber (1946) noted them in small numbers on the salt-water lagoons at Adak Island throughout the period of his observations and mentions specifically the dates November 22 and January 9.

The bird noted by Turner at Attu might well have been auritus, because Stejneger (1885) obtained a skeleton of one in the Commander Islands, though he considered it rare. Hartert (1920) also records two horned grebes wintering on the Commander Islands.

There is no evidence that the horned grebe nests in the Aleutian district, but, according to these records of its occurrence, it evidently winters in those waters.

\section{Family DIOMEDEIDAE}

\section{Diomedea nigripes: Black-footed Albatross}

Attu: A-la-gri-gich or Ah-le-gri-gich

A.tka: A-ga-líg-ahh or Ah-ga-lig-ach Agligax (Jochelson)

This is the albatross common in the North Pacific during our summer season, at least from May to October. The earliest dates that I have noted this bird were April 20-23, 1925, in the open 
sea from Ketchikan to the western part of Alaska Peninsula. The black-footed albatross cccurs commonly in the Gulf of Alaska; it was observed in the vicinity of Kodiak, and frequently along the Alaska Peninsula and the Aleutian chain, though it rarely was observed near land. This albatross also was seen in the waters of Bering Sea, just north of Alaska Peninsula and the Aleutians. We found these birds particulary plentiful at the Petrel Banks, north of Semisopochnoi Island. Laing (1925) reports them "about 100 miles north of Kyska Island." Though these birds were usually far offshore, there are two places where they came near land-Seguam and Kiska Islands.

Nelson (1887) was of the opinion that the northern limit of distribution was considerably south of the Aleutians and quotes T. H. Bean to the effect that latitude $51^{\circ}$ marked the northern limit. Turner (1886), on the other hand, stated that the species

is quite a common bird in some localities north of the Aleutian Islands. In Bristol Bay in June, 1878, I saw numbers of them in the vicinity of Cape Newenham ... Toward the western Aleutian Islands they are not common but are frequently met.

It is not certain that this albatress ranged beyond latitude $51^{\circ}$ $\mathrm{N}$. in the past, nevertheless it does so today, and, at least in the Bristol Bay region, it reaches nearly to latitude $58^{\circ} \mathrm{N}$. Further consideration of albatross distribution will be found in the discussion of the short-tailed albatross.

An interesting story was told to me by several old natives at Atka Island. They insisted that albatrosses used to nest in small numbers on Bobrof Island, on top of the mountain, in winter. Judging by the descriptive gestures of one informant, icicles formed on their beaks while the birds were incubating. This is indeed a strange legend. It seems unbelievable that any of these albatrosses could have tried to nest in the Aleutians, but at least these Aleuts were talking about the proper nesting season.

If I correctly understood the information given me by the Aleuts, they do not distinguish two species of albatrosses in the islands, possibly assuming that nigripes is the young of albatrus, in which case this story might more properly apply to albatrus.

A female D. nigripes collected June 17, 1936, near Seguam Island weighed $6^{1}+$ pounds and had a wingspread of 85 inches.

The black-footed albatross is said to feed on whatever becomes available at the surface of the water, including refuse from ships-this is true for our experience in the Aleutians. On one occasion, a dozen were following our ship; they were attracted by fish offal thrown overboard by the sailors, who 
were cleaning codfish. At times, we saw the albatrosses, accompanied by shearwaters and auklets, feeding in tide rips.

Cottam and Knappen (1939) reported on two stomachs of the black-footed albatross from the Aleutians. One stomach contained fish (mostly Scorpaenidae), 35 percent; remains of 6 or more squids, 55 percent; sea urchin, 2 percent; brown algae, 8 percent. The other stomach contained fish (mostly Scorpaenidae) 92 percent; Gammaridae, 1 percent; brown algae, 7 percent.

In 1941, Loye Miller (1942) found, in the course of experimental food studies off the coast of southern California, that "the greatest gooney appeal was provided by bacon drippings which had congealed to semisolid state." For better handling of this bait material, it was mixed with puffed rice before cooling. He remarked further that "Bacon grease seems to throw the birds almost into a frenzy. Some of them rushed right up under the overhang of the poop."

Miller summed up his findings as follows:

The most attractive bait discovered is animal fat. Bacon fat was superior to beef suet. The semisolid gelatin settling out from roast beef drippings was of no interest at all and was neglected after the first taste. Taste buds in the tip of the bill appear to be highly sensitive and discriminative. The turpentine-linseed flux of paints used in marking is very repugnant and seemed to be recognizable by odor before actual contact was made. I was repeatedly impressed by their seeming acuity of olfactory perception.

He noted, further, that in subsurface feeding the albatross would tip up, or actually submerge to a depth of at least 2 feet with wings partially spread. This suggests a trait similar to that of the slender-billed shearwater, though the latter is capable of descending to a depth of many fathoms.

\section{Diomedea albatrus: Short-tailed Albatross}

Kodiak: Kay-mah-rye-erk (Nelson)

As mentioned above, the Aleuts apparently do not have separate names for the two species of albatross. At least one Aleut identified albatrus as the adult bird, nigripes the young. Thus, the Aleut nomenclature is confusing, and the names already given for the black-footed albatross might apply equally well to the short-tailed albatross.

We are concerned here with what appears to be an extinct bird. We had thought that a few remained in the Aleutiar district, but when the one specimen we collected in 1937 proved to be immutabilis, serious doubt was thrown on the possibility that any of the light-colored birds were albatrus. 
Bering Sea appeared to be the particular domain of the shorttailed albatross in summer. Nelson (1887) defined its summer range from $50^{\circ} \mathrm{N}$. latitude northward through Bering Sea as far as Bering Strait. He reported them in the Aleutians and quotes T. H. Bean as having found them around the Gulf of Alaska, but he considered the mouth of Cook Inlet and the vicinity of the Barren Islands as their favorite resort. Nelson "found them very common between the islands east of Unalaska" during May 1877. Turner also found them plentiful among the Aleutians, as well as at Cape Newenham in the Bristol Bay region. Friedmann, who has examined bones unearthed from ancient village sites on Kodiak, Amaknak, Unalaska, Little Kiska, Atka, and Attu Islands, found numerous remains of this albatross, but he found no remains of nigripes. They are reported to have been abundant in the ricinity of the Pribilofs when whalers were active there, and they became scarce when whaling was abandoned.

Austin H. Clark (1910), writing of his expedition in 1906, reported that-

We first saw this species about 100 miles east of Unalaska on the day before our arrival at Dutch Harbor. On the next day, two were seen near the Aleutian chain, one of them within five miles of the islands. Two more were seen between Attu and Copper Island, on June 12; on the 20th one was observed about 20 miles off the Kamchatka coast, and the next day another in the Okhotsk Sea, near the mouth of the Aangan River. On October 1 this species was very common about the southern end of the Kurils, on both the inside and outside of the chain.

Clark believed that the birds were more abundant than these notes indicate, because they are very shy and not readily observed.

Stejneger (1885) reported that the species is not a rare visitor to the Commander Islands, and he, too, considered them "remarkably shyer than D. nigripes."

Nelson (1887) also considered them shy, though "natives of Alexandrovak sometimes spear them from their kayaks."

According to Otto Geist (in Murie 1936), in earlier days, near St. Lawrence Island, these birds " . . . were often caught on the pack ice near the island. This was often easy because the birds were very fat and could hardly make their way in the air."

Today, the short-tailed albatross is rare, or extinct. Although Nelson had reported it as common in Bering Strait and noted it at St. Lawrence Island, in 1887, Otto Geist, in the course of archeological work on St. Lawrence Island from 1926 to 1935, did not see this bird. However, bones were found in excavations, 
and natives stated that it had been present in considerable numbers at one time (Murie 1936). Bent (1922) reports that he did not observe this bird during a cruise along the Aleutian chain in June 1911. Laing (1925) observed two whitish albatrosses at a distance in the Kuriles in 1924, but he saw no others during two crossings of the North Pacific. In the course of many voyages across the Gulf of Alaska after 1920, I never saw a shorttailed albatross. In 1936 and 1937, we cruised about the Barren Islands several times and saw none, although this had been considered to be a favorite area for them by T. H. Bean.

It appears, then, that at one time the short-tailed albatross was plentiful in the Aleutian district and Bering Sea region in general, but that the population had suffered a drastic reduction in numbers, probably about 1900 or a little later.

Austin (1949) has indicated that Japanese fishermen and plume hunters were responsible for the destruction of this species on its nesting grounds. But it seems that the decline began long ago. Did the plume trade affect this species, as it affected the Laysan albatross? Whatever the facts might be, the concentrated nesting of a species on one or on a few small islands constitutes a serious hazard to its perpetuation.

There is a puzzling problem in distribution revealed by Friedmann's work on bones found in ancient village sites. All bones found on the Aleutian Islands proved to be those of $D$. albatrus, and not those of $D$. nigripes. This indicates that in earlier times $D$. albatrus was the common bird of the region and that $D$. nigripes was scarce or absent, at least close to the coast. Even at Kodiak Island, though there were some bones of $D$. nigripes, Friedmann found numerous bones of $D$. albatrus, thus confirming early reports of this bird's abundance in those more easterly waters.

Friedmann's findings from midden material, therefore, lend some support to Bean's designation of $51^{\circ} \mathrm{N}$. latitude as the northern limit of range of $D$. nigripes, even though Turner states that he saw this bird as far north as Bristol Bay. Otherwise, at least a few bones of this bird would have appeared in middens.

In his study of the distribution of these two forms off the California coast, Loye Miller (1940) did not find nigripes in channel waters near the coast, but found them farther out; however, there is evidence that albatrus did occupy the channel waters chiefly. He quotes Willett to that effect, and remarks: "The two birds seem to have divided the territory between them, as it were." He states, "I have taken from the channel Indian 
mounds great number of their [D. albatrus] bones, but never any of $D$. nigripes."

Here, we have a parallel with the situation in the Aleutians. In both areas (California and the Aleutian district), only the short-tailed albatross occurs in middens, except for some orerlapping of the two species at Kodiak. Is it possible that in early times $D$. albatrus was the species that came closer to land and was therefore more available? Apparently, in the north, too, these two species had "divicled the territory between them."

We need to know more about the whitish birds being seen today in the Aleutian district. Are some of these birds the remnants of the vanishing short-tailed albatross, or are they all Laysan albatrosses? If they are the latter, will that species eventually take over the range of albatrus?

Turner, in writing of the short-tailed albatross, mentions two birds that were killed at Attu in the latter part of March, 1881. He claimed that "this species passes the winter in this locality and may be found, during very severe weather, about the western end of Attu." And he believed that it nested somewhere in that region, which also was the belief of the Attu chief at the time of our visit there.

Nelson mentions a specimen, obtained by Dr. Bean, that had a wing spread of 88 inches.

\section{Diomedea immutabilis: Laysan Albatross}

We had not suspected that this bird occupied the Aleutian district until a specimen, collected near Ulak island, July 31, 1937, eventually proved to be of this species. On the field trip, we had assumed this specimen to be D. albatrus, and on the basis of that assumption we had recorded our observations on white albatrosses as albatrus. However, because Oliver Austin has pointed uut the extreme scarcity of specimens or certain records of the shorttailed albatross in recent years, and suggests its probable extinction, there must remain doubt about the records on our expedition. This, of course, throws much doubt on the possible existence of albatrus in the Aleutians today, but I shali record our observations for what they are worth, keeping in mind that the species observed was in doubt in each instance.

In these seasons of field work, we occasionally saw whitecolored albatrosses throughout the Aleutian islands. In 1936, we saw one between Seguam and Chagulak Islands on June 21. On July 31, we saw another sitting on the water between Buldir and 
Kiska Islands, and, later in the evening, we saw one nearer to Kiska Island.

In 1937, we saw them oftener: On May 31, 1 north of Seguam; on June 2, at least 3 west of Atka; on June 3, sereral near the Petrel Banks and 2 between IFiska and Segula; on June 17, 1 east of Semichi Islands; on June 18, 1 east of Buldir; and, on July 31, 1 specimen was taken at Clak Island, $178^{\circ} \mathrm{W}$. longitude.

In 1938, Scheffer reported the following: On August 11, 4 were seen south of Atka, 3 of these in 1 group; August 14, 1 was seen south of Khwostof; August 17, 1 was seen northwest of Semichi; August 25, 1 was seen south of Tanaga; and, on September 23, 1 was seen in the Gulf of Alaska off Cape Hinchinbrook.

On June 9, 1940, Gabrielson observed a white albatross following the ship in the Gulf of Alaska. In 1941, he saw the following: February 3, 1 was sighted near Amchitha, and on February 7, 2 were seen near Amchitha Pass; June 24, 1 was seen at Tanaga Bay; June 27, 1 was seen near Amchitka; and on July 22, 2 were seen near Attu.

Were all these birds the Laysan albatross, the same as the one specimen collected, or were some, or most, of them albatrus?

The specimen collected weighed 4 pounds 6 ounces. Its length was 301/2 inches, and wingspread was $77 \%$, inches.

During 1947, 1948, and 1949, on crusies for the Fish and Wildlife Serice in North Pacific waters, Karl W. Kenyon (1950) made noteworthy observations on albatross distribution. Alert to the confusion in sight identifications of light-colored birds, he gave close attention to field characteristics.

On October 13, 1948, Kenyon saw a Laysan albatross about 230 miles east of Kodiak, and Captain Carlson said that during 5 round trips to the Pribilofs he often saw 1 or 2 of the white albatrosses with the black wings and back at about this same place while crossing the Gulf between Kodiak and Cape Spencer but not in the Bering Sea.

Kenyon records a number of other sightings in the North Pacific, but south of the Aleutian chain. He received parts salvaged by Elmer C. Hanson from two dead birds at the Army air base at Amchitka, June 5, 1948, which were sufficient for identification as Laysan albatrosses. 


\section{Family PROCELLARIIDAE}

Puffinus tenuirostris: Slender-billed Shearwater

Attu: Á-la-mach

Russian, Commander Islands: "Tschornij Glupisch" (Stejneger

In summer, the slender-billed shearwater is distributed widely over the North Pacific and throughout the Bering Sea. On the Gulf of Alaska, we observed them often, singly or in small groups. Some of the birds that we thought to be slender-billed shearwaters may have been the sooty shearwater, $P$. griseus.

At Kodiak Island, howerer, $P$. tenuirostris has been identified, and we obtained a specimen there in 1936. Shearraters, believed to be this form, were noted May 10, 1936, near the entrance to Cook Inlet; one was noted near Barren Islands on May 11; they were numerous between Sutwik Island and Cape Kumlik on May 14 , and there was a flock at the entrance to Chignik Bay. On May 15, a few were seen near Nagai Island, in the Shumagins; on August 29, some were noted near Simeonof Island in this group, and some were noted between that point and the mainland; next day, between Kupreanof Harbor and Chignik, more were sighted. Again, on September 1, we passed through dense masses of shearwaters north of Karluk, in Shelikof Strait. These birds occur also on the north side of Alaska Peninsula and were seen as far east as the entrance to Bristol Bay.

Slender-billed shearwaters occur all through the Aleutian Islands, with their center of abundance apparently at the eastern end of the chain, among the Fox Islands. Lnimak Pass is a farorite feeding place, with large concentrations also observed in other places as far as the western end of Cmnak Island.

Many published accounts describe the hordes of shearwaters observed at various times. Arnold (1918), during an hour and a half, June 9, 1914, recorded 160,000 shearwaters in Unimak Pass. Probably the most outstanding was the flock noted by Scheffer in Umnak Pass on September 3, 1938. He sars, in his field report:

In the Pass we saw the greatest concentration of shearwaters that we have ever seen in the Aleutians. Captain Sellevold remarked that it was the greatest in his experience. The Pass is 3 miles wide. We estimated that the raft of birds extended for 25 miles by 2 miles wide, or an area of 50 square miles. From 5:30 a. m. to 8:00 a. m. the ship passed through ciense masses of the birds, about half of them on the water and half flying back and forth... At $5 \mathrm{p}$. m. the birds had thinned out by more than half.

Apparently this bird is much less abundant to the westward, though in 1941 Gabrielson saw "thousands" at Attu and "sereral 
thousands" at Atka. Stejneger (1885) considered it rather scarce in the Commander Islands. It appears to be relatively scarce in Bering Sea north of the Aleutian chain, though it does range far northward. In 1944, Gabrielson saw "thousands" between St. Natthew and Nunivak Islands and a "scattering of birds" between St. Matthew and Adak. Nelson (1887) mentions a specimen obtained by Dall in Kotzebue Sound in 1899 and adds, "just northwest of the straits, the last of August, 1881, quite a number of dark-plumaged birds were seen, with many Rodgers's fulmars, which appeared to differ in size and appearance from the latter, and which I am inclined to think belonged to this species." Nelson records the Eskimo name for the slender-billed shearwater in Kotzebue Sound, thus showing that it must habitually occur there. A number of specimens have been taken at St. Lawrence Island in recent years (Murie 1936). The Eskimos of this island have certain taboos in connection with eating the bird. A specimen is recorded from the Pribilofs.

According to Bent (1922), the northward migration is mainly in the western Pacific; and the southward migration is in the eastern Pacific. He says they occur in the Okhotsk Sea, as well as in Bering Sea.

Slender-billed shearwaters will feed on refuse from a ship's galley. On August 10, 1937, three of these birds came up to the stern of our ship as we drifted in the fog. They readily ate bits of beef and fish thrown overboard. They would dive for pieces that sank, keeping wings half opened, but propelling themselves entirely by their feet under water. Apparently they can go to a considerable depth; they would sometimes pursue a baited fishhook thrown in for cod and remain underneath for a considerable length of time.

On two occasions we watched a shearwater pursue an injured codfish that had been discarded by the sailors as being wormy; as the fish wiggled feebly through the water, the bird pursued it and snipped out pieces of the gills from the still-living fish.

But probably the most important food of the shearwater consists of crustaceans and other small invertebrates. On numerous occasions they joined with fulmars and auklets in the turbulent tide rips, where all were busy feeding. Sample tows taken in such places revealed a greater quantity of plankton than in adjacent areas unoccupied by birds. In this connection, it may be significant that the center of abundance of shearwaters in the Aleutians today coincides fairly well with localities where whales were once particularly abundant-in the Fox Island group. Per- 
haps both birds and whales were attracted by the swarming invertebrate life.

Cottam and Knappen (1939) reported on 10 stomachs of this species that were collected in Alaska. They tabulated the total contents as follows:

Amphipods, 13\%; schizopods, $15 \%$; undetermined crustaceans, $20.8 \%$; squid (Loligo sp.) $16.1 \%$; undetermined marine invertebrate flesh, possibly squid, $29.4 \%$; and fish, $5.7 \%$. Gravel was found in each stomach and averaged only slightly less than $40 \%$ of the contents.

In their summer range, the only foe of the shearwater that we could discover is the northern bald eagle. The shearwater furnishes one of the principal items of the eagle's diet, probably because of its great numbers. These birds also perish in storms, perhaps the storm mortality rate is higher than that caused by natural enemies. Early in September 1937 a heary rainstorm was raging for several days about Unimak Island. While the storm was still at its height, we began to find dead shearwaters on a strip of beach. They finally totaled over 30 ; one bird was still alive. The birds from this one sample beach may have been representative of the destruction of birds over a large area. In 1925, I frequently found dead shearwaters on the beaches of Alaska Peninsula.

On May 31, 1936, as we approached Cave Point on Unimak Island, a lone shearwater was sitting on the water. C. S. Williams shot it for a specimen, and it was found to be poor in flesh. On June 30, 1937, Scheffer shot one that was in a similar condition near Rat Island. As it sat on the water, we noticed that it appeared to be "dumpy." Grimell (1900) says, "On July 4th, 1899, I secured a single speciment about 4 miles off Cape Blossom. It was resting on the water not far from a small icefloe and was in an emaciated condition."

Certainly, there is a mortality element of some sort operating on the shearwater, as on other sea birds.

Occasionally, shearwaters come close to land. At least 1 was seen in Nelson Lagoon, and in 1925 they were noticed at the entrances to Izembek Bay, on the Alaska Peninsula, and at least 1 flew over the shallow bay. Some of the large flocks noted in the turbulent waters of rarious island passes are not far from the rocky points.

Chief Hodikoff, of Attu Island, declared that shearwaters formerly nested abundantly on Agattu Island and that a few were seen on Semichi Island in 1932. He said there were "not many" now since the introduction of blue foxes. He stated that 
they nested "on level ground, some in clumps of grass" and that as soon as the young were able to fly they left their nesting grounds.

It is interesting to note that, about 1879, Turner was on Amchitka Island with some Attu natives, when they picked up a dead shearwater. The natives told him that the birds "breed plentifully in the Semichi Islands." Though the breeding range of shearwaters is now well established, perhaps we should not entirely ignore native information of this kind.

\section{Puffinus griseus: Sooty Shearwater}

According to the fourth edition of the Check List of North American Birds, of the American Ornithologists' Union, the sooty shearwater occurs in the Aleutian and Kurile Islands. On all of our expeditions, we scrutinized flocks of shear'waters in an attempt to identify this species among the predominent slenderbilled shearwaters. Although we thought that we could see differences in some instances, positive identification was doubtful. But, in the series of specimens of shearwaters collected in the Aleutian district, a single specimen proved to be $P$. griseus.

Nichols (1927), speaking of his voyage between Seattle and the Aleutian Islancls, says:

Of the sooty shearwater I have no satisfactory identification, but am of the impression that it replaced the generally common slender bill farthest off shore at a point midway between the islands and the coast, and to some extent at least on the east side of the Gulf of Alaska.

\section{Pterodroma inexpectata: Scaled Petrel}

\section{Attu: Le-vi-dré-che}

This petrel has a wide range, but we have little information on it in the southern Alaskan waters. There is a record for Kodiak Island, a specimen collected by Fisher, June 11, 1882, that served as the type of Ridgway's Aestrelata fisheri. Wetmore collected a specimen at the Alaska Peninsula, August 6, 1911, and while crossing from Cape Muzon to Unimak Pass he observed a number of birds that appeared to be of this form. On the same expedition, A. C. Bent also observed the bird in the North Pacific, while sailing to the Aleutian Islands, and Rollo $\mathrm{H}$. Beck, who was a member of the expedition, took a specimen at Kiska Island on June 17.

Nichols (1927), speaking of seeing this petrel on his trip from Seattle to Nome, Alaska, says :

Seen in the Pacific on 1 day only, August 5, when midway between the islands and the west coast, noon position $53^{\circ} 36^{\prime} \mathrm{N} ., 145^{\circ} 37^{\prime} \mathrm{W}$. They were 
frequent all day, singly and in small groups, a conservative estimate for the total number, 30 .

We did not see this bird on our expeditions, but at Attu Island the native chief insisted that there was a third petrel, calling it le-vi-dré-che. He said that it is gray in color-if we understood him correctly-but that it is distinct from the forked-tailed and the Leach's petrels, with which he was also familiar and for which he had names.

The chief provided some native guides, and we visited two small islets, Cooper and Gibson Islands, which are adjacent to Attu. We searched diligently and hopefully, but we found only the other two species. Inasmuch as it is known to breed in New Zealand, and because the egg dates are "December 24 to January 7" according to Bent, one would not expect to find it nesting in the Aleutians. But in view of the Attu chief's confidence in the matter, there was a possibility that the bird may enter burrows to roost.

\section{Pterodroma cookii: Cook's Petrel Pterodroma cookii orientalis}

A. W. Anthony (1934, p. 77) recorded a specimen of this petrel, postively identified, which was taken at Adak Island by members of the crew of the U.S.S. Kingfisher. It was 1 of 2 such birds that came aboard the ship, and the specimen saved had been sent to the San Diego Zoo in California, where it was placed in the collection of Louis B. Bishop.

\section{Fulmarus glacialis: Fulmar}

Fulmarus glacialis rodgersii

Attu: Kil-u-ghoó-kin

Atka: Ah-ga-luch

Probably Russian Commander Islands: Glupisch (Stejneger)

The Atka name for fulmar should not be confused with their name for killer whale, which was recorded as $A^{\prime}$-ga-loh, with shorter syllables.

Fulmars are common in the North Pacific and Bering Sea region, though in varying numbers. They are seen on the Gulf of Alaska, in small groups, in company with the black-footed albatross and shearwaters. We found them in Shelikof Strait, between Kodiak-Afognak Islands and the mainland, and farther west near the Shumagins. A few were seen north of the Alaska Peninsula, east to Bristol Bay, and north to Nunivak and Nelson Islands. They were more abundant among the eastern Aleutians, 
and they are fairly prevalent throughout the chain, some having been noted at Wrangell Cape on the west side of Attu Island.

Arnold (1948) recorded a concentration of about 38,000 fulmars in Unimak Pass on June 9, 1944. Throughout the Aleutian district, the dark color phase predominates, though some concentrations of the light phase were encountered. On May 21, 1936, Cecil Williams estimated that 50 percent of the fulmars seen in Unimak Pass were light colored, and that most of those sighted on the north side of Unimak Island were whitish, though there were entire bands of dark ones.

It is interesting to recall that Nichols (1927) found "the dark phase to light phase about as 99 to 1" in Shelikof Strait; elsewhere in the Pacific, it was about 9 to 1 ; near Unimak Pass, the pale and dark birds "were in about equal numbers;" and in Bering Sea, they were almost all pale.

\section{Nesting}

Nesting fulmar colonies have been known in the Bering Sea region, on the Pribilofs, where light-colored birds are in the majority; on the Siberian coast opposite St. Lawrence Island; and at Copper Island, where light-colored birds are rare. Nesting places in the Aleutians had been suspected, but they had not been found. It was gratifying, therefore, to find several such colonies in 1936 and 1937, and in 1940 Gabrielson found other colonies east of the Aleutian chain.

In 1940 Dr. Gabrielson learned that Sea Otter Island, near Afognak, supports a colony of fulmars. This nesting colony would account for the fulmar flocks so often observed in Shelikof Strait. In the same year, on June 18, he found nesting colonies in the Semidi Islands, and says, "The enormous concentrations of Fulmars, for example, was a great surprise to us, as the colony apparently has developed since the previous exploration." In the Semidi group, he found the fulmars in "huge colonies" on Aghik and Choweit Islands, and there were fulmars also on Kateekuk, Anowik, Kiliktagik, and Suklik Islands. They were mostly of the dark color phase, with an occasional light-colored one.

In the Aleutians proper, we had found at least four nesting places. Among these, Chagulak Island is outstanding. As we approached this island on June 15, 1936, it loomed as a peaked mountain top rising sheer from the water. It affords nesting sites for a variety of sea birds, and a swarm of fulmars swirled above its top and milled about its slopes. On the cliffs of the south side there were small recesses in the red crumbly rock 
strata. Each of these recesses was occupied by a fulmar, nesting with a single egg. They nested also on other types of ledges and on the grassy slopes all the way to the snow line.

On the same day, we found another large fulmar colony on the neighboring island of Amukta. These two islands have the largest and the principal nesting colonies of fulmars in the Aleutian chain.

In 1937, we found fulmar's nesting in considerable number's on the reddish cliffs of Segula Island (also known as Chugul), though this group was not nearly so large as those on Amukta and Chagulak.

Another nesting place is Gareloi Island. Natives had assured us that fulmars nest there, though we did not find the birds on the first trip. In 1937, however, we found them in limited numbers on the south side of the island. According to the natives, their numbers had been decimated, at least on all accessible ledges, since the introduction of the blue foxes. The volcanic eruption of 1930 also disturbed them; however, if the foxes were removed, this colony should increase.

Natives told us that the fulmars nest on outlying rocks at Unalga Island, southwest of Gareloi, but we found none there in August. They are also reported to nest on Agattu, but we failed to find them.

It is highly probable that a nesting colony will eventually be discovered in the general vicinity of Unimak Pass, perhaps on some isolated chiff or islet at Unimak Island, because fulmar's are common in that area. A full schectule and bad weather prevented us from exploring that part of the Aleutian chain as thoroughly as we wished.

\section{Food Habits}

We had assumed that fulmars feed to a large extent on plankton, for we often found them congregated in tide rips, busily feeding. And Arnold (1948), observing a huge concentration of fulmars and shearwaters in Unimak Pass, found that they-

evidently were feeding on a type of reddish-orange water life. On occason, when one of the birds was hard-pressed to leave the area in the immediate vicinity of the ship, it would turn its head down and to one side and regurgitate a reddish-orange liquid substance.

However, records show a great variety in fulmar diet, including refuse from ships.

A. W. Anthony (1895) has pointed out an interesting feeding habit of the fulmar off the California coast. Speaking of a large jellyfish that is abundant along that coast, he says, 
I have often seen a fulmar sitting on the water by the side of a jelly fish, part of which it had eaten, so filled that it could scarcely move out of the way of the boat. Specimens shot while these Medusae are common I have always found with the stomach filled with these alone, and a half pint of the slimy mass will often run from their mouths when lifted from the water by their feet.

I think the fulmars enjoy a monopoly of this diet, for I have never seen other species eating it, nor will gulls, nor any sea birds that I have observed, pay any attention to a fulmar that is eating a jelly fish though they all claim their share if the fool is of a kind that they care for.

The abundance of the fulmars off this coast would seem to have some relation to the abundance of Medusae, since the winter of 1893-94 was noted for the almost if not entire absence of fulmars as well as jelly fish until some time in late February or March, when both jelly fish and fulmars appeared in small numbers.

This is quoted at some length because it reveals an important habit of the fulmar, which also was noted among the Aleutians, where a large brown jellyfish, Cyanea capillata, often proved an attraction to fulmars.

\section{Mortality Factors}

Aside from the danger from foxes on accessible nesting sites, the only other natural enemy on which we have information is the northern bald eagle. The fulmar appears to furnish an important item in the eagle's diet throughout the Aleutian Islands as a whole, though murres and other species may dominate the diet of individual eagle pairs. The drain on the fulmar population by eagles could not be significant, in view of the great variety of birds on which the eagle preys. More important are man's activities, such as the raising of blue foxes. Dead fulmars are found on beaches, but, at present, it is hard to estimate the results of storms or disease. At any rate, we have several large flourishing colonies of fulmars, and those that have been depleted should increase again owing to the protection now being given.

\section{Family HYDROBATIDAE}

\section{Oceanodroma furcata: Fork-tailed Petrel \\ Oceanodroma furcata furcata}

Attu: A-la-ma-gó Ké-kech

Atka:Ki-ki-tich-noch

Russian, Commander Islands: Sturmofka (Stejneger) The Atka name is applied to both this petrel and to Leach's petrel.

In 1939, Grinnell and Test separated the forked-tailed petrel into two races, designating the southern form O.f. plumbea, whose range is said to extend northward to "the Alexander 
Archipelago, just short of Cross Sound." Sitka birds proved to be intermediate, but closer to plumbea.

In looking over material from the Aleutian district, it is obvious that there is variation in the characters used by Grinnell and Test-size and color (light or dark)-and many Aleutian specimens are puzzling in this respect. A specimen from Kodiak is similar to the Aleutian group. One from Ugashik, on the north side of Alaska Peninsula, obviously is furcata. This also is true for two from Nushagak. But a series from Belkofski, on the Alaska Peninsula, are darker than other Aleutian specimensfully as dark as a series from Forrester Island, Stephen's Passage, Sitka, and Icy Strait_-though the Belkofski petrels are larger. Since we are dealing with average characters, it is clear that the birds from the Aleutian district, from Kodiak and Nushagak west to Attu Island, should be called O.f. furcata.

It is of interest to note that birds from the Commander Islands and Kar.chatka are paler and (on the average) larger than those from the Aleutian Islands. A few from the Aleutians are equally large and pale, and one from as far east as Nushagak is identical with many of the Kamchatka birds. These birds bear out Grinnell and Test's statement of an increase in size and a color transition from dark to pale, in the populations from south to north and west. Probably, we should consider the Siberian birds as the culmination of this trend toward larger size and paler coloration, and, for the present at least, we should class them with furcata of the Aleutian district.

The forked-tailed petrel ranges widely over the North Pacific and Bering Sea and is the dominant species among petrels there. From May 29 to June 4, 1911, Wetmore found these birds common on the Gulf of Alaska. Friedmann (1935) records several specimens and eggs from Kodiak. Specimens have been taken at Nushagak by Hanna and Johnson and have been taken at Ugashik by McKay. We observed them in the Shumagin Islands and found them to be abundant throughout the Aleutian chain. Stejneger (1887) found them nesting in the Commander Islands.

Nesting of this species in Bering Sea proper has not been reported, though the bird occurs far northward. Nelson (1887) found the birds off Nunivak Island in June 1877, but he speaks of them chiefly as autumnal visitors, as far north as St. Lawrence Island, Bering Strait, and Plover Bay, Siberia. Two specimens were secured from Kotzebue Sound. According to Nelson, they lingered in Bering Sea even after the formation of ice, and the Eskimos told him that they were captured on the ice, near air 
holes, in a weakened condition. He says that they were found on the lower Yukon, and that one was found about 75 miles up the Tanana River, near an air hole in the ice, late in November. These petrels are also recorded from the Pribilofs (Preble and McAtee 1923). Cahn (1947) reports from Unalaska: "Seen abundantly in the fall and winter far out in Bering Sea."

The Aleutians must be considered to be the stronghold of this petrel. We found them on most of the islands. Experience taught us that wherever we found petrel wings left by blue foxes, or petrel remains in fox droppings, it was safe to assume that the birds nested on the island.

The following islands were specifically noted as being nesting places for these petrels: Sanak group, Egg Island (in Akutan Pass), Uliaga, Kagamil, Chuginadak, Herbert, Yunaska, Chagulak, Amukta, Amlia (reported by natives), Atka (on Korovin Volcano, reported by L. M. Turner), Salt (until destroyed by fox raising), Kasatochi, Igitkin, Ulak, Bobrof, Tanaga, Ilak (reported by natives, but now destroyed by blue foxes), Gareloi, Semisopochnoi, Little Sitkin, Chugul (reported by natives), Kiska, Buldir, Agattu, and Attu. It is almost certain that the birds nest also on most of the other islands-on the Shumagins, and probably on other islands off the Alaska Peninsula. This list serves to show the uniform distribution of these birds.

It is well known that the forked-tailed petrel nests underground. It may make its own burrow, often as a side tunnel from the wall of the tufted puffin's burrow, or it may nest in natural cavities, such as those found in lava beds. Amukta Island furnishes a typical example, where the moss-covered lava formation had neat round holes through the vegetative crust leading in to irregular cavities beneath.

\section{Food Habits}

The forked-tailed petrel is said to skim the oil from the surface of the water near a wounded seal or whale, but we do not have extensive data on its food habits. Preble and McAtee (1923) record one stomach from the Pribilofs that contained a few fish bones. Scheffer made interesting observations at Kagamil Island on August 30, 1938, when about 25 forked-tailed petrels and 3 Leach's petrels were picked up on the deck of the ship. Six piles of regurgitated material on the deck contained broken remains of small fish-the largest was about the size of a man's little finger

\section{Mortality Factors}

The principal enemy of the petrel, so far as our observations 
go, is the introduced blue fox. Petrels appeared to be especially palatable to these carnirores, or perhaps they are easy prey at their burrows. On Salt Island the species had been entirely eliminated by foxes, and this appeared to be true of llak, also.

Petrels are attracted by ship's lights at night. They flock around the ship, chirping and chattering incessantly, striking the rigging and fluttering about the deck. Often, they get into staterooms, the galley, or other portions of the ship, and sometimes in the excitement an egg or two may be clropped on the deck. Joseph Mailliard (1898), writing of the petrels on St. Lazaria Island, Sitka Bay, quotes Grinnell as saying that it was impossible to keep a fire alight in the middle of the night because the petrels flew into it in such numbers that they extinguished it.

\section{Oceanodroma leucorhoa: Leach's Petrel Oceanodroma leucorhoa leucorhoa}

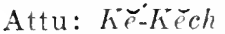

Atka: Ki-ki-tich-noch

Russian, Commander Islands: Malinka tishornaja sturmofka (Stejneger)

The Russian name given by Stejneger means a small black petrel. Leach's petrel has a more southern distribution than $O$. furcata and does not range far into Bering Sea. Though it nests throughout the Aleutian chain and on Copper Island, according to Stejneger, it is much less abundant than the other species. Farther south, it becomes much more abundant. Bent (1922) states that on St. Lazaria Island, at Sitka Bay of Baranof Island, Grimnell and Mailliard estimated that O. Iencorhoa outnumbered $O$. furcata four to one. They also are extremely numerous on Forrester Island.

On the Aleutians we found this ratio reversed. Among the remains of petrels left by foxes, those of $O$. leucorhon were scarce. The petrel colonies of any size were $O$. furcuta. When flocks of petrels fluttered about the ship's lights at night they were usually furcata, though sometimes there were a few leucorhoa. It is interesting to note that in 1941 Gabrielson found Leach's petrel outnumbering furcate at Kasatochi Island. There may have been a nesting colony nearby.

Thus, we find that these two species more or less intermingle in their ranges. But $O$. furcata has a more northerly center of abundance, and ranges farther north, while O. leucorhoa is more concentrated somewhat farther south, and does not reach far into Bering Sea. 
The natives declared that these petrels (probably referring to both species) nest "everywhere," but the following islands are the only ones for which we have precise evidence of nesting of Leach's petrel: Sanak Island group, Egg Island (McGregor, 1906), Amchitka (reported by Dall), Davidof, Kiska, Buldir, Agattu, and Attu. Dr. Gabrielson noted evidence of their presence on Amatuli Island, of the Barren Islands group, June 13, 1940. They were especially numerous on Buldir Island, where we found the greatest number of nesting burrows. No doubt they occur on a great many other islands, as the natives intimated, but probably in such small numbers that they are not easily detected.

On Buldir Island, where we had the best opportunity for examination, their burrows were found in the sandy banks above the beach and along a stream, as well as on high grassy slopes, well up on the higher part of the mountain. The burrows extended about arm's length, often with a very small entrance so that it was difficult to insert the hand, but generally there was an enlarged chamber at the end. In sandy soil, the burrows were larger in diameter; in sod, they were much smaller and the entrance was more obscure. There was a flat nest of dried grass in the end chamber. Usually, there was a single bird in the nest, but in at least 1 burrow there were 2 birds.

\section{Food Habits}

Leach's petrels have been observed following whales for food fragments, and they have been seen picking fish refuse in the vicinity of fishing boats. We obtained no additional clata on their food habits.

Mortality Factors

Foxes prey on these birds where nesting colonies are available.

\section{Family PHALACROCORACIDAE}

\section{Phalacrocorax auritus: Double-crested Cormorant} Phalacrocorax auritus cincinatus

Attu: Küch-tirch

Unalaska: T"chunǵ-ahh

Of the three species of cormorants nesting throughout the Alaska Peninsula and Aleutian Islands, the double-crested is much less common than the pelagic or the red-faced. It nests on Kodiak Island. Cahalane (1943) reported it to be abundant in the Kodiak-Afognak group, and Gabrielson noted a few at Whale Island and four in Uyak Bay. Probably it nests in the Barren Islands also. Several were seen at Ushagat Island of this group, 
on May 11, 1936. On May 7, 1936, we had seen several of these birds on Chisik Island, in Tuxedni Bay, Cook Inlet, obviously preparing to nest. C. J. Rhode noted a colony of about 50 cormorants on islands of Skilak Lake, Kenai Peninsula. Identification was uncertain, but it is probable that these were doublecrested cormorants.

Osgood (1904) recorded this cormorant nesting on islands of Iliamna Lake. He saw them flying up and down Nogheling River, and several were seen on Lake Clark (one specimen taken); however, he believed few, if any, nested on that lake. He states that from the Mulchatna River near the mouth of the Tikchick to Nushagak these cormorants were seen daily, but not in great numbers. Again, he saw several on Becharof Lake, October 4 to 7 , 1902.

Cahalane (1944) observed cormorants, "presumably all of this species" (double-crested), rather commonly in the Katmai region of the Alaska Peninsula in 1940, and he reported them in September on Naknek River, on Naknek Lake, at the south shore of Iliuk Arm, at the mouth of Savanoski River, on Brooks River, and on Brooks Lake. By September 27 and 28, they were relatively scarce on Naknek Lake and River. On the Pacific side, he reported them to be much more numerous and recorded them as "common to abundant" in the bays of the Katmai coast, October 4 to 7 .

On July 23, 1940, Gabrielson noted 1 or 2 double-crested cormorants on the Kvichak River, and on July 25, he reported 2 more on Iliamna Lake. In the same season, he also noted them at the Semidi Islands.

On August 29, 1936, we saw at least two double-crested cormorants near Simeonof Island, in the Shumagin group. They probably nest among those islands. On May 16 and 17, 1928, F. L. Jaques (1930) saw cormorants, which he thought to be this species, near the Shumagins and near Belkofski.

The largest colony of this cormorant was found by the writer in 1925, in Isanotski Strait, at the extreme tip of Alaska Peninsula. On the larger of the two Isanotski Islands, which was not over 150 yards long, there were at least 25 nests in a close group on a grassy slope. On July 27 the nests contained from 2 to 5 eggs, but usually there were 4 or 5 . A specimen was collected. It is interesting to note that Beals and Longworth, on June 10, 1941, 16 years later, stated in their field report that "Small colony of 50 or more birds nesting on the most northerly of the two Isanotski Islands." 
Donald H. Stevenson, who accompanied me in 1925, described cormorants nesting on a small island in Swanson Lagoon, on the north part of Unimak Island. His description, and the location of the nesting site, leaves little doubt that a colony of double-crested cormorants were nesting in Swanson Lagoon at that time.

Among the eastern Aleutians we found several nesting groups, though they were small in number. On July 16, 1936, we observed five of these cormorants perched on low rocks at one of the little islands (which we designated "Puffin Island") in Trident Bay, Akun Island. On June 7, we had seen about a dozen at the west end of Umnak Island; a specimen was taken here. Nesting was not actually observed in these instances. But on June 8, we found several of these cormorants nesting on Kagamil Island. Some also were found on Uliaga Island near by, and two small colonies were found on Carlisle Island. Seven nests, and a number of birds, were located on Herbert Island. The nests among the Islands of the Four Mountains were on ledges of sheer cliffs and in the walls of high caverns (sometimes very high), which was in great contrast to the nesting on the low Isanotski Islands, observed in 1925. In some cases, these cormorants were nesting in close proximity to red-faced and pelagic cormorants.

We observed no double-crested cormorants west of these islands. The natives of Atka assured us that this cormorant does not occur in that part of the Aleutians. We are fairly confident that today this species does not nest west of the Islands of the Four Mountains. Yet, the Chief of Attu appeared to be familiar with this bird; he gave us the native name and declared that formerly it was abundant, though it has become scarce in recent years. Austin H. Clark (1910), writing of his expedition of 1906, said "I have a note of a few [double-crested cormorants] being seen in Unalga Pass near Unalaska, and I found them at Atka, Attu, and Agattu." Turner (1885) also, writing of the Near Islands, reported double-crested cormorants to be abundant, resident, and breeding.

Clearly there has been a drastic change in distribution of this species since about 1906, (the time of Clark's notes). The cause of this restriction of range has not been determined.

The species $P$. auritus as a whole is quite versatile in nesting habits. Many of the prominent nesting sites in the northern part of the continental range are on low islands. Elsewhere, cormorants nest in trees and on cliffs as well as on low islands. 
Therefore, there must be adaptability in the species. The introduction of blue foxes on a large scale in the Aleutians discouraged the low-ground type of nesting; therefore, the birds nested in the cliffs in greater numbers. This change in nesting locale of the double-crested cormorant may have resulted in competition with the more agile red-faced and pelagic cormorants. It may be pointed out that in the absence of blue foxes, the double-crested cormorant would nest on low flat ground, away from cliffis-a habitat not usually desired by the other two species. What the human factor might have been in the ecological picture is hard to say, but, under conditions prevailing in recent years, cormorants could hardly succeed in nesting except on well-protected cliffs.

Whatever the factors, it is a fact that the double-crested cormorant has virtually disappeared from the Aleutians west of the group known as the Islands of the Four Mountains.

\section{Phalacrocorax pelagicus: Pelagic Cormorant Phalacrocorax pelagicus pelagicus}

Attu: Kri-li-ti-kch or Kri-li-ti-kich; Til-i-toch (1-year-old young)

Atka: Agh'-i-uh (possibly referring to any cormorant species) Agayux (Jochelson)

Russian, Commander Islands: Malinky Uril (Stejneger)

This is the most abundant cormorant in the North Pacific and Bering Sea region. We found them in the Bar'ren Islands, the Kodiak-A fognak group, Chisik Island in Cook Inlet, Sutwik Island, Chignik Bay, Shumagin Islands, and along the north side of Alaska Peninsula to Bristol Bay.

Hine (1919) said, "Colonies of this cormorant nested on the shelves of the sea wall along Katmai and Kashvik bays during the 1919 season."

Osgood (1904) found these birds on Becharof Lake. Gabrielson found them to be common in the Semidi Islands.

We found the pelagic cormorant to be numerous throughout the Aleutian Islands, and they are common in the Commander Islands (Stejneger 1885). This bird has a more northerly distribution than other species, for it occurs on both sides of Bering Sea and as far as the Arctic coast.

Ordinarily, this species was the more common in the waters about the Aleutian Islands, though among the birds actually nesting $P$. urile outnumbered $P$. pelagicus. There appeared to be a considerable number of nonbreeding $P$. pelagicus, in subadult plumages. In some cases we found no nests, though the birds were present in considerable numbers. 
Usually, the nests were placed on ledges of steep cliffs, though sometimes they were on overhanging walls of caverns well out of reach of the surging water. Only once was a different nesting site noted. In 1925, I found an unusual nesting situation near Izembek Bay at the west end of Alaska Peninsula. On Glen Island, at this bay, on May 20, there was a considerable colony of $P$. p. pelagicus in a compact group on a low point. Some of the birds had white flank patches at this time. On June 1, Stevenson reported that the birds were sitting on nests. On June 26, about 30 nests were counted, but there were no eggs. On July 27, the cormorants were still plentiful at Glen Island, but there had been no success in nesting.

The interesting fact in this instance is the unusual nesting site, which was a low sandy point above tidewater. While there had been a few birds in breeding plumage, the majority seemed to be immature birds. Amak Island, with immense cliff's occupied by large numbers of $P$. urile and only a few $P$. p. pelagicus, is about 12 to 14 miles out to sea. It was not determined whether this was an abortive attempt at nesting on Glen Island by cormorants crowded off Amak Island, or whether the birds were immature. Throughout the Aleutian chain, both $P$. urile and $P$. p . pelagicus are found nesting on the same cliffs.

While the pelagic cormorant is a salt-water bird almost exclusively, Osgood found it on Becharof Lake, as noted previously, and natives of Atka Island said these birds will go to the lakes of Amchitka Island in winter.

Cahn (1947) reports them at Unalaska as "abundant everywhere along the rocky shores from September to May," and Taber (1946) says the species was present at Adak in winter, where they continuously lived in salt water, never in fresh-water lakes. Sutton and Wilson (1946) found them at Attu in the summer and in the winter.

\section{Food Habits}

The food of this cormorant is assumed to be fish, but, according to Preble and McAtee (1923), a considerable percentage consists of various crustacea, at least in the Pribilofs. Sutton and Wilson, at Attu, obtained a specimen on February 28, and report: "Its stomach and crop were packed with small sculpins which it had caught in water about 15 feet deep along the west side of Casco Cove." 
Phalacrocorax urile: Red-faced Cormorant

Attu: Inǵ-a-tohh or Inǵ-a-torh

Atka: Inǵ-a-tohh

Russian, Commander Islands: Bolschoj Uril (Stejneger)

Walrus Island, in Bering Sea, has been consiclered the chief nesting place of the red-faced cormorant in Alaskan waters. It was a surprise, therefore, to find that the red-faced cormorant is the dominant nesting cormorant throughout the Aleutian chain.

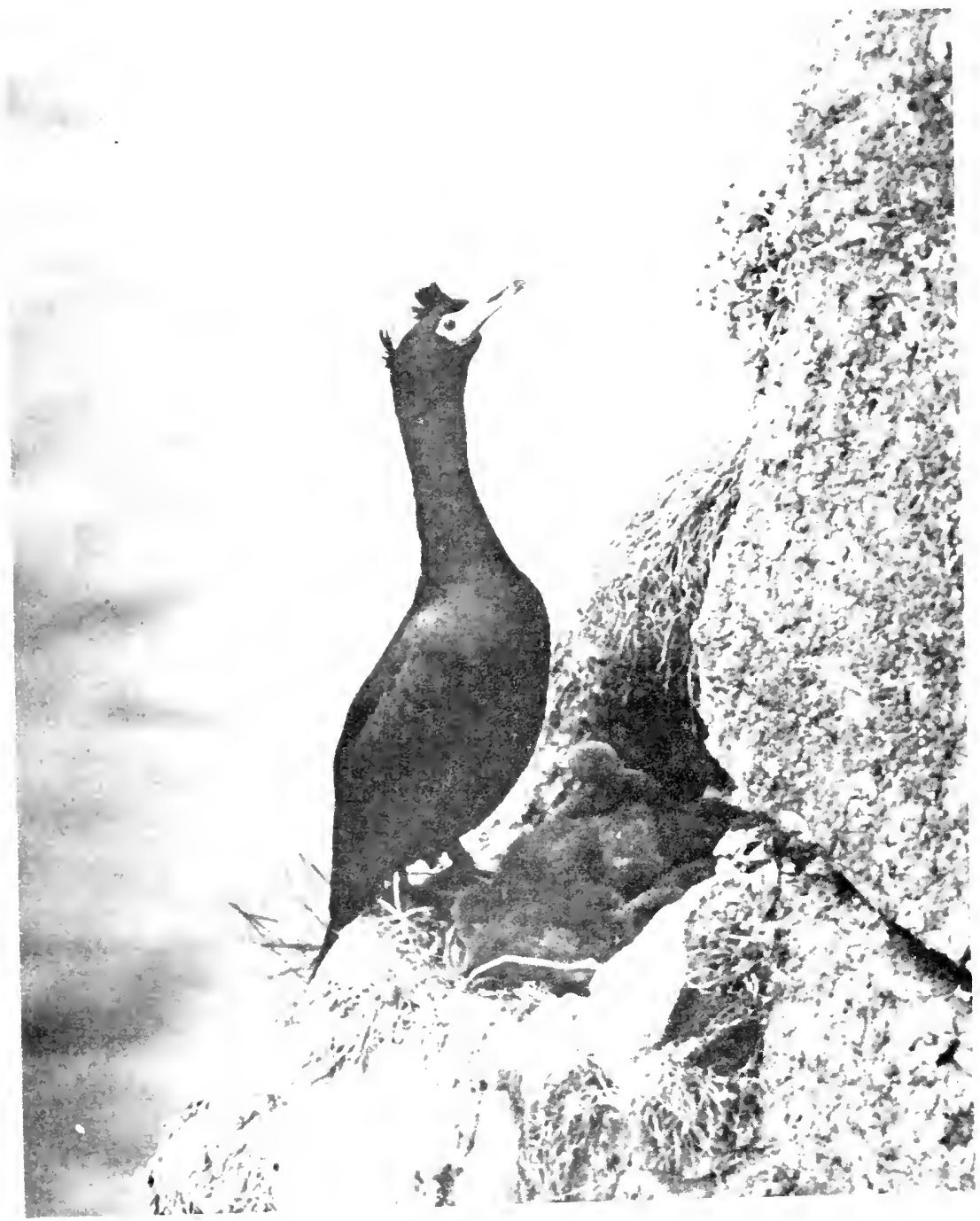

FIGURE 24.-Red-faced cormorant. 
On May 16, 1936, while anchored at Unga, in the Shumagin Islands, we discovered a good-sizer colony of red-faced cormorants on the precipitous cliffs of a rocky point. There were about 300 birds beginning to nest. Some of them were carrying nesting material; many had no nest at all. In our experience, this is the easternmost colony of this species.

In 1925, I found a colony on Amak Island, a small conelike island off the west end of Alaska Peninsula in Bering Sea. It was estimated that there were between 4,000 and 5,000 birds nesting on the high cliffs-by far the largest colony known south of the Pribilofs. When visited again in 1936, these birds were still nesting on the same cliffs, many of them carrying nesting material (on May 31). On May 22, 1928, Jaques (1930) observed this species near Port Moller.

Bogoslof Island is also occupied by ad-faced cormorants, mostly in the form of individuals scattered among a large number of murres.

While most of the Aleutian colonies of the red-faced cormorants are very small, there are a few sizable concentrations. On Adokt Island, one of the Baby Islands group in Unimak Pass, we estimated 500 nests. There were also large concentrations on certain islets in the Bay of Islands of Adak Island. But in many instances there were small groups, sometimes six or less.

Following are the islands, east to west, on which the redfaced cormorant was found nesting: Unga (Shumagins), Amak, Adokt and Excelsior of the Baby Islands group, Egg (probably), Poa, Tangik, Bogoslof, Ananiuliak near Umnak (not certain), Uliaga, Kagamil, Carlisle, Herbert, Yunaska, Chagulak, Amukta, Seguam, Ulak, Kasatochi, Igitkin (probably), Adak, Gareloi, West Unalga, Semisopochnoi, Amchitka, Little Sitkin, Davidof, Kwhostof, Kiska, Agattu, Semichi, and Attu.

These birds were identified at other islands, though nests were not actually observed. This gives the red-faced cormorant a fairly uniform distribution as a nesting bird from Unga and Amak Islands, and Port Moller, all the way to Attu, and they are known to nest still farther west, in the Commander Islands. The red-faced cormorant also winters in the Aleutian waters.

\section{Mortality Factors}

Birds which prey on the cormorants are the bald eagle, peregrine falcon, and glaucous-winged gull. In a study of the food habits of the bald eagle in the Aleutians it was found that cormorants had been taken for food frequently; however, the species of cormorants was not determined. It seemed likely 
that most of the remains that were examined were those of the pelagic cormorant, but no doubt the red-faced cormorant would be taken also where it is arailable. We found no remains of the double-crested species, but that form is relatively scarce.

On Amak Island, several carcasses of red-faced cormorants, probably killed by peregrine falcons that nested nearby, were found beneath the nesting ledges. Falcons are indicated as the predator because eagles would have carried their prey away to their feeding places.

Glaucous-winged gulls persistently seek the cormorant's eggs, and they are most successful when the parents are frightened off the nests, thus exposing the eggs to predation.

\section{Family ARDEIDAE}

\section{Ardea herodias: Great Blue Heron Ardea herodias fannini}

The heron seldom enter's the territory with which we are concerned. Osgood (1901) reports, "A great blue heron was seen at Hope by E. Heller." In the same general vicinity, May 8, 1936, the first mate of our ship reported seeing a heron early in the morning, as we were approaching Anchorage. It was recorded at Portage Bay (Nelson, 1887). So far as we know, then, this heron reaches the western part of its range at about the head of Cook Inlet.

\section{Family ANATIDAE}

\section{Olor columbianus: Whistling Swan}

Attu: Kon-kirch

Qumqix (Jochelson-dialect not given)

Atka: Ko-kin-yeh (or ko-kin-e-reeh ?)

Whistling swans nest on Kodiak Island and in suitable areas along the Alaska Peninsula. Osgood (1904) specifically mentions Swan Lake, Chulitna River, and "upper waters of the Nushagak system, and near the Ugaguk River and Becharof Lake."

Einarsen (1922) observed a swan with four young near Ugashik on June 26, 1922, and Jaques (1930) observed eight swans near Port Moller from May 24 to June 14, 1928.

While in the Katmai region in September 1940, Cahalane (1944) observed swans "from Kwichak River to Naknek," on tundra pools, on Lake Grosvenor, mouth of Savanoski River, between Iliuk Arm and Mount Katolinat and above New Savanoski Village. 
On July 19, 1940, Gabrielson noted three pairs of swans between Naknek and Brooks Lake, and on July 21, while flying over the country from Becharof Lake to Egagik, by way of Ruth, Ugashik, and Mother Goose Lakes, he saw numerous pairs of swans with 1 to 5 young among the many tundra pools and lakes of this area.

According to local residents (1936), swans nest on small islands in ponds near Ugashik River, and up the river from Nelson Lagoon. At Chignik I was informer that swans nest in Black Lake, the "second lake up Chignik River." Gabrielson was told that they nest in the King Cove-Cold Bay area.

In 1925, though none were found nesting, a swan was seen flying over Hazen Point in Izembek Bay on June 13, and or July 23 there was a group of three in a lake near the sand dunes there. In the same year, on April 29 and on several subsequent dates, two were seen at Urilia Bay, on Unimak Island, and a trapper said that he saw a few swans in that locality each year.

More recently, we have precise information that swans nest on Unimak Island, for in 1936 we obtained an egg, which, we were told, had rolled out of a nest on Ikatan Flats. The following year we learned that a pair had returned to the same flats.

In 1941, Beals and Longworth noted several swans at Unimak Island, and they reported that on August 31 a trapper observed 3 pairs near Swanson Lagoon-each pair with 2 young. It is also reported that a pair nested on Ikatan Flats in 1940.

Chase Littlejohn (manuscript notes) says, "Only a few seen at Morzhovoi Bay, where I know at least one pair reared their young in 1879. I found them with their parents in a lake still unable to fly on August 29."

Swans are not known to nest west of Unimak Island.

Dall (1874) reports the killing of three swans at Sanak Island in September 1872 by a sea-otter hunter, who said they were not uncommon there in the fall.

Apparently, swans have not been considered a part of the fauna of the Aleutian chain proper. Dall stated that they did not occur there, though Turner said a few wintered on Attu Island. it is possible that conditions have changed, for there is ample evidence that swans occur on many of the islands-at least in winter. At Atka Island, the natives assured us that swans winter in the Aleutians, and they specifically mentioned Kanaga and Amchitka, where swans had been observed on the lakes. On Amchitka, we found swan remains among the native buildings, 
and we learned that about 20 had been killed there the previous winter.

We also found swan wings on Semisopochnoi Island, thus showing that some had been killed there in winter by native fox trappers. Friedmann (1937) found four swan bones in midden material from Little Kiska.

The native chief on Attu Island assured us that swans winter abundantly among the lakes on the south side of that island, occurring in flocks of "eight, ten, to twenty-six." In 1924, the swans were said to have walked among the houses of the village, and, in 1932, "hundreds and hundreds" were seen among the lakes on the south side. Now, they occur only in small numbers. According to the natives, the swans arrive at Attu Island late in October, and they leave late in April.

\section{Mortality Factors}

It is probable that man has been the greatest enemy of the swan, for, under ordinary circumstances, the swan probably is able to protect itself against natural enemies. A trapper at Port Moller, on the Alaska Peninsula, told me that he had seen a swan defend itself against a red fox, and he doubted whether foxes were much of a hazard.

\section{Olor buccinator: Trumpeter Swan}

Quoting Friedmann (1937) on Kodiak Island: "A synsacrum and 2 tarsometatarsi were found in the superficial levels and another tarsometatarsus in the intermediate depths in 1935; in 1936 a metacarpal and the head of a humerus were collected."

There are no other records.

\section{Branta canadensis: Canada Goose \\ Branta canadensis leucopareia \\ Branta canadensis minima}

Attu: Legch

Atka: Luch or lug-ach, or lagix (Jochelson)

Resident whites: lanul geese

The white-cheeked geese were formerly common migrants throughout the Aleutian Islands area and nested on many of the islands. These populations now $(1936,1937$, and 1938) have been universaily reduced.

The forms of the white-cheeked groups of geese that nest in the Aleutian district is a question that has led to endless confusion. Our latest findings show that leucoparcia and minima are so inextricably associated throughout the Aleutians that it is desir- 
able to discuss them together. As far as we were able to learn, the Aleuts have only one name for this general type of goose. However, the Eskimos at Hooper Bay distinguish between these two forms, and they have a distinctive name for each form.

It should be noted here that in much of the previous work with these birds, the name hutchinsi was used to identify the form that we now call leucopareia (A.O.U. Check List); and this change has resulted in considerable confusion and misunderstanding of the literature.

It is certain that 2 forms of the white-cheeked geese nest in the Aleutians, but there is a question about the taxonomic rank to accord these 2 forms. As to considering them races of the same species, I agree with Bent (19:25) that "Both the cackling goose [minima] and the Hutchins goose [leucopareia] are said to breed on the Aleutian Islands, but it seems hardly likely that these two subspecies should occupy the same breeding range."

The situation we find here supports Taverner's conclusion (1931) and the findings of Aldrich (1946) that we have two species. Aldrich has proposed that the smaller species includes three subspecies: true hutchinsii (not leucopareia), minima, and asiatica, and that $B$. canadensis includes the other subspecies of this group. On June 23, 1911, a female was collected on Attu Island by R. H. Beck, which Bent (1925) recorded as minima. On June 13, 1937, John H. Steenis collected a male goose of this group on Agattu Island. These specimens were studied by Aldrich, and he agreed that the Attu syecimen was true minima, and that the one from Agattu was equally typical of leucopareia.

At Hooper Bay (south of Yukon Delta), we found the Alaskan cackling goose (minima) nesting nearest the sea, while the lesser Canada goose (leucoparcia) nested farther inland, though the two nesting ranges were adjacent. Two groups of Eskimos, an inland group and a coastal group, with slightly differing dialects, both recognized these two species of geese as different and had a name for each. With two geese populations nesting in such close proximity, without space for "intergrades," it would be illogical to consider them subspecies, aside from the facts shown by examination of characters. In the Aleutian district, these two species occupy ranges similar to the kinds in the Hooper Bay district.

Former numbers-Turner found "thousands" of geese on the Near Islands, of which Agattu and Semichi were the chief breeding grounds. They nested on Unaska, Amlia, Atka, Adak, Kanaga, Tanaga, Kiska, Buldir, Semichi, and Agattu. On some 
of these islands, the foxes had forced the birds to nest on offshore islets, and on Attu the natives hunted them extensively and clomesticated them, clipping the wings of young birds. Jochelson (1933) says: "Some of them breed on the Four Mountain Islands."

Bill Dirks, Atka chief, mentioned as former nesting grounds: Tanadak, Unak, and Tanaklak (all near Great Sitkin), as well as Amchitka, Ulak, Tanadak (the one near Kavalga), and Kiska. He also stated that at one time there had been a native village on Buldir, and that the rillagers used to pinion young geese to prevent them from migrating in the fall so that they would be available later in winter. Dirks recalled that his father once obtained 50 goslings on Buldir, and brought them to Atka, where he fattened them for food. Nelson (1887) saw a flock of domesticated geese at Unalaska, which had been obtained in the western Aleutians.

We must include Attu in the breeding range, for it was on that island that Beck collected the nesting goose examined by Aldrich and identified as minima. Evidently a few geese have been able to nest in spite of fores, and in primitive times undoubtedly a great many nested there.

As late as 1911, Wetmore reported at Kiska "Two flocks of rather good-sized geese were seen flying over high up June 18. One of the officers reported seeing two on an inland lake. None were taken." And, again at Atka, he reported, "a flock of geese seen flying high up June 13."

Austin H. Clark (1910) has presented a striking picture of geese in abundance:

This goose is the most abundant bird on Agattu, where it breeds by thousands. When we approached the shore we saw a number of geese flying about the cliffs and bluffs, and soaring in circles high in air. On landing I walked up the beach to the left and soon came to a small stream which enters the sea through a gap in the high bluffs, when I saw fifty or more of these birds along the bank preening their feathers. From this point I walked inland over the rough pasture-like country toward a lake where this stream rises. Geese were seen on all sides in great abundance, walking about the grassy hillsides in companies of six or eight to a dozen, or flying about from one place to another.

\section{Migration}

As would be expected, in the days when the lesser Canada goose and the Alaskan cackling goose flourished there was an east and a west migration along the Aleutian chain. In 1925, Donald Stevenson, former reservation warden, said that geese from the western Aleutians came eastward in the fall to join the throngs 
concentrated about Isanotski Strait. Atka natives said that geese passed eastward at Isanotski in August.

Chief Ermeloff, of Umnak, said that geese passed there "in the fall." Nick Kristensen, who has lived many years on Unimak Island, said geese arrived at Urilia Bay before they reached St. Catherine Cove, and he wondered, because Urilia Bay lies west of St. Catherine Cove, if this meant they "came from Siberia somewhere."

Jochelson (1933) says: "In April it flies to the west, in October to the east, resting on the islands."

It is evident that there was an annual fall migration eastward along the Aleutians. When the Aleutian birds arrived at the west end of the Alaska Peninsula, they undoubtedly joined the throngs of cackling geese that came down from the north.

On August 14, 1936, we noted six cackling geese flying southward over Nunivak Island. We were told that they linger a bit on the south side of Nunivak Island before continuing farther south. According to local information, they generally arrive at Unimak and the Alaska Peninsula about September 1, but they do not become numerous until 1 or 2 weeks later. Then, they assemble in surprising numbers and congregate at Urilia Bay, Swanson Lagoon, and St. Catherine Cove, all on Unimak Island, and at Izembek Bay, head of Morzhovoi Bay, Nelson Lagoon, and Port Moller on the Peninsula. In 1942, Gabrielson reported the first fall migrant at Izembek Bay as early as "late in July."

In 1925, accounts of the coming of the geese in "countless thousands" and "millions" testified to unusual concentrations, and it is safe to say that this area is the prinicpal gathering place for geese nesting along the shore of Bering Sea northward, as well as those from the Aleutians proper. The emperor goose and the 2 forms of the Canada goose all assemble here-of the two, the Canada geese are in the majority.

This area seems to be a place where the geese can fatten in the fall before continuing to their wintering grounds. They are said to feed to some extent on eelgrass; minima and leucopareia feed mostly on crowberry (Empetmu nigmu) and other berries and spend so much time on the slopes seeking these foods that they are known locally as "land geese"-distinguishing them from the "beach goose," which is the local name for the emperor goose.

The geese become very fat and leave for the south about November 1, though according to some reports it is as late as November 15 or 20 . Probably, the earlier date is the more 
usual one. In 1942, according to Gabrielson, the geese departed rather suddenly, eastward, on November 20.

This situation is quite comparable to that on the other side of the continent at the head of James Bay, a southern extension of Hudson Bay, where the blue geese spend more than 2 months fattening, and then continue south about November 1.

As the lesser Canada geese and the Alaskan cackling geese move south, they are noted in many other places, such as Metrofane and Mallard Bays in the Chignik area, at Simeonof Island in the Shumagins, and the Sanak Island group. Chase Littlejohn (manuscript notes) said: "A large number are seen annually at Sanakh in the fall where they remain for a short time at this season; they are very fat and toothsome... They are also numerous on the peninsula where they feed entirely on berries."

Our information on the white-cheeked group of geese for the more eastern parts of the Alaska Peninsula is, at this time, not as complete as the information that we have for other parts of this group's range. Osgood (190.1) reported a flock of the birds at the mouth of the Chulitna River on August 5, 1902. Others were seen later on the Mulchatna and were seen between the Mulchatna and Nushagak. On July 6, 1925, I saw a pair of geese, not specifically identified, on the tide flats of Izembek Bay; it is possible that they were nesting birds. In August 1911, Wetmore repeatedly saw "a small goose" on the marshes back of Thin Point. On July 28, 1911, he saw another at Morzhovoi Bay and saw three more on July 30. All of these, he provisionally identified as cackling geese.

The spring migration is much less noticeable, no doubt because the birds are intent on reaching the nesting grounds and therefore do not gather in large concentrations, and also because their numbers have been greatly reduced since the previous autumn. Residents at False Pass were undecided whether the geese pass through there in the spring. We were told that they also pass through the Chignik area, and at Simeonof Island in the Shumagins, and at Sanak Island farther west. At Sanak, we learned that the geese gather on the water enclosed by Sanak, Elma, and Caton Islands, though they do not linger there in the fall. This suggests that in the spring they have completed a lengthy fight orer the ocean, thus needing both food and rest. Chase Littlejohn, writing of the migration at Sanak in 1887-88, said, "They used to stop here on theil way north a few years ago, but they rarely if ever do now, for what reason I do not know." 
Evidently, the geese have resumed the practice in view of our information for more recent years.

Jaques (1930) reported that "Three flocks of what were probably cackling geese were migrating to the southwest May 16, inside the Shumagin Islands." They may have been headed for the Aleutians, judging by the direction they were taking.

It is evident, from information at hand, that the spring migration took place in April and part of May, but it was not so spectacular as the fall migration.

\section{Nesting Habits}

Agattu, in the Near Islands group, is the most favorable for geese. Most of the island is a lowland, liberally dotted with lakes. This makes it easy to understand why such islands as Semichi, Amchitka, Tanaga, and Kanaga were at one time a goose paradise-all of them have extensive lowlands with lakes.

There is another type of nesting habitat which is typified by Buldir Island-a domelike island rising sheer from the sea. Buldir possesses beaches and a small grassy valley cut by a stream. In this valley, where the grasses and sedges are heavy and rank, there were no geese. High on the mountain there are little depressions, benches, and valleys, which are cut by water courses. In this terrain, where the grasses and sedges are short and tender, there were geese-even though there is fog much of the time. So, on Buldir, the geese apparently have found an environment that is suited to them.

It is interesting to note that these geese do not hesitate to take to salt water. One, with two downy young, was seen in a bay at Agattu, and another was seen in the water near Chagulak, an island at Amukta Pass. The presence of a goose at Chagulak suggests another high-mountain habitat, because that island is extremely precipitous.

Present numbers-We have just enumerated the early accounts of "thousands" of geese, including Turner's "thousands" in the Near Islands, and Clarke's tale of abundance on Agattu. Today, the Aleutian district presents a striking example of the rapid decline of a species; the general opinion is that the fall concentrations in the False Pass area have greatly declined, apparently involving to some extent the geese from the more northerly nesting grounds.

We were surprised to find no sign of these geese on the lakedotted flats around the lower part of the Ugashik River, and in 1937 we observed only a few pairs of geese on Agattu Islandprobably less than 6 pairs in 4 days of traveling over the island. 
One pair had 2 young, and another had 5 young. In the Semichis, we found feathers and a few droppings on Alaid Island. On June 15, 1936, the captain and the mate of our ship saw a "small goose" of the cunadensis type near the shore of Chagulak Island, and we found signs of geese on Buldir. However, they had disappeared on most of the islands, and our total observations indicated that only a tew pairs remained in the Aleutians. In fact, these geese are so scarce that the migration is no longer noticeable, and some of the younger Aieuts didn't seem to know about it. When the remaining geese that go to the Aleutians are killed, it will be a long time for a migration to become reestablished, and consequently an extensive habitat for minima and leucopareia will lie racant.

Causes for decline-The natives, as well as several writers, have assumed that the disappearance of these geese from many islands was due to the introduction of blue foxes. Undoubtedly, this is true, yet on Buidir where there are no foxes, the geese are not plentiful. Uncioubtedly, another important cause for their decline is increased hunting along the migration route and on the wintering grounds in the south.

Administrative action has already been taken to free certain favorable islands, including Agattu, from foxes. Further, to preserve these geese, it remains for sportsmen to protect the birds on the wintering grounds. With such a combination of protection, it is still possible to prevent these geese from losing their present tenuous hold in the Aleutians, and perhaps it would be possible for them to build up to a point where they will be safe from extinction.

\section{Branta nigricans: Black Brant}

Attu: Agru-gé la-ghé

Nelson Island Eskimo: Nuli-hla-ra-nak

Hooper Bay Eskimo: Nuk-lu-nuk

Hooper Bay, a more inland dialect: Nuk-hu-gu-nuk

Nelson (Eskimo dialect): Luk-hlug-u-huk

Russian, Yana district: Njemok (Pleske)

Chukchi: Nedljuitti (Palmén)

The black brant is only a migrant in the Aleutian district, but it occurs in considerable numbers. In 1936, we were told at Port Moller that the brant appear there in April, and we received the same information for the Chignik area. We had seen them on northward migration neal Seymour Narrows, British Columbia, on April 21, and on Queen Charlotte Sound on April 
25. Donald Stevenson, in 1925, said that he had seen them at King Cove "late in April."

Apparently, the many bays at the western end of Alaska Peninsula are favorite gathering places for black brant in migration. In 1925, Stevenson and I observed them on Izembek Bay, where they were present on May 20 in small flocks, on the water and flying from point to point. However, some flocks contained as many as 200 birds, and about 5,000 black brant were estimated for the entire bay. The following day, at the east end of the bay, there were only a few groups.

Stevenson arrived at this bay on June 2 and found the brant to be plentiful. As he passed Applegate Cove, he saw a "swarm" of brant up the bay, rising and settling in a funnel-shaped mass. There were other groups of 50 to 75 brant flying up the bay, some of these joining the large flock. The following day he saw more of them, and, in each instance, they seemed inclined to move in a northeasterly direction.

On June 16, we saw a small flock and a single bird; next day we saw several small flocks near the outer sand islands. This was their last appearance.

In 1948, Gabrielson found black brant on the Sanak Islands on April 30, and the next day, at King Cove, he saw 100, or more, heading toward Cold Bay. In 1944, residents at Port Moller reported the first spring flight on April 26.

A. C. Bent (1925) quotes Chase Littlejohn as saying that the brant move westward along the Alaska Peninsula, 1 or 2 miles offshore, turn into Morzhovoi Bay, and thence go into the Bering Sea. This probably outlines the spring migration fairly accurately.

While we were at Nunivak Island on August 14, 1936, black brant had arrived from the north. Eskimo said that these brant remain on the inland lakes of that island for about 2 months, or until sometime in October, before continuing south. In the meantime, many others have gone farther south, because at Port Moller, on August 29, the residents said that the brant were due at that time and that they would remain there until about November 1, before continuing south. They also return to Izembek Bay during their migration.

Dall reported that black brant were nesting on some of the western Aleutians, but Nelson was undoubtedly correct when he assumed that these birds must have been small geese of the canadensis group. Friedmann (1937) records the following remains from native middens: One skull and 2 sterna from Little 
Kiska; 1 humerus from Atka; and 4 humeri from Attu. In 1936, the Attu natives told us that black brant appear there occasionally in the fall, sometimes in company with the emperor goose.

Stejneger (1885) reported the species occuring sparingly in the Commander 1slands in migration.

\section{Philacte canagica: Emperor Goose \\ Attu: Il-á-ghir-lich \\ Atka: Ka-ghu-mung \\ Qámgän (Jochelson)}

The emperer goose apparently does not commonly nest in the Aleutian Islands, nor on the Alaska Peninsula, but at least one record of nesting was established. During June 1925, a Bureau of Fisheries boat had stopper for a short time at Amak Island, on the way to Port Moller. The pilot informed me that during that stop at least three pairs of emperor geese were seen. On July 10, 1925, during a visit to Amak, I found the remains of a young emperor gocse in a bald eagle nest. The feet, stomach, and numerous pinfeathers were present in the nest, and were collected. This appear's to be the solithernmost nesting locality.

The Aleutian district is certainly the principal wintering place for emperor geese. We noted evidence of such occurrence and obtained statements of natives and others who were familiar with specific localities, and in 1941 and 1942 Gabrielson noted them as plentiful at a number of the islands he visited in the winter months. They are reported as spending at least a part of the winter as far east as Port Moller, on the north side of the peninsula, leaving when the ice formed but returning when the water opener again. Some of these geese winter at Urilia Bay on Unimak Island and on Izembek Bay; a few geese winter near Chignik on the south side of Alaska Peninsula, and some of them winter at Simeonof Island in the Shumagins. A banded bird was recorded at King Cove in the fall of 1926.

Turner (1886) makes the sweeping statement that these birds winter on the south sirle of Alaska Peninsula and on off shore islands as far east as Cook Inlet. Friedmann recorded bones of this goose in all layers of Kodiak middens. Today, they are less numerous along those shores, possibly because of the advent of white men and an increased kill resulting from modern weapons.

Emperor geese are known to winter in some numbers in the Sanak group. We found recent remains at Unalaska, June 3, 1936, and on Bogoslof Island, June 5, 1936. Eyerdam (1936) 
obtained two specimens at Unalaska on June 20 and on August 7, 1932. These geese are known to winter on the following islands: Unimak, Unalaska, Sanak, Umnak, Amukta, Seguam, Atka, Adak, Tanaga, Kanaga (abundant), Amchitka, Ulak (longitude $178^{\mathrm{C}}$ W.), Ogliuga, Kavalga, Semisopochnoi, Kiska, and Attu. The chief of Attu declared that they were in that locality in "millions." These are the islands on which we have specific information. Undoubtedly, emperor geese occur on many, if not all, of the other islands; almost certainly they occur on Agattu and Semichi, for example.

As may be expected, there are many records of winter occurrences farther south, in Washington, Oregon, and California. These records are numerous enough to suggest that some stragglers find their way into those southein localities quite regularly; however, the regular wintering area is confined to portions of Alaska Peninsula, the Shumagin and Sanak Islands, and the Aleutian chain. Apparently, they are rare on the west side of Bering Sea during the winter. Stejneger (1887) records two specimens taken at Bering Island, April 6, 1886.

The spring migration varies according to the locality and the age class. Natives declare that emperor geese leave Attu Island in April; Turner (1886) gave the date as the "latter part of March." He also stated that after the middle of Apri: considerable numbers of geese begin to arrive on the north side of Alaska Peninsula, particularly in the neighborhood of Ugashik.

In 1924, I observed the spring migration at the nesting grounds at Hooper Bay. The first migratory wave began about the middle of May and continued to the end of the month. There was another notable flight about June 5 and 6 , which appeared to end the migration of breeding birds. Nesting had begun at that time.

A second distinct migration at Hooper Bay took place from June 21 to July 1 . These were immature birds, probably all nonbreeders.

It was my good fortune to observe the other end of such migration in 1925, at Izembek Bay and Unimak Island. On April 29, 1925, and for several days following, flocks of emperor geese were noted at Urilia Bay, on the north side of Unimak lsland, many of them flying northeastward. On May 17, a flock of 250 was seen standing on an exposed sand bar in St. Catherine Cove. On May 20, they were common in Izembek Bay, and Donald Stevenson noted a flock of 300 there on June 2. We saw a similar-sized flock on June 8, at Moffet Cove, where they 
were noted throughout June in diminishing numbers. The last flock was seen on July 7. The time of gradual disappearance on Alaska Peninsula corresponds very well with the time of the late migration noted at Hooper Bay the previous year. The lingering flocks in Izembek Bay were mostly immature birds. One bird, which was collected in adult plumage, proved to be a nonbreeder.

A few late occurrences were noted farther west. C. S. Williams noted a group of about six emperor geese on Uliaga Island on June 8, 1936; and a bald eagle's nest on Kavalga Island contained remains that were fresh enough to indicate a kill in July.

Apparently, there is an eastward movement of emperor geese along the Aleutian chain, and a consequent "piling up" at favorite locations on the Alaska Peninsula, until the northern flights are well under way.

The exact reversal of this process occurs in the fall. Some time early in September, the emperor geese begin to arrive from the north in the vicinity of Izembek Bay. And, according to the enthusiastic accounts of local residents, these emperor geese are almost as numerous as the cackling geese before the latter declined in numbers. At Port Moller, emperors are said to arrive as early as the latter part of August. They congregate on Nelson Lagoon, Izembek Bay, head of Morzhovoi Bay, locally in Isanotski Strait, St. Catherine Cove, Swanson Lagoon, and Urilia Bay. Most of these geese move westward some time in November. Incidentally, Swarth (1934) states that emperor geese were present on Nunirak Island, to the north, as late as October 29, 1927. The Attu chief said that they arrive at that westernmost point in the Aleutians late in October.

Apparently, in fall migration the immature birds again lag behind their elders. According to Swarth, the first arrivals on Nunivak Island, observed by Cyril G. Harrold, August 20 to the middle of September", were white-headed adults. "On September 15 the first young birds (dusky headed) were seen and they were common thereafter."

\section{Food Habits}

It is well known that the emperor guose is largely a beach feeder" in fact, it has earned the local name "beach goose." Yet, it is reported as occasionaly feeding on the berries of the tundra, notably Empetrum nigrum. Swarth (1934) sums it up thus,

The emperor geese fed mostly upon the sea shore, but occasional flocks were encountered on the tundra, feeding upon berries. The one adult male 
of the series had its face stained and the throat and entire intestinal tract dyed blue from a diet of berries.

In the spring of 1925, these birds were feeding at low tide on tide flats in Izembek Bay. The tide is about an hour later at the head of Izembek Bay than at the entrance; the same situation exists between the two sides of the long Hazen Point. The emperor geese were well aware of this, and when their feeding grounds were flooded by the incoming tide they simply flew up to Hazen Point, crossed over a few hundred yards to the east side, where the flats were still exposed, and continued feeding. The narrower parts of this point were favorite flyways. In this area, the principal food was thought to be eel grass. On June 14, at the margin of a pond, it was noted that the grass was grazed off short; the area was trampled and was littered with droppings. However, the stomach of an immature bird found in a bald eagle's nest on Amak Island on July 10 contained remains of small crabs.

Emperor geese are often reported as feeding on some kind of kelp in winter. At Kanaga Island, we were told that they feed on kelp and the green shoots of Elymus, which, even in winter, may be found under the dead vegetation. One informant stated that the geese probed into the ground and pulled out the horizontal rhyzomes of Equisetum. We had noted droppings on Ogliuga Island consisting of the herbaceous parts of Equisetum arvense; but these droppings could not be positively identified.

Several observers in the Aleutians reported that emperor geese feed extensively on green "sea lettuce," as well as Fucus, and the "exposed roots" of Elymus.

Chase Littlejohn, apparently referring to Sanak Island and Morzhovoi Bay, says: "Here they live almost entirely on a bright green seaweed, locally known as sea lettuce, but at times eating small mussels."

Cottam and Knappen (1939) have presented a comprehensive statement on the food habits of the emperor goose, based on analyses of 35 stomachs. Few, if any, of these stomachs were obtained in the Aleutian Islands, yet the data agree fairly well with observations made in this area. Their findings (based on the contents of 33 stomachs) show 91.58 percent vegetable matter, and 8.42 percent animal matter. Their findings are further summarized as follows: Algae, 30.73 percent; eel grass and other pond weeds, 13.91 percent; grasses and sedges, 24.94 percent; undetermined and miscellaneous plant fiber, 22 percent; bivalve mollusks (Pelecypoda), 3.66 percent; crabs and other crustaceans, 2.18 percent; rodents and fishes, 1.76 percent; and miscellaneous animal life, 0.82 percent. 


\section{Mortality Factors}

At Sanak Island, a resident declared that one winter he found 15 dead emperor geese on the beach. Although he thought that the deaths were caused by the frozen condition of the freshwater creeks, the precise mortality factor here must remain inknown.

Among the natural enemies of the emperor goose is the bald eagle. However, there is no eviclence that the eagle materially affects the goose population.

\section{Anser albifrons: White-fronted goose Anser albifrons frontalis \\ Attu: Kog-a-la-gich' \\ Russian, latitudes of the Yana: Kasorka (Pleske)}

Bones of white-fronted geese are recorded by Friedmann in middens on Kodiak, Amaknak, Little Kiska, and Attu Islands. The Attu natives informed us that they have seen these geese in September; but they stated that the sightings are rare and that these geese do not winter there. Stejneger (1887) stated that occasionally these geese visit Bering Island in spring migration. Turner did not observe this species in the Aleutian Islands. In 1925, I learned of a trapper at False Pass who had a whitefronted goose in captivity; he had caught the goose at St. Catherine Cove during the previous autumn. Residents of the area stated that this goose is ver scarce around the west end of Alaska Peninsula.

The white-fronted goose is a rare migrant in the Aleutian chain; therefore, Turner (1886) no doubt was partly right when he said, "They probably never visit the islands lying west of the mainland, as that region does not contain their particular food in sufficient quantity to induce them to visit it." His further statement that the Russians at St. Michaels referred to it as the mur-dri-na goose, or lowland goose, is further explanation of its scarcity in the Aleutians, where most of the land is rugged. Farther east along the Alaska Peninsula, however, suitable ground is available, and we found nesting birds on the tide flats at Ugashik River. On May 27-29, 1936, at least six pairs were noted in that area.

Osgood (1904) records that he saw these birds at the base of Alaska Peninsula in 1902; he frequently saw them on the Chulitna River in early August, saw one on the Mulchatna River on September 3, and on the trip from the Mulchatna River to Nushagak he saw a considerable number of these birds each day. 
On July 23, 1940, Gabrielson observed three pairs of whitefronted geese along Kvichak River, above Naknek, and he was informed by natives that this is the common nesting goose at the base of Alaska Peninsula. He estimated that he saw 500 birds along the Chulitna River on July 26.

To sum up, the white-fronted goose nests on the eastern portions of Alaska Peninsula, at least as far west as Ugashik River; farther westward throughout the Aleutian district it is only a rare visitor.

\section{Chen hyperborea: Snow Goose}

On October 1, 1942, Gabrielson noted two snow geese with a flock of Canada-type geese at Cold Bay. Again, on October 20, 1944, he saw 4 large flocks flying over Olga Bay at Kodiak Island, and, on the same day, he stated that 1,000 to 1,500 birds settled near Kodiak village, where several were shot by the townspeople. He comments: "They are seldom seen here, though more frequently at the south end of the island."

This is the only information available for this goose. There are no records concerning the area to the west.

\section{Anas platyrhynchos: Mallard \\ Anas platyrhynchos platyrhynchos}

Attu: Argh'-ich

Atka: Aǵ-ich (apparently the same word in both dialects)

Russian, Commander Islands: Selesenn (Stejneger)

The mallard is widespread throughout the length of the Alaska Peninsula and Aleutian Islands, both as a breeding species and as a winter resident. Stejneger (1887) reported also that it was "resident, breeding numerously in Bering Island; comparatively rare on Copper Island." In 1886, Turner reported that the mallard was plentiful in the Aleutians in winter, and stated that it breeds sparingly on Agattu and Semichi Islands and that a few pairs were seen on Amchitka Island in the latter part of May 1881 - which indicates nesting. Our expeditions verify this information. In 1936, Attu natives stated that they had observed these birds nesting near streams, and stated that they winter there. The following season, on June 9, which was during the nesting season, we saw several mallards along the shore of Attu Island. Wilson (1948) observed them at Attu in the breeding season when some of them were paired. The last ones observed were on August 28. We found a number of mallards among the lakes of Agattu Island, and on.June 13 we found 
a female with eight clowny young. On June 21, 1937, a pair was seen among the lakes on the southeast part of Kiska Island, and another pair was seen in a lake at the South Harbor. On July 5, we flushed two males and a female from a pond on Amchitka Island. The natives of Atka also assured us that mallards are found there both summer and winter, which suggests nesting. June 20, 1941, Gabrielson saw a female with four young at Unalaska Island. The islands mentioned here are the principal ones that contain ponds and lakes. However, Cahn found this bird nesting at Unalaska Island.

Farther east, we obtained adritional nesting data. On May 7,1925 , I found a nest of 11 eggs at Urilia Bay, Unimak Island. On June 6, a nest of 5 fresh eggs was found in a stream valley below Aghileen Pinnacles, western Alaska Peninsula, and on June 23 a nest of $10 \mathrm{eggs}$ was obselved on the tide flat at Hazen Point, Izembek Bay. In 1936, residents at Port Moller assured us that mallards nest around Nelson Lagoon, and in 1928 Jaques (1930) found it a "common breeder in the Port Moller region." On May 29, 1936, we saw a single male at Ugashik River. We had seen a pair at Chisik Island, Tuxedni Bay, in Cook Inlet on May 6, and, on May 9, another pair was observed at Anchorage. According to Osgood (1904), "McKay found the species breeding at Nushagak and trok a number of specimens there in May and June, 1881." Gabrielson noted a few along Kvichak River July 23, 1940, including one brood of young. He also noted a male in the Barren Islands on June 13.

Mallards undoubtedly nest on various islands south of the Alaska Peninsula. On August 29, 1936, I sav two mallards on a pond on Simeonof Island, in the Shumagins, and the local rancher said they nest there. On Afognak Island, September 2, 1936, 14 mallards were seen in a lily pond. These could have been migrants, yet mallards undoubtedly nest there because they are known to nest on Kodiak, nearby.

As stated above, mallards winter throughout the territory under discussion. Localities where consiclerable numbers have been reported are Unalaska, Kanaga, and Unimak. We were told by natives of Unimak that when the bays and lakes freeze over, the mallards move to the unfrozen streams in the interior of the island and return to the lowlands only when the ice has disappeared.

In the summer and fall of 1936 there was an unusually large run of salmon up the streams of Unimak Island; at that time, mallards and other ducks, we were told, assembled there to feed on free-floating salmon eggs. 


\section{Anas strepera: Gadwall}

The gadwall has been considered to be "accidental" in Alaska, on the strength of two records for the Pribilof Islands. It was, therefore, of particular interest to find that this bird nests regularly in parts of Alaska.

On May 16 and 17, 1937, several pairs of gadwalls were found on the Copper River Flats, near Cordova, not far from the mouth of Eyak River. Evidently, these were paired birds that were preparing to nest.

Alfred M. Bailey (1927) reports a pair at Bartlett Cove, Glacier Bay, on August 9, and "felt sure" he had identified a band at Holkham Bay on September 25, ihough the light was poor.

Cahalane (1943) reports that two gadwalls were shot on October 2, 1940, at the head of Terror Bay, Kodiak Island.

Chase Littlejohn says "A few of these ducks were shot by me while on their way north in the spring at Dolgoi Island, near Belkofski. They were the only ones seen."

On the north side of Alaska Peninsula, where suitable marshlands are present, the gadwall is fairly common. On May 27 to 29,1936 , they were common on the tidal marsh and on numerous ponds adjacent to Ugashik River where they were courting and preparing to nest. Generally, a female would be seen flying about, pursued by two or more males. On May 28, this species was recorded as "the principal duck seen," and on May 29 "they and the scaups made up most of the duck population." A pair was collected for specimens.

At Port Moller, residents assured us that gadwalls nest plentifully in the lakes upriver from Nelson Lagoon.

On May 8, 1925, I observed 4 gadwalls near the shore of a lagoon at Urilia Bay, Unimak Island; 2 of these were taken for specimens. On May 21, five gadwalls were seen among the ponds on Hazen Point in Izembek Bay; gaciwalls were seen repeatedly as late as July 25.

Beals and Longworth, in a field report, mention that they saw 4 gadwalls on Unimak Island, March 19, 1941, 1 of which was collected. Local residents considered it to be uncommon.

Gabrielson reports a male and female on a lake at Izembek Bay, June 4, 1942. During the fall and winter periods of 1943 and 1944, he found them to be common among the KodiakAfognak Islands.

Turner (1886) records a specimen taken at Unalaska Island in December, 1878, and states that they are "abundant" along the Yukon Delta district in summer. Nelson does not mention it, 
however, and we did not see this duck in the Hooper Bay district in 1924.

Taber found 5 males and 4 females at Adak Island during the winter of $1945-46$.

Stejneger says (1887), "Reported by Dybowski as taken on Bering Island." Hartert (1920) mentions a specimen shot on Copper Island on May 13, 1911.

Thus, we find (as is the case with a rumber of species that require lowland marsh) that this duck liests along the lowlands on the north side of Alaska Peninsula, possibly also on Unimak Island, but it occurs only as a straggler in the Aleutians to the west.

\section{Anas acuta: Pintail}

Russian, Commander Islands: Vostrochnost (Stejneger)

This widely distributed bird is not common in the Aleutian clistrict, but it does occur here and there throughout the entire area. It is known to occur on Kodiak Island (Friedmann 1935; Howell 1948), where Gabrielson found it plentiful in fall and winter. Cahalane (19.4) observed pintails in several localities in the Katmai region in the autumn of 1940 , but his report implies that this species is not plentiful. Gabrielson noted a female on Naknek River on July 19, 1940, and on July 23 several females, evidently with broods, were noted on Krvichak River. He also found it at Unimak, Cold Bay, Izembek Bay, Shumagin Islands, and Kodiak-Afognak Islands; they were rather plentiful in the last-mentioned localities in fall and winter. Einar'sen (1922) found pintails nesting near Ugashik in 1922, and Jaques (1930) found it to be a common breeding hird around Port Moller in June 1928.

On May 23, 1936, we saw 2 pintails near Dillingham, Bristol Bay, and, on May 26, 2 more pintails were seen near Snag Point. On May 27 to 29, an occasional pair was seen on the flats near Ugashik River, where they evidently were nesting.

Residents on Unimak Island stated that pintails nest there, and this was verified by my observations in 1925. In that year, they were first seen at Urilia Bay on April 30. On May 4, Donald Stevenson saw 10 males flying about, and on May 17 a pair was seen at St. Catherine Cove. Pintails were also present on Izembek Bay, and on June 30, near Point Grant, in the midst of nesting Arctic terns and Pacific eider's, a nest of eight eggs was found. Near Frosty Peak, a female that obviously had eggs, or young, nearby was observed.

Turner did not observe the pintail in the Aleutians during the 
nesting season, and we found that the natives 'did not recognize pictures of the bird, yet the bird assuredly occurs in these islands. We noted pintails on a lake on Umnak Island May 30, 1937, and on August 23, 1937, Steenis obtained a specimen there. On June 16, 1936, C. S. Williams reported a pair on Amukta Island. Laing (1925) saw a small flock at Kuluk Bay, Adak Island, April 13, 1924. We noted a pair among the lakes at the southeast point of Kiska Island on June 5, 1937, and, in the same vicinity, on June 21 we saw two males and a female. Remains of a pintail were found in a bald eagle's nest on the north side of Little Sitkin Island, and, on June 17, 1937, a pair was observed on Alaid Island, of the Semichi group, which is near the western end of the chain. On Attu Island, Wilson (1948) found three pairs that he thought to be nesting.

Undoubtedly, all these records denote nesting throughout the Aleutian chain, though successful nesting in recent years may be adversely affected by the blue-fox industry.

Stejneger (1887) says pintails are very numerous on Bering Island, but less common on Copper Island.

Turner did not think pintails wintered in the Aleutians; however, he recorded them at Unalaska as late as November. Moreover, Beals and Longworth (field report) state that pintails are plentiful in winter in the vicinity of Unimak Island. On March 1, a flock of 25 was recorded; on March 16, 2 were noted; on March 26, a flock of 23 was noted. Moreover, Taber observed a flock of 48 that were wintering at Adak, in 1945-46.

\section{Anas falcata: Falcated Teal}

Rowland Wilson (1948) reports an unusual observation, in part, as follows:

On May 23 and 24, 1945, Lt. C. L. Stone and I observed a male and female of this handsome species, together with two Tufted Ducks and three male and four female Greater Scaups, on a little "pothole" pond inland from Murder Point [Attu Island]. We had abundant opportunity to watch the teals, for they were not shy. On the 24 th we saw the male diving several times. He went under rather awkwardly, giving us the impression that he was not used to such activity. The female did not dive while we watched her. . . Possibly they had been blown in from the west by a recent storm. 


\section{Anas crecca: Common Teal Anas crecca nimia}

Attu: Cheerrh-ook (obviously the Russian name)

Atka: Krech-cheer-tha (derivation from Russian is at least suggested by the middle syllable)

A taxciyax (Jochelson-probably the true Aleut name)

Russian, Commander Islands: Tschirok (Stejneger)

It is now well established that the breeding species of teal throughout the Aleutian chain is Anas crecca. During our expeditions, with only one exception, when a close view of males was possible, or when specimens were collected, the bird proved to be the common teal. Beals and Longworth collected a male at Unimak Island, June 11, 1941. This is the easternmost point for which we have a record of this bird. Swarth (1934) records 3 specimens, 2 males and 1 female, taken on Akutan Island, May 24, 1927. We found these teals common throughout the Aleutian chain, and they are to be found on most of the islands where suitable habitat is available. Bent lists a specimen collected by Lucien M. Turner on Atka Island, June 28, 1879, and one taken by J. Hobart Egbert on Kiska Island, July 14, 1904. He also states that in 1911 his party collected "quite a series" of specimens in the western and central islands, and every male proved to be this form. Laing (1925) records two males taken at Adak Island, April 13, 1924. On our own expeditions, several specimens were taken, including males on Kagalaska, July 4, 1936, and on Amchitka, July 24, 1936.

Gabrielson noted a pair of common teals on Amukta Island, June 25, 1940; he saw about a dozen on Amchitka, June 28, and saw other's at Tanaga, Ogliuga, Atka, Ulak, Kavalga, Segula, and Adak.

These teals are the most abundant fresh-water ducks in the Aleutians. Broods of young were seen on the small islands, Ogliuga and Skagul, and two broods were seen on Kanaga. On July 7, 1937, we found a nest of seven fresh eggs on Amchitka. On July 3, 1936, a female with two downy young were seen in a shallow grassy pond on Adak Island. The natives said that teals nest on Attu, and a male was seen on Agattu, June 15, 1937. On August 23, 1937, I counted at least 42 teals on a lake near Nikolski Village, Umnak Island, and Steenis, on the same day, saw a greater number. Pairs were seen on various other islands, and it is certain that they nest throughout the length of the Aleutian chain.

Stejneger (1887) reported the European (common) teal as an 
abundant visitor on Bering Island, but less common on Copper Island. The species also occurs in the Pribilof Islands.

Apparently, while nesting, the teals are less susceptible to the predations of the blue fox than are most other waterfowl, though the chief of Atka Village declared that they were much more numerous in early days. They generally occupy shallow, weedy ponds, though they also spend much time on the beaches-sometimes on boulder beaches. They feed extensively along the beach margin and are often found on salt water. This was noted particularly on Ogliuga Island. The nest found on Amchitka Island, July 7, 1937, was situated in the dense stand of Elymus bordering the ocean beach, and the female repeatedly was observed feeding on this open beach.

Cottam and Knappen (1939) have reported on the contents of five stomachs of this species, and say that "three out of four birds taken in coastal Alaska had fed almost exclusively on softbodied crustaceans." The authors felt that the high percentage of animal matter ( 80.2 percent) was probably not typical and would not be maintained in a larger series of stomachs. However, our observations on the feeding habits of these teals in the Aleutians are in accord with these findings from the stomach analyses.

Evidently, the common teal winters in the Aleutians. We were assured of this by the natives of Attu and Kanaga, and residents of Unimak also stated that teals winter there. Furthermore, Donald Stevenson, who spent several winters in the Aleutians, furnished positive evidence of it, for in his field reports he said, in part (referring to Unalaska Island),

They were again noted here Nov. 2, 1920, and at intervals in the month of November until November 21. Then again here January 7, 1921, to January 31, 1921. Being often observed feeding in small pools of salt water along the beach after the cold weather had set in and had frozen the fresh water streams. . . Existed in great numbers at Umnak Island, near Otter Point November 22, 1920, in small fresh water pond, and in large fresh water stream. ... O Observed about five hundred here Dec. 13, also noted here Dec. 18, 1920. Specimens taken were in a fine fat condition.

In 1943, Cahn noted 1 common teal at Unalaska Island on October 14, and 2 on December 2. Taber noted a flock of 47 at Clam Lagoon, Adak Island, from November 1945 to late January 1946. Sutton and Wilson saw a male at Attu, March 5, 1945.

\section{Anas carolinensis: Green-winged Teal}

The common teal occupies the Aleutian Islands, and the greenwinged teal occupies the Alaska Peninsula. There is some over- 
lapping in range. On June 5, 1937, Steenis and I observed 3 teals at a small pond on Kiska Island-at least 2 were males in bright plumage. One was clearly $A$. crecea, with a plain breast and a light-colored scapular streak. The other bird lacked the scapular streak, and plainly showed the crescent on the side of the breast. We both saw these markings, but we failed to note the markings of the third bird. It may have been a female. It is interesting to note that both species of teals occur on the Pribilofs.

Cahn, writing of his observations at Unalaska Island during the war years, says of the green-winged teal: "Observed in every month of the year except August in four years of observations; inhabits the same area as $A$. crecca, but more common." Taber did not record it as being present in winter at Adak.

Because of the difficulty of identification in the field, and because females of the two forms are indistinguishable, even with specimens, there is confusion about their ranges and the extent of territorial overlapping. Until more collecting is done, and because specimens of nimia east of Unimak are lacking, we may assume for the present that the birds of Alaska Peninsula are chiefly carolinensis. They occur in suitable locations along the peninsula. In 1925, they were noted on Unimak Island and Izembek Bay. In 1936, we were informed by residents that teals nest up the river from Nelson Lagoon, and we saw at least two teals at Ugashik River on May 29, 1936. Osgood (1904), however, found teals scarce in the interior of the base of Alaska Peninsula, and says,

One old female was seen on the Nogheling River July 21, and no more appeared until we neared the coast on the lower Nushagak River. Immense flocks were seen in late September in the vicinity of Nushagak. McKay obtained several specimens at Nushagak and at Ugashik.

The National Museum has a male green-winged teal that was taken at Nushagak, May 6, 1883, by Paul J. Kojevnikoff.

Cahalane (1944) has observed the green-winged teal on the mainland only once positively: a flock of 12 was seen September 24, 1940, near the mouth of Saranoski River.

Gabrielson saw several green-winged teals, obviously with broorls, up the Krichak River, July 23, 1940. On April 27, 1942, he positively identified 21 of these birds at King Core, and later he saw many more at Cold Bay.

Green-winged teals occur on Kodiak Island, according to Friedmann (1935) and Howell (1948). Cahalane and Gabrielson found them to be numerous in the Kodiak-Afognak area, but there are no records for the rest of the territory under discussion. 
Teals winter at Unimak Island, according to residents, and, according to Cahn, they winter as far west as Unalaska Island.

\section{Mareca penelope: European Widgeon}

Russian, Commander Islands: Svistsch or Svistun (Stejneger)

Four specimens have been collected on the Pribilof Islands, and Dall (1873) records a specimen taken at Unalaska, October 12,1871 . He says it is "not uncommon among the ducks brought in by the native hunters of that locality." He considered it to be a winter visitor, "migrating about May 1st."

On June 21, 1937, we found a pair at a lake back from the beach at the more southerly harbor on Kiska Island. As the two birds flew by, I clearly saw the buffy coloration on the head of the male. At that season of the year, a pair suggests nesting.

Stejneger (1887) records this bird as being a visitor to the Commander Islands in migration.

\section{Mareca americana: American Widgeon}

The American widgeon, or baldpate, is rare in the Aleutian district. On May 27, 1936, 2 or 3 were observed on the flat marshes near Ugashik River, and 2 males were seen May 29. We saw none to the westward, though Gabrielson records seeing a male and a female on a pond near Izembek Bay on June 6, 1942, and saw other's at Port Moller, July 7, 1946.

Osgood (1904) mentions specimens taken by McKay at Cape Constantine and Ugashik in September 1881.

Hine (1919) observed this duck occasionally in the Katmai Region in 1919, and he obtained specimens near the mouth of Katmai River.

Friedmann (1935) records seeing the baldpate at Kodiak, and a specimen was taken. He also (1937) reports that bones of this duck were found in middens on Little Kiska Island. Gabrielson records that the species was "common" in the Kodiak-Afognak Islands in the fall and winter months of 1943 and 1944.

Howell (1948) reports as follows for Kodiak: "Two were seen May 31, at Middle Bay, and one on June 16, at Bell's Flats," in 1944 .

Turner states that it is rarely seen on Attu Island.

Finally, Stejneger (1887) found a dead bird of this species among the sand dunes of Bering Island. 


\section{Spatula clypeata: Shoveler}

Attu: Koo-chu-tuh or Koo-chu-thoh

Russian, Commander Islands: Soksun (Stejneger)

The natives of Attu Island seemed to know this duck and had a name for it-if their iclentification is correct. They recognized a picture, agreed on the spoon-shaped beak, and claimed that the shoveler nests on Attu Island.

Stejneger (1887) considered it to be one of the rarer ducks on Bering Island, but he thought that it breeds there-hence, it would not be surprising to find it among the Near Islands.

We did not find the shoveler in the Aleutians, but on May 29, 1936, a male was seen among some other ducks in a pond near Ugashik River on the peninsula. Two specimens were taken by McKay near Nushagak, on August 14, 1881, and on September 24, 1882. Cahalane (1914) records 1 bird seen by him, September 7, 1940, on Brooks River, and Gabrielson observed 2 at Morzhovoi Bay, June 21, 1940--the westernmost point for which we have precise record.

The shoveler is scarce in the Aleutians and Alaska Peninsula, and it is comparatively scarce on other parts of the Bering Sea coast. The only place where we found them in considerable numbers was in the vicinity of Cordova, on the Copper River flats near the mouth of Eyak River. There, on May 16 and 17, 1937, we saw many of them engaged in courtship, evidently preparing to nest.

\section{Aythya americana: Redhead}

Attu: Ka-vé im'-much

The A. O. U. Check-List states that the redhead is a casual visitor on Kodiak Island, Alaska, and Friedmann (1935) mentions a specimen taken there by Rutter.

On June 16, 1936, I had a glimpse of a pair of ducks, identified as redheads, rising from a pond near the beach on Amukta Island. Upon arrival at Attu, Chief Hodikoff declared that a few ducks (like those in the picture of redheads that we showed him) nest on Attu and remain in winter. He gave us the native name, $K a-v$ 'e (head) im-much (round). He was certain of his identification.

At the time, we were concerned only with the redhead, but because of its similarity to the pochard, which occurs on the Pribilofs, it is possible that the Aleut chief was really referring to the Old World species, Nyroca ferina, and conceivably the birds that we noted on Amukta were also of that species. 


\section{Aythya valisineria: Canvasback}

In 1925 , I was told by a trapper that canvasbacks had been seen on Urilia Bay, on Unimak Island. It was thought at the time that he had confused the birds with some other canvas-backed type of duck. But the report is more plausible since Friedmann (1937) referred to this species-five humeri found in old middens at Dutch Harbor. The bird has also been recorded for the Pribilofs. No other records for canvasbacks were obtained.

\section{Aythya marila: Greater Scaup Aythya marila nearctica}

Attu: Han-o ka-vé-too

Russian, Commander Islands: Tschernik (Stejneger)

Four specimens of this species, which were breeding birds, were collected by Donald Stevenson at Izembek Bay in June 1925. On geographic grounds, also, the scaup of this region should be A. marila nearctica, rather than $A$. affinis. The American greater scaup was recorded from Kodiak Island by Friedmann (1935). Concerning this bird, Osgood (1904) says, "Scaup ducks, doubtless this species, were seen in small flocks along the Nushagak River September 4 to 9. McKay took them in May and July at Nushagak and Ugashik." And again, he says (1901), "a flock of six scaup ducks were seen on a pond near Tyonek September 17."

Cahalane records this duck on the Naknek River, where it was abundant, on September 28, 1940, and he found it to be common on Brooks Lake, September 9, though he did not see it in the more interior portions of the Katmai National Monument. He also said that they were fairly common in the liodiak-Afognak area.

On July 23, 1940, Gabrielson observed four broods of greater scaups on the Kvichak River. In later years, he saw them in numbers at Unimak, Atka, Kanaga, Unmak, Unalaska, Amchitka, Shumagin, Sanak, and Kodiak-Afognak Islands.

We saw two greater scaups near Chisik Island, Cook Inlet, May 7, 1936. On May 27-29, 1936, scaups were common, flying about in pairs, near Ugashik River. In June 1928, Jaques found them to be common near Port Moller. They were reported to be common near Chignik, maintaining their numbers better than other ducks in that vicinity.

In 1925, I found scaups nesting in Izembek Bay. About the middle of May of that year, there were small bands in St. Catherine Cove, at Unimak Island, swimming on the salt water or on the small ponds on the shore, sometimes segregating in pairs. In the mictdle of June, they were particularly common 
about Hazen Point, and they were seen elsewhere in Izembek Bay. On June 20, they were still flying about in pairs. On that date, a female was seen standing near a recently constructed nest cavity. On June 30,3 nests were found on small islands near Point Grant ; 2 of these nests contained 9 and 10 eggs respectively. The number of eggs in the third nest was not recorded. On July 26, a nest of seven eggs was found on a gull island.

Residents stated that scaups nest on Unimak Island.

Scaups were noted at intervals throughout the Aleutian chain. Four or five were seen near Nikolski, Umnak Island, on May 30, 1937; 7, mostly males, were seen on Corwin Lake on Atka, June 22, 1936 ; several were noted on Amchitka, July 1937; a flock of 30 was seen on a lake on Kiska, July 26, 1936 (where half a dozen were seen on June 4,1937) ; and several pairs were seen on Agattu Island in the middle of June 1937. Steenis observed four pairs and a female there, and other members of the party observed paired scaups. On June 15, 1937, on Agattu, I found a scoopedout nest cavity with a little down and some white breast feathers, which I thought to be a scaup nest. Austin H. Clark (1910) found this species to be rather common at Attu and Agattu.

Chase Littlejohn (manuscript notes) says, "Found breeding at Sanak, Ukamuk [Chirikof Island], and Morzhovoi Bay, each nest contained nine eggs. They congregate in large flocks in winter at Sanakh and remain so until spring, when they pair off and begin nesting."

The Attu chief assured us that scaups nest on Attu and winter there. On Kanaga Island, also, we were assured that scaups are plentiful in winter, and that they become very tame around the iock.

Taber found them wintering at Adak, and for Unalaska Island Cahn reports-

An abundant winter inhadicais of all the larger bays, in common with the Harlequin ducks and white-winged scoters. The greatest numbers occur in December and January, and the species disappears entirely in April as a rule; May 3, 1946 is the latest recorded date. It returns again a few at a time, in September and October, gradually ircreasing in abundance.

Sutton and Wilson found scaups wintering at Attu Island.

At Unimak Island, Narch 1, 1911, Beals and Longworth observed two rafts, of at least 1,500 scaups each, on Swanson Lagoon, and a trapper assured them that these ducks spend the winter there.

In several localities, mention was made of the scaup's habit of assembling near docks. In some cases, at least, fish offal appears 
to be the attraction. This was definitely reported to be the case at False Pass, where the ducks gather at the cannery docks during the fishing season.

\section{Aythya affinis: Lesser Scaup}

Friedmann (1935) lists the lesser scaup in the avifauna of Kodiak Island on the basis of osseous remains found in middens. We did not identify this duck on our expeditions, and we assumed that the scaups observed were of the larger form.

\section{Aythya fuligula: Tufted Duck}

Howland Wilson (1948) added this species to the list of Aleutian birds, bearing out our assumption that it could easily occur among the western islands. He reports seeing 2 males and 2 females in a little pothole, inland from Murder Point on Attu Island on May 23 and 24, 1945; he watched them for some time. and the "tufts of long, loose feathers which streamed down from the nape of each male" were noted in detail.

\section{Bucephala clangula: Common Goldeneye Bucephala clangula americana}

Attu: $H a-n o$ sakh-oi-a

Russian, Commander Islands: Gogol (Stejneger, referring to the closely related European form).

This may be the "whistler" amtátux, given by Jochelson, for which no dialect was mentioned.

Friedmann (1935) lists bones found in Kodiak middens, which he assigned to this subspecies on geographic grounds, and he mentions two specimens collected there by Fisher. On March 21, 1924, Laing (1925) observed three of these ducks at Uyak Bay of Kodiak Island.

Gabrielson noted that this duck is plentiful in the KodiakAfognak area in fall and winter; he found it in the winter at Unalaska, Umnak, Kanaga, and Atka, and at King Cove and Cold Bay in spring and fall.

I observed the goldeneyes in 1925 at Unimak Island. On April 29,1925 , I saw a pair flying over a lagoon at Urilia Bay, and on May 1, 1925, I saw a flock of about 10. On May 4, 1925, Donald Stevenson reported at least 200 on Peterson Lagoon. Identification could not be positive on all of these instances, but they were assumed to be americana on the basis of known distribution.

Friedmann identified a goldeneye humerus in middens of Dutch Harbor, and Laing (1925) observed nine goldeneyes at Unalaska, 
March 21 and 22, 1921; however, those were immature birds, or females, and identification of the species was doubtful. Turner, also, records this duck for Unalaska in December, and he says that it winters there.

Cahn reports the goldeneye for Unalaska Island, saying,

Strictly a winter visitor, present in considerable numbers but never in large flocks. Goldeneyes drift in by one's and two's in late October (October $24,1943)$, and are common in the larger bays during the period of December through February, at which time they disappear far more abruptly than they arrive. April 11, 1946, is the latest recorded date; this is unusually late.

Laing observed an unidentified goldeneye at Adak Island, and at Attu Island he positively identified two adult males that "were found ardently courting in a flock of six."

Taber found goldeneyes wintering at Adak Island in 1945-46.

When shown colored illustrations, the Attu chief picked out the common goldeneye and said it was plentiful there in winter, arriving in November and (he thought) leaving early in March.

Sutton and Wilson found them wintering at Attu. Stejneger (1885) reported that the European common goldeneye occurred at the Commander Islands in winter in small numbers.

Because there are so few specimens, and because racial identification cannot be ascertained in the field, it would be possible that the Old World form (keeping in mind that it is recorded from the Pribilofs) occurs in the western Aleutians and has not been detected. In the case of this form, we are leaning heavily on assuned geographical distribution.

\section{Bucephala islandica: Barrow's Goldeneye}

We saw several Barrow's goldeneyes at Seward, May 5, 1936; at least 12 at Port Chatham, Kenai Peninsula, on May 6; 2 at Chisik Island, Cook Inlet, May 7; and 1 male at Kodiak Island, May 13. Friedmann (1935) has given a number of records for Kodiak Island, and Gabrielson noted them in winter and fall at Unalaska and Kodiak-Afognak Islands.

With regard to the base of Alaska Peninsula, Osgood (1904) reported-

One was seen on the Nogheling River July 20, and one was killed there some days later; another was shot by W. L. Fleming on a small pond near the head of Lake Clark July 28. Several immature birds were killed at the mouth of the Chulitna River August 4. Rather common at intervals along the Chulitna River August 12 to 17; generally seen in family parties of 6 to 10. Near Swan Lake a flock of about 15 was seen feeding on a shallow lake in company with a flock of 10 swans. Seen almost daily in pairs or small flocks along the Malchatna and upper Nushagak September 3 to 6 . 
Cahalane (1944) found this duck "numerous in the upper portion of the Naknek River, September 4." They were also abundant in Amalik, Kaflia, and Kukak Bays on October 5 and 7. Hine (1919) considered it to be a common species in the Katmai Bay area, and he obtained a specimen there.

Thus, it would appear that the Barrow's goldeneye is confined pretty much to the basal part of Alaska Peninsula, adjacent island groups, and mainland areas as a breeding bird. The American common goldeneye, on the other hand, is the form generally encountered to the westward, as a migrant. There are no data to show that any goldeneye nests west of the more or less treecovered base of Alaska Peninsula.

\section{Bucephala albeola: Bufflehead}

Attu: Chirr-u-num Sakh-oi-a

Atka: Mith-i-mé-thruh

The bufflehead occurs sparsely throughout the Aleutian district. Friedmann's data (1935) show that this duck is rather common on Kodiak Island, and that it nests there. Osgood (1904) reports that "two specimens were seen at Cold Bay October 17 among some ducks killed on the bay by natives. One was taken at Nushagak by McKay, May 2, 1882."

We noted at least six buffleheads at Port Chatham, Kenai Peninsula, May 6, 1936. At Chignik, we were told that buffleheads are seen there in autumn. Gabrielson has seen them at Cold Bay, at the Shumagin Islands, and at Sanak Island.

We found two females in a pond at Ikatan Peninsula, Unimak Island, May 19, 1936. Beals and Longworth noted one at False Pass, March 7, 1941, and four on Ikatan Peninsula on April 15, 1941.

Turner (1888) says that this duck occurs in winter at Unalaska, where he obtained specimens, and he adds that they are rare to the westward, where they are present only in winter. Gabrielson found them in winter at Unalaska, Atka, Amchitka, and Umnak. Over a period of 4 years, Cahn saw only one bufflehead at Unalaska Island (on February 22, 1944).

Ray Clark, storekeeper on Umnak Island, said that butterballs (buffleheads) remain there in winter.

Wetmore (manuscript notes) says that R. H. Beck saw a pair of buffleheads in a pond back of Atka village on June 13, 1911; Laing (1925) saw "fully thirty-five" in a small lagoon on Adak Island on April 11, 1924. And Taber found the species wintering at Adak, where there were 32 birds noted in a census on January 13, 1946. 
The Attu chief stated that his island is within the wintering range of the bufflehead, but he insisted that they also nest on Attu, "up high."

Stejneger (1887) reports the bufflehead as "an accidental visitor during the winter of 1882-83" in the Commander Islands.

Incidentally, this bird is mentioned in a number of records for the Pribilof Islands.

\section{Clangula hyemalis: Oldsquaw}

Attu: Anǵ-lach

Atka : $A$-lang-ach

Unimak: Alg-nach'

Russian, Commander Islands: Sofka (Stejneger)

Russian, Yana region: Savka (Birula)

Chukchi: Pojgochek, male Achak, female (Palmén)

The oldsquaw is fairly common, especially in migration, and has been reported by most writers on southwestern Alaska. It occurs on Kodiak, and Osgood (1901) reports it from various places at the base of Alaska Peninsula and the Bristol Bay region. Einarsen (1922) reports several of these birds nesting near Ugashik in 1922. Laing (1924) counted as many as 200 at Dolgoi Island, March 23, 1921, and apparently he saw it in many other unidentified localities. He collected a specimen at Kodiak, March 21, 1924. Dall (1873) considered it to be abundant east of Unalaska.

We noted the bird at various points: 2 migrating flocks on the Gulf of Alaska, May 2, 1936; 150 birds at Chisik Island, Cook Inlet, May 7; a flock of 30 in Shelikof Strait, May 13; 1 bird in Nushagak Bay, May 23; and 2 birds on the flats at Ugashik River, May 27. They are said to arrive at Chignik "late in the fall."

The oldsquaw is common in migration along the Alaska Peninsula and adjacent islands, but we were unable to establish nesting records.

They are rather common in the Aleutians at certain seasons, especially in winter. In 1925, I found them to be numerous about False Pass in the latter part of April and in May. One was seen in St. Catherine Cove as late as May 20, but none was seen after that date. Beals and Longworth (field report) recorded them at False Pass and neighboring points on January 12, 13 , and 19, 1941, and they observed them daily through March and as late as April 10.

Wetmore (manuscript notes) saw 2 birds at Unalaska Island 
on June 7 and 11, 1911, and McGregor (1906) collected 1 female in worn plumage on July 20, 1901, at Tigalda Island.

Cahn often found them wintering at Unalaska Island; the earliest date was November 3, 1943, and the latest date was April 19, 1946. Taber found them wintering at Adak.

We did not see many oldsquaws in the Aleutians; however, at Atka Island we were told by the natives that they formerly had nested on that island, but not "since the foxes came." The natives said that these birds winter on Atka and Kanaga in large numbers. The Atka chief assured us that these ducks nest on Amchitka-he stated that although he had seen the young, he had not seen any nests.

Kiska Island appears to be one of the favorite localities for the oldsquaw. This island was mentioned by Dall as the western limit of its range. We saw several birds there as late as June 4 and 5, 1937, and Wetmore reported them to be fairly common near the entrance to Kiska Harbor, June 17 to 21,1911 . We also found oldsquaw remains in two bald-eagle nests on that island; oldsquaw remains were also found on West Unalga, and in eagle nests on Rat and Little Sitkin Islands.

Dall (1874) said that the oldsquaw was resident as far west as Kiska, but that it was not abundant. We learned from the Attu natives that it nests on Agattu and is abundant in the Near Islands in winter. This is substantiated by the report by Sutton and Wilson on Attu. The oldsquaws wintered there, and after March 4 they were observed courting. Turner (1886) said that few of these birds nested in the Aleutians, but that many of them wintered there. In 1887, Stejneger reported oldsquaws "breeding numerously on Bering Island." Gabrielson also observed them wintering as far west as Atka.

To sum up, Turner's statement (see above) applies very well to the Aleutian district as a whole.

\section{Histrionicus histrionicus: Harlequin Duck}

Attu: Kagh'-i-ach

Atka: Kagh'-a-thi-ga

Unalaska: Kanǵ-a-rich

Unimak: Kang-ath'-a-gich

Russian, Commander Islands: Kamenuschka (Stejneger)

This is the most abundant duck in the Aleutian Islands. We found harlequin ducks at practically every island that we visited, singly sometimes, generally in small groups, and occasionally in larger flocks. It is safe to say that, at one time or another, harlequin ducks occur at every island, large or small, from Uni- 
mak to Attu. Stejneger has reported them to be common in the Commander Islands.

They were also found east of the Aleutians-at Amak Island, at Izembek Bay, and at False Pass. In the Shumagin group, we observed them at Unga, Nagai, and Simeonof Islands. They were at King Cove, the Barren Islands, Afognak, Port Chatham on Kenai Peninsula, and at Seward. Osgood (1904) observed them along the Egegik River" and "about the mouths of the larger" streams that empty into Becharof Lake." He found them to be common at Kanatak and Cold Bay, and he mentions specimens taken by McKay and Johnson at Igushik and Nushagak.

Cahalane (1944) reported harlequins in large numbers in the general region of Katmai National Monument in the fall of 1940, and Hine (1919) considered them to be one of the most common ducks in the Katmai Bay area in the summer of 1919. Cahalane also recorded them as being abundant in the Kodiak-Afognak group in the fall of 1940, where Gabrielson noted 200 on June 16, 1940. W. Sprague Brooks (1915) observed them on April 19, 1913, at the Semidi Islands, and on April 22, 1913, he saw them at King Cove.

Although these birds occur on the north side of Alaska Peninsula, they are more common on the south side, which is more rugged. Evidently, these birds nest on Alaska Peninsula. On July 19, 1940, Gabrielson noted a pair flying along Kittiwake Creek, between Brooks and Naknek Lakes, and Friedmann (1935) states that Bretherton found them breeding in June on Kodiak Island. In the spring of 1925, I often observed two pairs along a stream just north of Aghileen Pinnacles, near the western end of Alaska Peninsula. Eventually, on June 3, only the males were seen; presumably, the females were nesting.

On July 16, 1911, Wetmore (manuscript notes) observed a female and a group of young in King Cove.

It is difficult to determine the status of the harlequin ducks in the Aleutians. The natives insisted that they nest along streams and that their nests are very hard to find. In way of substantiation, we found no nests and no broods of young. However, we found these birds on islands that had no suitable nesting streams. On the other hand, Austin H. Clark (1910) reported: "It was common about Atka, where 1 or 2 were seen inland on a small stream; on Attu and Agattu it was also numerous on the streams as well as along the coast."

Turner (1886) described a deserted nest on Unalaska Island, in a hollow formed by two blocks of rock. A native assured him 
that it was the nest of a harlequin duck. Here, again, our own experience was baffling. Though there were numerous cliffs and many available sites for nesting along the rocky shores, we saw no young brood throughout the two summers of observations.

Wetmore, however, had pertinent observations at Kiska Island in 1911, when he says (manuscript notes) that

some of them were already nesting along the base of a high rocky cliff, as they seemed very anxious while I was along there, those on the water whistling and swimming in small circles. I saw one or two females slipping quietly away from shore ahead of me, but flushed none from the beach itself.

Beals and Longworth found harlequin ducks wintering at Unimak Island, and stated that they nest there. Elsewhere in the Aleutians, natives said that they are more numerous in winter than in summer.

Stejneger (1885) found no evidence of nesting in the Commander Islands, and stated that the natives knew of no nesting.

From these various observations, it can be concluded that the harlequin ducks nest on the Alaska Peninsula, possibly rather commonly; that they also nest in numbers unknown in the Aleutian Islands; that immature birds, various nonbreeders, and males gather for the summer in these waters; and that they winter there in great numbers.

We had little opportunity to study food habits, and it must be assumed that, in the salt water, it consists of marine invertebrates. The teacher of the native school at Atka informed us that in the autumn of 1936, when there was a large run of salmon up the streams of Atka Island, harlequin ducks were seen on the streams, presumably feeding on salmon eggs. However, we have no certain data on this subject.

\section{Polysticta stelleri: Steller's Eider}

Chukchi: Kataadlin (Palmén)

This little eider of the Bering Sea region occurs abundantly along the Alaska Peninsula and the Aleutian chain at certain seasons-particularly in winter. It is recorded as far east as Kodiak, where Friedmann (1935) lists many specimens and observational records, including some bones from middens. Dall (1873) says it was observed in the Shumagins "in March, and in the summer months." The same writer (Dall 1874) reports them as wintering at Sanak Island, but he considered Unalaska to be the center of abundance for this species. He remarked upon the irregularity of their occurrence, because he had found Steller's eider, trgether with the Pacific eider, to be numerous at Unalaska 
in May 1872, however in May 1873 he did not see a single one of either species in that locality.

Osgood (1904) considered the Stellex's eider to be common about Bristol Bay, and he mentions specimens collected by McKay and Johnson at Nushagak and Ugashik. On October 4, 1940, Cahalane (1944) observed a group of 6 in Amalik Bay, and he saw 6 again (perhaps the same group) the next day. Gabrielson noted 2 males at Morzhovoi Bay June 21, 1940, and collected 1, which was not in breeding condition. In 1936, we observed several sizable flocks in Nelson Lagoon.

In 1925, I found this duck to be rather common in Izembek Bay. On May 17, 1925, there were small groups at St. Catherine Cove, Unimak Island, and on May 20 about 200 were seen there, as well as several bands offshore in Bering Sea. Several flocks, totaling at least 300 birds, were spending the summer in Izembek Bay; they used Glen Island, near its entrance, as their homeground. These were immature birds of both sexes, though there was an occasional one in adult male plumage. One male in adult plumage was collected on June 17. The testes were very small. None of the birds were seen on the adjacent marshlands, and there was no evidence of nesting.

Turner (1886) testifies to the presence of the Steller's eider among the Aleutians in winter, even to the western end of the chain. Stejneger (1887) said that they wintered in the Commander Islands in "countless numbers," arriving early in November and remaining until after the middle of May. Friedmann (1937) has recorded five humeri of this duck from middens on Little Kiska Island. Beals and Longworth observed them often in January, March, and April, 1941, and saw them as late as April 25, at False Pass.

Although we did not find the Steller's eider nesting, older records furnish rather good evidence of nesting on the Alaska Peninsula and Aleutian chain. A. C. Bent (1925) records some notes sent to Major Bendire in 1892 by Chase Littlejohn, which included a statement that "a few were nesting at Morzhovoi Bay in June." Dall (1873) writes of the pairing of these ducks at Unalaska and describes a nest found on Amaknak Island, May 18, 1872. It contained a single egg. Turner (1886) saw a few of these ducks at the western end of Attu Island in July 1880, and the natives told him that the species nested sparingly on Agattu Island.

Judging by the information available to us, we must recognize the strong probability that at one time the Steller's eider nested 
on Alaska Peninsula and Aleutian chain (though undoubtedly in small numbers), and that it wintered there in great numbers. It is also clear that there has been a great diminution in number's. On our two expeditions in 1936 and 1937, we were in the general region early enough to have observed these ducks before all of them had left their wintering grounds. We saw very few, and those that we saw were on the north side of Alaska Peninsula. We saw none in the Aleutian chain. We found the natives of Attu Island-who have had only limited contact with the white man-to be well versed in their local fauna, much more so than natives farther east. These Attu natives did not recognize pictures of the Steller's eider and declared that it does not occur there, even in winter. They could be mistaken; however, if we accept their testimony there must have been a great decline in numbers since 1880, when natives told Turner that these birds nest "sparingly" on Agattu Island.

A. C. Bent (1925) considers the principal migration route in the fall "southward along the Siberian coast of Bering Sea to their winter homes in the Kurile, Commander and Aleutian islands." It is probable that the migration along the Siberian coast is the greater one, but if the information furnished by the Attu Islanders proves correct (and since we know these birds do winter in the eastern Aleutians), it is unlikely that the Siberian birds go to the Aleutians. On the other hand, we now know that there are large nesting populations on the American shores-at Hooper Bay and Nelson Island-and we have observations pointing out that the eastern Aleutians and parts of Alaska Peninsula, even Kodiak Island, are the principal concentration points in winter. In view of these facts, we must conclude that there is also a southward migration down the Alaskan coast of Bering Sea to the eastern Aleutians and Alaska Peninsula, and that the majority of the birds wintering in the Aleutians nest on the Alaskan coast.

\section{Somateria mollissima: Common Eider Somateria mollissima v. nigra}

Attu: Kaf-segh'-ich, male

Chá-is, female

Kú-ku-toch, young

Atka: Ka-sam'-ich, adult (sex?)

Ku-ku-toch, young

Kasimax (Jochelson-dialect not given)

Russian (?), Copper Island: Pistrak (Stejneger)

Chukchi: Kupuken, male

Emngi, female (Palmén)

Common eiders were observed at practically every island of the 
Aleutian chain and are as universally distributed as the western harlequin duck, though not so abundant. Apparently, they are not plentiful on the Commander Islands, for Stejneger (1887) says that they breed in "very limited numbers in a few places on Copper Island, only occasionally flying over to Bering Island, round the shore of which a few may be seen in winter."

In the Aleutians, we saw these birds in small groups, generally paired, and they nest, or try to nest, throughout the Aleutian chain. Blue-fox raising has seriously interfered with nesting on certain islands.

Nesting of common eiders was determined for the following islands :

Attu-quite a number nesting on rocky islets in Massacre Bay.

Agattu-preparing to nest.

Semichi-nesting on islets in a lake.

Buldir-nesting on the beach (no foxes present).

Chugul, Little Kiska, Kiska-nesting reported by Wetmore in 1911.

Amchitka-nesting on offshore rocks and preparing to nest on beach.

Ogliuga-plentiful, many young birds seen.

Aiktak, Kavalga, Ulak, and Tanaga-nesting reported by Gabrielson.

Little Tanaga, Kanaga, Adak, Aso, Igitkin, Salt, Atka, Chuginadak.

Baby Islands-nesting on Adokt and Excelsior (no foxes present).

These are the nestings actually observed. The birds were observed at many other islands, where they were probably nesting. Were it not for the predations of introduced blue foxes, they undoubtedly would nest on practically all islands.

In 1925, I found nesting groups in Izembek Bay, Alaska Peninsula (particularly on Glen Island and islets near Point Grant), as well as on a gull island far nut in the bay. On May 22, 1936, we found flocks of common eiders in Nelson Lagoon, and in one place I counted 111 males on the beach. Residents said that they nest abundantly on some grass-covered sand islands there. Osgood (1901) mentions a young bird and a set of eggs secured by T. H. Bean in July 1880 at Chugachik Bay (Kachemak Bay). In 1936, we saw them in Ugashik River, but we did not remain long enough to determine their nesting status.

Thus, we have a fairly accurate and continuous record of nesting from Bristol Bay westward to Attu Island. 
On the south side of Alaska Peninsula, our observations are more scattered. Common eiders are known to nest as far east as Kodiak, and at Chisik Island, in Cook Inlet, we observed at least 12 pairs in the spring of 1936 . The local game warden assured us that they nest on Duck Island nearby, and on May 13, 1937, several common eiders were seen in Icy Straits-the farthest east that we had observed this species. Mrs. Frank C. Hibben (1942, p. 182) found them nesting in Glacier Bay, the most easterly nesting record for southern Alaska.

Gabrielson observed about 12 common eiders at Kodiak on June 14,1940 ; at least 40 birds and 1 nest were seen in the Semidi Islands on June 18; and a few were seen at Morzhovoi Bay on June 21.

As might be expected, companies of immature birds (nonbreeders) spend the summer in the waters along Alaska Peninsula and the Aleutians. Furthermore, this is the principal wintering ground for the species; they do not venture farther south in any great numbers.

\section{Nesting Habitat}

These eiders utilize a variety of nesting sites. Probably they would prefer low islands of gentle slopes (such as the sand islands of Izembek Bay), where they can nest in the grass. In such places, they nest both on the slopes and on the beach. Similar situations may be found in the Aleutians-the beach of Buldir Island is an example. There are few places in the Aleutians where they can nest with safety on the principal shorelines because of the introduced blue fox. We found a few birds nesting on the shores at Amchitka and Agattu, but, being adaptable, they now seek the grassy tops of offshore rocks and pinnacles, or islands in lakes, where they are protected by water. The natives assured us that they also nest on ledges of sheer cliffs, where foxes are unable to climb.

\section{Mortality Factors}

The blue fox is probably the most potent predator that the eiders face in the Aleutians. In addition to this introduced enemy, the northern bald eagle also obtains an occasional eider, but apparently it does not prey extensively on the species. In a total (taken during three seasons) of 466 food items that were identified in 32 eagle nests and at a few perching places, only 8 common eiders are represented. In one of these instances, the eider had a nest within 10 feet of an eagle's perch, and it was to be expected that the eagle would eventually seize the bird. It is surprising that so few eiders are taken by the eagle, because this duck does not 
appear to be agile on the wing and is present everywhere. Probably the great variety of "sea birds" attract the eagle's attention more readily.

Gulls and ravens are another potent factor in stabilizing the eider population, because they prey on the eggs and young. The raven is included here solely on the basis of fragmentary observations elsewhere. But the glaucous-winged gull was observed at times to be active in raiding eider nests. There is an interesting relationship here that has been noted frequently. Gulls and eiders often nest on the same area. Presumably, this should give the gulls a better chance to rob the nests of their duck neighbors; however, it does not appear to be that simple, and the situation deserves careful study. Assuredly, upon entering such a mixed nesting colony, one finds a number of eider nests already rifled; yet, many others have not been disturbed. It is noticeable that human intrusion, which forces the eiders to leave hurriedly without covering the eggs, gives a splendid opportunity to the first passing gull, and the gulls readily take advantage of it.

In 1925, in Izembek Bay, I found eiders nesting in the midst of a gull colony and found others nesting in a colony of terns. All these birds seek the same type of nesting terrain, regardless of neighborly problems. During that season, an effort was made to reduce the hazard for nesting eiders by carefully covering the disturbed nest with down, just as the bird would have done. So far as the results could be observed, this method was effective. One will sometimes find gull and eider nests in amazingly close proximity, apparently with no detriment to the eider.

After being hatched, the small duckling still faces danger from the gulls. A number of decimated broods were seen, and sometimes, as observed at Ogliuga Island, several families then join together in a band.

But in spite of all these nesting hazards, the eiders hold their own-they occupy the entire Aleutian district in fair numbers and are plentiful enough to utilize whatever nesting sites are available to them.

\section{Somateria spectabilis: King Eider}

Attu: Sakh'-uch

Sákux (Jochelson)

Russian and Yukat, latitudes of the Yana: Turkan (Pleske)

Chukchi: Jekadlin (Palmén)

Information on the king eider is incomplete. We know that it spends the winter among the Aleutian Islands, the Shumagins, along the Alaska Peninsula, and as far east as Kodiak, where 
Friedmann (1935) has recorded specimens taken and many bones found in middens. He also found many bones in middens of Dutch Harbor and Little Kiska. In the wintering season, Gabrielson found this eider at various points from Kodiak to Unalaska, and Hine (1919) obtained specimens near the mouth of Katmai River on June 25, 1919. Though we have relatively few published reports of king eiders from the winter range, these ducks must occur along the Aleutians and Alaska Peninsula and the adjacent seas in large numbers, judging by the striking northward migration we observed at Hooper Bay in the spring of 1924.

The Attu chief appeared to recognize this duck; he gave us a name for it and stated that a few of them nest at Attu Island and that a few winter there.

Judging by the relatively large number of bones found by Herbert Friedmann in the middens at Dutch Harbor and Kodiak, and considering the statement of the Attu chief that only "a few" winter there, the king eider evidently assembles in the greatest numbers among the eastern Aleutians and along the Alaska Peninsula. In 1925, I was told by local residents that many of these ducks winter at Isanotski Strait and at Wide Bay. Beals and Longworth (field report) observed king eiders at Isanotski Strait, Ikatan Peninsula, and at neighboring areas at intervals from early January to the latter part of May 1941; their numbers began to diminish in May, and at the end of May practically none were left. Four specimens were collected on January 13 and 24 and March 6.

In winter, Cahn found the king eider to be more common than the common eider at Unalaska Island, and he says,

present from early December to early March, usually in small flocks of three to six, or solitarily. Dec. 2, 1945, is the earliest record; April 3, 1944, the latest. The gizzard of a female found dead contained two specimens of the snail Callistoma.

Though we do not have nesting records for the Aleutians-the Attu chief's statement about their nesting on that island may properly be questioned-a number of king eiders spend the summer near Alaska Peninsula. In 1925, I observed a flock of about 200 birds (females and immature males) that spent the summer at Glen Island in Izembek Bay.

\section{Lampronetta fischeri: Spectacled Eider}

Information on this eider is disappointingly meager for the area under discussion. We saw none during the course of our expeditions to the Alaska Peninsula and the Aleutians. They are 
considered to be winter residents there, and A. C. Bent (1925) says they occur sparingly east to Sanak Island. Friedmann (1934) records a humerus from native-village middens on Kodiak Island. Dall (1873) records it as rare at Unalaska as a winter visitor, leaving there in May for northern nesting grounds.

Surprisingly enough, Turner (1886) says "This species occurs among all the Aleutian Islands, where it breeds and is a constant resident, but extremely shy." This certainly is not the case today. Dall's statement, above, would seem to be more credible.

\section{Melanitta deglandi: White-winged Scoter Melanitta deglandi dixoni}

Attu: Tru-pan-ach (obviously of Russian origin)

Atka: Ta-mu-ghá-luh

Russian, Commander Islands: Turpan (Stejneger)

The Kancidgix of Jochelson (dialect not indicated) may possibly refer to this duck.

White-winged scoters have always been common along the southern Alaskan coasts in spring migration, and in the course of several voyages they have been noted regularly in late April and early May along the southeastern Alaskan waters, as well as farther west. In 1936, we noted a few at Seward on May 5; at least 20 were noted at Port Chatham, Kenai Peninsula, on May 6; a few individuals were seen among the Barren Islands, May 10 and 11; and several were noted at Kodiak. They were common in Kupreanof Strait on May 13.

In the fall of 1940 , Cahalane found that scoters were numerous in the Kodiak-Afognak area. Early in September, he found them to be abundant in Naknek River, but none were seen by the end of September. He says (1944), "On the Pacific side of the area scoters were very numerous during the first half of October. They were 'abundant to very abundant' along the entire mainland coast from Katmai Bay to Point Nukshak."

On June 16, 1940, Gabrielson noted 100 scoters near Whale Island.

Osgood (1904) observed a flock of six scoters on Neekahweena Lake, about halfway up the Chulitna River on August 14.

Chase Littlejohn, referring to the area between Kodiak Island and the west end of Alaska Peninsula in 1887-88, wrote, "Seen often during winter. I saw a number of birds at Ukanuk in summer where I am sure they breed but for want of time I did not succeed in finding their nests."

In 1936, we found these ducks to be abundant in Nushagak 
Bay on May 26, and we observed several on lower Ugashik River on May 27 to 29.

Jaques (1930) noted them as abundant in southeastern Alaska, May 1 to 9, 1928, and saw a few about Port Moller, May 22 to June 2, 1928.

In 1925, I found them about the western end of Alaska Peninsula: At King Cove, April 25; plentiful at False Pass, April 28; a flock in Bering Sea near St. Catherine Cove (Unimak Island), May 17; and a few near Izembek Bay, May 20. As late as July 27 a few (possibly nonbreeders) were found along the coast in the vicinity of Izembek Bay.

We did not observe white-winged scoters in the Aleutians west of Unimak Island, but Wetmore (manuscript notes) reported "a great raft" of these birds at Tanaga Island, June 25, 1911, and he noted small flocks in Kiska Harbor, June 17-21, 1911; Gabrielson noted a few at Akun, July 9, 1941.

A. C. Bent (1925) suggests that the species may possibly breed in the Aleutians, basing his conjecture on these summer observations. This is possible, not only in the Aleutians but also on the peninsula, especially before the introduction of blue foxes on the islands. However, we have no nesting records for this entire district.

According to general information and statements of natives, white-winged scoters winter in large numbers in the Aleutians and along the Alaska Peninsula. In 1941, Beals and Longworth (field report) recorded these ducks at intervals from January 12 to June 12 in the region about eastern Unimak and the adjacent Alaska Peninsula, and Gabrielson recorded wintering birds from Kodiak to Unimak.

Cahn (1947) writing of Unalaska Island, says: "An abundant fall and winter visitor, especially from December to February." And Taber (1946) found a few of these birds wintering at Adak. Sutton and Wilson (1946) observed one scoter at Attu, March 17, 1945.

G. H. Mackay in 1891 (quoted in Bent 1925) gave an interesting account of a mass migration of white-winged scoters to their nesting grounds, as observed in Rhode Island. He stated that it generally took place about the middle of May and that the daily flight was begun in the afternoon.

We observed a similar occurrence on the other side of the continent when we visited Nushagak Bay in 1936. As we went up this bay on May 23, we saw large numbers of white-winged scoters assembled there, some of them flying about in pairs. The following is quoted from our field report; 
On the evening of May 26, as we were going back out through Nushagak Bay, we observed flock after flock of white-winged scoters flying high in the air in goose-like formation, all heading up the bay in a general 'inland' direction. Some flocks contained 75 or 100 birds. It appeared that we were witnessing a movement, en masse, from a temporary salt-water meeting place to the inland nesting grounds.

\section{Melanitta perspicillata: Surf Scoter}

We observed this bird in considerable numbers in the spring, on the way to the Aleutians, along the coast of southeastern Alaska. They (apparently all males) were particularly numerous on the south side of Millbank Sound on April 25, 1936. One large flock arose from the water and strung out for a mile. It must have contained at least 1,000 birds. There were other smaller flocks. We saw 4 or 5 of these birds at Port Chatham, Kenai Peninsula, on May 6, whicl was the last sighting.

Surf scoters are known to occur at Kodiak Island. Cahalane (1944) says: "All of the surf scoters seen were on the Shelikof Strait coast of Katmai National Monument, Oct. 4 to 7 . They were 'common' in Kinak Bay, but were abundant from Katmai to Amalik Bay and in Kaflia and Kukak Bays." Gahrielson also observed them at Kodiak in early spring and fall.

Laing (1925) observed these birds in spring as far west as Dolgoi Island, south side of Alaska Peninsula, but he saw none west of there.

On July 23, 1940, Gabrielson noted four old males up the Kvichak River, and in winter he saw a few at Unimak.

Wetmore (manuscript notes) reported, "A small flock of scoters, that I took to be this species, was seen June 4 in Lost Harbor, on Akun Island, and others were seen June 10 and 11, in Chernofski Harbor (Unalaska Island)." He reported none west of that point.

Da!l (1873), referring to the surf scoter under the name Melanitta velvetina, says: "Killed Oct 27th, 1871, at Unalaska, and noticed at intervals there during the winter. It was not seen at the Shumagins, though it may occur there. A winter visitor."

Beals and Longworth reported a single male as False Pass on March 1, 1941, remarking that they saw this bird on several occasions.

Cahn observed 3 scoter's at Captain's Bay, Unalaska Island, April 3, 1943, and saw 1 on March 16, 1945; Taber saw 1 at Adak, December 14, 16, and 23, 1945. 
Austin Clark (1910) reports that "A few were seen at Attu and Agattu."

Turner is the only observer who states that the surf scoter is "common among the Aleutian Islands," and is "abundant" in winter. He also says that "The surf duck is the svestu'n or whistler, of the Russians." There is much confusion in Turner's account. While the surf scoter does make a whistling sound with its wings, the vocal whistling is so characteristic of the common scoter that if any 1 of the 3 scoters should be so designated, it should be Oidemia n. americana. If sound of wings is the criterion, then deglandi is outstanding. Furthermore, Turner (1886) says of $O . n$. americana, "The male is noted for the gibbosity of pinkish-white near base of bill; the lower edge of the swelling is deep red, gradually blending with the black of the rest of the bill." Assuredly, this fits perspicillata and not americana, and testifies to Turner's confusion on these species.

In any case, the surf scoter is comparatively scarce today in the Aleutians.

\section{Oidemia nigra: Common Scoter \\ Oidemia nigra americana \\ Attu: Hoo-vai-ach \\ Atka: Koo-ghang-ach \\ Russian (reported at Unimak): Swiss-toon (No doubt the svestun applied by Turner to perspicillata.)}

Laing (1925) observed the common scoter at Kodiak, March 21, 1924, and Friedmann (1935) has recorded a number of specimens from Kodiak Island, though we do not have nesting records from there. Cahalane (1943) noted a small number of these birds in Viekoda Bay in the fall of 1940, and he saw a larger number in Uyak Bay. He also reported that this scoter was numerous in the fall of 1940, along the coast from Katmai to Amalik Bay, but he reported that noticeably fewer birds were seen north of this area. A few were noted in Kaflia and Kukak Bays.

Osgood (1904) reported a few broods of young on ponds near Lake Clark, and he adds "Females with young were also seen occasionally along the more sluggish courses of the Chulitna River."

On July 19, 1940, Gabrielson noted adults on Naknek River, and he saw a female with three young on a small lake at Egegik. On July 23, he noted three broods up Kvichak River and noted the species again near Iliamna Lake on July 24 to 26.

On May 23, 1936, we noted 15 or 20 males among large numbers 
of white-winged scoters in Nushagak Bay. These probably were migrants. On May 29, several flocks were flying about at the mouth of Ugashik River, and on the adjacent marshes two pairs were discovered among the ponds, the males whistling. Apparently, these birds were preparing to nest.

Jaques (1930) observed them "about Moller Bay and on freshwater pools on the tundra, May 23 to June 20-not common." This, too, suggests nesting.

In 1925, I saw this species at the western end of Alaska Peninsula-a flock of both sexes at King Cove, April 25, and a few at False Pass on April 28. On June 13, small bands were flying about on Izembek Bay, whistling. By June 20, the birds were generally paired; on June 13, a female, taken for a specimen, contained a perfectly formed, hard-shelled egg. There can be no question about these birds nesting at Izembek Bay, chiefly at Hazen Point.

At Unimak Island we were told that this duck nests at Swanson Lagoon, which would be expected.

Laing (1925) observed this duck at Dolgoi Bay, March 23, and says: "From Unalaska, where twenty-five were seen on March 26, the species was present in most of the harbors as far as Hitokappu in the southern Kurils, May 7. It was noted at Copper Island, Oest, Kamchatka, or Petropavlovsk." This statement indicates that it was noted along the Aleutian chain.

Bishop (1900) recorded a number of these ducks off Unalaska, October 5, 1899.

The Atka natives stated that this scoter winters sparingly in the Aleutians, while the Attu natives said that it was abundant there in winter. This is also borne out by Gabrielson's observations on wintering bircts from Kodiak to Atka.

Beals and Longworth noted common scoters quite often in various places about the east end of Unimak Island from January 19 to June 12, 1941.

Cahn (1947) reported for Unalaska Island: "Common in very large flocks in all the major bays from December to February, inclusive." Taber (1946), writing of Adak for the winter of 1945-46, states, "This was the most common bird of the area; it was seen in groups of 2 to 70 on the salt lagoon and the open sea." Sutton and Wilson (1946) found it wintering commonly at Attu.

Bent (1925) records this bird as nesting in the Aleutian Islands; this is verified by the A.O.U. Check-List (fourth edition). It is possible that both statements are based on Turner's account. 
But, considering (1) the apparent confusion of the three scoters by Turner (shown by his description and misplacement of the Russian names); (2) that Bent and his party did not observe it nesting there in 1911 ; (3) that we did not find any evidence of it nesting there on expeditions throughout the chain, when all islands were examined; and (4) that none of the Aleuts reported it nesting; then we must conclude that nesting of the common scoter in the Aleutian Islands as a whole must remain in doubt.

\section{Mergus merganser: Common Merganser \\ Mergus merganser americanus}

Attu: Chu-vai-ach, Siss-uch

Tan-num-ak-tum sak-oi-a

Chunǵ-ung-é-koo-loo-ghearch

Ha-Ka chai-ri-too

Russian, Commander Islands: Bolschoj Krachal (Stejneger)

Friedmann (1935) records a number of specimens from Kodiak, as well as a number of eggs, which he said to be those of the common merganser, and he quotes Bretherton as saying that this duck nests on Kodiak.

Osgood (1904) had very little information on this merganser for the base of the Alaska Peninsula, but he mentions an adult male killed at Becharof Lake.

Cahalane (1944) observed several on the Naknek River on September 4, 1940.

Jaques (1930) found flocks of these ducks (most were males) near Port Moller in late May and June, but he saw no sign of nesting.

In 1936, we were informed by residents at Chignik that two kinds of mergansers occur there.

A number of records of occurrence are available for Unalaska, probably because it has always been a prominent port where vessels put in during voyages through that region. Dall (1873) said several specimens were taken there on December 20, 1873, and he adds that none were seen in the Shumagins. Turner says they winter at Unalaska, but do not breed there. Eyerdam (1936a) reports that two birds were collected at Unalaska on June 10 and August 6, 1932.

We saw no common mergansers in the Aleutians. The chief of Attu Island, who furnished the series of names for this bird, said that a few common mergansers nest there but that they are more numerous in winter.

To sum up, the common merganser occurs sparingly from 
Kodiak to Attu; the best evidence of nesting comes from Kodiak Island; and (possibly) it nests on Attu Island. We know that it is an inland form-more so than $M$. serrator.

\section{Mergus serrator: Red-breasted Merganser Mergus serrator serrator}

Attu: Cruch-ah'-lich

Atka: A-ga-lai-ahh

Agláyax (given by Jochelson as applying to two species)

Russian, Commander Islands: Krakhal (Stejneger) (The Attu name is undoubtedly a corruption of the Russian.)

This is the commoner merganser of the Aleutian district. It breeds on Kodiak Island (Friedmann, 1935), and Cahalane (1943) found it generally very abundant in the Kodiak-Afognak group in 1940. He also observed it in various places in the Katmai region, where Hine (1919) also reported it to be common.

Osgood (1904) found it "exceedingly abundant on all the lakes and rivers" visited at the base of Alaska Peninsula, and he mentions seeing broods of young on Iliamna, Chulitna, Kakhtul, and Nushagak Rivers. He remarks, "From start to finish probably more mergansers were seen than any other species of water bird, with the exception of the large gulls."

Gabrielson also noted this duck in 1940 on the rivers tributary to Bristol Bay. There were at least 50 broods of young, in all ages, on the Kvichak River, July 23.

This merganser was reported as common at Chignik, and Jaques (1930) found it paired on King Salmon Creek, near Port Moller after June 11, "possibly breeding."

On May 26, 1936, we saw two females in Nushagak River at Snag Point, and a pair was seen back on the marshes among the lakes near Ugashik River, where they probably nest.

In 1925, I found this merganser nesting about Izembek Bay, and, on May 25, 1925, 4 were seen on a mountain stream below Aghileen Pinnacles. (On May 4, and on several subsequent days, red-breasted merganser's were noted at Urilia Bay, on Unimak Island.) On July 5, a nest with six eggs was found on a small island near Point Grant, and another nest was found on a little island far out in Izembek Bay, in the midst of a colony of glacous-winged gulls. Red-breasted mergansers with molting wing feathers were seen late in July.

Chase Littlejohn, in 1887-88, said that this duck breeds at Sanak and at Morzhoroi Bay, where they remained all winter.

McGregor (1906) found three nests on Round Island, Beaver Inlet, Unalaska Island, July 4, 1901. On June 3, 1936, we saw 
six of these mergansers at Unalaska--Wetmore also had observed them here on June 6 and 7,1911 , and had collected a specimen.

At Unalaska Island, Cahn (1947) found a brood of 9 young in the Makushin Valley swamp, June 23, 1944, and he observed a brood of 11 downy young on Coxcomb Lake, July 4, 1945.

On August 15, 1937, we flushed a female from a grass-topped islet off the shore of Amlia Island. We had found 3 pairs on Kiska Island, June 4 and 5, where Wetmore had seen 1 pair in .June 1911. We found a foot of red-breasted merganser in an eagle's nest on Buldir. On June 17, we saw a flock of 7 at Semichi Islands; 6 were noted on Amchitka Island. Incidentally, Dall (1874) had reported that Amchitka was the only place in the western Aleutians where this species had been observed.

In 1936, we noted a flock of seven red-breasted mergansers on Corwin Lake, Atka Island, June 22. Several were seen on Kanaga, June 29, and eight were seen in a lake on Kiska, July 26. At Adak Island, July 3, two were seen in Bay of Islands, and three or four in Kuluk Bay. June 26-27, 1911, Wetmore found them to be fairly common in the small lakes back of Bay Waterfalls, Adak Island, where he found a brood of nine downy young about a week old-he suspected that there was a brood in another lake. And on September 3, 1944, Gabrielson found a brood on Amchitka, thus definitely establishing a nesting record for that part of the Aleutian chain.

The Attu chief said that these ducks nest on Attu, and Atka natives reported them nesting on their island. Turner also reported them nesting on Atka.

We can definitely state that the red-breasted merganser nests from Kodiak to Attu, and, according to Stejneger (1885), it is a very common breeding bird in the Commander Islands.

Apparently, it winters in the Aleutians also (though perhaps in small numbers), because Taber (1946) observed them at Adak from December 9, 1945, to January 13, 1946.

\section{Family ACCIPITRIDAE}

\section{Accipiter gentilis: Goshawk Accipiter gentilis atricapillus}

The goshawk occurs on Kodiak Island, as shown by specimens recorded by Friedmann (1935). Harrold saw one on Sitkalidak Island, near Kodiak, in May 1927 (Swarth 1934). Howell (1948) found a goshawk nest July 9, 1944, located in a 35-foot spruce at Middle Bay, Kodiak Island-there was a single young, which flew 
from the nest. Osgood (1901) saw goshawks flequently near Tyonek, and two immature birds were collected. Osgood (1904) again reported a goshawk at lliamna Pass, July 13, 1902, and several immature birds were observed repeatedly at the mouth of Chulitna River. Later, he observed the species at Nushagak.

This sums up normal distribution of the goshawk in the region under discussion, though on August 15, 1946, Gabrielson recorded one at Dutch Harbor, and, on August 20, he noted another at Simeonof Island in the Shumagins. Ordinarily, the goshawk is confined to the Kodiak-Afognak area and the base of the Alaska Peninsula-the regions that contain the forested areas.

\section{Accipiter striatus: Sharp-shinned Hawk Accipiter striatus velox}

Friedmann (1935) records a specimen collected by Bischoff on Kodiak Island, March 10, 1869. Osgood (1904) reports seeing a sharp-shinned hawk on the Mulchatna River, September 3, 1902; apparently, these are the only records for the area here considered-this bird sharing the forested areas with the goshawk. But Swarth (1934) reports a specimen taken on Nunivak Island, north of the area here considered, on September 14, 1927. This bird was found among the boulders on the shore, far from any forest, which is a most unusual occurrence.

\section{Buteo lagopus: Rough-legged Hawk Euteo lagopus s.johannis}

We observed the rough-legged hawk at Kodiak and Afognak Islands. Friedmann (1935) has recolded a number of specimens in both light and dark color phases from Kodiak, and he mentions Bretherton's statement that this species nests there. Osgood (1904) reports a nesting pair on an islet in Lake Clark, and he observed one bird near the mouth of Chulitna River and another on the lower Nushagak. McKay took a specimen in 1881 on the Aleknagik River.

Cahalane observed these hawks on the west side of Alaska Peninsula, on Naknek River and Three Forks, in September 1940, and, in the same year, Gabrielson noted one at Kodiak, June 14, and one at Dillingham, July 17.

Gianini (1917) observed these hawks nesting in "fair numbers," in Stepovak Bay, in 1917. In 1911, Wetmore found them to be fairly common near Frosty Peak, and he noted one at Unalaska.

In 1925, I found a number of nests on cliffs about Izembek 
Bay and at least 4 nests on Amak Island, and I noted five or six hawks on Unimak Island. In 1936, when our party visited Amak Island very briefly, two rough-legged hawks were noted there again. They occur also in the Shumagins, because we saw one at Unga Island.

Rough-legged hawks have been noted by various ornithologists in the Fox Islands group. We saw them on East Unalga, Un-

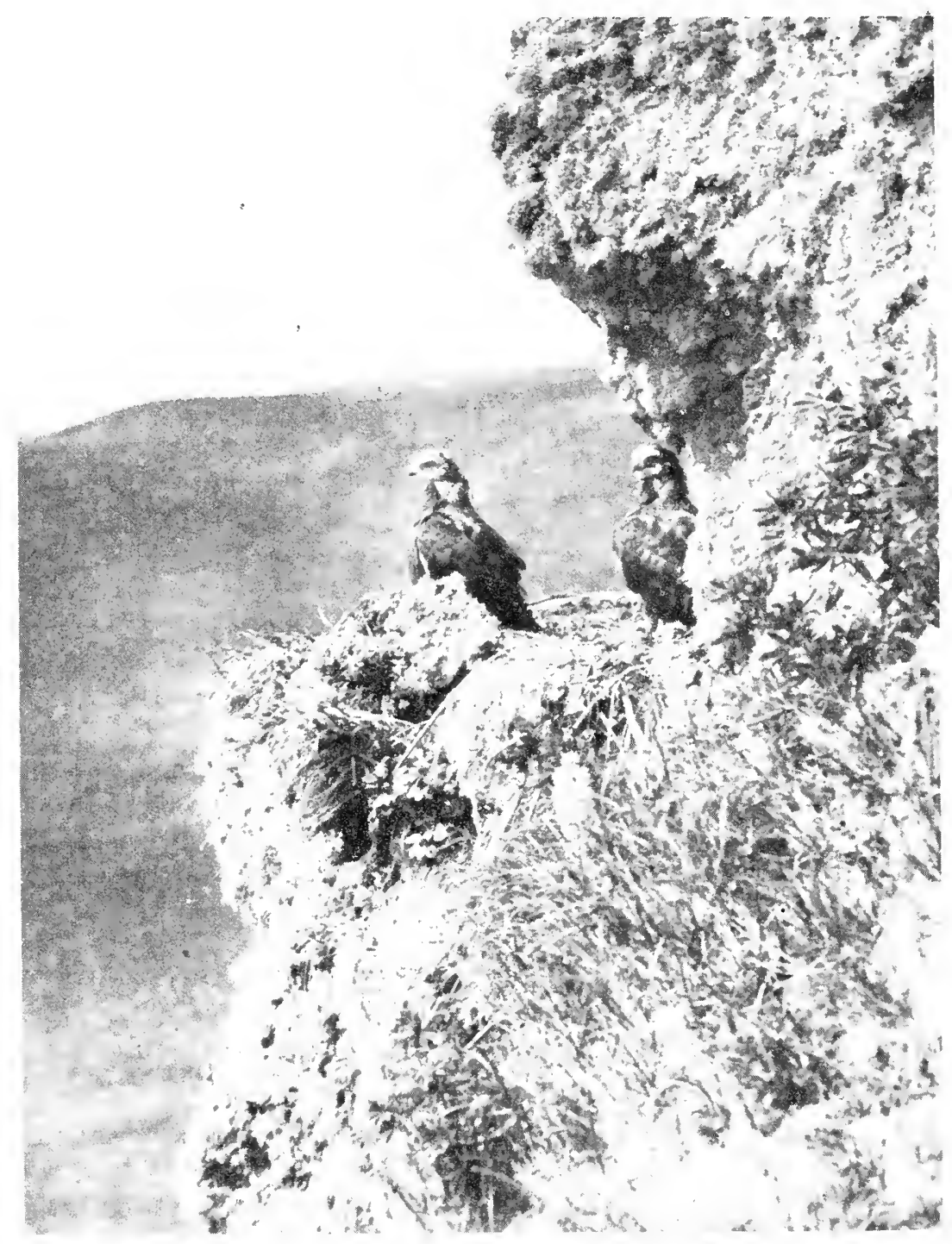

FIGURE 25.—Rough-legged hawk. 
alaska, Umnak, and Ananiuliak (the last is a smaller island off the west end of Umnak). Swarth (1934) reports that these hawks were seen almost daily on Akutan from May 17 to June 13, 1927, by Harrold, nesting and in both color phases. He also found this species nesting at Unalaska.

Our own observations, and the published record, show that rough-legged hawks nest along the Alaska Peninsula and on suitable offshore islands, and westward in the Aleutians as far as Ananiuliak Island-but no farther. It is significant that this breeding range coincides exactly with the distribution of rodents, for no rodents originally occupied the Aleutian Islands west of Ananiuliak. Rats and ground squirrels have been introduced on a few islands to the westward, but eviclently these introductions have not yet affected the original distribution of the roughlegged hawk.

Rodents constitute the chief item in the diet of these hawks, as was verified by a number of observations. Speaking of the area about Frosty Peak, Alaska Peninsula, Wetmore reported in 1911: "The thousands of ground squirrels (Citellus) here furnished them an abundant food supply as the crops of those taken testified."

On Amak Island, in 1925, I found a quantity of mouse fur, three Microtus, and the wing of a Savannah sparrow in a roughlegged hawk's nest. Microtus amakensis is the only rodent there. The stomach of a female hawk collected by Harrold on Akutan Island contained two field mice Microtus.

Stejneger (1885), speaking of Archibuteo lagopus, said that it was occasionally seen in the Commander Islands, and he thought that it might become established there, because mice had been introduced.

\section{Aquila chrysaëłos: Golden Eagle Aquila chrysaëtos canadensis}

Both Turner and Dall reported the golden eagle to be abundant in the Aleutians. Austin H. Clark (1910) reported: "I observed this species once on Unalaska and sereral times on Atka, where it appears to be rather common."

Chase Littlejohn (manuscript notes), speaking of the area from the southwest end of Kodiak Island to the end of Alaska Peninsula, including adjacent islands, says,

Saw quite a number of these fine birds but only obtained one, which was unavoidably lost to my collection. He was caught in a steel trap. A couple 
of days before, he had killed and eaten a silver fox which was in a trap. It seems he returned to pick up the fragments and was himself caught. He measured nine feet from tip to tip.

The exact locality was not given.

In 1936, Douglas Gray and C. S. Williams saw an eagle at Unalaska, which they described as having considerable white on the tail, but with a terminal clark band. This assuredly suggests that the bird was a golden eagle. At Chignik we were told that one had been killed there, but we did not see the specimen.

Cahn (1947) writes, "While probably not rare in the higher and wilder parts of Unalaska Island, this species is uncommon around Dutch Harbor. Two records in four years: June 17, 1944, over Mt. Ballyhoo, and August 7, 1944, sitting atop a mast on a ship anchored at a dock."

Osgood (1904) refers to a specimen that was supposed to have been collected by McKay at Nushagak, but he was unable to find it in the National Museum collection.

Friedmann (1937) found a sternum of this species in midden material from Kodiak Island-the only record for that locality.

Thus, we have quite a number of records (mostly based on observations); however, authentic specimens are rare. It is a little difficult to conceive of the golden eagle as abundant in the Aleutians, in view of observations dating back to the time of Turner and Dall, but there seems to be ample evidence to conclude that at one time the bird was more common that it is today. It is now only an occasional straggler in the Aleutian Peninsula region.

\section{Haliaeetus albicilla: Gray Sea Eagle}

Friedmann (1935) records osseous remains of the gray sea eagle from village middens on Kodiak Island. Bishop (1900) reported the first record of this bird for North America- a young female that was found dead at Unalaska, October 5, 1899. Again, in 1905, he records a specimen that was taken at Vancouver Island, March 18, 1898.

Eyerdam (1936) says, "Several of these birds were seen on Unalaska Island on May 25th and May 30th. One was killed near Dutch Harbor by a seaman from one of the coast guard cutters, who kept the claws, tail and wing feathers for souvenirs." It is unfortunate that a specimen was not saved, since it is rather remarkable to casually see "several" of a species so rare in North America. 
Cahn (1947) reports seeing one of these birds at Dutch Harbor on May 16, 1945, and he reports that he watched it under favorable circumstances for 10 minutes. Sutton and Wilson, at Attu, watched two dark-headed, white-tailed eagles, identified as this species, on March 15, 1945.

We did not see this bird on any of our expeditions. A number of times we thought that we had sighted one, but each time it proved to be a bald eagle in one of its immature plumages. These plumages can be confusing, and we felt that records of the gray sea eagle should be based on specimens.

\section{Haliaeetus leucocephalus: Bald Eagle}

\section{Haliaeetus leucocephalus alascanus}

Attu: Tirrǵh-luch

Atka: Tiǵ-a-lach

A-waich'rich (immature)

Alaska Peninsula: Tikh-lukh (Wetmore)

The bald eagle is commonly distributed throughout the length of Alaska Peninsula and arljacent island groups, and the Aleutian chain. It is numerous in some places. In the Aleutians, nearly every island that we visited had at least 1 , often 2 or more, pairs, nesting. They are numerous about the larger islands. Williams noted 15 eagles in Bay of Islands, Adak Island, July 2, 1936, and more were found on other parts of the island. On June 29, we saw several at Kanaga Island. The caretaker of a foxranching establishment there had killed 14 of these eagles for the bounty, and he planned on raiding 20 more nests later.

For some reason, the bald eagle is scarce in the Near Islandsincluding Attu, Agattu, and Semichi. We observed a single pair on Agattu in 1937, but we saw none at Attu or Semichi and the natives assured us they were very scarce. However, we found a nest on Buldir Island, and from that point eastward bald eagles were common.

Not only do eagles occur along the Alaska Peninsula, they also occur on the offshore island groups. In 1940, Gabrielson observed them in several places at the base of Alaska Peninsula. At Kodiak, in 1936, one merchant erected a sign advertising the fact that eagle feet were acceptable as cash (bounty could be collected for them).

\section{Plumage and Other Color Changes}

Too few specimens were handled to obtain precise information on plumage changes. A. C. Bent (1937) states that he believes the bald eagle assumes the adult plumage in the fourth year. 
Field observations on numerous immature birds in Alaska were confusing, and we were unable to correlate some plumage patterns with age.

The downy-young plumages are well known and are well described by Bent. However, the color of beak, eyes, and other soft parts is not so well known. A young bird in the dark-down stage on Ananiuliak Island had a slate-colored upper mandible, the cere was of a similar color, but it was of a little lighter shade. The tip of the lower mandible was similar to the upper in color, but posteriorly the margin of the gape was flesh color, becoming paler posteriorly and shading into a near-yellow at the corner of the mouth. The lores were dull bluish. The iris was dusky brown, and the pupil was blue. The eyelids were pale plumbeous. The feet were a yellowish-clay color, and the claws were slaty.

The first-year plumage is dark; as Bent says, "uniformly dark 'bone-brown' to 'clove brown' above and below; the flight feathers are nearly black, but there is usually a slight sprinkling of grayish white in the tail." In the first year, both the bill and cere are of a blackish-slate color. The iris is brown, and the pupil is black. At this stage, the eyelids are still plumbeous.

The plumages preceding the final adult stage are hard to define. There appears to be much variation, probably over a 2year period. Assuming a 2-year period for the postjuvenal phases, the plumage varies in the degree of white mottling. The essential feature is a pattern that includes patches of dullwhite mottling on scapulars and back (which, in flight, show as three distinct areas), and light-colored upper tail coverts and considerable white in under parts. In one phase of this plumage, which must be in the second year, the bill and cere are still blackish and the eye is still a rich brown. The preocular area is essentially white, the eyelid is plumbeous, and the gape is dull yellowish. The feet are yellow.

A later phase, which possibly may represent the third year, still includes the dark bill, with a dull-yellowish hue appearing on the lower mandible and the margin of the cere. The eye is dull yellow also, and a yellowish tinge is encroaching upon the preocular area. The eyelid is gray, and the gape is yellow. There is much light speckling on the head, though the head is chiefly brownish. The specimen on which this description is based did not have the light mottling on upper parts falling into a pattern of three light patches, as was seen on many birds; instead, it was more scattered. 
In still another phase, which is quite advanced, the head is white, speckled with a blackish hue. The beak is a dull-yellowish tone-perhaps best designated as tan, somewhat streaked with a slaty tone. The lower mandible is bright yellow at the base. The cere is a mixture of gray black and yellow. The eye is yellow (as in the adult), the eyelicl is a brighter yellow, the preocular area is pale yellow, and the gape is a rich, bright yellow.

These are the advancing stages in cievelopment, the transition from dark "soft parts" to the characteristic yellow of the adult, but it was not possible to allocate all of these plumages to age groups.

\section{Nesting}

Trees are absent in the area except in a limited portion of the base of Alaska Peninsula, therefore nests are placed on cliffs or pinnacles, or on low ground. Many nests are inaccessible to man by ordinary means of climbing. Frequently, a nest is placed on the top of a pinnacle, which sometimes is separated from an adjacent cliff by a narrow chasm, and which is surrounded by water, at least at high tide. At times, the nest is placed on a cliff, where it may be fairly accessible to man. In one case, on Buldir Island in 1936, a nest was found on a small rock outcrop on a slope, where one could walk to it without climbing. The same place was visited the following year; the former nesting site was abandoned, and the eagles (probably the same pair) had made their nest on the flat grassy valley bottom below. There was not even a hummock at the nest location.

In 1925, on Unimak Island, a nest containing eggs was placed on the top of a smooth sand dune. It is interesting to note that on June 9, 1941 (16 years later), Beals and Longworth reported finding an eagle's nest on a sand dune in the same locality. As a rule, eagles seek inaccessible locations on cliffs and obviously prefer pinnacles.

Nests are generally built by assembling a layer of dried grasses, mosses, and other vegetable debris. Sometimes kelp is used. Kelp nests are rimmed with the dried stems of Heracleum and Ligusticum, which are the largest material available in lieu of twigs from trees. In some cases, however, the eagles use sticks from the driftwood on the beach.

Eagles build various types of nests. The nest on the sand dune, already mentioned, consisted of a cavity that was 360 $\mathrm{mm}$. wide and $130 \mathrm{~mm}$. deep, heavily lined with dry grass, bits of moss, and a small amount of dead eelgrass from the beach. 


\section{NORTH AMERICAN FAUNA 61 , FISH AND WILDLIFE SERVICE}

A number of large dry stalks of Heracleum lanatum lay around the rim, though these were not used in the construction of the nest proper.

Another nest was on a rock mass rising from a slope on Amak Island. A few dried plant stems were the only evidence of nest construction, and the single young sat on a bare spot, well trampled, on top of the rock, surrounded by a fringe of green grass.

Another nest on the same island was somewhat similar. It was on the grassy top of a high cliff. Two well-feathered young perched in a bare trampled spot about 8 feet long, which was crescent-shaped because of a hump in the middle of the space. There were the usual dry cow parsnip stems around the edge, but there was practically no nesting material in the center.

A third nest on this island was more substantial, consisting of dry grass with dry cow parsnip stems around the rim.

These scanty nests contrast sharply with a nest found at Amukta Island, June 16, 1936. This nest, on top of a pinnacle, was built of kelp, grasses, and driftwood to a height of 4 feet. A nest observed at Kanaga Island, June 29, 1936, was on the grassy top of a pinnacle; it was made mostly of moss and had a wide platform rimmed with dry stems of Heracleum and Ligusticum and a few driftwood sticks.

A nest on the grassy top of a columnar rock on the shore of Kiska Island was in the form of a bulky mass, consisting mostly of kelp.

Still another nest, on a rocky point of Little Sitkin, was built largely of dry stems of Heracleum and Ligusticum and willow roots, with a lining of finer vegetation. The willow there is a prostrate form, whose roots often are partly exposed by wind erosion.

These examples illustrate the general type and the variations of bald eagle nests. Some of the bulky nests resulted from an accumulation of material over a long period-a typical example was found at Amchitka Island, July 11, 1937. This nest-a shallow affair-was made mostly of moss on the grass-topped point of a pinnacle rising from the beach. It rested on a mass of old sod and soil to a depth of about 6 feet. This accumulation was filled with bird bones. Evidently, this accumulation had been built up by annual increment of debris left by nesting eagles for many seasons.

Our various expeditions were usually too late in the season to observe eggs-there were young in nearly every case. The 
number of young, in a series of 34 nests, varied from 1 to 3 per nest, though in 1941 Beals and Longworth reported a nest with 4 young. In 1 nest, there was 1 live youngster and 1 partly eaten dead youngster; in 2 other nests, there was 1 young and 1 rotten egg containing an embryo. All of these must be considered as having had two fertile eggs originally. On that basis, there were 12 nests with 1 young, 17 nests with 2 young or eggs, and 5 nests with 3 young.

In every nest that we observed, the nesting birds were whiteheaded adults. One report, from Cecil Williams in 1936, indicated a nesting pair, in immature plumage, on Uliaga Island.

\section{Food Habits}

I have discussed the food of this eagle in detail in "Food habits of the northern bald eagle in the Aleutian Islands, Alaska" (Condor, 1940, rol. 42, No.4, pp. 193-202). The data presented were based on examination of 28 nests. In addition to this published material, data from 4 other nests are available, comprising 21 more food items. This additional material agrees with the published percentages.

In the Aleutian district, birds constitute the major part of the bald eagle's diet-58.9 percent on the basis of material obtained in 1936; 86 percent for 1937. As would be expected, most of the birds taken are the so-called sea birds, chiefly shearwaters, fulmars, cormorants, glaucous-winged gulls, murres, ancient murrelets, paroquet auklets, crested auklets, and horned and tufted puffins. Fulmars and shearwaters head the list. Two ravens had been eaten. Other's taken included: Petrels, kittiwakes, pigeon guillemots, ptarmigan, least auklets, and ducks, though none of these are taken in great numbers. Ducks were not preyed on extensively, probably because of the abundance of other birds, although harlequin ducks, oldsquars, European teals, pintails, common eiders, red-breasted mergansers, and three emperor geese were identified in food remains.

Mammals are not universally available to eagles in this district and are seldom found in the diet. The ground squirrel is by far the most common mammal captured. Others, which occasionally are taken, are the house rat, the field mouse, the blue fox, and, possibly, the domestic sheep at Umnak Island. In 1938, Scheffer reported that one of the men in charge of the sheep on Umnak Island declared that he had never seen eagles bothering live sheep. though they will eat carrion. Another informant, a sheep herder at Unalaska, said that eagles will not bother healthy sheep, but they will attack rying ones and will feed on dead ones. 
He had seen both ravens and eagles feeding on carcasses of winter-killed sheep. Beals and Longworth, in 1941, reported that local residents on Unimak Island believer that the bald eagle kills caribou fawns. However, this would need verification. It is known, of course, that eagles feed on dead whales and seals.

It has been thought that bald eagles kill many blue foxes. But, according to the evidence we obtained, this is not the case in the Aleutian district. The remains of only one fox were found in an eagle nest, and these remains could have been carrion because we found a few dead foxes on the beaches. To further refute this theory, many blue fox families were being raised successfully in the vicinity of eagle nests.

A moderate percentage of fish and invertebrates is eaten by the bald eagle. To what extent this eagle feeds on dead or spawning salmon on the Alaska Peninsula was not determined. In July 1911, at Morzhovoi Bay, Wetınore observed them feeding on dog salmon taken from shallow rapids. Edward D. Crabb (1923) apparently found fish remains to be prominent in nests examined along Alaska Peninsula; there were parts of seven Dolly Varden trout in one nest. Edward J. Reimann (1938) observed a bald eagle taking a mullet out of the water, reaching for it with one foot. Beals and Longworth found two sockeye salmon and the head of a sea gull in a nest on Unimak Island, June 9, 1941. We did not see bald eagles capture live fish, but Atka mackerel were often observed near the surface of the water, where an eagle could very easily seize one.

In the Aleutian chain proper, the main food of the bald eagle consists of sea birds. There are some indications that fish of various kinds are more prominent in the diet along the Alaska Peninsula, where we did less work on this bird. At any rate, there is abundant evidence that the eagle is not a serious detriment to man's interests throughout the Aleutian district.

\section{Banding}

A number of nestling bald eagles were banded in the Aleutian Islands in 1937. Of these, six returns were obtained. All six had been banded in June; 1 on Little Kiska Island, 2 at Little Sitkin, and 3 (all in one nest) on Rat Island. The following winter, all of these were killed by natives on Attu Island. This shows a westward drift of immature eagles, at least in the western part of the Aleutian chain.

These eagles are permanent residents in the Aleutian district, summer and winter. 


\section{Haliaeetus pelagicus: Steller's Sea Eagle}

In the course of all our expeditions to the Aleutians, a Steller's sea eagle was never observed, though we scrutinized all eagles closely for such a possibility. Charles H. Gilbert's specimen from Kodiak Island (1922) is the only record of a specimen obtained from the Aleutian district; howerer, more recently, Friedmann (1935) has recorded several bones of this species from middens on Kodiak Island. G. Dallas Hanna $(1919,1920)$ has recorded a specimen taken in the Pribilofs in December 1917. These are the only records for North America based on actual specimens. Austin H. Clark (1910) reported seeing one of these eagles near Unalaska on May 26, 1906.

Leonard Stejneger (1885) says of this eagle: "The habitat is especially the mainland of Kamschatka, where it is abundant, but also all the countries bordering the Okotsk Sea. On Bering Island it is only an occasional risitor, being chiefly an inland bird preferring the quiet river's and lakes surrounded by dense forests."

\section{Circus cyaneus: Marsh Hawk Circus cyaneus hudsonius}

Friedmann (1935) records a specimen taken on Kodiak Island by Bretherton on April 2, 1894. Osgood (1901) reports the marsh hawk near. Homer and Hope, in the Cook Inlet region, and again, in August 1902, he found them at intervals along the Kakhtul River and occasionally, all the way to Nushagak. Cahalane (1914) observed 4 marsh hawks in Katmai National Monument in September and October 1940; 2 of these were males.

We did not see any of these hawks west of Kodiak Island during three expeditions, nor does Wetmore record any west of Kodiak Island in his field report for 1911. But Turner (1886) records a flock of 10 of these hawks at Unalaska, and he remarks that it is a rare summer visitor to Attu Island; however, this statement is surprising in riew of present-day information. Those observed at Unalaska must have been a migrant group. But Cahn (1947) contributes the raluable information that he observed a male in Makushin Swamp, Unalaska Island, June 7, 1943, and saw a female orer the swamp at the end of Captain's Bay on July 7, 1944.

Although the marsh hawk may occasionally appear to the westward, it certainly prefers the meadows and marshes of the more wooded parts of Alaska, including the base of Alaska Peninsula and the Kodiak-Afognak group. Along the north side 
of Alaska Peninsula all the way to the west end, and on Unimak lsland, numerous marshy areas with an abundance of mice and birds may be found; yet, this treeless region generally is avoided by the marsh hawk.

\section{Family PANDIONIDAE}

\section{Pandion haliaetus: Osprey Pandion haliaetus carolinensis}

This bird has not been recorded from the Kodiak-Afognak Islands, but Osgood (1904) reports it to be quite common on nearly all watercour'ses that he has traveled, and he specifically mentions the Nogheling, Chulitna, and Kakhtul Rivers-all these are north of Lake Iliamna.

Cahalane (1944) saw 2 American ospreys-1 at Naknek River, September 4, 1940, and the other at the outlet of Brooks Lake, September 7.

In 1940, Gabrielson saw 1 osprey at Wood River Lakes, July 18; he observed 1 at Brooks Lake, July 19, and he saw another niear the upper end of Iliamna Lake on July 25.

There are no records of sighting the American osprey farther west, but Stejneger (1885) said that it is an occasional visitor in the Commander Islands and that is is very abundant in Kamchatka. This is another bird that does not venture out into the treeless areas to nest.

\section{Family FALCONIDAE}

Falco rusticolus: Gyrfalcon

Falco rusticolus uralensis

Attu: Kus-sum Ah'-ghu-lich

The Attu chief described a bird larger than the peregrine falcon, and gave us the above name. (If it were different from the peregrine falcon, and larger, it could hardly be anything but a gyrfalcon.) The chief cleclared that it nests and winters on Attu Island. Austin Clark (Collins et al. 1945, p. 37) says "Lieutenant Nelson, an experienced falconer, believes he saw gyrfalcons on Kiska, though only one, in the white phase, was identified with certainty."

We did not identify this bird on any of our expeditions, nor did Wetmore record it. Nelson (1887), using the name Falco rusticolus gyrfalco, said that it was very common along the Bering Sea coast, but less common in the Aleutian Islands. Swarth 
(1934), using the name Falco rusticolus candicans, records a pair seen on Akutan and several on Unalaska by Cyril G. Harrold. Beals and Longworth report-

March 2, False Pass: 1 falcon, very light, almost grey, on a cliff approximately 1500 feet elevation. March 14, False Pass: 2 at elevation of 1800 feet, color white. March 24, False Pass: 1 with color predominantly white, flying over alders back of cannery. May 13, False Pass: 2 almost pure white falcons at 1500 feet.

These are all sight records, and one cannot be sure which form of gyrfalcon was represented. But there are several specimens in the National Museum that are referable to uralensis: Three were taken at Nushagak, September 1, 1881, October 20, 1881, and December 5, 1882; and a juvenile specimen was obtained from Herendeen Bay, taken July 15, 1890, by C. H. Townsend, and marked by Friedmann as "Prob. uralensis." Friedmann has also recorded 2 from Kodiak Island, 1 taken by Fisher, September 18, 1882, and the other (no longer extant) by Panshin in 1871.

On September 21, 1942, Beal obtained a specimen at Cold Bay, on Alaska Peninsula.

Stejneger (1885) listed Falco rusticolus and Falco islandus for the Commander Islands. The former, he sars, is not uncommon in winter-feeding chiefly on "the numerous field mice which now infest that island,"-and possibly nests there. He states that $F$. islandus breeds there in limited numbers.

Hartert (1920) records 4 white and 4 dark immature birds and 1 white and 3 clark adults from the Commander Islands, all taken in winter; he lists them all under Falco rusticolus candicans.

\section{Falco rusticolus obsoletus}

In the National Museum there is a specimen taken by McKay at Ugashik in 1881; it was identified by Friedmann as obsoletus. To what extent this bird occur's in the Aleutian district is unknown, nor do we know how many of this form were represented in the sight records listed under uralensis.

Bond (1949) has thrown some doubt on the classification of western American gyrfalcons, but I have not had an opportunity to evaluate the situation.

\section{Falco peregrinus: Peregrine Falcon Falco peregrinus anatum}

We did not obtain specimens of anatum in the Aleutian district, though Friedmann (1935) records a specimen from Kodiak Is- 
land, which he suggests may possibly have been a migrant or vagrant. Likewise, the duck hawks reported by Captain Ammann and Lieutenant Nelson on Kiska (Clark 1945, p. 36) would have to be migrants or vagrants if we are to retain the subspecific status of these forms. There is, of course, the possibility that these birds were wanderers from Siberia (F. p. calidus).

\section{Falco peregrinus pealei}

Attu: Ah'-ghu-lich

Atka: Ah'-ghu-lich

Commander Islands: Agulekh (Stejneger)

Russian, Commander Islands: Tschornij Jastrip, black hawk (Stejneger)

The Aleuts of the Commander Islands speak the language of the Aleutian Islands, and, evidently, the name for this falcon is the same in all dialects.

It is pretty well established that the nesting birds of the Aleutian chain are pealei, and that this form also nests in the Commander Islands. Probably the same form occupies the Alaska Peninsula and adjacent island groups. However, there is a specimen of $F$. $p$. anatum recorded by Friedmann from Kodiak Island, and we did not collect specimens of $F$. p. pealei east of the Aleutian chain.

We found this falcon to be common throughout the Aleutians. It nests on nearly all the islands, usually on high inaccessible ledges. It is a resident breeding bird and also winters in the Aleutians.

As would be expected, the peregrine falcon feeds chiefly on birds. Casual observations revealed that the least auklet and the crested auklet are taken-one falcon was seen carrying a crested auklet. It has been reported as capturing ptarmigan and shorebirds, but it is believed that sea birds furnish a large portion of its food.

\section{Falco columbarius: Pigeon Hawk Falco columbarius bendirei}

Friedmann (1935) records a number of specimens of bendirei from Kodiak Island, though, as he points out, Peters states in his check-list of the birds of the world that suckleyi is the breeding bird of Kodiak Island. The 1931 A.O.U. Check-List considers the Kodiak birds to be bendirei. Two specimens were obtained from Kodiak by Gabrielson, August 8, 1945.

Osgood (1904) records specimens from the Nogheling and Chulitna Rivers, Nushagak Village, and Aleknagik Lake, and he observed others on the Kakhtul and Nushagak Rivers. He also 
reported them common in the Cook Inlet region-specifically mentioning Hope and Tyonek (1901).

Cahalane (1944) observed a pigeon hawk on lower Ukak River, September 9, 1940, and saw another on Windy Creek, September 16.

Hine (1919) also found these little hawks to be common in the region of Katmai Bay in the summer of 1919.

The pigeon hawk is exceedingly rare farther west, but there are a few records available. Turner (1886) mentions a specimen taken at Unalaska in 1879. Bailey (1926) says "Hendee collected one at Unalaska Sept. 25, 1922, and saw another the next day."

Captain G. A. Amman reported a pigeon hawk, not positively identified, on Kiska Islancl.

Taber had an opportunity to observe a pigeon hawk rather closely at the military establishment on Adak Island on December 9, 1945.

It must be considered rare in the Aleutians, however.

Hartert (1920) records a female Falco columbarius insignis collected on Bering Island, June 10, 1915.

\section{Falco sparverius: Sparrow Hawk \\ Falco sparverius sparverius}

The only record of the sparrow hawk is the statement by Dall (1873) that one was killed at Unalaska in the fall of 1871, but it was not preserved. There are no other records of this species in the entire area under discussion; therefore, Dall's inability to preserve the specimen is unfortunate.

\section{Family TETRAONIDAE}

\section{Canachites canadensis: Spruce Grouse}

Osgood $(1901,1904)$ found spruce grouse to be plentiful in the wooded portions of the base of the Alaska Peninsula and the Cook Inlet region. Friedmann (1935) refers to a specimen from Kodiak Island, which was mentioned by Baird, Brewer, and Ridgway. Cahalane (1944) found this bird to be abundant in the spruce forests north of Mount Katolinat, in the fall of 1940, and saw evidence of its presence north of Savanoski River. The Kodiak Island record had been referred to the Valdez spruce grouse, C. c. atratus, by Friedmann, but it is not known what the Alaskan Peninsula birds would be referable to.

This bird could not be expected to occur west of the forested portions of Alaska Peninsula. 
Lagopus lagopus: Willow Ptarmigan

Lagopus lagopus alascensis

Aleut: Alladek (Wetmore)

The willow ptarmigan, distributed throughout the Alaska Peninsula, is represented by two races, L. l. alascensis and L. l. muriei. Gabrielson and Lincoln (1949) referred the subspecies on the Alaska Peninsula proper to alascensis, as distinct from the races on nearby islands.

Alaska willow ptarmigan were observed at the west end of the Alaska Peninsula in 1925. About the middle of May, the males were strutting and crowing in a lively fashion at Izembek Bay. On June 14, very few females were seen. Evidently, they were incubating, because on June 22 I found a nest of nine eggs, pipped, ready to hatch, and late in July there were broods of young on the marsh at Moffet Bay.

Concerning the boldness of males at this time, I find the following in my field notes for June 3 :

The female was sulking among the alder stems on the shore of a pond and I stood on a rise nearby. The male rushed between me and his mate, growling, puffing out his chest, and elevating his combs. He was a splendid bird as he strutted, following his mate as she sneaked along in the brush but keeping out in the open himself, evidently to attract attention away from the female. I was within 15 feet of him at times.

On July 3, Donald Stevenson watched a pair of ptarmigan protesting the approach of a brown bear. The bear had been walking across a gentle slope toward the mountains and evidently had disturbed a brood of young birds. Both parents were pretending to be crippled before the huge intruder. The bear made several lunges at the birds, but finally continued on its way.

\section{Lagopus lagapus muriei}

Aleut: Alladak (Wetmore)

This ptarmigan occurs on Kodiak Island, Unga, Nagai, Little Koniuji, Simeonof, and Popof Islands of the Shumagins, and Atka, Unalaska, and Unimak of the Aleutians.

This willow ptarmigan was described by Gabrielson and Lincoln in 1949, as follows: "As compared with L. l. alascensis, this race is much redder and darker when skins in comparable plumages are compared. L. l. alascensis is buffy; the new race, murici, more reddish and darker, near walnut brown, while alexandrae [of Baranof and adjacent islands] is dark brown to bister."

As to distribution, they commented: "Somewhat to our sur- 
prise, all birds from Morzhovoi Bay, only a few miles across from False Pass, certainly belonged to alascensis, while those from Unimak Island just as definitely belonged to the island group (muriei)."

Beals and Longworth (field report, 1941) reported numerous ptarmigans on Unimak from February 26 to April 10, in flocks of 25 to 300 birds. They noted, on March 6, at False Pass as follows: "Large flocks of 300 or more birds each flew about the alders back of the cannery. We saw several flocks of 75 to 100 birds in Sourdough Flats and vicinity the same rlay." On March 24 , they reported "ptar'migan by the hundreds" in the valley back of False Pass. On March 31, at Ikatan Valley, they saw 3 flocks of 100 birds each, and saw numerous groups of 10 to 15 birds. On April 2, at Sourdough Flats, they reported, "Flock after flock of 100 to 150 or more each all through this area. The flocks kept moving ahead of us until several thousand ptarmigans were gathered in one large brood across the valley floor. It looked and sounded like a gigantic chicken ranch." On April 10, at False Pass, a flock of "several hundred" were noted; the males were "reddish brown about the hear and shoulders."

During field work on Unimak Island in May, 1925, I found these ptarmigan common in the lowlands and on the middle slopes of the mountains. On April 30, I saw three males that had acquired much of the brown plumage, but on May 4 the females that I observed were still mostly white, though speckled with brown. On May 5, I saw one male in almost complete summer plumage.

An interesting incident occurred on May 19, 1925, at St. Catherine Cove. I was about ready to leave my cabin, when the clattering call of a male willow ptarmigan souncled close by. The call was followed by a light patter on the floor of an adjoining shed. Before going into the shed to investigate, I glanced out the window and saw a peregrine falcon. In the shed, I found a cock ptarmigan that ran out through the open door, only to return almost at once. But my presence proved too much for him, and he finally bolted out through the open cioor and, with lusty crowing, took flight and disappeared over a rise. By this time, the falcon was some distance away.

\section{Lagopus mutus: Rock Ptarmigan}

The rock ptarmigan occurs on the Alaska Peninsula, on the eastern Aleutian Islands as far west as Yunaska, on the middle and western Aleutians from Atka Island as far west as Kiska 
and, on the extreme western end of the chain, Attu Island. It is represented by eight subspecies: nel.soni, yunaskensis, atkhensis, chamberlaini, sanfordi, gabrielsoni, townsendi, and evermanni.

As reported elsewhere (Murie 1944, p. 122), the rock ptarmigan of the Aleutian Islands-Alaska Peninsula district fall into two groups: A dark, more or less blackish group (in summer plumage), and a yellowish group (also in summer plumage). The dark group, comprising nelsoni, yuntskensis, and evermanni, occupies the Alaska Peninsula and the eastern Aleutians as far west as Yunaska, with the representative subspecies evermanni on the extreme western end of the chain, Attu Island. The yellowish group, comprising the other five forms, occupies the middle and western Aleutians from Atka Island as far west as Kiska.

The five so-called yellowish ptarmigan races in the middle Aleutians are actually very similar in appearance and are hard to distinguish without a series for comparison purposes. The fact that so many forms can be separated within such a comparatively limited area can be explained only by the partial isolation afforded by island habitat, though a given race is not necessarily confined to a single island, but may occupy a group of islands.

Close knit as these five "yellowish" races are, it is still possible to separate them. The three eastern forms, atkhensis, chamberlaini, and sanfordi (the most difficult to distinguish one from another), form a group characterized by pale coloration, and, more particularly, by finer barring in the plumage. The two western forms, gabrielsoni and tounsendi, have much heavier barring.

As Bent has pointed out, middle-Aleutian ptarmigan occupy lowland areas, comparatively speaking, in contrast with the highmountain habitat of rock ptarmigan farther east. This does not mean that the middle-Aleutian races avoid highlands; they occur on relatively high ground on Atka and Kiska, and elsewhere. But the terrain of these islands is not particularly rugged, nor of the high-mountain type. Amchitka, for instance, is a low island. It is true, as Bent has said, that these rock ptarmigan live to a large extent in grassy areas, but it does not necessarily follow that they have responded directly to environment by taking on color's that blend with the color of dead grass. This is a possibility, but at present we do not have sufficient facts for a conclusive decision.

\section{Lagopus mutus nelsoni}

Nelson's rock ptarmigan is a dark race that occurs throughout the Alaska Peninsula area, including Kodiak and Afognak is- 
lands, the Shumagins, and other neighboring island groups, and west in the Aleutians as far as the Islands of the Four Mountains.

We had suspected that birds from the Islands of the Four Mountains might have developed new characteristics due to isolation. Ground color of the plumage of birds taken on these islands in early summer differs in tone from that of evermanni or ridgwayi (of the Commander Islands) - although there is a slight olivaceous cast, the predominating shade is yellow-brown. The ground color also differs from that of specimens of nelsoni from Unalaska and farther east, tending to gray rather than to red in overall effect. Such differences, if real, are too insignificant to warrant naming a new form. They can best be referred to a slight deviation from the usual in nelsoni. There is a similar situation at Kodiak and neighboring localities, where nelsoni shows an approach to dixoni (of southeastern Alaska), because the ground color of nelsoni has a slightly grayish cast.

The females of each Aleutian form cannot readily be distinguished, but there is a discernible difference between females of relsoni (which represent the darker forms) and the females of the middle Aleutians (which represent the pale forms). On female neisoni, barring is black, broad, and in contrast; whereas, on the pale forms, the barring is less shaip, and the bars tend to be discontinuous with a softer effect.

Spring-plumage changes in Nelson's rock ptarmigan come much later than the changes in willow ptarmigan. A 1-pound specimen, collected on Ushagat of the Barren Islands group on May 11, 1936, was still mostly white. On May 7, 1925, I found, on Unimak lsland, that the plumage was still nearly all white. On May 14, 1925, males were seen with well-speckled plumage, but it was a long time before these birds attained full summer dress. On June 6, in the Izembek Bay region on Alaska Peninsula, males still had considerable white in the plumage, but the females had changed completely into summer plumage. A female taken on Dolgoi Island, May 24, 1937, contained well-developed eggs.

Nelson's rock ptarmigans are largely inhabitants of the high mountains, though they are not confined to the steeper parts. They are often found on gentler mirldle slopes-in this respect, they resemble the rock ptarmigan of interior Alaska.

\section{Lagopus mutus yunaskensis}

The Yunaska rock ptarmigan was described by Gabrielson and Lincoln (1951) on the basis of a specimen collected by Gabrielson on Yunaska. As might be suspected, although it is grayer 
than nelsoni, it seems to be more nearly allied to this darker group to the east. Although its range is thought to be confined to Yunaska, this is not certain.

\section{Lagopus mutus atkhensis}

Atka: A-gha-dé-gach, or A-gha-dé-gah

Agdikax (Jochelson)

Although native names seem to apply to rock ptarmigan in general, it seems appropriate to apply the Atka dialect name to this form found on Atka Island. Turner's rock ptarmigan may possibly occur on Amlia Island (separated from Atka by only a narrow pass), though no specimens were collected on Amlia. Whether this form occurs eastward as far as Seguam is unknown, but it is logical to assume that it does. It may be expected that atkhensis also occurs westward to the next group of islands, and that it intergrades with the neighboring form, chamberlaini, of Adak.

One is struck by the grayish color of atkhensis, even in flight, as compared with nelsoni. This color is generally more rufescent than chamberlaini, though both birds have the characteristic variegation of gray and rufescent patches. In fact, atkhensis and chamberlaini are hard to distinguish, though, when a good series of each is laid out for comparison, the difference can be seen.

On April 4, 1924, Laing obtained a series of 15 birds on Atkaa few of these birds were still in full white plumage. The birds were just beginning to molt into summer dress, a change that appears to be slightly earlier in atkhensis than in nelsoni on Unimak Island.

Rock ptarmigan have always been abundant on Atka, as many visiting collector's have testified. They are able to maintain their numbers in spite of the blue foxes. It was on Great Sitkin-a neighboring island-that I obtained the only direct evidence of cyclic behaviour among the Aleutian ptarmigan. John Taylor, who had a lease on Great Sitkin to raise blue foxes, said that he had placed 14 foxes on the island in 1934. At that time ptarmigan were numerous- "Thousands of them" was the way he expressed it. When Taylor returned to Great Sitkin the following year, ptarmigan were scarce. He did not think that the blue foxes on this large island could have been responsible for such a swift and marked decrease. There had been red foxes on the island before the planting of the blues. This sudden decrease in the ptarmigan population appears to have been a case of the characteristic "die-off" of ptarmigan. Similar fluctuations were not reported for Atka Island. 


\section{Lagopus mutus chamberlaini}

Chamberlain's rock ptarmigan is known only from Adak Island, but it undoubtedly occur's on neighboring islands. It is somewhat grayer than atkhensis, and is darker on the top of the head and upper neck-an effect, not particularly striking, that results from a greater number of black markings. No doubt chamberlaini and atkhensis intergrade on some of the intermediate islands.

Laing (1925) found rock ptarmigan on Adak "even more numerous" than on Atka. He collected five males on Adak, April 13, 1924, that had started to molt into summer plumage. The date, like that for the molt into summer plumage by atkhensis, is unlisually early for ptarmigan.

\section{Lagopus mutus sanfordi}

Sanford's rock ptarmigan is abundant on Kanaga, Tanaga, and neighboring islands. Bent (1932), speaking of Tanaga, says: "The ptarmigan were tamer and more abundant here than on any of the other islands that we visited; we shot more than 40 in one afternoon." The two specimens we obtained on Kanaga Island are referable to sanfordi, showing that this race occupies Tanaga and Kanaga, at least.

As Bent said, Sanford's rock ptarmigan is paler than chamberlaini, and is somewhat more ochraceous than either chamberlaini or atkhensis. Bent (1932) says:

Although I described and named this race myself (1912), in honor of my friend Dr. Leonard C. Sanford, who cooperated with me in organizing our expedition to the Aleutian Islands, I must confess that it is only slightly differentiated from the Adak ptarmigan. We all noticed a difference when our birds were collected, and when we laid our series of about 40 specimens of sanfordi beside nearly as many of chamberlaini, it was easy to see that the Tanaga bixds were appreciably paler than the Adak birds. The Tanaga birds are therefore the lightest in color of any of the Aleutian ptarmigan, and have the finest vermiculations.

\section{Lagopus mutus gabrielsoni}

Gabrielson's rock ptarmigan occurs on Amchitka Island, the type locality, as well as on Little Sitkin Island and Rat Island. We have no specimens from Semisopochnoi Island, where this form may occur also. In 1938, Scheffer obtained, on Amchitka, a specimen whose crop was filled with berries of Empetrum nigrum, no doubt a farorite food of all these rock ptarmigan.

In summer plumage, the male gabrielsoni differs from sanfordi 
in that the ground color is more uniformly dark, and the bars are broader and extend farther down the flanks and back; it differs from townsendi in that the coarse barring is not restricted to the anterior part of the body, and the ground color is paler and less ochraceous.

\section{Lagopus mutus towrsendi}

Differences between townsendi and gabrielsoni have just been given. Townsend's rock ptarmigan is found on Kiska and on Little Kiska Islands. We have no specimens to prove that it occupies Chugul Island. It is possible, but unlikely, that townsendi is found on Buldir Island, far to the west; in any event, we found no ptarmigan there on several visits.

\section{Lagopus mutus evermanni}

Attu: $A$-ti-ka-took-ach

Russian, Commander Islands: Kuroptka or Kuropaschka (Stejneger)

Russian, Yana River region: Mala Kuropatka (Pleske)

(The Attu and Russian names undoubtedly refer to all rock ptarmigan.)

Evermann's rock ptarmigan occupies Attu Island. Apparently, ptarmigan have always been scarce on Attu, even before the introduction of blue foxes. According to Turner (1886), the natives reported ptarmigan on Agattu Island, but we did not obtain specimens there on our visit in 1936.

Comparison of evermanni with ridgwayi (of the Commander Islands) shows that evermanni, darkest of the rock ptarmigan series, is closely related to the Commander Islands form. In ridgwayi, the ground color shades from dark buckthorn to hazel. This ground color varies with different specimens and on different parts of the body; it is heavily overlaid with a close pattern of fine black vermiculation and is spotted with blackish feathers. In the Attu evermanni, the ground color suggests buckthorn brown, as in ridgwayi; but it is duskier and less rufescent, and the black vermiculations are more closely woven and the black feathers are more prevalent. The plumage characteristics in evermanni give the effect of a darker bird than ridgwayi. Comparing evermanni and ridgwayi with nelsoni from the Islands of the Four Mountains in the eastern part of the Aleutian chain, we find that there is a general resemblance among the three, but that ridgwayi and evermanni show the closest affinity, while, in ground color, nelsoni tends to be more olivaceous with an abundance of Dresden brown. 


\section{Family GRUIDAE}

\section{Grus canadensis: Sandhill Crane Grus canadensis canadensis}

This sandhill crane nests on practically the entire length of Alaska Peninsula, so it is not surprising that Friedmann (1935) includes this species in the avifauna of Kodiak Island also, on the basis of a reported specimen as well as on bones found in middens.

On May 26, 1936, a crane was heard calling on the tundra at Snag Point, Nushagak River; cranes were heard several times on the flats about Ugashik River, and, on May 27, one was observed flying high in the air. On May 29, there was a pair and a group of three, on the tide flats. Curiously enough, 1 bird in this group of 3 appeared to be much larger than the others, giving the appearance of an adult with 2 immature birds. It is believed that cranes nest on the flats along Ugashik River.

A local trapper said that cranes commonly nest upriver from Nelson Lagoon, and Gabrielson received reports of cranes in the Cold Bay district.

In 1925, I found cranes on Unimak Island and adjacent parts of Alaska Peninsula, and, on May 1, 1925, two cranes were seen at Urilia Bay. On May 21 and 22, 1925, at Moffet Cove, on Izembek Bay, a pair, or a group of 3 , were noted on several occasions, and on June 14, 1925, Donald Stevenson saw 1 bird. This bird (seen by Stevenson) was very fearless, and we thought that its mate probably was on a nest not far away. On July 18, on a marsh in another part of Moffet Cove, a pair of cranes tried to decoy us away-evidently they had their young nearby.

Thus, it is clear that the crane nests in suitable areas along the Alaska Peninsula, probably also at Urilia Bay, Unimak Island. If it nests at Unimak Island, this point probably is the western limit of its breeding range.

On August 24, 1937, I found the decomposed remains of a crane (evidently a migrant straggler) on the beach of Bogoslof Island. Turner (1886) states that the natives reported killing a crane on Attu in October. In Turner's opinion, this bird was a storm-driven straggler.

But Austin H. Clark (1910) gives us a more significant observation when he says-

On the morning of June 8 while ashore on Agattu Island I encountered a pair of these birds, but could not succeed in getting anywhere near them. On being flushed, they never flew for any great distance, but always alighted far out in the open pasture-like areas, out of reach from any rocks or other suitable cover. 
It is not impossible that cranes nested occasionally on flat, lake-strewn Agattu Island.

Hartert (1920) records two adult specimens, a male and a female, from the Commander Islands, and states that they probably visit that area from time to time.

\section{Family RALLIDAE}

\section{Fulica americana: American Coot}

\section{Fulica americana americana}

The only record of this bird was obtained by Gabrielson. On December 1.0, 1943, John Gardner, of False Pass, observed this bird in a small stream near his home. It remained for several days and appeared to be sick; on December 15, it was killed by a dog. The head, wings, and feet were saved for identification. Residents of the community had never seen a coot there before.

\section{Family HAEMATOPODIDAE}

\section{Haematopus bachmani: Black Oystercatcher \\ Attu: Hét-gich \\ Hekh (Turner) \\ Atka: Hếch \\ Hegis (Turner) \\ Unalaska: Hekh (Turner) \\ Hckli (Clark) \\ Russian: Morskoi Ptookh, "Sea Cock" (Turner)}

(The variations in native names are unquestionahly due to individual speech mannerisms, and represent the same name in all dialects.)

Speaking of Haematopus osculans, Stejneger (1885) says,

The Russians of Kamtschatka apply to this bird especially the name Ptuschok (pl. "Petuschki"), a chicken, a term used for Simorhynchus pygmaeus by the natives of Bering Island, for Leucosticte griseonucha by those living on the Prybilof Islands (according to H. W. Elliott), and to other birds in different parts of the vast empire where the Russian tongue is spoken.

It woukd not be surprising, then, to have this name appear, variously applied, in western Alaska.

The black oystercatcher breeds commonly from Kodiak Island westward for the length of Alaska Peninsula, especially on islands. We recorded one at Chignik, but we did not record the species on the shore of Alaska Peninsula. On May 11, 1936, one was found on Ushagat (Barren Islands), and we observed them also on Kodiak Island. 


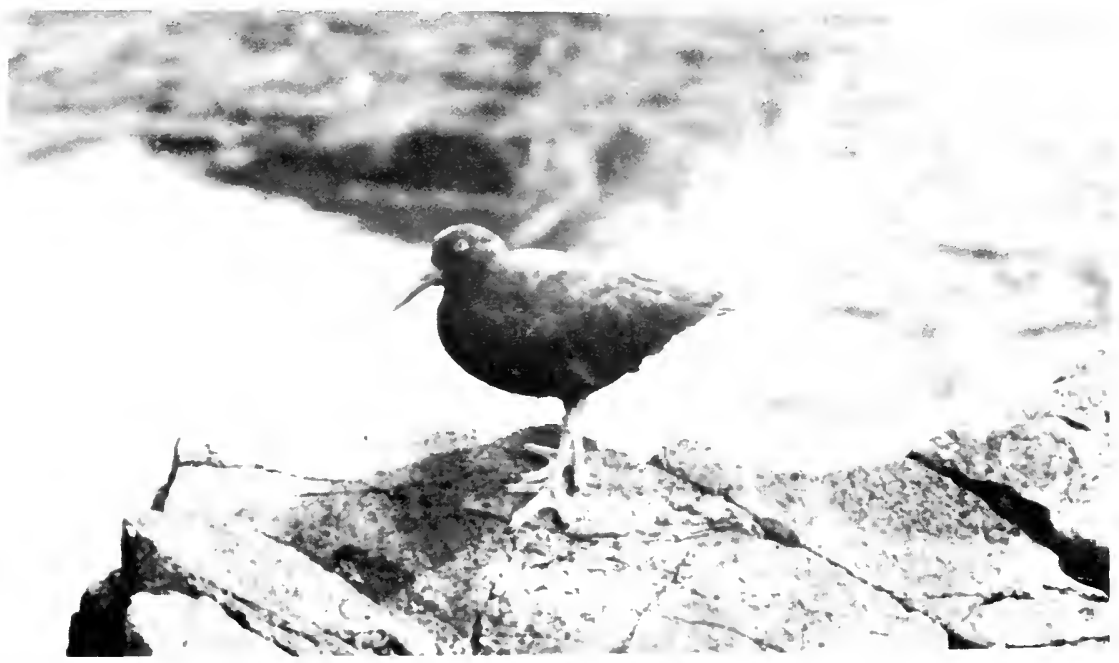

Figure 26.-Black oystercatcher.

In 1940, Gabrielson noted 6 of these birds at Whale lsland, and he saw 15 or 20 in the Semidi Islands.

On May 16, 1936, we obtained a specimen of the black oystercatcher on Nagai Island, in the Shumagins.

Chase Littlejohn (manuscript notes, 1887-88) wrote: "Found from Sanakh to Kodiak in limited numbers. Their warning cry at the approach of man if heard by the sea otter causes the latter to make off at once, for this reason they are much hated by otter hunters." Turner also mentions the reactions of seaotter hunters.

The north side of Alaska Peninsula is not suitable for this bird because it lacks a rocky-shore habitat. But the bird nests on Amak Island, near the west end of the Peninsula, which is probably the eastern limit of its nesting range in Bering Sea.

In the Aleutian Islands proper, the black oystercatcher occurs on nearly every island and is a farly constant feature of the rocky-shore fauna. On Attu Island, howerer, we saw none, and we were assured by the native chief that they do not occur there. This probably is true of all the Near Islands. We have no record of this bird west of Kiska. Turner points out (1886) that the distance between Kiska and the next island, Buldir, may be too much of an over-water flight for this bircl. Strangeiy enough, in $\mathbf{1 8 8 5}$, Turner had reported it as a rare risitor to Attu, occurring oftener on Semichi and Agattu. 
In this connection, it is interesting to note Stejneger's remarks on Haematopus osculans, of Siberia (1885): "This bird comes only as a rare visitor to the [Commander] islands during the migration seasons. This is rather strange, as it inhabits the nearest coast of the mainland."

Perhaps the oystercatchers are merely conservative-lacking the exploratory tendency of some other species-and have not yet had time to extend their range to the end of the Aleutian chain. However, if we believe Turner's report of 1885, rather than his report of 1886, the oystercatchers had reached Attu in 1885.

Apparently, oystercatcher's do not exceed a certain population density and are scattered rather thinly along rocky shores.

Usually, there were only a few pairs on an island (about six), although more birds can be found on the larger islands. But sometimes, in summer, they gather in loose flocks. On Ogliuga Island, August 6, 1936, at least 25 or 30 were seen. On tiny Salt Island, off the shore of Atka, on July 8, 1936, a flock of 13 was noted.

A nest was found June 28, 1936, on a small islet off Little Tanaga Island. The nest was in the grass-merely a shallow depression lined with a few bits of barnacle shells-and contained two eggs. Gabrielson (1941) found a nest on Tanaga Island that contained 2 young and 1 pipped egg.

\section{Family CHARADRIIDAE}

\section{Charadrius dubius: Litîle Ringed Plover Charadrius dubius curonicus}

The only record of the little ringed plover is the one by Schalow (1891, p. 259), for Kodiak Island, which originally was recorded as Charartrius alexandrinus Pallas. Oberholser (1919) concluded that this record should be identified under Charadrius dubius curonicus, and it was so listed in the 1931 A. O. U. Check List. This record is considered doubtful, and has been dropped from the 5 th edition of the A. O. U. Check List.

\section{Charadrius semipalmatus: Semipalmated Plover}

The semipalmated plover is recorded from Kodiak Island (Friedmann 1935), and we observed two on the beach of Ushagat, Barren Islands, May 11, 1936. Howell (1948) found a nest with eggs at Kodiak Island, May 31, 1944. It occurs throughout the length of Alaska Peninsula. G. D. Hanna collected a 
specimen, May 23, 1911, at Nushagak. Gianini (1917) found them to be common about Stepovak Bay on the south side of Alaska Peninsula, where they appeared to be nesting, in May and June 1916. Jaques (1930) recorded them on the north side near Port Moller. We saw three at False P ass, Unimak Island, August 23, 1936. In 1925, I observed the species at False Pass and at St. Catherine Cove, May 16 and 17. In the latter part of May 1925 they were found again in a valley below Aghileen Pinnacles, near Izembek Bay, and at Applegate Cove. At the time, it was believed that they were nesting. Wetmore found a few of these birds at Thin Point, near Cold Bay, in August 1911, and he obtained two immature specimens at the east base of Frosty Peak on August 6. Beals and Longworth, reporting on False Pass, in 1941, noted one on a gravel bar of an old stream bed May 9, and remarked that " 2 are seen on this gravel bar every time we pass. They were not observed after the 25th of May." In 1940, Gabrielson also noted three of these birds at Morzhovoi Bay. Donald Stevenson obtained a specimen on Unimak Island, May 25, 1922, and made this notation: "Arrived about May 1st. Rather common along glacial stream beds. Breeds."

McGregor (1906) obtained a male and a female in English Bay, Unalaska Island, Nay 27, 1901, and he obtained two immature birds on Unimak Island, August 14.

In view of all these observations, the evidence is rather conclusive that the semipalmated plover nests as far west as Unalaska Island.

\section{Pluvialis dominica: American Golden Plover Pluvia'is dominica fulva}

Attu: Svegch

Simix (Jochelson) (Probably refers to this bird; no dialect given)

Osgood (1904) says of this species at the base of Alaska Peninsula :

A few small flocks were seen on the tide marshes and along the mud flats about Nushagak September 12 to 26. Several were seen at Igagik and others occasionally along the Ugaguk River, as far up as the mouth of Becharof Lake. Specimens were taken at Nushagak by McKay in June, 1881.

Hine (1919) observed these birds at Kashvik Bay in 1919, and he collected a specimen on August 24.

Friedmann (1935) records a number of specimens and observations of this bird at Kodiak, where it is no doubt a regular migrant. 
Farther westward, records are available all the way to Attu. On May 16, 1925, Donald Stevenson saw a bird at False Pass, which he thought was the golden plover. Eyerdam (1936) says "Frequently seen and collected at Unalaska and Unimak Island." Dall (1872) reports a specimen of "Charadrius virginicus, Borck" taken June 22, 1872, at Popof Island, in the Shumagins. Turner (1886) observed a golden plover at Sanak in July 1878, and on May 17, 1879, at Atka Island, he identified the plucked body of a golden plover. Again, in the early part of October 1880, he saw two golden plovers on the beach at Massacre Bay, on the south side of Attu Island.

Gabrielson obtained specimens at Cold Bay and in the Shumagins, in 1943 and 1944 respectively.

On June 3, 1937, we observed a golden plover circling over the stormy sea between Segula and Semisopochnoi Islands.

The chief of Attu village declared that he knew of the golden plover; he recognized a colored picture of it, gave us the Aleut name, and referred to it as the "goid snipe." He insisted that this plover nests commonly on Attu Island, and that it remains until October.

The reported nesting on Attu requires verification, but it is safe to say that the golden plover may appear anywhere-as a migrant or nonbreeder, at least, from Kodiak Island to Attu Island, though it does not appear to have been observed in great numbers.

Stejneger (1885) remarker that "The individuals of fulvus breeding in America migrate in winter along the Asiatic coasts, thus giving evidence of the way in which the species once immigrated into Alaska." The records here given, however, are proof of a migration along the Alaskan coast. Conover (1945) has shown that both the American and Asiatic forms occur in Alaska, and that fulva predominates on the Bering Sea coast of Alaska. Thus, both forms could occur in the Aleutian district.

\section{Squatarola squatarola: Black-bellied Plover}

Friedmann (1935) says of the black-bellied plover, "The only Kodiak record I have found is a specimen referred to by Salvin and Godman in their description of this species in their great work on Central American birds."

Osgood (1904) says "Two black-bellied plover were collected by McKay at Nushagak Aug. 8 to 14, 1881."

Turner (1886) says "They occasionally occur in the spring migrations on the Aleutian Islands, the more abundantly on the 
western islands than those in the vicinity of Unalaska. I saw several on Sanakh Island in the spring of 1878 , and also in late August of 1879."

Stejneger (1885) says that they occur on the Commander Islands in fall migration only.

We saw none of these bircis on any of our expeditions.

\section{Aphriza virgata: Surfbird}

Turner (1886) says of the surfbird "At Sannakh Island in 1878 , and at Kodiak in 1881, I saw several individuals of this species, but under circumstances which rendered it an impossibility to collect them."

Friedmann (1934) records a specimen to the northward at Goodnews Bay on the Bering Sea coast, taken August 12, 1933.

The Attu chief, who is well versed in his native avifauna, did not recognize a picture of this bird.

\section{Arenaria interpres: Ruddy Turnstone Arenaria interpres interpres}

Commander Islands (natıve): Kidmalgikh (Stejneger)

Russian, Commander Islands: Kasnonogoj Kulik, i.e., red-legged sand snipe (Stejneger)

A series of specimens was available for study: 2 from Nushagak, 1 from King's Cove, 2 from Unimak Island, 1 from Unalaska, 2 from Umnak Island, 1 from Ogliuga Island, and 1 from "Aleutians." In addition to these (which we examined), McKay obtained a turnstone at Nushagak, August 12, 1881.

We carefully compared the above-mentioned specimens with series of $A$. $i$. morinella from eastern localities and with specimens of $A$. i. interpres. The relationship between these two forms did not seem to justify the insertion of an intermediate subspecies, such as $A$. $i$. oahuensis, as has been proposed. Moreover, the present series from the Aleutian district agrees with the characters of A. i. interpres. One specimen, No. 118845 of the U. S. National Museum, taken by William Palmer, at Unalaska, May 19, 1890, is much like morinella and perhaps could pass for that race, especially because of the coloration of the head. But, when the extensive black on upper parts and the restricted brown areas and paleness on the wings is considered, it seems best to refer it to interpres.

On May 22, 1936, we observed a small flock of turnstones, believed to be of this species, at Nelson Lagoon. On August 20, 2 or 3 ruddy turnstones were seen at Port Moller, where they were feeding on the beach with Aleutian sandpipers. 
In 1925, I took three specimens of ruddy turnstones at St. Catherine Cove, Unimak Island-others were seen, including one at False Pass.

Wetmore observer them at King's Cove in August 1911; McGregor (1906) noted them on Unimak Island, August 14, 1901, and he obtained two specimens on Amaknak Island, August 17.

Laing (1925) found 10 of these birds at Unalaska on August 8, 1924, and collected 3. Cahn (1947) saw one ruddy turnstone, in company with other sandpipers, at Summer Bay, Unalaska Island, July 18, 1944.

Gabrielson found small groups of ruddy turnstones at Amchitka in September 1944.

Littlejohn (1887-88) wrote "Plentiful in the fall at Sanakh where some remain during winter. They are very fat and toothsome. Also numerous at Morzhovoi Bay."

We found small flocks at Ogliuga and Skagul Islands, on July 23 and August 5, 1936, and the following year they were seen again at the same place on July 27 and on August 4. One specimen was taken. On June 5, 1937, we saw 1 on Kiska Island; on July 31, we saw 1 on West Unalga; and on August 2, we saw 12 on Ilak Island.

Turner (1886) says "The turnstone is of more frequent occurrence in the region about the shores of Bristol Bay, the Alaska Peninsula, and the Aleutian Islands; perhaps more common on the western islands of that chain than to the eastward. I saw individuals at Attu, Amchitka, Atkha, and in the vicinity of Belkovsky village." And he adds: "They do not arrive on the Aleutian Islands until the middle of May, and none were observed anywhere after the 1st. of October."

Nesting throughout this region was not established. Stejneger (1885) states, concerning the Commander Islands, that they are at least migrants, and that possibly some of them breed.

\section{Arenaria melanocephala: Black Turnstone}

Bretherton (1896) found the black turnstone breeding on Kodiak Island, and Friedmann (1935) lists a number of other records for that island. Osgood (1904) collected one black turnstone at Lake Clark, base of Alaska Peninsula, July 23, 1902, and observed others at Nushagak. He also mentions specimens taken in June, July, and August, at and near Nushagak and Ugashik, by McKay and Johnson.

During August, Hine (1919) found these birds at Kashvik Bay in increasing numbers; by August 25, they were one of the most 
abundant shorebirds, being observed in flocks of at least 100 . Specimens were taken. Evidently, this is in the migration route.

July 23, 1940, Gabrielson found this turnstone to be common along Kvichak River, above Naknek.

We frequently saw the black turnstone on the tide flats at Ugashik River, May 27 to 29, 1936. One day, I noted 8 pairs, and found a deserted nest containing 3 eggs. Evidently, the birds were on their nesting grounds, which were confined to the tide flats rather than to the somewhat higher mossy areas farther back.

Littlejohn (notes) wrote "Saw one flock in the spring at Sanakh. Tried hard to obtain a specimen but failed. They were very wild."

Turner (1886) saw one of these turnstones at Belkovsky, south side of Alaska Peninsula, in the early part of August 1881. He says that they were reported to be plentiful on Unga and Sanak Islands, where natives claimed this bird interfered with hunting of marine mammals by making its characteristic outcries. The natives had stated that the black turnstone is not found on "Unalashka and other islands west of the mainland."

\section{Family SCOLOPACIDAE}

\section{Capella gallinago: Common Snipe Capella gallinago delicata}

Attu: Goo-lech'-arch (?)

The Attu chief insisted that he recognized a picture of a Wilson's snipe and gave us the native name, adding that the bird nests on Attu as well as on other islands. Since this is at variance with all other information, one must seriously question it. There is the possibility that the chief was referring to an allied form from Siberia, which resembles the Wilson's snipe, and which may occur sometimes in the Near Islands.

On May 12, 1936, a Wilson's snipe was performing high in the air over Kodiak Island, evidently on its nesting ground. Again, on May 25 and 26, several of these snipe were performing at Snag Point, Nushagak River. Osgood observed this species at various parts of the base of Alaska Peninsula, and, he records a specimen taken by McKay, April 25, 1882 (1904). Hanna also obtained a specimen at Nushagak, May 16, 1911.

Cahalane (1944) observed the common snipe in several places within the Katmai National Monument in 1940, and on July 17, 1940, Gabrielson saw two snipe at Dillingham. 
Jaques (1930) found these birds in the Port Moller region in June, and Bent (1927) includes the Shumagin Islands in the breeding range.

In 1925, I noted one common snipe at Urilia Bay, Unimak Island, on May 3, and another was heard several times at Moffet Cove, Izembek Bay, on July 22. Uncloubtedly these were nesting birds, so there is good evidence that the nesting range reaches westward at least as far as the Shumagins and Unimak Island.

\section{Numenius phaeopus: Whimbrel Numenius phaeopus hudsonicus}

The occurrence of curlews or whimbrels was rather sketchy and none was found breeding. Osgood (1904) reported three specimens collected by McKay at Nushagak in August 1881. Cahalane observed a flock of seven flying in an easterly direction about 5 miles above Naknek village, on Naknek River, September 2,1940 .

On July 23, 1925, I observed a flock of six curlews flying over the marsh at Moffet Cove, Izembek Bay. On June 5, 1937, 2 curlews were seen at Kiska Island in company with 16 Pacific godwits and a ruddy turnstone. Again, on July 30, a curlew was seen on Kavalga Island. These were thought to be phaeopus, but specimens were not taken, and it is possible that some, or all, were tahitiensis. Stejneger (1885) reports the eastern whimbrel as a migrant on Bering Island.

\section{Numenius tahitiensis: Bristle-thighed Curlew}

On July 23, 1940, Gabrielson recorded in his field notes, for the Kvichak River, above Naknek, "Flock of 20 flew over. Dufresne has seen as many as 200 in the past 3 days around Naknek."

This is the only record we have, but, in 1924, we had observed migrating flocks of immature birds at Hooper Bay, and it is logical that bristle-thighed curlews should pass over the basal part of Alaska Peninsula in migration.

\section{Actitis macularia: Spotted Sandpiper}

Friedmann (1935) lists the spotted sandpiper in the Kodiak avifauna on the basis of four specimens collected by Wosnessensky during 1842-43. Speaking of the base of Alaska Peninsula, Osgood (1904) says-

When we arrived at Lakes Iliamna and Clark, in the latter part of July, the majority of the spotted sandpipers, which doubtless breed in the region, 
had migrated, and only scattering stragglers remained. One small flock of 8 or 10 hornotines was seen nervously flitting from point to point along the gravelly beaches of Lake Clark July 25. Some days later a few belated individuals were found along the lower part of the Chulitna River. Practica'ly all were gone before August 10.

We found none of these birds farther west.

\section{Tringa glareola: Wood Sandpiper}

There is a single record of this bird for Sanak Island-a specimen taken by Chase Littlejohn on May 27, 1894 (Littlejohn, 1904). The bird was found among some Aleutian sandpipers, and another, thought to be of this same species, was seen.

Stejneger (1885) reported it rather common and breeding in the Commander Islands.

\section{Heteroscelus incanum: Wandering Tattler}

Russian, Commander Islands: Tschornij hulik (Stejneger)

A wandering tattler was seen on Kodiak Island, May 12, 1936, and 6 or 7 were seen on the beach at Karluk, Kodiak Island, September 1. Hine (1919) collected two specimens at Katmai Bay in 1919. Gabrielson noted a wandering tattler near Iliamna Lake on July 24 and 26, 1940, and he noted the species at Cold Bay, King Cove (with specimens), and Kodiak, as well as at Dutch Harbor and Amchitka. We obtained a specimen on Nagai Island, Shumagin group, May 16, 1936, and we saw one at False Pass, August 23. Scheffer saw one on Sanak Island, August 28, 1937. Nelson (1887) had seen one on Sanak Island, May 15, 1877.

The wandering tattler has frequently been reported in the eastern Aleutians. Bishop (1900) obtained 2 at Unalaska, October 5, 1899; McGregor (1906) recorded 2 specimens from English Bay, Unalaska Island, June 2, 1901: Laing (1925) saw 4 at Unalaska, where Turner also recorded 1; and Swarth (1934) reports 6 at Akutan, which includes 3 specimens taken.

On July 16, 1911, Wetmore obtained a breeding female at King Cove, Alaska Peninsula, and said he judged that she had young in the vicinity. He found the birds to be common there in August.

In 1925, I observed wandering tattlers at False Pass and Izembek Bay. On May 21, there was a pair on the beach, calling and perching on various boulders. On July 19 and 23, there was a pair and a single bird on a small gravelly stream flowing out of the marsh at Moffet Cove. August 8 and 9, there were several on the gravelly stream at False Pass, and, the next day, five 
were collected on the rocky beach at Ikatan Peninsula. These last-mentioned were extremely fat. Local residents said that these birds occur on streams in the vicinity of Becharof Lake.

Undoubtedly, the wandering tattler nests along the gravelbordered streams in this region. It was on such a habitat that Adolph Murie and I found a nest in Mount McKinley National Park in 1923, and, considering the available evidence, it is more than likely that the wandering tattler nests along the Alaska Peninsula, on Kodiak Island, and probably on other suitable adjacent islands. It is possible that it nests on many of the Aleutian Islands farther west also. Turner" (1886) said: "Among the Aleutian Islands it was observed once on Unalaska, several on Atkha, and twice on Attu." Clark (1910) reported it at Unalaska, Agattu, and Attu Islands, but it was not common. Scheffer saw one at Atka, June 1, 1937. We also noted one on Kiska Island, June 5, 1937, and obtained a specimen on Herbert Island, August 22.

Stejneger (1885) reported this bird to be common in the Commander Islands, and he suspected that it nested there. While visiting those islands, he also obtained a specimen of Heteroscelus brevipes. It is possible that some of our sight records in the Aleutians represent the latter form. It can be expected in the Aleutians, for it has been found on the Pribilofs.

\section{Totanus melanoleucus: Greater Yellowlegs}

Osgood (1904) described a pair that evidently was nesting at a small pond on the portage trail between Lake Clark and Lake Iliamna. He found the species again at Swan Lake and Mulchatna River, and he mentions two specimens taken by McKay at Nushagak, August 14 to 28, 1881. Hine reported that it commonly nested along the shore of Katmai Bay (1919). We observed two of these birds at Anchorage in 1936, and we were informed by local people that the species nests there. Bretherton said that it occurs on Kodiak Island and that it probably breeds there. Howell reports seeing two birds at Kodiak on May 9, 1944. In 1940, Gabrielson found this bird to be common on Alaska Peninsula; he obtained a specimen, and saw others, at Cold Bay in September 1942.

We observed three greater yellowlegs on the beach at Port Moller, August 20, 1936. On July 7, 1925, I observed one of these birds circling about on Amak Island, and from July 18 to 24 they were common on the marsh at Moffet Cove, Izembek Bay.

Evidently, this bird nests at the base of Alaska Peninsula, 
and it is possible that it nests as far west as the end; however, this is not certain.

\section{Totanus flavipes: Lessar Yellowlegs}

We did not encounter this species on our expeditions to the Aleutian Islands, and records are few. Friedmann (1935) mentions a specimen (not available) collected by Bischoff on Kodiak Island; its occurrence at Karluk River was reported by Bean in 1889. Cahalane reported (1943) that he saw "considerable numbers of these birds September [1940] on mud flats exposed by falling tide on the Naknek River below the rapids."

\section{Calidris canutus: Knot}

This species is mentioned here on the strength of Turner's remark (1886): "I have not observed this bird west of Ugasik, on the eastern end of Aliaska, where it was quite plentiful in the latter part of June 1878." Presumably, it migrates through the Aleutian district, but we do not know the subspecies that are involved.

\section{Erolia ptilocnemis: Rock Sandpiper Erolia ptilocnemis ptilocnemis}

Using material that is available in the U. S. National Museum, ptilocnemis, couesi, quarta, and maritima were carefully compared. The last-named species appeared to be more stable in characters than the forms from Bering Sea. In some instances there was a close similarity, shown, for instance, between certain specimens of couesi from the Aleutians and specimens of maritima; winter plumages are quite similar. There seemed good reason to include them all as forms of one species-maritima. However, Conover (1944) studied a much greater series-more than 500 specimens-and concluded that two basic species exist. His conclusion is followed here.

E. p. ptilocnemis is larger than the other Bering Sea forms, and it is paler, both in summer and winter plumages. Compared with coucsi, there is more tan color in the plumage of the back (less of the rusty brown and less of the black admixture). Even the primaries and tail are of a lighter color.

In immature plumage, the feather's of the back are dark and narrowly edged with rusty brown in a smooth regular pattern, thus being distinguished from the broadly edged feathers of the adult at that time of year. In this immature plumage, the differ- 
ence in color of upper parts between ptilocnemis and couesi is not striking. The under parts of ptilocnomis are much paler with a pale buffy and gray area across the breast, the throat is nearly white and finely spotted, and the streaks on the breast and upper flanks are narrow and pale. In contrast, the under parts of coucsi in the same plumage are heavily and boldly streaked and spotted, thus giving the bird a darker appearance. In the winter plumage also, ptilocncmis is markedly paler than couesi.

In all races, the measurements of wing and exposed culmen average greater in the female than in the male. Measurements, in millimeter's, of 13 males and 19 females of ptilocnemis are as follows:

Males: wing, 118 to 132 (125.6); exposed culmen, 27 to 32 (29.3)

Females: wing, 125 to 136 (129.5); exposed culmen, 29.5 to $37.5(33.4)$

The Pribilof sandpiper nests on St. Matthew and the Pribilof Islands, but, as would be expected, it occurs on Alaska Peninsula and the Aleutian Islands in migration. Probably, it winters in this area to some extent. At any rate, among the specimens examined there are at least four from the Bristol Bay region that are referable to ptilocnemis. One of these, a female, was taken by C. L. McKay, at Point Etolin, April 8, 1883. Three others were collected by J. W. Johnson, at Nushagak, April 1 and April 18, 1885. McGregor (1906) records that this species was collected on Unimak Island, August 14, 1901, and on Tigalda Island, August 5, 1901.

\section{Erolia ptilocnemis couesi}

Attu: Too-loo-goó-yuch

Atka: Chu-lich'-tah

Alaska Peninsula: Tsoo-gooch (Wetmore)

Russian, Commander Islards: Lajdinij kulik (Stejneger)

In measurements, coues $i$ is quite comparable to maritima and quarta, but all three are definitely smaller than ptilocnemis. The Aleutian sandpiper is decidedly darker than the Pribilof sandpiper-the markings on the under parts are bolder and heavier; the upper parts contain more black and a greater proportion of rusty biown. In this respect, couesi approaches quarta.

Measurements, in millimeter's, of 29 males and 24 females of coucsi are as follows:

Males: wing, 110 to 123 (117.1); exposed culmen, 25 to 34 (27) 
Females: wing, 113.5 to 127 (120.5) ; exposed culmen, 27 to 33 (30.7)

The Aleutian sandpiper nests throughout the Aleutian Islands, where it is the common shorebird; it also nests along the Alaska Peninsula and adjacent islands-at least as far east as Port Moller (Jaques 1930), and undoubtedly all the way to the base of the Peninsula. Hine (1919) observed it at Katmai Bay in 1919. At least two specimens in immature plumage were taken by Johnson, at Nushagak, July 11 and 18, 1884, and another was taken April 18, 1885-all these specimens appear to be couesi. There may be some question in regard to the breeding status of this bird on Kodiak Island; however, it winters there.

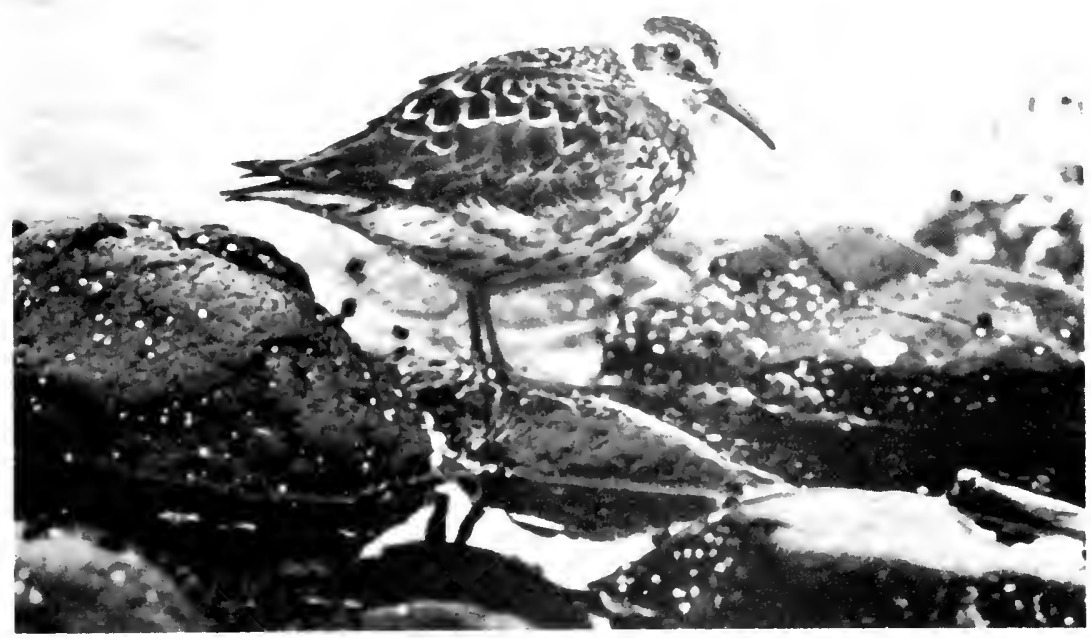

Figube 27.--Aleutian rock sandpiper.

The winter range includes all of the Alaska Peninsula-Aleutian district.

\section{The Nesting Period}

Extensive observations on the nesting of the Aleutian sandpiper were possible in 1925, when I spent a season on Unimak Island and the adjacent part of Alaska Peninsula. On April 29, flocks of Aleutian sandpipers (as many as 20 birds) were feeding along the lagoon at Urilia Bay. The first mated pairs were noted on May 3; these mated birds had left the shorelines and were nesting on the mossy tundra. By May 7, they had become 
more plentiful, and mating was in full swing. At this time, flocks were still common on the beaches-several flocks were noted at St. Catherine Cove on May 17. A flock of 150 to 200 birds, feeding on the tide flat, occasionally would rise, maneuver, wheel, and turn in the air (in characteristic sandpiper fashion), then settle back on the beach. Thereupon, a great babel of chattering would arise, as they all dabbled busily in the wet sand and mud.

On May 18, a single bird was collected on the beach. It proved to be a female with an egg almost ready for the shell. The next day, a flock of 400 was seen. The significance of seeing these large flocks at the same time that others were nesting is hard to determine. They must have been nonbreeders or late nesters.

On May 23, these sandpipers were common on the higher tundra back of Moffet Cove, Izembek Bay trilling and calling, evidently nesting or still making preparations. Some had obviously selected the nesting place or had eggs. By May 28, egg laying was definitely under way.

A nest containing four eggs, found June 5, was a cavity in the ground lined with a few tiny leaves-diameter was $100 \mathrm{~mm}$.; depth was $53 \mathrm{~mm}$.

These nesting habits were verified on later expeditions (in 1936 and 1937) throughout the Aleutian chain. Some sandpipers nested close to tidewater, others nested back in the hills-sometimes a considerable distance from a body of water. On June 1, 1937, on Atka Island, I found 2 nests, each containing 4 eggs. They were shallow depressions in a mass of low vegetation, lined with bits of lichens, straws, and dwarf-willow leaves.

Another nest, with four eggs, was found June 4, high up on Kiska Island. It was a depression in the moss beside a rock; the cavity was 3 by 4 inches wide, and 11/2 inches deep.

On June 22, 1936, on Atka Island, I found a dead, newly hatched young. On June 22, 1937, Scheffer found a brood of 4 recently hatched young on Little Kiska Island. Another brood of 4, several days old, was found on Little Sitkin Island on June 27 ; and, on June 29, a brood of 3 was found on Rat Island.

I heard the mating song of the Aleutian sandpiper at Izembek Bay in 1925. Quoting from my field report, the song suggested-

the droning trill of toads, varied by a repetition of "per-deerrrr, per-deerrrr" ... very much like the red-backed sandpiper's call, but shorter. Later on, when frightened from their nests, they had a variety of alarm calls. As they flew away, they would call "Ka-deer, ka-deer, ka-deer," similar to the notes of mating time, but shorter and sharper, and they also uttered a very rapid "uh-uh-uh-uh-uh-uh-uh." 
Wetmore, in his field report for 1911, says: "The males have a trilling note, almost a whinny that is hard to describe. Also a quick musical whistled turdle turdle, on the Carolina wren order."

The first signs of flocking were noted early in July. On July 5, 1937, a group of 3 adults was observed flying along the beach on Amchitka Island, and, from July 10 to July 20, 5 or 6 were seen in groups several times. On July 24, 1925, two immature birds were collected at Izembek Bay, and several flocks were seen. On July 29, 1937, flocks of 40 or more were seen on Ogliuga Island; after July 29, they generally were seen in flocks.

\section{Erolia ptilocnemis quarta}

Russian, Commander Islands: Lajdinij kulik (Stejneger)

Ernst Hartert (1920) described quarta from the Commander Islands and said-

The purple sandpiper of the Commander Islands differs from E.m.couesi from Alaska and the Aleutian Islands as follows: 'In the winter plumage the foreneck and jugulum are darker slate-colour and less mixed with white. In the full summer plumage the edges to the feathers of the upperside are much wider and of a brighter ferruginous, so that the upperside looks quite rust-red, with mostly concealed black centers to the feathers. The wings measure 121-127, in one female even $130 \mathrm{~mm}$.'

In the series from the Commander Islands (in the U. S. Nation Museum), 6 males and 5 females measure, in millimeters, as follows:

Males: wing, 117-129 (121); exposed culmen, 25.5-28.5 (27).

Females: wing, 120-126.5 (122.8); exposed culmen, 27.5-33 (29.5)

These measurements easily fall within the size range of couesi.

While it is true that quarta is essentially a Siberian form, there are a number of records for Alaska. A. C. Bent (1927) reported these birds, at least one of which was a breeding bird, from Attu Island. Two specimens in the U. S. National Museum, Nos. 131763 and 131764 (probably the ones mentioned by Bent), assuredly are quarta. Another Attu specimen, No. 201468, is very similar to the less brightly colored specimens from the Commander Islands. There is another specimen, No. 298506, from Izembek Bay, Alaska Peninsula, that is very similar to quarta and is practically identical with a specimen from St. Lawrence Island, No. 165056. Another specimen, No. 230608, from Morzhovoi Bay, has the coloration of quarta. Moreover, Bailey (1943) records two specimens from Cape Prince of Wales, taken June 6, 1922, that were identified as quarta. 
Four specimens were collected by F. L. Beals on Unimak Island in January 1941. One of these is very dark, thus agreeing with the description of quarta in winter plumage, and another is nearly as dark as quarta. These specimens have not been identified definitely.

It should be pointed out that in the series from Bering Island (the type locality), there are several specimens that lack the extreme of bright rufescence which characterizes quarta; in fact, these specimens are very similar to average couesi. One specimen from Bering Island, No. 89037, is as pale as some ptilocnemis.

In the light of this circumstance, it is difficult to evaluate the Alaskan records. Are these stragglers of quarta, or are they extremes in variation within the population of couesi? Until more Siberian material is obtained, and until a more extensive knowledge of quarta is at hand, it may be best to accept our records as straggler's of the Old World form.

Since the above studies were made, Conover (1944) reviewed the group and referred the mainland birds north of Alaska Peninsula to tschuktschorum.

\section{Erolia acuminata: Sharp-tailed Sandpiper}

Specimens of this sandpiper have been obtained in various parts of Alaska, including St. Lawrence, St. Michael, and Nunivak Islands, the Pribilofs and the Russian-held Commander Islands. We saw none of these birds on our expeditions to the Aleutian Islands, but Bailey (1925) reported the capture of a specimen (a young of that year) by Hendee, on Unalaska Island, on September 27; and Bishop (1900) obtained a specimen at Unalaska, on October 5, 1899. Undoubtedly, this species occurs in the Aleutian district during migration more often than is shown by published records.

\section{Erolia melanotos: Pectoral Sandpiper}

The pectoral sandpiper proved to be exceedingly rare. Osgood (1904) says "One was taken by Johnson at Nushagak October 15, 1884. The species was not seen by our party." Gabrielson saw three of these birds up the Kvichak River, July 23, 1940.

On July 23, 1925, I observed two birds in the grassy marsh at Moffet Cove, Izembek Bay, which were believed to be immature pectoral sandpipers, but, unfortunately, specimens were not obtained. The Alaska Peninsula should be in the migration route.

Bishop (1900) obtained a specimen at Unalaska October 5, 
1899; Turner (1886) reports taking 3 specimens on Attu Island; and Hartert (1920) reports taking 2 specimens from Bering Island.

Eventually, this bird may be found nesting on some of the favorable habitats on the north side of Alaska Peninsula, such as those near Ugashik River, but at present the nearest known nesting locality, reported by Friedmann, is at Goodnews Bay (1933).

\section{Erolia bairdii: Baird's Sandpiper}

Friedmann (1935) records a number of specimens from Kodiak Island; only one of these specimens is now available for verification. This specimen was taken by Townsend, August 15, 1888.

According to Nelson (1887), Dall recorded Baird's sandpiper from Kodiak and from Amak Island, north of Alaska Peninsula, but there are no specimens to support these records.

More recently, August 7, 1945, Gabrielson obtained a specimen at Wide Bay, Alaska Peninsula. Furthermore, he recorded them at Togalak Island, August 5, 1911; at Unalaska, Adak, Amchitka, Shemya, Agattu, and Kodiak in 19.13; and at Amchitka, Adak, and Kodiak in 1944. These records reveal that this bird is more numerous in the Aleutian district than was formerly supposed.

\section{Erolia minutilla: Least Sandpiper}

Attu: Kre-a-ma-ghré--choo(?)

The chief of Attu village said that he recognized a colored picture of the least sandpiper, and he gave us the native name for it. But because the lack of striking markings makes identification difficult, and because we have no records for the western Aleutians, the chief's statement needs verification.

During our brief stops at Kodiak Island we did not see this bird, but Friedmann (1935) records 6 adults and 9 downy young from Kodiak in the Thayer collection. We observed least sandpipers at Port Chatham, Kenai Peninsula, May 6, 1936, and we observed it again on Ushagat Island, Barren Islands, May 10, where two specimens were taken. Several of these birds were noted at Chignik on May 14, and, on May 24, 1937, a pair was seen on Dolgoi Island.

Hine (1919) observed a few least sandpipers, and took a specimen, near the mouth of Katmai River, July 23, 1919.

Dall (1873) reported it to be rather abundant along the beaches of Popof Island, in the Shumagins, June 20, 1872, and he obtained specimens at that time. 


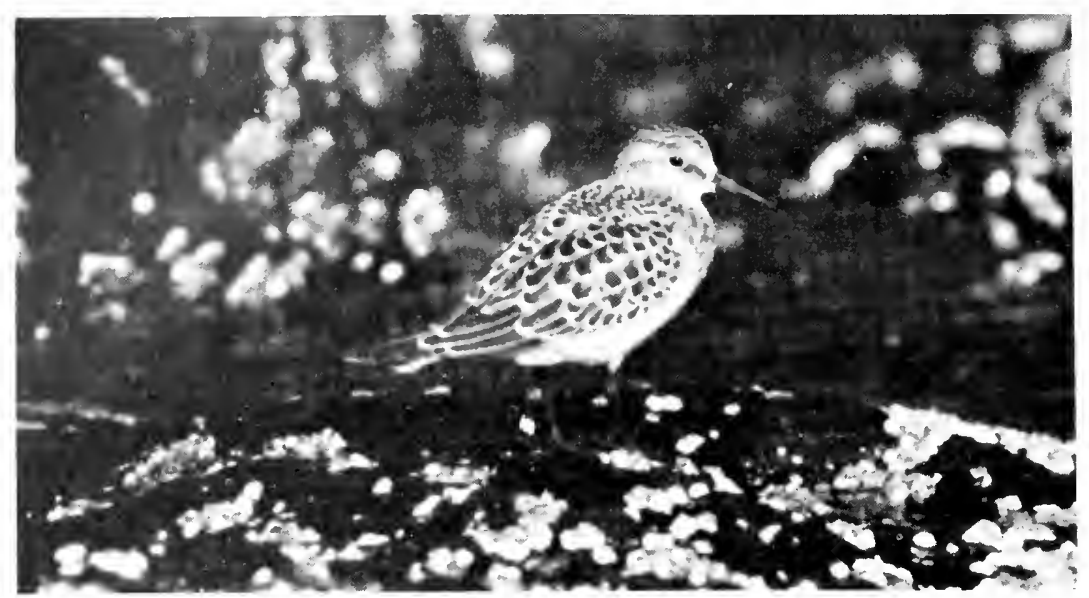

FIGURE 28.-Least sandpiper.

On May 25, 1936, six, or more, least sandpipers were found in the marshy vegetation at Snag Point, Nushagak River, where they were evidently nesting; the following day, a male, with incubation patches, was collected. The flight song was heard here also.

Jaques (1930) reported that after May 25 this bird was abundant about Port Moller in the vicinity of tundra pools. In 1911, Wetmore observed the species in August at King Cove near Thin Point. Late in July, he saw them at Morzhovoi Bay under circumstances that suggested they had just finished nesting. He also mentions seeing them on August 25 between King Cove and Little Koniuji Island, and on August 26 he saw them off Chignik Bay. Gabrielson, on June 21, 1940, found 6 or 8 in a high meadow at Frosty Peak, and he took specimens there and at Unalaska, Alaska Peninsula, and the Shumagins. Gianini (1917) reported them to be common and breeding at Stepovak Bay, where he found a nest with four eggs.

In May 1925, I observed these sandpipers about Urilia Bay and St. Catherine Cove, Unimak Island, where they were common by May 19. At Hazen Point, Izembek Bay, a paix was seen on May 21, and, on May 29, birds were observed going through their mating performance in the valley below Aghileen Pinnacles. Evidently these birds were nesting in the marshy valley bottom. Least sandpipers were found nesting commonly at Hazen Point, where a nest was found on June 22 . The nest consisted of a slight cavity in the matted vegetation, with a few small round leaves in the bottom, and it contained four well-incubated eggs. On June 
20, a small flock, probably nonbreeders, was noted at Hazen Point. During July, this sandpiper was common near Frosty Peak and the islands near Point Grant, and, on July 24, a number of flocks, probably immature birds, were feeding on the tide flats.

Chase Littlejohn (notes) wrote that he "Found [it] breeding from Kodiak to Sanakh, but not in great numbers, a few remain during winter."

McGregor (1906) obtained a specimen on Amaknak Island, May 17, 1901, and obtained another on Tigalda, August 5. Eyerdam (1936) obtained a specimen at Unalaska on May 17, 1932, and Gabrielson collected one there on July 4, 1946. Swarth (1934) records two specimens taken on Akutan Island on May 19 and 31, by Cyril G. Harrold, who had remarked that "Several pairs were observed on the flats on Akutan Island. The male has a strange flight song consisting of a repetition of several low notes uttered while the bird is alternately gliding and hovering."

On May 30, 1937, a pair of least sandpiper's was seen by our party at Nikolski Village, Umnak Island.

We have no records beyond Umnak, but the data indicate that the least sandpiper nests as far west as Akutan-very probably as far as Umnak.

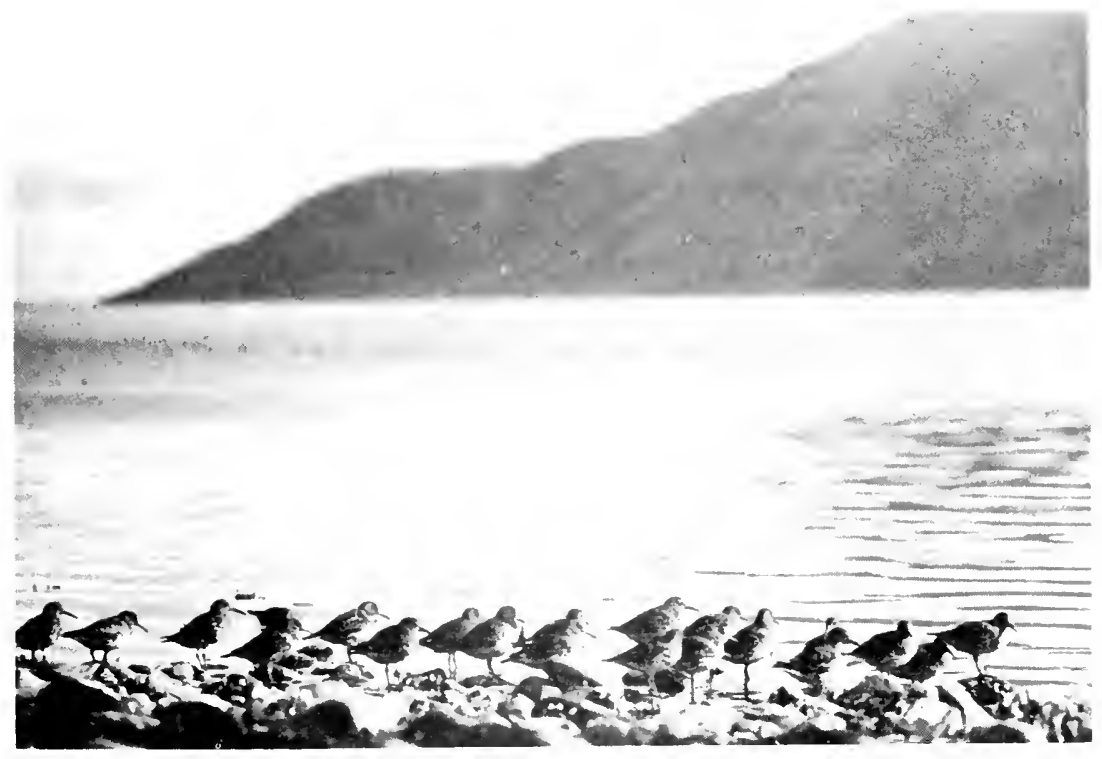

Figure 29.-Least sandpipers. 
Erolia alpina: Dunlin

Erolia alpina pacifica

The red-backed dunlin, or sandpiper, occurs in some localities on the Alaska Peninsula. Osgood (1904) observed several flocks flying up and down the Egegik River on September 29. He mentions several specimens taken by McKay at Ugashik in May and July 1881. G. D. Hanna obtained three specimens at Nushagak on May 31, 1911, and Hine obtained a specimen near the mouth of Katmai River, August 23, 1919.

The specimens taken by McKay suggest nesting. Certainly, in 1936 we found good evidence of nesting at Ugashik River; these sandpiper's were common on the tide flats on May 27 and 29. They were paired and evidently breeding. One was obviously flushed from a nest, though the nest was not found.

On April 29, 1925, I saw a red-backed dunlin feeding on the shore of a lagoon at Urilia Bay, Unimak Island, in company with some Aleutian sandpipers. This may have been a migrant because none were found nesting on the marshes about Izembek Bay. The dunlin's westernmost nesting locality on Alaska Peninsula is, so far as we know, the tidal marshes about Ugashik River.

Taber (1946) noted a few red-backed dunlins wintering on Adak Island.

Stejneger (1885) reported this bird as a migrant in the Commander Islands.

\section{Limnodromus griseus: Short-billed Dowitcher Limnodromus griseus caurinus}

A series of specimens from various parts of the Alaska Peninsula is available, and comparison of these birds with those in other series from differing localities brings up the question of the subspecific status among the dowitchers. Specimens from Point Barrow, St. Michael, Hooper Bay, Fort Yukon, Nushagak, Ugashik, and the west end of Alaska Peninsula were examined and compared with numerous specimens from eastern localities.

At the time that these comparisons were made, it appeared that the Alaska Peninsula birds should properly be included with scolopaceus. Since then, Pitelka (1950) has studied this genus intensively with nearly 3,000 specimens. On the basis of this study, he concluded that scolopaceus and griseus are distinct species, and that griseus includes three forms-griseus, hendersoni, and a new subspecies, caurinus. Previously, Aldrich (1948) had concluded that intergradation between populations could be 
demonstrated among North American dowitchers and, therefore, cnly one species was involved.

The designation of $L$. g. caurinus as the breeding form for southern Alaska would tend to solve some of the classification problems of Alaska Peninsula specimens. However, it still seems difficult to visualize specific status for scolopaceus, as proposed by Pitelka. As one example, a female from Nushagak, with the spotting of the underparts characteristic of the griseus group, was mated with a male, that was heavily barred on the underparts, typical of scolopaceus. Should we consider this to be a case of hybridization between two ordinarily isolated species, or should it be consiclered a case of intergradation between two races of the same species? A parallel situation exists in the case of the fox sparrows at the base of Alaska Peninsula.

A specimen from Ugashik River, Alaskà Peninsula, was compared with one from La Saline, Athabaska River, which, presumably, is the range of the proposed race hendersoni. Both are males-the Canadian specimen was taken May 12, 1920, and the Alaskan specimen was taken May 27, 1936, from a mated pair. These two specimens are almost identical. The longer bill is on the Canadian bird, $60.5 \mathrm{~mm}$., while the bill of the Alaskan bird is $54.5 \mathrm{~mm}$. The wing of the Canadian bird is smaller than that of the Alaskan bird $(144 \mathrm{~mm}$. and $147 \mathrm{~mm}$.). Both birds are deep buff, with very little spotting, the round spots occurring on the sides of the breast and on the flanks. The Alaskan bird has a little more white on the belly than the Canadian bird, though the latter has a pale, noticeably whitish edging on the feathers of the under parts. On the upper parts, the Canadian bird is somewhat darker buff than the Alaskan one. If a mixed series of these birds were laid, it would be most difficult to separate them.

Another specimen from Nushagak River is mostly white underneath and rather heavily spotted. This is a female; the wing measures $145.5 \mathrm{~mm}$., and the bill measures $62 \mathrm{~mm}$. Neither of these two Alaskan specimens has barring on the side of the breast. Without knowledge of the locality, one would place these two, both breeding birds. with the Canadian group; however, other birds from Nushagak show plumage associated with typical scolopaceus. Indeed, most significant of all, the female from Nushagak, lacking the bars, was mated with a male that was heavily barled. Other birds from the Bering Sea coast vary greatly in degree of spotting, in amount of barring, in amount of white underneath, and in shade of solid buff color. Length of bill also varies greatly-even within each sex group. 
In view of so much variation, obvious in any series from a given locality, and because of the extreme overlapping shown here, it would seem that subspecific variation best expresses the nature of the forms.

Friedmann (1935) reports one record for Kodiak Island, "two specimens collected by Wosnessensky in 1842-1843, now in the Zoological Museum of the Academy of Sciences at Leningrad."

As mentioned above, we found several breeding birds on a low marshy area near Snag Point, Nushagak River, in 1936, and a female, collected there on May 25, contained two eggs almost ready for deposition of the shell. Several pairs were seen on the tide marshes at Ugashik River, May 27 and 29.

Jaques (1930) observed several of these birds, and collected one at Port Moller, June 12, 1928.

At Izembek Bay, near the west end of Alaska Peninsula, Donald Stevenson collected an immature female, July 2, 1925, and I obtained another immature female there, July 24, 1925. These birds possibly could have been migrants, but we believe they were on their nesting grounds. The locality is excellent habitat for this bird.

Cecil Williams, a member of our party in 1936, reported seeing a long-billed dowitcher on Bogoslof Island, June 5, at the little "sulphur lake." On such a barren island, this sighting is a most surprising occurrence.

\section{Ereunetes pusillus: Semipalmated Sandpiper}

Eyerdam (1936) reports that this bird was collected at Unalaska and Unimak - the only report of this species for the Aleution district. I have not had an opportunity to see these specimens.

\section{Ereunetes mauri: Western Sandpiper}

Friedmann (1935) mentions that specimens were collected on Kodiak by Bischoff, August 10 to 15, 1868. These are the only positive records based on specimens. This bird should occur there in migration more commonly than these meager records show. On May 10, 1936, C. S. Williams obtained a specimen on Ushagat, one of the Barren Islands, which are not far from Kodiak. Osgood (1904) mentions two specimens collected by McKay at Nushagak, and Hine (1919) observed them commonly in the Katmai-Kashvik Bay area, where he collected specimens. Wetmore found these birds to be common near Thin Point, on the Alaska Peninsula, August 3 to 13, 1911, and back of King 
Cove, July 12 to 20, 1911. Eyerdam (1936) reported that he collected specimens at Unalaska and Unimak, and Gabrielson obtained a specimen at Cold Bay, July 20, 1942.

Turner (1886) stated that "This sandpiper is abundant in all the Aleutians. At Atkah and Amchitka it is extremely abundant." Turner's observations must have been made during certain migration periods. Certainly, his statement does not fit presentclay conditions, because, except for Eyerdam's records, no one else appears to have seen these birds in the Aleutians.

\section{Limosa fedoa: Marbled Godwit}

Osgood (1904) says of this species that "Two immature specimens of the marbled godwit were taken by McKay at Ugashik July $16-18,1881 . "$

This is 1 of the 3 unusual records of this species for Alaska.

\section{Limosa lapponica: Bar-tailed Godwit \\ Limosa lapponica baueri}

Attu: Mí-u-keegh

Atka: Chu-ée-geeh

Dall obtained a specimen on an islet in Akutan Pass, June 2, 1872, and he noted it at Unalaska, June 9. He stated that it breeds there. Nelson (1887) said "On May 26, 1877, while I was at Unalaska, a native brought in half a dozen of these birds, and on June 3 I obtained three other's from the sandy beach of a small inner bay." He said that they appeared to be migrating.

Cahn observed one of these birds near Unalaska Island, on the beach of Hog Island, May 21, 1946.

Turner (1886) said that-

This godwit is found on the Aleutian Islands in the latter part of May as it is on its way to the northward. On Atkah Island I obtained three specimens. They were on the sandy beach of the west side of Nazan Bay. They remain but a few days, and are probably stragglers from the main body of their kind.

At Amchitka I saw four of this species on May 24, 1881. They were in Constantine Harbor of this Island.

I do not think they breed on any of the Aleutian Islands.

Joseph Grinnell (1910) has also recorded two specimens taken at Unalaska by C. L. Hall on May 29 and June 4, 1894.

Donald Stevenson obtained a male bird on Unimak Island, June 3, 1922, and noted that "A few observed, this one only taken. Was very thin and weak. Sex organs swollen." 
Chase Littlejohn (manuscript notes for 1887-88) noted thatMany of these seen in the spring going north at Morzhovoi Bay but they do not stop, they take almost the same route as the black brant but do not bother about flying around the sand bar. As they are not seen in the fall they must take some other route.

\section{A. C. Bent (1927) said-}

On its spring migration the Pacific godwit passes through the Aleutian Islands and the Pribilof Islands on its way to its breeding grounds in northwestern Alaska. I saw two birds on Atka Island on June 13, 1911, probably belated migrants; it has been said to breed near Unalaska, but this seems hardly likely.

On our own expeditions, we met with this bird only once. On June 5, 1937, we found a flock of 16 Pacific godwits, 2 Hudsonian curlews, and a European turnstone at the south end of Kiska Island. Two specimens of the godwit were taken.

We have no records for the Alaska Peninsula, and we have no proof of nesting in the Aleutians. According to Stejneger (1885), this bird is a regular migrant in the Commander Islands.

\section{Limosa haemastica: Hudsonian Godwit}

Osgood (1901) wrote "Nine specimens were taken by Bischoff at Fort Kenai. At least two of these are still in the National Museum-one an adult in breeding plumage, the other in fall plumage."

A. C. Bent (1927) wrote that "It has been reported from Alaska (Kenai, Nulato, Ugashik, mouth of the Yukon River, and Point Barrow)."

These observations show that this godwit rarely appeared near the base of Alaska Peninsula.

\section{Crocethia alba: Sanderling}

Chase Littlejohn (manuscript notes for 1887-88) says "Only three seen during my stay, and these were seen during very cold weather. Twice alone and once with Aleutian sandpipers." $\mathrm{He}$ does not mention localities here, but his observations covered the general region from Kodiak to Sanak Island.

On February 7, 1941, F. L. Beals obtained a male specimen on Amchitka Island.

Stejneger (1885) reports the sanderling to be a rare migrant in the Commander Islands. 


\section{Family PHALAROPODIDAE}

\section{Phalaropus fulicarius: Red Phalarope \\ Attu: A-chi-li-rhá-rch}

Russian, Yana River region: Plavounetz, more often Petouschok (Pleske)

We observed flocks of red phalarope in spring migration as well as later in the summer, when some of them may have been returning from the north. On May 22, 1937, several flocks were seen in Shelikof Strait, many in the red piumage, and the next day, they were common all the way between Sutwik Island and the Shumagins. These were chiefly in the red plumage. On August 26, as we approached East Unalga Island from Unalaska, flocks were seen, this time in whitish winter plumage. On the evening of May 21, 1936, while passing off shore from Unimak Island in Bering Sea, we saw bands of red phalaropes, totaling nearly 100 , flying over the water. On July 15 , over 100 were flying near the Baby Islands in Akutan Pass, and near Rootok Island. Next day, more of these birds were seen near Rootok Island. On two occasions, they were seen feeding along a line of dead kelp.

Cahalane (1943) says "N. J. Benson told me that in August 1940 he had seen a flock of 'at least five thousand' of the "whale bir's' in Shelikof Strait."

Turner (1886) wrote that he "saw but few of these birds at Nushagak. At the mouth of Ugasik River, and the low grounds surrounding it, I saw hundreds of these birds."

Jaques (1930) says that the red phalarope was "First seen near the Shumagin Islands May 15 and 16, at Moller Bay, and throughout Bering Sea on the northward voyage." And again, "Only one bird (at Port Moller) was seen on or near the shore."

There is a strong probability that a few red phalaropes nest on parts of Alaska Peninsula. Turner's observations at Nushagak and Ugashik, and the bird noted by Jaques at Port Moller, suggest nesting, because these are birds of the open sea when on migration. Furthermore, on Nay 25, 1925, I found a female along the stream flowing northwesterward from Aghileen Pinnacles, on the north side of Alaslia Peninsula, and on May 29 another female was flushed from a pond in the upper end of the same valley. On June 22 Donald Stevenson shot a female at Hazen Point; he thought that this bird had incubation patches.

Nelson (1887) says "It is an abundant summer visitant on the Near Islands, and breeds abundantly on some of the Commander group."

Turner, on the other hand, (1886) says "I have no record 
of their occurrence in the Aleutian Islands. They may occasionally occur there with other species."

Stejneger (1885) merely reports a flock seen at sea, near the Commander Islands. Hartert (1920) records five specimens taken on the Commander Islands, and he remarks that the late dates, May 25 to June 16, suggest breeding.

Clark (1910) reports that when he approached Unalaska "thousands of these birds were seen, mostly in flocks of from fifty to a hundred or more, but many singly or in small companies."

The chief of Attu Village said that the red phalarope does not nest in the Aleutians, but he stated that it is plentiful there in winter. This probably is true, though the above data gives good evidence of nesting along the Alaska Peninsula.

\section{Lobipes lobatus: Northern Phalarope \\ Attu: Chirr-teǵ-ech \\ Chimt-khukh (according to Turner) \\ Atka: Chir-riź-ing-ah}

Large numbers of the northern phalarope migrate along the southern Alaskan coast. On May 8, 1937, while passing through Snow Pass in southeastern Alaska, we enjoyed the impressive spectacle of several thousands of northern phalaropes resting on the water. There was much dead kelp, which apparently afforded good feeding. On May 16 and 17, northern phalaropes were abundant on the tide flats at Eyak River, near Cordova, and local residents declared that they nest there. On May 11, 1936, we observed a small group between the Barren Islands and Afognak Island, and on May 13 we saw a flock of about 25 in Kupreanof Strait as well as smaller groups near Kodiak Island. All of these flocks were seen over open water, where they sometimes alighted and swam about.

Cahalane (1944) observed two northern phalaropes in the Katmai region in September 1940, and Hine (1919) noted them on a number of occasions near the mouth of Katmai River where he obtained specimens.

Littlejohn wrote: "Seen often at sea in large flocks and found nesting at Kodiak and Sanakh in April 1888."

On May 25, 1936, two were seen near a pond on the tide flat at Snag Point, Nushagak River, evidently preparing to nest, and, on May 27 and 29, on the tide flats at Ugashik River, many more seemed to be preparing to nest. Some were seen in small flocks, others in twos and threes.

Jaques (1930) found this bird "abundant about the Port 
Moller region in all sorts of pools on the tundra after June 1 until our departure on June 22."

Gianini (1917) noted the species at Stepovak Bay as "one of the most common and interesting of the smaller birds. Every pond had a pair or more... I found no nests nor saw any young, yet these birds breed there."

In 1911, Wetmore found these phalaropes evidently breeding in the Morzhovoi Bay region.

In 1925, I observed many northern phalaropes, obviously breeding, in the wet valley bottom below Aghileen Pinnacles, on Hazen Point, and on the marshes at Moffet Cove. Two males that were collected June 15 had incubation patches, and, on July 19, Donald Stevenson saw a young bird.

Turner (1886) says: "Hundreds of them were seen on the low grounds on the northern side of Alaska."

The northern phalarope also nests on many of the Aleutian Islands. We found them on Unimak, Unalaska, Atka, Little Tanaga, Adak, Amchitka, Ogliuga, Little Sitkin, Kiska, Little Kiska, Buldir, Semichi, and Agattu. Swarth (1934) reports a pair taken on Akutan.

Wetmore found them nesting on Adak, Tanaga, and Kiska, and he believed that they nested on Atka.

Turner (1886) says that they are abundant on the western islands in the Aleutian chain, and he adds that many of them breed on Atka, Amchitka, Semichi, and Agattu.

On Buldir Island, we were much interested to find two of these birds high on the mountain, in the area occupied by nesting geese.

Stejneger reported the northern phalarope to be a common breeding bird in the Commander Islands.

\section{Family STERCOR.ARIIDAE}

\section{Stercorarius pomarinus: Pomarine Jaeger}

Russian, Yana and Indigirka regions: Terbei (Pleske)

Chukchi: Aumuklinuadl'-ukanodlin (Paimén)

According to Pleske, the Russian name "Terbei" applies to jaegers in general. He states that in northern Siberia, people of various languages use one name for all jaegers, adding "large" or "small" for the different kinds. Similarly, among some Eskimos I found that the same name was applied to parasiticus and longicaudus. 
The pomarine jaeger proved to be a rare birt in the Aleutian district, and there was no evidence of nesting.

On the evening of May 21, 1936, several miles off Urilia Bay, Unimak Island, 3 pomarine jaegers passed the ship-2 were together, followed by a single bird that Cecil Williams identified at close range. On May 22, another pomarine jaeger was seen offshore from Nelson Lagoon, Alaska Peninsula, and several others were seen farther east later in the day. On two occasions, we noticed a jaeger trying to rob an Arctic tern. On May 23, three or four jaeger's were seen in outer Nushagak Bay. Farther west, on July 4, three jaeger's were observed between Little Tanaga and Kagalaska Islands. They probably were pomarinus, because they were large and were light underneath; however, positive identification was impossible. Another was seen at West Unalga Island on August 3.

Pomarine jaegers were seen again in 1937. One was seen near Resurrection Bay on May 20; 1 was observed near the Shumagins, May 23, and several were seen near Deer Island, May 24; 1 was seen near Unimak Island, May 25; and 1 was sighted west of Kiska Island, June 6 . One June 17, the captain of our ship counted 7 of these birds off Semichi Islands-I verified 4 of them. Later in the day, another was seen at sea, farther eastward. On August 19, at Cape Cheerful, near Unalaska, there were quite a number of these jaegers among the shearwaters, and on August 24 one was seen near Bogoslof, among gulls and shearwaters.

Austin H. Clark (1910) saw a pomarine jaeger at Bower's Bank in Bering Sea on June 3-this is the only one that he noted.

Pomarine jaegers were always found either at sea or well offshore, they never were seen on land. Apparently, the waters about the Alaska Peninsula and the Aleutians afford excellent foraging for nonnesting individuals. Jaegers probably parasitize gulls and shearwaters in this area, though no doubt they are also capable of feeding directly from the water, where marine organisms are so abundant.

In 1924, we found the pomarine jaeger nesting commonly at Hooper Bay, and no doubt the nonbreeding individuals would be attracted to the Aleutian area, which must lie in their migration path.

Hartert (1920) records two specimens taken on the Commander Islands. 


\section{Stercorarius parasiticus: Parasitic Jaeger}

Attu: Klí-pa-soch

Atka: Ké-uch

Russian, Commander Islands: Rasbojnik (Stejneger)

Chukchi: Uadl' Ukangodlin (Palmén)

The parasitic jaeger nests on Kodiak Island (Friedmann 1935; Bent 1921), throughout the Alaska Peninsula, and along the Aleutian chain. On May 23, 1936, 2 of these birds were seen in outer Nushagak Bay; on May 25, 3 were seen, and, the next day, 2 were observed over the marshy tide flats at Snag Point, Nushagak River. On May 27 and 29, a number of these birds were seen flying about over the tide flats at Ugashik Riverboth the light- and dark-color phases were noted. C. S. Williams collected one in the light-color phase. On August 26, there were five (all of which were in the light-colored phase) over the marsh at Sand Point, Popof Island.

On June 18, 1940, Gabrielson saw a pair at the Semidi Islands, and on July 17, he saw three birds at Dillingham. On July 19, he saw 12 parasitic jaegers on Naknek River.

Jaques (1930) says the parasitic jaeger was "Common along shore and over the tundra north of Port Moller, where it was breeding in June."

In 1925, I found these jaeger's to be numerous about Izembek Bay during the nesting season, and I suspected that they were nesting, though proof was lacking. Wetmore reported these birds "tolerably common" about Morzhoroi Bay, and Gianini (1917) found them quite common about Stepovak Bay.

We saw this bird frequently throughout the Aleutian chain. They were in pairs, on characteristic tundra habitat, and they acted in a manner typical of nesting. Unfortunately, we had no time to hunt for nests.

On June 12, 1936, 4 pairs of jaeger's were found on Chuginadak Island; June 14, 1 was seen on Herbert; June 18, a pair was seen on Seguam; June 29, 3 were seen on Kanaga; July 23, 2 were seen on Ogliuga; July 26, several were observed on Kiska; July 30, 3 were sighted on Attu; July 31, at least 21 were seen high up on Buldir; August 4, 5 were seen on Kavalga and 3 were seen on Skagui Island.

In 1937, they were noted again: June 4 and 5,6 were seen on Kiska; June 7 and 10, 4 were seen on Attu; June 11 to 15, common on Agattu; June 17, 6 were seen on Semichi; June 18, abundant on Buldir; June 21, common on Kiska; June 22, a pair was seen on Little Kiska; June 23, 3 wel'e seen on Chugul; June 27, a pair was seen on Little Sitkin; June 30 , at least 2 pairs were 
seen on Rat Island; July 4, 3 were seen on Semisopochnoi; July 5 and 11, about 7 were sighted on Amchitka; July 29, at least 4 were seen on Ogliuga; July 30, three or four were observed on Kavalga; July 31, 2 were seen on West Unalga ; and on August 2, 2 were seen on Ilak.

On the Alaska Peninsula, the black-color phase of the parasitic jaeger is particularly common, though the light phase probably predominates. In the Shumagins, all five birds seen were light colored.

Among the Aleutian Islands, however, the light-color phase is a rarity. More than 100 parasitic jaegers were recorded, and, of this number, only 4 were specifically mentioned in our field notes as being light colored; nearly all the rest were mentioned as being definitely dark. Possibly in no other area is the parasitic jaeger population so uniformly dark.

Stejneger" (1885) says of the color phase that "On the Commander Islands the dark form is the most common. A few only with white lower surface were seen and one secured."

Hartert (1920) obtained 4 adults in the Commander Islands with white underparts, and he obtained 3 of the dark phase.

Dall (1874) noted the same tendency, believing, however, that the dark color was in the immature plumage; this becomes obvious when he says "nor have we ever obtained any in completely adult plumage. All our specimens are of a nearly uniform dark slate color."

Bent (1921) has suggested that the dark color phase may be a distinct species. That appears doubtful, however. Bent quotes Grinnell as saying that he found a light and a dark bird mated. On two occasions in the Aleutians we observed trios, one of which was white. Unless we can show that normally the two color types keep segregated in breeding, with only an occasional crossbreeding that may be construed as hybridization, it will be better to consider that they are color phases.

A dark-color phase, becoming dominant or very prominent locally, is known among other animal species-for example, in the case of the marmot in parts of the Rocky Mountains, the ground squirrel in eastern Alaska, and the Arctic fox in the Aleutians.

\section{Food Habits}

The name of this bird suggests its food habits. It is known to rob gulls and terns of their food. The Arctic tern and European turnstone were seen pursuing parasitic jaegers, evidently recognizing them as foes. On Alaska Peninsula, there was evidence 
that these jaegers were seeking fragments of salmon left on the banks by brown bears. On Buldir Island, where parasitic jaegers were so numerous, a colony of nesting glaucous-winged gulls probably furnished a food supply for the jaegers.

On Agattu Island, 24 pellets were obtained; these pellets contained the remains of 17 forked-tailed petrels, 3 murres, and 5 unidentified birds. Of the last mentioned, 2 were possibly paroquet auklets and 1 was a small, sparrow-sized bird.

Some of these items, especially the murres, were undoubtedly carrion. A nesting colony of forked-tailed petrels, near the perch where the pellets were obtained obviously was the source of the items found in the pellets-however, the method of capture was not ascertained. It is, of course, possible that the jaegers found parts of petrel carcasses left by blue foxes.

Certain observations suggest that the parasitic jaeger is not solely a carrion eater and robber, but that it hunts part of the time in the manner of a hawk. On Semisopochnoi Island, Douglas Gray and I sat on a slope in the midst of a least auklet colony and watched the performance of a parasitic jaeger. For over an hour, we watched the bird repeatedly pursue these little auklets as the flocks came in from the sea. It did not stoop from a height, but it would single out a bird and follow it as swiftly as possible on the level or at various angles, in irregular flight. There are two possible interpretations. It may have been trying to capture an auklet, or it may have been trying to make it disgorge. So far as we could see, in spite of its persistence, it did not succeed in either purpose.

Stejneger (1885) says, of the Commander Islands: "In the autumn they seem to feed to a great extent on the berries of Empetrum nigrum, and their excreta at that time are colored dark blue."

\section{Stercorarius longicaudus: Long-tailed Jaeger}

Chukchi: Ankakenuadl-ukangodlin (Palmén)

The long-tailed jaeger is rare in the Aleutian district. Friedmann (1935) records a few bones found in middens on Kodiak Island. Osgood (1904) reports one on Iliamna Lake, July 16, 1902, and he records specimens taken by McKay at Nushagak and Ugashik in July and August 1881.

On July 17, Gabrielson recorded a long-tailed jaeger at Dillingham; and, on July 19, he noted three on Naknek River.

Gianini (1917) is the only observer who has reported these jaegers to be common; his observations were made at Stepovak 
Bay, where he collected a specimen. Apparently, Wetmore did not observe them on Alaska Peninsula in 1911, and I did not positively identify this jaeger at Izembek Bay in 1925.

Turner (1886) says "The Long-tailed Jaeger is rarely seen on the Eastern Aleutian Islands. I saw one on Sannakh Island in July, 1878. I saw a few at Atkah Island in 1879, and two at Attu Island in $1880 \ldots$ This species is reported to breed at the Semichi Islands."

Friedmann (1934) reports a number of bones of this jaeger found in middens on Amaknak Island.

Stevenson obtained a specimen on Ilak Island, September 8, 1921.

We observed it only once in the Aleutians. On June 13, 1937, I watched a bird in the normal light-colored plumage, flying about with three parasitic jaegers.

Clark (1910) reports seeing one on Bower's Bank, Bering Sea.

Hartert (1920) records two specimens from Commander Islands. Stejneger (1885) stated that they do not nest there.

\section{Family LARIDAE}

\section{Larus hyperboreus: Glaucous Gull}

\section{Larus hyperboreus hyperboreus}

Russian, Murman coast: Kluscha (Pleske)

Chukchi: Yttak, tchikerga (Palmén)

Though the glaucous gull normally nests north of the Aleutian district, it reaches this area in considerable numbers in winter and in migration to more southern localities. As Friedmann suggested (1935), it is practically certain that Turner was in error when he reported "countless thousands" of these gulls on cliffs at Kodiak. Friedmann records several bones found in middens on Kodiak, adding, "Macoun mentions a bird in the Henshaw collection, and 3 eggs taken in June, 1880, now in the Mailliard collection, [which] are the only other records I have found."

While these are recorded under the name Larus $h$. hyperboreus, they could possibly refer to $L$. $h$. barrovianus. We do, however, have at least one undoubted specimen of $L$. $h$. hyperboreus-a male taken at Unalaska Island by Wetmore on June 9, 1911. Though this specimen was listed by Oberholser (1918) under $L$. $h$. barrovianus, examination of the speciman shows that it has the massive beak that characterizes $L$. $h$. hyperboreus, the measurements being greater than in barrovianus. Since it is 
known that the eastern glaucous gull nests on St. Matthew and Walrus Islands, we would expect it to visit the Aleutian district at times, though the western glaucous gull would be most prevalent. Oberholser (1918) also mentions Diomede Islands for this form.

\section{Larus hyperboreus barrovianus}

Though the status of barrovianus has been belabored repeatedly by able ornithologists, certain specimens obtained in the Aleutians induced me to examine the whole question again. More than 200 specimens were examined in the U. S. National Museum and in the American Museum of Natural History in New York.

It is useless to deny the difficulties in recognizing barrovianus as a distinct form. In studying series from a given locality, one is confronted with specimens that do not fit a given description. Gulls are variable, and one must be cautious in arriving at conclusions. On the other hand, if one is careful to give due weight to breeding territory, and to allow for migration to explain certain irregularities, many of these difficulties disappear.

All gulls of the species hyperboreus are pale mantled, but true hyperboreus is noticeably paler than barrovianus. Furthermore, hyperboreus is definitely larger and has a decidedly larger and more massive beak. Listed measurements do not adequately express the difference. Depth of bill of the two forms overlaps, or meets, at about $23 \mathrm{~mm}$., though most of them are above, or below, this figure, and a difference of even $2 \mathrm{~mm}$. makes a considerable difference in appearance.

A good series of specimens from Foint Barrow and the east shore of Bering Sea are remarkably uniform in the characters assigned to barrorianus - the clarker mantle, the smaller size, and especially the smaller bill. Available specimens from eastern North America are confusing, but it is notable that when winter specimens are eliminated, and apparent breeding birds are used, they fall more generally into the group of hyperboreus. This was especially true of Greenland, where a good series of breeding birds presented a clear picture of Larus $h$. hyperboreus, as here described.

The confusing aspect of the distribution of these two forms is the considerable number of small-sized birds found along the Atlantic coast in winter, which apparently agree with barrovianus, but which are far from the type locality. Possibly we should expect this. Oberholser gave the breeding range as extending along the Arctic coast as far east as "the territories of 
Yukon and western Mackenzie." It is entirely possible that the breeding range extends much farther east. Among specimens examined, $L . h$. hyperboreus was found to the westward across northern Eurasia, Greenland, and northeastern North America as far west as Baffin and Ellesmere Islands. In any case, it may be expected that many of the birds can find their way from Arctic Canada to the Atlantic coast in winter. The gulls are farranging birds. Steller's eider has been recorded from the Gulf of St. Lawrence (Fisher 1900).

It seems logical to consider Larus $h$. hyperboreus as breeding throughout the Arctic regions of Siberia and Europe, traveling as far west as Baffin and Ellesmere Islands (and probably neighboring areas) and, from the west, traveling eastward to the Bering Sea coast of Siberia. In Bering Sea, the birds obviously have come eastward as far as St. Matthew and Walrus Islands. There is a specimen from St. Matthew taken by G. D. Harna on July 9, 1916. Gabrielson obtained a breeding specimen on St. Matthew Island in the summer of 1940. He noted particularly that the breeding colony consisted of birds obviously larger than the glaucous-winged gulls. It may be remarked that the size of the average barrovianus is not far different from glaucescens, including the size of bill. Therefore, the birds noted on St. Matthew Island by Gabrielson would be the larger hyperboreus.

Thus, $L . h$. barrovianus has a breeding range that includes the Bering Sea coast of Alaska and the Arctic coast of Alaska and Canada eastward, possibly across most of the Northwest Territory. Collections of breeding specimens would aid in this determination. There are indications that the two forms meet in the Pribilofs, for there is an immature bird from St. Paul Island that agrees with barrovianus, and another that seems to be intermediate. (No. 118716, U.S. National Museun)

There are a number of records of the smaller barrovianus in the Aleutian district. The records that are not supported by specimens, or specimens that were not examined, are included here on geographic grounds.

Oberholser (1918) listed specimens from the following places: Unalaska, November 1, 1903; November 12, 1904; July 4, 1901 (nestling) ; Amak Island, July 18, 1911 (nestling.)

Wetmore reported seeing a "finely marked" glaucous gull in Unimak Pass on June 4, 1911. (The specimen that he collected on June 9, at Unalaska, proved to be hyperboreus.)

Swarth (1934) records two immature specimens taken on Akutan, May 18 and 21, 1927. Laing (1925) obtained two immature specimens at Unalaska, March 26 and 28, 1924. 
Friedmann (1934) reports two bones from middens on Amaknak Island, and (1937) a bone from Dutch Harbor middens, a skull and a femur from Little Kiska, and two skulls from Attu. Undoubtedly these were not subspecifically determined. In 1937, in the dirt foundation of a bald eagle's nest on Amchitka Island, I obtained two humeri that appeared large enough to be a glaucous gull. This identification was later supported by Friedmann, who thought the bones were slightly undersized (which would indicate barrovianus.)

Bishop (1900) reported seeing several of this species at Unalaska October 4, 1899.

Another specimen collected at False Pass by Donald Stevenson, April 28, 1925, is an immature bird typical of barrovianus. Still another, similar to the above, was taken on Unimak Island by F. L. Beals, April 5, 1941, and another one at Unalaska, March 5, 1942.

Cahn (1947), under heading of Larus hyperboreus, reports seeing a few at Unalaska, and Taber (1946) reports a few wintering at Adak. It would be difficult to determine the subspecies without specimens, but Sutton and Wilson (1946) observed immature glaucous gulls wintering at Attu. On March 17, when they made a count, there was a glaucous gull for every 25 glaucous-winged gulls. It is significant that they noted that the size was similar to that of glaucous-winged gulls, suggesting barrovianus.

We did not find nesting birds of this species on either Unalaska or Amak Islands, therefore it is surprising to recall that Oberholser had listed his two specimens as "nestlings."

\section{Larus glaucescens: Glaucous-winged Gull \\ Attu: Hlí-ka \\ Chá-larch, immature \\ Atka: Shlú-ka \\ Slikkax (Jochelson) \\ Chiá-li-arch, immature \\ Culígidax, immature (Jochelson)}

Russian, Commander Islands: Tschaika, gull in general (Stejneger)

The Aleut names given the glaucous-winged gull are obviously the same in both dialects and resemble the Russian.

This is the common breeding gull throughout the length of Alaska Peninsula, the Aleutians, and other islands, including the Kodiak-Afognak group. Osgood (1904) reported them nesting on islands in Iliamna Lake and at Becharof Lake, and he observed them at Nushagak. On July 24 and 27, 1940, Gabrielson found 
glaucous-winged gulls common about the upper end of Iliamna lake, and he found a nesting colony on some small rocky islets. In flying over the tundra between Egegik camnery and Becharof Lake, he found these gulls to be common everywhere.

The species is the nesting gull on the Commander Islands; also it nests in Kamchatka, the Pribilofs, and as far north as St. Lawrence Island (Nurie 1936).

\section{Nesting}

Glaucous-winged gulls nest in a great variety of sites-on high ledges on cliffs (as near False Pass), on high grassy slopes of islands (a favorite site), on low rock islets, or on the sandy shores

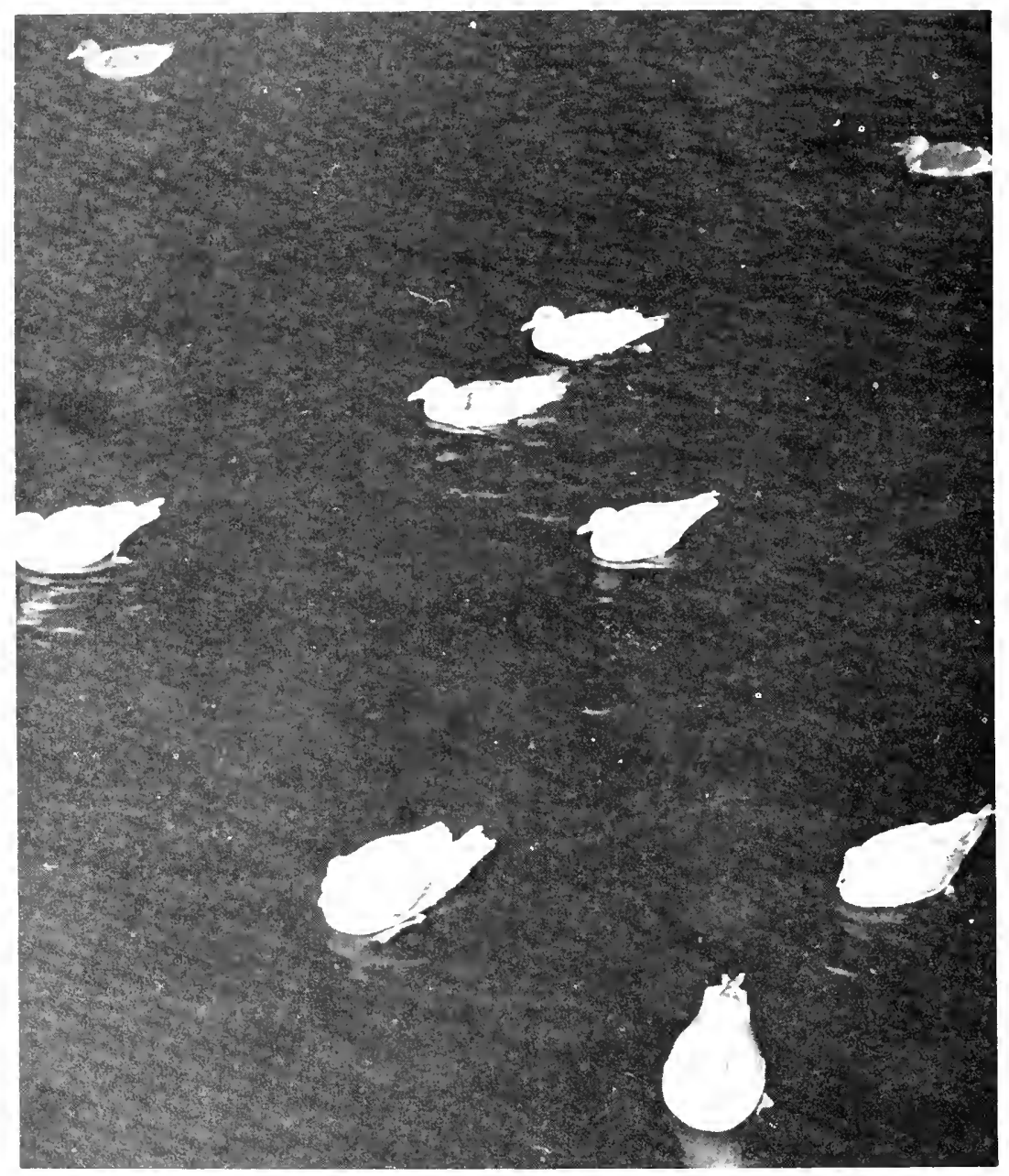

FigURE 30.-Glaucous-winged gulls. 
amidst the rank growth of Elymus. The most important requirements seem to be a handy source of food, and protection from mammalian intrusion. As in the case of many other birds, if blue foxes inhabit an island, the gulls nest on offshore rocks.

Size of colonies varies from a few inclividuals to as many as 5,000 birds - this is an estimated count of birds that I observed nesting on Glen Island, at the entrance to Izembek Bay in 1925. A colony on a high green slope above the cliffs on Amak Island numbered about 2,000, and, on Amagat Island, there were at least 2,000. Throughout the Aleutian chain to the westward, however, the colonies numbered from 50 to 150 , rarely more than 400 . The large numbers in the colonies (mentioned above) may be due to the large food supply provided by the refuse at the cannery at False Pass, the salmon fragments left by brown bears on the Alaska Peninsula, and the fish that the gulls are able to obtain in the salmon-filled streams.

Nests are usually the typical gull structure-a mass of vegetation consisting of grasses, dry kelp or eel grass rolled up by the tide, with dry sponges and other debris mixed in. Frequently, however, the nest is a depression with a scanty lining of grass or other material, and in some instances the gulls had merely formed a depression in a windrow of kelp and eel grass above the usual high-tide mark.

The eggs are of the well-known large gull type, but considerable varis.ion was found. The color tone (speaking in general terms) varied from brownish to greenish. One unusual set of two eggs were a plain light-blue color without brown markings.

Curiously enough, a corresponding rariation in color was noted also among the downy young. The majority had a buffy color tone, but a few were blue gray with no buffy color.

The downy young gull is precocious and is wonderfully adept at hiding at an early age, and therefore it is hard to find where vegetation is rank. On open sandy nesting grounds, the young are likely to run, and they take to the water fearlessly, swimming out a considerable distance. When once started in flight over open ground, these youngsters go headlong and do not stop until they think a safe distance has been attained, even though pursuit has stopped.

One young bird, with its gullet bulging with food, presented an ungainly and ludicrous sight running across the beach. It stopped to spew up food several times until its throat had regained its normal proportions, then it took flight. This action was observed repeatedly. Was the bird consciously lightening its 
cargo to quicken its speed, or was it a peace offering, an early ranifestation of the adult reaction to jaegers' attack? Possibly it is only a nervous reaction and may be common to the young of several species, such as cormorants and pelicans, which promptly spew up their food when disturbed.

\section{Food Habits}

The omnivorous habit of the glaucous-winged gull is well known; it is a glutton in the presence of an abundant food supply. Wetmore (manuscript notes, 1911) wrote of the gulls near the cannery at False Pass that-

Everything is gobbled up greedily, and some of the birds can hardly rise in the air when gorged. I have seen one of them choke down two full-sized dog salmon heads entire, and stand gasping and choking for several minutes with an enormous lump in the throat.

Gulls congregate in large numbers at the cannery docks to feed on the refuse, and are accepted as welcome scavengers. For the same purpose they follow the ships, and they gather to feed on the carcasses of stranded whales or seals or on dead fish thrown up by the tide. They found abundant food at the whaling station at Akutan. On Alaska Peninsula and Unimak Island, where Alaska brown bears feed on salmon, the gulls gather to pick up the leavings.

The natural food taken by the glaucous-winged gulls depends on the environment. In 1925, at Izembek Bay and at St. Catherine Cove on Unimak Island, I found these gulls feeding chiefly on crabs. A small yellow-brown, hairy variety is very common in these waters, and the gulls consistently hunt for it. On the ocean beach, they stalk about at low tide and eat crabs. As the tide ebbs, many crabs are left on the beach, covered with a layer of sand so that they present only a slight lump on the smooth beach surface, however the gulls are expert in finding them. In Izembek Bay, parts of which run nearly dry at low tide, the gulls find a good crab-hunting ground. Food remains on nesting grounds of Glen Island and other points in the bay consisted almost entirely of crab remains, and many empty carapaces were strewn along the beaches, picked clean by the gulls. The smaller crabs are swallowed whole.

The gulls manage to find an occasional clam, and there also is an occasional dead murre or codfish on the beach-additional items in the gull's diet.

On Amak and Bogoslof Islands, the glaucous-winged gull specializes in murres' eggs and young. Nesting gull colonies were situated at a convenient distance from murre cliffs, and the 
gulls flew along the ledges boldly, hunting eggs in a businesslike manner. The murres cackled and presented a pointed beak, but the gull usually managed to snatch the egg of an absent neighbor.

Common-eider and gull colonies are often closely associated, because of similar habitat preferences-an islet safe from blue foxes. An eider nest and a gull nest are sometimes situated only a few feet apart, apparently in good neighborly relations. Yet the gulls seize the eggs or the downy young of the Pacific eider when they have an opportunity. In fact, it appears that the gulls manage to devour an appreciable percentage of eider increase, both in eggs and young.

Other nesting birds may be thus preyed upon under favorable circumstances. On Semichi Island, Scheffer and I were passing a lake, when a common loon swam off at our approach, leaving two downy young. A glaucous-winged gull swooped down, picked up a young loon and flew off with it, pursued by another gull.

Certain adult birds are also taken by gulls. On Semisopochnoi Island, in a least auklet rookery, 137 glaucous-winged gull pellets were collected and analyzed, with the following results:

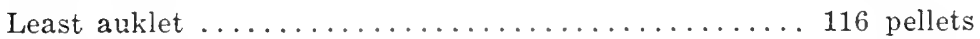

Forked-tailed petrels ................... 3 pellets

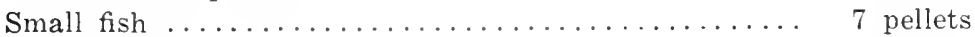

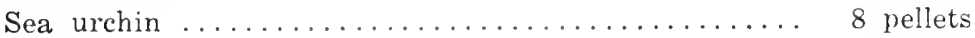

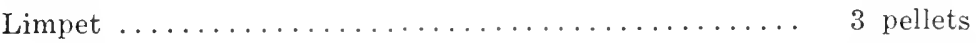

On Gareloi Island we found gull pellets that contained both least and crested auklets, and two fulmar eggs.

Some of the bird material, especially that of the crested auklets, probably was carrion left by blue foxes; however, our observations were not conclusive.

The sea urchin is another important item in this gull's diet throughout the entire Aleutian district.

At Unalaska, on May 27, 1937, we saw a large flock of these gulls, chiefly immature birds, feeding back in the hills; apparently they were pulling up small clumps of grass. Regurgitated material consisted mainly of seeds, but we did not have time to make a thorough study of this incident.

Where the gulls depend on the tides for their food, they naturally adapt their foraging periods to the time of ebb tide. This was noted particularly in Izembek Bay. At Glen Island, it was noted that fewer birds were present at the colony during low tide; when the tide came in, the colony was in full force. Incidentally, it seemed that by means of a division of labor, the nests remained guarded while a part of the colony fed. 
On Hazen Point, June 13, 1925, I watched large flocks of gray, immature gulls resting 400 yards inland from shore during ebb tide. This area was covered with numerous oval pellets composed of crab fragments. I also found clam shells, which were partly overgrown with vegetation. Obviously, this was a favorite, perhaps an ancestral, resting area, where nonbreeding glaucouswinged gulls had rested and digested food gleaned from the last ebb tide.

\section{Ecological Relations}

It is clear that the clever, adaptable glaucous-winged gull finds its living in a great variety of ways, effectively filling the ecological niche in which it happens to find itself. What is the effect on its environment?

The gull is a scavenger, and the effect of its food habits may be somewhat beneficial to man. Gleanings from the beach, which include crabs, clams, sea urchins and other "shellfish" probably do not upset any balance and, so far as we know, have no bearing on human interests in the area considered here.

As for depredations in murre and eider colonies, we did not work out the ecological problem in any systematic way, yet certain observations may be significant. Perhaps nowhere are depredations more severe than in a murre colony. However, on Bogoslof Island, where such gull depredations on eggs and young have continued for a long time, the murres were present in great numbers and were utilizing all the available nesting sites. The same situation seemed to prevail on other islands. For more detailed consideration of this matter, the reader is referred to the discussion of the murre.

Likewise, the Pacific eider, which also is preyed upon by these gulls, appears able to produce a satisfactory increase in population by the end of the summer. It should be remembered that this eider is not preyed upon by man to any appreciable extent, except for the robbing of nests for fresh eggs in a few localities. Viewing the situation as a whole, it appears that, at least in the Alaska Peninsula-Aleutian Islands district, the Pacific eider and the murre, as well as other species, survive in satisfactory numbers in spite of the gulls.

The glaucous-winged gull is believed to feed on salmon eggs and to prey upon the spawning salmon in shallow streams. This question would require special study, with attention given to the breeding habits and ecological requirements of salmon and the percentage of loss occasioned by the gulls. Naturally, such de- 
tailed work could not be attempted in the course of our general investigation.

\section{Larus schistisagus: Slaty-backed Gull}

This bird is seldom seen on the Alaskan coastline, though it is common on the Siberian side of Bering Sea. Nelson (1887) records a specimen taken by Bean, October 1, 1880, at the head of Chernofski Bay, Unalaska, saying, "the birds were abundant there at the time." He adds: "Further work in this region may show that this specimen is of regular and common occurrence at many points on the Alaskan coast, although it was not noted by myself nor by any previous explorer there."

The slaty-backed gull has continued to be rare, however, and has seldom been seen. Swarth (1931) wrote "None collected but several identified in life [by C. G. Harrold] from time to time. An adult was shot from the ship but lost, between Kodiak and Akutan, May 16, and others were seen at Cape Etolin [Nunivak Island] on August 27 and 29."

Gianini (1917), speaking of Steporak Bay, Alaska Peninsula, says "I noted but one or two here."

Clark (1910) observed a few in Unalga Pass, near Unalaska, but saw no more until he reached the Commander Islands.

In the course of three expeditions to the Aleutians I saw a dark-mantled gull only once-at Bogoslof Island, August 24, 1937, when a single gull of this kind was noted among some glaucouswinged gulls. The specimen was collected and proved to be schistisagus.

On February 14, 1941, F. L. Beals obtained a good specimen of a female at Atka Island, and on March 15, 1942, he obtained parts of another at Sanak. Gabrielson saw 1 at False Pass on March 16, 1942, and was told of 1 at Unalaska, March 20.

\section{Larus argentatus: Herring Gull Larus argentatus smithsonianus}

Friedmann (1935) says "The only definite Kodiak specimens known to me are two birds collected by Wosnessensky in 1842 or 1843, another taken on August 30, 1906 and a number of bones unearthed from old Eskimo middens by Hrdlicka in 1934." He also recorded (1937) bones of this gull from middens at Dutch Harbor, Little Kiska, and Attu.

Jaques (1930) reports "One immature near the Shumagin Islands."

Cahalane (1944) observed a number of gulls on Naknek River, 
Naknek Lake, and Brooks Lake in 1940, which he believed were of this species, and Gabrielson, in 1940, observed the species at various points along the base of Alaska Peninsula.

Taber reports Larus argentatus wintering at Adak Island, but specimens were not obtained. Sutton and Wilson observed a few among the gulls wintering on Attu Island.

We saw no herring gulls on any of our expeditions.

\section{Larus argentatus vegae}

According to the 1931 Check-List, this gull "occurs casually in Bering Sea and on the coast of Alaska to the Aleutian Islands." Swarth (1934) obtained three gulls of the argentatus type from Nunivak Island, which could not be satisfactorily identified. Many of the sight records of herring gulls centered around the base of Alaska Peninsula, where they appeared to be too common to be the Siberian-ranging vegae; all such records are here included under smithsonianus.

Clark (1910), referring to Larus vegae, says: "This gull was rather common in Unalga Pass, near Unalaska, and was seen again, though not in any numbers in Avacha Bay, Kamchatka."

There is at least one specimen of this gull-a female collected by F. L. Beals at Unalaska on February 14, 1942.

\section{Larus delawarensis: Ring-billed Gull}

In 1911, Wetmore recorded in his field notes: "In August I noted a few ring-billed gulls about the head of the lagoon back of King Cove, where they were feeding on dead dog salmon, that lay in a creek bed. I shot one for identification but did not preserve it."

This is the only record of this species west of Prince William Sound.

\section{Larus canus: Mew Gull Larus canus brachyrhynchus}

Turner (1886) makes the surprising statement that "Among the Aleutian Islands these birds congregate in many thousands on the cliffs to breed." Obviously, this is an error, since he describes very well the nesting habitat of kittiwakes, and not the marsh or lake habitat chosen by the short-billed gull. In view of this, it is hard to credit his further remarks on the food habits of this gull at Atka and Amchitka.

Nelson (1887) states the situation more in keeping with the 
usual findings when he says "Although perhaps occurring as a straggler on the Eastern Aleutian Islands during the migrations, it is nearly or quite unknown on the other islands of Bering Sea, except those closely bordering the shoreline."

On September 7, 1938, Scheffer noted a few of these gulls feeding on scraps at the Akutan whaling station, and, on September 8 , he noted them with glaucous-winged gulls feeding on refuse behind the ship.

Friedmann (1937) has recorded two humeri of this gull from middens on Attu Island.

Aside from Friedmann's find, there are no records west of Akutan. In 1925, I noted this species at the cannery at False Pass, and, on May 25, 1937, a few were seen at Ikatan Peninsula. There are suitable lowland nesting places on Unimak Island.

Nests and eggs were found among some small ponds on Dolgoi Island on May 25, 1937. Evidently, nesting was just beginning, for only one of the nests contained eggs. These gulls were observed also at Sand Point and Unga, in the Shumagins, August 29, 1936.

In 1911, Wetmore observed short-billed gulls at Thin Point Bay and King Cove, and Gianini (1917) reports them at Stepovak Bay. On May 17, 1936, we found a widely scattered colony of short-billed gulls on a wide marshy flat at Belkofski; this colony consisted of fifty to several hundred pairs. This was the largest "colony" discovered.

In 1925, I found these gulls nesting about Izembek Bay in moderate numbers. Jaques (1930) found them to be common in June in the Port Moller region, where they nest, and, at Snag Point, Nushagak River, we found them to be common on May 23 to 26,1936 . They also were numerous on the tide flats near Ugashik River, where they were preparing to nest.

Hine (1919) noted the species at Kashvik Bay and obtained a specimen.

We saw one on May 12, 1936, at Kodiak, and we saw three or four at Nagai, one of the Barren Islands, on May 16. We had found them to be common at Seward on May 5; we saw a few at Chisik Island, Cook Inlet, May 7; and we saw some that appeared to be preparing to nest at Anchorage on May 9.

This fairly well outlines the nesting range-from Unimak Island to Kodiak, Seward, and Bristol Bay-which contains the marshland that this gull desires.

Taber (1946) reports four of these gulls at Adak Island, January 12, 1946. 
Food Habits

Little was learned about the food habits of the short-billed gull. In 1925, I found these gulls on the tuncira back of Izembek Bay, among the salmon streams. No doubt they feed on fish scraps left by the Alaska brown bears, but they also eat salmon eggs. Where the water was a little deep, the gulls would drop headfirst and partly submerge in order to reach the salmon eggs on the bottom. The stomach of a bird taken for a specimen was crammed full of salmon eggs.

\section{Larus philadelphia: Bonaparte's Gull}

This little gull is found only sparingly in most of the area here considered, though it is abundant in southeastern Alaska. At Petersburg, a favorite gathering place, flocks assemble at the docks of the shrimp cannery and feed on the refuse. At Juneau, they were eating herring roe attached to fish nets, and we found them again at Cordova. They are reported to be a plentiful summer bird, and they nest at Yakutat (Shortt 1939).

Though they might be expected on Kodiak, such records have not been found. On May 5, 1936, several were noted at Seward, and one was seen there on May 21, 1937. On May 9, 1936, several were seen at Anchorage, and a pair seemed to be preparing to nest at a small marsh, near town.

Osgood (1904) reports a pair of these gulls, evidently nesting, on Lake Iliamna, July 16, 1902, and he mentions specimens taken by McKay and Johnson at Nushagak, at Lake Aleknagik, and at Ugashik. Jaques (1930) found about 40 near Port Moller on June 10, and Hine observed large flocks and took specimens in Kashvik Bay about August 1, 1919. Cahalane found them common on Naknek River, September 3 and 4, 1940, and saw one on Savanoski River, September 20. In 1940, Gabrielson observed these gulls in the Bristol Bay region, and, in 1945, he obtained two specimens at Chignik.

McGregor (1906) found this species among the Krenitzin group of the Aleutians as follows: a bird and a wing found at Tigalda Bay on August 6; about 30 seen off Ugamak on August 12; 1 seen off Tigalda, and 4 seen off Poa, on August 15. He states that they were abundant at Dutch Harbor, August 17.

Bishop (1900) reported these gulls common at Unalaska, October 4-5, 1899.

The base of Alaska Peninsula and the Cook Inlet region lie within the normal breeding range of this gull. Occurrences westward on Alaska Peninsula can hardly be considered nesting 
records without further proof, and certainly this would be true also of those seen in the Aleutians.

\section{Larus ridibundus: Black-headed Gull Larus ridibundus sibiricus}

On June 4, 1937, Douglas Gray noted 3 strange gulls among the glaucous-winged gulls in Kiska Harbor, at Kiska Island, and took 1 for a specimen. This was at first hastily identified as a Bonaparte's Gull, but, on later examination, it proved to be $L . r$. sibiricus, which is the only positive record for North America (Murie 1945).

\section{Rissa tridactyla: Black-legged Kittiwake Rissa tridactyla pollicaris}

Attu: Teegle-ah'-girch

A tka: Teegle-gá-gha

Russian: Commander Islands: Gavaruschka, "on account of its loquacity" (Stejneger)

Chukchi: Kakyttack (Palmén)

The Pacific kittiwake can truly be said to occur throughout the entire length of the Alaska Peninsula and the Aleutian chain; however, it nests only in suitable places. Gabrielson (1940) has described the large colony at Resurrection Point, near Seward, and he recorded two large colonies on Whale Island, near Kodiak. The largest colony we observed was on Chisik Island, Cook Inlet. Some estimates of the number of birds on Chisik Island ran as high as 25,000 birds. At any rate, we judged this to be the largest kittiwake colony that we observed on our trip, though it may be rivaled by the Resurrection Bay and Whale Island rookeries.

We observed groups of these birds along both sides of Alaska Peninsula, as far east as Bristol Bay on the north side. Cahalane found them in some numbers in the Katmai region, and Hine observed them at Katmai Bay in 1919-though they did not appear there until about August 10. Gianini (1917) reports a small colony on a rocky islet in Steporak Bay. Gabrielson found them to be common in the Semidi Islands, and we found them in the Shumagins. There is a colony on a rocky headland on Unga Island. They nest in large number's on Amak Island, and there is a small colony on some cliffs at Cave Point, on the north side of Unimak Island.

We found the Pacific kittiwake in moderate numbers, with occasional concentrations, throughout the Aleutian chain. There 


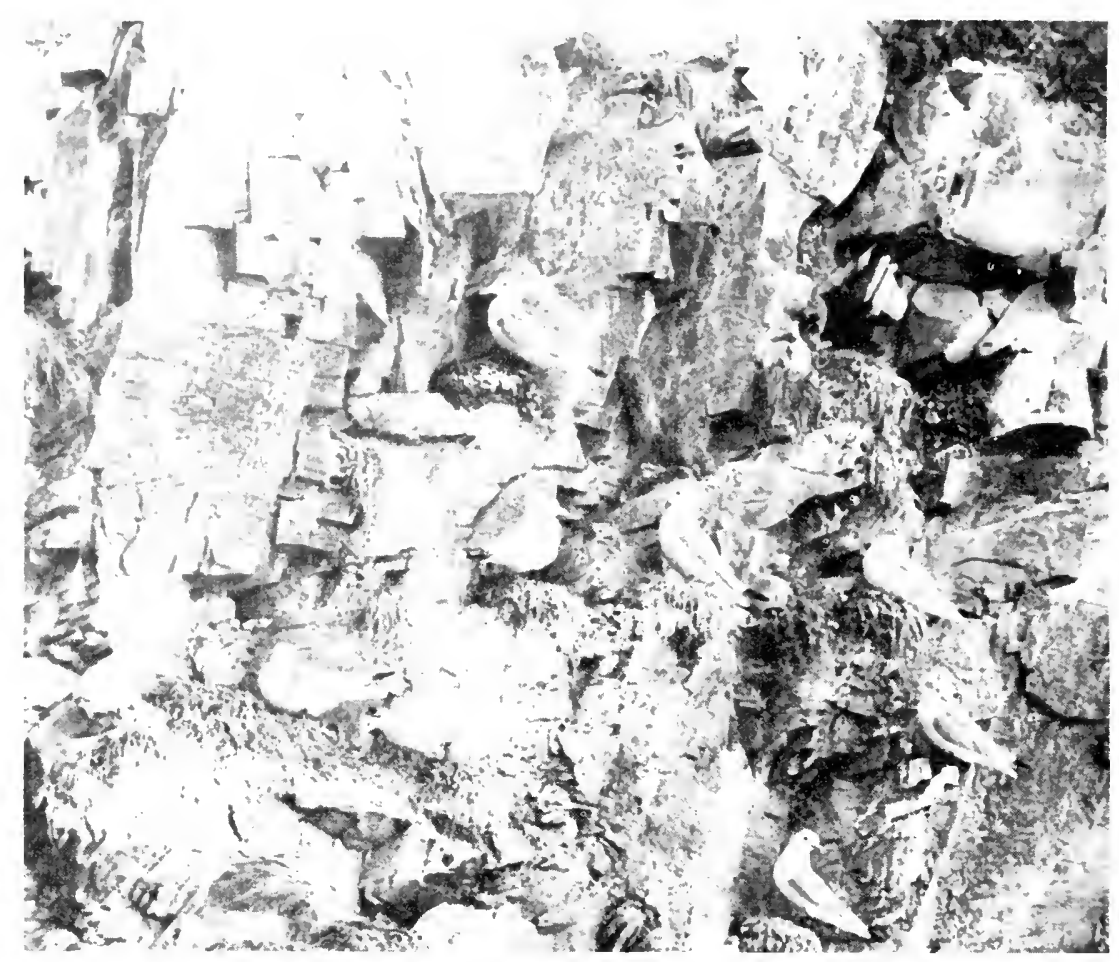

FIGURE 31.-Black-legged kittiwakes.

are nesting colonies on Chagulak, Amukta, Koniuji, Buldir, Unalga, Alaid (of the Semichi group), Agattu, and Attu. There were at least 2 colonies on Attu Island; 1 of them was on Wrangell Cape, which is the westernmost point in the Aleutians. There were at least 3 colonies on Agattu, 1 of which contained 300 to 400 birds.

An interesting observation was made in regard to the colonies cn Attu and Agattu, where we noticed a number of birds in immature plumage perching on points near the nesting pairs. Because of the time of year (too early for full-grown young), these birds must have been 1-year-olds that were lingering about their birthplace.

\section{Rissa brevirostris: Red-legged Kittiwake}

Aleut: Gagiiyax (Larus brevirostris Jochelson)

Russian, Commander Islands: Krasno-nogaja gavaruschka (Stejneger)

Clark (1910) reported that "The red-legged kittiwake was seen in small number's at sea near Unalaska, but became more 
common in the western part of the Aleutian chain and about the Commander Islands. It was not found in Kamchatka nor in the Kurils."

Bishop (1900) says "One was seen by Osgood at Unalaska (Dutch Harbor) Oct. 5, 1899."

Nelson (1887) found them "in considerable number's" at Unalaska on May 26 and Friecimann (1937) has recorded two humeri from middens on Kodiak Island.

We have no nesting records based on specimens. Nelson (1887) says it is an "abundant summer resident in both the Near and Commander islands." He had never been there and obviously was quoting Turner. In 1885, Turner stated, writing of the Near Islands, that the Pacific kittiwake was not abundant and was not known to breed there, while brevirostris was an abundant breeding bird. No specimens were taken. In 1886, speaking of the Aleutians as a whole, he said,

The Aleutian Islands and the Pribylof group are its home. On Akutan quite a number were observed on a high cliff near the village on that island. In the same year (1878) I saw a few at Sannakh, and in later years I frequently saw them passing the vessel which I was on. To the westward this kittiwake occurs more plentifully than tridactyla, with which it associates.

It is true that Clark reported the red-legged kittiwake becoming "more common in the western part of the Aleutian chain," but, on the whole, the situation today appears to be the reverse of what Turner reported. Certainly we cannot say that the Aleutians "are its home." We found that pollicaris was the abundant bird in the Near Islands-based on careful examination of specimens and of birds on nesting cliffs-while Turner stated that it did not breed there.

Wetmore, in 1911, and Gabrielson, in 1940, failed to note the red-legged kittiwake in the Aleutians; Bent does not report any nesting records, but he assumes that it nests there on the strength of the records mentioned above.

On our expeditions we observed kittiwakes closely at all times, but we never identified brevirostris. All of the birds that we collected proved to be the Pacific kittiwake.

Turner (1886) obviously confused the short-billed gull with the kittiwake, and it is possible that he was in error in his account of the nesting of brevirostris.

At any rate, we can be assured that the red-legged kittiwake appear's in the Aleutians as a migrant, because the observations listed above probably involve migrants. The bird may also nest in the Aleutians, but, in view of the uncertainties, any such claim 
should be based on a precise observation, or on specimens of breeding birds.

Hartert (1920) and Stejneger (1885) reported both species nesting on the Commander Islands, usually in separate colonies, according to Stejneger, though he once found both species nesting on the same cliff.

\section{Xema sabini: Sabine's Gull \\ Xema sabini woznesenskii}

Friedmann (1935) reports a specimen from Kodiak, taken by Bischoff, July 25, 1868, and Gabrielson observed one there on August 10, 1945. Osgood (1904) apparently did not observe it at the base of Alaska Peninsula, but he records a specimen taken by McKay at Lake Aleknagik. Hanna obtained a specimen at Nushagak, May 31, 1911.

These birds undoubtedly nest on Alaska Peninsula, however. At Ugashik River, May 27 to 29, 1936, they were common on the tide flats, in pairs, obviously preparing to nest. This area is identical in character with the nesting habitat of this species noted at Hooper Bay in 1924. It is probable that Sabine's gull nests farther west-at Port Heiden and Port Moller for example. We could not examine those areas thoroughly, but, on May 22, at least one bird, in immature plumage, was seen offshore opposite Nelson Lagoon, and Jaques (1930) reports an adult at Port Moller on May 23, 1928.

There is no evidence that these birds nest to the west of Nelson Lagoon, although they have been observed much farther west. On May 18, 1936, one was seen at False Pass, Unimak Island. On May 11, 1925, I saw one at Urilia Pay, and McGregor (1906) obtained a specimen on Unimak Island, August 14, 1901. In June 1937, the natives of Atka Island obtained a specimen, which they presented to us-this specimen is the westernmost record in the Aleutians.

Hartert (1920) records a specimen of an adult male from the Commander Islands, which apparently is the only record for those islands.

\section{Sterna hirundo: Common Tern Sterna hirundo hirundo}

The only record of this bird is a brief statement by Wetmore in his field report of 1911: "I saw several common terns 50 miles off Tigalda Island, June 4." 


\section{Sterna paradisaea: Arctic Tern \\ Attu: Ki-ti-ki-tée-ach \\ Atka: Kri-thich'-tha \\ Russian, Yana region: Tschernogrudka (Birula) \\ Chukchi: Tekechyak (Palmén)}

Arctic terns nest in suitable places all the way from Kodiak Island to Attu. Walker (1923) observed a small colony in Alitak Bay, Kodiak Island, and reports them nesting at least as far south as Taku Glacier, near Juneau. We were informed that a colony of terns, presumably of this species, nested at Bear Bay, near Belkofski, and on an island in Pavlof Bay. Walker has also recorded terns as being common on Simeonof Island, in the Shumagins.

On the north side of Alaska Peninsula a few Arctic terns were seen at Ugashik River, probably nesting, and there was a nesting colony at Nelson Lagoon. In late July 1940, Gabrielson found them to be common on the basal portions of Alaska Peninsula, particularly between Bechar of Lake and Egegik cannery, on the Wood River Lakes, along Kvichak River, and on the upper end of Iliamna Lake.

In 1925, I found them nesting at Izembek Bay, a few in the marshy bottom of the valley running north from Aghileen Pinnacles; a group of 40 and a group of 200 on two small islands near Point Grant; and at least 2 pairs at a small pond near the base of Frosty Peak.

In 1940, Gabrielson found 10 pairs and 3 nests at Morzhovoi Bay on June 21.

In the Aleutians proper, we were told that there was a colony on Kanaga, a few were seen on Tanaga, and we found several colonies on Ogliuga and Skagul. A flock of eight or ten was seen at the south end of Kiska Island, and we noted 15 or 20 at a low reef in Massacre Bay, Attu Island, June 9, 1937. Evidently, there were nesting or preparing to nest. Three pairs were nesting on a small island of a lake on Alaid, and another pair was nesting on the middle island of the Semichi group. Turner reported them plentiful here, and breeding. A few birds were noted at Semisopochnoi and Amchitka, and in 1938 Scheffer saw one at Sanak Island.

The Arctic tern is not abundant among the Aleutian Islands, and the islands mentioned here are probably the majority of those occupied by these terns. Coionies are usually small, and even one or two pairs may be all that nest in a given locality.

Arctic terns nest in the Commander Islands. 
Food Habits

We did not obtain extensive data on food habits. However, we noticed that Arctic terns followed in the wake of our ship when traveling through Bristol Bay. It is possible that the terns desired to feed on the ship's refuse, as gulls commonly do, but it seemed more likely that these terns intended to feed on the small invertebrates, which were brought to the surface by the churning action of the ship's propellers.

\section{Sterna aleutica: Aleutian Tern}

This tern was first discovered on Kodiak Island and was described by Baird from a specimen taken there. As Friedmann has pointed out, there is one specimen and an egg taken by Bischoff on June 12, 1868, when these terns were breeding on Kodiak Island, and, in addition, the National Museum has 12 other eggs taken by Bischoff in that same year, as well as 4 eggs taken by W. J. Fisher in July 1882. But because originai data slips are not present, there can be some doubt as to identification of these eggs. Bretherton noted the birds associating with Arctic terns as late as 1895, but there were no later records until Howell (1948) reported a colony of 50 pair's nesting on Double Island, at Kodiak, June 11, 1944. These, too, were associating closely with a colony of 100 pairs of Arctic terns.

Nelson (1887) described 2 nesting places, 1 on an island about a mile from St. Michael in the mouth of the "canal," the other on an island "some 18 miles to the eastward, along the coast, and less than a mile from the Eskimo village of Kegikhtowik."

In 1920, I visited the first-mentioned of these two islands. The Aleutian terns were still there, but the island was being used as a slaughtering ground for reindeer, and all the nests were trampled by the animals. Fragments of downy young birds were noted. More recent information indicates that these terns no longer nest on this island.

Ernest P. Walker found Aleutian terns nesting on Strawberry Island, Situk River flats, near Yakutat (1923).

Friedmann (1933) reports a colony of Aleutian terns nesting at the mouth of Goodnews Bay. These were discovered by D. Bernard Bull, who estimated between 60 and 75 pairs, together with some Arctic terns. Mr. Bull obtained 1 of the birds with the eggs. As Friedmann says, this is no doubt the largest colony now known on our shores.

Jaques (1930) says "Several hundred were seen at Port Moller, May 22 to 30 ," but he says nothing about nesting. We saw none 
on our visit to Port Moller in 1936, but found Arctic terns nesting at Nelson Lagoon. As many as "several hundred" Aleutian terns would indicate a nesting colony, the largest yet known, but unfortunately there are no further details. It is to be hoped that a good nesting colony will be found on that part of Alaska Peninsula.

In 1925, I thoroughly investigated reports of the nesting of this tern on Unimak Island. Donald H. Stevenson, who had spent 5 years in the Aleutians, reported a colony of Aleutian terns on a little sand island in St. Catherine Cove, on the east end of Unimak Island, and a local guide, John Gardner, appeared to know the species and corroborated Stevenson's statement. However, upon investigation it was found that the powerful tidal currents prevailing there, which no doubt had deposited the little island originally, had washed it away again since Stevenson's last visit. He had collected specimens, some of them at that breeding place. Moreover, on May 20, 1925, I observed 3 terns at St. Catherine Cove, 1 of which was identified as alentica. The other two, though not observed so closely, were probably the same. On the whole, there is good reason to accept this record of nesting, the first for the Aleutians proper.

Not far from this locality, at Izembek Bay, on Alaska Peninsula, we obtained good evidence of nesting. On June 16, 1925, we saw a number of Aleutian terns flying toward Point Grant, and one was shot for a specimen. This specimen was a male with incubation patches. On June 30, three or four terns flew by at an island near Point Grant. Two specimens that were taken proved to be a breeding male and a female.

We covered this area pretty thoroughly, but we found no nesting colonies; however, it is safe to say that Aleutian terns were nesting somewhere in that vicinity. Possibly a few were nesting in the Arctic tern colony, undetected by us, or they may have been in a group by themselves.

On August 14, 1936, C. S. Williams picked up a wing on Nunivak Island, which proved to be that of an immature Aleutian tern.

There are a number of specimens taken on Sakhalin Island in 1914. Stejneger did not find them in the Commander Islands, but Hartert records a specimen, a male, taken in 1911 on Copper Island, the first record for the Commanders.

The Aleutian tern apparently shifts its nesting place in the face of adverse circumstances. This can be construed as an adaptability of survival value. It is possible that this rare species will become more safely established in the Alaskan avifauna. 


\section{Family ALCIDAE}

Uria aalge: Common Murre

Uria lomvia: Thick-billed Murre

Uria aalge inornata

Uria lomvia arra

Attu: Oo-la-rhook-ta

Atka: O-loonǵ-thrah

Sakitax (Jochelson)

Russian (?), Commander Islands: Are (Stejneger)

Undoubtedly, natives do not distinguish the two species. The Commander Island name given by Stejneger (referring to the sound made by the birds), which is assigned to Uria l. arra, may be Russian.

Necessarily, these two species will have to be discussed together, because, in many cases, it was not known which species of murre predominated in a rookery. Only a few birds could be identified because the two species were intimately associated on the nesting cliffs.

In early spring, murres can be seen at frequent intervals from the Kodiak-Afognak region to the end of Alaska Peninsula, and in most places throughout the Aleutian chain. Many of these probably are migrants.

Beals and Longworth (field report for 1941), writing of Unimak Island, said-

Murres were far from plentiful through the month of March... One or two birds a day at the most were all we saw until well into April. On March 16 we saw two birds in full summer plumage... Through May only scattered pairs and small groups of $3-5$ birds were encountered. From the last of May until leaving the island June 17, larger bunches were being seen, groups of 15 and 20 in full summer plumage. They nest on Bird Island near Ikatan Peninsula we are told.

Cahn speaks of the murre at Unalaska Island as "a rare and solitary fall, winter and spring visitor."

There are numerous nesting colonies, often associated with kittiwakes. Gabrielson (1940) has described the large colony associated with kittiwakes at Resurrection Point. He also found some birds nesting at Kodiak and saw large numbers in the Semidi Islands. At the Semidis only irornata was identified.

Among the outstanding murre colonies that we visited was the one on Amak Island. In 1925, I spent 9 days on this island and came to the conclusion that most of the thousands of birds on the cliffs were Pallas thick-billed murres. 
Bogoslof Island is noted for its sea lions and its murres. Here again, although both species are present, we concluded that Pallas murres were in the majority. In 1938, Scheffer estimated that there were about 50,000 of these birds on Bogoslof.

There is a notable colony, consisting of both species, on the steep cliffs of Kagamil Island; however, we could make no estimate of the relative abunclance of each.

Chagulak and Amukta Islands also have their murre colonies, and we found a small group on Seguam-all of these colonies contained both species. On Chagulak, the Pallas thick-billed murre again seemed to predominate. Both species nest on Kasatochi, and unidentified murre colonies were seen at a distance on Koniuji. We found 2 colonies on Attu and 3 colonies on Agattu.

Other small groups nest on various cliffs, and the murre is found almost everywhere throughout the Aleutian chain and along the south side of Alaska Peninsula. On the north side of the Peninsula, however, they do not occur as a nesting bird east of Amak Island, because the low relatively flat coastal plain does not afford proper nesting sites.

At Agattu Island, on June 11, 1937, we obtained a specimen of Pallas's murre that was weak, very thin, and still in winter plumage.

\section{Ecology of the Murre}

The ecological reactions between gulls and murres have already been discussed, but further attention should be given this question with special reference to the mure. It is a well-known fact that large gulls, in this instance L. glaucescens, visit bircl-nesting colonies (such as those of murres) to feed on eggs and young. When one observes this relationship in action for the first time, one becomes apprehensive that the prey species will be drastically reduced in numbers, or exterminated, through interference with the reproducing function. However, the more one studies this problem, the more one is impressed with the principle of mutual racial adjustment, or balance.

Amak Island may be cited as an example. There are the usual colonies of glaucous-winged gulls adjacent to the murre cliffs, together with several nesting pairs of northern bald eagles and Peale's falcons. I visited this island in the summer of 1925 , in the month of July. There was plenty of time to take stock of the avifauna of this little island, for we had to remain 9 days before the weather permitted departure in the small boat. In 1936, we visited the island again, which gave us the opportunity for comparison after an interval of 11 years. Conditions had obviously 
remained static. There were the numerous murres and gulls, and about the same number of nesting eagles and falcons.

On Bogoshof Island, in 1937, we watched the glaucous-winged gulls seizing eggs and young murres, apparently on a large scale. In 1938, Scheffer remarked in his field report, "On the island [Bogoslof], more murres were noted this year resting on the cliffs or vertical bluffs where the party landed in 1937 and 1938." Apparently, the colony was not only holding its own, but it may have been increasing. The bluffs mentioned by Scheffer were not in the main nesting grounds, and were not typical, nor perhaps as favorable, in some respects. Possibly these bluffs were in reality an overflow area in a crowded bird population.

R. A. Johnson (1938) has presented a detailed study of predation of gulls in murre colonies, based on his own specific studies of Atlantic murres and great black-backed gulls, as well as reports of other ornithologists. One factor is disturbance by a human intruder, which makes the murres more vulnerable to attack by gulls. Johnson believes that the fear response by the murres is very important, and that it is a colony response. Once a decline in a murre colony is begun and the colony becomes con-

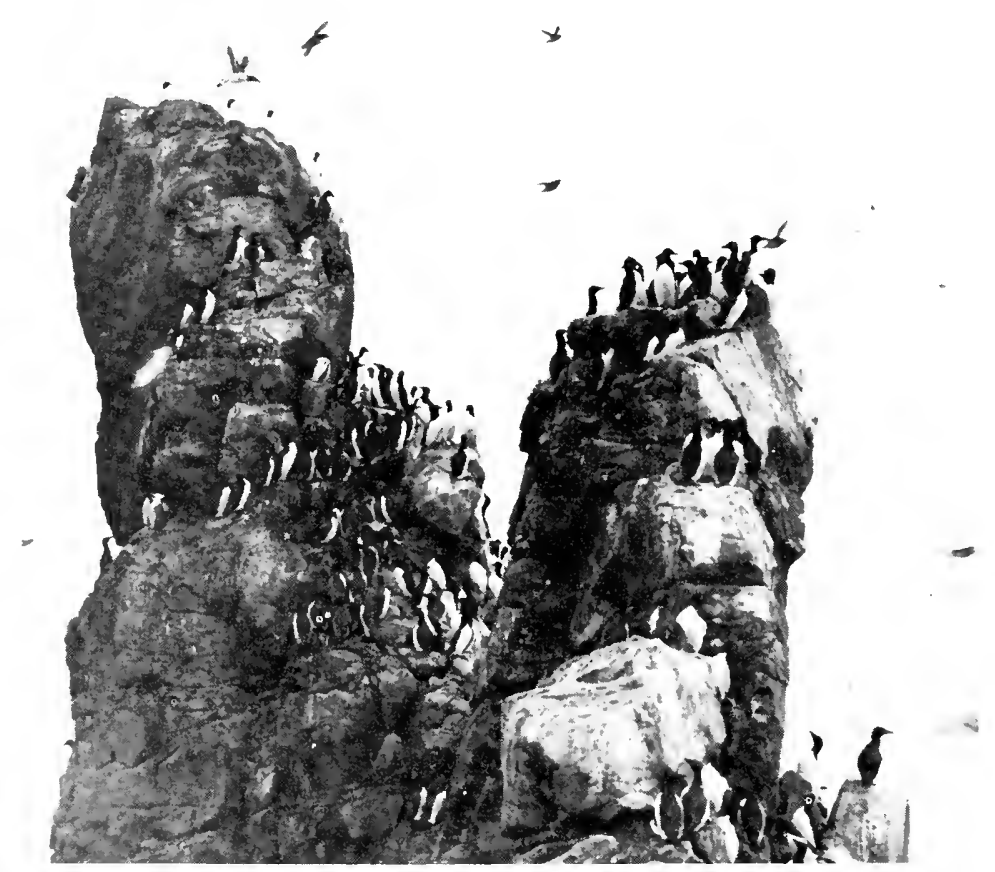

Figure 32.-Colony of Pallas's thick-billed murres on nesting cliffs of Bogoslof Island. 


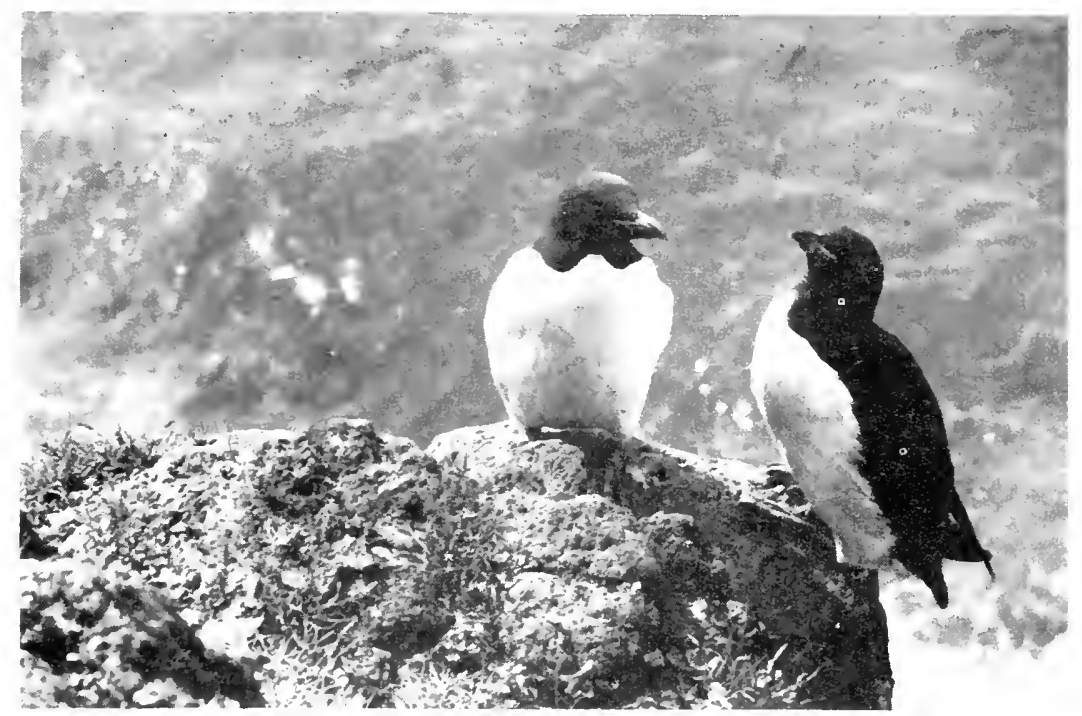

Figure 33.-Pallas's thick-billed murres.

ditioned to the fear stimulus, either by human disturbance or by excessive predation, progressive reduction of the colony may result.

In the Aleutian district, no such drastic reduction of a population came to our notice. Probably there is a minimum of human intrusion. Furthermore, in many cases the historical background was unknown.

The murre is one of the animal species preyed upon rather extensively by raptorial forms. Yet, it does not find it necessary to produce more than a single young in a season. On the other hand, it nests in close-packed colonies and exists in large numbers, and it seems that local predation has little effect.

In common with some other sea birds, murres often succumb to the elements and are found washed upon the beach.

Beals and Longworth, reporting for Unimak Island in 1941, wrote:

Between April 2 and 4 numerous dead and sick murres were along all the beaches. We counted 37 dead birds along 3 miles of beach. The condition was general along the strait [probably Isanotski strait], we were told. Oldtimers on Unimak told us that this happens every spring and that some years the beach is black with dead birds. Swimming in close to the waterline many of them appeared to be sick or very weak and hardly able to dive in shallow water. Altogether we saw 38 dead birds and 40 or more very weak ones along 3 miles of beach. For three days before this heavy winds and snow blew from the southeast. 
One would expect such heavy mortality over a considerable area to be disastrous, but the reproductive rate seems ample to cope with all such natural opposing forces, as well as with predation.

\section{Cepphus columba: Pigeon Guillemot}

\section{Cepphus columba kaiurka}

Attu: Seev'-luch

Siblux (Jochelson)

Atka: Seem-luch

Simlux (Jochelson)

Commander Islands: Kajurka (Stejneger)

Russian, Commander Islands: Svistun (Stejneger)

There may be an error in the Commander Islands names. Stejneger told me that both Aleut and Russian was spoken on those islands. The supposed native name, Kajurka, appears to have the structure of Russian, and Svistun is essentially the same name that Turner found applied to a scoter in the Aleutians, and that I found applied to the American scoter by residents on Unimak Island. The race found in the Commander Islands is $C$. $c$. kaiurka.

The pigeon guillemot is so universally distributed, from Kodiak Island to Attu, that an enumeration of localities is superfluous. Along the north side of Alaska Peninsula it was observed at Moller Bay by Jaques (1930), and specimens have been taken at Nushagak.

Usually they are found in small groups. Possibly the largest aggregation was a loose band of 40 seen at Chugul Island, west of Atka. They nest among boulders on the shore or in crevices of cliffs.

Birds were occasionally seen with an unseasonable whitish suffusion on the plumage, suggesting the winter dress. The first one was noted June 24, 1937, at Davidof Island, and another was noted on June 26, at Little Sitkin. Several were noted at Rat Island, June 30; several were seen at Tanaga on August 3; one was seen at East Unalga, August 26; and several were seen at Sanak on August 29. During this period the vast majority were, of course, in the plain black summer dress.

Apparently, two races of this guillemot breed in the Aleutians. Robert W. Storer (1950) has described Cepphus columba adianta, giving its range from the mouth of the Columbia River "north to and including the Alaska Peninsula and the Aleutians at least as far west as Umnak Island." This would leave the Aleutians west of Umnak and the Commander Islands to the race Cepphus columba kaiurka. I have not had an opportunity to investigate this, but the A.O.U. Check List has not recognized the validity 
of adianta, therefore at present we may call this species, which breeds on the Alaska Peninsula and on the Aleutian chain as far as Umnak, $C$. c. columba. The race that is breeding on the more western Aleutian Islands and the Commander Islands is probably kaiurka, as indicated by Storer.

In 1941, at Unimak Island, Beals and Longworth noted 4 birds in winter plumage, and 5 in summer plumage on March 26; a group of 15 birds in summer plumage was seen on April 8; and 8 in mottled plumage were noted on April 21.

\section{Brachyramphus marmoratum: Marbled Murrelet Brachyramphus marmoratum marmoratum}

On our expeditions we observed this bird frequently in southeastern Alaska, where it is common. On May 6, 1936, a bird in the black and white plumage was seen at Port Chatham, Kenai Peninsula; on May 11, at least 6 were seen between the Barren Islands and Afognak ( 1 of these birds was in the black and white plumage); and on May 11, one or two birds (believed to be of this species) were seen south of Alaska Peninsula and southwest of Sutwik Island. Other murrelets were seen, but under circumstances unfarorable for identification.

Marbled murrelets occur at Kodiak, as shown by Friedmann's well-documented account, and may nest there. Osgood (1904) says "Several murrelets (apparently this species) were seen on Kanatak Bay October 13. A single immature specimen (No. 106605 U.S.N.M.) was taken near Nushagak by J. W. Johnson, Sept. 5, 1885."

Cahalane reports (1944) "I saw these birds commonly along the Shelikof Strait coast, from Katmai Bay northward. They seemed to be most abundant in Kukak and Hallo Bays."

On July 27, 1940, Gabrielson observed a number of marbled murrelets at the upper end of Iliamna Lake.

Gianini (1917) reports seeing this species at Stepovak Bay.

In 1925, I observed murrelets on both sides of Alaska Peninsula, near the western end, but positive identification was difficult. The marbled murrelet was most abundant on the south side, between Ikatan Peninsula and Amagat Island, where several pairs were taken.

The species has been recorded frequently from Unalaska. Nelson (1887) found it there in May 1877 and says that it breeds there. Bailey (1925) reports a specimen taken there by Hendee on September 24, 1922, and Clark (1910) secured a female at Dutch Harbor. Laing (1925) obtained a "breeding female with 
bare brood patches" at Unalaska on August 8, 1924, and he saw a murrelet at Adak Island, but he was doubtful of identification.

There is no information on the nesting of the marbled murrelet beyond Unalaska Island.

\section{Brachyramphus brevirostre: Kittlitz's Murrelet}

Glacier Bay has been shown to be the center of abundance of the Kittlitz's murrelet (Grinnell 1909), but of course it occurs much farther west and north.

Actual records for the Kodiak-Afognak Islands are not at hand, though the birds undoubtedly have occurred there. Osgood (1904) mentions three specimens taken by McKay near Nushagak, April 3, 1883, and Jaques (1930) obtained a specimen at Port Moller, June 6, 1928. Laing (1925) obtained a male in full winter plumage at Chignik Bay on March 22, 1924, and on July 27, 1925, I took a specimen in Isanotski Strait. Stevenson obtained a specimen there on August 3, and obtained one in Izembek Bay on June 17.

It is of interest here to note that a specimen was taken on June 21, 1933, at Goodnews Bay, north of Alaska Peninsula, which was recorded by Friedmann (1934).

Nelson (1887) obtained a specimen at Unalaska the last of May 1877; Turner (1886) obtained one there on April 24, 1879, and says that they are not rare at Amchitka and Atka, though he obtained no specimens at the latter places. He quotes natives as saying that this species occurs throughout the year at Sanak Island.

On June 9, 1937, I collected a pair of Kittlitz's murrelets in Massacre Bay, Attu Island. The female had brood patches, and dissection showed that egg laying had taken place. The Attu chief knew this species and said that it nests on Attu and Agattu but does not winter there. According to him, the birds build a nest similar to that of kittiwakes, on ledges of cliffs, and lay two eggs.

According to Turner's information from natives (1886), "The nest is placed among the roots of the large tussocks of grass on the edges of bluffs and cliff ledges." He stated that the birds lay a single pure white egg.

F. E. Kleinschmidt (Thayer 1914) also refers to a white egg when he quotes Chester A. Reed, the data of Capt. Tilson: "Kittlitz Murrelet-a pure white egg found in a hollow under a bunch of rank matted grass on Sanak Island, June 25, 1899."

In May and June 1913, Kleinschmidt collected eggs of this bird, 
the nesting place being high in the mountains in the vicinity of Pavlof Bay. Some eggs were obtained from birds collected, but one egg was found on the bare lava rock, from which the bird was flushed. The egg, as described by John E. Thayer (1914), is not white, as had been reported, but "has a ground color of olive lake, dotted all over with different-sized markings of dark and light brown. Two others, taken from the oviduct of birds May 29, 1913, had a ground color of yellow glaucous, with dark brown spots over the whole egg."

More recently, the species was found breeding at Wales, Alaska, on July 10, 1934, by an Eskimo, who sent the skin (of an incubating female) to the Chicago Academy of Sciences. The next year, on June 29, the Eskimo obtained an egg. Edward R. Ford (1936) described the egg as having "the ground color of the Xantus murrelet egg figured as No. 6 on PI. 49 of Bent's 'Diving Birds of North America'. The markings are similar too, in character, but in color are black or very dark brown. In shape it is exactly like the Marbled Murrelet's egg shown as No. 5 on Pl. 48 of the same work."

There is one other record, not in an ornithological journal, but in a paper-covered pamphlet published by Rev. Bernard R.

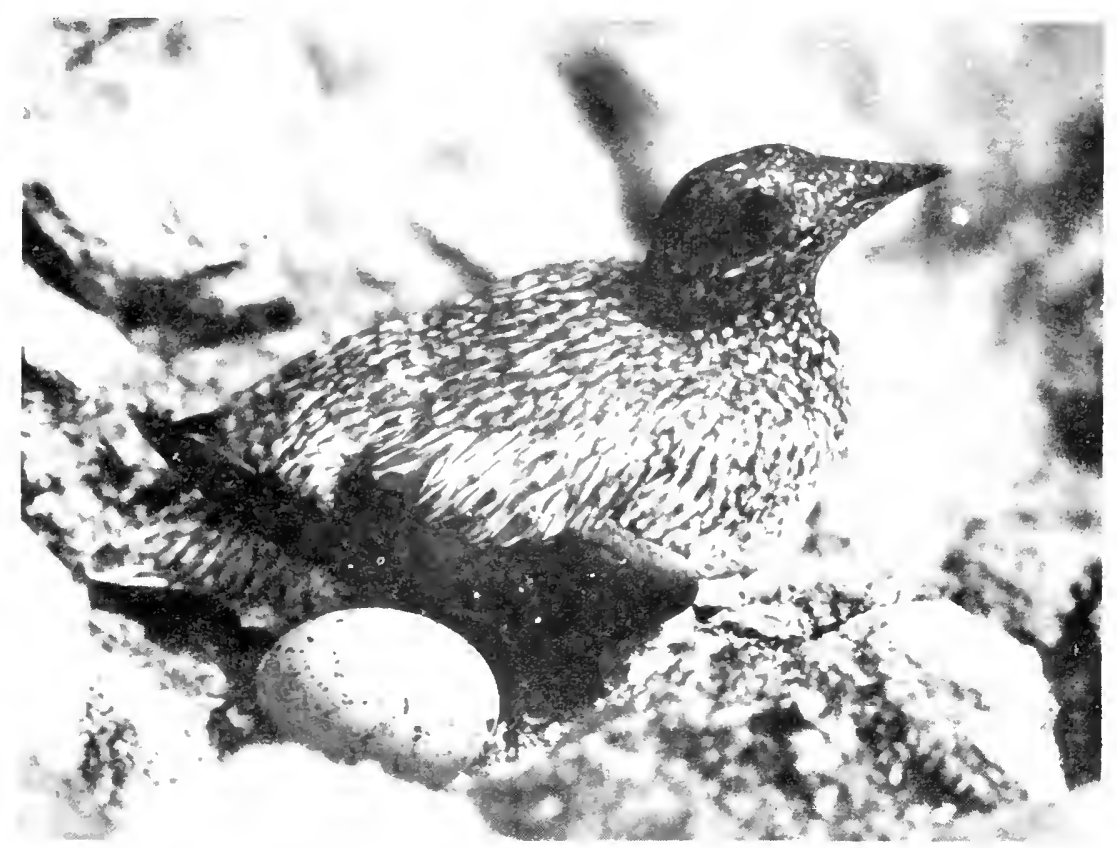

Figure 34.-Kittlitz's murrelet beside its egg. (Photo by Bernard Hubbard.) 
Hubbardd (apparently for the tourist trade), entitled "One Hundred Pictures of Little Known Alaska." Among other pictures, there is a photograph of a "Rare merelet and egg," which undoubtedly is that of the Kittlitz's murrelet. The caption explains that

This very rare web-footed bird usually nests far from water on the rocky crests of mountain ridges. This specimen, unafraid of the camera, was gently lifted off its egg and photographed. The picture was taken in midJuly in the unmapped northern section of the Katmai National Monument on the Alaska Peninsula and is regarded as the only one in existence of this unusual bird and its egg.

\section{Synthliboramphus antiquum: Ancient Murrelet}

Attu: Satrch

Sátáx and qidánax (Jochelson)

Atka: Kriz-yung-a

Russian (?), Commander Islands: Starik, "old man" (Stejneger)

This murrelet is definitely established as a breeding bird of Kodiak Island (Friedmann 1935), and we saw it at intervals all the way to the western end of the Aleutian chain. Jaques (1930) saw several near Belkofski, May 17 and 18, 1928; and McGregor (1906) obtained a specimen at the west side of Unimak Island, August 14, 1901.

Probably this bird appear's only rarely, if at all, along the north side of Alaska Peninsula, but in the Shumagins, on May 23, 1937, we found flocks of them to be quite common. Chase Littlejohn (Bendire 1895) has given us a vivid account of numbers of these birds nesting on Sanak Island, but on our brief visit to that island in 1937 we learned that large colonies of sea birds no longer nest there. Evidently, they have disappeared because of man's exploitation of fisheries, with the attendant disturbance, and be-

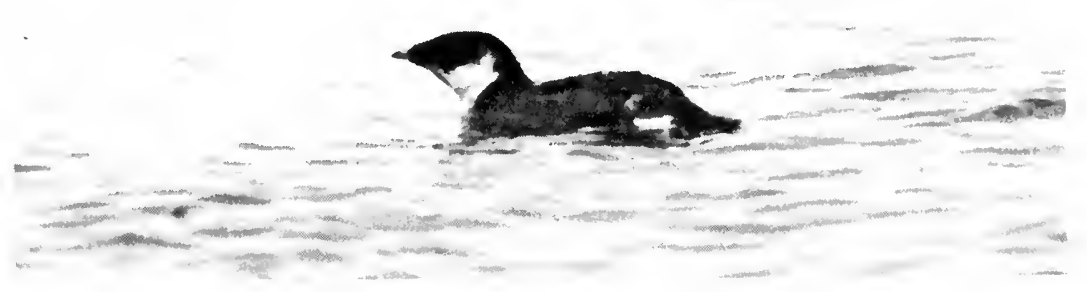

Figure 35.-Ancient murrelet. 
cause of the blue-fox industry. Nelson (1887) states that Dall found the ancient murrelet breeding abundantly at the Chica Islets, in Akutan Pass, near Unalaska, and he adds that Dall found them to be abundant throughout the Aleutian chain.

Turner (1886) obtained a specimen at Atka, June 12, 1879, and says "Among the Nearer Islands this Murrelet is abundant in summer, breeding, and is sparingly resident; rarely coming to Attu, but more plentiful on the western end of Semichi and the south side of Agattu."

We recorded them specifically at Umnak, Kagamil, Carlisle, Herbert, Amukta, Adak, Amlia, Salt, Igitkin, Kasatochi, Gareloi, Ogliuga, Kiska, Little Sitkin, Buldir, and Semichi Islands.

Beals and Longworth found them at Unimak Island in small groups from March 24 to April 27, 1941, and saw them again on August 28, 1941.

We found the ancient murrelets nesting in burrows; a cold egg was found on one occasion in the burrow of a tufted puffin. Early accounts and the statements of natives agree, however, that these murrelets also nest in clumps of tangled grass.

Clark (1910) says "Ancient murrelets were very common all about the shores of the Aleutian Islards and in the bays and harbors, being rather more numerous about Atka, Attu, and especially Agattu, than elsewhere."

Cahn found them "not uncommon during the winter months" around Unalaska Island.

This is one of the species that undoubtedly has greatly declined in recent years, as a result of increase of the blue-fox industry.

\section{Ptychoramphus aleutica: Cassin's Auklet Ptychoramphus aleutica aleutica}

Atka: Mak-cheeth-ah

It proved to be a little difficult to identify this bird when speaking with the natives, but it is believed the native name given above is correct. We could obtain no name in the Attu dialect, as the people did not seem to know the bird.

While the Cassin's auklet is supposed to range "from the Aleutians and Queen Charlotte Islands to Lower California," it is by no means equally abundant throughout this range, nor uniformly present therein. It is known to nest at Kodiak (Friedmann 1935). To the westward of that place it is no longer common. It formerly nested in large numbers on Sanak Island, according to local residents and early accounts (Bendire 1895), but today it has nearly, if not entirely, disappeared from that 
nesting ground. However, on May 23, 1937, we saw several Cassin's auklets not far east of the Shumagins. On August 26, 1937, several flocks were noted off Lava Point, Akutan Island, and, on the next day, neax Kaligagan Island in Unimak Pass, a few groups were noted. George Ermeloff, former chief of Umnak Village, stated that this auklet nested on Keegaloo and Adugak Island, but added: "I guess foxes finish now."

On June 14, 1936, at least 12 of these birds were feeding in the tide rips off the shore of Yunaska Island in company with the more numerous whiskered auklets.

Paul Dirks, former resident of Atka, said that years ago Cassin's auklets were numerous, "millions of them," on 2 small islands, 1 on the north side of Amlia, the other on the south side. He assumed that they were still there, but some native bystanders from Atka remarked that there are not so many there any more, for the blue foxes now swim over to these small islands. Paul's brother, Bill Dirks, chief of Atka Village, said these auklets also nest on one of the small islets at the east end of Tagalak, on Ikiginak, Oglodak, Amtagis, on a small islet in Iskum Bay (Atka Island); on a small islet in the bay west of Amlia Pass; on two pinnacles just west of Cape Idalug (Amlia Island); and on Tanadak, south of the east tip of Amlia. All of these islands mentioned by the Dirks brothers are in the general vicinity of Atka and Amlia Islands. It may be mentioned that Turner (1886) obtained his one specimen from Atka Island.

On July 7, 1936, at Kasatochi Island, a number of these auklets were identified among the vastly more abundant least and crested auklets.

Ilak Island was mentioned as another nesting place, but natives pointed out that blue foxes recently had been placed on that island. On our visit to Ilak Island, we found no live Cassin's auklets, but a few must have been present, for we found their remains in at least three blue-fox droppings.

Clark (1910) noticed these birds about Unalaska, Atka, and Agattu, and he saw a few at Attu. We found none of these birds west of Ilak.

In earlier times, the Cassin's auklet was considered a delicacy by the Aleuts, and Paul Dirks described one method of capture. A fire was built at night near their nesting place. As the birds came to the fire, dazzled by the light, they were seized and thrown into a bag. This attraction to light suggests the similar behaviour of the petrels. 


\section{Cyclorrhynchus psitfacula: Parakeet Auklet \\ Attu: Á-bo-chee-arch \\ Atka: Krech-mó-ga-tha}

Russian, Commander Islands: Bjele-bruschka, "white breast"

Bjele-bruski, plural (Stejneger)

The parakeet auklet has been found nesting on Kodiak Islandwhere a few specimens have been taken, and where Fisher collected seven eggs in 1884 (Friedmann 1935). Apparently, that is the easternmost point in its nesting range, and probably it is not abundant there. We saw none in Kodiak-Afognak waters on our voyages, and they do not seem to be abundant along the Alaska Peninsula. On May 14, 1936, we found a few near Sutwik Island. On May 18 and 19, some of this species were identified among the numerous crested auklets feeding near Ikatan Peninsula of Unimak Island, and, on May 21, a flock of 100 or more was seen near Cape Lazarof of that island. In the following year, we again noted these birds near Ikatan Peninsula, and they were fairly common near the Shumagins on May 23, 1937.

These auklets apparently do not nest on the north side of Alaska Peninsula. On April 30, 1925, I found a dead parakeet auklet at Urilia Bay, Unimak Island; this was the only one seen in a summer's work in that area. They do not nest on Amak Island.

Throughout the Aleutian Islands, however, this auklet is well distributed. On June 4, 1911, Wetmore observed "large flocks of paroquet [parakeet] auklets" in Unimak Pass. We found these birds in small numbers at Umnak, Kagamil, and Uliaga; they were quite plentiful at Carlisle, where they nest, and several were nesting on Chagulak. (In 1940, Gabrielson found them to be numerous there.) Nearly 150 were seen at Herbert Island, and several thousand of these birds nest on Seguam. A few were noted at Kagalaska, Aso, Tanaklak, Unak, Igitkin, Ulak (50 to 100), Kasatochi, Koniuji, Ogliuga, and Unalga. They were abundant on Gareloi, Kiska, and Buldir, and were seen in fair numbers on Semisopochnoi. A few were also noted at Segula (Chugul), Khwostof, Little Sitkin, Amchitka, near Kavalga, Ulak (178 ${ }^{\circ} \mathrm{W}$. long.), Ilak, and East Unalga. Probably the principal nesting colonies are those at Gareloi, Kiska, Buldir, and Seguam, while more-detailed study may show that Semisopochnoi also harbors a great many more than we noticed.

We did not record the parakeet auklets in the Near Islaris, but Turner (1895) reported it to be plentiful on Agattu, and Clark (1910) said that it was "rather numerous in Unalga Pass 


\section{NORTH AMERICAN FAUNA 61, FISH AND WILDLIFE SERVICE}

as we approached the harbor of Unalaska, and was met with at Atka, Agattu, and Attu, though in small numbers."

It also nests in the Pribilofs.

Stejneger (1885) reported it to be a common nester in the Commander Islands, though not numerous, and said that they arrive there about the end of April. Turner intimated that they do not winter in the Near Islands.

The parakeet auklets nest among large boulders on the beach and in crevices in rocky cliffs, also on slopes where the rocks are partly covered with vegetation. This bird has been considered quite solitary in habits, and although this is true for the most part, they occasionally occur in flocks of moderate size. They often gather in flocks on the water just out from the beach, where they sit and chatter in chorus; then they may suddenly disappear from the shoreline and if one were to inspect the beach at such time it would seem that there were no auklets in the vicinity.

We concluded that the parakeet auklet does not consistently fly far out to sea to feed, as is common with other species of auklets. Its principal food seems to consist of small crustaceans.

In his notes for 1938, Scheffer reports that, on August 12, at Ogliuga Island, the stomach of a 2 -foot cod contained the entire body of a parakeet auklet.

\section{Aethia cristatella: Crested Auklet \\ Attu: Ku-noó-yuch \\ Atka: Ku-noó-yuh \\ Commander Islands: Konjuga (Stejneger) \\ Pribilofs: Canooskie, "Little Captain" (Preble) \\ Eastern Aleutians: "Sea quail"}

Apparently, Kodiak Island is the eastern limit of the nesting range of the crested auklet. We saw none east of there. Friedmann (1935) lists a number of specimens from Kodiak, and Laing observed them there in March (1925). Though the birds occur along the Alaska Peninsula, we did not discover nesting colonies there and did not see them in numbers until we reached Unimak Island. There, especially about Ikatan Peninsula, we saw them in characteristic flocks. Dense masses of them would fly over the water, and drop into it, in unison, with a splash, apparently disappearing from sight momentarily, but then appearing suddenly like a dark carpet undulating with the swells. We saw some of these birds opposite Urilia Bay, on the north side of Unimak Island, but we did not learn where these Unimak birds nest. We were told that they do not nest on the Sanak Island group. 
In the Shumagins, however, the crested auklets evidently have nested in huge numbers. Townsend (1913) has given us a vivid account of his experience with these birds at Big Koniuji, in the Shumagins. In Yukon Harbor there were "myriads" of these birds, and Townsend declares that here the crested auklets were more numerous than the least auklets were on St. George, in the Pribilofs.

The crested auklet occurs along the north side of Alaska Peninsula, but not as a nesting bird. Turner (1886) observed them in Bristol Bay and along the north side of the Peninsula. Osgood (1904) records 2 specimens taken by J. W. Johnson at Nushagak on April 22, 1885, and he records 2 specimens taken by McKay at Nushagak and Ugashik.

This auklet nests throughout the Aleutian chain, though usually not in great numbers. There are sizeable colonies, however, on Chagulak, Seguam, Koniuji, Kasatochi, Gareloi, Semisopochnoi, Kiska, and Buldir, and, of course, there are lesser colonies on other islands. Turner (1885) reported them to be plentiful and nesting in the Near Islands. Hartert (1910) noted a few near Unalaska, "but at Atka, Attu, and especially Agattu, they were much more plentiful." Stejneger (1885) reported this bird nesting on both of the Commander Islands, though not abundantly.

\section{Nesting and Feeding Habits}

The crested auklet nests deep in crevices among boulders on the beach, in cavities in cliffs, or among jumbled lava rock on high slopes. When feeding, they fly in compact flocks and often go far out to sea.

On August 9, 1937, we had an opportunity to observe large numbers of foraging crested auklets. They came in flocks through the pass between Tagalak and Ikigmak Islands (which lie west of Atka), and the water in, and south of, the pass was dotted with the birds. Here, they were literally "loading up" with food to take back to their young, and some were so full they could hardly fly. From our knowledge of the existing nesting places in this section of the Aleutians, we knew that these swarms of auklets must have come from Koniuji or Kasatochi, or both, and that they would have a distance of at least 10 miles to fly with their loads of food. It is certain, then, that crested auklets will go at least 10 miles out to sea to forage, perhaps farther.

Observations on the nesting grounds show that small crustacea form an important part of the diet. The rocks about the nest crevices were streaked pink with excrement or with material occasionally spewed out by the birds. 


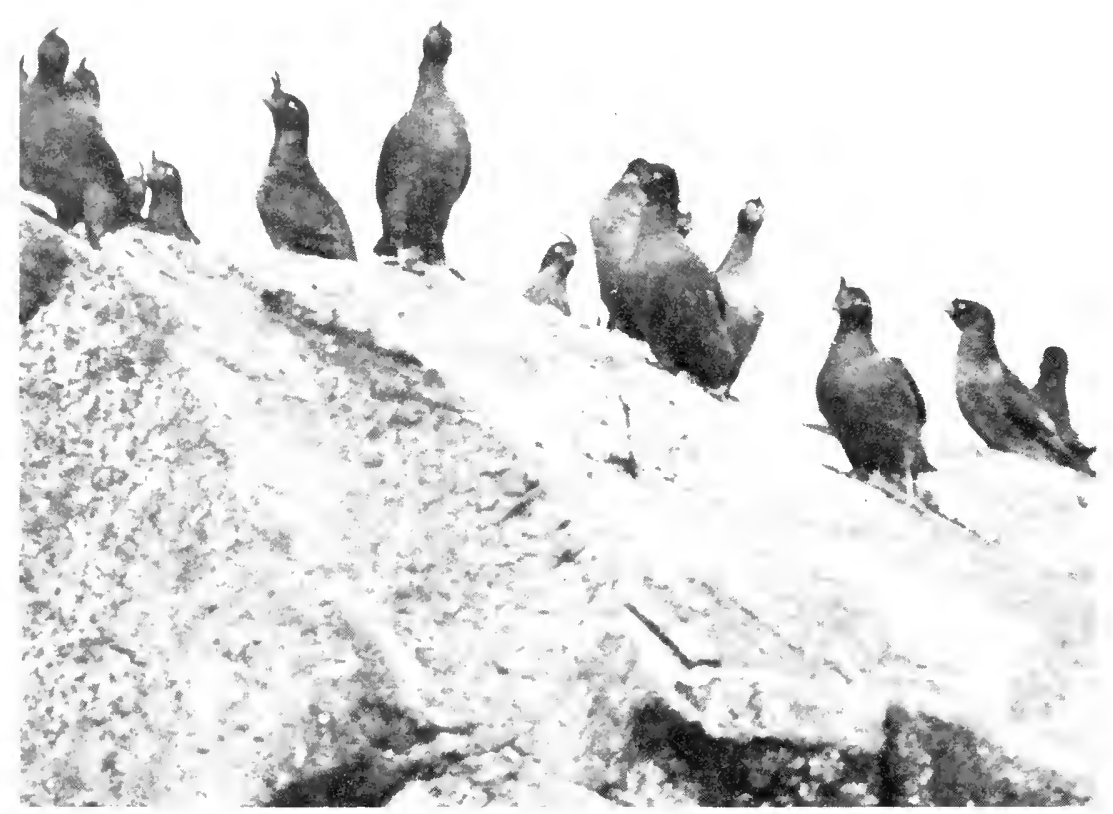

Figure 36.-Crested auklets.

C. H. Townsend has characterized the food situation for the auklets very well when he said (1913) :

We found that a considerable part [of the food] of this [crested] and other kinds of auklets consisted of amphipod crustaceans or "beach fleas," as they are called, when found under bits of seaweed along shore. These small crustaceans, less than a quarter of an inch in length, are amazingly abundant in Alaskan waters and, as a never-failing food supply, account for the surprising abundance of auklets of all kinds.

G. Dallas Hanna reported that in the vicinity of the Pribilofs he found crested auklets in two cod stomachs. One of the stomachs contained 1 bird and the other stomach contained 2 of these birds. Cod are bottom feeders, therefore he points out that the birds must have descended 30 fathoms-the depth at which these two cod were caught (Preble and McAtee 1923). 
The crested auklet winters around the Aleutian Islands, northward in Bering Sea waters, and southward in the North Pacific. Judging by Gabrielson's observations, they winter in great numbers in the Kodiak region. Some of the sea birds succumb in violent winter storms. A crested auklet was blown far inland about September 21 or 22, 1937, and was found at Nulato, at least 85 miles from the nearest point in Norton Sound (Geist 1939).

Residents on Unimak Island reported that sometimes they find hundreds of dead crested auklets on the beaches.

\section{Aethia pusilla: Least Auklet}

Attu: A-la-ma-gam hí-li-gi (see next species)

Atka: Choo-cheah

Bent (1919) remarks, probably on the authority of Turner (1886), that this bird is said to breed on Kodiak Island. We saw none that far east in the breeding season, and Friedmann (1935), who has recorded only a few winter specimens from that island, rightly concludes that "it must be either very scarce, or local, or of only sporadic occurrence." We saw none of these birds until we reached the Aleutian Islands, and they do not nest on Amak Island, where so many other species nest, though Turner (1886) reported seeing it in that vicinity.

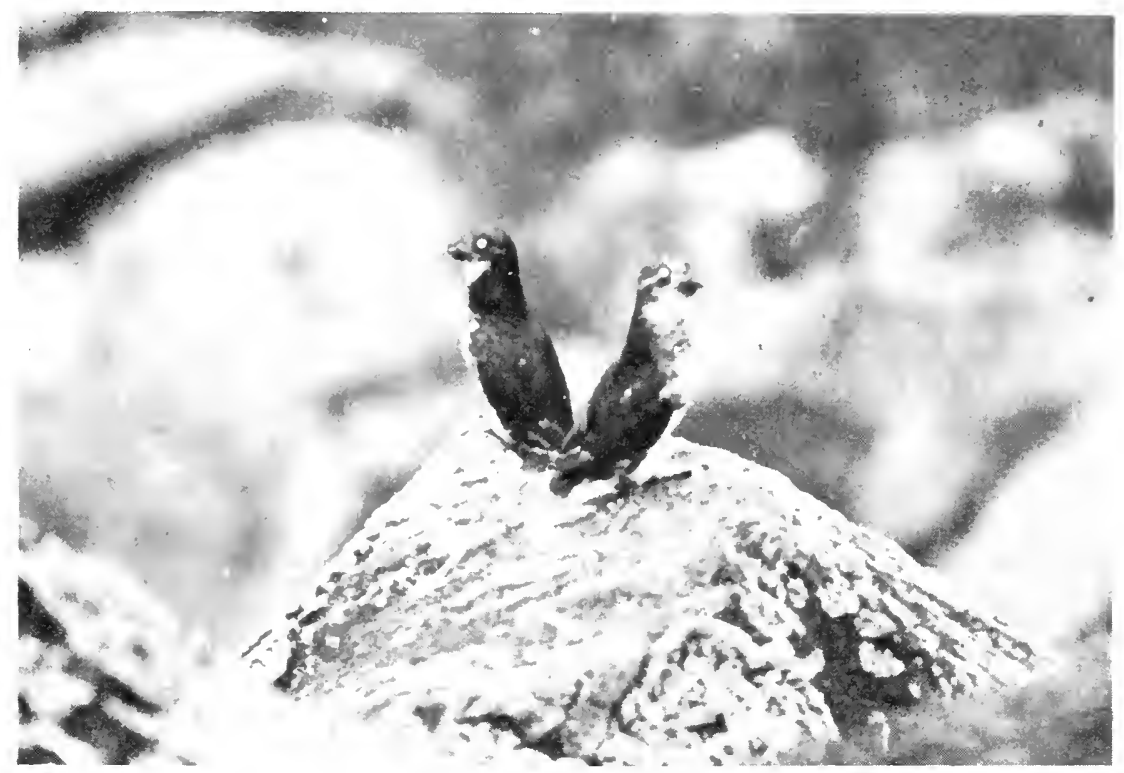

FigURE 37.-Least auklets. 
In Unimak Pass, however, these birds occur in numbers and have been recorded there by Bent (1919), Wetmore (field notes), and Nelson (1887). Laing (1925) observed them in Akutan Pass.

During our various expeditions, no least auklets were identified east of Amlia, where we saw a few. On Koniuji and Kasatochi, a little farther west, they are very numerous and there are large colonies on Gareloi, Semisopochnoi, Segula, Kiska, and Buldir. This group of islands contains the principal least auklet populations in the Aleutians, and, on some of these islands, they were concentrated in greater numbers than the other auklets.

We found trace of this species on a few other islands-a few were seen at Amatignak, a wing was found on Tanadak, and the remains of a few birds were found on Bobrof, where blue foxes had feasted.

We did not find them in the Near Islands, though Turner reported them near Semichi (1886) and breeding on Agattu. Nelson undoubtedly was quoting Turner when he wrote (1887) "This species is abundant on the Near Islands where it breeds on Agattu, but does rot winter there."

Possibly, the breeding range has been curtailed since Turner's observations by the introduction of foxes. We know from native reports that least auklets were once abundant on Bobrof Island but that now they are rare because of the introduction of blue foxes.

\section{Nesting and Feeding Habits}

In the manner of other auklets, this species nests among boulders on the beach, in openings in cliffs, and in jumbled lava beds. We found the greatest concentrations on extended beds of lava that were partly covered with vegetation, and on the mountainous slopes of islands such as Gareloi, Segula, and Semisopochnoi.

In common with other auklets, this bird feeds on small crustaceans, and it has the habit of loading itself with food on a foraging trip at sea to the extent that, when it comes back to the nesting place, it often literally "spills over" on landing. Hence, the pink material that is so prevalent on the nesting grounds.

Stejneger has reported on the contents of the crops of several specimens from the Commander Islands. Briefly stated, the contents were as follows: One crop contained several small Gammaridae; the stomach and crop of another contained Gammaridae and Palaemonidae; one crop was crammed with small Palaemonidae; and another crop contained amphipods. 
The least auklets gather in large swarms-from a distance, they sometimes give the impression of swarms of insects, or of smoke. In flight, the flocks change shape, twisting like drifting smoke, and sometimes the "bottom" seems to drop out of the flock in some sudden maneuver.

No attempt was made to estimate the total numbers in any given colony, but, while anchored offshore at Gareloi on the evening of July 29, 1937, I watched a constant procession of least auklet flocks moving out to sea, low over the water. After some time, I decided to count the flocks for a given period of time. During 5 minutes, I counted 106 flocks with an arerage of 50 birds per flock. This indicated that 5,300 least auklets passed out to sea in $\mathrm{my}$ line of vision during those 5 minutes. By that time, a parallel line of flocks had begun to return to the island.

We observed least auklets foraging at sea about 6 or 7 miles from their nesting place on Kiska Island. Apparently, this was the limit of their feeding range, though it could vary with the distribution of organisms on which they feed. We also have seen them flying at night. Aleuts informed us that least auklets winter in the Aleutians and that, in winter, they continue to enter their rock crevices for shelter-thus giving the blue foxes a further opportunity to prey upon them. Stejneger (1885) says

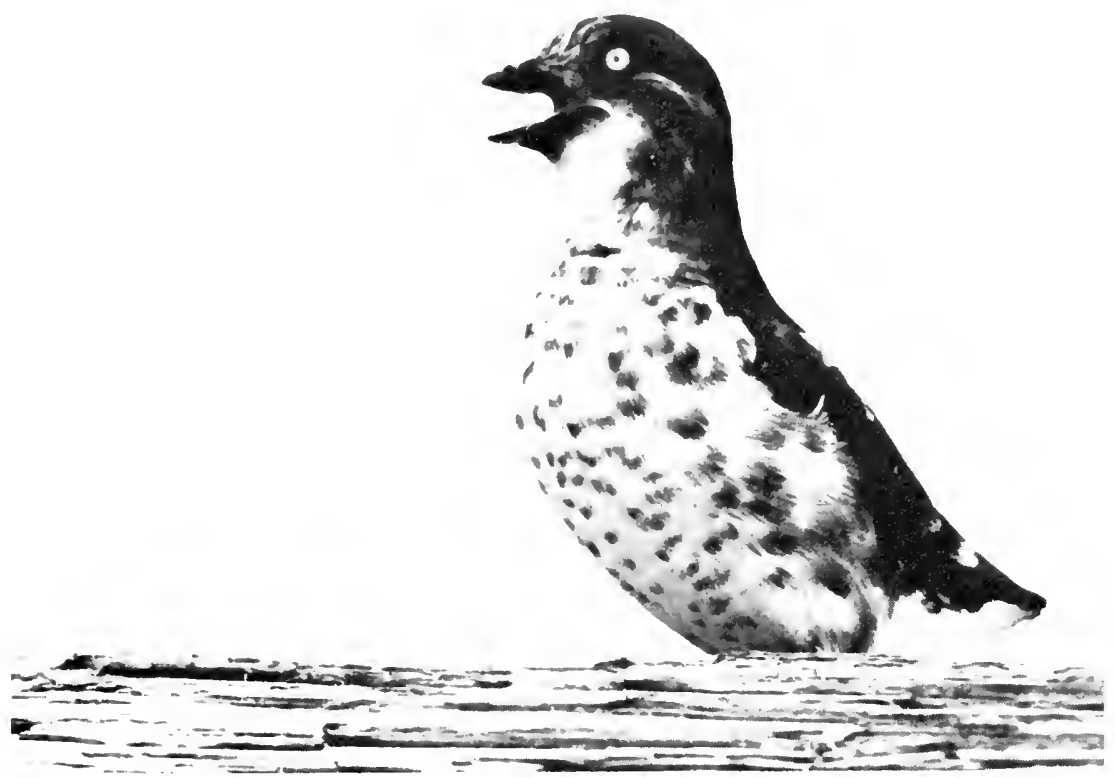

FIGURE 38.-Least auklet. 
"They evidently winter on the open ocean somewhere about the islands [Commander Islands]."

F. L. Beals collected a specimen at Atka on January 31, 1941, and collected another at Unimak Island, April 5, 1941. Gabrielson observed them in moderate numbers in winter among the easternmost Aleutian Islands.

\section{Aethia pygmaea: Whiskered Auklet}

Attu: Choo-chiri-ech

Atka: Tooch'-much

Aleut, Copper Island: Too-roo-toork (Stejneger)

Russian, Commander Islands: Malinka Konjuga, "small crested auklet", a local usage on Bering Island, or the general term Petuschka (Stejneger)

There probably is some confusion in these native names. The Attu name for the whiskered auklet, as given above, apparently corresponds to the Atka name for the least auklet, choo-cheah. This, in turn, seems to correspond to choochkie, or its variants, as so often recorded as the least auklet in the Pribilofs. Yet, we had actual specimens for identification and the Attu natives insisted that the whiskered auklet is identified by the name given above.

This bird, which is the rarest of our auklets, is restricted in range and numbers, though it probably was more abundant in the past. Dall (1874) discussed a bird obtained by him in Unimak Pass in 1865, which was described by Coues as Simorhyncus cassini, and says: "Brandt refers cassini to the immature form of Kamchaticus, but Kamchaticus has never been authentically identified from the Aleutian chain, and I doubt its occurrence there." Dall believed that this bird was the young of the ancient murrelet, "Brachyrhamphus antiquus." Nelson (1887) referred to this specimen and considered it to be the young of the whiskered auklet.

McGregor (1906) mentions specimens taken at Dutch Harbor on June 8; one taken from Easy Cove, Akun Island, in winter dress; and a pair taken in fall plumage in Akutan Harbor on August 19.

We found no evidence of the whiskered auklet east of the Islands of the Four Mountains. Today, these auklets nest on a number of islands from the Four Mountains group westward as far as Chugul, near Kiska, though in small numbers. They may still occur as far east as Akutan, though we saw none there.

We obtained 1 specimen at Kagamil, saw at least 300 at Herbert Island, and saw several flocks at Chuginadak. There were at least 250 near Yunaska; they were found nesting on Chagu- 
lak; and at Seguam we counted 138 and noted others. The Aleuts said that they nest at Amlia Island. Turner (1886) reports seeing them at Nazan Bay, Atka Island, and he obtained three specimens there, which were brought in by natives from the base of Korovinsky Volcano. Laing (1925) obtained specimens at Atka and reports "about a hundred" in Kuluk Bay, Adak Island, on April 11. In 1940, Gabrielson also recorded the species on Atka, where he obtained a specimen, and he saw several hundred between Carlisle and Kagamil islands.

Still farther west, we found a few of these birds at Little Tanaga; we observed 11 at Umak, about 100 at Aso, about 6 near Igitkin, two or three at Ulak, and saw 5 at Chugul. They nest on Kasatochi, and the natives assured us that they also nest on nearby Koniuji. We found a few at Gareloi, and saw three at Ulak $\left(179^{\circ}\right.$ W.) ; the Aleuts reported them to be nesting on Segula (or Chugul), near Kiska.

Turner reported the whiskered auklet "quite abundant" in the Near Islands (1886), and Nelson agrees, evidently on the basis of Turner's report. However, we saw none in the Near Islands, and it is probable that this bird, as well as other species, has decreased in numbers since the time of Turner's observations. Stejneger (1885) found these birds nesting commonly on Copper Island and saw a few on Bering Island.

In 1936, we observed about 1,000 whiskered auklets during the season, and we estimated that there would be at least 2,000 in the Aleutians, though this figure could prove to be ridiculously low.

\section{Nesting}

The nesting habits of the whiskered auklet are the same as those of the least auklet. According to the natives, this species also winters in the Aleutians and, as is the habit of the least auklet, it enters the rocky crevices to roost, thus being subjected to blue-fox depredations. Fortunately, the principal nesting islands for this species have now been withdrawn from fox farming.

\section{Food Habits}

Stejneger (1885) reported that these birds feed mainly on gammarids.

Of 5 stomachs collected in June 1936, and reported upon by Cottam and Knappen (1939), 3 stomachs contained copepods (Xanthocalanus sp.) exclusively. Another stomach contained 60 percent soft-bodied crustaceans (amphipods, isopods, and copepods) ; 40 percent of one fish (Scorpaenidae); and a trace of spider. The fifth stomach contained 10 percent of unidentified 
soft-bodied crustaceans and 90 percent of fragments of what appeared to be mollusk eggs.

\section{Cerorhinca monocerata: Rhinoceros Auklet}

Bent (1919) gives the breeding range of this species as "west to the Aleutian Islands (Atka, Agattu, and Umrak Islands)." We found no trace of this bird on any of our expeditions. Friedmann (1935) records two specimens taken at Kodiak Island in 1842 or 1843 by Wosnessensky, and he mentions that they were observed there by Brandt. He has also recorded three humeri from middens on Little Kiska Island (1937).

Austin H. Clark (1910) said: "This species was observed in limited number's at Atka and at Agattu, and in the northern Kurils I occasionally noticed small companies on the water as far south as Simushir."

Cahalane (1943) reported: "I observed a number of these auklets on Octobel 4 between Amalik and Katmai Bays." This observation was made in 1940.

Hartert (1920) wrote of the Commander Islands: "Cerorhinca monocerata was obtained by Grebinitzki, but neither Stejneger nor Sokolnikoff came across it."

\section{Fratercula corniculata: Horned Puffin}

Attu: Ka-geé-ach

Atka: Ka-geeth'-ah.

Russian, Commander Islands: Ipatka, (pronounced Ipatok on Copper Island) Stejneger

The horned puffin is so universally distributed and so common that it is hardly of interest to single out a particular locality. As Bent (1919) has aptly stated it:

The horned puffin is essentially an Alaskan and a Bering Sea bird, being found breeding throughout the whole length of the Alaskan coast, from Cape Lisburne, north of the Arctic Circle, south nearly to British Columbia; it also breeds westward throughout the Aleutian Islands and on all the coasts and islands of Bering Sea.

It also breeds on the Commander Islands and the Siberian coast.

We found the horned puffin on all suitable islands, from Kodiak to Attu, including the Shumagins and Sanak; Gabrielson found them in the Semidis. The only factor that limits their distribution is unsuitable terrain. Naturally, they do not nest on the low shores of the north side of Alaska Peninsula, but they do nest on nearby rocky Amak Island. There were at least a few at nearly every island of the Aleutian chain. 
Perhaps one of the largest horned puffin colonies that I observed in 1925 was on Amagat Island, near the mouth of Morzhovoi Bay. I estimated that the colony contained 15,000 birds.

The horned puffin is less abundant than the tufted puffin, in whose company it generally nests. 'The fact that it has a different nesting habit may account for its smaller numbers, for its particular nesting habitat may be less arailable than that of the tufted puffin. While the latter burrows in the sod, the horned puffin seeks a crevice among large boulders or in a cliff. Its habit of nesting in burrows already has been described, and Bretherton (1896), writing of Kodiak Island, states that it digs its own burrow. This, however, cannot be considered to be a normal procedure, for, as stated above, its distinctive nesting habitat is in rock crevices.

There were a few places where this species equaled, or exceeded, in numbers the tufted puffin, as at Gareloi and Agattu, and possibly at Davidof and Khwostof. Gabrielson considered them to be more abundant on Chagulak. They were nearly as abundant as the tufted puffin on Little Sitkin Island.

According to the natives, the horned puffin winters in the Aleutians.

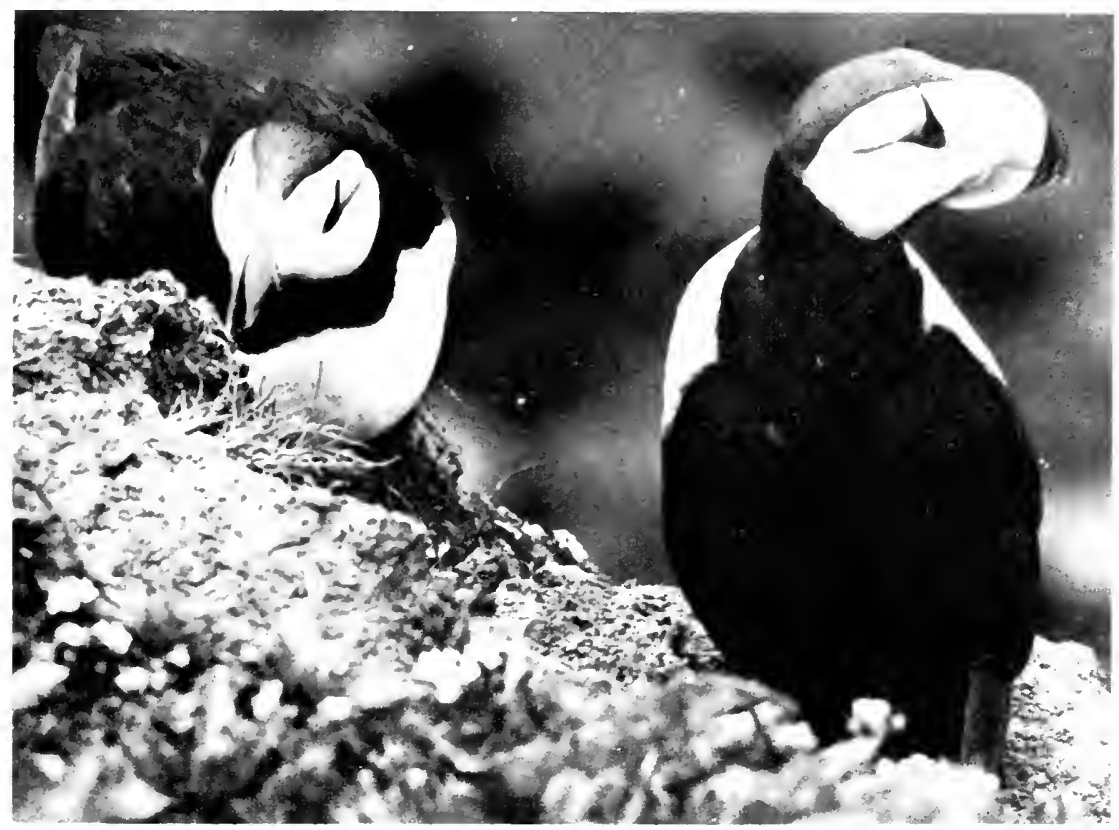

Figure 39.--Horned puffins. 


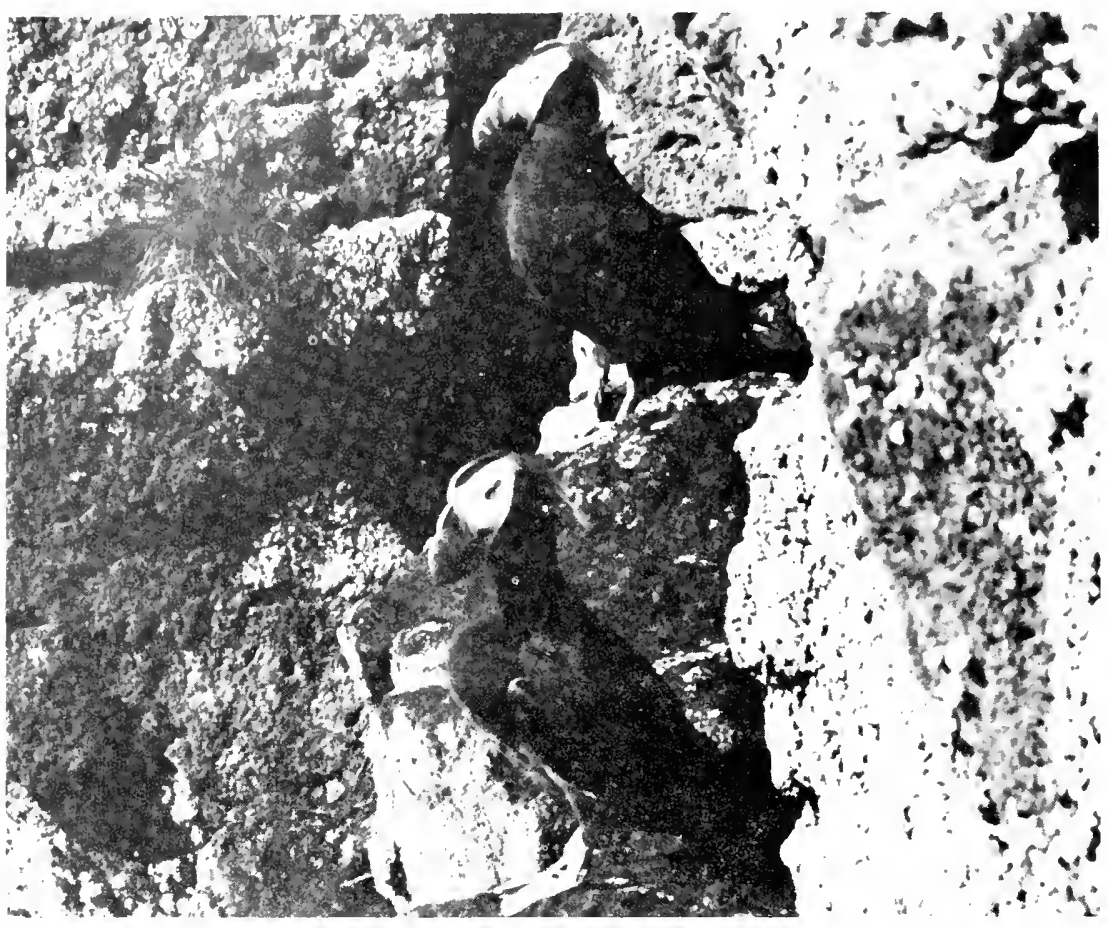

Figure 40.-Tufted puffins.

\section{Lunda cirrhata: Tufted Puffin}

Attu: Och'-choch

Kong-o-luch, the young.

Atka: Ok-chuh or Ok-chuch

Ux́oux (Jochelson)

Russian, Commander Islands: Toporok, Toporki, plural (Stejneger)

The tufted puffin is even more plentiful than the horned puffin; it probably is the most abundant single species in the Aleutian district. We noted them in the Barren Islands, Kupreanof and Shelikof Straits, and the Shumagins and Sanak groups. Gabrielson recorded them in the Semidis. Some islands, such as Uliaga, in the Four Mountains group, contain large numbers of these birds. When a shot is fired, there is a shower of puffins sailing out and down from the high grassy slopes. A small island in Trident Bay of Akun Island was thoroughly honeycombed by puffin burrows. Gabrielson described Bereskin Island, near Akutan, as being honeycombed in the same manner. Many other islands harbor thousands of these birds. They occur on Bogoslof, and Stejneger considered this bird to be the most numerous of the Alcidae in the Commander Islands. 
The tufted puffin, unlike corniculata, normally digs a burrow in the turf for its nest, though it will nest in a natural opening, such as a crevice among jumbled blocks of stone.

The natives say that the tufted puffin winters among the Aleutian Islands. Apparently, they begin to arrive at their nesting sites in May.

Arnold (1948) who recorded data on populations of North Pacific pelagic birds, makes the comment that-

These data indicate that the Fulmar, Tufted Puffin (Lunda cirrhata), Shearwater (Slender-billed?) (Puffinus sp.), and Black-footed Albatross are the only birds that could be classed as truly universal pelagic birds in the area concerned... During periods of high winds and rough water, the Tufted Puffin was the only bird of the four with a decided tendency to "ride out the storm" on the water rather than remain aloft.

The above statement is understandable when one considers the inability of the puffin to remain aloft in soaring flight. Remaining in the water is a necessity, but it also is proof of its hardihood.

\section{Family CUCULIDAE}

\section{Cuculus saturatus: Oriental Cuckoo Cuculus saturatus horsfieldi}

On June 29, 1937, at Rat Island, Steenis saw a strange bird on the beach as he was returning from the day's field trip. He shot it for a specimen and thus obtained the first cuckoo that has been recorded for the Aleutian district.

Deignan (1951) recently reexamined 3 specimens of Cuculus from St. Lawrence Island, Wales, and St. Paul Island for the benefit of the A.O.U. Committee on Nomenclature, and he concluded that all 3 are referable to Cuculus saturatus horsfieldi. I then called attention to this specimen from the Aleutian Islands and forwarded a second specimen from St. Lawrence Island to Duvall for determination. He and Deignan examined these 2 specimens and reported them to be the same as the other 3 (Murie 1952). The five North American specimens, then, are finally resolved as Cuculus saturatus horsfieldi.

\section{Family STRIGIDAE}

\section{Bubo virginianus: Great Horned Owl Bubo virginianus algistus}

This owl, of course, is confined to the wooded regions. Osgood (1904) observed several at the base of Alaska Peninsula and 
considered it to be fairly common. He heard one at Iliamna Village, July 14; heard another at the mouth of Chulitna River, August 6; heard one on lower Kakhtul River, September 1; and collected an immature bird at the forks of Upper Chulitna River, August 16. He also recorded a specimen taken by McKay near Aleknagik River, August 24, 1881.

Friedmann (1934) reported six ulnae of a horned owl in middens on Kodiak Island, which could be algistus; but there would be some doubt about this because lagophonus occurs in neighboring areas. Grinnell (1910) recorded lugophonus, an adult male, taken on Kenai by A. Seale, August 5, 1906. Specimens are needed from Kodiak.

\section{Nyctea scandiaca: Snowy Owl}

Attu: Ah'-vai-ach

Russian: Sovà (Birula)

Russian, Commander Islands: Sitsch (Stejneger)

Chukchi: Jakkadlej (Palmén)

Stejneger remarked that, according to Pallas, the name "sitsch" is applied to Nyctala tengmalmi in Russia proper.

The snowy owl occurs mostly as a straggler over the Aleutian district. Friedmann (1935) records a specimen taken by Fisher, at Kodiak, in March 1882. Osgood (1904) found a mounted specimen in the trader's store at Nushagak and learned that it was a regular winter visitant there, as well as at Egegik and Becharof Lake. He also mentions specimens taken by McKay on the Mulchatna River and at Lake Aleknagik. These occurrences are not surprising, for the snowy owl nests regularily at Hooper Bay to the north, and we know from the Eskimo that it nests in the interior of Nunivak and Nelson Islands also.

In 1925, and again in 1936, local residents assured me that the snowy owl occurs in winter about the western end of Alaska Peninsula and Unimak Island. Dall (1873) observed a number of skins in the possession of people at Unalaska, where it was said to be "resident." Friedmann (1937) found a femur among bones collected in a village site on Little Kiska, and Turner (1886) also obtained a specimen at Unalaska and said that according to the natives it is "only occasionally seen there." He adds that it is quite common on Agattu, where it is a constant resident, but that it rarely visits Attu. On May 8, 1944, Gabrielson saw what appeared to be three immature snowy owls near Sand Point, and he was assured that they occur throughout the year in that area. 


\section{Cahn reported it -}

Rare on Unalaska Island but present in the uninhabited and rugged interior. On January 22, 1943, I saw a male that had been shot near Pyramid Mountain; on February 5, 1945, I saw another male shot near Unalaska village. During the war, men stationed on Bogoslof Island, 40 miles northward of Dutch Harbor in the Bering Sea, shot three during the winter of 1943.

The Attu chief told us that it nests on Attu.

Stejneger, writing in 1885 of the Commander Islands, said that the snowy owl, which formerly was considered to be rare (though nesting), was now becoming common. He stated that it has increased in numbers after the introduction of mice. Nine stomachs contained only arvicolae, and one stomach contained bird remains.

Although we did not see the snowy owl in the Alaska Peninsula and Aleutian Islands, it is evident from the records that it visits the region, especially in winter, and that it may nest in the Near Islands, and possibly in the Shumagins.

\section{Surnia ulula: Hawk-Owl Surnia ulula caparoch}

The hawk-owl is fairly common in the wooded portions of the base of Alaska Peninsula, where Osgood collected several specimens (1904) in the following localities: at the head of Lake Clark (an immature bird); at the mouth of Chulitna River; and at a locality a few miles above the mouth of Chulitna River. He also mentions a specimen taken by Mchay, on the Aleknagik, and four specimens taken by Johnson, at Nushagak. Cahalane observed several of these orls at Mount Kalolinat and other localities in the Katmai region in September 1910. Friedmann (1935) records a number of specimens and eggs taken on Kodiak Island, and Gabrielson also obtained specimens there. Howell (1948) obtained a specimen at Kodiak Island, June 6, 1944, which contained developing eggs. All of these localities are typical nesting habitat for the hawk-owl.

Farther west, sightings of the hawk-owl would be accidental, and no records of such sightings have been found.

\section{Asio flammeus: Short-eared Owl Asio flammeus flammeus \\ Attu: Too-toó-tooch \\ Atka: Too-toó-tuch}

The short-eared owl is a common breeding bird at least as far west as Unalaska. Skins and eggs have been collected on Kodiak Island (Friedmann 1935). We saw 1 on Ushagat, Barren Islands, 
on May 10, 1936, and saw 1 near Sand Point, Popof Island, on May 16. Osgood (1904) found it plentiful at the base of Alaska Peninsula. The first mate of our ship reported seeing one flying offshore at Bristol Bay, May 23, 1936.

In 1925, I noted several of these owls at Moffet Cove, at the west end of Alaska Peninsula, and others were seen on Umnak Island at Urilia Bay, St. Catherine Cove, False Pass, and Ikatan Peninsula. All of these localities contain excellent marshy nesting places. In the evening of May 13, 1925, we watched a shorteared owl soaring and hooting high in the air at False Pass, in its mating performance.

In 1936, a short-eared owl was found on Amak Island; this owl was found, not on marshland, but on a high grassy slope, where mice were plentiful.

On August 26, 1937, we collected a short-eared owl on Akutan Island. In 1902, McGregor reported that "The short-eared owl was observed on Amaknak Island June 23, where one was flushed from its nest containing two eggs. The nest consisted of a deep hollow on a hillside, and was neatly lined with grass." In 1906, he reported taking a specimen on Amaknak Island. It is known to occur on Unalaska, where the natives say it nests commonly. Dall (1873) reported finding these owls nesting in burrows on Unalaska. Swarth, also (1934), reports 1 seen on Unalaska and 1 on Akutan, and Eyerdam (1936) observed 1 on Unalaska. Turner (1886), Nelson (1887), Clark (1910), and Cahn (1947) all observed this bird at Unalaska, and Gabrielson saw one there on June 18, 1943.

Certainly, the occurrence and nesting of this owl is well established for Unalaska. West of that island, however, it appears to be rare. Turner (1886) intimates that it is common in the Aleutian Islands, yet he mentions only two places west of Unalaska where he observed it-Atka and Attu. Natives told us that although the short-eared owl does not nest in the western Aleutians, it occurs there in winter. In 1936, while at Atka Island, we were told that in the previous winter a short-eared owl had been shot on an adjacent islet, and our informant volunteered to guide us to the place. Upon searching the vicinity we found the wings and part of the body, which was sufficient for identification. The stomach, which we found also, contained the remains of a common house rat.

The short-eared owl has a nesting distribution quite similar to that of the rough-legged hawk in this district. It is practically certain that more detailed work on Umnak, lying just west of 
Unalaska Island, will reveal the presence of this owl. In that event, the westward nesting distribution of these two birds coincides with the westward distribution of small native rodents. Ground squirrels have been introduced on Kavalga, and rats have been introduced on Rat and Atka islands, but these artificial innovations have not yet influenced the nesting distribution of these two raptores. It is of ecological significance, perhaps, that the only owl that we obtained west of Umnak (at Atka Island) had eaten a rat, which is the only rodent available there.

\section{Aegolius funereus: Boreal Owl Aegolius funereus richardsoni}

There are only a few records of this owl in the area here considered, and some of these records are doubtful. Friedmann (1935) reports a specimen and a set of eggs collected at Kodiak by Fisher in June 1882. The identity of the eggs is open to question as they are no longer available. Osgood (1904) says-

The catalogue of the National Museum records one specimen of Richardson owl, taken at Nushagak by J. W. Johnson February 20, 1884. I have been unable to find this specimen in the Museum, but since the occurrence of the species in the region is altogether probable, and since most of the names entered in the catalogue are correct, the record may be accepted.

On the basis of this information, the wooded portions of the base of Alaska Peninsula and Kodiak Island may be considered as part of the range of this little owl. How much farther west it may occur is problematical. Gianini (1917) reports for Stepovak Bay: "The guide told me of a small owl he had often seen in the alders and willows but I was never fortunate enough to see one. On several occasions, late in the afternoon, I heard the notes of some species of owl and I thought it might be Richardson's."

Likewise, Wetmore reported, in his field notes for 1911, under the heading "Nyctala t. richardson?", "a small owl was reported to me as seen occasionally in a little thicket of stunted spruces on Expedition Island, in Unalaska Harbor. I looked for them, but could not find them."

With further reference to this locality, Laing (1925) says: "At Unalaska, Mr. Donald A. Stevenson pointed out the only growing spruce clump on the island as the ustial roosting place of a shorteared owl, but time did not allow of verification."

Did these two reports refer to the same species? Certainly, verification is needed, but eventually we may learn that the Richardson owl occurs in the alder thickets that far west. 


\section{Family TROCHILIDAE}

\section{Selasphorus rufus Rufous Hummingbird}

On May 21, 1937, four or five rufous hummingbirds were seen at Seward. Osgood (1901) says "Mr. T. W. Hanmore, who has been stationed at Tyonek for 11 years, says that he has seen hummingbirds there several times. This is doubtless near the limit of the range of the species, as the bird has not been recorded farther north."

There is one other curious occurrence. On June 20, 1936, Howard Jensen, a member of the ship's crew, declared that he saw a hummingbird on the beach at Uliaga Island. When questioned, he described it as a "brown bird," smaller than a winter wren, with a long bill. He did not see a red gorget, but he noted a whirring of the wings and heard their sound and described the bird as darting here and there in the air. He assured us that he "knew a hummingbird when he saw one." This man was a good observer and had assisted us considerably in our work. His description fits the hummingbird pretty well. Yet, this occurrence would be offered here with some hesitation except for the fact that Swarth (1934) reported that a hummingbird (species unknown) was seen by Cyril G. Harrold on August 9, 1927, at Cape Etolin, Nunivak Island. Possibly we may accept the Uliaga Island record, with Swarth's, as unusual occurrences. Because of Jensen's description of a "brown bird," and because of the geographic possibilities, the logical species would be Selasphorus rufus.

\section{Family ALCEDINIDAE}

\section{Megaceryle alcyon: Belted Kingfisher Megaceryle alcyon caurina}

Friedmann (1935) recorded the kingfisher on Kodiak Island, and, on September 19, 1940, Cahalane observed several on the small lakes and streams north of Kodiak Village. Cahalane (1943) also found kingfishers "fairly common in the lake country of the Katmai region, as well as in the bays of Shelikof Strait." Osgaod (1904) observed a kingfisher on Kakhtul River, August 28, 1902, another on August 31, and another on the Mulchatna River on September 3. We saw a kingfisher at Port Chatham, Kenai Peninsula, May 6, 1936.

There are some records farther west on Alaska Peninsula. Gabrielson noted it at King Cove and Cold Bay, and he recorded 
one nesting at Sand Point, in the Shumagins. In 1925, I learned that a local guide, John Gardner, has seen a kingfisher at False Pass in the autumn of 1924, probably in October. He stated that he had seen one there in the previous autumn, but that they did not summer there.

On August 23, 1936, these 10-year-old reports were verified when we saw a kingfisher at False Pass. Again, in 1938, Scheffer saw one at False Pass, back of the cannery buildings. In 1941, Beals and Longworth reported that, as of January 13, "one bird seen daily for several weeks," and later reported "one bird seen about the cannery buildings all through Narch and April." Gabrielson also noted them at False Pass in winter.

Cahn reports from Unalaska Island that-

I have three records for this species, all in the area of Captain's Bay: On August 17, 1943, a male and female were seen flying over the tip of that bay; on August 21 a single individual was seen near the village of Unalaska; and on July 27, 1944 a male was seen and heard near the mouth of the Shaishnikof River.

This suggests possible nesting as far west as Unalaska, though it has not been verified.

Gabrielson observed the kingfisher in winter as far west as Unalaska, and he reported that one was killed at Nikolski Village, on Umnak Island, and was identified by the village school teacher.

\section{Family PICIDAE}

\section{Dendrocopos pubescens: Downy Woodpecker Dendrocopos pubescens nelsoni}

Friedmann (1935) has summarized what we know of this bird's occurrence on Kodiak Island, listing a number of specimens taken there. Swarth (1934) had referred to the Kodiak bird as leucums, but, after comparing a number of specimens from this island with mainland forms, Friedmann concluded that it should be referred to the interior-Alaska nelsoni.

We saw none elsewhere, and Osgood did not mention the species in his report on the base of the Alaska Peninsula. Cahalane, however (1944), records that a male was observed between Iliuk Bay and Mount Katolinat on September 19, 1940.

\section{Picoïdes arcticus: Black-backed Three-toed Woodpecker}

Osgood (1904) records a single specimen taken by McKay on the Mulchatna River in March 1883. No other data have been secured on this species for the territory here considered. 
Picoïdes tridactylus: Northern Three-toed Woodpecker Picoides tridactylus fasciatus

I saw one, and heard another, of these birds at Kodiak, May 12, 1936. Friedmann (1935) lists at least four specimens taken there.

Osgood (190.1) noted this species at Iliamna Village, at Keejik Village on Lake Clark, on the Chulitna River, and near the head of Lake Clark, where he took two specimens. He also mentions a specimen taken by McKay on Nushagak River, January 10, 1882.

Cahalane (1944) observed one at the outlet of Ukak River, September 12, 1940.

\section{Family TY'RANNIDAE}

Sayornis saya: Say's Phoebe

Sayornis saya yukonensis

Osgood (1904) took a specimen of this bird at the mouth of Chulitna River, August 6, 1902, which was the only one seen. We have no other records for this area.

\section{Family ALAUDIDAE}

\section{Eremophila alpestris: Horned Lark} Eremophila alpestris arcticola

Osgood (1904) says "A small flock of 10 or 15 was seen flying about the summit of 'Portage Mountain,' between the head of the Chulitna River and Swan Lake, August 19."

The Alaska Peninsula should offer satisfactory nesting habitat for horned larks, but we have no records of their presence. Harrold Etolin saw one among the sandhills 2 miles south of Cape Etolin, Nunivak Island, on August 28, 1927 (Swarth 1934).

\section{Family HIRUNDINIDAE}

\section{Tachycineta thalassina: Violet-green Swallow}

Tachycineta thalassina lepida

A violet-green swallow was seen flying over the tide flats at Point Gustavus, Icy Strait, on May 12, 1937, and several were noted at Seward on May 21. We saw none west of Seward, but Osgood (1904) found them in considerable numbers at Iliamna Village, and he saw a few on Iliamna and Clark lakes. 


\section{Iridoprocne bicolor: Tree Swallow}

On May 13, 1937, we saw two of these birds at Point Gustavus, Icy Strait. Friedmann (1935) mentions a reported sight record of a family group on the northern part of Kodiak Island on July 27, 1929. Osgood (1904) identified a few at Iliamna Village. On May 25 and 26, 1936, we observed at least six at Snag Point, Nushagak River. Turner, also, observed these birds on Nushagak River (1886). On July 17, 1940, Gabrielson found these swallows common at Dillingham; he saw some at Brooks Lake, July 20, and noted one at Iliamna Lake, July 24.

There is a specimen in the National Museum taken by G. D. Hanna at Lake Aleknagik, June 17, 1911.

As would be expected, the tree swallows are confined to the wooded basal part of Alaska Peninsula.

\section{Riparia riparia: Bank Swallow Riparia riparia riparia}

Aleut (dialect uncertain): Agámdax' (Jochelson, for "the swallow")

In his work at the base of Alaska Peninsula, Osgood found that, on the Nushagak River between the mouth of the Tikchik and Kakwok, most of the high banks "were drilled along the upper edges with their characteristic holes," and he mentions that specimens of the bank swallow were taken at Nushagak by McKay. Osgood obtained a specimen at Lake Iliamna, July 17, 1902. Turner (1886) found them "quite plentiful on Nushagak River."

On June 17, 1940, Gabrielson observed two bank swallows at Karluk weir on Kodiak Island. On June 19, he noted 5 of these birds at Chignik Bay; on June 21, he saw at least 12 at Morzhovoi. Bay; on 'suly 17, he saw several at Dillingham; on the next day they were common at Wood River Lakes; on July 21, they were noted at Brooks Lake; and on July 21, they were common in the tundra region between Becharof Lake and Egegik cannery.

On May 30 and June 4, 1925, I found several bank swallows along the upper part of the stream flowing into Izembek Bay from Aghileen Pinnacles. Near Point Grant, in Izembek Bay, there was a nesting colony on a steep bank of one of the islands. A bank swallow was seen on Amak Island, July 7, and, on Augus, 9, several were seen at False Pass.

In 1911, Wetmore collected specimens of bank swallows nesting in small numbers at some sandy cutbanks at the head of Morzhovoi Bay. Gianini (1917) saw one at Stepovak Bay. Beals and Longworth reported, May 22, 1941, at False Pass that "First 
swallows seen today. They were flying about a small pond up Lee's valley." Twenty-five or thirty were seen there until the observer's left in June. It was reported that the swallows nested in banks. Gabrielson found them at False Pass, Chignik, Cold Bay, and in the Shumagins, and he obtained specimens at Wide Bay and Cold Bay.

We have no records of bank swallows west of Unimak.

\section{Hirundo rustica: Barn Swallow}

Hirundo rustica erythrogoster

A specimen from Kodiak was collected by Bischoff in 1888, and Friedmann (1935) mentions other observations there. Osgood (1904) found them breeding commonly in the vicinity of Lake Iliamna and Lake Clark, and he observed them at the mouth of Chulitna River. Turner (1886) found the barn swallow in considerable numbers at Nushagak, where it nested. On July 21, 1940, Gabrielson recorded two or three of these birds at Ugashik Lake, and, on July 24, he saw at least 12 about some buildings at the upper end of Iliamna Lake.

Gianini (1917) found a pair nesting on a house at Stepovak Bay, and, in 1925, I observed several barn swallows among the cannery buildings at Ikatan Peninsula, Unimak Island, where they evidently were nesting. At Unalaska, the barn swallow has been observed by many naturalists, including Turner, Dall, Nelson, Wetmore, Clark, and McGregor. The last-named observer (McGregor 1906) found a pair nesting "on a rocky shelf in the face of a sea cliff."

There is no satisfactory evidence as yet that the barn swallow occurs west of Unalaska Island-Turner stated that, in his opinion, it does not.

There is a series of specimens in the National Museum. Among these, at least three are from Unalaska, and others are from Lake Iliamna and Nushagak. These were carefully examined and show that the bird of the Aleutian district is typical erythrogaster.

\section{Family CORVIDAE}

\section{Perisoreus canadensis: Gray Jay Perisoreus canadensis pacificus}

Osgood (1904) found this jay to be common from Iliamna Pass to Nushagak. Speaking of the Cook Inlet region (1901) he says "Occasionally seen. One morning, after a light fall of snow, a 
small party of jays visited our camp in the mountains near Hope. A few were also seen at Tyonek. A large series was taken by Bischoff at Fort Kenai."

Nelson (1887) speaks of this bird occurring throughout "the Sitkan and Kodiak region." It is not clear whether he had specific reference to Kodiak Island.

Cahalane (1944) found them "common in the spruce-aspen 'forest', and wherever scattered trees occurred," in the Katmai region.

Normally, this bird would, of course, be confined to the wooded region, though Gianini (1917) reports that he saw 4 of these birds one day at Stepovak Bay, a surprising record. No specimens were taken.

\section{Pica pica: Black-billed Magpie Pica pica hudsonia}

Turner and Nelson both reported the magpie as common on Kodiak Island, and Friedmann (1935) has listed many specimens taken there. In 1940, Cahalane observed several on Kodiak Island and found them in many places in the Katmai region. We noted magpie feathers at Port Chatham, Kenai Peninsula, in 1936. On May 10, 1936, we saw a magpie on Ushagat, Barren Islands; on May 13, we saw one on Afognak; on May 16, we saw several birds and a nest with eight eggs on Nagai Island, Shumagins; and, on August 26, we saw several at Sand Point, Popof Island, in the Shumagins. We also noted one on Dolgoi Island, May 24, 1937. In 1940, Gabrielson observed the magpie at Kodiak, Sand Point (in the Shumagins), and Brooks Lake. Turner (1886) heard of its presence at Belkofski, and he saw one on Unga, in the Shumagins. Gianini (1917) found magpies and nests at Stepovak Bay, and Wetmore found them nesting at King Cove and saw them at Belkofski.

Dall had stated (1873) that magpies do not occur on the north side of Alaska Peninsula, but, in 1925, I found them nesting at Moffet Cove, Izembek Bay. Undoubtedly, magpies are more plentiful on the Pacific side.

Curiously enough, we did not find any on Unimak Island, and local residents said that they do not occur there, nor on other Aleutian Islands. 
Corvus corax: Common Raven

Corvus corax principalis

Attu: Ká-ga-lach

Atka: Kang-lach'

Russian: Woron (Pleske)

Voron (Stejneger)

Chukchi: Uedlje (Palmén)

Pleske applies the Russian name to Corvus corax corax, Stejneger applies it to Corvus behringianus, but, of course, the Fussian common name has a general application.

The raven is universally distributed throughout this entire district, from Bristol Bay, Seward, and the Kodiak-Afognak group westward to Attu Island. We noted them at the Barren Islands, Shumagins, Amak Island, anc throughout the Aleutians, where at least one or two were found at nearly every island. Gabrielson observed them in the Semidis.

In his field notes for 1911, Wetmore described the actions of numerous ravens at the village on Unalaska Island, where they were very tame and acted as scavengers. Turner also (1886) found this bird to be a scavenger about villages in the Aleutian Islancls. In 1925, when I collected several specimens of the Alaska brown bear in the mountains west of Pavlof Volcano, ravens gathered in large numbers to feed on the carcasses. They also were seen along salmon streams, where they probably find fragments of salmon left by bears, just as the gulls do. And they join the gulls in gleaning food, dead or alive, on reefs or beaches at low tide.

During the war, the military establishments from Dutch Harbor to Attu furnished abundant garbage for ravens and sea gulls.

Ravens are by no means exclusively carrion eaters. Pellets found on Amak Island contained remains of field mice, Microtus, and sea urchins. At St. Catherine Cove, Unimak Island, a raven was flushed from the partly eaten body of a female willow ptarmigan. They have been reported as killing incubating birds on their nests, and this may have been an example of that occurrence, though the evidence was not conclusive.

Cahn, at Dutch Harbor, says "Twice I have watched a raven kill a rat, the second time a young Bald Eagle was also watching, and when the rat was dead, the eagle took it away from the raven without argument."

At Kanaga Island, the caretaker of fox-raising operations said he had trapped about 150 ravens in the previous winter. He stated that ravens will kill blue foxes in traps and that he has found remains of blue-fox pups in raven nests. Whether adult 
blue foxes are killed in traps by ravens, and whether the raven will seize and carry off blue-fox pups, and, if so, the frequency of such an occurrence, are facts that should be established by accurate observation. The ecological status of the raven should be determined by a comprehensive study.

In 1938, Scheffer was informed by someone at Umnak Island that ravens will "gang up" and kill full-grown sheep. "Four or five birds peck at the head until the sheep stands still with head bowed and allows the birds to pick off flesh." Another sheep herder said that ravens will pick the eyes out of weak sheep. This last habit has been observed elsewhere, when ravens have begun to pick at the eyes of a dying animal. In all such cases, it is important to know the condition of the animal preyed upon, as well as other attendant circumstances.

In turn, the raven itself is preyed upon occasionally, as shown by remains sometimes found in northern bald eagle nests.

\section{Corvus caurinus: Northwestern Crow}

The crow is common at Seward, where it patrols the beaches, and it is abundant in the Kodiak-Afognak Islands group. At Afognak Village, on September 2, 1936, we found a flock of 50 to 75 birds.

We did not see this bird anywhere to the westward, and I was unable to find any record of its occurrence on the base of Alaska Peninsula.

\section{Nucifraga columbiana: Clark's Nutcracker}

There is a specimen in the National Museum of a Clark's nutcracker, which was taken by J. W. Johnson at Nushagak, November 5,1885 . This is the only information on this bird for the Alaska Peninsula, and of course it is not found west of there.

\section{Family PARIDAE}

\section{Parus atricapillus: Black-capped Chickadee Parus atricapillus turneri}

The black-capped chickadee is wiclespread; it occurs from the base of Alaska Peninsula and Kodiak to the Shumagins, though too little work has been done in intermediate localities to determine relative abundance. Both Osgood (1904a), who found this bird sparingly throughout portions of the base of Alaska Peninsula and Friedmann (1935), who examined the speci- 
mens from Korliak, concluded that the bird of this region is turneri.

Subsequently, Duvall (1945) reviewed the black-capped chickadees of North America and assigned turneri to "The coast of Alaska north to St. Michael; west to the Aleutian Islands (Shumagins etc.), Kodiak Island; south to southeastern Alaska (Haines), northern British Columbia (Atlin), southern Yukon, and central-southern Mackenzie; and east to Great Bear Lake in west-central Mackenzie."

Cahalane (1944) "found them quite frequently and in some abundance west of the Aleutian Range" in September 1940.

On our expeditions, we heard a chickadee in the woods near Afognak Village, September 2, 1936; we heard one in the alders at Sand Point, Popof Island, August 26; and heard at least 6 pairs on Nagai Island, Shumagins, May 16, where we collected 2 specimens.

Gianini (1917) saw several chickadees at Stepovak Bay on one occasion. He listed them as Penthestes cinctus alascensis and said they looked much like the eastern black cap. Undoubtedly, these birds were $P$. a. turneri, judging by his own description and by the fact that the Alaska gray-headed chickadee resembles the Hudsonian chickadee.

Gabrielson observed these chickadees at Kodiak, King Cove, and the Shumagins.

\section{Parus hudsonicus: Boreal Chickadee Parus hudsonicus hudsonicus}

Osgood (1904) found this chickadee at long intervals in the timbered portions of the base of Alaska Peninsula and collected several specimens. In 1940, Gabrielson saw them on Naknek River and Brooks Lake, and he obtained two specimens in the latter locality.

In 1940, Gabrielson noted two chickadees on Kodiak which he called Hudsonian chickadee. Friedmann (1935), under the heading of Penthestes rufescens rufescens, says "all that I have been able to learn of this chickadee on Kodiak Island is that Finsch states that Bischoff observed it there. Apparently he collected no specimens." On geographic grounds, considering Gabrielson's sight identification and the absence of specimens of rufescens that far west, it is more likely that it is a form of the boreal chickadee that occurs there.

At least 15 specimens from the Bristol Bay region, and 2 from Brooks Lake, were available and were compared with large se- 
ries from interior and southeastern Alaska. In this study, I was again impressed with the importance of restricting comparisons to comparable seasonal plumages. Neglect of this procedure can lead to erroneous conclusions.

Of the series available, Osgood obtained 2 from Nushagak on May 28, 1911, and G. D. Hanna obtained the others in 1912, 2 from Doonochchogaweet Mountains, 1 from Kakwok River, 45 miles from its mouth, and 8 from 80 miles up the Kakwok River. Gabrielson obtained 2 from Brooks Lake. These all appear to be $P$. $h$. hudsonicus, the form occurring in interior Alaska, though some of these are not typical of true hudsonicus from interior Alaska and Canada. At least seven of them, from Nushagak and Kakwok River, appear to be a little paler than normal, especially on the crown. On the back, too, the general tone is more plumbeous, rather than the usual olive brown. These are in spring plumage, therefore the differences noted may be seasonal ones. At any rate, the series is referable to typical hudsonicus rather than to columbianus, and it furnishes evidence that the range of hudsonicus extends southward to the base of Alaska Peninsula.

\section{Parus hudsonicus columbianus}

Although this form has not been identified on the Alaska Peninsula proper, there is a specimen taken by Osgood at Tyonek, in Cook Inlet. Another specimen, taken by Osgood on July 31, 1902, at Lake Clark (though in badly worn plumage and hard to place), was referred to columbianus on the basis of some new plumage that was coming in. Gabrielson (1944) reported specimens of columbianus from Kodiak Island and Brooks Lake.

\section{Family CERTHIIDAE}

\section{Certhia familiaris: Brown Creeper}

At present, the brown creeper has not been recorded from the Alaska Peninsula proper; however, it occurs on some parts of the adjacent mainland. On February 4, 1922, I obtained a specimen at Susitna. Bischoff obtained a specimen at Fort Kenai, May 6 , 1869 ; C. H. Townsend took a specimen in Cook Inlet, April 8, 1892; and Osgood obtained another specimen from Hope, Cook Inlet, August 31, 1900. Then, on June 13, 1944, Howell (1948) saw two brown creepers at Bell's Flats, Kodiak Island. Lack of specimens from the geographical area covered in this report makes it impossible to identify the subspecies of brown creeper that breeds in the eastern portions. 


\section{Family CINCLIDAE}

\section{Cinclus mexicanus: Dipper Cinclus mexicanus unicolor}

Judging by published records, the dipper occurs from Kodiak and Bristol Bay to Attu Island. Osgood (1904) obtained a specimen near Lake Clark and one at Cold Bay, and he records five specimens taken by McKay at Mulchatna River. On September 5, 1940, Cahalane (1944) saw a northern dipper at Brooks Falls in the Katmai region. The dipper is known to occur on Kodiak Island (Friedmann 1935), and Cahalane saw several on Afognak Island in 1940.

Gianini (1917) saw one at Stepovak Bay, and his guide considered these birds to be very common in the swift streams in that district. On June 21, 1940, Gabrielson observed the species at Morzhovoi Bay. In 1925, I found several in small streams in the valley below Aghileen Pinnacles. In that same season, 1 was seen at Urilia Bay, Unimak Island, and at False Pass, where Scheffer also saw 1 on September 8, 1938. Eyerdam (1936) has reported the dipper as occurring on Unimak Island and at King Cove.

Beals and Longworth, in their field report for 1941, sum up the status of the dipper on Unimak Island, saying-

Common on Unimak Island. Every stream seems to have its quota of these birds and we often found them four and five to the mile of stream. On Sourdough Flats we enjoyed a concert given by four dippers on the same little bend of the stream. They are well known to everyone on the island.

According to residents, the dippers winter on Unimak.

Swarth (1934) reported several specimens from Akutan, where it was considered to be common.

Dippers have been reported from Unalaska by several observers (Dall, Turner, Bishop, Cahn), and we obtained a specimen there.

We did not find the dipper on any island west of Unalaska, though there are many streams that should furnish suitable habitat. Turner (1886) stated that he saw a dipper in a little stream that emptied into Chichagof Harbor, Attu Island; he did not obtain a specimen. He remarked that it was extremely rare and that few natives had any knowledge of the birds. 


\section{Family TROGLODYTIDAE}

\section{Troglodytes troglodytes: Winter Wren}

Attu: Kach-tai-ach Kit-rich

Atka: Kat-chraí-uh

Russian, Commander Islands: Limaschinka (Stejneger)

The name given by Stejneger is undoubtedly Russian, meaning "Little chew of tobacco," which has been adopted by many Aleuts. This bird is the "limmershin," as reported from the Pribilofs.

Oberholser (1919) proposed that all of the winter wrens be combined under the European species troglodytes. After examining the forms from the Bering Sea region, I found no difficulty in bridging the gap between the Old World and the New World via the Aleutians. Pallescens, of the Commander Islands, and meligerus, of Attu, are not much different; in fact, they have more charactei's in common than have meligerus and wrens of the more eastern Aleutians.

On the other hand, the most difficult gap to bridge to make them all conspecific, is the gap between helleri of Kodiak Island and either semidiensis of the Semidis, or petropinilus of the Fox Islands group. The Aleutian wrens, and the one on the Semidis, are comparatively long billed. Helleri and its nearest relatives, pacificus and hiemalis, are short billed. In this character, the two groups do not intergrade. Coloration may approach more closely in the two groups, but color comparisons in the winter wrens (in the plumages usually available) are rather complex, and it is difficult to know what factor constitutes real intergradation. It should be pointed out, however, that there is a long distance between Kodiak and the end of Alaska Peninsula; in fact, there are many hundreds of miles of territory from which specimens are not available, and one could assume intergradation there. Furthermore, petrophilus from Unalaska, and alascensis from the Pribilofs, are the closest in color and measurements to helleri, though they do not intergrade. It could be reasonably argued that these two at least show a trend toward helleri and that intermediate areas will eventually produce the intergrades. Furthermore, helleri has the longest bill of the hiemalis group. Yet, the Semidi wren, whose habitat is not far from Kodiak (relatively speaking), is decidedly of the long-billed group.

The three short-billed wrens, helleri, pacificus, and hiemalis, naturally fall into one group, possibly into one species, and the other forms throughout the Aleutians and the west side of Ber- 
ing Sea fall into another group or species. Some such course was suggested by Swarth (1931), who wished to regard the "North American, the Bering Sea, and the Old World group, each as a separate species."

There has not been opportunity to review the Old World wrens, and because they have generally been placed in the species troglodytes, that name is the most convenient to use for the Aleutian group until the relationships with the Old World group can be determined.

The Aleutian winter wrens are a difficult group to identify because their plumages vary so greatly with wear and we do !ot always have comparable plumages for study. Giving these facts their due weight, we cannot speak with too much assurance in some cases, nor can we rely too much on island isolation to produce new characters.

The winter wren is one of the few small land birds found commonly throughout the Alaska Peninsula-Aleutian district. This is a bird of the rocky shoreline, nesting in rock crevices. It was not found far inland; in fact, it apparently prefers the vicinity of the sea, and it finds its favorite habitat on islands.

On Amchitka Island, July 11, 1937, I found a family of young winter wrens on the beach, and, a few days later, I found a nest with eggs. This nest had been placed in the timber structure of an old barabara. On July 17, these eggs hatched. They were probably a second laying.

\section{Troglodytes troglodytes helleri}

This is the wren of the Kodiak-Afognak Islands. It has not been determined if it also occurs on the adjacent parts of Alaska Peninsula.

This winter wren is quite similar to pacificus in coloration, when comparable plumages are used. The bill, however, is slightly longer. Measurements are as follows:

helleri $(9$ males) $\ldots \ldots \ldots \ldots \ldots \ldots 10$ to $11.5 \mathrm{~mm}$; average, $11.1 \mathrm{~mm}$. pacificus (5 males, chiefly from Alaska) ... 10 to $11 \mathrm{~mm}$.; average, $10.4 \mathrm{~mm}$.

\section{Troglodytes troglodytes semidiensis}

This form is confined to the Semidi Islands. According to Brooks (1915), it is "similar to $N$. alascensis, but less rufescent, especially above; bill longer." He gave the length of culmen of two males, including the type, as $16 \mathrm{~mm}$. This is in contrast with the average of $11.1 \mathrm{~mm}$. for helleri. 


\section{Troglodytes troglodytes petrophilus}

This wren is much like alascensis from the Pribilofs, but, with comparable specimens, the upper parts appear to be somewhat more rufescent and the under parts are definitely paler, or grayer. The bill of petrophilus averages slightly longer than that of alascensis, though the difference is small, and these two differ from other Aleutian wrens in having somewhat shorter bills. Measurements of the exposed culmen are as follows:

petrophilus (11 males) ........... 13 to $14.5 \mathrm{~mm}$; average, $13.9 \mathrm{~mm}$. petrophilus (4 females) ........... 13 to $14 \mathrm{~mm}$; average, $13.2 \mathrm{~mm}$. alascensis (3 males) .............. 13 to $13.5 \mathrm{~mm}$; a verage, $13.3 \mathrm{~mm}$. alascensis ( 7 females) ........... 12 to $13.5 \mathrm{~mm}$; average, $13 \mathrm{~mm}$.

This wren occurs on Unalaska, Amaknak, Unalga, and Akutan Islands. One would expect to find it also on Umnak and Akun Islands, but we do not have specimens from these two islands.

\section{Troglodytes troglodytes stevensoni}

This wren was described by Oberholser on the basis of specimens from Amak and Amagat islands, near the west end of Alaska Peninsula. It was described as being slightly less rufescent than petrophilus and with a slightly longer bill and middle toe. I found it very difficult to distinguish this form from petrophilus by color, though the slightly longer bill was apparent in the four adult specimens available. Most of the birds in the series are young, and the material seems inadequate to determine the status of this small group. The adult Aleutian wrens taken during the nesting season are so irregular in condition of plumage that a very extensive series should be at hand to adequately evaluate its taxonomic position. For this reason, I can not attempt to ascertain whether these easternmost specimens of the Aleutian chain show the slightest trend toward helleri, whose habitat is far to the east, on Kodiak.

Sterensoni is known from Amak and Amagat Islands, and it can be expected to occur on adjacent parts of Alaska Peninsula and on Unimak Islancl.

\section{Troglodytes troglodytes seguamensis}

Gabrielson and Lincoln (1951) described this form on the basis of specimens from the islands of Seguam, Amukta, and Yunaska. They commented that "This is the palest and grayest of all the Aleutian races," and it appears, logically, to be an intermediate race between petrophilus to the east and tanagensis to the 


\section{NORTH AMERICAN FAUNA 61, FISH AND WILDLIFE SERVICE}

west. The wrens from the Islands of the Four Mountains are described as not typical of petrophilus, but somewhat intermediate between it and seguamensis. However, in the present state of our knowledge, we probably should include the Islands of the Four Mountains in the range of seguamensis.

\section{Troglodytes troglodytes tanagensis}

After careful study of a series of specimens, tanagensis appears to be slightly less rufescent than petrophilus. In length of bill, it differs significantly, tanagensis having a decidedly longer bill. Measurements of culmen of 12 males and 7 females are as follows :

Males 14 to $16 \mathrm{~mm}$; ; average, $14.9 \mathrm{~mm}$. Females .................. 13.3 to $15.5 \mathrm{~mm}$; average, $14.8 \mathrm{~mm}$.

Since Gabrielson and Lincoln's determination of T. t. seguamensis, we must confine the range of tanagensis to Tanaga and the immediately adjacent islands.

\section{Troglodytes troglodytes kiskensis}

This wren is paler, but more tawny, than meligerus. It is also more tawny than tanagensis. In length of culmen, it appears to average greater than either of the other two. Measurements of culmen, in millimeter's, of 8 males and 8 females are as follows:

Males ...................... to $16 \mathrm{~mm}$; average, $15.6 \mathrm{~mm}$. Females ................. 14 to $17 \mathrm{~mm}$; average, $15.2 \mathrm{~mm}$.

This wren occupies the Rat Islands group, from Kiska to Amchitka. There are specimens from Kiska, Little Kiska, Davidof, Little Sitkin, Semisopochnoi, and Amchitka; and there are three specimens from Ogliuga Island, in the Andreanof group-supposedly in the range of tanagensis, which appeared referable to kiskensis.

\section{Troglodytes troglodytes meligerus}

The wrens of the Aleutian chain fall into two groups that may be distinguished pretty well at the extremes of the total range. The wrens of the westernmost islands, and we may include the Commander Islands, show a marked tendency toward a dusky, grayish cast, while those of the eastern Aleutians, including alascensis, of the Pribilofs, are more rufescent.

$T$. t. meligerus is quite similar to T.t. pallescens of the Commander Islands, sharing with that form the general duskiness 
and the more-extensive barring and spotting of the under parts, which separates these forms from kiskensis. The under parts are noticeably grayer than those of kiskensis, the latter being more tawny. But meligerus is the darkest one of the group.

There is a single specimen from Agattu Island-a mummified, extremely dark, immature bird. The fact that this single specimen is immature makes it impracticable to identify it with certainty, though one would expect it to be meligerns. Four specimens from Buldir Island, 2 immature and 2 in worn breeding plumage, are referable to meligerus-this is most interesting, because Buldir (the most isolated island in the Aleutian chain) is a lone island, far from either Kiska or Attu.

\section{Family TURDIDAE}

\section{Turdus migratorius: Robin \\ Turdus migratorius migratorius}

We found robins common at Snag Point, Nushagak River, on May 25 and 26, 1936. We saw them at Seward on May 21, 1937. Osgood (1904) says-

A few robins were seen near Iliamna Village, and one specimen was taken there July 15. From this point on to the upper Chulitna River robins were seldom seen, though once in a great while we heard their familiar note. They were quite abundant in small flocks about Swan Lake August 25, and considerable numbers were also seen near there in the brush and young timber around the base of the "Portage Mountain."

Cahalane (1943) reports-

I found that robins were numerous in the willow-cottonwood-spruce thickets on Naknek River at Big Creek on the early morning of September 4. They were probably migrating. I did not see any after leaving the river on that date and passing into the lake region in the National Monument.

Gabrielson noted a few robins on Afognak Island on June 15, 1940, and he found them to be common at Dillingham on July 17.

There are specimens in the National Museum from Nushagak, Kakwok, and Lake Iliamna.

\section{Ixoreus naevius: Varied Thrush Ixoreus naevius naevius}

At least six specimens from Kodiak Island were examined. These were collected by F. Bischoff, in 1868; by C. H. Townsend, in 1888 ; by A. K. Fisher, in 1899; and by R. H. Beck, in 1919. All these specimens are typical naevius, thus suggesting that this 
form also would be found on the adjacent Kenai Peninsula. We found varied thrushes to be common at Port Chatham, Kenai Peninsula, May 6, 1936. One was seen in the driftwood on the beach of Ushagat, Barren Islands, May 11, where there is only a trace of forest growth. We saw them at Seward on May 21, 1937, and on Kodiak Island, May 12, 1936, varied thrushes appeared to be the most common bird. Several were noted on Afognak, May 13 and September 2, and Cahalane and Gabrielson found them to be abundant on Afognak in 1940 .

\section{Ixoreus naevius meruloides}

A number of specimens are available in the National Museum from the Bristoi Bay region. C. L. McKay obtained 2 specimens 10 miles below Lake Alleknagik and 1 on the Nushagak River in 1881. J. W. Johnson obtained 1 at Nushagak in 1885, and G. D. Hanna obtained 2 at Nushagak and 1 on the Kakwok River in 1911. All these specimens are referable to meruloides and furnish another example of how the eastern and northern avifauna extends to the base of Alaska Peninsula.

Osgood (1904) noted two of these birds on the Kakhtul River, and Gabrielson found varied thrushes to be common at Dillingham on July 17, 1940.

\section{Hylocichla guttata: Hermit Thrush Hylocichla guttata guttata}

A number of specimens of the Alaska hermit thrush are in the National Museum, including a good series from Kodiak, one each from Hope and Tyonek, Cook Inlet, and others from Lake Clark, Nushagak, Kukak Bay, Chugachik Bay, King Cove, and Frosty Peak. Hine (1919) obtained a specimen at Katmai Bay on July 25,1919 . Thus, the range of this thrush is established for the length of Alaska Peninsula.

The species has also been observed by various naturalists. In 1940, Gabrielson found these birds to be very common on Afognak Island, and he noted two or three at Chignik Bay. Howell (1948) records 6 nests with eggs at Kodiak Island from June 9 to July 4, 1944-one nest with $3 \mathrm{eggs}$, one nest with $5 \mathrm{eggs}$, and four nests with 4 each. We observed several of these birds at Kodiak and Afognak Islands on May 12 and 13, 1936, and, on May 11, we found two or three birds on Ushagat, Barren Islands, on a high slope where the principal vegetation is crowberry. On May 15,1936 , many of these thrushes were singing among the alders 
on Nagai, Shumagin Islands, and, on the next evening, several thrushes were noted in the alders at Sand Point, Popof Island. On May 24, 1937, we heard several thrushes singing on Dolgoi Island, west of the Shumagins.

In 1911, Wetmore found hermit thrushes to be "tolerably common" in the alders at King Cove and in the alders at the east base of Frosty Peak, and he obtained specimens. Gianini (1917) reports that he observed the bird at Stepovak Bay.

I found the hermit thrush in the alders back of Izembek Bay, early in June 1925. One of these birds was in the last alder patch at the head of the valley below Aghileen Pinnacles. Two or three thrushes were heard singing at the base of Frosty Peak on July 3.

On July 15, Donald Stevenson heard thrushes singing on the rocky slopes of Amak Island; although he had a distant view of them, they were too wary for him to obtain a specimen. There is no shrubbery on Amak, the tallest vegetation being Heracleum lanatum.

Beals and Longworth, in their field report of 19.1, on Unimak Island, stated that they heard the first thrush of the spring at False Pass on May 12. Next day, they saw five of these birds in the alder thickets. Between May 12 and June 17, "they could be heard whenever we patrolled the valley floors and even up to 5-6000 ft. elevation." No specimens were taken, but "their song, habits and appearance are the same as our Russet-backed thrushes of Southeastern Alaska." Later, in May 1944, Gabrielson obtained a specimen at King Cove, and, in 1946, he took specimens from Popof and Aghiyuk Islands.

The hermit thrush is most common in this region, and the lack of conflicting information leads us to suppose that it is the hermit thrush that is most common on Unimak Island. However, specimens are needed for positive identification.

Nelson (1887) has discussed the impropriety of assigning Gmelin's name "Tirdus aoonalascensis" to this bird, the type of which was suppused to have come from Unalaska. He pointed out that no other naturalist has observed it there. However, we found the hermit thrush on such barren islands as Amak and Dolgoi, and (apparently) as far west as Unimak; therefore, it is not at all improbable that a specimen could have been obtained on Unalaska. But Nelson's thesis remains correct, especially since he demonstrates that the original description was inadequate. 


\section{Hylocichla ustulata: Swainson's Thrush \\ Hylocichla ustulata incana}

Osgood (1904) reported finding this thrush in the Lake Clark and Lake Iliamna region and he obtained a specimen at Lake Clark on July 24. This specimen is in the Fish and Wildlife Service collection at the U.S. National Museum. It is a male in juvenal plumage and probably was taken not far from its nesting area. A. Wetmore (manuscript notes) heard this species singing July 12 and 16 at King Cove. We did not identify this form on any of our trips to the Alaska Peninsula.

\section{Hylocichla minima: Gray-cheeked Thrush Hylocichla minima minima}

Osgood (1904) writes-

A gray-cheeked thrush was seen at Swan Lake August 25, and another a few days later on the Kakhtul River; a third was collected near the mouth of the Kakhtul River September 1. This specimen is more olivaceous than any other I have seen, which is perhaps due to its being in newly acquired fall plumage.

Friedmann (1935) records a number of specimens from Kodiak Island, and the National Museum has a number of specimens from Nushagak, Lake Aleknegik, and Kakwok River. Gabrielson obtained specimens at Dillingham on July 18, 1940, and at Naknek River and Brooks Lake on July 10, 1946.

This bird has a wide distribution, occurring on the Pribilofs, St. Lawrence Island, and parts of Siberia. Wallace (1939) remarks-

One striking feature of the distribution of this form is its apparent preference for coastlines, island, rivers, and lakes. The presence of sheltering thickets of alder and willow bordering the streams and water courses in these otherwise treeless regions presumably accounts for such a pattern of distribution.

At present, this species has not been recorded west of the base of Alaska Peninsula, though it could occur somewhat farther west.

\section{Luscinia calliope: Siberian Rubythroat Luscinia calliope camtschatkensis}

This species was collected on Kiska Island by F. B. McKechnie on June 17, 1911, and he saw two others. Still another was seen there on June 19 by Wetmore (Bent 1912). These are the only records for North America. 


\section{Family SYLVIIDAE}

\section{Phylloscopus borealis: Arctic Warbler Phylloscopus borealis kennicotti}

Osgood (1904) obtained two specimens of this bird near Iliamna Village, and he records a specimen taken by McKay near Aleknegik River on August 24, 1881. Two specimens were taken by J. W. Johnson at Nushagak on June 19, 1884, and Hanna obtained a specimen at Lake Aleknegik on July 2, 1911.

On July 19, 1940, Gabrielson saw 3 of these birds at Brooks Lake and collected 1 of them, and he obtained another at Dillingham.

According to Parkes and Amadon (1948), the Kennicott arctic warbler "winters commonly in the Philippine Islands and sparingly in the Indo-Chinese countries, Malaysia and the East Indies east to the Moluccas; known to migrate through eastern China (Shantung, Yunnan)."

\section{Regulus satrapa: Golden-crowned Kinglet Regulus satrapa amoenus}

A number of specimens are in the National Museum that were collected by Bischoff and Townsend on Kodiak Island. Gabrielson noted the species on Afognak in 1940, and he found it to be common on Kodiak Island in the winters of 1941 to 1944, where he collected two specimens.

This bird could be expected in the wooded parts of Alaska Peninsula, but Osgood did not record it, except for the Cook Inlet region, where he found it "moderately common." A study of this species by Aldrich (manuscript notes) indicates that birds of this region are referable to amoenus, and that olivaceus is restricted to the narrow coastal strip from Sitka, Alaska to Oregon.

\section{Regulus calendula: Ruby-crowned Kinglet Regulus calendula calendula}

Osgood (1901) mentions a male taken by Bischoff at Fort Kenai, and remarks that "Examination of this specimen does not show any characters that approach those of Regulus calendula grinnelli, which is found on the coast only a short distance farther south."

We heard one singing at Port Chatham, Kenai Peninsula, on May 6, 1936, but we saw none west of there, nor did Osgood 
record any for the base of Alaska Peninsula. However, Turner (1886) reports seeing one at Nushagak on June 28, 1878.

On June 14, 1940, Gabrielson noted one on Kodiak Island. The bird from Kenai Peninsula is $R$. c. calendula, therefore the Kodiak birds would undoubtedly be the same.

\section{Family MOTACILLIDAE}

\section{Motacilla alba: White Wagtail Motacilla alba lugens}

During the expedition in 1913 and 1914 on which Joseph Dixon and W. Sprague Brooks were the zoological collectors, several of these wagtails were seen on the beach of Attu Island early in May 1913, and, on May 4, an adult male was collected. This is the only occurrence known for the Aleutian district; it was reported by John E. Thayer and Outram Bangs in 1921.

This bird is a regular migrant in the Commander Islands, according to Stejneger (1885).

Turner (1886) observed a wagtail at Attu Island on May 18, 1881, which he thought would be $M$. a. ocularis, though he mentions the possibility of its being $M$. a. lugens. The specimen was not secured, and there must remain some doubt about the identity. Turner quotes Seebohm to the effect that a specimen of Motacilla amurensis had been collected by Wosnessensky on April 23, 1845, on Oorogan Island "possibly either one of the Kurile or one of the Aleutian Islands." Oorogan Island cannot be identified, therefore this record too must remain doubtful.

Stejneger (1885) records a specimen from Bering Island.

\section{Motacilla flava: Yellow Wagtail Motacilla flara tschutschensis}

This wagtail is not common in the area here considered, though it has been observed numerous times in the Bristol Bay region, where it is considered to be a breeding species. Osgood (1904) states that McKay and Johnson obtained four breeding birds at Nushagak, and he concludes that "This is doubtless near the southern limit of its breeding range on this continent." Turner also (1886) found this bird at Nushagak in the breeding season.

We did not find this bird on the Alaska Peninsula or in the Aleutian chain, but Turner (1886) reports seeing one on Attu Island on October 8, 1880. He adds that the bird does not breed in the Aleutians. The 1931 Check Iist states that this wagtail migrates through the western Aleutian Islands to eastern Asia. 


\section{Anthus spinoletta: Water Pipit Anthus spinoletta pacificus}

Attu: Assu Ka-vij'

A series of 13 breeding birds and 2 in winter plumage from Unalaska was available for study, as well as one breeding bird each from Fort Kenai, King Cove, Morzhovoi Bay, Chogiung, Nushagak, Sanak, and Unimak Island. There was also a series from Sitka, Hoonah Sound, and Ketchikan, Alaska, and White Pass, Yukon Territory, as well as others from interior Alaska and eastern North America.

The series from Unalaska and other parts of western Alaska is grayer on the back than those from Alberta and Mackenzie, and the under parts of the Alaska birds average paler, though the coloration varies from a definite pinkish buff to rather pale individuals. This is not due to wear, because some of the most-worn specimens are the most buffy. Also, the spotting on the breast varies from very sparse to very heavy.

In winter plumage, the western Alaskan birds are a little browner, and the Canadian birds are slightly, but noticeably, more olivaceous.

When compared with a small series from White Pass, Ketchikan, and other southeastern localities, which are presumed to be pacificus as described by Todd (1935), the Aleutian birds correspond very well and therefore are referred to pacificus.

It was difficult to separate the birds from Alberta, Canada, at least those used in this study, from the birds described as alticola from Colorado, Idaho, and Wyoming.

The pipit occurs from the base of Alaska Peninsula to Attu Island, thrugh it is not equally abundant everywhere. Osgood found them near Kakhtul River, McKay obtained specimens at Nushagak, and Hine observed them, and obtainer specimens, at Katmai and Kashvik Bays.

We noted the birds at Ugashik River on May 29, 1936. On May 14, we found them at Chignik, and, on May 16, 2 were heard singing at Unga and 2 were heard at Sand Point, Popof Island. Several were heard singing at Unimak Island on May 19 and 20, and, on May 24, 1937, pipits were commonly seen on Dolgoi Island. John Steenis obtained a specimen at Sanak Island on August 28, 1937, and two were seen on Bogoslof on August 24.

In 1925, I found pipits to be common on the north side of Alaska Peninsula, mainly in the mountains above the alder growth. There were pipits at False Pass on the mountains near 
Aghileen Pinnacles, Frosty Peak, and Amak Island, where young birds were flying about on July 10 .

In 1911, Wetmore found pipits to be common at the east base of Frosty Peak, Morzhovoi Bay, and King Cove, where they nested above the alder growth on mountain sides. He also found them to be common at Unga. Gianini (1917) observed them at Stepovak Bay.

In 1940, Gabrielson noted a pipit above timberline on Kodiak Island, noted four or five at Morzhovoi Bay, and noted one on Metrofania Island. In subsequent years, he found them to be rather common in many localities, including Akutan and Unalaska.

Howell (1948) found the pipits on Kodiak on the open grassy slopes above 1,500 feet. A nest sunk in the ground with its rim flush with the surface, containing four well-incubated eggs, was found on June 17.

Nelson (1887) observed pipits on Unalaska Island and says that specimens have been obtained on Kodiak. Laing (1925) collected pipits on Unalaska. McGregor (1906) found them at Dutch Harbor, Unimak Island, and Aektok Island. Swarth (1934) reports specimens taken by Harrold on Akutan, where it was common.

We found pipits to be fairly numerous on Unimak and Unalaska, but they were scarce farther west. One was seen on Amchitka Island on July 24, 1936. The chief of Attu was familiar with the bird and gave us the native name.

Turner (1886) reports it throughout the Aleutian Islands and specifically mentions Unalaska, Atka, and Attu. We did not see the species in the Near Islands.

Cahn reports for Unalaska that "Pipits arrive in early May (earliest date, May 3, 1944), and remain until mid-September."

Nesting

In general, pipits nest chiefly on high ground, above the alder zone where such growth occurs, and on the more or less barren mountain tops or ridges of the western islands. They occasionally occur on lower ground, however, even in the nesting season. After the nesting season, when they begin to form small flocks, they often feed on the beaches, among the tide-rolled masses of dead kelp.

Swarth (1934) mentions a nest with six eggs found by Harrold on Akutan on a "bare wind-swept ridge about 1,000 feet above the sea." Swarth also mentions another nest with six 
fresh eggs, found on June 19, on Unalaska, at an elevation of about 500 feet.

On June 10, 1925, in the valley bottom below Aghileen Pinnacles, I found a nest on mossy ground, almost completely overhung by vegetation, mostly grass. The nest was made of fine roots in the outer structure, then a layer of old fine grass, dark in color, and an inner lining of fine clean grass. Outer diameter was $110 \mathrm{~mm}$.; inner diameter was $67 \mathrm{~mm}$.; and depth was $40 \mathrm{~mm}$. There were six eggs in the nest.

\section{Anthus cervinus: Red-throated Pipit}

This species is credited to the Aleutian Islands on the authority of Zander (1853). Stating its general distribution, Zander says that it is widespread, reaching from Dalmatia and Lapland, through the adjacent part of Asia to the islands near America, and also in Egypt and Nubia ("durch den angrenzenden Theil von Asien bis zu den Inseln bei Amerika verbreitet").

This is a vague reference in a general statement of distribution. It does not specify specimens taken nor type of observations made, nor does it identify the "islands near America" that he mentions. Apparently, subsequent authors have assumed that he meant the Aleutian Islands. Certainly, Zander did not state the case adequately, and, although it is possible that the species occurs on the Aleutians, we should have better evidence.

\section{Family LANIIDAE}

\section{Lanius excubitor: Northern Shrike Lanius excubitor invictus}

Osgood (1904) records specimens from the mouth of Chulitna River and Swan Lake, and he observed the bird on Kakhtul River and near Nushagak. McKay obtained specimens at Ugashik, and Cahalane (1943) "found shrikes to be fairly common on the west side of the Aleutian Range" in the Katmai region. Friedmann (1935) mentions 2 specimens from Kodiak, and Gabrielson observed 3 of these birds at Kodiak also.

These records refer to the base of Alaska Peninsula and neighboring localities, where some timber is present, but the bird also occurs far to the west on treeless terrain. In 1936, Petri, who was warden in the U. S. Bureau of Fisheries at Chignik, told us that shrikes occur commonly in that locality.

On May 5, 1925, I saw a shrike on a trapper's hut at Urilia Bay, Unimak Island. Arthur Neuman, of Ikatan Peninsula, 
said shrikes occur on Unimak and that on several occasions he had seen them carrying mice, or hanging them in the willows. He had once seen a shrike harrying a ptarmigan.

Beals and Longworth reported seeing 10 shrikes near False Pass, between January 11 and May 15, 1941. Presumably, some of these sightings may have been duplications. They saw a pair on one occasion. They remarked that "Residents of Unimak Island recognize them and their murderous work among the smaller song birds."

A more western record for this bird in the Aleutians is Gabrielson's observation at Unalaska Island, July 3, 1941.

Taber, writing of Adak Island, reports-

On January 9, 1946, a female mallard was seen flying along a small stream near Shagak Bay; a shrike struck at her back twice as she flew. The mallard lit in the water and the shrike hovered characteristically over her for a moment and then lit on a barbed wire fence. The ground was snow covered at this time, leading to the supposition that this shrike was extremely hard pressed for food.

\section{Family PARULIDAE}

\section{Vermivora celata: Orange-crowned Warbler Vermivora celata celata}

The orange-crowned warbler was collected by McKay at Nushagak, where it breeds, and Osgood (1904) observed a few about Lakes Iliamna and Clark, and took specimens. We obtained a specimen at Snag Point, Nushagak River, May 25, but we saw none farther west.

\section{Vermivora celata lutescens}

This is the form known to inhabit the Cook Inlet region. Nelson (1887) mentions a specimen taken by Bischoff at Fort Kenai, the type locality, and says that it occurs on Kodiak. Howell reported them to be common on Kodiak, where he found four nests. He considered them "sparsely but regularly distributed in the wooded valleys" of this island. Friedmann (1935) lists three Kodiak specimens. It is interesting to note that it is lutescens, from Kenai Peninsula, and not celata, from Alaska Peninsula, that has reached Kodiak Island.

\section{Dendroica petechia: Yellow Warbler Dendroica petechia rubiginosa}

Aldrich (1942) has presented convincing evidence that the golden and rellow warblers are conspecific, and, because the 
name petechia has priority, all of them are placed under that species.

The Alaska yellow warbler has an extensive distribution. Osgood (1904) observed the bird, and obtained specimens, at Lake Clark and Lake Iliamna and on the Chulitna River, and he mentions specimens taken by McKay and Johnson at Nushagak. Hine (1919) obtained a specimen, and observed the species, on various occasions about Katmai Bay. Friedmann (1935) records a number of specimens from Kodiak, and it is evident that it breeds there. In June 1940, Gabrielson found the yellow warbler to be common on Kodiak and Afognak Islands; he noted several on the Semidi Islands, and he recorded the bird as common at Chignik Bay. Later, he observed it on Unimak Island, Nelson Lagoon, Wide Bdy, and Cold Bay.

Gianini (1917) obtained a specimen at Stepovak Bay, and he saw others, but he remarks that they were not common there. On July 3, 1925, I saw one of these warbler's below Frosty Peak, and I observed another at False Pass on August 9.

Beals and Longworth, in their 1911 field report, reported the yellow warbler to be common on the eastern part of Unimak Island. These birds were referred to by residents as "little yellow canaries." One had been seen there May 5, and two were seen on May 20.

The alder brush is the home of the yellow warbler.

\section{Dendroica coronata: Myrtle Warbler Dendroica coronata hooveri}

Osgood (1904) found this warbler to be abundant about Lake Clark and took several specimens. He also observed it at the mouth of Chulitna River. McKay took specimens at Nushagak, and Turner (1886) found it to be abundant there in June 1878. Gabrielson observed it at Brooks Lake, July 10, 1946.

\section{Dendroica striata: Blackpoll Warbler}

Osgood (1904) considered this to be the most common warbler that he saw at the base of Alaska Peninsula from July 14 to August 12. He observed it at Iliamna Village, Lake Clark, and Nogheling River. McKay obtained a specimen 80 miles up Nushagak River and obtained another on Aleknagik Lake.

Gabrielson saw this warbler at Dilingham, July 17, 1940. 
Seiurus noveboracensis: Northern Waterthrush

Seiurus noveboracensis notabilis

Osgood (1904) observed a pair of these birds at Iliamna Village on July 14, and he found them to be quite common at the mouth of Chulitna River on August 3. A specimen was taken by McKay 85 miles up the Nushagak River on June 6, 1881 .

On May 26, 1936, I repeatedly heard a song in the alders and willows at Snag Point, Nushagak River, that I identified as that of the waterthrush, but I could not get a glimpse of the birds.

\section{Wilsonia pusilla: Wilson's Warbler} Wilsonia pusilla pileolata

This warbler inhabits the entire length of Alaska Peninsula. Osgood (1904) frequently found it at the base of the Peninsula, Hine (1919) reported it to be common in lower Katmai River valley and secured specimens, and Friedmann (1935) recorded many specimens from Kodiak.

On May 23 and 26, 1936, these warblers were heard singing in the willows and alders at Snag Point, Nushagak River. On August 20, as we approached Port Moller (but still several miles offshore), three Wilson's warblers hovered about the ship for some time and occasionally settled on the deck.

In June 1940, Gabrielson noted this warbler commonly on Kodiak Island; he saw a few on Semidi Islands, and he noted them as common at Chignik Bay. Howell reported this "the most numerous warbler" on Kodiak. Later, he saw them on Unimak Island, at Cold Bay, at King Cove, at Pavlof Bay, and at Nelson Lagoon.

In 1925, I found these birds below Aghileen Pinnacles, near the western end of Alaska Peninsula-the first sighting was on May 29. They were common in the alders at Moffet Cove, Izembek Bay, and two were seen on Hazen Point on June 22.

Gianini (1917) found them to be common, and nesting, at Stepovak Bay.

In 1911, Wetmore reported this warbler as common at King Cove; he saw one west of Morzhovoi Ray, and he said that they were common at the east base of Frosty Peak.

\section{Family ICTERIDAE}

\section{Euphagus carolinus: Rusty Blackbird}

Osgood (1904) recorded several occurrences of the rusty blackbird at the base of Alaska Peninsula: A specimen taken near 
Keejik Village, Lake Clark, July 24; observations made near the headwaters of Chulitna River; and several seen at Ikwok Village, on Nushagak River, September 5. McKay obtained a specimen on Nushagak River and two at Lake Aleknagik. Osgood obtained 2 specimens at Tyonek, Cook Inlet, and he mentions 2 others taken there by Bischoff.

Friedmann (1935) records a specimen taken on Kodiak Island by Reichenow, October 22, 1906. Cahalane (1943) found the rusty blackbird to be abundant at Kodiak in the fall of 1940 .

\section{Family FRINGILLIDAE}

\section{Pinicola enucleator: Pine Grosbeak \\ Pinicola enucleator alascensis}

The type specimen of the Alaska pine grosbeak (No. 86510, U. S. National Museum) was taken by McKay near Nushagak on June 9, 1881, and he obtained others on Nushagak River and Lake Aleknagik. Hanna obtained two specimens at Ahyoowaytha Creek and two on Kakwok River in 1912. We found the skeleton of a female at Snag Point, Nushagak River, on May 25, 1936.

\section{Pinicola enucleator flammula}

Specimens from Kodiak and other localities along the coast to Sitka were compared with a series from Bristol Bay and interior Alaska. The colors are confusing, but the coastal birds, including those from Kodiak, have larger bills. Thus we find still another subspecies on Kodiak that apparently has been derived from the southern Alaskan coast, rather than from the north.

At least eight specimens from Kodiak were available for study, collected by Panshin, Ridgway, Osgood, and R. H. Beck. In 1940, Gabrielson noted the bird on Kodiak and Afognak Islands. Howell also observed this grosbeak on Kodiak, and, on June 9, 1944, he found a nest with three fresh eggs; he obtained a specimen on Kodiak, November 12, 1944.

\section{Leucosticte tephrocotis: Gray-crowned Rosy Finch}

For a proper understanding of the relationships of the rosy finches of the Alaska Peninsula, Kodiak, and Aleutian Islands, it became necessary to examine, as a whole, the group occupying Alaska and the Bering Sea region. As a result of this study, the group appears more closely knit than previous taxonomic usage 
has indicated. There appears to be gradation from the smaller birds of the eastern and southeastern part of this territory to the large birds of the Aleutians and Commander Islands. The various forms should be included under the species tephrocotis. This parallels the series of song sparrows, which have shown a similar development.

\section{Leucosticte tephrocotis littoralis}

The rosy finches of Kodiak Island have been difficult to identify. Nelson had reported that both griseonucha and littoralis occur there together, and Friedmann (1935) listed both forms for Kodiak. Allen J. Duvall (to whom I am indebted for further comparisons with additional material after the initial study had been made) finds that Robert Ridgway had at first designated the Kodiak birds as a new form in his manuscript notes, but that later he changed his mind. In 1901, McGregor named the bird Leucosticte kadiaka and defined it as similar to $L$. griseonucha, but with a smaller bill and smaller, weaker feet and claws. Grinnell (1901) pointed out that five specimens from Kodiak in the collection of Leland Stanford University indicated that-

an almost complete gradation between Leucosticte tephrocotis of the Sierra Nevada and griseonucha of the Aleutian and Pribilof Islands. Such being the case, then the latter form is a subspecies of tephrocotis, as long ago contended (L. tephrocotis var. griseonucha Coues Key, 1872, p. 130).

It has been difficult to obtain breeding birds from Kodiak, and specimens from there may be migrants. Thus, it would seem that the kadiaka form must be assumed to be merely intergradation between the birds of the Aleutians farther west and littoralis farther east and south, and it is not included in the Fifth Edition of the A. O. U. Check-List.

Leucosticte tephrocotis littoralis is known to occur from White Pass, Yukon Territory, south to central Oregon. But a specimen taken by Adolph Murie at Savage River, Mount McKinley National Park, September 2, 1923 (298055, U. S. National Museum), proved to be littoralis, thus extending its range considerably northward. In 1926, Joseph Dixon (1938, p. 121) obtained additional specimens there, which also proved to be littoralis. On May 28, 1955, Adolph Murie obtained another specimen of littoralis in Mount McKinley National Park. On the other hand, two specimens that I obtained at Bettles, Alaska, October 17, 1924 (298085 and 298086, U. S. National Museum) are L. $t$. tephrocotis. 
The specimens just referred to here suggest the following distribution: L. t. tephrocotis is the more-inland form, occurring in eastern Alaska and extending its range chiefly along the Brooks Range; littoralis is a coastal form, ranging through southeastern Alaska and occupying the more southern mountain ranges, including the Alaska Range, at least as far west as the Mount McKinley region; and kadiaka is a form intermediate between littoralis and griseonucha, occupying the Kodiak-Afognak island group. The specimen from Nushagak suggests an influence from the Kodiak form, therefore we may assume that kadiaka also occurs on nearby parts of Alaska Peninsula.

\section{Leucosticte tephrocotis griseonucha}

Attu: Kohl-grhá-ghuch

Qúlgax and Ulugásix (Jochelson)

Atka: Chá-nuh

This well-known, large-sized rosy finch ranges throughout the Aleutian Islands and probably over a large part of Alaska Peninsula. We found them to be common, and nesting, on Amak Island on May 31, 1936 (where I had also observed them in 1925), and we saw them among the alders at Chignik on May 15, and at Belkofski on May 17. Laing (1925) also observed them near Chignik, and, in 1911, Wetmore saw them with young at the east base of Frosty Peak and at Unga, in the Shumagins. Scheffer noted them at Sanak Island in 1938.

The distance that this form extends northeastward along the Alaska Peninsula is not known, but Gabrielson obtained four specimens on the Semidi Islands that sire referable to griseonucha.

For the most part, the Aleutian rosy finch is a beach bird, spending much of its time among the boulders and the coastal bluffs. But it also is found in the high interior of islands, especially where lava beds are present. It is fond of feeding about buildings and trappers' huts. At Ikatan, Unimak Island, they were common about the cannery buildings, and, on Amchitka Island, these birds used some abandoned houses as roosting places, entering through broken windows. Sometimes a bird is trapped in this way, being unable to find the small hole through which it entered, and, of course, eventually starves.

In July, on Amchitka Island, the rosy finches were found to be feeding on plant seeds, including those of Poa sp. and Alsine sitchana.

Reporting on Adak Island, Taber says, "These birds were present throughout the winter, feeding on the heads of composites which projected above the snow. Even after the heaviest snow- 
storms, some dry vegetation always seemed to be exposed. The Rosy Finch flocks varied from 6 to about 30 individuals."

In 1937, the first family of young on the wing was seen on Buldir Island on June 18, and another such family was seen on Little Kiska Island on June 22.

Two other forms are of interest here. Leucosticte tephrocotis umbrina, from the Pribilof Islands (Murie 1944, p. 122), has become differentiated as a darker bird, about the same size as griseonucha, and L. t. maxima, the Commander Islands rosy finch, is the largest of the group. The bird of the Commander Islands is of the American type; the nearest Siberian form, brunneinucha, from Kamchatka, is of an entirely different group. Thus, the rosy finches show a gradual increase in size north and west through the Aleutian district-culminating in the largest one being found on the Commander Islands (which is the farthest point reached to the west), and the darkest one being found on the Pribilof Islands.

\section{Acanthis hornemanni: Hoary Redpoll Acanthis hornemanni exilipes}

Chukchi: Kedliptschekadlin (Palmén)

Osgood (1904) observed flocks of these birds at Nushagak and lower Nushagak River in September, and they were common at Becharof Lake, Kanatak, and Cold Bay during October. McKay and Johnson have collected specimens in breeding plumage in June and July at Nushagak, and Cahalane (1943) reports a group near the outlet of Katmai River on October 4, 1940.

We did not see this bird. Wetmore, however, according to his field notes for 1911, heard a redpoll in the mountains west of Morzhovoi Bay on July 26, and he suspected that it may have been this species. He felt certain that it was not $A$. f. flammea.

Stejneger (1885) lists this redpoll as a winter visitor in the Commander Islands.

\section{Acanthis flammea: Common Redpoll Acanthis flammea flammea}

Osgood (1904) found this redpoll to be common about Lake Iliamna and Lake Clark and the Chulitna River. McKay and Johnson have taken specimens at Nushagak, and Hine (1919) obtained specimens at Katmai Bay, where they began to appear about the middle of July. Gabrielson found several on the Kvichak River on July 23, and they were common at Iliamna Lake on July 24. We observed these birds at Snag Point, Nushagak River, 
May 25 and 26, 1936. Redpolls also occur on Kodiak Island, apparently the year round according to the specimens recorded by Friedmann (1935). Howell (1948) observed them frequently on Kodiak, and, on June 19, he found a nest with four eggs in an alder bush.

The common redpoll also is found far to the west. In June, 1940, Gabrielson noted this bird at Chignik Bay, at Sand Point on Popof Island, and at Morzhovoi Bay. We noted them at Sand Point on August 26, 1936, and, on May 24, 1937, two or three were heard singing on Dolgoi Island.

Arthur Neumann, a resident at Ikatan, Unimak Island, described a "small brown bird with pink head" that came to feed on crumbs he put out for birds.

In May 1925, I found redpolls to be common on Unimak Island, in the alders back of False Pass, where the first flock were seen April 27. Late in May, redpolls were trilling and singing among the alder patches below Aghileen Pinnacles.

Beals and Longworth found redpolls in flocks at False Pass in the winter and spring of 1941. Specific dates mentioned are: January 19, February 24, March 13 and 18, and May 2, 3, and 23. Flocks, which often were seen in alder thickets, numbered from 10 to 60 birds.

McGregor (1906) found redpolls nesting on Unalaska Island. We saw them on Unalaska on July 12, 1936, and Gabrielson saw them nesting on several occasions. Wetmore refers to one of these birds that Bent saw on Amaknak Island on June 7, 1911, and Turner (1886) records the species from Unalaska, adding that it does not occur west of that point. Probably they do not nest farther west, but, on July 28, 1937, we saw 2 redpolls on the beach of Ogliuga Island, and, on July 31, we saw 2 more on West Unalga Island. However, these may have been migrants. Gabrielson saw a flock of nine birds on Atka Island on January 31, 1941. Taber saw a single redpoll on Adak Island on December 16 and 30, 1945, and Sutton and Wilson (1946) record one on Attu on February 18, 1945.

Stejneger (1885) mentions this species in the Commander Islands, but he thought that it probably does not nest there.

\section{Acanthis flammea holboellii}

This subspecies was taken by McKay and Johnson at Nushagak. We have no other records of it, but redpolls are not always readily identified, and it might be overlooked in mixed flocks unless a good view is obtained. 
Stejneger (1885) considers this to be a resident of the Commander Islands.

\section{Spinus pinus: Pine Siskin \\ Spinus pinus pinus}

Apparently, the pine siskin occurs only sparingly at the base of Alaska Peninsula. Osgood (1904) obtained one at Iliamna Village, and he saw a few other's there and on the Nogheling River. He saw a large flock at Tyonek and obtained three specimens from it, but he saw the bird nowhere else about Cook Inlet (1901).

Friedmann (1935) indicates that the pine siskin occurs regularly on Kodiak Island, and Beal obtained a specimen at Kodiak on March 16, 1947. Apparently, however, it is not abundant in this part of Alaska.

It is interesting to note that on March 9, 1942, Gabrielson saw a group of about 15 birds, which he thought to be siskins, in a grove of spruce trees at Sand Point in the Shumagin Islands, and on April 20, 1943, Lieutenant Eddy, of the U. S. Navy, positively identified eight or ten siskins in the same spruce grove at Sand Point.

\section{Loxia curvirostra: Red Crossbill Loxia curvirostra sitkensis}

This crossbill occurs on Kodiak Island, which probably is the western limit of its range. Friedmann (1935) records three specimens taken there by Bischoff on May 18 and June 13, 1868, which were the only records he could find. We observed a group of 12 crossbills feeding on spruce cones on Afognak Island, but positive identification of the species was not possible.

Osgood (1901) mentions a specimen taken at Graham Harbor, in Cook Inlet, in 1892, by C. H. Townsend and B. W. Evermann.

\section{Loxia leucoptera: White-winged Crossbill Loxia leucoptera leucoptera}

This crossbill seems to be more common than sitkensis in this area. Osgood saw a few at Lake Clark and Iliamna (1904), and many specimens have come from Kodiak (Friedmann 1935). On June 15, 1940, Gabrielson obtained a specimen on Afognak Island. McKay got a specimen in January, 1883, on Mulchatna River, and Osgood (1901) found them to be common in Cook Inlet and obtained specimens at Hope. We did not observe these birds on our expeditions. 


\section{Passerculus sandwichensis: Savannah Sparrow Passerculus sandwichensis anthinus}

Examination of a fairly large series of specimens revealed that the birds of the Kodiak-Afognak group, Barren Islands, base of Alaska Peninsula, and Cook Inlet average smaller than P. s. sandwichensis, and therefore they are referred to anthinus. The length of bill usually is $10 \mathrm{~mm}$. instead of $11 \mathrm{~mm}$. The bill of sandwichensis, on the other hand, rarely is less than $11 \mathrm{~mm}$., and it often reaches $12 \mathrm{~mm}$. in length, sometimes more. The length of wing averages less in anthinus. There is some overlapping of characters.

Localities represented by specimens are Kodiak, Middleton Island, Barren Islands, Nushagak, Ugashik River, Chogiung, Kakwok, Lake Iliamna, Hooper Bay, and Hope and Tyonek in Cook Inlet.

In June 1940, Gabrielson found Savannah sparrows to be common at Amatuli, Barren Islands, Kodiak, Afognak, and Semidi Islands. Allen Duvall, who examined two immature specimens taken in the Semidis by Gabrielson on August 5, 1945, states that these are referable to anthinus on the basis of measurements, but that it is not certain that they had reached full development. There also is a specimen from Wide Bay, on the peninsula, that appears to be anthinus.

There are some puzzling specimens. I took a specimen on May 29, 1936, at Ugashik River (original No. 3536) that is larger than usual, however the beak is not so heavy as most sandwichensis, and it seems referable to anthinus.

On May 12 and 13, 1936, we heard Savannah sparrows singing on Kodiak and Afognak Islands. On May 10 and 11, a number of these birds were feeding on the gravel beach at Ushagat, Barren Islands, and specimens were obtained. On May 14, a Savannah sparrow passed our ship between Sutwik Island and Cape Kumlin ; it is possible that these were migrating. On May 2, near Yakutat, 1 of these sparrows had settled on our forward deck, and the first mate reported 2 other "sparrows" on the deck.

Howell found them to be common on Kodiak. On June 9, 1944, he found a nest, containing 5 fresh eggs, in a swampy area at Middle Bay, and, on June 17, he found a nest with 4 half-incubated eggs in an open growth of grass and moss at an elevation of 1,500 feet.

Under the heading of alaudinus [anthinus], Osgood (1904) says-

Breeding abundantly on the treeless slopes and in the small grassy moun- 


\section{NORTH AMERICAN FAUNA 61, FISH AND WILDLIFE SERVICE}

tain valleys on the west side of Iliamna Pass, where one specimen was taken July 12. Seen in small numbers in open places in the vicinity of Iliamna Village and along the Nogheling River. None were seen about Lake Clark until August 7, when they suddenly appeared in considerable numbers near the mouth of the Chulitna River, not in the open swamps, but in scattering twos and threes in the thick willow brush, evidently preparing for migration. After this date none were seen. McKay and Johnson found the species breeding at Nushagak.

Hine (1919) obtained specimens at Katmai Bay, June 22 and July 8, 1919, and found the species to be common there.

We found these sparrows at Snag Point, Nushagak River, on May 25, 1936, and on May 27 and 29 they were common at Ugashik River, being the principal passerine bird in that locality.

Presumably, the birds here recorded would all be anthinus. It is difficult to know where to place the line of demarcation on Alaska Peninsula between anthinus and sandwichensis, but the Wide Bay specimen suggests that anthinus extends at least that far southwest.

\section{Passerculus sandwichensis sandwichensis}

\section{Unalaska: Saksagada (Wetmore)}

This is the largest of the Savannah sparrows, and it has the longest bill. In a large series from Unalaska, and many more from other localities, the bill measures from 11 to $12 \mathrm{~mm}$. longonly five specimens in a series of more than 80 had a bill shorter than $11 \mathrm{~mm}$. A few bills were as long as 13 to $13.5 \mathrm{~mm}$. Length of wing, in this series, is also greater than that of anthinus. There are some, of course, that approach the intermediate status. One specimen (No. 298534, U. S. National Museum) from Izembek Bay has a fairly small bill, but it does not fit into the series of anthinus very well and has a long wing. Another specimen (No. 164927), from Stepovak Bay, has a bill that is $11.5 \mathrm{~mm}$. long, with a slightly smaller body; this bird is larger than anthinus and should be placed with sandwichensis. Thus, the range of this subspecies extends eastward at least as far as Stepovak Bay, and, as there is a specimen of anthinus from Ugashik River, the meeting place for these two subspecies would comprise the area between Stepovak Bay and Ugashik River.

On May 2, 1936, we found Savannah sparrows to be common at Yakutat. They seemed to be large and robust and could have been sandwichensis on westward migration. The bird occurs on Kodiak Island, where it is undoubtedly a migrant. Bischoff collected an immature bird on Kodiak Island in July 1868, and Bretherton obtained an adult in July 1893. 
In 1941, Beals and Longworth noted the first Savannah sparrow at False Pass on May 1; they became abundant after this date. In 1925, I noted the first sparrow at Urilia Bay, Unimak Island, on May 7. They had become common at False Pass by May 13, 1925.

Thus, the migration period can be limited to the first part of May.

After May 13, 1925, Savannah sparrows became common in all the lowlands, including the grassy islands of Izembek Bay and the mountain valley to Aghileen Pinnacles. They were common on Amak Island, where young birds were on the wing by July 11, and, in late summer, they were noted on Amagat Island and at Ikatan.

In 1936, we found them to be common on Unimak Island, Amak, Unalaska, Baby Islands, and Tangik Island, near Akun. In 1937, we saw a considerable number of them on Unalaska, and, on August 29, they were common on Sanak. On May 16, 1936, they were present on Nagai and Popof, in the Shumagins, where they were again observed on August 26. We took a specimen on Dolgoi, May 24, 1937.

Gianini (1917) noted these birds at Stepovak Bay. In 1911, Wetmore found them to be common at Morzhovoi Bay, at King Cove, at Belkofski, and at the east base of Frosty Peak.

In 1940, Gabrielson reported these birds to be common at Morzhovoi Bay, Akutan, Carlisle, and Amukta, and in following seasons he found them to be plentiful in numerous places throughout this area, including Uliaga, Kagamil, Yanaska, and Adak, but he saw none on Amchitka.

McGregor (1906) found this species on Unalaska, Amaknak, Unalga, Tigalda, Unimak, Akutan, Akun, Egg, and Aektok Islands. He says, "The sandwich sparrow was abundant on every one of the Krenitzin Islands, and on most of them they fairly swarmed, outnumbering all other land birds combined."

In 1936, we saw them on Ananiuliak (near Umnak Island), Kagamil, Uliaga, Chuginadak, and Carlisle. In 1937, we noted them on Ananiuliak and at Nikolski Village on Umnak. On August 22, they were common on Samalga Island, which is low and grassy, and we noted one on Herbert Island.

Cahn writes of this sparrow on Unalaska, "Apparently arrives in numbers overnight; by late May (earliest date, May 20, 1943) or early June they are suddenly everywhere among the tundra grasses, and in full song at once. During June, July and August they are extremely abundant and nest in the open tundra." 
In summary, the Aleutian Savannah sparrow is abundant and occupies the western part of Alaska Peninsula, the Fox Islands, Islands of the Four Mountains, and has been seen as far west as Amukta, where Gabrielson collected a specimen on June 25, 1940, and on Adak, where he found many adults and young.

Farther west, they are rare, and they were not seen on any of our expeditions; however, Turner (1886) reported that he saw a few at Atka Island in 1879 and a few on Attu in 1880. The Attu chief did not seem to know of the bird.

Nesting

McGregor (1906) obtained several sets of eggs that indicate the nesting period: A nest with 4 slightly incubated eggs was found on June 27 in Beaver Inlet; 5 slightly incubated eggs were found June 28 at English Bay; 5 moderately incubated eggs were collected on July 20 on Tigalda; a set of 4 eggs was found on July 28 on Akun; and 2 females were collected on July 15 and 16 at Dutch Harbor, each of which contained eggs. Some of these data suggest a second laying.

Wetmore found a nest of five fresh eggs at Unalaska, June 9, 1911. By July 7, apparently all the young had been hatched.

When Savannah sparrows are flocking, they are prone to feed along the beaches.

\section{Junco hyemalis: Slate-colored Junco Junco hyemalis hyemalis}

Osgood (1904), writing of his expedition at the base of Alaska Peninsula, says, "Up to the second week in August juncos were seen almost daily from Iliamna Village to the lower Chulitna River."

They are not recorded from Nushagak. Osgood found this junco to be common at Hope and collected specimens there. We saw several of these birds at Seward on May 21, 1937, and Gabrielson found them on Kodiak in November and December.

\section{Junco oreganus: Oregon Junco Junco oreganus oreganus}

Turner (1886) reported that he obtained a specimen of the Oregon junco at Unalaska Island on April 8, 1879, but I could not find the specimen in the National Museum. Turner says further that he saw "numerous individuals" at Karluk, Kodiak Island, where they were hopping about the village.

These identifications must be held in doubt. Miller (1941, p. 
275 ) lists the western boundary for the Oregon junco as southeastern Alaska; it is nonmigratory, and clings to the forest habitat. The nearest junco population is hyemalis, from the base of Alaska Peninsula and Kenai Peninsula-we have no junco records west of this area.

\section{Spizella arborea: Tree Sparrow Spizella arborea ochracea}

Osgood (1904) found the tree sparrow to be common along his route through the base of Alaska Peninsula, and McKay collected specimens at Nushagak. Turner also (1886) observed the bird at Nushagak, and, on May 25, 1936, we obtained a specimen at Snag Point, Nushagak River.

Cahalane (1944) reported that he saw the species at Big Creek on Naknek River, September 4, 1940, and near the outlet of Savanoski River on September 6. In the same year, Gabrielson found them to be common near Iliamna Lake on July 24 . He obtained specimens at Iliamna Lake, at Dillingham, and at Naknek. On August 7, 1945, he noted the species at Wide Bay, and on August 17, 1946, he saw these birds at Pavlof.

\section{Zonotrichia leucophrys: White-crowned Sparrow Zonotrichia leucophrys gambelii}

\section{Osgood (1904) says-}

First seen on the portage between lakes Iliamna and Clark, where it was found in company with $Z$. coronata [atricapilla] July 18. Scattered individuals were observed later about Lake Clark and along the Chulitna River. One specimen was taken and a few others were seen near Swan River August 27. They were quite rare at this time, and the majority that breed in the region had doubtless migrated. One specimen was taken at Nushagak as late as September 18. Specimens were also taken at this locality by McKay June 6 to August 9, 1881.

Howell (1948) found these birds on Kodiak "Common in the valleys and on the slopes of the mountains up to 1500 feet." On June 10, he found a nest, containing five well-incubated eggs, just below the snow line. On June 13, he found a nest with 4 eggs, and, on June 19, he found a nest with 5 eggs at Bell's Flats.

We obtained a specimen at Snag Point, Nushagak River, May 25, and Williams saw a Gambel's sparrow at Sand Point, Popof Island, May 16.

On July 19, 1925, near Moffet Cove, Izembek Bay, I saw a bright-plumaged male and heard another. These are the westernmost records of this bird-though specimens were not taken, 
identification was almost certain. This was verified in July 1942, when Beals and Gabrielson obtained a specimen, and noted others, at Izembek Bay.

\section{Zonotrichia atricapilla: Golden-crowned Sparrow}

This fine-looking sparrow is perfectly at home throughout the length of Alaska Peninsula, on Unimak Jsland, and the Shumagins. There are many records of its occurrence. Osgood (1901) found it to be common around the village of Hope, and he saw it occasionally in the mountains nearby. On a later expedition, he found it to be very common about Iliamna Bay and Iliamna Village, and he saw a few at Lake Clark, which he considered to be as far as these birds go into the interior (1904). He mentions the fact that these birds are erratic in migration, straggling along irregularly. He refers to one of these stragglers which was taken by McKay and Johnson at Nushagak on November 5 .

Cahalane (1944) observed a flock of these sparrows in the lower Ukak River Valley, September 11, 1940, and Hine (1919) evidently found them to be common in the general region of Katmai National Monument.

The golden-crowned sparrow is a common nesting bird on Kodiak Island, where Friedmann (1935) has obtained many specimens. In the summer of 1940, Gabrielson noted the species on the Barren Islands, Kodiak Island, Afognak Island, Semidi Islands, at Chignik Bay, and Dillingham, and he took several specimens. Later, he saw this bird at Umnak, the Shumagins, and other peninsula localities.

Gianini (1917) found them to be fairly common at Stepovak Bay, remarking that he heard them first on May 28. In 1911, Wetmore observed them at the east base of Frosty Peak, King Cove, and in the mountains west of Morzhovoi Bay.

On the 1936 expedition, we noted this sparrow at Yakutat, May 2; at Ushagat (Barren Islands), May 10; at Kodiak, May 12; at Chignik, May 14 ; at Nagai and Popof Islands, Shumagins, May 16 (again on Popof Island, August 26) ; and we saw several at Snag Point, Nushagak River, May 25 and 26. A sparrow was heard singing on Amak Island, May 31, and Williams secured a specimen there. In 1937, we saw this bird at Seward, May 21, and on May 24 they were common, singing and evidently nesting, on Dolgoi Island, west of the Shumagins.

In 1925, I observed this sparrow about the west end of Alaska 
Peninsula and Unimak Island. My field studies were summarized in a report, as follows:

May 22, near Moffet Cove on Izembek Bay, I heard the first goldencrowned sparrow. Next day there were many. [In 1941, Beals and Longworth reported the first ones at False Pass on May 5.] They were common among the alders, as far as these bushes grow up the valley toward Aghileen Pinnacles. They were noted in the alder patches at the base of Frosty Peak, at False Pass, and Ikatan. While not as numerous as some other sparrows, the golden-crown nests commonly throughout the region covered, though local range is naturally governed by the boundaries of the alder patches, which are by no means universally distributed. This statement, however, must be subject to some exceptions, for on July 10 and 11 three males were singing and on July 15 a specimen was taken on Amak Island, where there are no alders and the largest form of vegetation is the cow parsnip.

On one occasion I heard a distinct variation of the song. Instead of three notes in decending scale, the usual second and third notes were reversed. It was the normal song for this bird, as I heard it day after day in the same clump of alders near camp.

\section{Passerella iliaca: Fox Sparrow Passerella iliaca zaboria}

The fox sparrows of this region present an interesting distributional pattern. At the base of Alaska Peninsula there are a number of specimens of typical a aboria. G. D. Hanna collected three specimens in May and June 1911, at Nushagak (Nos. 231281, 231282, and 231283, U. S. National Museum). He also obtained an immature male at Kakwok, August 19, 1911 (No. 239707). There is another taken at Nushagak on June 20, 1881 (No. 86535). And on May 26, 1936, I obtained a specimen on the Nushagak River, at Snag Point (original No. 3528). Osgood also mentions a specimen taken at Nushagak, by McKay, June 6, 1881, which I have not examined. Furthermore, on July 17, 1940, Gabrielson recorded several eastern-type fox sparrows at Dillingham (with one specimen) and, the next day, he saw several at Wood River Lakes.

At any rate, the birds occupying the base of Alaska Peninsula, in the Nushagak district, apparently are typical zaboria from the interior Alaska fox-sparrow population, which has found here an outlet to the southwest coast of Alaska.

Here, too, it has come in contact with another fox sparrow population-the unalaschcensis group. There are several interesting specimens that have intermediate characters-two immature birds, (Nos. 239705 and 239706, U. S. National Museum), taken by Hanna at Kakwok, and another (No. 110105) taken by J. W. Johnson in this general area, July 14, 1885. The streaking on the 
back, so characteristic of iliaca and almost absent in unalaschcensis or insularis, is much subdued and clouded over by the duskiness of the coloration. The spotting on the breast is slightly bicolored, as in iliaca, but it is more like that in unalaschcensis. Osgood (1904) evidently referred to one of these specimens, the adult taken by Jolnnson, and described it as "intermediate in character between iliaca and unalaschcensis, but nearer to iliaca."

Swarth (1920), in his revision of this genus, properly recognized three fox sparrow groups, the iliaca group, the unalaschcensis group, and the schistacea group. He considered all these to be subspecifically related, but this relationship is complex, and not entirely clear. In the same general area occupied by the iliaca group, as mentioned above, there are typical specimens of the unalaschcensis group. Osgood (1904) reported-

One specimen was taken and several were seen in the mountains near Iliamna Bay July 12; two others, one adult and one immature bird, were taken at Iliamna Village July 14 ; and another young bird was taken on Lake Iliamna at the Nogheling portage July 18. These agree well with birds from the Shumagin Islands and localities to the westward on the Alaska Peninsula...

A specimen of typcial unalaschcensis in fresh fall plumage was taken at Nushagak September 19; another, which is not quite typical, but easily referable to unalaschcensis, was taken at the same locality by J. W. Johnson October 22, 1884.

The last two specimens just mentioned may have been fall migrants, though they were north of the known breeding range, rather than south of it. But omitting these as possible breeding birds, there is hardly room for an area of intergradation between the known breeding ranges of these two well-marked forms. As Osgood suggested many years ago, there does not appear to be gradual intergradation here. The intermediate specimens described above show the abrupt mixtures found in hybrids.

Apparently, altivagans is the form in which we may look for complete intergradation with typical iliaca. Specimens of altivagans available for this study did not show complete intergradation. Presumably this may take place somewhere in Alberta. On the whole, on the basis of material that is available at present, iliaca seems to be a species apart, although it may be proper to assume intergradation with altivagans somewhere in Canadian territory. Therefore, granting subspecific status, iliaca is an example of a subspecies that intergrades with another subspecies at one part of its range and becomes a species, with hybrids, where it meets another subspecies of the same group, as at the base of Alaska Peninsula. 


\section{Passerella iliaca unalaschcensis}

The three subspecies of the unalaschcensis group that are involved in the present study are unalaschcensis, insularis, and sinuosa. Minute examination of material available, which was strictly segregated into seasonal lots, brought out general differences as follows: All are brown in general coloration, but unalaschcensis is the palest and grayest of the three. Insularis averages browner, sometimes with a slight olivaceous trend, and often is a markedly richer brown. Sinuosa is the darkest; in some seasons it is a deeper, "ruddier," brown, sometimes merely more dusky. Probably the chief distinction of sinuosa is the darker, or duskier, quality. These forms are very close and are very difficult to distinguish, especially the difference between insularis and simuosa. Incidentally, in some instances it was found that worn July specimens could not be assigned with certainty. August specimens, with their fresh plumage, were very satisfactory, but they were not comparable with spring specimens. Furthermore, it was found that considerable change takes place in the plumage during the spring from April through June, and apparently this change is much greater than the change that takes place throughout the entire winter period. It was only by a faithful adherence to seasonal segiegation of specimens that reasonable identification could be made.

The Shumagin fox sparrow, as stated above, is characterized by a grayer coloration, and some specimens from Unimak Island show this to a remarkable degree. In fact, fox sparrows from Unimak seem to be slightly different from fox sparrows in the Shumagins and the Peninsula. Howerer, this extreme grayish character is not entirely consistent even among Unimak Island specimens, and it is possible that there is a slight dichromatism in this group. At least, there is variation.

We hear'd fox sparrows singing at Chignik, May 14, 1936, and on May 16, we saw them in the Shumagins on Unga, Nagai (abundant), and Popof (common). Specimens were taken. In August, they were very common in the alders at False Pass. On May 21, 1937, we saw several and collected two on Dolgoi Island.

Gianini (1917) saw a few at Stepovak Bay. In 1911, Wetmore saw them in the mountains west of Morzhovoi Bay, and he found them nesting commonly at King Core and at the east base of Frosty Peak. In 1940, Gabrielson saw the birds on the Semidis, Chignik Bay, and at Sand Point in the Shumagins.

There is an important specimen in the collection of the Museum of Vertebrate Zoology, at Berkeley, Calif., which is an adult male 
taken by C. I. Hall at Unalaska, June 4, 1894. It is almost as gray as the specimens from Unimak Island, though the tail is slightly more rufescent. Speaking of this specimen, Grinnell (1910) says-

No Fox Sparrow has been previously secured from Unalaska 'unless the Aoonalashka Bunting of Latham really came from there' (Ridgway, Birds of North and Middle America, Vol. I, 1901, p. 389). So that the present specimen assumes a decided importance. This bird bears out all the characters of the race called unalaschcensis, as defined by Ridgway, and doubtless indicates the western limit of the range of that form.

In view of these uncertainties, Cahn (1947) makes an important contribution when he reports, for Unalaska Island "One was seen on June 5, 1944, at the foot of Mt. Ballyhoo."

The 1931 Check List gives Unalaska as part of the nesting range of the Shumagin fox sparrow, and the two records mentioned above may have been nesting birds. Yet, Harrold (Swarth 1934) says-

No fox sparrows were found on Akutan Island. The only cover consists of salmon-berry canes and a few stunted willows here and there, of an average height of about 18 inches. Unalaska, although having slightly larger bushes, was just as unfavorable, and none of this species was seen there either.

Apparently, the fox sparrow has occurred only sporadically on Unalaska, and actual nesting has not been established. It is interesting to note that a specimen was obtained by Hanna on St. Paul, Pribilofs, May 20, 1919 (which is in the breeding season) and an immature male was taken by Harrold on Nunivak Island on September 9.

So far as is known, Unimak Island marks the western limit of the breeding range of the Shumagin fox sparrow, as well as the western limit of a habitat that is typical and fully occupied. If the unique record from Unalaska was a breeding bird, it probably was an accidental occurrence. The regular breeding range extends eastward at least as far as the Shumagins and the Alaska Peninsula opposite these islands. Still farther eastward, on portions of the peninsula from which we do not now have specimens, this subspecies must merge so thoroughly with insularis that it would be impractical to separate them.

There are two specimens in the National Museum (Nos. 105767 and 18.1003) that are hard to identify. They are from Nushagak, taken on October 22, 1884, and on September 19, 1902, and may have been migrants. These specimens appear to be unalaschcensis. (Since these studies were made, Gabrielson has obtained many specimens from Alaska Peninsula, which have not been compared with the series here discussed.) 


\section{Nesting}

The following is quoted from my field report for 1925:

On returning to False Pass from Urilia Bay I found the fox sparrow plentiful among the alders. May 13 they were singing everywhere. They are common both on Unimak and the Peninsula, among the alders. Two nests were found in the valley below Aghileen Pinnacles, June 2, constructed as follows:

No. 1. Outer structure of old brown coarse vegetation, mostly grass; inner structure of fine dry grass, a little porcupine hair, and a few feathers. Sunk in the ground on the side of a little bank, in moss, completely screened by salmonberry stems and grass, 6 feet from edge of alder patch. Outside diameter $140 \mathrm{~mm}$; ; inside diameter $70 \mathrm{~mm}$; d depth $68 \mathrm{~mm}$.; five eggs.

No. 2. Outer structure of dead grass, inner structure finer grass, with a few feathers, the whole sunk evenly in the ground under some large overhanging alder stems. Ferns were just emerging near rim. Outside diameter $100 \mathrm{~mm}$., inside diameter $70 \mathrm{~mm}$., depth $47 \mathrm{~mm}$.; five eggs.

\section{Passerella iliaca insularis}

This is the bird of the Kodiak-Afognak Island group, though specimens have been taken elsewhere. It undoubtedly occurs on adjacent parts of Alaska Peninsula and nearby islands, though the limits of its breeding range are unknown. There are two specimens taken by Osgood at Lake Iliamna on July 12 and July 14, 1902. These are intermediate in character, but probably should be called insularis. Furthermore, two others taken by Osgood at Hope, in Cook Inlet, also appear referable to insularis. We obtained two specimens on the Barren Islands on May 10 and 11,1936 , that are referable to insularis in comparable plumage. I have not examined a specimen taken by Hine in Katmai River Valley, July 9, 1919, and I have not examined specimens from the Semidi Islands, which also are available.

In summary, insularis is the fox sparrow of the Kodiak-Afognak Islands, Barren Islands, and (according to a few available specimens) the adjacent parts of Alaska Peninsula. Probably it extends eastward for an unknown distance to merge with sinuosa, and westward to the range of unalaschcensis.

We observed many of these birds, singing, on May 12, 1936, on Kodiak Island, and on the next day on Deranof Island near Afognak; we saw them on Afognak on September 2. Gabrielson noted the birds on Kodiak and Afognak in June 1940, and on that occasion he thought that it was the most abundant bird on Afognak. 


\section{Melospiza lincolnii: Lincoln's Sparrow Melospiza lincolnii lincolnii}

Birds observer in the Cook Inket region by Osgood evidently were considered to be the tripial form, for he salys (1901), An adult male was taken at Hope August as, and a few others weres soen while we were there. The specimen taken shows none of the characters attributed to Melospriza lincolni striate langrilis l.

On July 27, 19.10, Gabriclson colleded a lincoln's sparrow at the upper end of lliamma Lake, the only record we have for the base of Alaska Ponimsula.

\section{Melospiza melodia: Song Sparrow}

Attu: ('hi-glu-r'high

Atka: (hig-uinch

The song sparrows oceupy the Aleutian distrid (as here defined) from Attu Island to kodials. Gabrielson and lincoln (1951), who leviewed the Alaskan somg sparrows, halve chatacterized them as follows, to state the matter very brietly.

\section{Melospiza melodia maxima}

Described as a new form, dilloring from sumeliet in being browner, with a larger beak. Ramge extends from Atka to Altu.

\section{Melospiza melodia sanaka}

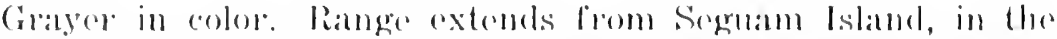
Alentians, eastward to Strpovak liay on Alaska Peninsula and to the Somidi lstands, including other islands sonth of the westorn part of the peninsula (Sanak, Shmmagins, and many ofhors).

\section{Melospiza melodia amaka}

This is a new race, deseribed by Gabrielson and lineoln-

Resembles marima from the western Alentians in color and extansive brown maskings, but somewhat more heavily marked with lorown than that race both on back and breast; in most availables sperimens the brown markings also somewhat brighter. Cleser in color to morimu than to the greographieally

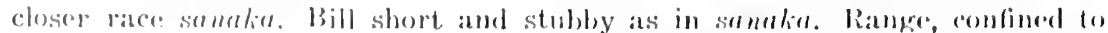
Amak Island, a rocky island north of the west end of Alaskat Peninsulia some 15 miles.

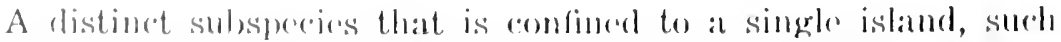
as Amak, maty serem incongroums when one consider's the rextonsive ranges of the other forms. Ifowever, Amak is somewhat 


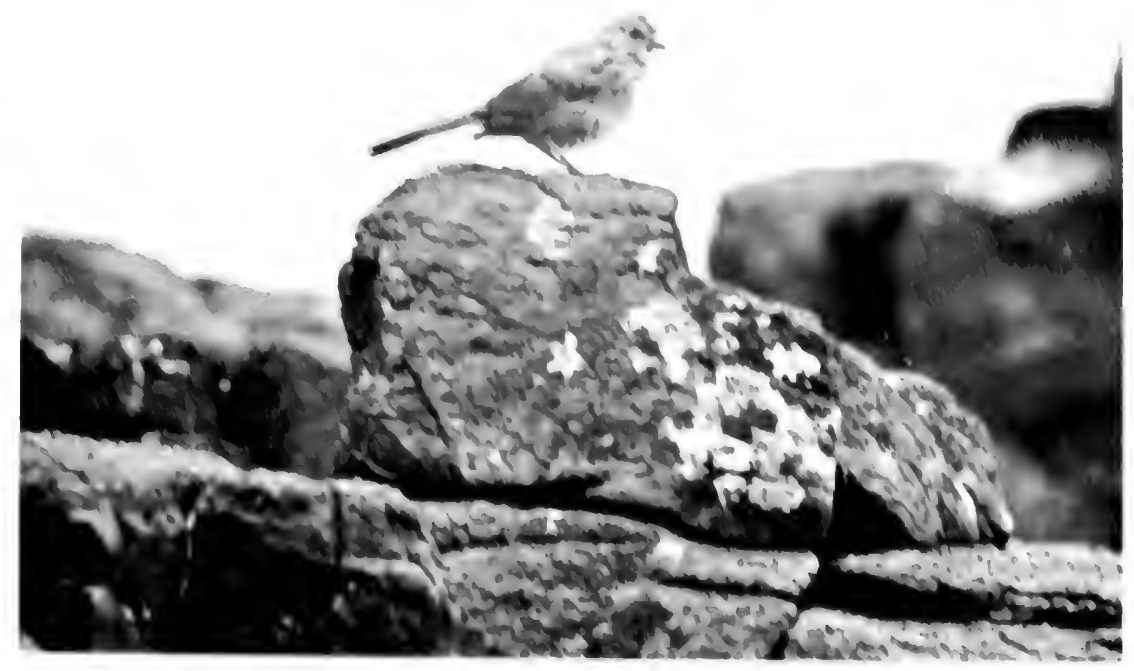

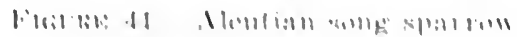

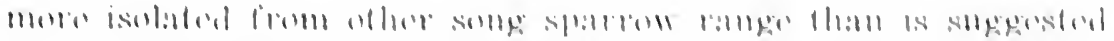

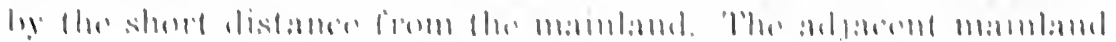

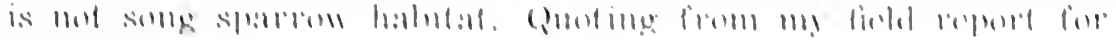
19190

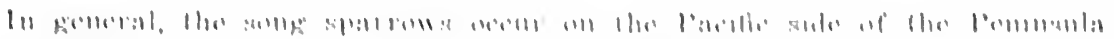

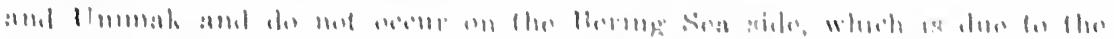

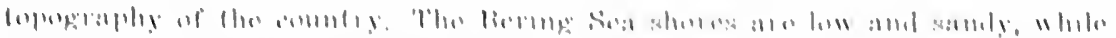

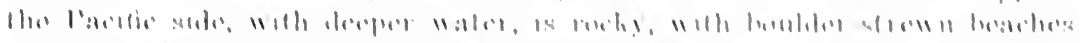

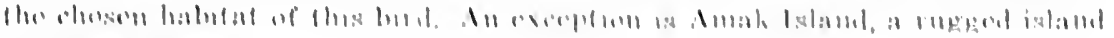
in linvine. sis.

\section{Malospiza molotia imignis}

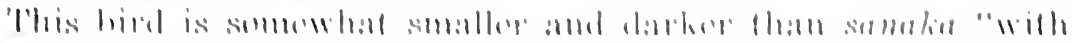

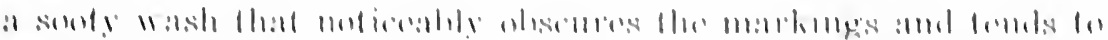

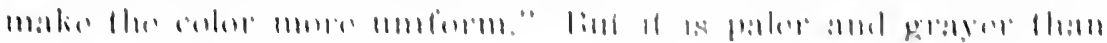

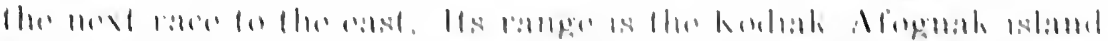

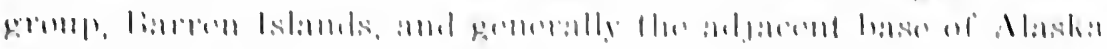

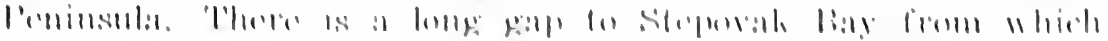

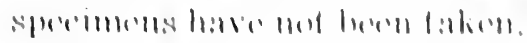

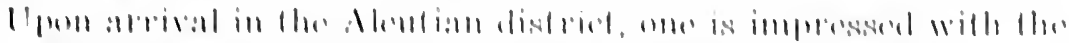

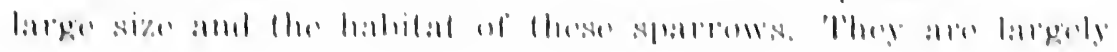


littoral, living in boulders or on cliffs, although they ascend into grassy areas to nest. Here, as elsewhere, the song sparrow seems to delight in finding a mass of driftwood, which it substitutes for the brush heaps of interior country in the south.

Song sparrows often frequent buildings, especially unused barabaras or huts. In a cabin on Herbert Island, August 22, 1936, Scheffer found 30 dead adult and immature song sparrows, together with several individuals of other species. Evidently, they had entered by a small opening and failed to find a way out. On Segula Island, I found a dead immature song sparrow floating in a keg of water at a trapper's cabin.

On Kasatochi Island, a song sparrow was seen within the crater rim, which rises about 1,000 feet above the beach. However, the inner walls of the crater descend abruptly to a crater lake, far below, creating an aspect of a sloping cliff above water, as on the seashore.

These sparrows nest in the grass on slopes adjacent to the beach. We found a nest at East Anclior Cove, Unimak Island, May 19, 1936. It was in ryegrass on a slope a considerable distance from the beach. The nest was tucked away under a mass of clead grass and was macte of fine, smooth, nicely bleached grass stems. There were three downy young.

A similar nest, in a similar situation, but abandoned, was found on Unimak Island, June 7, 1936. On Kiska, June 5, 1937, Steenis found a nest containing three eggs. It was placed deep in the vegetation and was built of fine grass stems. Incidentally, on that same day, Douglas Gray reported a curious performance-a song sparrow followed him along the beach for about a mile.

Cahn (1947) reports that the song sparrow was abundant at Unalaska Island from April 7 to September 22, 1945. He found that the young left the nest by early July; a second nesting was suggested by observing a nest with newly hatched young on August 8, 1945.

Although there may be local movements due to the approach of winter, the song sparrows of the Aleutian district are permanent resicients. Cahn reports them to be absent in winter in the Dutch Harbor area, but Taber found them all winter on Adak, and Sutton and Wilson (1946) found them in winter on Attu. As this spar'row evidently finds its food on the beach at the tide's edge, subsistence is possible year round where the sea never freezes and where the ebb and flow of tide is dependable. 


\section{Calcarius lapponicus: Lapland Longspur Calcarius lapponicus alascensis}

Attu: Chir-loch

Atka: Chí-loch

Unalaska: Chelookh (Wetmore)

Commander Islands: Tschelutschjek (Stejneger)

Chukchi: Tumkup (Palmén)

This is one of the most common passerine birds throughout the Aleutian chain, the Alaska Peninsula, and adjacent islands, and it also occurs on Nunivak Island and the Pribilofs. The Alaska longspurs probably inhabit every island in this district at some time of the year. Furthermore, this bird has a welldistributed habitat, ranging from the beach line to the upper mountain sides and lava beds, although it evidently prefers grassy flats and slopes. We saw them on the flat lowlands at Ugashik River, on the sand dunes at Urilia Bay, as well as on the' slopes of such islands as Amak, Ananiuliak, and Uliaga.

The Attu chief stated that longspurs leave Attu in August and return early in April. This is fairly well verified by Beals and Longworth, who reported in 1941 that the first longspur was seen on Unimak Island on April 16. They further stated that none were seen when they returned to the island, August 31. We noted longspurs on Sanak Island as late as August 28.

In 1925, I had an opportunity to note the progress of the nesting season at Unimak Island and Alaska Peninsula. The first longspurs, two small groups, appeared among the sand dunes at Urilia Bay on April 30. A few were seen each day afterward; they were heard singing on May 3 ; they were common and were heard singing on May 5; and they were numerous on May 8. On May 16, they were noted as common at False Pass; they were common at St. Catherine Cove on May 17; and were common on May 28 at Izembek Bay. On June 14, a nest of four eggs was found on Hazen Point, Izembek Bay, and, the following day, a number of specimens were taken. The females of this group of specimens had brood patches, which were absent on the males.

On June 18, 1936, we found a nest on Seguam Island. It was sunk in the vegetation and was built of fine dried grass stems with few longspur feathers. There were four young, with yellow down.

On May 24, 1937, longspurs were common on Dolgoi Island; they were singing, and some of them evidently were nesting. On June 1 , they were very active, singing, on Atka Island-this probably was at the height of the nesting period. On June 22, I found a nest with 5 eggs in a clump of anemones on Little Kiska 
Island, and Steenis found another nest with 4 eggs. Apparently, the male sings throughout the entire nesting period.

In 1936, young birds on the wing were seen as early as July 2. On July 11, 1937, four or five young birds were seen flying about on Amchitka Island. On August 22, Scheffer found 2 dead longspurs in a cabin on Herbert Island, together with 30 dead song sparrows.

The Alaska longspur is lighter in color than typical lapponicus. Concerning the birds of the western Aleutians, Ridgway says (1901), "The great contrast in coloration is just as marked between specimens from the extreme western Aleutian Islands (Atka, Adak, and Attu) and the extremely dark form (C. $l$. coloratus) of the Commander Islands as between the latter and specimens from the Pribilofs and Unalaska."

\section{Plectrophenax nivalis: Snow Bunting Plectrophenax nivalis nivalis}

It is probable that some eastern snow buntings winter in the Aleutian district. According to Ridgway (1901), this form winters at Unalaska, the Shumagins, and at other points in southeastern Alaska. Osgood (1904) reports-

One specimen was taken on the beach at Nushagak, September 20, and another was seen in company with it. A small flock was seen on Becharof Lake, October 6, and a few more were seen in the mountains between Becharof Lake and Kanatak. Numerous specimens were taken at Nushagak by McKay and Johnson. Most of these are winter birds, but at least one (No. 110128 ) is in full nupital plumage. It was taken July 3, 1886, which would indicate its breeding in the vicinity. It also breeds at Cold Bay, where Maddren found it nesting in high rocky cliffs in the summer of 1903.

Hine (1919), and other members of the 1919 expedition of the National Geographic Society noted snow buntings on mountain tops of the Katmai region and in Katmai Canyon. A pair were noted, singing, in upper Mageik Creek. These observations indicate nesting.

Specimens from Kodiak have been taken in the migration period, but Turner (1886) states that he saw these birds "at Kodiak in the early part of August, 1881. At the latter place young birds of the season were abundant." On June 18, 1940, Gabrielson noted snow buntings on the Semidi Islands.

Howell (1948), reporting for 1944, says of the snow bunting on Kodiak Island--

Seen only on the top of a mountain near Bell's Flats. Here ten were seen on June 25. They were above the snow line near the crest of the mountain at an elevation of about 2500 feet. Numerous bare areas in the extensive 
snow fields were overgrown by low grass. In one of these a nest was found which contained five young three days old. The nest was in a crevice in some rocks that was too small to admit my hand until some overhanging moss was removed.

Thus, we know that the eastern snow bunting nests in suitable places on Kodiak Island and at the base of Alaska Peninsula, westward as far as Becharof Lake, and probably in the Semidis. It may be assumed that nivalis intergrades with townsendi somewhere on Alaska Peninsula.

\section{Plectrophenax nivalis townsendi}

Attu: Kó-ka-noch

Atka: Math'-a-wach

Unalaska: Masnikh (Wetmore)

Russian, Commander Islands:Sniegirok, plu. Snegirli (Stejneger)

Russian: Snegir (Zitkow, Birula) or Seryi Snegir (Tolstow)

Chukchi: Ptochekadlin (Palmén)

This snow bunting nests throughout the Aleutian Islands, preferring the high, rocky terrain. We considered it likely that snow buntings inhabited most of these islands.

Turner (1886) observed snow buntings at Belkofski in July 1881, and Gianini (1917) found snow buntings in the mountains at Stepovak Bay. In 1911, Wetmore found the birds to be common in the mountains near Morzhoroi Bay. Without question, snow buntings nest in the high country throughout Alaska Peninsula. Somewhere along this Aleutian Range, probably well to the east, townsendi must intergrade with nivalis. Of course, townsendi is known to nest also on Nunivak, the Pribilofs, the Shumagins, the Commanders, and the Bering Sea coast of Siberia.

In 1925, I observed snow buntings at King Cove on April 25, and on April 26 and 27 I saw more of these birds at False Pass. Subspecific identification was not made in these instances, but, later, the birds were found on the nesting grounds and were identified as tounsendi. On May 4, a male was heard singing among the lava beds near Urilia Bay, Unimak Island, where they were common. Soon, their songs were ringing everywhere in the rugged lava. Later, they were found among the high rocks at False Pass; at the head of the valley near Aghileen Pinnacles; on the rocky slopes of Frosty Peak; on Amak Island; and on Ikatan Peninsula. Immature birds were flying about on Amak Island on July 11. On August 10, at Ikatan, a family of young birds on the beach was observed learning to fly.

In 1941, Beals and Longworth found snow buntings on Unimak Island all winter. 
In the Aleutians, the snow bunting is found from the shoreline to the high mountains, but it seems to prefer the mountains.

The nest of the snow bunting may be placed among lava rocks, in crevices or cliffs, or under a ledge of a rock on fairly level terrain. On June 4, 1937, Douglas Gray found a nest with three eggs under an overhanging rock on Kiska Island.

On June 12, 1937, on Agattu Island, I found two nests. One was in the form of a deep grassy cup, with a few feathers worked in, placed under a ledge of a flat rock on fairly level ground. It container four eggs.

The other nest was located under an overhanging boulder, and it had feathers of a forked-tailed petrel woven into the structure. This nest also contained four eggs.

On June 14, also on Agattu Island, a similar nest made of grass was found in a hollow under a flat rock. There were four eggs.

According to the Attu chief, the snow bunting is a permanent resident in the Near. Islands.

\section{Plectrophenax hyperboreus: McKay's Bunting}

This species nests only on Hall and St. Matthew Islands, but it occurs in migration in the Aleutian district. Nelson (1887) describes a bird of this species taken at Unalaska in January, and several specimens were taken at Nushagak Bay by McKay and Johnson. Without doubt, this bird is quite common on Alaska Peninsula and the Aleutian Islands in winter.

\section{Emberiza rustica: Rustic Bunting Emberiza rustica latifascia}

The only record of this species for North America is a small series of skins obtained on Kiska Island in June 1911 by Wetmore and F. B. McKechnie. On June 17, Wetmore found a dead bird, which was estimated to have been dead about a month, and another dead bird was found by McKechnie. In his field notes, Wetmore says further-

On June 19, while making the rounds of my traps, I flushed a small bird that flew up with a faint tsip, and dove immediately into the grass along a creek. The flight was quick and with an up and down motion, and the bird showed two white outer tail feathers. I flushed it again after some tramping, and shot it on the wing, and found it a fine specimen of the bird found on the seventeenth. A hundred yards further I flushed another on a grassy slope, and missed it the first time. When it got up again I shot it, but the wind carried it so that I was not able to find it, though I searched carefully. No other's could be found. The one taken was a female, in fine plumage, but exceedingly fat. 
FAUNA OF THE ALEUTIAN ISLANDS AND ALASKA PENINSULA 261

Apparently, these birds represented a straggling group that had landed on Kiska Island. On our visits to Kiska Island in 1937 we spent considerable time on lowlands and uplands, but we did not encounter this species. 


\section{Mammals}

\section{Family SORICIDAE}

Sorex cinereus: Cinereous Shrew

Sorex cinereus hollisteri

This western Alaska form of cinereus is distributed throughout the length of Alaska Peninsula and on Unimak Island. A mummified specimen from Tigalda Island, obtained by Stevenson in April 1925 , marks the westernmost record of this shrew.

More than 200 specimens have been collected, chiefly in the district here under discussion. We have specimens from the basal parts of Alaska Peninsula and adjacent territory, including such localities as Nushagak, Kakwok, Lake Aleknagik, Lake Clark, Iliamna Lake, Katmai, and Becharof Lake. There are specimens from Port Moller, Cold Bay, Chignik, King Cove, Frosty Peak, Izembek Bay, and Unimak Island, but we have no specimens from Kodiak-Afognak Islands, the Shumagins, or other outlying islands.

In 1925, I found these shrews to be abundant at Izembek Bay, and I obtained specimens at Urilia Bay, St. Catherine Cove, and False Pass on Unimak Island. They were found in the grassy margin of ponds as well as on the higher tundra. On May 5, 1925, as Donald Stevenson and I came upon a high grassy flat above a lagoon at Urilia Bay, we heard a faint squeaking in the grass and caught glimpses of shrews darting here and there. To quote from my notes:

I imitated the squeaks, and presently a shrew came bobbing over the grass right up to me and I pounced on him. Soon another came along in response to my squeaking, but disappeared in a tuft of grass. Then a third came up and I caught him. Stevenson caught another and we missed several. These shrews came from a distance of 20 to 25 feet. Those caught (original Nos. 1979,1980 and 1981) were all males, with enlarged testes. They probably responded to the squeaking in the spirit of battle with another male, or perhaps with the expectation of finding a female.

Stevenson trapped two females at Izembek Bay; one had 11 embryos, and the other had 8. 


\section{Sorex tundrensis: Tundra Saddle-backed Shrew}

This well-marked shrew is represented by specimens from Nushagak, Kakwok, Lake Weelooluk, and Lake Aleknagik. Robert T. Orr $(1939$, p. 251) records a more-recent specimen taken by Dallas Hanna in 1937 at Wide Bay, which is the farthest west that this animal has been recorded. Lack of other specimens suggests a limited distribution farther west on the peninsula.

\section{Sorex hydrodromus: Unalaska Saddle-backed Shrew}

In view of the uncertainties concerning the Unalaska saddlebacked shrew (the only known specimen is in Russia), every effort was made to obtain specimens, but without success. Our stops at Unalaska were necessarily brief, and no shrews of any kind were found.

In 1911, Wetmore was told by the natives that shrews were present on Unalaska Island, but no specimens were taken.

Donald Stevenson, who spent 5 year's in the Aleutians from 1920 to 1925 , had reports of shrews on Unalaska, but he got no specimens.

Therefore, the original specimen and description are all we have on this species. In 1937, E. Raymond Hall had an opportunity to examine the original specimen in the Zoological Institute of the Academy of Sciences in Leningrad. He has kindly furnished a copy of his notes, which are here quoted in full.

\section{ADDITIONAL EVIDENCE INDICATING THAT \\ SOREX HYDRODROIUS DOBSON IS A MEMBER OF THE SOREX ARCTICUS GROUP OF SHREWS}

Sorex hydrodromus Dobson from Unalaska Island, Aleutian Islands, Alaska, was diagnosed in the original description (Annals and Mag. Nat. Hist., ser. 6; vol. 4 p. 373, November 1889) as resembling Sorex vulgaris of the Old World in dental characters but resembling Neosorex in possessing swimming fringes on the digits. Jackson, who was unable to examine the type specimen or topotypes, in his "A Taxonomic review of the American long-tailed shrews" (N. Amer. Fauna No. 51, July, 1928) tentatively assigned the species to the Sorex arcticus group, with the suggestion that S. hydrodromus might be the same as Sorex tundrensis or at most subspecifically distinct.

Bearing in mind the uncertainty as to the relationships of this shrew, I was glad to take advantage of the opportunity which Prof. B. Vinogradov and his assistant, Mr. A. J. Argyropulo, afforded me to study the type specimen when I visited the Zoological Institute of the Academy of Sciences in Leningrad in August 1937.

The assumed type is an immature female, no. 2389, Zoological Museum of the Academy of Sciences of Leningrad, Union of Soviet Socialist Republics, collected by I. G. Vosnesensky at Unalaska, Aleutian Islands, Alaska, some 


\section{NORTH AMERICAN FAUNA 61 , FISH AND WILDLIFE SERVICE}

time between 1840 and 1848 (see Essig, E. O., p. 777, "A History of Entomology," The Macmillan Co., New York, 1931).

The specimen was preserved in alcohol, in a small jar containing no other specimen. An unattached label in the jar bears the catalogue number, "2389, "Unalaska" and "Wosnesensky". A label on the outside of the jar bears the data given on the label inside the jar and also the words "Sorex hydrodromus type". The specimen is poorly preserved and has lost much of the hair. From the parts preserved, it is ascertainable that the animal was darker-colored above than below. The hairs remaining on the tail are of the same reddish color on the top, bottom and sides of the tail. Dissection of the specimen revealed the uterine horns as small structures which certainly had not recently contained young. Upon removal, the skull was found to have the left side of the brain case broken in and to be broken in two along the plane of the cribiform plate. Fortunately, another specimen, an adult female, containing 6 embryos, $5.8 \mathrm{~mm}$. in crown-rump length, taken at Unalaska by Vosnesensky in 1848, is available at the Zoological Institute at Leningrad. This specimen, no. 2370, also an alcoholic, proved to have a perfect skull. Nos. 2389 and 2370 , measured respectively as follows: Total length, 97, 93; length of tail, 42.8, 32.6; length of hind foot, with claws, $13.4,12.3$.

\begin{tabular}{|c|c|c|c|c|c|c|c|c|c|c|}
\hline Species and locality & 窇 & ֻே & 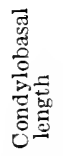 & 焉离 & 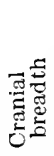 & 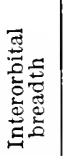 & 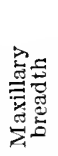 & 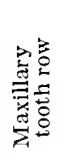 & $\begin{array}{l}\text { Wear of } \\
\text { teeth }\end{array}$ & Remarks \\
\hline $\begin{array}{l}\text { Sorex hydrodromus: } \\
\text { Unalaska }\end{array}$ & 2389 & 암 & 16.1 & 6.0 & 8.2 & 2. $8^{*}$ & 4.45 & 5.3 & None & $\begin{array}{l}\text { Type, body } \\
\text { in alcohol }\end{array}$ \\
\hline Sorex: Unalaska...... & 2370 & o ad & 16.0 & 6.3 & 8.0 & 3.2 & 4.7 & 5. 6 & Moderate & $\begin{array}{l}\text { Body in } \\
\text { alcohol }\end{array}$ \\
\hline Sorex pribilofensis.... & 2437 & $? \mathrm{ad}$ & $?$ & 6.1 & 7.8 & 3.2 & 4.8 & 5.55 & $\begin{array}{l}\text { Moderate, } \\
\text { but less } \\
\text { than } \\
\text { above }\end{array}$ & $\begin{array}{l}\text { Coll. by } \\
\text { Vosnes- } \\
\text { enski }\end{array}$ \\
\hline
\end{tabular}

* Probably least interorbital breadth.

The hairiness of the tail is about the same in no. 2370 and Sorex arcticus, No. 39709, of the Mus. Vert. Zool., from Barrow, Alaska, and the fringe of hair on the sides of both the fore- and hind-feet are not appreciably different. The skull of no. 2370, compared with M.V.Z. 39710 (one of 2 specimens of $S$. tundrensis taken with me from the United States to use in comparison), has less protruding upper incisors and a slightly "flatter" brain case, due in each instance, I think, to the greater age of no. 2370 which, however, is smaller in every measurement taken. Otherwise, when viewed from the side the two skulls have identical contour in the dorsal longitudinal axis. Also, when the same two skulls are viewed from directly above they are, to my eye, of identical outline excepting in the rostrum which appears to be broader, relative to its length, in no. 2370 , even allowing for the lesser protusion of the incisors in that specimen-a circumstance which magnifies the impression of greater relative breadth.

When comparison is made between Sorex pribilofensis (cat. nos. 2485 and 
2437 of Leningrad Aca.d. Sci.) from St. Paul Island, and no. 2370, the latter is seen to differ in wider (labial to lingual side) molars, seemingly broader rostrum and certainly less continuous ridge on unicuspid. In $S$. pribilofensis there is a ridge continuous from the tip of the unicuspid on down into the cingulum without a break, whereas in no. 2370 from Unalaska there is a notch, or break, in this ridge where it meets the cingulum, although the notch is shallower than in a specimen of Sorex tundrensis (no. 39710 , Mus. Vert. Zool., from Barrow, Alaska ) which may be said to have a distinct notch separating the internal ridge from the cingulum. In no. 2370 the pigmentation stops short of the cingulum. The holotype of Sorex hydrodromus agrees with no. 2370 in the presence of the notch and in the extent of the pigmentation. Nevertheless, in the holotype of hydrodromus the molar teeth are narrower than in no. 2370 and about the same width as in Sorex pribilofensis.

My conclusion is that Sorex hydrodromus is a recognizable kind (species or subspecies) of Sorex best placed in the arcticus group. In structure of unicuspids it bridges the gap between $S$. tundrensis and $S$. pribilofensis. If specimens from the base of the Alaska Peninsula are morphologically intermediate between S. hydrodromus and populations of S. tundrensis east of the base of the Alaska Peninsula, perhaps S. hydrodromus should be treated as only subspecifically distinct from $S$. tundrensis-otherwise as a full species. To judge from measurements (published by Ognev in Vol. 1 of his "Mammals of the U. S. S. R.", 1928) of the various subspecies of Sorex ultimus, $S$. hydrodromus is a smaller animal.

In a further communication, Hall expressed the opinion that hydrodromus probably should rank as a full species rather than as a subspecies. In that connection, it is interesting to note that from Unalaska to the Bristol Bay region there are hundreds of miles of territory from which no specimens of saddle-backed shrews have been taken. This would indicate ample isolation on Unalaska for the formation of a species.

\section{Sorex obscurus: Dusky Shrew Sorex obscurus shumaginensis}

Unalaska:Chichimukthah (Wetmore)

In southwestern Alaska, this shrew has a range that is roughly coextensive with that of $S . c$. hollisteri. About 200 specimens are available in the Fish and Wildlife Service collection, some of which are from the following localities: Nushagak River, Kakwok, Lake Aleknagik, Ugaguk River, Dillingham, Cold Bay, Becharof Lake, Katmai, Chignik, King Cove, Morzhovoi Bay, Port Moller, Frosty Peak, Izembek Bay, Unimak Island, and the Shumagins. In 1937, on Sanak Island, I obtained a shrew that proved to be shumaginensis.

In the field, we noted that this shrew was about as abundant as hollisteri, and that it inhabited grassy areas and wet places. Wetmore reported it to be especially abundant along little streams. 
At Sanak Island, where this shrew is common and is known as the "pig-nosed mouse," it readily enters buildings.

It is of considerable interest that $S$. o. shumaginensis occurs on island groups, such as the Shumagins and Sanak, while specimens of S. c. hollisteri have not been obtained from such localities, apparently being confined to the Alaska Peninsula and Unimak. The picture may change, however, with more extensive field work. At present, we have no specimens of shrews from the Kodiak-Afognak group.

\section{Microsorex hoyi: Pigmy Shrew Microsorex hoyi eximius}

Only 2 specimens of this rare shrew have been obtained in this district-one was taken by Maddren on the south branch of Chulitna River (west of Lake Clark), and another was taken 80 miles up the Kakwok River.

\section{Family VESPERTILIONIDAE}

\section{Myotis lucifugus: Little Brown Bat Myotis lucifugus alascensis}

We saw no bats on any of our expeditions, but Osgood (1904) mentions seeing several of them, presumed to be this form, at Iliamna Village and near the head of Lake Clark, in July. True (1886) records a specimen taken by McKay at Iliamna Lake in the spring of 1882 , and he mentions many specimens taken by W. J. Fisher on Kodiak Island.

Captain G. A. Amman has compiled a list of birds, mammals, and plants, which were observed or collected chiefly by him or by Private Edward D. McDonald, while stationed on Kiska Island with the 87th Mountain Infantry Regiment from August 15 to December 5, 1943. Included in the list is a bat observed at Kiska. Naturally, this would not represent a resident species, because a bat could not survive in the environment of the Aleutians. It would have to be a storm-driven waif that had been blown a great distance from its normal territory.

\section{Family URSIDAE}

\section{Euarctos americanus: Black Bear}

Kenai, Indian: Terdeeshlah (Osgood)

Osgood (1904), concerning the distribution of the black bear, stated that- 
The Indians of Iliamna village say that according to tradition a few black bears were formerly found in the mountains northeast from there, but that in recent years none have been seen. As far as we could learn they do not occur elsewhere in the region. Their westward limit on the Pacific side of the peninsula is about coincident with that of the coniferous trees, which cease a short distance east of Iliamna Bay. The westernmost records of the black bear known to the writer are those of two killed at Chinitna Bay in 1901 by the party of J. H. Kidder, of Boston, Mass.

True (1886) mentions the skins of two young bears brought in to Kakwok on April 30, 1882. Osgood suggested that these may have been the young of the large brown bear.

Nelson (1886) probably was confusing this species with the brown bear when he stated that it occurred throughout the Alaska Peninsula and Unimak Island, as well as on Kodiak. He also refers to Veniaminof's statement that the black bear was found on the "eastermost" of the Aleutians. There is no evidence that the habitat of the black bear extends beyond the last timber at the eastern end of Alaska Peninsula.

\section{Ursus arctos: Brown Bear Ursus arctos gyas}

Aleut, Alaska Peninsula: Tunarokh and Chuchiuk (Wetmore)

Tanghakh or Tanghaghikh (Geoghegan)

For many years there has been much speculation about the status of the large number of so-called Alaska brown bears, as described years ago by $\mathrm{C}$. Hart Merriam. In the first place, early writers were inclined to consider all of the "brown bear" forms on both continents, to be of one species. In 1954, Marcel A. J. Couturier published a monograph, "L'Ours Brun," on the brown bears and grizzlies of the world, putting them all into one species, Ursus arctos L. In 1953, Robert Rausch adopted the one species, Ursus arctos, for the grizzly and the brown bear.

We find great individual variation in size and color in the same locality. In his color movies of bears in the Mount McKinley region, Adolph Murie shows a small, very light-colored male and a large dark male, both near a rather large female. At the approach of the large male the small, light-colored male arose on his hind legs, looked over the large newcomer, then fled. Some grizzlies in this region are nearly white, many are shades of brown, and, in 1953, my brother and I skinned a large grizzly that had been shot at a road camp. This animal was black, with a little brown tipping to the hairs, which was not noticeable at a little distance.

In his studies, Rausch also found much variation in the skulls from a given locality. Without attempting to revise the whole 
group of Alaska grizzlies, on the basis of my field observations and the studies I have cited above, it seems wise to assume North American and Palearctic bears of the brown group conspecific. Furthermore, in view of my field observations and as a result of the more recent work of Rausch, it seems improbable that there is more than one form occupying Alaska Peninsula. Therefore, I list for the Alaska Peninsula only one subspecies, U. a. gyas.

The great size of the Alaska brown bear has caught the imagination of the public, and it is a favorite trophy for the sportsman, as well as for the camera enthusiast. The estimates of weight of this animal probably are not greatly exaggerated.

Necessarily, most of the information on weight is based on estimates, but some authentic figures have been reported.

Loring (1907) gives the weight of one bear as 1,010 pounds.

There are some interesting data on a male bear, Ursus gyas, that lived for many years in the National Zoological Park in Washington, D. C. The bear died September 30, 1914, and was measured by Vernon Bailey. A record of weights, kept since its capture at Cape Douglas, Alaska Peninsula, on May 24, 1901, were published by Townsend Whelen (1946) as follows:

\begin{tabular}{|c|c|}
\hline & Pounds \\
\hline May $24,1901 \ldots$ & 18 \\
\hline January 9, 1902 & 180 \\
\hline June $15,1903 \ldots \ldots$ & 450 \\
\hline January 18,1904 & $62 \overline{5}$ \\
\hline January 28,1905 & 770 \\
\hline February 26, 1906 & 890 \\
\hline March $11,1907 \ldots$ & 970 \\
\hline March 21, 1908 & 1,050 \\
\hline January $20,1911 \ldots$ & 1,160 \\
\hline September 30,1914 & 1,020 \\
\hline
\end{tabular}

Measurements of this bear, taken by Vernon Bailey at time of death, were as follows: Total length, 2,590 $\mathrm{mm}$.; tail vertebrae, $120 \mathrm{~mm}$.; length of hind foot, $350 \mathrm{~mm}$. (claws were worn short) ; height at shoulder, 1,380 mm.; girth back of shoulders, 1,760 mm.; girth at belly, $2,305 \mathrm{~mm}$.

The bear had attained an age of about 131/2 years; cause of death was attributed to rupture of the abdominal aorta. At time of death, it was described by Bailey as being "in fine muscular condition, but not fat."

Allen (1904) reports the measurements of a specimen taken at Port Moller as follows: Total length, $2,057 \mathrm{~mm}$; tail vertebrae, $127 \mathrm{~mm}$. ; hind foot, $349 \mathrm{~mm}$. ; shoulder height, 1,068 mm. ; weight, approximately 1,600 pounds. The weight was estimated.

Anderson (1909) obtained a bear, June 1, 1909, on Unimak Is- 
land, that weighed 1,325 pounds-the skin weighed 135 pounds. Anderson gives the height at shoulder as 48 inches; height at hip, 3 feet 10 inches; girth back of shoulders, 10 feet; and width between ears, 14 inches.

McCracken (1920) obtained a bear at Frosty Peak, whose weight was estimated to be between 1,600 and 1,800 pounds. The tanned skin was 11 feet 4 inches long, and "the skull was 181/4. in. long one-half inch under the world's record according to Washington, D. C. authorities."

Beasley (1910) shot a bear at Port Moller that weighed 1,200 pounds.

I obtained a large male bear north of Pavlof Volcano, May 30, 1925. Total length was $2,100 \mathrm{~mm}$. The skin, when laid out loosely, measured 11 feet. It made a heavy pack load, weighing well over 100 pounds. The bear was estimated to weigh roughly about 1,000 pounds. This probably was a conservative estimate because he was extremely fat. The fat on the rump was so thick that the tail bone was completely buried in the layer, and the tail itself was not visible. There were large bare places on both elbows, which were calloused as a result of the bear lying about on the rocks.

Brown bears have been abundant on Alaska Peninsula. McCracken (1924) says-

On my sojourn in the section around the western end of the Alaska Penin. sula, which was in 1922 between the breakup of spring until August, I saw 190 brown bears. The fact that we saw 28 bears in a single day, and as high as 12 in sight at the same time, is in itself good evidence of the numbers to be found.

In primitive times, brown bears are said to have been gregarious and very plentiful. Even today, on Unimak Island, where the primitive state has been preserved, groups of at least seven or eight bears have been noted.

In areas that are extensively hunted, the large, old, male bears tend to become scarce, though there may be many females, younger animals and cubs.

The dates of hibernation are not definitely known, and no doubt there is much variation among individuals. Many bears probably come out of hibernation some time in April. Beals and Longworth (field report) saw their first bear on April 15, 1941; after this date, sightings became common. In 1925, I saw the first bear on May 5, ambling about the lower edge of the lava beds at Urilia Bay. The bear country on the mainland was not investigated until May 24. At that time, it was evident that the bears had 
been out of hibernation for quite a while. The bears that we observed at this time were very sluggish, still fat, and apparently did not require large quantities of food. A local guide said that he once found a bear sleeping on a snow patch, and the trail leading to the bear had thawed away. The guide believed that bears sometimes remain several days in one spot.

In early spring, the bears remain high in the mountains, in the upper valleys, among the rocky ledges and high snowfields, as well as in the lava beds. During May and early June, there is still much snow in the mountains, especially in scattered deep drifts, and the weather is often cold and stormy. But the bears are immune to such weather and generally are seen resting on exposed rocky ledges or snow banks. This is their habitat until at least the middle of June, though a few may appear in the lowlands much earlier. Bear trails were found on the slopes of Pavlof Volcano and on many of the high ridges, as well as on the glacier in the shadow of Aghileen Pinnacles.

For the most part, the spring diet consists of grass and roots, varied occasionally by a ground squirrel. The stomach of a male killed on May 24 contained a ground squirrel, various roots, and a mass of Equisetum (horsetail). A large male killed on May 30 had only a handful of roots in the stomach. The stomach of a female killed on June 3 was empty, but the intestines contained a considerable amount of grass. At this time of year, there is little else for the bears to eat, unless they occasionally find some carrion.

When the salmon ascend the streams in June, the bears seem to subsist largely on salmon. However, they do not entirely forsake the highlands. Long trails leading back to the highlands show the routes of travel down to the salmon streams, though the bears often sleep near the streams, in the alder thickets. The bears scoop out beds along the banks, and sometimes pile up moss and other vegetation to form a mattress. We found one such structure at Izembek Bay, and, in 1911, Wetmore described a similar heap found at Morzhovoi Bay, at a salmon pool: "On the bank above this was a curious bed of moss and grass dug up from the ground around piled up a foot deep and twelve feet square. Below it were smaller ones freshly made about two feet square and all padded down as though bruin had been sitting on them."

I have observed a bear capturing salmon only once. It took place in July 1925, when I was photographing a bear that was s.ttenpting to dig out a ground squirrel. The bear seemed to be 
lazy, and after a short time he stopped digging and ambled over to a shallow stream near my place of concealment. He splashed noisily through the stream and ran through some shallow riffles where he seized two or three of the swarming salmon with his teeth.

In some streams there were deep pools that showed claw marks on the bottoms and sides far underwater. Evidently, these marks were made by bears that were fishing, but the method of capturing salmon in such places was not observed.

In autumn, when berries ripen, a new food supply becomes available. On Unimak Island, the bears then seek the salmonberry thickets and feed on the ripe fruit. Many other berries are eaten also. Osgood (1904) mentions crowberry (Empetrum nigrum), which are eaten in "great quantities," and various species of Vaccinium. There were indications that roots and grass are eaten in the fall, and it was reported that bears occasionally are seen on the beach, where they probably would eat anything edible that had washed ashore.

Bears are always on the lookout for carrion. Some caribou carcasses appeared to have been eaten by bears, but there was no indication that the brown bear will kill caribou under normal circumstances.

A striking feature of the brown-bear country is the characteristic bear trail. In marshy ground, the bear trail forms a wellmarked path, in which a man can sink to the ankles. But on firm ground, on the higher mossy tundra, the trail consists of two welldefined ruts with a high center. In one instance, where the trail led over a slight embankment, the ruts had been worn so deeply that the bear's chest had rubbed on the high hump between the ruts. The bear had literally "high-centered."

One often finds a trail in which individual footprints are preserved. Each bear has carefully stepped in the tracks of his predecessors until the well-worn trail becomes a zig-zag series of holes. It was only with great effort that I could step far enough to walk in these tracks. This type of trail was usually found in the vicinity of a large boulder, where a bear was accustomed to lurk, or where the trail led to a den or some other local point of interest. The trails with uniform ruts generally extended for long distances.

Occasionally, an abandoned trail is evidenced by clumps of grass that have found a foothold in the disturbed ground in each footstep. Griggs (1922) mentions an interesting bear trail in the volcanic ash of Katmai, in which drifting grass seeds had lodged and taken root in the individual footprints. 
Much has been written about the ferocity of the Alaska brown bear. The great strength of the bear cannot be doubted, but danger from this bear is dependent upon its disposition at a given moment. There have been some disastrous encounters with this huge beast, but a detailed analysis of such cases will not be attempted here. However, during my experience on Alaska Peninsula there was not a single instance when the bear did not try to get away, even when wounded. One bear that was photographed at close range, a matter of some 30 or 40 feet, started for the photographer at the sound of the shutter, and I must admit considerable nervousness at the time, but it was obvious that he was advancing out of curiosity. The bear fled when we shouted and brandished a rifle vigorously. On the same day, another bear, coming slowly along a trail straight for the camera, heard the camera at close range and stopped. This bear was more suspicious and Tralked off reluctantly, obviously puzzled. In neither case did I wish to shoot, unless it was unavoidable. Indeed, except for a head shot, it might have been dangerous to shoot at such close range.

Apparently, some residents of Unimak Island had little fear of the brown bear. Arthur Neumann related that on one occasion he had forced a group of bears into the rough water of Swanson Lagoon on a stormy day to watch them struggle in the choppy waves.

The Alaska brown bear deserves respect and should be approached carefully, because it can cause considerable damage for a few moments even after being shot through the heart. It is best to realize that although this bear is not particularly vicious, it is very curious and is likely to investigate anything unusual. The bear's eyesight is not good, which may account for its close approach at times.

An interesting incident occurred on the slope of Pavlof Mountain. A companion and I sighted several bears high on a slope. At the first shot, the largest bear rolled downhill, obviously shot in the head (incidently, this was a regrettable shot because the bear was wanted for a specimen). Three other bears followed the rolling carcass, pell-mell, and it was apparent that they were yearling cubs that were instinctively following the mother. The mother rolled by very near us, and dropped off a small cliff at that point. The three young bears followed headlong, and we could hear them grunting, but at the very brink of the little cliff they suddenly braced themselves and stopped. After a detour, they approached the dead bear farther down the slope, 
but suddenly they became frightened and fled. Either the death of the mother, or our scent, had frightened them. Upon examination, it was discovered that there was a small amount of milk in the udders of the mother. Next day, the cubs were seen again on the same mountain slopes; they were wary and seemed able to shift for themselves.

It has been said that the female brown bear has cubs only every other year, or only over an interval of three years. This may be true, for the female mentioned above had no young cubs that year, and there may be some irregularity and individual variation in the breeding cycle. The young number from two to four; two are the usual number.

According to some reports from the western end of Alaska Peninsula, brown bears may go into hibernation in December, as late as Christmas. Osgood (1904), speaking of the base of the peninsula, on the authority of natives there, said that they go into hibernation early in November, and even in October, but he adds that the time of hibernation may vary with the severity of the weather. They occasionally may emerge during the winter.

Brown bears find dens in the lava rocks. I was told of several such caves at the north base of Shishaldin Volcano on Unimak Island. They are said to extend for a disance of as much as 100 feet. In 1925, I explored such a cave in a lava bed near Shishaldin. It formed an underground tunnel some 30 or 40 feet long and proved to be unoccupied at the time, though there were huge footprints on the floor.

\section{Ursus arctos middendorffi}

This has been assumed to be the largest of all the Alaska brown bears, though Merriam, in his monograph on these animals, suggests that the peninsula bear may be fully as large. With information at hand, we are not in a position to decide.

This bear occupies the Kodiak-Afognak Island group, apparently including some of the smaller islands. E. M. Ball, of Afognak, writing to Barton W. Evermann, of the Bureau of Fisheries, January 10, 1914, says-

It is true that the brown bear is found on Sliuyak and Raspberry Islands, as well as Afognak. The east end of Raspberry Straits is very narrow and shallow and is often dry during heavy ebb-tides so that bears can cross from one island to the other without entering the water. It is highly probable that they swim across these straits. Presumably there are only a few bears on Raspberry at this time. On Shuyak, however, bears are comparatively plentiful, and the number is believed to be fairly constant as local hunters seldom go that far for them. Shuyak Straits are narrow though deep, and there may be some travel to and from Afognak Island. 
Bears should have no difficulty reaching any of these islands, because residents of Unimak Island stated that bears have been known to swim across Isanotski Strait, from the Alaska Peninsula.

I have not had firsthand experience with this Kodiak bear, but undoubtedly its habits are quite similar to those of the Alaska Peninsula bears. At times, the bears have interfered with domestic stock raising on Kodiak Island, but I have no recent information, and there is no report based on consistent study of the question.

\section{Thalarctos maritimus: Polar Bear} Thalarctos maritimus maritimus

Information on the occurrence of the polar bear in the Aleutian district is vague and unsatisfactory. In volume 2 of "Voyages of Captain James Cook", mention is made of white bear skins seen in Prince William Sound, in May 1778. Evermann (1922) lists the polar bear among the marine mammals of the Pacific. They have been known to occur on the Pribilofs, and Preble and McAtee (1923) quote W. L. Hahn to the effect that the latter had found in the St. Paul Island log, "under date of September 20, 1874, an entry stating that a party visited the cave on Bogoslof and brought back a bear skull known to have been there since the time of the first occupation of the island."

This is the most definite record we have for the Aleutian district, though St. Paul is several hundred miles north of the chain. Polar bear's could visit the Aleutians or Alaska Peninsula only by means of ice floes drifting south-no doubt this is possible, but it would be a rare occurrence.

\section{Family PROCYONIDAE}

\section{Procyon lotor: Raccoon}

Turner (1886) reported, "I have heard, on what I consider reliable authority, that the Raccoon is not uncommon in the south portions of the Alaskan mainland."

Such occurrence has not been substantiated. However, in 1936, it was learned that A. W. Bennett and A. C. Bryant were operating a blue-fox farm on Long Island, near Kodiak. A number of years previously they had stocked the little island with raccoons from Wisconsin, Minnesota, Michigan, and North Dakota. In the year's 1932, 1933, and 1934, dead raccoons had been 
found at intervals on the island. In a single year, 12 to 15 dead raccoons were found, as well as some sick ones-the sick ones apparently were paralyzed, dragging the hind quarters.

There were still a few raccoons at large on Long Island in 1936.

\section{Family MUSTELIDAE}

\section{Martes americana: Marten Martes americana actuosa}

Indian or Aleut (?), Iliamna Village: Kcheegocha (Osgood)

Russian: So-bel (Buxton)

Osgood (1904) reported the marten as being scarce at the base of Alaska Peninsula. We have, indeed, very few records of it. There are five skulls from Kakhtul River in the Fish and Wildlife Service collection that were taken by Hanna in 1912. Naturally, these animals are confined to forested areas and would not be found far out on Alaska Peninsula.

Nelson (1887) says marten occur on Kodiak Island, but I have not seen specimens from there.

\section{Mustela erminea: Weasel \\ Mustela erminea arctica}

Aleut (dialect?): Samikakh (Geoghegan)

Aleut Iliamna Village: Ameetahduk (Osgood)

Indian, Iliamna Village: Tahkiak and Kahoolchecnah (Osgood)

Russian: Gor-no-stai-e (Buxton)

Hall (1951) has placed the weasels in three groups: The least weasels, rixosa; the long-tailed weasels, frenata; and the shorttailed weasels, erminea. Accordingly, the weasel of Alaska Peninsula becomes Mustela erminea arctica.

These weasels occur throughout the entire length of the Alaska Peninsula and Unimak Island, as well as the Kodiak-Afognak group. They are common on Unimak Island but have not been found on any islands farther west. Specimens have been obtained at the following localities: Nushagak, 1 by Osgood; Ugashik River, 6 by McKay, and 1 by Hanna; Kakwok River, 1 by Hanna; Lake Aleknagik, 1 by Hanna; Lake Weelooluk, 1 by Hanna; Becharof Lake, 3 by Osgood and Maddren; Chignik, 7 by J. Oliver; Frosty Peak, 1 by Wetmore; Unimak Island, 1 each by Gardner, Murie, and Beals.

Crabb (1922) reports a specimen from Pavlof Bay. No doubt, there are other specimens, obtained by various collectors, that I have not examined. 
Weasels are reported to occur on Kodiak Island, but specimens were not arailable. Jack Benson, agent of the Alaska Game Commission, in a report dated June 30, 1940, commented that weasels on Kodiak and Afognak were not as plentiful that year. In 1936, on a visit to Kodiak and Afognak Islands, we were assured that weasels occur there, and we were shown a photograph of a live weasel as proof.

\section{Mustela rixosa: Least Weasel Mustela rixosa rixosa}

Though this little weasel has been seldom observed in this area, it is known to occur as far west as Unimak Island. In 1925, a trapper informed me that he had caught a least weasel near Izembek Bay and had intended sending it to the Biological Survey, but he said that the specimen had been neglected and lost.

In 1941, Beals reported that this weasel, though not plentiful on Unimak Island, is known to most of the residents there. He saw one at St. Catherine Cove and another at False Pass; the latter was taken for a specimen. This animal was seen trying to capture snow buntings, but it was not successful.

\section{Mustela vison: Mink}

Mustela vison ingens

Aleut, Morzhovoi Bay: Illigitookh (Wetmore); ilgitukh (Geoghegan)

Aleut (?), Iliamna Village: Emachamooduk (Osgood)

Egegik: Kochcheechuk (Osgood)

Kenai: Yarkeechah (Osgood)

This is assumed to be the form occupying the Alaska Peninsula. Hollister (1913) says: "Though specimens from the Alaska Peninsula are placed with ingens, these show an approach toward melampeplus." Evidently, the mink occurs throughout the length of the peninsula and on Unimak Island. Specimens, mostly skulls but also a few skins, are available from various localities: Kakhtul, 2; Kakwok, 1; Kakwok River, 7; Lake Weelooluk, 5; Lake Aleknagik, 1; Becharof Lake and between Portage Bay and Becharof Lake, 73; Cold Bay, 3; Stepovak Bay, 1; Chignik and Chignik Bay, 2; Frosty Peak, 1. No specimens are available from Unimak Island, but mink are known to occur there, for trappers mention their occurrence as a matter of course. In 1925, a trapper told me that he had trapped six minks at Urilia Bay in the winter of 1924-25. In 1936, another trapper of Unimak Island remarked that minks were increasing in numbers, and, in 1911, Beals saw mink tracks at False Pass and neighboring localities. 
On July 21, 1925, I saw a mink at Moffet Cove, Izembek Bay. In 1911, Wetmore had seen proof of the presence of mink at Morzhovoi Bay, Frosty Peak, and King Cove.

In 1936, we were informed at Afognak that there are mink on that island, but Jack Benson, of the Alaska Game Commission, reported in 1940 that there are no mink on the KodiakAfognak group. It is of interest to note that a blue-fox farm on Long Island (near Kodiak) has released mink.

I have not seen specimens from the Kodiak-Afognak group, and there are no records of mink west of Unimak.

\section{Gulo luscus: Wolverine}

Aleut (dialect?): Khachimoyughnakh (Geoghegan)

Russian, Siberia: Rus-so-makah (Buxton)

The wolverine never becomes abundant, being largely a solitary animal, but it occurs throughout the length of Alaska Peninsula and on Unimak Island. There are wolverine skulls in the Fish and Wildlife Service collection from upper Nushagak River, from the area between Portage Bay and Becharof Lake, from Chignik, and from Frosty Peak. Allen (1903) describes a specimen taken at Oksenof Bay, Unimak Island.

In 1925, I found evidence of wolverines at the west end of Alaska Peninsula. A wolverine was seen on May 25 on a ridge west of Aghileen Pinnacles, and, on June 3, another was seen north of Aghileen Pinnacles high on a rocky slope. Wolverine tracks were seen on several occasions, and a wolverine, identified by tracks, was noted as having fed on a brown bear carcassit had carried off a foreleg.

In 1925, it was reported that wolverines were extremely scarce on Unimak Island. By means of extensive inquiries, Donald Stevenson had estimated that over a 20-year period before 1925, four male wolverines had been killed on Unimak Island. However, in 1936, we saw tracks on the beach at Ikatan, and, in 1941, Beals and Longworth stated that wolverines were plentiful on Unimak. They saw their tracks "on practically all the beaches from Swanson Lagoon to Banjo Bay." On January 13, they watched a wolverine foraging along the beach at Ikatan, and, on April 22, they saw a very dark animal, almost black, high on a mountain on Ikatan Peninsula.

It was reported that a wolverine, killed near Pavlof Mountain, had small rock fragments embedded in the skin of the head and neck. The hair was gone from these spots, but the skin had healed perfectly. It was surmised that these pieces of rock could 
have been small fragments of lava material 'from an eruption of Mount Pavlof.

\section{Lutra canadensis: Otter \\ Lutra canadensis yukonensis}

Aleut: Ahkweeah (Osgood) Morzhovoi Bay: akhuyakh (Geoghegan)

Aleut, Ahkwenkh (Wetmore)

Russian: Nee-drah (Buxton)

This mustelid species ranges throughout the length of Alaska Peninsula and Unimak Island, but we have no records farther west. Wetmore reported that they were partial to salt water as well as fresh, "frequently swimming boldly out to the islands, lying off the coast."

In 1925, I learned that a local trapper had caught 10 otters at Urilia Bay in the winter of 1924-25.

\section{Lutra canadensis kodiacensis}

Goldman (1935) distinguished the Kodiak otter from the mainland form. The type is a skull from Uyak Bay, Kodiak Island, collected by C. Hart Merriam in 1899. There are a number of other skulls from the same island. Otters occur on both Kodiak and Afognak Islands, and in 1936, we saw a number of otter skins at Afognak Village.

\section{Enhydra lutris: Sea Otter}

Enhydra lutris lutris

Attu: Chach'toch Caxtux (Jochelson)

Atka: Ching-á-tho Cna-tux (Jochelson)

Morzhovoi Bay (dialect?): Chngatukh (geoghegan); Chgatluk (Wetmore) Base of Alaska Peninsula: Ahchgh-nahchgh (Osgood)

Kodiak: Ach-an-ah (King)

Kwakiut Indian: Kas-uh (Dawson)

Russian: Bobr Morskoi (Steller), "sea beaver"

Bobry, adult males

Matka, females

Koschloki, 1-year-olds

Medviedki, "little bears"-cubs

The northern sea otter is described as being larger than the southern sea otter of the California coast, E. l. nereis. I collected a single specimen at Ogliuga Island on August 4, 1937. It was an old male, weighing 80 pounds, and its measurements, in millimeters, were as follows: Total length, 1,390; length of tail vertebrae, 315 ; and length of hind foot, 242. 
The sea otter is stockier than the land otter, Lutra canadenis, and has acquired other special modifications. Its specialized food habits (discussed later) do not call for great agility, and this may be one reason for the development of a heavier, somewhat less streamlined body than the ancestral form-if we may assume the ancestral form to be similar to that of the present-day Lutra. But the sea otter has become more aquatic than its ancestors, with much less dependence on land, and it has developed seal-like flippers on its hind feet. Its front feet, on the other hand, appear to have responded to a specialized use in handling sea urchins and hard shells of mollusks that make up its principal food. The soles of the front feet have become very thick hard pads, and the toes have more or less coalesced-judging by the specimen examined in detail (mentioned above) the toes are hardly functional as separate digits. The claws have become very weak and pale colored and are placed well up on the dorsal surface of the toes. They probably have little use. The whole structure of the front paw indicates that it is used largely for resisting abrasion from hard sea urchins and shells; it seems incapable of manual dexterity. In fact, the animal seems incapable of holding anything in one "hand." Yet, I have watched sea otter's feeding and have seen them use one paw to toss away, with a forward motion, an umwanted fragment of shell or other substance. Possibly it was only "pushed" away. (Karl WT. Kenyon,

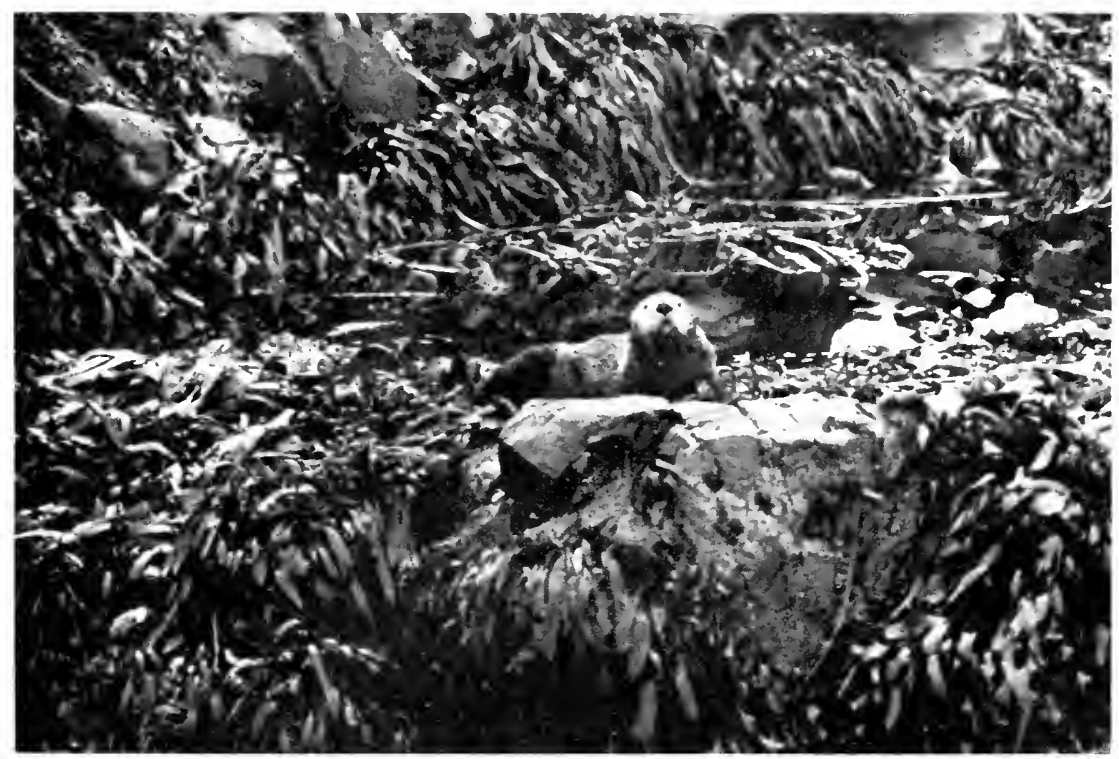

FiguRE 42.-Sea otter. 
in correspondence in 1957, writes that a subadult female in the Seattle Zoo is very clexterous. It uses its front digits almost like finger's in grooming and feeding operations.)

It is well known that the molariform teeth have been greatly modified for a special diet, and have departed strikingly from the mustelid type. Instead of the teeth having a shearing function, they are used for crushing, and have taken a bunodont form.

A most interesting feature of the sea otter dentition is the prevalence of cavities in the molariform teeth. Among the more or less fragmentary skulls and jaws found in Aleut village sites, a considerable percentage of the teeth had cavities, large and small. E. M. Fisher (1941) has given a detailed discussion of this and other features of the sea otter's dentition, and she intimates that rather active evolutionary changes may be taking place. She suggests that the difference in diet between the southern and northern sea otter may account for the greater prevalence of cavities in the teeth of the northern form. As interpreted by Fisher, the dental formula of the adult would be

$$
\frac{\mathrm{I} 1,2,3-\mathrm{C} 1-\mathrm{Pm} 2,3,4-\mathrm{M} 1}{\mathrm{I} 1,2-\mathrm{C} 1-\mathrm{Pm} 2,3,4-\mathrm{M} 1,2} \times 2=32 \text {. }
$$

The sea otter is generally dark brown, with considerable variation, although this variation may be due to age. Some old animals, as typified by the old male obtained by the writer at Ogliuga Island, are a dull, dark brown, becoming black on legs, but with a pale-brown head and neck-this pale coloration extends down on the chest, where it becomes almost straw-colored. The under side of the tail is paler than the body. White hairs are sprinkled throughout the pelage. In most of the darker animals these silvery hairs become more conspicuous. The younger adults are much darker, often blackish, with fine, lustrous fur.

The young pups are a very light brown. In every case, from the pup to the grizzled old male, the head and neck is paler than the body, and this difference is accentuated in the very old ones.

\section{General Habits}

There is a voluminous literature on the habits of the sea otter, much of it largely repetition of what was reported by the earliest observers, including Steller. Only in the last few year's have we begun to study the sea otter in any great detail, and there is much to learn. Therefore, I will not attempt to give a comprehensive life history of this interesting mammal.

Of chief interest to the biologist is the fact that this member of the weasel family has resorted to a marine environment and has 
gone a long way in adapting itself to a strictly aquatic life. It is interesting to note that, according to reports, the "land otter" of the Aleutian district readily takes to salt water at times; apparently, this also is true of the otter of Great Britain.

The sea otter spends most of its time in the water. When wishing to sleep, it simply lies on its back and dozes, sometimes with a strand or two of kelp across the body serving as an anchor, whether intentional or not. When feeding, the animal dives for its food, then lies on its back to eat, using its chest for a table. On specimens from Alaska that were examined, the hair on the chest was somewhat worn, no doubt through this use in feeding. When the little pup wishes to sleep, it curls up on the mother's abdomen, and both mother and offspring lie quiescent on the water. The offspring also climbs aboard the mother to nurse.

When startled, the mother puts an arm around the little one and dives with it. On some occasions, the mother seemed to pat the little one on the head first, as if by this patting or pushing motion she were warning it of the impending immersion. This was never clearly seen, however, and it needs to be verified. If merely worried or suspicious, the mother seizes the pup with her arm and swims away with it.

Generally, when startled, the sea otter rises erect in the water for a better view of the intruder before diving. It swims readily on its back, as well as on its belly. In fact, the observer soon gains the impression that the sea otter spends most of its life floating on its back.

The sea otter does come ashore, however, and there are favorite hauling-out places for certain individuals. One or more mothers may climb out on a kelp-covered rock, with their youngsters, where they squirm about and fondle their little ones and endlessly dress their fur. Sometimes a pup will wander off to the water, or will be reluctant to climb out on the rock. Then the mother persistently forces him, nudging and pushing, until he complies with her desire to haul out on the rocks. Occasionally, a male will join the group. We also saw lone individuals, apparently adult males, curled up on a rock, where they may lie long enough for the fur to dry. Even here, they appear restless, and may raise their heads to look about, yawn, rub their faces with their paws, or otherwise dress their fur.

It is reported that sea otters go ashore in times of severe storms, but that sometimes they succumb in heavy surf on the reefs. 
Reproduction

Sea otter breeding was observed once in Aleutian waters. It took place in the water, as the pair rolled over and over, sometimes being at the surface, sometimes underneath, the male grasping the female at the head with his teeth. This was on July 23, 1936, at a time when the female had a small dependent pup. The pup had been left at the outer edge of the kelp patch, where it swam about calling for its mother. This circumstance indicates that the female may breed in successive years. Scammon (1874) remarks that the gestation period is supposed to be 8 or 9 months. Probably it is fully that long.

Many observers agree that breeding may take place at almost any time of the year, because young of different ages can be seen at any season. Fisher (1940) appears to have definitely noted this during her research on the California sea otter. It is known that the young are born on the kelp beds, but in Alaskan waters, where kelp beds disappear during the winter, the procedure is uncertain. Herendeen (1892) claims that the young are born at sea-he did not mention kelp beds.

\section{Food Habits}

It is well established that the northern sea otter feeds largely on sea urchins, and that this diet is supplemented by considerable quantities of mollusks, including mussels, chitons, limpets, snails, and others; and with lesser quantities of crabs, octopuses, and other items-fish play a minor role in the diet. More detailed analyses of the diet of the northern sea otter are given by Williams (1938), Barabash-Nikiforov (1935), and Murie (1940).

Although the sea otter has, to a large extent, forsaken fish as an important item in the diet, apparently it still enjoys such food on occasion. Chase Littlejohn (1916) reports an interesting incident: A sea otter was seen approaching his ship, but it dived. Presently, a fisherman pulled in a codfish and, as the fish came to the surface, the sea otter was seen clasping it in its paws.

One feature of the feeding habits deserves special mention, because it involves the use of tools. It was first seen in detail in California (Fisher 1939, and Murie 1940). Briefly stated, the sea otter dove for food and when it came to the surface the observer saw a rock lying on its chest or abdomen. The animal held a small mussel (or whatever the food morsel might be in such instances) in both paws and pounded it on the rock to break it. When feeding, the sea otter has a habit of rolling over occasionally in a complete turn, then continuing with its repast. Sometimes, it performs this roll with a rock and mollusk both 
on the chest. Naturally, it must clasp both of these objects to its body during the roll, but it does this very adroitly and casually, and it continues unconcerned with its meal.

\section{Mortality Factors}

The natural mortality factors affecting the sea otter are almost unknown. The northern bald eagle has been suspected of preying on young sea otters, and it is possible that this may occur on rare occasions. But it is notable that in our study of the food habits of this eagle (see under that species), not a single instance of such predation was found upon examination of eagle nests in the center of abundance of sea otters. It was concluded that eagle predation on the sea otter must be negligible.

Two mammals, the sea lion and the killer whale, have frequently been mentioned as sea otter enemies, but we had little opportunity to verify this. We rarely saw these animals near any sea otters, and although occasionally we saw killer whales cruising by the outer edge of a kelp bed, we could not identify its prey. However, the killer whale is known to eat fur seals, therefore it is reasonable to suppose that it will pick up a sea otter when the opportunity is presented. At any rate, the sea otter has demonstrated in recent years that it can increase in numbers and extend its range when it is protected from human hunters. Identification, and degree of predation, of its natural enemies must be determined by thorough scientific study.

It is a well-known fact that dead sea otters occasionally are washed up on the beach. On our expeditions, we found a number of skeletons on the beaches, from which blue foxes or eagles, or both, had eaten the flesh. It is said that a sea otter sometimes succumbs in the heavy surf in winter. Pups, as well as large adults, are included in casualties thus recorded on the beach. In the postwar years a higher mortality rate has become evident and many dead sea otters have been found. The cause is not yet known.

From the evolutionary standpoint, the sea otter seems to be in an intermediate or transitional stage. The peculiar dental specialization has been mentioned, as well as the prevalence of cavities in the molariform series. These cavities are present in fresh specimens as well as in remains from old Aleut village middens. Fisher (1940) has reported an instance of gastric perforations in a sea otter found dead on a California beach.

One cannot refrain from speculating whether the specialization in food, which involves hard and sharp mollusk shells, tests and spines of sea urchins, barnacles, and similar materials that 


\section{NORTH AMERICAN FAUNA 61, FISH AND WILDLIFE SERVICE}

are ingested together with the soft digestible parts, are causing the sea otter some difficulty. Do some individuals succumb through injuries causer by such materials? How are the tissues responding to the demands for taking care of such rough fare?

It is obvious that the sea otter does not meticulously select only the soft parts. Apparently, it relies on crushing the shells with its teeth (and the teeth have developed enormously to meet the need) and then proceeds to swallow a considerable portion of shells, tests, and spines. Even the byssus of the mussel, often with pieces of stone or coral attached, is swallowed. In one instance, pebbles marle up 21.8 percent of the contents of one scat. All such material passes through the alimentary tract, therefore it would not be surprising if serious injury occasionally resulted. It would be interesting to know how many of the sea otters washer up on the beach in Alaska have internal injuries similar to the gastric perforations reported by Miss Fisher.

On the other hand, from the standpoint of the sea otter population as a whole, the organism appear's to be coping with the demands successfully. Rate of reproduction is slow-one young per year-yet, when released from the pressure of the fur trade, the sea otter has multiplied rapidly.

\section{Distribution and Numbers}

It is well known that in primitive times the northern sea otter ranged along all of the southern Alaskan coast, including the Aleutian chain and Alaska Peninsula. It ranged southward, evidently intergrading with the southern form at some unknown point, and the southern form ranged from this point southward as far as the coast of Baja California. The northern sea otter also occurred in the Commander Islands and southward into the Kurile Island chain, and they were numerous about the Pribilof Islands. Littlejohn (1916) reported schools of 400 sea otters in the early days of hunting along the Kuriles.

The decline of the sea otter population is a striking instance of the near extinction of a species through unregulated commercial exploitation. Before the coming of the white man, sea otters were extremely numerous and the skin was used by the Aleuts for clothing and (according to the chief of Atka Village) for a lining of the interior of their underground huts. We found Aleut mummies in a cave on Kagamil Island that were wrapped, in part, in sea ntter skins.

When the Pribilofs were first visited, the sea otters were abundlant. Preble and McAtee (1923), quoting Elliott and Littlejohn (1916), state that 5,000 sea otter's were killed in the first year of 
occupation of the Pribilofs. Veniaminof, speaking of the Pribilofs, stated that the animals became scarce in 1811, and that they were extinct 30 years later (Preble and McAtee 1923).

In the Aleutian district, the Russians found a rich harvest of sea otter furs and exploited it vigorously. Without citing the voluminous statistics on the shiploads of furs sent back to Russia, let it suffice to say that the sea otter population could not stand up under the continued excessive harvest. History tells us that the Russians, sensing the end of a lucrative industry, attempted to regulate the killing of sea otters. But a new complication had entered the picture. Trading ships from the south had discovered this great fur resource-Americans, French, and others. Although the Russians could impose regulations on their own people, they found it hard to deal with this new foreign influx. The sea otters continued to decline in numbers and probably reached their low point shortly after 1900 . When almost all were destroyed, protection was finally granted.

For years, the fer remaining sea otters found a refuge in the Aleutians. Their status was hidden in the fog and mystery of this seldom-visited island chain, and for years naturalists feared that this animal species had lisappeared from American fauna.

But, as mentioned above, complete protection had finally become a reality, and it soon became evident that the animal had survived in sufficient number's to perpetuate itself. In spite of occasional poaching, in 1936 we found substantial sea otter populations in several places throughout the Aleutian chain, and we made a conservative estimate of at least 2,000. Most heartening of all, they were extending their range, not only in the Aleutians, but also along Alaska Peninsula. However, on our last visit to Sanak Islands the sea otters had not reappeared, although at one time this area was one of the best sea otter hunting territories (since our visit, five sea otter's have been seen).

The range of the sea otter raises a puzzling point. There seems to be a difference of opinion as to the distance that the sea otter will venture from land. It is generally believerl, and observations bear this out, that sea otters normally will live close to shore where they find their food in comparatively shallow water. Yet, there are reports of sea otter's being seen far out at sea. On our expeditions, we never saw any of these animals far from land. However, at one time sea otters were numerous in the Pribilof Islands, and they must have made a long sea journey to reach these islands. After World War II, it was found that sea otters had increased still more and had extended their range. 
Littlejohn (1916) believed that sea otters live on squids when fill from land. He did not think that the otter could dive deeper than 60 fathoms, and because its normal sea-bottom diet was not available, it ate squid.

Sea Otter Hunting

At the height of the commercial exploitation of the sea otter, a number of hunting methods were used. The Russians utilized the skilled Aleuts for this purpose. The various methods have often been described, and the subject will be only briefly mentioned here.

One methor was to spear the animal from the native boat. Several boats would surround the animal and keep it diving repeatedly until it was exhausted. In the meantime, spears were thrown until the animal was dead or helpless. Later, when the rifle was used, three boats would surround the otter, according to Littlejohn (1916). Here, too, the object was to keep the otter diving quickly, to prevent a long dive, until someone could manage an effective shot.

A dead sea otter will float, which insures recovery of an animal killed by any type of weapon. It is reported, also, that sea otters were sometimes clubbed to death on reefs or rocky shores, where they had taken refuge from severe storms. At such times, the noise of the wind and surf would drown out any sound of approach by the hunter. Littlejohn (Hall 1945, p. 90) has described how natives would creep around on the rocks during dark nights, feel for the otters, then club them on the head.

Nets also were used. These nets were set in favorable locations frequented by sea otters, and, according to Littlejohn, they were very effective.

The encouragement of natives to secure sea otter skins on a large scale, promiscuous hunting by whites (who outfitted ships for that purpose), combined with pelagic sealing, produced a large and profitable fur harvest for many years.

Sea Otter Management

The return of the sea otter in satisfactory numbers, at a time when we are being made conscious of wildlife management, makes the subject especially pertinent. In the case of the sea otter, the first step in management was to provide protection, and to enconrage spread to all of its ancestral range. This process is now under way. From what we know of the food habits of the sea otter, the food supply should be ample to support a large population without artificial manipulation.

Apparentr, the Russians are experimenting with, and study- 
ing, the sea otter of the Commander Islands (May 1943), and it is said that the Japanese have been managing the sea otters of the Kurile Islands on a commercial basis. The southern sea otter is increasing along the California coast. All in all, this interesting animal has already regained much of its lost range, and it can be assumed that it has attained a lasting place in the American fauna.

\section{Family CANIDAE}

\section{Vulpes fulva: Red Fox \\ Vulpes fulva alascensis}

Aleut, Morzhovoi Bay: Ikowukh (Wetmore)

From vocabulary compiled by R. H. Geoghegan at Valdez in 1903: Ukhaching

Russian: Lee-see-sha (Buxton)

Russian, Siberia; See-way-doos-ka (cross fox)

The red fox is plentiful throughout the Alaska Peninsula and is found on the eastern Aleutian Islands. Unimak Island, in particular, has a large fox population, and the species occurs also on Akun, Unalaska, Umnak, Chuginadak, Amlia, Adak, Kanaga, and Sanak Islands. Foxes occur on Dolgoi, which was utilized for commercial fox propagation-it is possible that the fox originated here in that fashion. Great Sitkin, also, was said to have had some red foxes. Those on Amlia and Adak Islands are the silver-gray color phase.

Kellogg (1936) found bones of the red fox to be one of the most abundant mammal remains in Aleut middens on Kodiak Island.

The westward expansion of the red fox, in its various color phases, on the Aleutian chain is uncertain, but it certainly must have occupied the easternmost group of islands. General historical accounts give us a few clues. In his "History of Alaska, 1730-1885," Bancroft (p. 120) states that in 1758 Glottof started for the Aleutians, and wintered at Bering Island. The following summer, he arrived at an unknown island, probably Umnak, where he remained for 3 years. He returned with a cargo of furs, including the black foxes from the Aleutian Islands. The shipment included 11 sea otters, 280 sea otter tails, 1,002 black foxes, 1,100 cross foxes, 400 red foxes, 22 walrus tusks, and 58 blue foxes.

Again (p. 154), Bancroft remarks, "In 1764, when the first black fox skins had been forwarded to the empress, gold medals 


\section{NORTH AMERICAN FAUNA 61, FISH AND WILDLIFE SERVICE}

were awarded to the merchants Orekhof, Kulkof; Shapkin, Panof, and Nikoforof." He says, "Ocheredin's share of the proceeds was 600 sea otter's, 756 black foxes, 1230 red foxes; and with this rich cargo he arlived at Okhotsk on the 24th of July 1770." These skins were obtained from Akutan, Unalaska, or adjacent islands.

There are other passages worthy of record. On page 123, Bancroft states that the ships Gavril and Vladimir combined forces in 1760 and hunted Umnak, Sitkin, Atka, and Seguam, where they obtained about 900 sea otters, 400 foxes of various kinds, and 432 pounds of walrus tusks.

On page 153 of Bancroft's account, we find reference to a 1766 expedition by Solovief, during which he obtained 500 black foxes.

Bancroft (p. 169) further states that-

Shiloff, Orekhof, and Lapin, in July of the same year (1770), fitted out once more the old ship Sv Pavel at Okhotsk, and dispatched her to the islands under command of the notorious Solovief. By this time the Aleuts were evidently thoroughly subjugated, as the man who had slaughtered their brethren by hundreds during his former visit passed four additional years in safety among them, and then returned with an exceedingly valuable cargo of 1,900 sea otters, 1,493 black, 2,115 cross, and 1,275 red foxes. He claims to have reached the Alaskan Peninsula, and describes Unimak and adjoining islands.

The wording of this passage would lead us to believe that Solovief did not go far east of Unimak. If that is true, he undoubtedly obtained his foxes among the eastern islands, the group designated as the Fox Islands, from Unimak to Umnak inclusive. In all of these early cargoes of fox furs, there is an amazingly high percentage of black and cross color phases-these two phases greatly outmumbering the normal red color phase. There had not been time for artificial development of such strains on so great a scale, and there is no record of such breeding activities at that time. Therefore, it is evident that in the eastern Aleutian district a natural concentration of the melanistic type of the red fox had taken place, comparable to a similar development of the Arctic fox in the western Aleutians, Commanders, and Pribilofs. This may prove to be a significant biological phenomenon, when the active factors become understood.

It is probable that the dark color phases occurred also on Alaska Peninsula, and it is almost certain that excessive killing of these daxker kinds, on a selective basis because of their greater value, has served to bring the population back to a practically uniform trpe, the red phase. The silver fox persists on Amlia Island, but this island has been leased and the foxes are con- 
trolled artificially. We can no longer find the dark kinds in any numbers on Unalaska, where they were first found.

The following table shows the proportions of these color phases in the cargoes of three ships. The records of other cargoes are not used here because they appear to have been of a selective nature, not comparable for this purpose. For example, some cargoes showed only black fox, and some cargoes showed no cross fox.

\begin{tabular}{|c|c|c|c|c|c|c|c|c|}
\hline \multirow{3}{*}{$\begin{array}{l}\text { Command- } \\
\text { er of } \\
\text { expedition }\end{array}$} & \multirow{3}{*}{$\begin{array}{l}\text { Name } \\
\text { of } \\
\text { ship }\end{array}$} & \multirow{3}{*}{$\begin{array}{l}\text { Year } \\
\text { of } \\
\text { return }\end{array}$} & \multicolumn{6}{|c|}{ Snecies of foxes obtained } \\
\hline & & & \multicolumn{2}{|c|}{ Black fox } & \multicolumn{2}{|c|}{ Cross fox } & \multicolumn{2}{|c|}{ Red fox } \\
\hline & & & Number & Percent & Number & Percent & Number & Percent \\
\hline $\begin{array}{l}\text { Glottof.-. } \\
\text { Solovief... } \\
\text { (No record) } \\
\text { (No record). }\end{array}$ & $\begin{array}{l}\text { (No record) } \\
\text { (No record). } \\
\text { Sv Andrei... } \\
\text { Sv Prokop -- }\end{array}$ & $\begin{array}{l}1761 \ldots \\
1774 \ldots . \\
173 . \\
\text { (No record). }\end{array}$ & $\begin{array}{r}1,002 \\
1,493 \\
996 \\
20\end{array}$ & $\begin{array}{c}40 \\
30.6 \\
33.1 \\
- \\
-\end{array}$ & $\begin{array}{r}1,100 \\
2,115 \\
1,419 \\
40\end{array}$ & $\begin{array}{l}44 \\
43.3 \\
47.2\end{array}$ & $\begin{array}{r}400 \\
1,275 \\
593\end{array}$ & $\begin{array}{l}16 \\
26.1 \\
19.7\end{array}$ \\
\hline \multicolumn{3}{|c|}{ Average percent of cargoes................. } & $\ldots$ & 34.6 & & 44.8 & & 20.6 \\
\hline
\end{tabular}

At the time of these expeditions, the red fox probably had not reached as far west as Kanaga (where a few have been present in recent years). It is difficult to evaluate the present distribution because of the extensive commercial manipulation of the Aleutian fauna. We can be confident, however, that the red fox originally occupied the so-called Fox Islands, as far west as Umnak at least; it may have occurred as far as the Andreanofs, much farther west. Though Bancroft, writing a general history of Alaska, was not specific in mentioning the Aleutian fauna, he did make some helpful observations. His generalization on fur bearers at least gives us helpful indications:

The distribution of fur-bearing animals during the last century was of course very much the same as now, with the exception that foxes of all kinds came almost exclusively from the islands. The stone-foxes-blue, white, and gray - were most numerous on the western islands of the Aleutian chain and on the Pribilof group. Black and silver-gray foxes, then very valuable, were first obtained from Unalaska by the Shilof and Lapin Company and at once brought into fashion at St. Petersburg by means of a judicious presentation to the empress.

This passage confirms the general conclusion that blue foxes were confined to the western islands and red foxes (with their color phases) were limited to the eastern islands.

Turner (1886) reported the red fox "as far west as Umnak." Speaking of the cross and silver fox, he said that they occur in "All of Alaska, except the extreme western Aleutian Islands." 


\section{NORTII AMERICAN FAUNA 61, FISH AND WILDLIFE SERVICE}

Food Habits

In the summer of 1925 , I had an opportunity to frequently observe foxes on Unimak Island and Alaska Peninsula. They were foume on some of the sand islands at Izembek Bay-it is probable that they reached these islands by traveling over the ice during the winter. They spent much time on the beaches of these islands, where they dug for clams which they located by scent. They also picked up crabs at low tide and ate codfish or other carrion thrown up on the beach.

On Unimak Island, Unalaska, and some other localities, rodents become important in the diet and the foxes spend more time inland.

In 1911, Wetmore examined a den in the Morzhovoi Bay region, where he noted fragments of ptarmigan and ground squirrels. $\mathrm{He}$ also noted that foxes came down to the beach at Thin Point to feed on the many stranded flounders.

Beals and Longworth (field report, 1941) found red foxes to be well distributed over Unimak Island, but noted that they were concentrated in the coastal areas, where they could feed on the beaches. "Sandfleas were present in unbelievable numbers under boulder's and in rotting kelp. Scores of droppings were composed almost entirely of these little fellows. The valley floors were littered with mounds and tunnels made by small rodents and here again we found fox droppings showing only hair and bones of rodents. We found hundreds of instances where nesting burrows harl been torn out and the inhabitants eaten."

They also found ptarmigan to be unusually abundant, observing flocks of 300 to 400 birds, and they remarked: "Fox-eaten ptarmigan were found often enought to indicate them as having an important place in his diet."

The contents of 57 red fox droppings from Dolgoi Island were found to contain the following items, listed in number of occurrences:

\begin{tabular}{|c|c|c|}
\hline Item & Number & Percent \\
\hline$\ldots \ldots \ldots \ldots \ldots \ldots \ldots \ldots \ldots \ldots \ldots \ldots$ & . 38 & 52 \\
\hline Bird $\ldots \ldots \ldots \ldots \ldots \ldots \ldots \ldots \ldots \ldots$ & 16 & 21.9 \\
\hline Beach fleas (Crustacea) ............... & . $6^{*}$ & 8.2 \\
\hline Sea urchin (Strongylocentrotus drobachiensis) & $4^{*}$ & 5.4 \\
\hline MIussel (Hytilus sp.) ................ & $2 *$ & 2.7 \\
\hline 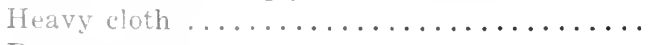 & 2 & 2.7 \\
\hline 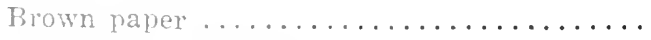 & 2 & 2.7 \\
\hline Hair seal (Ihrea spo) ................. & 1 & 1.3 \\
\hline 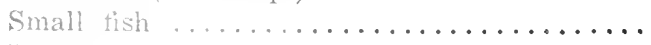 & 1 & 1.3 \\
\hline 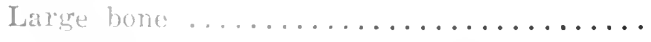 & . 1 & 1.3 \\
\hline
\end{tabular}

* Such forms atre listed as times occurring, rather than as actual number of individuals. 
At least two of the birds represented here were of sparrow size and may have been captured, but the others were larger birds and (since we found no bird colonies on this island) probably were carrion washed up on the beach. One dropping contained 100 percent sea urchin, three others contained 100 percent beach fleas.

The contents of 25 red fox droppings from Unalaska Island, based on number of items, were as follows:

\begin{tabular}{|c|c|c|}
\hline Item & Number & Percent \\
\hline Citellus. & .. 16 & 48.5 \\
\hline Microtus ... & $\ldots 9$ & 27.3 \\
\hline Dicrostonyx & $\ldots$ & 6 \\
\hline Bird $\ldots \ldots$ & $\ldots$ & 18.2 \\
\hline
\end{tabular}

In this case, rodents furnish the buik of the food. The droppings were collected in summer. It is interesting to note that on Chuginadak, on Amlia, and probably on the sand islands in Izembek Bay, there are no rodents and the red fox evidently adapts itself to beach combing.

\section{General Habits}

There is no doubt that the life history of the Alaskan red fox follows a normal pattern, but there are certain unusual traits. One of these unusual traits is the remarkable tameness of certain "wild" foxes. Frequently, I approached quite close to a fox as it went about its usual business without giving me much attention. A most unusual incident occurred on Operl Island, at Izembek Bay, in the summer of 1925. A red fox that was hunting on the beach allowed me to approach with the camera to within 5 feet. The animal had fed well on the beach, juclging by the contour of its body. When the tide came in, the animal left the beach and wandered into the sand dunes, where it eventually lay down to rest. It closed its eyes and went to sleep while I photographed it within a distance of 6 or 8 feet. The animal was still sleeping when I departed.

Local trapper's assured me that foxes lose this extreme tameness on the approach of winter.

On another occasion, Stevenson and I came upon a group of five beach-feeding red foxes that exhibited more normal traits, particularly an aversion to swimming. They were at the tip of a narrow sand spit that was separated from the main beach by a narrow channel of water. This was an ideal situation for a picture, assuming that they would hesitate to swim the channel.

We quickly reached the base of the sand spit and, dividing the 
width equally between us, we walked slowly toward the foxes, camela ready. The foxes immediately sensed that they were trapped ancl acted at once. One after the other, three of them chose to lace past us, rather than to swim a distance of 7 or 8 yards to the main beach. At high speed, a fox charged straight at us and passed within 5 or 6 feet. There was hardly time to change film before another fox, frantic because it was cornered, came rushing past us in the same manner, and the third fox followed the other two. Meanwhile, the remaining foxes swam across the lane of water and reached the main beach.

\section{Management}

On Unimak Island, there is an annual limit to the trapper's take-each legal trapper is allowed a maximum of 50 red foxes for the trapping season. This appears to be a satisfactory arrangement, and the fox population has not been unduly depleted. Even on the Alaska Peninsula, where no bag limit is in effect, the fox population has remained fairly stable. The same is true of Umnak. There were reports that the status of the red fox on Unalaska was not so favorable; however, fox signs were quite common when we visited there in 1936 and 1937.

On other Aleutian Islands to the westward, red foxes are handled as private property and are either harvested at intervals, as on Amlia, or are being eliminated in favor of blue foxes.

\section{Alopex lagopus: Blue Fox}

Attu: Mis-si-sirch' Chir-ri-ech

Mis-si-si Kón-uch (white fox)

From vocabulary compiled at Valdez by R. H. Geoghegan: Aikagulih

Morzhovoi Bay: Ikowkookmuh (Wetmore)

Russian, Siberia: Gcl-o-ba pee-scez-(a) (Buxton)

$$
\text { Pee-seetz-(a), "white fox" (Buxton) }
$$

The original distribution of the Arctic fox in the Aleutians is difficult to determine because of the fact that foxes have been placed on many of the islands for commercial breeding. The Chief of Attu Village insisted that the blue fox had been introduced in the Aleutians by man. Remington Kellogg, who examined many bones from old village sites excavated by the late Ales Hrdlicka, reported that no fox bones appeared in material from the Aleutians, though he found them in midden material from Kodiak.

Certain historical records counteract this evidence. Ivan Petroff (1881), speaking of A tka Island, stated "even the blue fox (Vulpes lagopus), now confined to but few localities throughout Alaska, is still found here." Concerning Attu, he said, "On account of 
the scanty supply of sea otters the natives have turned their attention to the protection and preservation of the bhe fox, and of these they now kill about 200 annually, with every prospect of increasing their stock in hand." Again, he says: "The blue fox exists now on several of the Aleutian Islands, where it was found by the first discoverers in 1741." He mentions that traders reported the presence of blue foxes to a limited extent at Ugashik, on Alaska Peninsula.

However, Petroff's records may be doubted, because he says that the red fox is "everywhere" on all the Aleutians, as far as Attu, on the Pribilofs, and on the Shumagins, and he also states that the brown bear is present on the Shumagins.

There is historical evidence that originally there were blue foxes on at least a part of the Aleutian chain, as well as on the Commander Islands. It is a well-known fact, first reported by Steller, that, when Bering and his crew were wrecked on Bering Island on their return from Alaska in 1741, Bering Island was well populated with foxes. Speaking of this island, Bancroft (1886, p. 88) says, "The only animals visible on land were the pestsi or Arctic foxes, exceedingly bold and rapacious. They fell upon the carcasses and devoured them almost before the survivors could make preparations for their burial. It seemed to be impossible to frighten them away." Again (p. 112), he says, "This vessel was named the Yeremy and carried the castaways to Kamchatka in the autumn of 1752 , with a cargo of 820 sea otters, 1,900 blue foxes, and 7,000 fur seals, all collected on the island upon which they were wrecked." A footnote explains that this island probably was one of the Commander Group.

Bancroft continues (p. 100), "Besicles Bering Island, Bassof also visited Copper Island, and collected 1,600 sea otters, 2,000 fur seals, and 2,000 blue Arctic foxes. From this trip Bassof returned on the 31 st of July $1746 . "$

Such commercial records show that the Commander Islands were heavily populated with blue foxes in early times. BarabashNikiforov (1938, p. 424) points out that Alopex lagopus beringensis Merriam is the form on Bering Island and Alopex l. semenovi Ognev on Copper Island; and that the latter is the larger and darker of the two forms.

Historical records also point to the presence of blue foxes on the Near Islands of the Aleutian Chain. Early Russian expeditions obtained profitable cargoes of furs from these western islands. Bancroft (1886) furnishes several pertinent passages. On page 112 he says, "During the same year, 1749, the mer- 
(hants Rymskoi and Tyrin sent out the Shitrika Sv Ioam to the Noul latunds, the vessel returning in August 1752 with 700 sea otters and To() blue foxes."

On page 118, he refers to Attu Island when he says, "After living on this island in peace with the natives for over a year, Tolstykh departed with 5,360 sea otters and 1,190 blue foxes, ancl reached Kamchatka in the autumn of 1758."

Again, this historian reports (p. 155), "The Vladimir, owned by Krassilnikof and commanded by Soposhnikof, sailed in 1766 , and returned from the Near Islands with 1,400 sea otters, 2,000 fur seals, and 1,050 blue foxes."

Dall (1870, p. 499) stated that blue foxes had been intro-

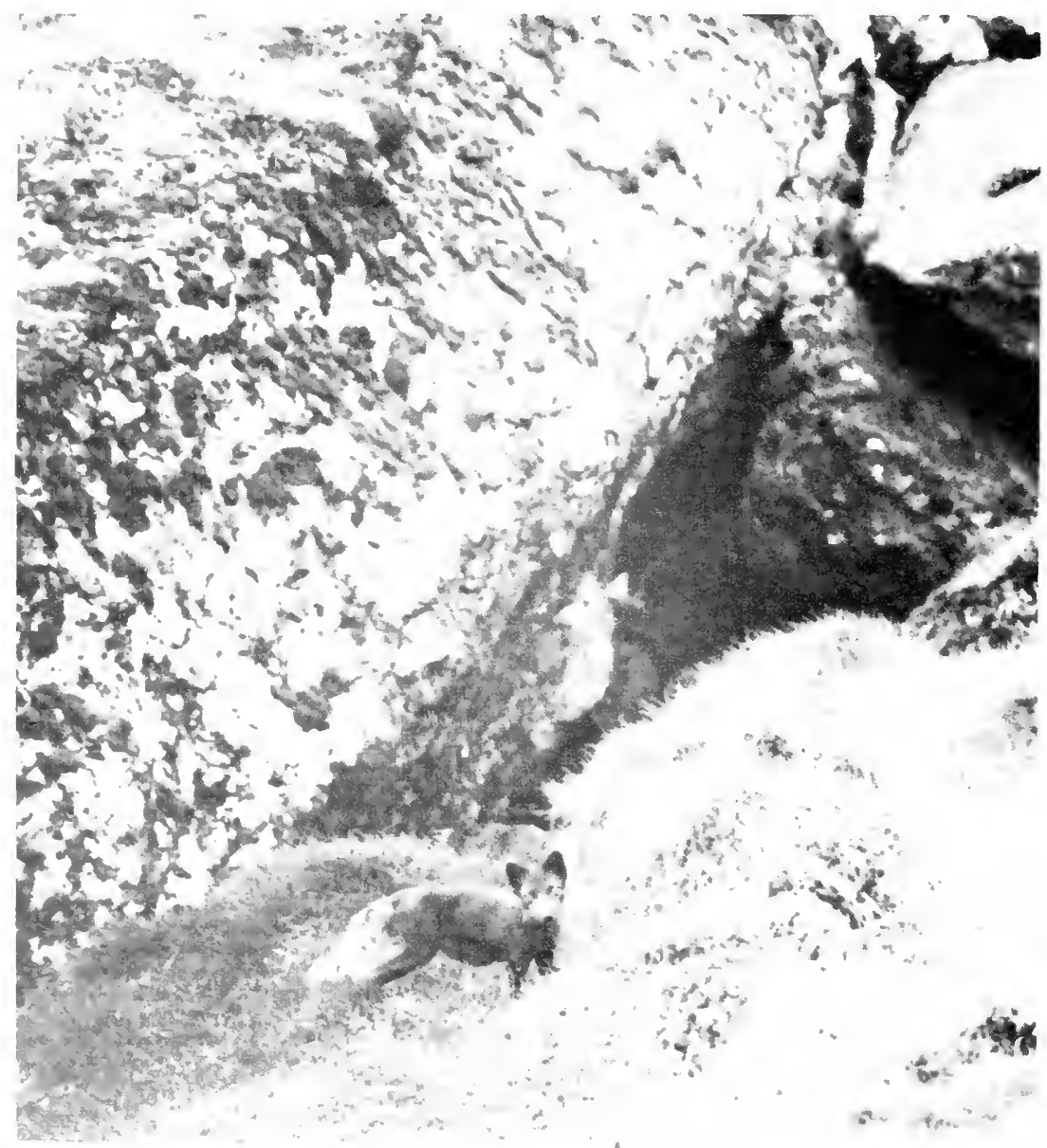

FIGURE 43.-Blue fox. 
duced for commercial purposes on most of the islands by the Russian-American Company. He adds that the earliest visitors to the Aleutians found "tame" foxes on the larger islands and assumed they had originally been placed there by man. However, with due consideration of the well-known "tameness" of the Arctic fox in all its range, including Greenland, the lack of wildness is no indication of any degree of domestication.

Elliott (1897, p. 180) wrote that blue foxes were introduced on Attu "many years ago." The above records, however, furnish good evidence to the contrary.

At present, there is no evidence that blue foxes occupied the eastern Aleutians. From available records it is reasonable to conclude that blue foxes originally occupied only the Near Islands of the Aleutian chain. Even today, the next island eastward, Buldir, has no foxes and apparently has never had them. It is one of the few islands on which geese are able to nest unmolested by foxes. Evidence is lacking that blue foxes occupied any islands east of Buldir.

It is possible that the blue foxes of the Near Islands originally were derived from the Commander Group. Ice floes from more northern latitudes could have drifted down, at rare intervals, to provide the necessary bridge or ferry - red foxes have been known to reach the Pribilofs over the ice, and a crossing to the Aleutians could easily be made.

The Arctic fox, apparently chiefly of the white color phase, occurs rather sparingly on the Alaska Peninsula. Osgood (1904) reported-

Straggling individuals of the Arctic fox are not infrequently found as far south as the north shore of the Alaska Peninsula, doubtless having followed the pack ice in winter. One was killed by fishermen near Igagik in the spring of 1902. They are also said to be found in the Togiak district and very rarely at Nushagak.

In 1911, Wetmore wrote (of the Morzhovoi Bay region), "One white fox is reported to have been killed on the Bering Sea side here in the winter of 1908. It is supposed to have come down on the ice in winter. No other's were known."

I found no evidence of Arctic fox at the western end of Alaska Peninsula in 1925, but in $1936 \mathrm{I}$ was informed by a resident at Port Molier that there were some white foxes about 60 miles northeast of that place in 1914. In 1936, the late Alexis Yatchmeneff, who had been chief of one of the Aleut villages, said that before the Russians came there were red, cross, and silver foxes on Unalaska but there were no white or blue foxes. 
Kellogg (1936) found no bones of the Arctic fox in the midden material from Kodiak Island, though the red fox was abundantly represented. Probably this fox never ranged on the more rugged Pacific side of Alaska Peninsula.

It appear's, then, that the Arctic fox, mostly in its blue color phase, reached the westernmost Aleutians from the Commander Islands, while the Alaskan continental form straggled out, at least part way, on Alaska Peninsula.

\section{Food Habits}

The leasing of islands for the purpose of raising blue foxes has a direct influence on the native fauna, therefore particular attention has been given to the food habits of the blue fox in the Aleutians. Accordingly, we made every effort to learn what constituted the fox food on each island. This was accomplished by the only two methods possible-observation and the analysis of droppings. Such studies were made on about 40 islands, though data from a few of these were meager. Table 1 presents the food habits data obtained on 22 islands, from the contents of more than 1,800 blue fox droppings. While a much greater number would be desirable from any given island for a complete picture of the food habits pattern in percentages, the data here presented agree closely with our field observations and furnish an accurate statement of the food that is available and utilized by the blue fox in the Aleutians.

It had been assumed by lessees operating in the Aleutians that sea urchins were the most important food item, supplemented by birds and beach drift. We found that sea urchins, though acceptable, do not rank in importance with amphipods (tiny crustaceans commonly referred to as beach fleas). Crustaceans were found in 26.1 percent of the droppings studied, and sea urchins were found in 2.1 percent (see table 2 ).

Beach fleas appear to be the most commonly available food item. They swarm on the beaches, where windrows of dead kelp furnish a favorite habitat. They lurk under bits of wood, or under anything else that may lie on the sand and preserve the required moist shelter underneath. It is easy for a fox to pick up a full meal of sand fleas; on the other hand, sea urchins must be picked up at low tide and in limited areas on exposed reefs or other favorable spots. An island with extensive beaches, either sand or gravel, is favorable for foxes. An island with a rocky shore, and with few or no beaches, is not satisfactory; here, the foxes must rely on sea birds, as long as the bird colonies last. Throughout the Aluntians, life is concentrated pretty much along 
the shoreline, and there are few land birds. The sea birds depend on the ocean for food and generally are found at, or near, the shores. The life-giving tides are the principal source of food. There are no native rodents west of Ummak, but ground squirrels have been placed on Kavalga for fox food, and rats accidentally were introduced on Rat Island in early days. Foxes feed on both of these animals.

On Rat Island, 28.8 percent of fox droppings contained rats, and about 40 percent contained beach fleas. Rat Island has extensive beaches, and most of the rats are confined to the beaches because of the nature and clistribution of the vegetation.

Rats have also been introduced on Atka and are eaten by foxes, but our data for that island are too meager for tabulation. On Unalga Island, in the Fox Islands group, blue foxes were feeding on field mice, but these rodents are not available on most of the Aleutians.

A stranded whale, or a dead seal or sea lion, often becomes an important item of fox food. We witnessed a whale being eaten on Yunaska lsland, but a whale on the beach of Kanaga was hardly touched-this was explained by the caretaker who stated that most of the foxes were on the other side of the island.

The importance of birds in the blue fox diet is evident in the tabulation. In the Aleutians as a whole, they furnish 57.8 percent of the food, though the percentage varies on different islands, depending on availability. Land birds are relatively unimportant. They are hard to capture and do not gather in large groups. But the concentrated colonies of petrels, auklets, and related species furnish rich hunting grounds. In addition to the droppings tabulated in table 1, for Kasatochi Island, we found a single fox cache under a rock that contained 65 crested auklets, 37 least auklets, 1 whiskered auklet, 1 parakeet auklet, and 1 pigeon guillemot, and there were more birds farther back under the rock. On Bobrof Island, we found remains of 103 petrels, 6 tufted puffins, 4 least auklets, and 1 pigeon guillemot. On Semisopochnoi, we listed remains found at dens as follows: 107 least auklets, 18 crested auklets, 3 tufted puffins, 1 horned puffin, 1 murre, and 7 fork-tailed petrels.

Necessarily, insects are a miror item in the diet, yet it is interesting to note that of the 10 droppings from Kiska Island that contained larvae of Noctuidae, one dropping consisted of 50 percent, another 75 percent, of these caterpillars.

There is an interesting item from Kagamil Island. Two droppings contained skin from Aleut mummies. When we examined 


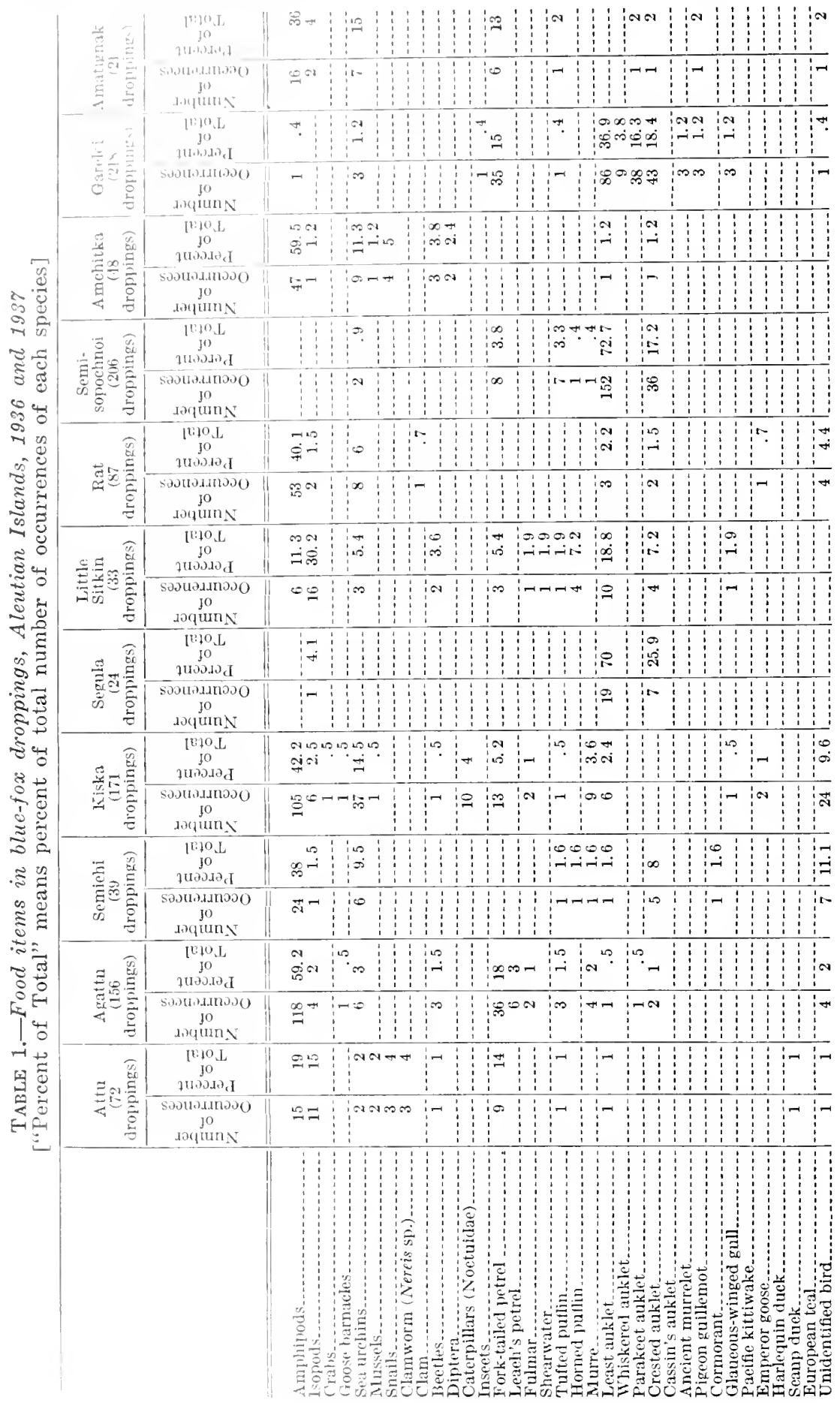




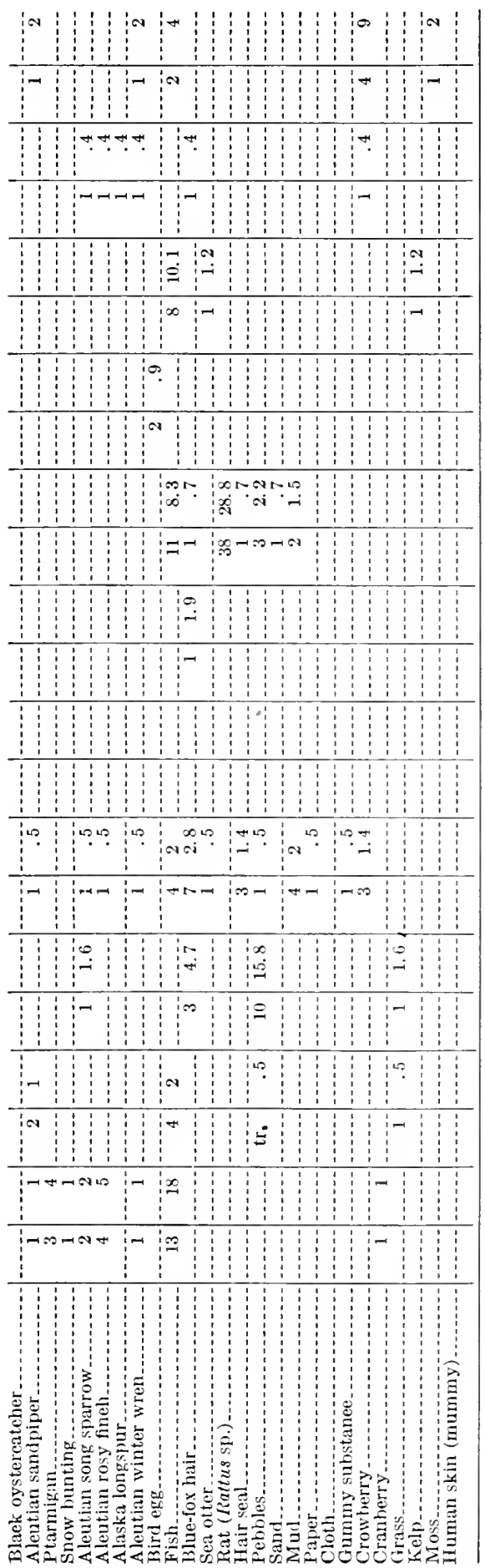


300 NORTH AMERICAN FAUNA 61, FISH AND WILDLIFE SERVICE

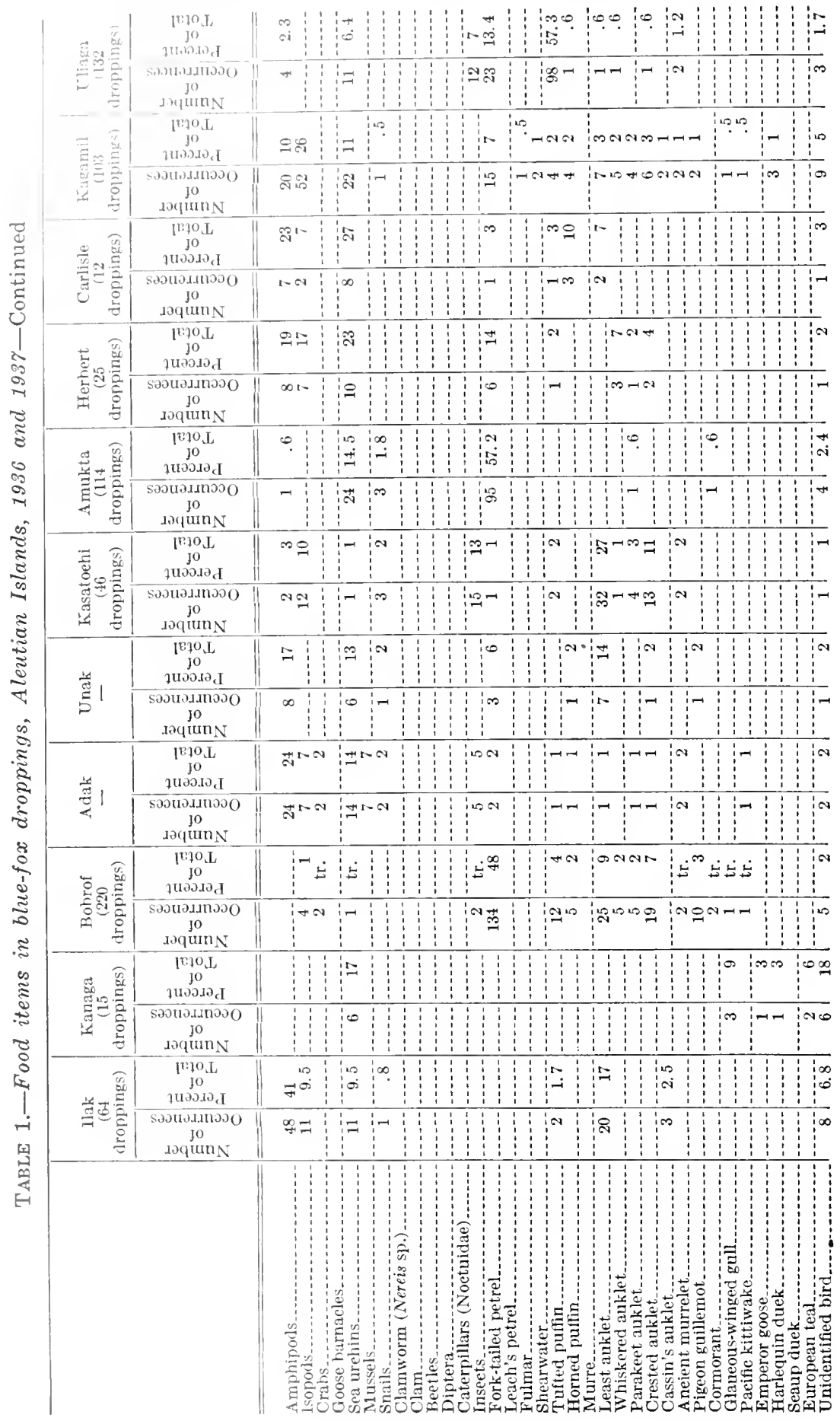




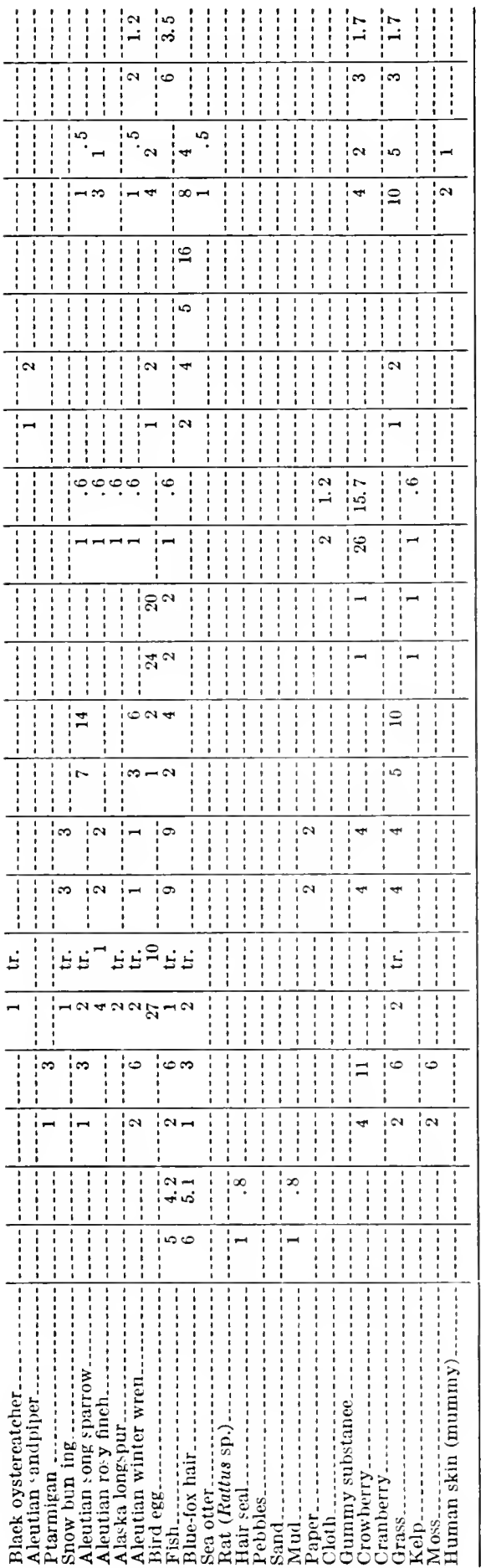




\section{NORTH AMERICAN FAUNA 61, FISH AND WILDLIFE SERVICE}

TABLE 2.-Summary: Food items in blue-fox droppings, Alcutian, Islands, 1936 and 1937

\begin{tabular}{|c|c|c|}
\hline \multirow[b]{2}{*}{ Food item } & \multicolumn{2}{|c|}{ Oeeurrences } \\
\hline & Number & Pereent of total \\
\hline 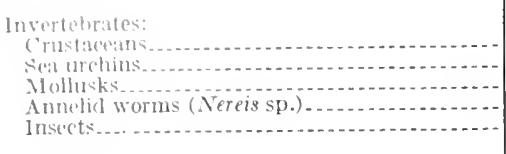 & $\begin{array}{r}653 \\
53 \\
30 \\
3 \\
45\end{array}$ & $\begin{array}{c}26.1 \\
2.1 \\
1.1 \\
.1 \\
1.75\end{array}$ \\
\hline 'Total $\ldots . . .$. & 784 & 31.3 \\
\hline 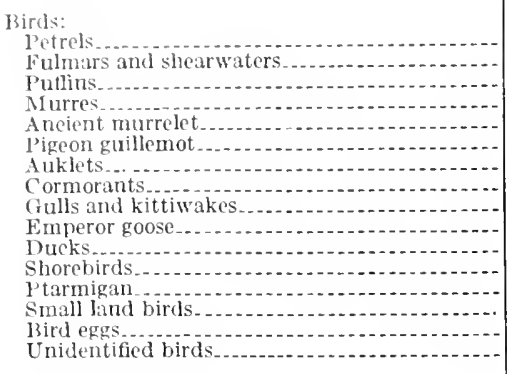 & $\begin{array}{r}396 \\
9 \\
158 \\
15 \\
13 \\
17 \\
604 \\
4 \\
12 \\
4 \\
7 \\
7 \\
4 \\
56 \\
59 \\
83\end{array}$ & $\begin{array}{c}15.8 \\
.35 \\
6.3 \\
.6 \\
.5 \\
.7 \\
24.1 \\
.1 \\
.4 \\
.1 \\
.2 \\
.2 \\
.1 \\
2.2 \\
2.3 \\
3.3\end{array}$ \\
\hline Total & 1,448 & 57.8 \\
\hline Fish & 70 & 2.7 \\
\hline $\begin{array}{l}\text { Mammals: } \\
\text { Blue fox } \\
\text { Sea otter } \\
\text { Rat } \\
\text { Hair seai } \\
\text { Human skin (mummy) }\end{array}$ & $\begin{array}{r}37 \\
3 \\
38 \\
5 \\
2\end{array}$ & $\begin{array}{c}1.4 \\
.1 \\
1.5 \\
.2 \\
.08\end{array}$ \\
\hline Total & 85 & 3.3 \\
\hline $\begin{array}{l}\text { Vegetation } \\
\text { Misecilaneous (mud, pebbles, paper) }\end{array}$ & $\begin{array}{l}86 \\
28 \\
\end{array}$ & $\begin{array}{l}3.4 \\
1.1 \\
\end{array}$ \\
\hline Grand total $\ldots$ & 2,501 & 100 \\
\hline
\end{tabular}

a cave filled with mummies (which are now in the U. S. National Museum), we discovered that blue foxes had torn some of these apart, literally limb from limb, and had made themselves thoroughly at home in the mummy cave. Obviously, blue foxes find human flesh tasty, either fresh or dried. The tabulations also inrlicate cannibalism. Presumably, most of the foxes that were eaten were carrion.

\section{Disposition and Habits}

The Arctic fox is known to be tame and unafraid in the presence of man, not at all like the red fox. Steller has given a vivid account of the reactions of blue foxes to Bering's shipwrecked crew. They were exceedingly bold, and on some occasions they would begin nibbling on exposed parts of a person if he were lying where a fox could get at him. 
An interesting experience on Rat Island illustrates the surprising behaviour of these animals at times. To quote from my field notes-

I sat down to rest on a ridge. Through the tall grass I could see two adult foxes and a well-grown young in the draw below me. I was sharpening my pencil and one of the foxes evidently caught the motion of my hand, and saw my head and shoulders. The young fox disappeared and one of the old foxes came charging straight up the slope. To my amazement it came all the way, ran up to me, poked me in the arm, apparently with bared teeth for it was a sharp sensation, then ran off a little distance. Immediately, the other fox started up the hill in the same manner. But at this point, I quickly stood up and waved it back. Both foxes then stood at a little distance and barked at me.

The blue fox is a clever hunter. According to the Aleuts, sometimes a fox will catch an emperor goose when it is asleep and has its head tucked under its wing. On occasion, too, a fox will stand on a point of rock where ducks are diving and, when a duck is rising in the water nearby, the fox will jump in and seize it while it is still below the surface. The Aleuts added that the blue fox will jump in the water and seize salmon. Incidently, Homer Jewell, a member of our party, said that he had known of several dogs in southeastern Alaska that would seize salmon in the water.

Blue foxes readily swim from one island to another when the distance is not great; sometimes they will attempt this where there are strong tidal currents and are carried off to sea and lost. Foxes also can climb moderate cliffs with ease. Occasionally, one will even leap across a chasm and down to the top of a pinnacle where ducks are nesting, then clamber down the pinnacle, and swim back to shore.

Foxes have learned to take every possible advantage over birds, and the birds must nest on sheer cliffs or inaccessible offshore rocks to be entirely safe.

\section{Birds vs. Blue-Fox Industry}

Possibly, there are areas where bird colonies are so huge that the Arctic fox has made only an insignificant reduction in the number of birds. In the Aleutian Islands, there are some large bird colonies, and the foxes take their toll. In some instances, this has not as yet made a great difference, but, in many other instances, great changes have taken place. On some of the smaller islands the birds have been almost eliminated, and on many islands such birds as eider ducks have ceased to nest, except on a few offshore pinnacles where they can find protection. The cackling goose and lesser Canada goose have become so scarce 


\section{(0) 1 NORTII AMERICAN FAUNA 61, FISH AND WILDLIFE SERVICE}

that it is somewhat doubtful whether they can survive in the Aleutians. If the migration to these islands should cease, these species mould disappear from the Aleutian fauna. Certain rare species, too, are threatened. The whiskered auklet is not abundant, and the Cassin's auklet has become very scarce.

No native rodents occur on most of the islands, hence there is no food for foxes except for the birds and invertebrates, and the drift on the beaches. Many of the islands are small, and the fox populations are under commercial management, which necessarily strives for the greatest possible fox numbers. Many of the islands have rocky shores with a minimum stretch of beach where foxes can feed. These are some of the factors that cause a special hazard to the Aleutian bird colonies.

\section{Canis lupus: Wolf}

Canis lupus pambasileus

Aleut: Alixgikh (Geoghegan)

Russian: Volk (Buxton)

The wolf has ranged the entire length of the Alaska Peninsula, and is referred to by Osgood (1904, p. 40). He found tracks near Lake Clark and around the portage between Chulitna River and Swan Lake, and he was told of wolves occurring on Alaska Peninsula. Turner (1886, p. 208) reports it as being present on Unimak Island, stating that it reached this island over ice that sometimes jams into False Pass. Nelson $(1887$, p. 238) quotes Veniaminoff to the effect that wolves were resident on Unimak Island and that two were killed on Akun Island in 1830-this is the farthest west that they have been reported.

In 1911, Wetmore saw tracks of wolves in the King Cove region. In 1925, I obtained further information on wolf distribution in that western district. Donald H. Stevenson, at that time resident fur warden there, reported that six wolves were killed on Unimak Island in 1912. He had unverified reports that the last ones were killed in 1914. It was learned that two wolves were killed in the winter of 1918 at the west end of Alaska Peninsula. This had been a hard winter, the two wolves were poor, and their fur was greasy, showing that they had been living off a whale carcass. Griggs $(1922$, p. 315) found wolf tracks at Mount Tratmai in 1916, and he mentions reports of wolf packs in former rear's.

In 1.936, wolves were reported to be plentiful on Mulchatna River, in the Lake Clark region, and in the Nanwhyenuk Lake and Takneli Lake country, but there were no recent reports of wolves warkd along the Peninsula. 


\title{
Family FELIDAE
}

\section{Lynx canadensis: Canada Lynx Lynx canadensis mollipilosus}

Osgood (1904, p. 39) reported that lynx were scarce at the base of the Alaska Peninsula, according to the natives, though in 1901 (p. 67) he recorded that lynxes were fairly common in the Cook Inlet region. Griggs (1922, p. 315) stated that trappers had reported the capture of lynxes within the Katmai National Monument.

In 1911, Wetmore wrote-

The lynx is not common in the region around King's Cove, but a few are reported every year. It has been known from the region around Cold Bay for as far back as the trappers could remember, but has come into the region west of Nelson's Lagoon, on the Bering Sea side, within the last 4 or 5 years. Its food is reported to be the Arctic Hare.

Thus, it is evident that the lynx has occurred far out on the Alaska Peninsula, beyond all timbered areas. It is not reported from the Kodiak-Afognak group, where varying hares were introduced only recently.

\section{Family OTARIIDAE}

\author{
Eumetopias jubata: Steller Sea Lion \\ Attu: Káv-rch \\ Atka: Kow'-uhh \\ Aleut (dialect?): Qa'hwax (Jochelson) \\ Khawakh (Geoghegan) \\ Russian: Sivutcha (Steller)
}

Sea lions are found throughout all of southwestern Alaska, extending to Attu Island, where we saw some at its westernmost point, Cape Wrangell. There were colonies, numbering from 40 or 50 to several hundred individuals, at such places as Amak Island, Bogoslof (the outstanding herd), Carlisle, Yunaska, Chagulak, Amukta, Segula, Semisopochnoi, Ilak, and Buldir. Bogoslof has by far the largest and most spectacular herd-so outstanding that it deserves special consideration as an object of particular scientific, as well as popular, interest. In 1938, Scheffer estimated 800 sea lions were on Bogoslof.

The Aleuts use the skin of the sea lion for leather, and find the flesh very palatable. On one occasion, I ate the flesh of a young sea lion and found that it was decidedly acceptable. 


\section{NORTH AMERICAN FAUNA 61, FISH AND WILDLIFE SERVICE}

\section{Callorhinus ursinus: Northern Fur Seal \\ Attu: Hla-koó-yach \\ Laku'dax (Jochelson) \\ Aleut (dialect?): Lakukh (Geoghegan) \\ Russian: Kot (Steller)}

The fur seal migrates to and from the Pribilof Islands by way of various passes throughout the Aleutian chain, and, at such times, they may be found, well offshore, south of Alaska Peninsula.

In 1925, I was told of some unusual overland movements of these seals near the western end of Alaska Peninsula. At that time, Nick Kristensen, a local trapper at False Pass, stated that fur seals in fall migration had been observed going up Nelson Lagoon, then crossing overland to the Pacific. Stevenson, a reliable observer, related that several people had reported fur seals going overland from the Bering Sea side, across the narrow strip into Morzhovoi Bay, and that they had crossed the sandspit at St. Catherine Cove as well as the sandspit at Village Cove on the opposite mainland.

In regard to overland movements of seals, it is interesting to recall Bailey's notation of a report of an Eskimo at Cape Prince of Wales to the effect that spotted seals and ribbon seals had migrated overland out of lagoons to reach open water to the south, because of ice conditions in the lagoons. In this instance, they crossed high country, and traveled several miles a day.

There appeared to be a general understanding among the Aleuts that fur seals hauled out on Buldir. Island in the past, and some of the natives insisted that they bred there. These stories came from natives of Attu as well as Atka. In 1937, Bill Dirks, a brother of the chief of Atka Village, insisted that fur seals were on Buldir. He told me that he had landed there years ago and had killed some for their furs. He was confident that these seals would still be hauling out on Buldir.

At this point, it is of interest to quote a short note from Scheffer, who wrote under date of January 28, 1942, that-

In a collection of notes bequeathed to us by G. Dallas Hanna there appears a card with the following statement: "August 1 [1902]-Judge and Lembkey shown a pup fur seal taken by the officers of the Manning this summer on Bowldir Island." The statement was attributed to the official log of St. Paul Island, Alaska.

In American Field (1902, vol. 53, p. 198), there is a report of "recent nems" from Washington, D. C., to the effect that Captain Charles H. Mctellan, commanding the U. S. Revenue Cutter 
Manhattan had reported to Captain Shoemaker of the Revenue Cutter Service the discovery of a new fur seal rookery in the Aleutian Islands, on "Bouldyer Island." It was stated that Lieutenant Berthodd had approached the herd closely enough to observe that none of the seals had been branded.

In 1938, Scheffer was told by Bill Dirks, of Atka, that his father lived on Buldir Island for a month in 1900 and had killed several fur seals there. He also said that A. C. Goss visited the northwest end of Buldir in 1920 and had reported the presence of fur seals and sea lions.

We tried to find fur seals on Buldir, but we found only a sea lion rookery on a beach of an offshore islet. However, we were unable to make a landing. When I mentioned this sea lion rookery to the chief at Atka, he was not surprised. He stated that he knew of the presence of sea lions there, and he added that the fur seals would be there too.

In spite of our negative findings, all the evidence seems to show that, at one time, the fur seal was to some extent a resident as well as a migrant in the Aleutians.

\section{Family PHOCIDAE}

\section{Phoca vitulina: Harbor Seal Phoca vitulina richardii}

Attu: Ish'-u-gich

Atka: Ish'-u

Aleut (dialect?): Isukh (Geoghegan)

Hisook (Wetmore, at Morzhovoi Bay)

lshooik (Osgood).

Russian, Siberia (Gichiga): Ola (Buxton)

Russian, Ikhotsk, Ayan, Pengina, and Marcova: Largha (Buxton)

It is interesting to note that Nelson (1887, p. 262) gives Ish-ógik as the Eskimo name for the ringed seal (Pusa hispida), which is extremely rare, or absent, in the Aleutians, and is not distinguished from Phoca vitulina by the Aleuts.

The harbor seal occurs all along the southern Alaskan coast, and throughout the length of the Aleutians. We did not find it to be particularly abundant, but we sighted single animals or small groups here and there. In 1925, it was rather common along the Pering Sea side of Alaska Peninsula.

In his revision of the Genus Phoca, Doutt (1942, p. 120) identified specimens of this race from Alaska Peninsula between Katmai and Kanatak and between Portage Bay and Becharof Lake, from Izembek Bay, Nagai Island in the Shumagins, from Kagamil 
Island, and from Adak Island. He gave the range of this form as the "American side of the North Pacific Ocean." Obviously, this is the seal of the Aleutian district, but there is a possibility that the more western form, $P$. v. largha, may occur near the western islands.

These seals will enter fresh water. Osgood (1904, p. 49) mentions reports of a spotted seal living in the fresh waters of Lake lliamna, and he says that most of those killed were taken either near the outlet of the lake or in Kvichak River, "which seems to indicate that the animals whether distinct or not, go back and forth from Bristol Bay to Lake Iliamna."

Among the Aleutian Islands, seals were usually found in the kelp beds, but they do not always seek such a habitat. I had a fine opportunity to study these animals in the spring and summer of 1925, at Unimak Island and at the west end of Alaska Peninsula. They were very common at that time. They hauled out on the boulder's of the reef at Amagat Island and basked on the kelp-covered bouldiss near the beaches of Amak Island. In Urilia Bay, they hauled out on the sand along the entrance to Rosenberg Lagoon, and in Izembek Bay they hauled out on shoals and sandbars at low tide. A small sand island in the channel between Operl and Neumann Islands was a favorite hauling-out place.

Seals pick a resting place that provides ready escape, always near deep water. If the ebbing tide recedes from a boulder on which a seal is resting, the animal will move to another rock, nearer to deeper water. When navigating the shallow Izembek Bay with our whaleboat, we could steer a deep-water course by noting the location of resting seals.

Mothers and pups appear to be very affectionate, swimming near each other and occasionally touching noses. A little one would try to climb to its mother's perch on a rock. After a while, the mother might lazily roll into the water to join it; later, both might be able to clamber out on the same perch.

On June 17, a young seal was taken for a specimen-the stomach was filled with milk. On July 10, Stevenson and I each observed a pup nursing.

We found a number of deserted pups, probably those whose mothers had been killed. A deserted pup had been picked up at False Pass in May. On June 16, I found a pup on Neumann Island, at the edge of the grass far from water, since the tide had ebberl. A dead pup lay on a hauling place on a small sand island. A very lean pup was found on Glen Island on June 30; when we 
approached, it hurriedly scrambled into the sea. We noted a dea $\mathrm{I}$ pup on this island on July 27. On June 17, a pup was swimming near the beach calling for its mother. We answered its call, and it responded several times by coming out on the sand at our feet, but it retreated hastily when it learned its mistake, and finally it swam out to sea. The pups have a plaintive, moaning call, which is quickly identified by the mother. The adults have a lower and more raucous voice.

On July 27, a partially blind seal swam near the beach at Glen Island. One eye was white, and the other was partly white. It could see me only when it faced me squarely.

On June 17, it was noticed that the seals were shedding their hair. Old hair was found in their beds, where they had been basking on the beach. At this time, some were a dirty yellowish color; some were mixed, partly light and partly dark; and others were all clark. Evidently, these color variations were stages of pelage change.

On June 24, 1937, a female seal was taken for a specimen at Khvostof Island, and her pup was kept alive for a time. Part of the navel cord was still attached, and it was evident that the pup was recently born. It had the typical dark, spotted coat of this species of seal. The mother weighed 220 pounds.

As one would expect, the seal was much prized by the Aleuts, and was used for food and for other purposes. Wetmore, writing of Unalaska and neighboring islands in 1911, stated that "The hide is used for varjous purposes and oil is tried out of the blubber. The gut is split and dried and used for many purposes. It is sold in the store like cloth at about 15 cents a yard."

\section{Pusa hispida: Ringed Seal}

\section{Russian (Siberia): Ak'-ee-pah (Buxton).}

Turner (1886, p. 206) implies that this seal occurs in the Aleutians, but from his casual statement it is obvious that he had no specimens to support his opinion. Nelson (1887, p. 262) does not mention any locality farther south than St. Michael, but there is a specimen in the National Museum (No. 227077) that was obtained near Chogiung, Bristol Bay, by Hanna in 1913. This is a seal of the ice floes and would not be expected to occur regularly in the Aleutian district. Straggler's may have come that far at times in winter with southward-drifting ice.

\section{Pagophilus groenlandicus: Harp Seal}

This is another seal whose reported presence in the Aleutians must be seriously doubted. Turner (1886, p. 206) gives as its 
l'ange: "All the Arctic shore, Bering Sea, and the Aleutian Islands." There is no evidence of its presence in the Aleutians. Allen (1880, p. 641) refer's to Pallas and Steller as recording it from Kamchatka, and he says that Temminck mentions having examined three skins obtained at Sitka. On Temminck's record, Nelson (1887, p. 263) expresses serious doubt: "considering that we have no subsequent record of its capture in that now well-known region, and that it is unknown from the Aleutian Islands and is of such extreme rarity in Bering Sea, that record can be safely considered as more than doubtful."

I agree with Nelson's opinion without any hesitation. In fact, Doutt (1942, p. 90), considering the complete lack of specimens from the western Arctic and Bering Sea, has some doubt about it being circumpolar in distribution, although Nelson described the skin of a young individual from Cape Prince of Wales, and described several individuals that were seen at close range in the pack ice near Wrangel and Herald Islands.

\section{Histriophoca fasciata: Ribbon Seal}

Russian: Fre-lat-ah and Mandar-ka (Buxton)

This is a rare and little-known seal, but apparently it is quite migratory, and there is a possibility that it has been found among the Aleutian Islands. Allen $(1880$, p. 681) refers to Pallas as recording the range as far south as the Kurile Islands, and refers to Von Schrenck as stating that Wosnessenski obtained specimens that had been killed on the east coast of Kamchatka. Allen also states that Yon Schrenck had seen skins of ihese seals that had been killed on the southern coast of the Sea of Okhotsk. Allen further states that Dall had obtained specimens from Cape Romanzoff, and he quotes Scammon as follows: "It is found upon the coast of Alaska, bordering the Behring Sea, and the natives of Ounalaska recognize it as an occasional visitor to the Aleutian Islands."

\section{Erignathus barbatus: Bearded Seal \\ Erignathus barbatus nauticus}

Russian, (Siberia): Nerpah

Russian, Kamchatka and Marcona: Lock-tock (Buxton)

Nelson (1887, p. 260) says-

The Bearded Seal is rather common along the Alaskan coast of Bering Sea south to Irristol Pay, but it is not found on the Aleutian Islands nor about the Fur-Seal group, except possibly as a winter visitor with the icerack about the latter islands. On the coast south of Cape Vancouver they are far less cummon than north of that point. 
Osgood (1904, p. 47) obtained a shull of this seal from the natives near his camp on Ugagik River. The animal had been killed there on October 3, 1902.

On May 23, 1936, in Bristol Bay, Captain Sellevold, who was in command of our ship the Brown Bear, reported that he saw a seal that "dived like a fur seal," that is, sliding over head first, with humped back, but that it had a "white streak" on its face. It is true that this is the diving habit of the bearded seal, and the so-called "white streak" may have been the appearance of the long whiskers of this seal.

A skull is in the National Museum (No. 260363) that was obtained from Kodiak Island by Aleš Hrdlička.

Bill Dirks, Atka Chief, said that in the winter of 1935-36 two strange large seals arrived at Atka Island on ice floes after a period of northerly winds. It is probable that these were bearded seals, for the natives were familiar with their own common harbor seals.

\section{Family ODOBENIDAE}

\section{Odobenus rosmarus: Walrus Odobenus rosmarus divergens}

Aleut (dialect?): Amgadakh (Geoghegan) Amagadookh (Wetmore)

Russian: Morsjec (Elliot)

The walrus was never known south of Alaska Peninsula or the Aleutian Islands in any numbers. Elliott (1882, p. 98) wrote-

no walrus are found south of the Aleutian Islands; still, not more than 45 or 50 years ago, small gatherings of these animals were killed here and there on the islands between Kodiak and Oonimak Pass; the greatest aggregate of them, south of Bering straits, will always be found in the estuaries of Bristol bay and on the north side of the peninsula.

On October 9, 1923, Walker wrote, "One individual was killed in the fall of 1921 or spring of 1922 at the head of Cold Bay (north of Deer Island), on the south side of the Alaska Peninsula."

Apparently, there was even a more southerly distribution in primitive times. Golder (1922, p. 292) quotes from the journal of Chirikov's ressel, the St. Paul, under date of July 16, 1741, the locality being near Cape Addington in southeastern Alaska: "Observed many ducks and gulls of different species, also sea animals-whales, sea lions and walrus."

The same author (p. 295) quotes again for July 23, 1741, somewhere in or near Lisianski Strait: "At the eleventh hour a 
walrus swam past our ship." And again (p. 298), for August 1, 1711, near Cape Elizabeth, the southwestern point of Kenai Peninsula: "A walrus dived near the ship."

If we may accept these early records, and they appear to be authentic, in primitive times the walrus must have ranged at least as far south and east as Prince of Wales Island in southeastern Alaska, possibly farther. It should be noted that this is actually not farther south than the north shore of Unimak Island. However, if there had been large herds in southeastern Alaska, surely some of them would have survived long enough to have been more generally recorded. It is reasonable to conclude that walruses occurring south and east of Alaska Peninsula were only in small groups and that they represented the southern fringe of their distribution.

The Aleutian Islands west of Unimak are not properly in the walrus range, but Turner (1886, p. 207) records a 2-year-old male killed at Attu Island in September 1880.

In 1938, Scheffer recorded the following statement by Pete Olson, of Unalaska Island:

I went to Anderson Bay near Makushin with my power dory and towed a walrus up on the beach. It had been killed by natives, was two or three years old, and had a body about two thirds as long as my twenty foot dory. The walrus was beached and the natives took some meat. A doctor on the Coast Guard boat "Haida" took the head, cleaned off the meat, and saved the skull. This happened in the late fall of 1926 or 1927.

Such records represent strays.

Walruses feed on clams on the ocean floor, therefore we would not expect to find optimum habitat in the deep waters that are so prevalent in the western Aleutians. On the other hand, we know that walruses existed in great numbers in Bering Sea, whose shallow waters afford favorable feeding grounds. It is significant that Bristol Bay, whose shallow waters and mud and sand bottom were the home of great numbers of walruses in earlier days, now has very few.

Several places on the north side of Alaska Peninsula were visited by great number's of walruses, though early accounts do not always specify precise localities. It is obvious that the "south side of Bristol Bay" harbored large walrus herds. Local residents indicated that the vicinity of Ugashik had one or more hauling-out places.

Osgood (1904, p. 49) reported in 1902 that-

A very limited number of walruses still occur about some of the small islands in Togiak Bay west of Nushagak, and on the north coast of the Alaska Peninsula in the vicinity of the native village of Unangashik. Large 
quantities of walrus bones, witnesses of bygone slaughters, are to be found at various points along the peninsula. One such place was reported by the fishermen of Igigik, who had recently found it while on a hunting trip near there. From their accounts, the remains must be in great quantities.

Great numbers of walruses are known to have been killed at Port Moller. In 1911, Wetmore reported that a few walruses were still to be found on "Walrus Island", in Izembek Bay, near the west end of Alaska Peninsula. In 1925, when I visited Izembek Bay, parts of walrus skulls were found on Hazen Point and on the ocean beaches of the Kudiakof Islands. These are a string of sand islands that extend across the mouth of Izembek Bay. About 14 miles offshore at this place is isolated Amak Island, which has a long boulder beach thickly strewn with old walrus bones. Assuredly, at one time this was a much-used resting place for these animals.

In 1936, the late Alexis Yetchmenef, Aleut chief then residing at Unalaska, said that in 1880 to 1883 , during his visit at his old home in Morzhovoi Village, walruses were numerous on the north side of Unimak Island and were found in St. Catherine Cove. On one occasion, while hunting on Unimak Island, he saw 40 or 50 walruses leaving the island. For 2 years they were plentiful there. Then, in 1898 or 1899, some white men "did a lot of shooting there," and the chief believed that the walrus left for that reason. Unimak Island undoubtedly marks the westernmost point in this area that is reached by the walrus in any numbers, because it also marks the western end of suitable habitat.

In 1887, E. W. Nelson (1887, p. 270) said, "Today it is safe to say that the number of these animals in existence is not over 50 percent of the number living ten year's ago, and a heavy annual decrease is still going on."

In a letter dated March 4, 1921, C. L. Andrews wrote to E. W. Nelson, at that time Chief of the U. S. Biological Survey-

The walrus should be looked after. They are increasing, and are again coming to the Alaska Peninsula in small numbers where they, in Russian days, were by thousands. But the skin and ivory hunters will again wipe them off the waters if nothing is done to stop it. If handled properly an industry of at least a million dollars a year could be perpetuated in their skins, oil, and ivory. I can't get the record of the amount brought down for the last 8 or 10 years, the customs do not give it, but I know of 2800 skins being in Seattle about 4 years ago, and the "Belvedere" was lost in the Arctic "walrusing" last year.

An occasional walrus is still seen in the vicinity of Nunivak Island, but the herds that Elliott thought would be "preserved indefinitely" are gone from Bristol Bay and Alaska Peninsula. Moreover, there is no assurance, with modern transportation 
and with modern firearms in the hands of the natives, that the northern herds will survive. Eskimos still kill walruses for food and clothing. But with the use of firearms about 50 percent of the animals sink and are lost. Today the walrus poses an important conservation problem.

\section{Family SCIURIDAE}

\section{Marmota caligata: Hoary Marmot Marmota caligata caligata}

Russian, Siberia: Tar-bah-gan (Buxton)

Howell (1915, p. 58) gives the distribution of the marmot as including much of southern and interior Alaska, Kenai Peninsula, and Alaska Peninsula as far west as the Port Moller region. Allen (1904, p. 278) records a marmot taken at "Muller Bay." The type locality is Bristol Bay. They do not occur in the KodiakAfognak Islands.

Captain Cook (1842, p. 358), writing at Unalaska, states that foxes and weasels were the only quadrupeds seen, but he adds that he was told that there were hares, and the "marmottas" mentioned by Krasheninikoff in October, 1778. This statement probably refers to the general region of Unalaska, and if the "marmottas" are referable to "marmot," as used later, it is important to note that this name was often applied to the ground squirrel, Citellus. Marmot Island obviously was named for the ground squirrel. There are no records of marmots west of Port Moller.

\section{Citellus parryii: Ground Squirrel Citellus parryii ablusus}

Aleut (dialect?):Anúmuchgh (Osgood)

Russian, (Morzhovoi Bay): Everaskha (Wetmore)

Russian, Siberia: Ov-ráhs-ka (Buxton)

The type locality of this ground squirrel is Nushagak, and it inhabits the entire length of Alaska Peninsula and Unimak Island. The ground squirrels from the Barren Islands, between Kenai Peninsula and Afognak Island, also are this form, instead of kodiacensis. These ground squirrels were introduced on Unalaska Island by Samuel Applegate, of the U. S. Signal Service, and they became plentiful in their new home. Osgood (1904, p. 31) states that Applegate obtained the ground squirrels at Nushagak. In 1936, Chief Alexis Yetchmeneff told us much the same story, giving the date of the introduction as 1896 or 1897, 
but he thought that they had come from Unimak Island or Morzhovoi Bay. The chief was a little uncertain about the precise locality, and Osgood's statement was very definite, so it is likely that they came from Nushagak. In any case, it is the same subspecies.

According to Bill Dirks, chief of Atka Village, 10 or 12 ground squirrels were brought from Unalaska by Nick Bolshanin and were liberated on Kavalga Island, in 1920, where they increased in number. These two introductions, on Unalaska and Kavalga Islands, were the only ones that we learned about.

It is obvious that ground squirrels are able to cross narrow channels of water to reach adjacent islands. In 1925, I was informed that a ground squirrel had been seen swimming across a bay in Isanotski Strait. It came to a net, ran along on the floats for a distance, then swam on again.

When I arrived at King Cove on April 25, 1925, the ground squirrels were active, though it was not known how much earlier they had been out. On May 2, on Unimak Island, it was noted that they were sluggish and not much in evidence, which probably was due to the cold, disagreeable weather that prevailed at that time. Beals and Longworth, in 1941, saw the first ground squirrels on April 15. A trapper, Nick Kristensen, declared that occasionally he had seen ground squirrel tracks in January, presumably in warm spells of weather, but that he had dug them out in winter and found them fully dormant. Osgood (1904, p. 32) said "The animals were more or less active at Cold Bay as late as October 18, although comparatively cold weather was prevailing."

On May 25, 1925, on a plateau near Aghileen Pinnacles, I discovered that ground squirrels had burrowed up through the snow from their place of hibernation, and were living on this snowfield, sometimes wandering far from the burrow.

On June 3, a ground squirrel was observed pulling a big mouthful of grass into a den, no doubt for a nest for the young. Others were similarly engaged on subsequent days-the last observation being on June 8 .

Though the food of the ground squirrel is chiefly vegetation, they will eat animal matter. Several came to my camp on Alaska Peninsula to nibble at the fat on a bear hide stretched out to dry. The stomach of a specimen taken on Unimak Island May 8, 1925, examined by the Food Habits Research Section of the U. S. Biological Survey, contained the following items: 
21 caterpillars and lepidopterous pupae, 60 percent; 1 tipulid larva and 6 Bibio larvae, 4 percent; 2 beetles (Cryobius sp.); 1 ichneumonid and a spider, trace; 2 berries (Vaccinium sp.) 2 percent; a few leaves of Empetrum nigrum and other vegetable matter, 34 percent.

In 1937, Scheffer noted that on Kavalga Island the ground squirrels were cutting out the basal parts of Anemone narcissiflora and Ligusticum above the roots. In 1938, on Unalaska Island, he noted again that ground squirrels were eating out the center of basal parts of stems of the anemone, and he found wilted tops and outer layers of stems near the burrows.

On Kavalga Island, the blue foxes feed to some extent on ground squirrels, and on Alaska Peninsula the Alaska brown bears dig them out of their burrows.

\section{Citellus parryii nebulicola}

This form occupies the Shumagin Islands, and was observed on Nagai, Simeonof, and Koniuji Islands in this group.

\section{Citellus kodiacensis: Ground Squirrel}

Howell (1938, p. 103) considered this form distinct enough to be a full species. Its range is confined to Kodiak Island.

There is a peculiar circumstance connected with this species. Howell refers to Osgood's statement that the ground squirrels of Kodiak Island were introduced from North Semidi Island (Osgood obtained this information from a native). Petroff (1884, p. 139) states that "The animal [ground squirrel] does not exist on the island of Kodiak, but abounds on some of the smaller islands." And again, 1936, Petellin, of Afognak, informed us that ground squirrels occur on Chirikof and Semidi Islands and on Marmot Island, but none are on Kodiak or Afognak Islands. Yet, Howell records 45 specimens from Kodiak Island. There is a confusion here that should be cleared up when an opportunity is offered. During our short visits on Kodiak and Afognak Islands, in 1936 and 1937, we did not see the ground squirrel, but, in 1938, Scheffer obtained two secimens at Kodiai

\section{Tamiasciurus hudsonicus: Red Squirrel}

Tamiasciurus hudsonicus kenaiensis

Osgood (1904, p. 30) expressed the distribution of red squirrels very well when he said-

Red squirrels were found sparingly in the timbered regions. . . This scarcity of red squirrels is doubtless because they reach the extreme western limit of their range in this region. Specimens were taken at the following localities: 
Nogheling Portage, Lake Clark (near head), mouth of Chulitna River, Neekahweena Lake, south fork Chulitna River, Kakhtul River (near Malchatna junction). Howell gives the range of this form as reaching as far east as Yakutat.

It is to be expected that red squirrels range as far as the evergreen forest at the base of Alaska Peninsula. Presumably, this animal does not occur on Kodiak or Afognak Islands.

\section{Family CASTORIDAE}

\section{Castor canadensis: Beaver Castor canadensis canadensis}

Beavers are known to occur in the Bristol Bay region, and they are trapped there. McKay obtained a specimen at Kokwok on December 17, 1881. Osgood (1904, p. 32) found evidence of beaver at various points in the wooded region about the base of Alaska Peninsula. A. G. Maddren obtained a skull at Becharof Lake in October 1903. But the designation of the range of beaver in this country must await further field work.

Kellogg (1936, p. 37) found beaver bones in native midden remains from Kodiak Island. This would suggest that beavers occupied Kodiak Island at one time, though it is possible that these beaver remains might have been brought there by natives. At any rate, beavers were introduced on Kodiak Island in $1925 \mathrm{by}$ the Alaska Game Commission. In 1936, we found them to be well established there. In 1938, Scheffer noted heavy utilization of Sitka spruce by beavers in a pond near Kodiak; "Several hundred stumps 1-6 inches in diameter were seen around the shore. Peeled and unpeeled spruce sticks were used in the dam and lodge-We noted some utilization of willow and Teratrum.... The Salmonberry, though abundant, was apparently not utilized."

\section{Family CRICETIDAE}

\section{Synaptomys borealis: Lemming Mouse Synaptomys borealis dalli}

This mouse is confined to the basal parts of the Alaska Peninsula, and eastward. In Fish and IVildlife Service collections there are specimens from Lake Clark, Lake Iliamna, Chulitna River, Lake Aleknagik, and Kokwok, on Nushagak River. 
Lemmus trimucronatus: Lemming

Lemmus trimucronatus minusculus

As might be expected, this mouse ventures out a considerable distance on Alaska Peninsula. Its range is roughly shown by the following specimens in the Fish and Wildlife Service collection: 1 from Chogiung, 11 from Kakhtul, 24 from Kakhtul River, 20 from Chulitna River, 2 from Kokwok River, 2 from Kokwok, on Nushagak River, 6 from Nushagak, and 5 from Chignik Bay. The last mentioned show that further collecting will undoubtedly show a greater distribution on the more westerly part of the Peninsula.

\section{Dicrostonyx groenlandicus: Collared Lemming Dicrostonyx groenlandicus rubricatus}

Lemmings that, for the present, are referred to this subspecies are found throughout the length of Alaska Peninsula and Unimak Island. The few specimens we have from the western part of Alaska Peninsula and Unimak Island do not entirely agree in color with the typical rubricatus coloration.

These specimens suggest a strong tendency toward the gray pelage of stevensoni from Umnak Island. But in view of the variations in the characters of this lemming, and the small number of specimens at hand, it is difficult to state the relationships of the lemmings in this interesting region.

In 1925 , when I visited the west end of Alaska Peninsula and Unimak Island, an attempt was made to collect a good series of specimens, but the lemmings were scarce that year and only four were obtained on Unimak Island. They had their burrows on the higher tundra and among the lava beds.

\section{Dicrostonyx groenlandicus unalascensis}

The lemming from Unalaska Island was described in 1900 on the basis of skulls taken from owl pellets, and for a long time we knew nothing of its external characters. Many attempts had been made to trap specimens, and during our brief stops at Unalaska in 1936 and 1937 we tried to obtain some, but without result. We did find remains of these mice, however, in red fox droppings.

In 1931, Gilmore succeeded in trapping two specimens on Unalaska Island, and he has described them in detail (1933, p. 257). Apparently, this form, like the one on Umnak Island, does not acquire a white winter coat. 


\section{Dicrostonyx groenlandicus stevensoni}

This lemming, described by Nelson in 1929, is similar to $D . g$. unalascensis in that it is grayer in coloration than rubricatus, and does not become white in winter. It is quite common on Umnak Island, but no lemmings or other native mice are found farther west in the Aleutians.

In 1937, we were informed by Mr. Stacey, owner of the domestic sheep on Umnak Island, that about 1927, as nearly as he could remember, lemmings became abundant. "Millions," he said, and "so hard on the grass" that he feared they would "run him out of the sheep business." The following year the lemmings were scarce.

The dates were a little uncertain, but apparently it was about that time that a Captain Nelson, passing by Umnak Island, came upon big "schools" of lemmings out at sea.

A news account in the "Seward Gateway," dated April 18, 1932, possibly refers to this same incident, and may fix the date more accurately :

Trappers on Umnak Island, in the Aleutian group, report the recent migration of millions of lemmings from the island. It is said the lemmings traveled in immense multitudes, in a straight line to the seashore, apparently in obedience to some blind mechanical impulse of nature.

During the migration they moved onward in parallel columns. One trapper could not induce them to deviate from the straight line. The remarkable migration terminated in Bering Sea and ended in the drowning of all that survived the rough journey down from the higher regions of Umnak Island.

In his interesting book, "Fifty Years below Zero," Charles Brower mentions a striking lemming migration (1943, p. 123). It occurred in the latter part of May 1888, near Point Barrow. The lemmings came from the southeast, at first a few bands, then in "solid masses," until the "whole land was black with them." "The main body, moving seaward on a 10-mile front, took 4 days to pass the station. They kept on over the sea ice, finally leaping into the water and swimming offshore until drowned."

These are striking examples of lemming migrations entering the sea, in the historic manner of those of Norway. It illustrates an innate tendency of this rodent group as a whole, shared by the lemmings of Point Barrow (which turn white in winter), and their grayer and southernmost relatives of Umnak Island.

In the spring of 1924 I observed numbers of mice of the genus Lemmus in the edge of the shore ice at Hooper Bay, in the Yukon Delta region. Some of these were wet. Though no actual migration was noted, nor any massed concentrations, the circumstances 
suggested that this lemming may have in some degree the tendency that is so strong in Dicrostonyx.

\section{Clethrionomys rutilus: Red-backed Mouse Clethrionomys rutilus dawsoni}

The wide-ranging red-backed mouse is found practically throughout the whole length of the Alaska Peninsula, for Wetmore obtained a specimen at Frosty Peak, which is not far from the west tip of the peninsula. Furthermore, in 1925, I was informed that in the general vicinity of False Pass there was a "red" mouse, whose description accurately fitted that of Clethricnomys. No evidence of its presence on Unimak Island was obtained.

\section{Microtus oeconomus: Meadow Mouse Microtus oeconomus kadiacensis}

Osgood (1904, p. 34) discussed the spucimens from the base of the Alasika Peninsula, and remarked that-

All of these seem to be more similar to kadiaccnsis than to typical operarius, though to a slight extent they partake of the characters of each. From the examination of a very large series of both it appears that in color operarius and kadiacensis are absolutely alike, and that in cranial characters they are very closely related.

After careful and painstaking study of this material, it seems best to assign $M$. o. kadiacensis to Kodiak Island exclusively. It is incleed only slightly differentiated, but it may be recognized. It is possible that age has something to do with the character of the skulls from Kodiak, but they appear less robust than those of $M$. oeconomus operarius. The nasals are slightly different in shape, and the incisive foramen in skulls of kadiacensis tend to be a little shorter and wider.

\section{Microtus oeconomus operarius}

Aleut (dialect?): Asookitah (Wetmore)

Meadow mice inhabiting the Bering Sea coast, including Bristol Bay, the Alaska Peninsula, and Unimak Island, appear to be referable to operarius. Those found on Unimak Island do not appear to be quite typical, but the differences are so slight (if they really exist in comparable specimens) that there seems to be no sound basis for separating them.

Four specimens of meadow mice were obtained on Sanak Island. Curiously enough, these could hardly be said to differ from the mice on Unimak Island and the Peninsula, though they are 
more isolated than popofensis of the Shumagin group. The feet and tail of those from Sanak are dark (as on the Peninsula); the feet and tail are darker than on unalascensis and duskier than on kadiacensis, the latter being essentially browner. On the whole, this small series from Sanak Island cannot be differentiated from operarius, and should be included in that form.

Meadow mice were abundant on Dolgoi Island in 1937, but none were trapped, and they were plentiful on Sanak Island, where they are known as "gophers." In 1936, they were extremely abundant at Cape Pankof, Unimak Island, but they were exceedingly scarce on other parts of the same island. Some signs of mice were seen on Ushagat Island, in the Barren Island group, but no specimens were obtained.

In 1911, Wetmore found meadow mice to be scarce in the places he visited at the west end of Alaska Peninsula. In 1925, I found meadow mice to be fairly common on Unimak Island, but I found them to be scarce on the mainland and almost unknown in some localities. Specimens were obtained by finding limited colonies here and there. These mice preferred grassy locations, in contrast with the lemmings' choice of the mossy tundra, yet an occasional group could be found on the mossy tundra living in a stray patch of grass. In general, they were common about lagoons and the grassy lowlands, and could be found among lava rocks, particularly about the edge of rock masses, where grass generally occurs. These mice were fond of the beaches and the sand dunes, where the principal vegetation is the coarse wild rye (Elymus). In grassy places, where the snow had recently melted, the winter runways were conspicuous. The mice had a liking for the banks of little gullies, where they had numerous burrows-quite often, there were single burrows, at least there was a single entrance with a little pile of excavated dirt. In the sand dunes, the mice run about without well-defined runways; they have routes of travel among the coarse grass stems, as shown by their tracks, but the shifting sand prevents establishment of permanent paths.

On May 17, 1925, at St. Catherine Cove, several food caches were found in the sand dunes, just out of reach of the tide. A small external opening led into a tunnel that slanted downward about 1 foot beneath the surface, to the stored food. In one case, the cache consisted of about 17,560 seeds of beach sandwort, Honckenya peploides, together with dried stems and fragments of fruit capsules, and 403 large seeds of a composite, as well as a trace of Elymus (bits of stem and leaves and fruit). In another cache, 2 feet distant, there were only undetermined roots-both 
caches totaled about half a peck. The shifting sands must have coverer those openings repeatedly, therefore the mouse undoubtedly found the spot by a sense of location and scent.

At Urilia Bay, we found another cache that was made up of bases of stems of undetermined plants and roots.

\section{Microtus oeconomus popofensis}

This is another slightly differentiated form, occupying the Shumagin Islands. Specimens have been obtained on Popof and Unga Islands. This mouse is, of course, very similar to operarius, but the skull appears to have a more slender rostrum, with a little longer and definitely wider incisive foramen. Judging from specimens at hand, the underparts of popofensis are more tawny than in the specimens from the mainland.

In 1936, these mice were extremely abundant at one place on Unga Island, near a bird colony. The ground was honeycombed with burrows, and mice were seen running about occasionally.

They are known in the Shumagins as well as on Sanak Island, as "gophers," while shrews are called "mice."

\section{Microtus oeconomus amakensis}

Strangely enough; this form, which has the most restricted range, is one of the best defined. The skull differs from all other mice in this species, particularly in the occipital region-the flat occipital surface contrasts with the convex surface in the other forms. In this feature, the skull of amakensis suggests the appearance of skull of $M$. o. kamtschaticus, though the series of the latter is small and not entirely comparable. Also, the incisive foramen of amakensis is short and blunt, contrasting with the attenuated foramina in other forms. The feet and top of tail are paler than in the other forms.

It is puzzling that this form, which is confined to small Amak Island located only 14 miles north of the coast of Alaska Peninsula, is more distinct than the mice on other islands that are equally as far, or farther, from the mainland. It is possible that unfavorable transportation aspects have tended to isolate this island, thus emphasizing a distinct for'm.

In 1925, when I visited Amak Island, meadow mice were extremely abundant. Runways were everywhere, in the grass, underground, under driftwood, among old whale bones on the beach, as well as among the lava rocks and moss on the higher portions of the island. When walking over the low ground, we 
often broke through into a maze of underground burrows. When setting traps, I could hear the traps snapping a short distance behind, as the mice were already being caught. Nany of those caught were young mice, and there was a remarkable preponderance of females.

Several mice were infested with ticks, Ixodes angustus, sometimes three or four on one mouse. Many others were covered with mites, a gamasid, probably Hacogamasus sp.

There were numerous beetles in the mouse runways, some of which fed on the trapped mice. One of these was the common carrion beetle, Necrophorus sp., and two others, Nebria sp. and Scaphinotus marginatus, were obtained there, though these latter were not seen feeding. Dung beetles, Aphodius sp., and rove beetles gathered at the anus of dead mice, attracted by the traces of dung.

Such an aggregation of more or less parasitic invertebrates in a dense mouse population could be an important element in the cyclic behavior of these rodents.

At the time of this heary peak population on Amak Island, both lemmings and meadow mice were scarce on Alaska Peninsula. And none of the beetles, mentioned above, were noticed that summer, either on Alaska Peninsula or on Unimak Island.

\section{Microtus oeconomus unalascensis}

This form is more readily distinguished from $M$. o. operarius than most of the other subspecies. The skull shows wider nasals, the convexity of the occipital plane is greater, and apparently it is a somewhat larger animal.

This mouse occupies Unalaska Island, and a specimen from nearby Unalga Island is referable to this form. There is no knowledge concerning its presence on Akutan and Akun Islands, nor on other smaller islands in that vicinity. Meadow mice apparently are not found on Umnak Island; at least, we obtained only lemmings when we trapped there. Therefore, Unalaska may be the westernmost point reached by Microtus in the Aleutians.

On Unalaska Island, in 1936, I found meadow mice in the characteristic grassy meadow habitat, just as on Alaska Peninsula and Unimak Island. And, in 1925, Sterenson stated that in times of heavy mouse population on Unalaska Island, numerous beetles had ruined mouse specimens in the traps, just as they did on Amak Island. 


\section{Microtus pennsylvanicus: Meadow Mouse Microtus pennsylvanicus drummondii}

This form of mearlow mouse barely enters the area here under discussion. There are specimens in the Fish and Wildlife Service collection from Lake Clark, Kakhtul River, and Nushagak. Probably, the Drummond meadow mouse does not range much farther west than the base of Alaska Peninsula.

\section{Ondatra zibethicus: Muskrat \\ Ondatra zibethicus zalophus}

Muskrats are common in the Bristol Bay region and the eastern part of Alaska Peninsula. Specimens have been taken in many localities of this area, including one as far west as Ugashik, which was obtained by C. L. Mckay in 1881. There is a series of specimens in the Fish and Wildlife Service collection from Becharof Lake, including the type. In 1925, I was told by residents of False Pass that muskrats are not found farther west than Port Moller, the implication being that they do occur in that locality. This is not supported by specimens at present.

Stevenson reported that L. A. Levigne, "a few years ago" (before 1920), brought some muskrats to Unalaska and turned them loose in a fresh-water pond near Captain's Harbor. "They were observed the next spring but have not been seen since, may have starved, or possibly have migrated to some other location."

About 1925, the Alaska Game Commission introduced muskrats on the Kodiak-Afognak group of islands, and they have become established. Scheffer obtained three specimens on Afognak Island in 1938.

Apparently there are no muskrats on Nunivak Island, in Bering Sea, and the distribution here recoided suggests that muskrats require a habitat that is associated with vegetation found in, or near, forested areas. They do not thrive on islands or other areas where the vegetation is low to the ground.

\section{Family MURIDAE}

Mus musculus: House Mouse

Mus musculus domesticus

Presumably, the house mouse has been introduced in most of the settlements of southwestern Alaska, and we made no particular effort to study its distribution. In the Aleutian Islands proper, where native rodents are nearly always absent, exotic introduc- 
tions have a peculiar interest, because of possible adaptation to a rodent-free environment. We do not have specific information for Unalaska Island, where presumably the house mouse must have been introduced in the settlement. In the western, rodent-free islands we took pains to study this question and found a single record-on Kiska Island. In the summer of 1937, signs of mice were found in a cabin on Kiska Island and many traps were set. A single house mouse was caught, possibly the only one on the island, though since the occupation of the Aleutians by military forces it is to be expected that mice and rats have been brought to this and other islands.

The mouse from Kiska evidently came from Seattle in freight shipments. It proved to be Mus musculus domesticus, rather than a form from the Asiatic side. Schwartz and Schwartz (1943, p. 66) have shown that the West European house mouse, from which our American commensal mice were derived, is $M . m$. domesticus, and not $M, m$. musculus as heretofore assumed.

\section{Rattus norvegicus: House Rat}

\section{Russian: Krisi}

Rats were introduced in the Aleutian Islands during the Russian occupation. Rat Island had received its name from the Russians as early as 1790 , hence the rats must have arrived at an earlier date. Rats also are found at Unalaska and at Atka. At Atka Village, the rats were very troublesome. The natives could not raise gardens at Atka because of these pests, so they crossed over to rat-free Amlia Island and planted their gardens. The rats have managed to cross over to the little islands in Nazan Bay, and they may soon invade Amlia Island (if they have not already done so since the military occupation of that island). Rats are reported from Kiska by G. A. Amman (correspondence). They were not there before World War. II. It is probable that rats have been introduced to Attu, Amchitka, and Adak as a result of military operations.

In addition to Atka Village, rats have become feral on both Atka and Rat Islands. On Atka Island, we found their l'unways in the heavy grass, and we saw cut plant stems, which were much like those of Microtus, but longer. Burrows were found in some places. In the spring, we found large areas where the rats had dug up the bulbs of Fritillaria camschatcensis, and Scheffer found that the rats had eaten the basal parts of the stems of Anemone 
narcissiftora, much in the manner of ground squirrels on Unalaska and Kavalga Islands.

On Rat Island, these rodents were confined to the beaches in, or near, the fringe of heavy vegetation. They found a convenient refuge among the boulders on the beach and proved to be extremely wary. The interior of this island supports a very short type of vegetation, not at all suitable for cover-hence the choice of the shoreline by the rats.

To what extent blue foxes prey on rats is not certain. These rodents are extremely wary and alert, and the foxes may not find them easy hunting. Bald eagles get an occasional one, but rats had tumneled into the peatlike foundations of two eagle's nests on rock pinnacles on Rat Island and were living there below while the eagles were raising their young.

On one occasion, a short-eared owl had appeared at Atka Island, far out of the range of native rodents, and it was promptly shot. When we found the remains about a year later, in 1936, we were able to determine that the stomach contained parts of a rat.

\section{Family ZAPODIDAE}

\section{Zapus hudsonius: Jumping Mouse Zapus hudsonius alascensis}

Jumping mice occur throughout the length of Alaska Peninsula. There are specimens from Lake Aleknagik, Chulitna River, Lake Clark, Lake Iliamna, Kokwok, Nushagak, Chignik, Frosty Peak, and Izembek Bay.

I obtairred a male specimen at Izembek Bay on June 23, 1925, in the grass at the edge of a pond. At that time, I learned that jumping mice are found on Unimak Island. Several people had observed them there; 1 man, in the course of some excavation work, caught 4 of them. Harry Wilson, on Ikatan Peninsula, had one of these mice in a tin can, but when I arrived there a few days later, the mouse had escaped. In 1941, Beals and Longworth reported that Nick Kristensen had found one of these mice at his house at False Pass, where several others had drowned in a shallow dug well, and Arthur Neuman had reported them as being plentiful about Ikatan Village several year's previously. In these instances, though no specimens were obtained, the mouse is easily identified, and there is no reason to doubt the reports. Therefore, we may conclude that Unimak Island is occupied by Zapus. 


\section{Family ERETHIZONTIDAE}

\section{Erethizon dorsatum: American Porcupine Erethizon dorsatum myops}

Morzhovoi Bay: Noon (Wetmore)

Porcupines are found along the entire length of the Alaska Peninsula. Osgood (1904, p. 38) suggested that their fondness for the aments and young leaves of the alders may cause them to wander some distance beyond the forest proper. In fact, recent records prove that some of them live several hundreds of miles beyond the forest. At Izembek Bay, in 1925, I found alder cuttings that had been made by porcupines in winter. Evidently, in the summer they were living on green herbaceous plants.

In 1911, near Frosty Peak, Wetmore observed that a porcupine had shuffled along the beach for more than 2 miles before turning inland, evidently nosing around bunches of kelp.

So far as we know, the porcupine is not found on Unimak Island.

\section{Family OCHOTONIDAE}

\section{Ochotona collaris: Collared Pika}

Apparently, pikas are rare at the base of Alaska Peninsula, though True (1886, p. 221) quotes from McKay's notebook: "Said to be very plentiful in the mountains. The Indians in their vicinity have a superstitious dread about killing them, and can not be hired to do so."

McKay obtained two specimens in the Chigmit Mountains. We have no other specimens from this region.

\section{Family LEPORIDAE}

\section{Lepus americanus: Varying Hare Lepus americanus dalli}

Osgood (1904, p. 39) found these hares to be abundant about Lake Clark and along Chulitna River. Specimens have been taken at Nushagak, Lake Aleknagik, Ekwok, and Kakwok River. They probably do not range far beyond the timbered areas.

Varying hares were introduced to the Kodiak-Afognak Islands by the Alaska Game Commission and are now established there. The introduced stock was obtained from territory along the Alaska Railroad on the mainland. 
Lepus othus: Arctic Hare

Lepus othus poadromus

Russian: Zaisch (Buxton)

Siberian (Chukchi?), Okhotsk, Gichiga, Marcova: Oo-skon (Buxton)

Arctic hares are found throughout the Alaska Peninsula and Bristol Bay region (which is the principal range). So far as we know, none are found on Unimak Island. There is a specimen in the Fish and Wildlife Service collection, which is understood to have been collected by Kleinschmidt on June 9, 1913, on Popof Island-which is rather surprising. We have no information of its presence on the Shumagins.

In 1936, we found abundant signs of Arctic hares at Snag Point, near Nushagak, and learned that they live in the alder thickets. In 1925, I observed them at the west end of Alaska Peninsula and obtained a specimen. There, too, they inhabited the thickets, and in summer, when the vegetation was leafed out, they were next to impossible to see, but they came out of the thickets in the evenings to feed.

\section{Family CERVIDAE}

\section{Cervus canadensis: Elk (Wapiti) \\ Cervus canadensis roosevelti}

The wapiti is not indigenous to Alaska, but it was introduced on the Kodiak-Afognak Island group. At present, the animals are mostly on Afognak Island, though individuals have crossed over to Whale Island and Derenof Island. The original animals were obtained from the Olympic Mountains in Washington. These elk appear to be thriving in their new environment.

\section{Odocoileus hemionus: Black-tailed Deer Odocoileus hemionus sitkensis}

The Sitka black-tailed deer was introduced on Long Island, a rather small island not far from Kodiak. This deer became extremely abundant before 1935, then it began to die. A. W. Bennett, who uses the island for fur farming, found many carcasses, and he noted that raccoons, which he had placed on the island, also were dying during that period. The surviving deer were very poor. 


\section{Alces alces: Moose Alces alces gigas}

Russian: Los (Buxton)

Moose are found throughout the basal part of Alaska Peninsula, where Osgood and others noted their presence in the wooded regions. Griggs (1922, p. 314) found them in the Katmai Region. Osgood (1904, p. 29) wrote:

Moose are scatteringly distributed on the Alaska Peninsula and extend farther west than has been generally supposed. In a native's camp on the Ugaguk River I saw fresh meat and pieces of the skin of a moose which was killed about October 1 on the upper waters of the King Salmon River, a northeastern tributary of the Ugaguk. One of our guides, from Igagik, said that he killed two small moose near the Ugashik Lakes in the fall of 1901. During the spring of $1903 \mathrm{~A}$. G. Maddren received reports that nearly 20 moose were killed by natives in the vicinity of the Naknek River. A moose was said to have been killed several years before as far west as Port Moller, but no confirmation of the report could be obtained.

It is not surprising to find moose beyond the limits of coniferous forest, for this happens in many parts of their range. Stragglers could easily find their way as far west as Pert Moller.

\section{Rangifer arcticus: Barren Ground Caribou Rangifer arcticus granti}

Atka: Itkayech (Saur)

Unalaska: Ithayok (Saur)

Morzhovoi Bay: Ikthinkh (Wetmore)

Grant caribou range throughout the Alaska Peninsula and Unimak Island. It is said that they were on Unga Island, in the Shumagins, in considerable numbers at one time (Allen 1902, p. 127), and caribou were reported on Deer Island. In July 1925, I found a caribou skeleton on Amak Island, 12 or 14 miles north of Alaska Peninsula. The bones were very old, partly buried in moss and other vegetation. Part of an antler from another individual also was unearthed. Kellogrg (1936, p. 37) found caribou bones in midden material from old village sites on Kodiak Island. In primitive times, it is evident that caribou were more plentiful on Alaska Peninsula and Unimak Island and "overflowed" to other islands, possibly to more islands than is shown by these meager records.

Jochelson (1925, p. 36) found a "reindeer" antler spoon in a village midden on Umnak Island. This spoon, or the antler, may possibly have come from Unimak Island in trade.

As reported elsewhere (Murie 1935, p. 59), caribou of Alaska Peninsula were at one time more closely associated with main- 
land herds by way of the Bristol Bay region. This is suggested by Osgood (1901, p. 28) who mentions particularly the Lake Clark and I take Iliamna district as caribou country. Johnson $(1886$, p. 65) saw them on the tundra near Nushagak in April 1886, and McKay had obtained specimens there in 1882 .

The field reports and conversations of Donald Stevenson, fur warden in the Aleutians from 1920 to 1925, revealed great fluctuations in the numbers of caribou on Unimak Island. In the early eighties and nineties, there was much caribou hunting by sea otter hunter's, with the result that caribou were greatly reduced in numbers about 1894. When only a few hundred remained, hunting decreased and, as caribou were more plentiful on the peninsula at that time, annual migrations brought an influx of new stock which raised the herd to "full carrying capacity" of the island by 1905 .

Stevenson said that no large migrations across Isanotski Strait have taken place since 1908. A few crossed since then, in both directions, but the last known crossing was made by 46 caribou that passed over near St. Catherine Cove in December 1916. He said that the caribou began to decline in numbers after 1908, but that they had been increasing again more recently (as of 1925). At that time (1925), he had made a tentative estimate of 7,000 to 10,000 animals. After my season's work, I accepted the lesser figure as the more probable one.

On Unimak Island, Urilia Bay seemed to be one of the favored caribou habitats. On April 29, we saw more than 40 caribou on the grass flats around the lagoon, and, a few days later, 51 were counted from one point. During this period the caribou subsisted chiefly on dead vegetation, except for Heracleum lanatum and Coelopleumum gmelini, two robust plants that were just appearing in green rosettes - these plants were eagerly eaten by the caribou.

Winter's often are stormy and disagreeable on Unimak, and Stevenson suggested that a series of severe winters might have been one cause of caribou fluctuations. In 1925, there were reports of finding many dead caribou, and I found a number of skeletons. In one instance, the animal (a bull) obviously had cied in a resting attitude. On May 8, I found a diseased yearling bull that was blind in both eyes.

As there has been public concern in recent years about the increase of wolves, it is important to note that wolves were scarce during the periods of decline of caribou on Unimak Island in those earlier years, and at the time that so many caribou died, in 1925, there were no wolves. Obviously, much additional investigation is necessary for an understanding of the caribou. 
In 1925, we had estimated that there were about 5,000 caribou on Alaska Peninsula, which was a decline in numbers since earlier times. Wolves were not a problem at that time. Speaking at the Alaska Science Conference at Washington, D. C., on November 10, 1950, on "Predator Control Problems in Alaska," Dorr D. Green reported that "The Alaska Peninsula, which once supported hundreds of thousands of caribou, has a herd that is now reduced to about 2,500 animals, of which 2,000 are probably reindeercaribou hybrids."

In a letter of January 1959, David L. Spencer, supervisor of Kenai National Moose Range, wrote me concerning caribou on Unimak Island:

For a long time there were none, but about 3 years ago we found 14 during a rather incomplete survey. Last winter Jones and Burkholder estimated 150 on the island. . . Apparently there is a movement back and forth over False Pass at the end of the Peninsula. We do know this occurs, as it has been witnessed.

The population of caribou at the end of the Alaska Peninsula has for a long time been low but appears to be building up somewhat now. . . 5,000 animals would be a rather rough current estimate of the entire Peninsula herd.

Whatever the actual numbers in early times, the fact that today the caribou have interbred so extensively with the domesticated reindeer spells the doom of Rangifer arcticus granti as a subspecies, perhaps as a wild game animal.

\section{Rangifer sp.: Reindeer}

\section{Russian: O-láin (Buxton)}

Reindeer herds have been introduced in the Bristol Bay region, and, in more recent years, they have been placed on Alaska Peninsula. When one considers the scarcity of lichens, and the inevitable hybridization with reindeer, it becomes obvious that the native caribou undoubtedly will be supplanted.

Many years ago, reindeer had been placed on Umnak Island. They were not serving any useful purpose and were finally sold by the Federal Government to the owners of domestic sheep on the island. The sheep owners wished to kill off the reindeer because they competed for forage with the sheep. However, the reindeer had not been entirely eliminated as late as 1937, and we were informed that the principal use being made of them was as fox bait in trapping operations.

Reindeer also had been placed on Atka Island. As long as these animals remained close to the village, the Aleuts utilized them, but 


\section{3:3 NORTH AMERICAN FAUNA 61, FISH AND WILDLIFE SERVICE}

when the reindeer moved to more-distant parts of the island, the natives lost interest.

The Government teacher would sometimes organize an expeclition to procure reindeer meat, but, on the whole, the Aleuts preferled fishing:

Accolding to the Government teacher stationed on Atka Island in 1937, some of the reindeer appeared to be diseased and very pool. Some had "pus in the joints" and some had lesions above the hoofs.

It must be concluded that reindeer have proven to be a failure in the Aleutian district and that, while they are able to subsist to some extent, the forage in this area is not suitable for intensive reindeer raising.

\section{Family BOVIDAE}

\section{Oris dalli: Dall Sheep (White Sheep) \\ Oris dalli dalli}

Russian: Dee-ke bar-an "Wild Sheep" (Buxton)

$$
\text { Osgood (1904, p. 30) says- }
$$

White sheep are found in small numbers in the mountains between Lake Clark and Cook Inlet, and are probably more or less continuously distributed from there northward along the Alaska Range. They are not reported from the mountains near Iliamna Bay, so it is probable that they do not occur farther west than the vicinity of Lake Clark.

There are two specimens in the National Museum obtained by Mckay from the Chigmit Mountains (which proves to be an indefinite locality designation, meaning somewhere in the mountains back from Nushagak).

\section{Family HYDRODAMALIDAE}

\section{Hydrodamalis gigas: Steller Sea Cow}

Russian: Morskaia korova (Steller)

Our knowledge of the sea cow depends mainly on the account of Steller, who, in the disastrous winter when Bering's expedition was wrecked on Bering Island after discovery of Alaska in 1741, had ample opportunity to study this animal at first hand. The sea cow furnished food for Bering's party, as well as for other expectitions that used the Commander Islands as a starting point for Alaska. It was exterminated by 1768.

There has always been a question whether this animal had 
ever occupied the Aleutian Islands. Stejneger (1883, p. 84) said Wosnessenski had obtained a rib of a sea cow from Attu Island, and, in conversation, Stejneger expressed the belief that sea cow remains might be found on Agattu Island.

Goode et al. (1884, p. 136), wrote as follows concerning this find :

Wosnessenski found a rib of the animal on Attu, the last island of the archipelago, but as Brandt suggests, it may have been derived from a Rhytina washed thither by the waves. Mr. Lucien Turner kindly informed me that an aged Aleut woman stated that Rhytina had been seen at Attu by her father, but such testimony is, perhaps, not altogether satisfactory.

Thus, we have some evidence that the sea cow may have occurred on the westernmost Aleutian Islands, and it would be extremely interesting to have identification of bones from old Aleut village sites. To date, studies of such midden material have not revealed the presence of sea cow remains, and, on the whole, it is likely that this animal never inhabited these islands except. as an accidental straggler.

\section{Family BALAENIDAE}

\section{Eubalaena sieboldii: Pacific Right Whale}

Aleut (Umnak?) : Kulámax (Jochelson)

This whale ranged in the Aleutian waters in former times, but since whales of all kinds have been destroyed so extensively, some species have become exceedingly rare, and the right whale is seldom, if ever, seen any more. Osgood (1904, p. 27) mentions a stranded whale between Kanatak and Wide Bay in 1902, which he tentatively assumed to be the right whale. True (1904, p. 270) quotes Pechuel to the effect that a right whale was killed near the Aleutians. Birkeland (1926, p. 26) stated that he knows of only two right whales that were killed at the Akutan whaling station, dating from about 1914 (he has a photograph of one of the two whales mentioned). We saw none of this species on our expeditions to the Aleutians.

\section{Balaena mysticetus: Bowhead Whale}

Aleut (Umnak?) : Ugamáxcax' (Jochelson)

Essentially, this is an Arctic whale that came into Bering Sea and visited the Kuril and Aleutian Islands, but it has become rare in the Aleutians. We obtained no certain records of it during our visits. 


\section{Family ESCHRICHTIDAE}

\section{Eschrichtius glaucus: Gray Whale}

The gray whale is known to range northward through Bering Sea, but we did not identify this species on any of our trips. It should be explained that no one in our party felt himself exper't enough to identify many of the whales that were seen. The Captain and some of the ship's crew had had some experience with whales, but they were unable to identify many that were seen. Under such circumstances, our observations were exceedingly sketchy, except for the more-easily identified species. Turner (1886, p. 200) reported seeing several gray whales in Unimak Pass in June 1878.

\section{Family BALAENOPTERIDAE}

\section{Balaenoptera physalus: Finback Whale}

Aleut: Chi kakh' lukh (Turner was uncertain about the application of this name.)

The finback is still present in considerable numbers in the Aleutians, though it is not as plentiful now as in the past. We saw several and they were being taken in 1937 at the whaling station on Akutan Island. At the latter place, we obtained data on several fetuses that had been collected by S. Halvorsen, who had been stationed there by the Coast Guard. This data follows:

Finback fetus, female, collected June 9, 1937, latitude $53^{\circ} 25^{\prime}$, longitude $164^{\circ} 39^{\prime}$. The fetus was 4 feet long; the mother was 67 feet long.

Finback fetus, female, collected June 10, 1937, latitude $53^{\circ} 22^{\prime}$, longitude $166^{\circ} 30^{\prime}$. The fetus was 3 feet 4 inches long; the mother was 60 feet long.

Finback fetus, male, collected July 28, 1937, latitude $54^{\circ} 06^{\prime}$, longitude $166^{\circ} 45^{\prime}$. This fetus was 16.7 inches long; the mother was 67 feet long.

\section{Balaenoptera borealis: Sei Whale}

The sei whale was observed at various times among the Aleutian Islands; identification was made by Captain Sellevold. It was recorded various times at Segula and Atka Islands and in Unimak Pass, and at Atka Island a whale spent most of a day cruising about in the harbor and often came near the ship. A few motion pictures of it were obtained.

On September 3, 1938, Scheffer recorded 2 sei whales near the ship in Umnak Pass, and later in the day, he noted 3 more.

In 1937, the United States Bureau of Fisheries reported the 
capture of a sei whale among 376 whales taken in Alaska that year.

\section{Sibbaldus musculus: Blue Whale}

We did not definitely identify a blue whale on our trip. On July 14, 1937, Captain Sellevold believed a number of whales seen spouting near Unalaska were blue whales. A number of this species were taken by the Akutan whaling station that summer, and we were given the head of a fetus for a specimen.

\section{Megaptera novaeangliae: Humpback Whale}

Aleut (dialect?): Chi thukh (Turner was uncertain about the application of this name.)

Humpback whales were seen at various times. In 1937, we recorded 1 at Agattu Island, 1 at Semichi, at least 4 (possibly more) at Kiska, and 3 at Amchitka. Sometimes this whale would dive straight down in shallow water, practically stand on its head, then fall over with a resounding splash of its flukes. This action was seen often.

\section{Family PHYSETERIDAE}

Physeter catodon Sperm Whale

Aleut (dialect?): Agthá gik (Turner)

Sperm whales were very scarce. One was definitely identified near Kiska Island on June 3, 1937, and they were being taken at the Akutan whaling station. Sperm whales are not difficult to identify, and we felt that most of our identifications were accurate.

\section{Family DELPHINIDAE}

\section{Grampus rectipinna: Pacific Killer Whale}

Attu: $A^{\prime}$-ga-ghi-ach

Atka: $A h^{\prime}-g a-l o h$

Ah'-ga-luch

Aleut (dialect?) : Aǵ-lyuk (Turner)

In the Atka dialect, the name is very similar to that of the fulmar. The difference appears to be one of syllable length, or stress, which was not possible to record satisfactorily.

The killer whale of the Aleutian district clearly shows the white elongated spot posterior to the eye and the gray patch posterior to the dorsal fin. These marks were noted on every 
killer whale that we saw closely enough for identification. It is of interest to note Turner's remarks on the killers (1886, p. 198) :

The Aleuts speak of the killer as Aǵ-lyuk; and, to another species, which they recognize, they give the name Um-gu-likh. I have seen what I believe to be 2 species, and perhaps 3 species, of the so-called "killers," swimming together, all moving in the same direction.

Dall (1870, p. 579) lists two killers for Alaska, Orca ater, and Orca rectipinna. We did not obtain the impression of more than one kind of killer whale, but our observations could not be conclusive on that point.

The killer whale is common along Alaska Peninsula and throughout the Aleutians. We found a dead one on Agattu Island. We generally saw them in small groups, or alone, but as many as 25 in a school were recorded. The most common number for a group was three. Ernest P. Walker (unpublished notes) has recorded some large schools of killer whales. On September 16, 1913, in Icy Straits, he saw a school of 500 or more; on July 19, 1915, near Port Armstrong he saw another school of about 300 . He quotes Captain Louis L. Lowe to the effect that he had seen schools of 400 to 1,500 off the southwestern end of Kodiak Island, and, in April 1922, he saw a school of about 1,000 off Ugak Island near the Kodiak coast. "They were apparently headed northward and were no doubt keeping close company with the fur seals."

Again, Walker says-

Captain Haynes says that on only one occasion has he seen a large school of killers or thrashers. This was early in June near Unimak Island, where he encountered a remarkable assemblage of various whales, seals, and other life feeding and many killers were present. There was a great deal of fighting accompanied by leaping.

Turner (1886, p. 198) reported seeing as many as 150 at one time, in the Aleutians.

Such large aggregation suggest a migration, and, as Walker says, they probably are rare occurrences.

We frequently found killer whales cruising along the borders of kelp beds. On one occasion, a killer passed directly under our dory - a rather disconcerting experience. We obtained no direct evidence of their food habits, but Turner saw a killer whale kill a nearly full-grown sea lion at Bogoslof Island, and, at Tigalda Island, he watched two killers attacking a large finback whale. He had also seen them following schools of smelt, which suggests a diet including fish. 


\section{Globicephala scammonii: Pacific Blackfish}

Our information on this dolphin is very meager. Dall (1869, p. 333) reported it in Bering Sea, and Osgood (1901, p. 25) reported it in the Queen Charlotte Islands. We found no evidence of its presence in the Aleutians.

\section{Lissodelphis borealis: Right-whale Porpoise}

This species is rather vaguely listed as ranging into Bering Sea. Turner mentioned it briefly in his report on the Aleutians, and he mentioned native names for some porpoises which he was unable to identify, but he had no positive information to offer on this form. I have been unable to find precise information for the Aleutian district.

\section{Lagenorhynchus obliquidens: Pacific Striped Porpoise}

Aleut (dialect?): A-ga-makh'-chikh (Turner)

Turner (1886, p. 197) reported that he saw a number of dolphins sporting about the ship at Amchitka Island, and he described them thus:

These creatures were only about eight or nine feet in length and had numerous markings, stripes, or bars, along the sides and throat. These markings were two or three inches wide and of a sulphur-yellow color, while the back and sides were bluish-black.

Two or three persons on the vessel declared they had seen the same species in the waters of the Japan coast, and gave the name Japan Dolphins to those seen near Amchitka. I do not know to what species they should be referred.

We saw none of these dolphins in the Aleutian area, but Turner's description suggests the striped dolphin.

\section{Phocoena vomerina: Pacific Harbor Porpoise}

Aleut (dialect?): A-lá gikh (Turner)

Russian: Svinka (Turner)

Osgood (1904, p. 27) records two skulls obtained at Kanatak by Maddren in the fall of 1903. Preble and McAtee record a number of specimens from the Pribilof Islands. True (in Jordan 1899, p. 353) reported-

A few bones of a small porpoise, apparently of this species, were picked up at St. Paul June 3, 1890, and two small schools were seen in the harbor at Unalaska May 20 and 21, the same year. A specimen of this species was obtained by Mr. Charles H. Townsend at Captain's Harbor, Unalaska, August 17, 1895.

Turner $(1886$, p. 200) stated that he saw these porpoises in the 
Aleutians and near Kodiak, and he said that they were common in Captains Harbor, at Unalaska, where they came up close to the wharf. He stated that two were caught on hooks baited for codfish.

On May 23, 1937, among the Shumagin Islands, we saw 2 of these porpoises near our ship, and, on August 13, 1937, 3 were seen in the harbor at Atka Island.

\section{Phocoenoides dalli: Dall Porpoise}

The type locality for Dall porpoise is near Adak Island, but we did not find them plentiful in the Aleutians. On July 20, 1936, a school of these porpoises was playing about the ship, between Kasatochi and Atka Islands, and a few were seen in the Aleutians in 1937. On August 8, 1938, Scheffer recorded two porpoises north of Yunaska Island. We found them to be much more plentiful in the waters of southeastern Alaska. Walker (unpublished notes) likewise found them scarce in southwestern Alaska, and, during a 3-month cruise in the summer of 1922 , in a small boat between Juneau and Unalaska, he saw these porpoises only once. He wrote that Captain T. S. Haynes did not recall having seen dalli in Bering Sea and said they are not plentiful along Alaska Peninsula.

Walker found that one male weighed 199 pounds, and he measured the length of four specimens as follows: male, 1,760 $\mathrm{mm}$. ; female, $1,575 \mathrm{~mm}$.; female, $1,817 \mathrm{~mm}$; and another (sex unknown), $1,880 \mathrm{~mm}$.

The stomach of one of Walker's specimens contained only the flesh and beaks of squicls. One contained mainly squid, with a trace of fish; one contained squid and a few bones of fish; and another contained a few squid beaks and at least $1 / 2$ pound of small fish.

\section{Family MONODONTIDAE}

\section{Delphinapterus leucas: White Whale (Beluga)}

Aleut (dialect?): Há-thakh (Turner)

Russian: Bi-loo-hah (Buxton)

We saw no white whales on any of our expeditions. Osgood (1904, p. 27) wrote:

White whales or belugas often came into the mouth of the Nushagak River or the neighboring small bays in pursuit of salmon, on which it is said to feed cuite extensively ... Belugas are said to occur also on the south side of the ninsula, about the mouth of Cook Inlet. 
Kellogg (1936) found bones of this whale in miclden material from ancient village sites on Kodiak Island.

\section{Family ZIPHIIDAE}

\section{Berardius bairdii: Baird Beaked Whale}

This species is generally spoken of as ranging in Bering Sea, and Turner mentions it tentatively for the Aleutian Islands. We did not obtain evidence of its presence in the Aleutians, nor for the waters of southwest Alaska.

\section{Mesoplodon stejnegeri: Stejneger Beaked Whale}

This rare whale was described from Bering Island, and it could be expected to occur in the Aleutians. The Ziphiidae have seldom been observed, and we have very little information about them.

\section{Ziphius cavirostris: Cuvier Beaked Whale}

This is another whale that may occur in the Aleutian district, but we did not identify any. True (1910, p. 2) lists a specimen found in Kiska Harbor in September 1904. Walker (unpublished notes) mentions descriptions of whales by Captain Earling taken off the southeast Alaskan coast, which suggest both Berardius bairdii and Ziphius cavirostris. The Aleuts of Attu Island assured me that there were "many other" whales in the Aleutians, but the difficulty of describing the different species to the Aleuts precluded any satisfactory listing of names.

On several occasions, we found remains of unknown whales on beaches. Further work is necessary to clarify whale distribution in the Aleutian Islands. 


\section{References}

AIDRICH, JOHN W.

1946. Speciation in the white-cheeked geese. Wilson Bulletin, vol. 58, No. 2, pp. 94-103.

1948. Additional light on the races of the dowitcher. Auk, vol. 65, No. 2, pp. 285-286.

Allan, Alexander.

1910. Hunting the sea otter. Horace Cox Press, London, England. Allen, J. A.

1870. The eared seals (Otariadae), with detailed descriptions of the North Pacific species With an account of the habits of the northern fur seal (Callorhinus ursinus), by Charles Bryant. Bull. Harvard Museum Comparative Zoology, vol. 2, No. 1, pp. 1-108.

1878. The geographical distribution of the mammalia, considered in relation to the principal ontological regions of the earth, and the laws that govern the distribution of animal life. U.S. Geological and Geographical Survey, Bulletin, vol. 4, No. 2, pp. 313-377.

1880. History of North American pinnipeds: a monograph on the walruses, sea lions, sea bears, and seals of North America. U. S. Geological Survey Misc. Publ. 12, 785 pp.

1893. The geographical origin and distribution of North American birds, considered in relation to faunal areas of North America. Auk, vol. 10 , No. 2, pp. 97-150.

1898. The sea otter. A review of C. L. Hooper's "Report on the sea otter banks of Alaska." American Naturalist, vol. 32, pp. 356-358.

1902a. A new bear from the Alaska Peninsula. Bull. American Museum Natural History, vol. 16, pp. 141-143.

1902b. A new caribou from the Alaska Peninsula. Bull. American Museum Natural History, vol. 16, pp. 119-127.

1902c. Vulpes alascensis. Bull. American Museum Natural History, vol. 16, p. 225 .

1902d. The hair seals (Family Phocidae) of the North Pacific Ocean and Bering Sea. Bull. American Museum Natural History, vol. 16, pp. 459-499.

1902e. The American and European herring gulls. Auk, vol. 19, No. 3, pp. $283-284$.

1903a. Report on the mammals collected in northeastern Siberia by the Jesup North Pacific expedition, with itinerary and field notes by N. G. Buxton. Bull. American Museum Natural History, vol. 19, art. 4, pp. 101-184.

1903b. Mammals collected in Alaska and northern British Columbia by the Andlew J. Stone expedition of 1902. Bull. American Museum Natural History, vol. 19, art. 21, pp. 521-567.

1904. Mammals collected in Alaska by the Andrew J. Stone expedition of 1903. Bull. American Museum Natural History, vol. 20, art. 24, pp. 273-292.

American Ornithologists' Union.

1931. Check-list of North American birds. Fourth edition.

1957. Check-list of North American birds. Fifth edition. 
Anderson, J. Wylie.

1909. Hunting Ursus gyas on Unimak (Alaska). Outdoor Life, vol. 24 , pp. 533-544.

ANDERSON, R. M.

1934. Notes on the distribution of the hoary marmots. Canadian FieldNaturalist, vol. 48, No. 4, pp. 61-63.

ANDERSON, R. M., and A. L. RAND.

1943. Variation in the porcupine (genus Erethizon) in Canada. Canadian Jour. Research, vol. 21, pp. 292-309.

A NDRews, C. L.

1938. Children of the sea. Alaska Sportsman, vol. 4, No. 7, pp. 8-9, 27-28, 31-32.

ANDREWS, ROY C.

1909a. Observations on the habits of the finback and humpback whales of the eastern North Pacific. Bull. American Museum Natural History, vol. 26, pp. 213-226.

1909b. A summer with the Pacific coast whalers. Jour. American Museum Natural History, vol. 9, No. 2, pp. 21-30.

ANTHONY, A. W.

1895. The fulmars of southern California. Auk, vol. 12, p. 100.

1906. Random notes on Pacific coast gulls. Auk, vol. 23, No. 2, pp. 129-137.

1934. A new petrel for North America. Auk, vol. 51, No. 1, p. 77.

ANTHONY, H. E.

1928. Field book of North American mammals. Putnam and Sons, New York, N. Y.

ARNOLD, LeE W.

1948. Observations on populations of North Pacific pelagic birds. Auk, vol. 65 , No. 4 , pp. 553-558.

ArNy, Samuel A.

1952. Taxonomic status of the bank swallow of North America. Condor, vol. 54, No. 6, pp. 356-357.

Austin, O. L., JR.

1949. The status of Steller's albatross. Pacific Science, No. 3, pp. 283295.

BAER, K. E. voN.

1838. Anatomische und zoologisohe Untersuchungen über das Walross (Trichechus rosmarms) und Vergleichung dieses Thiers mit anderen See-säugethieren. Mem. Ac. Sci. Leningrad s. 6, sec. 2, Sci. Nat., vol. 4, pp. 97-236.

Bailey, AlFred M.

1922. Notes on the yellow-billed loon. Condor, vol. 24, No. 6, pp. 204-205.

1925-26. A report on the birds of northwestern Alaska and l'egions adjacent to Bering Strait. Parts I to X. Condor, vol. 27, Nos. 1-6; vol. 28 , Nos. $1-4$.

1927. Notes on the birds of southeastern Alaska. Auk, vol. 44, Nos. 1, 2, 3, pp. 1-23, 184-205, 351-367.

1928. An unusual migration of the spotted and ribbon seals. Jour. Mammalogy, vol. 9, No. 3, pp. 250-251.

1930. The pintails of northwestern Alaska. Condor, vol. 32, No. 5, pp. 264-265. 
1931. Specimens from Point Barrow, Alaska. Condor, vol. 33, No. 2, p.

78.

1932. Additional recolds from Cape Prince of Wales, Alaska. Condor, vol. 34 , No. 1, p. 47.

1933. The Baikal teal from King Island, Alaska. Auk, vol. 50, No. 1, p. 97.

1934. Additional records for the Barrow region, Arctic Alaska. Condor, vol. 36, No. 4, p. 169.

1943. Birds of Cape Prince of Wales, Alaska. Proceed. Colorado Museum Natural History, vol. 18, No. 1, pp. 1-113.

BAIRD, S. F.

1869. On additions to the bird fauna of North America, made by the Scientific Corps of the Russo-American Telegraph Expedition. Trans. Chicago Academy Science, vol. I, pp. 311-325.

BANCROFT, HUBERT Howe.

1886. History of Alaska, 1730-1885. San Francisco.

BARABASH-NIKIFOROV, I. I.

1935. The sea otters of the Commander Islands. Jour. Mammalogy, vol. 16, No. 4, pp. 255-261.

1937. Taxonomic observations on white whales. Jour. Mammalogy vol. 18 , No. 4, pp. 507-509.

1938. Mammals of the Commander Islands and the surrounding sea. Jour. Mammalogy, vol. 19, No. 4, pp. 423-429.

Barrett-Hamilton, G. E. H.

1897. Remarks on the Pacific walrus. Proceed. Zoological Society London, pp. 266-267.

Bartsch, P., and H. A. Rehder.

1939. Two new marine shells from the Aleutian Islands. Nautilus, vol. 52, No. 4, pp. 110-112, pl. 8 .

BEAN, TARLETON H.

1882. Notes on birds collected during the summer of 1880 in Alaska and Siberia. Proceed. U. S. National Museum, pp. 144-173.

1889. Birds, bears, and fishes. Forest and Stream, vol. 33, pp. 348-368.

1891. The pike family (in two parts). Forest and Stream, vol. 36, pp. $210,233$.

Behle, William H.

1941. Additional data concerning the subspecific status of the cormorants of Great Salt Lake. Condor, vol. 43, No. 6, pp. 286-289.

BendiRe, Charles.

1895. Notes on the ancient murrelet (Synthliboramphus antiquus), by Chase Littlejohn, with annotations. Auk, vol. 12, No. 3, p. 270.

Benson, Seth B., and Thomas C. Groody.

1942. Notes on the Dall porpoise. Jour. Mammalogy, vol. 23, No. 1, pp. 41-51.

Bent, Arthur Cleveland.

1912. Notes on birds observed during a brief visit to the Aleutian Islands and Bering Sea in 1911. Smithsonian Misc. Collections, vol. 56 , No. 32 .

1919. Life histories of North American diving birds. U. S. National Museum Bull. 107. 
1921. Life histories of North American gulls and terns. U. S. National Museum Bull. 113.

1922. Life histories of North American petrels and pelicans and their allies. U. S. National Museum Bull. 121.

1923. Life histories of North American wildfowl order Anseres (Part I). U. S. National Museum Bull. 126.

1925. Life histories of North American wildfowl order Anseres (Part II). U. S. National Museum Bull. 130 .

1926. Life histories of North American marsh birds. U. S. National Museum Bull. 135.

1927. Life histories of North American shore birds order Limicolae (Part I). U. S. National Museum Bull. 142.

1929. Life histories of North American. shore birds order Limicolae

(Part II). U. S. National Museum Bull. 146.

1932. Life histories of North American gallinaceous birds. U. S. National Museum Bull. 162.

1937. Life histories of North American birds of prey order Falconiformes (Part I). U. S. National Museum Bull. 167.

1938. Life histories of North American birds of prey order Falconiformes and Strigiformes (Part II). U. S. National Museum Bull. 170.

BENT, Silas.

1857. The Japanese gulf stream. Bull. American Geographical Society, vol. 2, pp. 203-213.

BiRKELAND, KNUT B.

1926. The whalers of Akutan. Yale University Press, New Haven, Conn.

Bishop, Louis B.

1900a. Birds of the Yukon legion, with notes on other species. In Results of a biological reconnaissance of the Yukon River region. North American Fauna, No. 19, pp. 47-96. U. S. Biological Survey, Washington, D. C.

1900b. Descriptions of three new birds from Alaska. Auk, vol. 17, No. 2, pp. 113-120.

1905. The gray sea-eagle (Haliaeetus albicilla) in British Columbia. Auk, vol. 22, No. 1, pp. 79-80.

1915. Description of a new race of Savannah sparrow and suggestions on some California birds. Condor, vol. 17, No. 5, pp. 185-189.

1927a. The status of the Point Barrow gull. Condor, vol. 29, No. 4, pp. 204-205.

1927b. The plumages of certain gulls. Condor, vol. 29, No. 4, pp. 201-202.

BISHOP, S. E.

1904. The cold-current system of the Pacific, and source of the Pacific coast current. Science (new ser.), vol. 20, pp. 338-340.

BOLIN, ROLF L.

1938. Reappearance of the southern sea otter along the California coast. Jour. Mammalogy, vol. 19, No. 3, pp. 301-303.

BOND, R. M.

1949. Characteristics of the gyrfalcons from the Bering Sea area. Condor, vol. 51, No. 5, pp. 228-229. 
BoNe, SCOTT C.

1920. Annual report of Governor of Alaska on the Alaska game law,

1421. U. S. Department Agriculture Circ. 225.

BRETHERTON, BERnARD J.

1896. Kodiak Island, a contribution to the avifauna of Alaska. Oregon

Naturalist, vol. 3, p. 45.

BRUCi, HJALMAR.

1936. Some zoogeographical problems of the northern Pacific. Science

(new ser.), vol. 83, pp. 101-103.

Brodkorb, Pierce.

1933. Remarks on the genus Limnodromus Wied. Proceed. Biological

Soc. Washington, vol. 46, pp. 123-128.

Brooks, Alfred H.

1906. The geography and geology of Alaska. U. S. Geological Survey Professional Paper 45.

Brooks, Allan.

1922. Notes on the American pine grosbeaks with a description of a new subspecies. Condor, vol. 24, No. 3, pp. 86-88.

1926. Notes on the status of the Peale falcon. Condor, vol. 28, No. 2, pp. $77-79$.

BRooks, S. C.

1934. Oceanic currents and the migration of pelagic birds. Condor, vol. 36 , No. 5 , pp. 185-190.

Brooks, W. Sprague.

1915. Notes on birds from east Siberia and arctic Alaska. Bull. Harvard Museum Comparative Zoology, vol. 59, No. 5, pp. 361-413.

BYERS, H. R.

1934. Air masses of the North Pacific. Bull. Scripps Institute Oceanography Technology, ser. 3, pp. 311-353.

CAHALANE, Victor H.

1943. Notes on the birds of the Kodiak-Afognak Island group. Auk, vol. 60 , No. 4 , pp. 536-541.

1944. Birds of the Katmai Region, Alaska. Auk, vol. 61, No. 3, pp. $351-375$.

Cahn, Alvin R.

1947. Notes on the birds of the Dutch Harbor Area of the Aleutian Islands. Condor, vol. 49, No. 2, pp. $78-82$.

CAPPS, StePhen R.

1934. Notes on the geology of the Alaska Peninsula and Aleutian Islands. U. S. Geological Survey, Bulletin 857-D, pp. 141-153.

CARVER, W. H.

1928. Notes from St. George's Island, Alaska. Murrelet, vol. 9, No. 3, pp. 63-65.

1929. More observations from St. George's Island, Alaska. Murrelet, vol. 10, No. 1 , pp. $15-17$.

Chapman, Frank M.

1902. List of birds collected in Alaska by the Andrew J. Stone Expedition of 1901. Bull. American Museum Natural History, vol. 16, pp. $231-247$.

1904. A common loon at Seldovia, June 30, 1903. Bull. American Museum Natural History, vol. 20. 


\section{Chase, Earl, and Ralph Donahue.}

1944. Report from the services. Pvt. Donahue finds plenty of life in the barren Aleutians. Animal Kingdom, vol. 47, No. 1, pp. 11-13.

Chinard, Gilbert.

1937. Le Voyage de La Pérouse sur les Côtes de l' Alaska et de la Californie (1786). Baltimore, Md.

\section{Clark, Austin H.}

1887. The Pacific walrus fishery. In The fisheries and fishery industries of the United States, 1887, Sec. 5, Part 2, pp. 311-318.

1907. Eighteen new species and one new genus of birds from eastern Asia and the Aleutian Islands. Proceed. U. S. National Museum, vol. 32 , pp. 467-475.

1910. The birds collected and observed during the cruise of the United States Fisheries Steamer "Albatross" in the North Pacific Ocean, and in the Bering, Okhotsk, Japan, and Eastern Seas, from April to December, 1906. Proceed. U. S. National Museum, vol. 38, pp. 25-74. Collins, Grenold.

1940. Habits of the Pacific walrus. Jour. Mammalogy, vol. 21, No. 2, pp. $138-144$.

Collins, Henry B., Jr., Austin H. Clark, and Egbert H. Walker.

1945. The Aleutian Islands: Their people and natural history. Smithsonian Institute War Background Studies 21, Pub. 3775.

CoNover, H. B.

1941. A study of the dowitchers. Auk, vol. 58, No. 3, pp. 376-380.

1943. Races of the knot (Calidris camutus). Condor, vol. 45, No. 6, pp. $226-228$.

1944. The North Pacific allies of the purple sandpiper. Zoological Ser., Field Museum Natural History, vol. 29, No. 11, pp. 169-179.

1945a. Notes on some American shorebirds. Condor, vol. 47, No. 5, pp. 211-214.

1945b. The breeding golden plover of Alaska. Auk, vol. 62, No. 4, pp. 568-574.

COOK, J AMES.

1842. Voyages of Captain James Cook. Vol. II (Home Library), Burt Press.

Соoк, J. A.

1926. Pursuing the whale; a quarter-century of whaling in the Arctic. Houghton Press.

COOKE, Wells W.

1915. The yellow-billed loon; a problem in migration. Condor, vol. 17 , No. 6, pp. 213-214.

\section{Corney, Peter.}

1821. Voyages in Northern Pacific in 1813-18. Honolulu, 1896. (Reprinted from the London Literary Gazette of 1821.)

Cottam, Clarence, and Phoebe Knappen.

1939. Food of some uncommon North American birds. Auk, vol. 56, No. 2, pp. 138-169.

Couturier, Marcel A. J.

1954. L'Ours Brun. Grenoble France.

COWAN, I. MCT.

1939. The sharp-headed finner whale of the eastern Pacific. Jour. Mammalogy, vol. 20, pp. 215-225. 
('HABk, EMWARI) I).

1)2: The Sykes Alaskan Expedition of the University of Oklahoma of 1021. Proceed. Oklahoma Academy Science, vol. 2, pp. 60-65.

1923. A note on the economic status of the bald eagle in Alaska. Auk, vol. 40, No. 3, pp. 419-423.

DALI, WILLIAN H.

1869. Note on the "blowing" of whales. American Naturalist, vol. 3, pp. 333-334.

1870. Alaska and its resources. Boston, Mass.

1873. Notes on the avifauna of the Aleutian Islands, from Unalaska, eastward. Proceed. California Academy Sciences, vol. 5.

1874. Notes on the avifauna of the Aleutian Islands, especially those west of Unalaska. Proceed. California Academy Sciences, vol. 5, pp. 270-281.

1875. Alaskan mummies. American Naturalist, vol. 9, pp. 435-438.

1876. On the marine faunal regions of the North Pacific: An introductory note to the report on Alaskan hydroids, by S. F. Clark. Proceed. Academy Sciences Philadelphia, vol. 3, No. 28, pp. 205-208. 1920. The Pliocene and Pleistocene fossils from the Arctic coast of Alaska and the auriferous beaches of Nome, Norton Sound, Alaska. U. S. Geological Survey Professional Paper 125-C, pp. 23-37.

DALL, William H., and H. M. BANNister.

1869. List of the birds of Alaska, with biographical notes. Trans.

Chicago Academy Science, vol. I, pp. 267-310.

Davis, Whlliam B.

1944. Geographic variation in brown lemmings (genus Lemmus). Murrelet, vol. 25, No. 2, pp. 19-25.

DEIGNAN, H. G.

1951. The genus Cuculus in North America, a reconsideration. Condor, vol. 53, No. 3, rp. 154-155.

Delacour, JEAN, and ERNST MAYr.

1945. The family Anatidae. Wilson Bulietin, vol. 57, No. 1, pp. 3-55.

DICE, LEE R.

1922. Biotic areas and ecologic habitats as units for the statement of animal and plant distribution. Science, vol. 55, No. 1422, p. 104.

1923. Life zones and mammalian distribution. Jour. Mammalogy, vol. 4, No. 1, pp. 39-47.

1932. A preliminary classification of the major terrestrial ecologic communities of Michigan, exclusive of Isle Royale. Papers Michigan Academy Science, Arts and Letters, vol. 16, pp. 217-239.

Dixon, Joseph.

1916. Migration of the vellow-billed loon. Auk, vol. 33, No. 4, pp. 370-376.

1938. Fauna of the National Parks of the United States. Birds and Mammals of Mount McKinley National Park. U. S. National Park Service Fauna Ser. 3.

DUVALL, ALLEN J.

1945. Distribution and taxonomy of the black-capped chickadees of North America. Auk, vol. 62, No. 1, pp. 49-69.

DWIGHT, JONATHAN, JR.

1904. The exaltation of the sub-species. Auk, vol. 21, pp. 64-68. 
1906. Status and plumages of the white-winged gulls of the genus Larus. Auk, vol. 23, No. 1, pp. 25-43.

1919. Reasons for discarding a proposed race of the glaucous gull (Larus hyperboreus). Auk, vol. 36, No. 2, pp. 242-248.

1925. The gulls (Laridae) of the world; their plumages, moults, variations, relationships, and distribution. Bull. American Museum Natural History, vol. 52, pp. 63-401.

EINARSON, ARTHUR S.

1922. Alaska Notes. Murrelet, vol. 3, No. 3, p. 4.

Elliot, Daniel Giraud.

1896. Descriptions of an apparently new species and sub-species of ptarmigan from the Aleutian Islands. Auk, vol. 13, No. 1, pp. 24-29.

1901. A synopsis of the mammals of North America and the adjacent seas. Pubs. Field Columbian Museum Zoological Ser., vol. 2.

1903. Description of an apparently new subspecies of marten from the Kenai Peninsula, Alaska. Field Museum Natural History, Zool.

Ser. 1903, pp. 151-173. Chicago.

Elliott, Henry W.

1897. Our Arctic province. Scribner's Sons, 1886.

EVERMANN, BARTON WARREN.

1913. Eighteen species of birds new to the Pribilof Islands, including four new to North America. Auk, vol. 30, No. 1, pp. 15-18.

1921. The Ano Nuevo Steller sea lion rookery. Jour. Mammalogy, vol. 2 , No. 1.

1922. Why not save the marine mammals of the Pacific? Pan-Pacific Union Bull. 34, pp. 12-16.

EYERDAM, WALTER J.

1933. Sea otters in the Aleutian Islands. Jour. Mammalogy, vol. 14, No. 1.

1936a. Notes on birds collected or observed during the summer of 1932 in the eastern Aleutian Islands, Alaska. Murrelet, vol. 17, Nos. 2-3, pp. 48-52.

1936b. Mammal remains from an Aleut Stone Age village. Jour. Mammalogy, vol. 17, No. 1.

Figgins, J. D.

1904. Field notes on the birds and mammals of the Cook's Inlet region of Alaska. Abstracts of Proceed. Lirnean Society New York, Nos. 15-16, pp. 15-39.

FINDLEY, JAMES S.

1955. Speciation of the wandering shrew. University of Kansas Pub. lications vol. 9, No. 1, pp. 1-68.

Finley, William L.

1927. Camera hunting in the Northland. Nature, vol. 9, No. 2, pp. $72-78$.

FISHER, A. K.

1900. The occurrence of Steller's eider (Eniconnetta stelleri) in the

Gulf of St. Lawrence. Auk, vol. 17, No. 1, p. 65.

Fisher, Eidna M.

1939. Habits of the southern sea otter. Jour. Mammalogy, vol. 20, No. 1, pp. 21-36.

1940a. A sea otter with gastric perforations. Jour. Mammalogy, vol. 21 , No. 3, pp. 357-359. 
1940b. Enrly life of a sea-otter pup. Jour. Mammalogy, vol. 21, No. 2, pp. 132-137.

1941a. Notes on the teeth of the sea otter. Jour. Mammalogy, vol. 22, No. 4, pp. 428-433.

1941b. Prices of sea-otter pelts. California Fish and Game, vol. 27, No. 4, pp. 261-265.

Foerste, A. F.

1931. Ancient life in the Arctic. Ohio Jour. Science, vol. 31, pp. 243254.

FORD, EDWARD R.

1936. Kittlitz's murrelet breeding at Wales, Alaska. Auk, vol. 53, No. 2, pp. 214-215.

Forest and Stream.

1893. The sea otter and the Aleuts. Vol. 40, No. 6, p. 111.

Friediann, Herbert.

1933a. The Chinese cormorant on Kodiak Island, Alaska. Condor, vol. 35 , No. 1 , pp. $30-31$.

1933b. Notes on some birds of Goodnews Bay, Alaska. Condor, vol. 35, No. 6, pp. 239-240.

1934a. The Mongolian plover and other birds at Goodnews Bay, Alaska. Condor, vol. 36 , No. 2 , p. 89.

1934b. Bird bones from old Eskimo ruins in Alaska. Jour. Washington Academy Science, vol. 24, No. 5 .

1934c. The Siberian rough-legged hawk in Alaska. Condor, vol. 36, No. 6, p. 246.

1935. The birds of Kodiak Island, Alaska. Bull. Chicago Academy Science, vol. 5, No. 3, pp. 13-54.

1936. Notes on Alaskan birds. Condor, vol. 38, No. 4, p. 173.

1937. Bird bones from archeological sites in Alaska. Jour. Washington Academy Science, vol. 27, No. 10.

Gabrielson, Ira N.

1940. America's greatest bird concentrations. Bird Lore, vol. 42, No. 6 , pp. 496-506.

1941. Anerica's greatest bird concentrations, Part 2. Audubon Magazine, vol. 43 , No. 1, pp. 15-23.

1943. Additional bird records from Alaska. Auk, vol. 60, No. 4, p. 604.

1944. Some Alaskan notes. Auk, vol. 61, Nos. 1-2, pp. 105-130, 270-287.

Gabrielson, Ira N., and Frederick C. Lincoln.

1949. A new race of ptarmigan in Alaska. Proceed. Biological Society Washington, vol. 62, pp. 175-176.

1951a. Post-mortem color change in bird specimens. Condor, vol. 53, No. 6, pp. 298-299.

1951b. A new race of ptarmigan from Alaska. Proceed. Biological Society Washington, vol. 64, pp. 63-64.

1951c. The races of song sparrows in Alaska. Condor, vol. 53, No. 5, pp. 250-255.

1951d. A new Alaskan race of the winter wren. Proceed. Biological Society Washington, vol. 64, pp. 73-74.

1959. Birds of Alaska. Wildlife Mgmt. Inst., Washington. $922 \mathrm{pp}$.

Geist, Otto William.

1939. Sea birds found far inland in Alaska. Condor, vol. 41, No. 2, pp. $68-70$. 


\section{Gianini, Charles A.}

1917. Some Alaska Peninsula bird notes. Auk, vol. 34, No. 4, pp. 394402.

Gilbert, Charles H.

1922. Kamchatka sea eagle at Kodiak, Alaska. Condor, vol. 24, No. 2, p. 66.

Gilmore, Raymond M.

1933. Notes on the Unalaska collared lemming. Jour. Mammalogy, vol. 14 , No. 3, pp. 257-258.

1946. Arctic mammalogy. In A program of desirable scientific investigations in Arctic North America. Arctic Institute of North America Bull. 1.

GOLDER, F. A.

1922. Bering's voyages and an account of the efforts of the Russians to determine the relation of Asia and America. American Geographic Society, vols. 1 (1922) and 2 (1925) New York, N. Y.

Goldman, EDWARD A.

1935. New American mustelids of Martes, Gulo, Lutra. Proceed. Biological Society Washington, vol. 48, p. 180.

1936. A new otter from Kamchatka. Jour. Mammalogy, vol. 17, No. 2.

Goode, GEorge Brown, and others.

1884. The fisheries and fishery industries of the United States, sec. 1, part 1. 47th Cong., 1st Sess., Senate, Misc. Doc. 124. Washington.

Griggs, Robert Fiske.

1922. The Valley of Ten Thousand Smokes. National Geographic Society, vol. 15 , No. 1, 341 pp.

1934a. The problem of Arctic vegetation. Jour. Washington Academy Science, vol. 24, No. 4, pp. 153-175.

1934b. Growth of liverworts from Katmai in nitrogen-free media. American Jour. Botany, vol. 21, pp. 265-277.

1934c. The edge of the forest in Alaska and the reasons for its position. Ecology, vol. 15, No. 2, pp. 80-96.

1936. The vegetation of the Katmai district. Ecology, vol. 17, No. 2, pp. $380-417$.

1938. Timberlines in the northern Rocky Mountains. Ecology, vol. 19, No. 4 , pp. $548-564$.

1946. The timberlines of northern America and their interpretation. Ecology, vol. 27, No. 4, pp. 275-289.

GRIN NELL, JOSEPH.

1900. Birds of the Kotzebue Sound Fiegion, Alaska. Pacific Coast Avifauna, No. 1, pp. 1-80.

1901a. Record of Alaskan birds in the collection of Leland Stanford University. Condor, vol. 3, No. 1, pp. 19-23.

1901b. The proper name for the Kodiak Savannah sparrow. Condor, vol. 3, p. 85.

1901c. Two races of the varied thrush. Auk, vol. 18, No. 2, pp. 142145.

1902. The western barn swallow. Condor, vol. 4, No. 3, p. 71.

1909. Birds and mammals of the 1907 Alexander expedition to Southeastern Alaska. University California Publ. Zoology, vol. 5, No. 2, p. 1. 
1910a. Miscellaneous records from Alaska. Condor, vol. 12, No. 1, pp. $41-43$.

1910b. Birds of the 1908 Alexander Alaska expedition. University California Publ. Zoology, vol. 5, pp. 361-428.

1920. The existence of sea birds a relatively safe one. Condor, vol. 22, No. 3, pp. 101-103.

1938. Ocean waifs and what they mean for distribution. Condor, vol. 40, No. 6, pp. 242-245.

1939. Proposed shifts of names in Passerculus-a protest. Condor, vol. 41 , No. 3, pp. 112-119.

Grinnell, Joseph, and Frederick H. Test.

1939. Geographic variation in the fork-tailed petrel. Condor, vol. 41, No. 4, pp. 170-172.

Guberlet, Mrs. M.

1936. Animals of the seashore. 412 pp. Metropolitan Press, Portland, Ore.

HALL, E. RAYMOND.

1929. Mammals collected by C. D. Brower at Point Barrow, Alaska. University California Publ. Zoology, vol. 30, No. 4.

1936. Mustelid manmals from the Pleistocene of North America. Carnegie Inst. Washington Publ. 473, pp. 41-119.

1945a. Chase Littiejohn, 1854-1943: Observations by Littlejohn on hunting sea otters. Jour. Mammalogy, vol. 26, No. 1, pp. 89-91.

1945b. Four new ermines from the Fracific Northwest. Jour. Mammalogy, vol. 26 , No. 1 , pp. $75-85$.

1957. Vernacular names for North American mammals north of Mexico. U. Kans. Museum Nat. Hist., Misc. Pub. 14. 16 pp.

Hanna, G. Dallas.

1917. The summer birds of the St. MIatthew Island bird reservation. Auk, vol. 34, No. 4, pp. 403-410.

1919. Additions to the avifauma of the Pribilof Islands, Alaska, including species new to North America. Jour. Washington Academy Science, vol. 9, No. 6, pp. 176-177.

1920a. Additions to the avifauna of the Pribilof Islands, Alaska, including four species new to North America. Auk, vol. 37, No. 2, pp. $248-254$.

1920b. Mammals of the St. Matthew Islands, Bering Sea. Jour. Mammalogy, vol. 1 , No. 3 .

1921. The Pribilof sandpiper. Condor, vol. 23, No. 2, pp. 50-57.

1922. The Aleutian losy finch. Condor, vol. 24, No. 3, pp. 88-91.

1923a. Random notes on Alaska snow buntings. Condor, vol. 25, No. 2 , pp. 60-65.

1923b. Rare mammals of the Pribilof Islands, Alaska. Jour. Mammalogy, vol. 4, No. 4.

1924. Sperm whales of St. George Island, Bering Sea. Jour. Mammalogy, vol. 5, No. 1.

1940. Siberian peregrine falcon in North America. Condor, vol. 42, No. 3, pp. 166-167.

HARTERT, ERNST.

1910-22. Die Vögel der palaarktischen Fauna. Systematische Ubersicht der in Europa, Nord-Asien und der Mittelmeerregion vorkommenden Vögel. 3 vols. (vol. 1, 1910; vol. 2, 1912-21; vol. 3, 1921-22). Berlin, Germany. 
1915. Notes on falcons. Novitates Zoologicae, vol. 22, pp. 167-185. London.

1920. The birds of the Commander Islands. Novitates Zoologicae, vol. 27, pp. 128-158. London.

HartLaUb, G.

1883. Beitrag zür Ornithologie von Alaska. Jour. für Ornithologie, vol. 31, pp. 257-286.

\section{HATTER, JAMES.}

1949. The status of moose in North America. Trans. 14th North American Wildlife Conference, pp. 492-501.

HEATH, HAROLD.

1920. The nesting habits of the Alaska wren. Condor, vol. 22, No. 2, pp. $49-55$.

Heller, EdMund.

1910. Mammals of the 1908 Alexander Alaska expedition, with descriptions of the localities visited and notes on the flora of the Prince William Sound region. University California Publ. Zoology, vol. 5, No. 11, pp. 321-360.

Henshaw, H. W.

1878. On the species of the genus Passerella. Bull. Nuttall Ornithological Club, vol. 3 , No. 1, p. 3.

1884. On a new gull from Alaska. Auk, vol. 1, No. 3, pp. 250-252.

Herendeen, E. P.

1892. Hunting the sea otter. Forest and Stream, June 1892.

HERSEy, F. S.

1916. A list of birds observed in Alaska and northeastern Siberia during the summer of 1914. Smithsonian Misc. Collections, vol. 66, No. 2.

1917a. The status of the black-throated loon (Gavia arctica) as a North American bird. Auk, vol. 34, No. 3, pp. 283-290.

1917b. The present abundance of birds in the vicinity of Fort St. Michael, Alaska. Auk, vol. 34, No. 2, pp. 147-159.

1920. The probable breeding of the Aleutian tern in southeastern Alaska. Condor, vol. 22, No. 6, pp. 203-204.

Hibben, Mrs. Frank C.

1942. Pacific eider nesting at Glacier Bay, Alaska. Condor, vol. 44, No. 4, p. 182.

HiNe, JAMES S.

1919. Scientific results of the Katmai expedition of the National Geographic Society. Part X. Birds of the Katmai Region. Ohio Jour. Science, vol. 19 , No. 8, pp. 475-486.

Hollister, Ned.

1913. A synopsis of the American minks. Proceed. U. S. National Museum, vol. 44, pp. 471-480.

HOMEYER, E. F. voN.

1880. Meine ornithologische Sammlung. Jour. für Ornithologie, vol. 28, pp. 152-157.

HOOPER, C. G.

1897. Report on the sea-otter banks of Alaska. Treasury Doc. 1977, Washington, D. C., 35 pp. 
IIOWELL, A. BRAZIER.

1935. Observations on the white whale. Jour. Mammalogy, vol. 16, No. 2.

Howell, Artitur H.

1915. Revision of the North American marmots. North American Fauna No. 37. U. S. Biological Survey, Washington, D. C.

1936. A revision of the American Arctic hares. Jour. Mammalogy, vol. 17, No. 4, pp. 315-337.

1938. Revision of the North American ground squirrels. North American Fauna No. 56. U. S. Biological Survey, Washington, D. C.

HoWELL, JoSEPH.

1948. Observations on certain birds of the region of Kodiak, Alaska. Auk, vol. 65, No. 3, pp. 352-358.

HubBs, CARL L.

1941. Predator control in relation to fish management in Alaska. Trans, 5th North American Wildiife Conference (1940), pp. 153-162.

HubBs, CARt L., and L. P. Schultz.

1929. The northward occurrence of southern forms of marine life along the Pacific Coast in 1926. California Fish and Game, vol. 15, pp. $234-240$.

HUEy, LAWRENCE M.

1931. Three noteworthy bird records from Barrow, Alaska. Condor, vol. 33, No. 1, pp. 36-37.

HULTÉN, ERIC.

1933. Aleutiska Öarne, en Geografisk och naturhistorisk oversigt. Svensk Geografisk Årsbok. Meddel. fran Lunds Universitets Geografiska Institution, Ser. C, No. 85.

1937a. Flora of the Aleutian Islands and westernmost Alaska Peninsula with notes on the flora of Cominander Islands. Stockholm.

1937b. Outline of the history of Arctic and Boreal biota during the Quaternary period. Stockholm.

1939. Two new species from Alaska. Contribution to the flora of Alaska II. Botaniska Notiser, Lund.

1941-1950. Flora of Alaska and Yukon. Lund Universitetets Åsskrift N. F. Avd, 2. Band 37-46. Nr. 1. Kingl. Fysiografiska Sallskapets Handlingar. N. F. Bd. 52-61. Nr. 1. Parts I to X.

Hutchinson, Isobel Wylie.

1937. Stepping stones from Alaska to Asia. $246 \mathrm{pp}$. Blackie \& Son, Ltd., London and Glasgow.

JACKSON, H. H. T.

1928. A taxonomic review of the American long-tailed shrews. North American Fauna No. 51. U. S. Biological Survey, Washington, D. C. JACOBI, A.

1939. Etwas vom Seeotter. Aus der Natur, vol. 16, No. 6, pp. 180-183. JAGGAR, T. R., JR.

19177. Expedition to the Aleutian Islands. Technical Review, Boston, Mass.

1929. Napping the home of the great brown bear. National Geographic Magazine, vol. 55, No. 1, pp. 109-134.

JAQUES, Francis LEE.

1929. Cranes crossing Bering Strait. Auk, vol. 46, p. 230. 
1930. Water birds observed on the Arctic Ocean and the Bering Sea in 1928. Auk, vol. 47, No. 3, pp. 353-366.

Jewett, Stanley G.

1921. Pribilof fur seal on the Oregon coast. Jour. Mammalogy, vol. 2, No. 4.

1933. Fourth record of the Pribilof fur seal on the Oregon coast. Jour. Mammalogy, vol. 14, No. 4.

JOCHELSON, WALDEMAR.

1925. Archeological investigations in the Aleutian Islands. Carnegie

Inst. Washington Pub. 367.

1933. History, ethnology, and anthropology of the Aleut. Carnegie Inst. Washington Pub. 432.

JOHNSON, J. W.

1886. Reindeer in Alaska snows. Forest and Stream, vol. 27, No. 65. JOHNSON, R. A.

1928. Predation of gulls in murre colonies. Wilson Bulletin, vol. 50, No. 3, pp. 161-170.

JONES, E. LESTER.

1915. Report of Alaska investigations in 1914. U. S. Bur. Fisheries. JoRDAN, DAvid STARr, and others.

1899. The fur seals and fur-seal islands of the North Pacific Ocean.

U. S. Treas. Dept. Comm. on fur-seal invest. U. S. Government Printing Office, Washington, D. C., 1898-99.

Jourdain, F. C. R.

1933. On the Palaearctic element in the A. O. U. Checklist (4th ed.). Auk, vol. 50, No. 2, pp. 201-204.

JUDGE, JAMES.

1909. The blue foxes of the Pribilof Islands. Science (new ser.), vol. 29, No. 745 , pp. 598-599.

1912. The blue foxes of St. Paul and Otter Island, Alaska. Ann. Rept. American Breeders' Association, vol. 7-8.

KELlogG, ReMington.

1929. What is known of the migrations of some of the whalebone whales. Smithsonian Rept. Publ. 2997 (1928), pp. 267-494.

1931. Whaling statistics for the Pacific Coast of North America. Jour. Mammalogy, vol. 12, No. 1, pp. 73-77.

1932. New names for manmals proposed by Borowski in 1780 and 1781 . Proceed. Biological Society Washington, vol. 45, p. 147.

1936. Mammals from a native village site on Kodiak Island. Proceed. Biological Society Washington, vol. 49, pp. 37-38.

KeNYON, KARL W.

1949a. Distribution of the Pacific kittiwake in November and December of 1948. Condor, vol. 51, No. 4, p. 188.

1949b. Fur seals and murre chicks. Condor, vol. 51, No. 6, pp. 273274.

1950. Distribution of albatrosses in the North Pacific and adjacent waters. Condor, vol. 52, No. 3, pp. 97-103.

KitTlitz, F. H. von.

1858. Denkwurdigkeiten einer Reise nach dem russischen Amerika, nach Mikronesien und durch Kamtschatka. 2 vols., Gotha. 
KilinscinMidt, F. E.

1919. Killing a flock of brown bears in Alaska. Outdoor Life, vol. 43, pp. 69-72, 139-142.

KNOPF, ADOLF.

1910. The probable Tertiary land connection between Asia and North Anerica. University California Bull., Dept. Geology, vol. 5, pp. 413-420.

KobBe, William H.

1902. The status of certain supposed species of the Genus Larus. Auk, vol. 19, No. 1, pp. 19-24.

KumLein, LUDWiG.

1879. Contributions to the natural history of Arctic America, made in connection with the Howgate Polar Expedition, 1877-78. Bull. U. S. National Museum, No. 15.

Kuroda, NAGAMICHI.

1924. Two new murine rodents from Kurile Islands, Japan. Jour. Manmalogy, vol. 5, No. 2.

Laing, Hamilton M.

1925. Birds collected and observed during the cruise of the "Thiepval" in the North Pacific, 1924. Victoria Memorial Museum, Canada, Museum Bull. 40, Biol. Ser. 9.

LINCOLN, FREDERICK C.

1926. The migration of the cackling goose. Condor, vol. 28, No. 4, pp. $153-157$.

Littlejohn, Chase.

1904. The capture of Totanus glareola in Alaska. Condor, vol. 6, No. 5, p. 138.

1916. Habits and hunting of the sea otter. California Fish and Game, vol. 2, No. 2, pp. 79-82.

LÖPPENTHIN, BERNT.

1932. Har Maagerne bestemte Aedepladser? Dansk Ornithol. Foren.

Tidsskr., vol. 26, Nos. 3-4, p. 143.

Loring, J. Alden.

1907. The bears of North America. Outdoor Life, vol. 19, pp. 217225, 325-332, 433-438, 565-572.

LYON, M. W., and W. H. OsGooD.

1909. Catalogue of the type-specimens of mammals in the U. S. National Museum, including the Biological Survey collection. U. S. National Museum Bull. 62.

McCormick, C. M.

1898. Bear hunting on the Alaska Peninsula. American Field, vol. 50, No. 9, pp. 162-163.

McCracken, Harold L.

1920a. When the sea otter flourished. Forest and Stream, vol. 90, No. 6, pp. 298, 332, 333 .

1920b. The Alaskan grizzly. Field and Stream, vol. 24, pp. 903-907.

1920c. After the Arctic caribou. Field and Stream, vol 25, pp. 485489.

1924. The game situation in Alaska. American Forests, vol. 30, No. 366, pp. 323-362.

1925a. The mysterious sea otter. Nature Magazine, vol. 5, pp. 169-172. 
1925b. The great Alaskan brown bear. Nature Magazine, vol. 6, pp. 212-216.

1929. The mysterious sea otter. The Sportsman, vol. 6, No. 5, pp. 71-72.

MACFARLANe, RODERICK Ross.

1905. Notes on mammals collected and observed in the northern Mackenzie River district, Northwest Territories of Canada, with remarks on explorers and explorations of the Far North. Proceed. U. S. National Museum, vol. 28, p. 717.

McGREgor, RichaRd C.

1201. New Alaskan birds. Condor, vol. 3, No. 1, p. 8.

1902. A list of birds collected in Norton Sound, Alaska. Condor, vol. 4, No. 5, pp. 135-144.

1906. Birds observed in the Krenitzin Islands, Alaska. Condor, vol. 8 , No. 5, pp. 114-122.

MAILliaRd, JOSEPH.

1898. Notes on the nesting of the fork-tailed petrel (Oceanodroma furcata). Auk, vol. 15, pp. 230-233.

1922. Eggs of the Aleutian rosy finch. Condor, vol. 24, No. 3, pp. 92-93.

Mailliard, Joseph, and G. Hanna.

1921. New bird records for North America with notes on the Pribilof Island list. Condor, vol. 23, No. 3, pp. 93-95.

Marshall, Edison.

1923. In the land of the Kodiak. Outdoor Life, vol. 52, pp. 333-338.

MaY, Alan G.

1943. The northern sea otter. Natural History, vol. 52, No. 1.

MEINERTZHAGEN, R.

1926. Introduction to a review of the genus Corvus. Novitates Zoologicae, vol. 33, pp. 57-121, pls. 1-12. London.

MERrian, C. HART.

1897. Descriptions of five new rodents from the coast region of Alaska.

Proceed. Biological Society Washington, vol. 11, pp. 221-223.

1900. Descriptions of twenty-six new mammals from Alaska and British

North America. In Papers from the Harriman Alaska expedition.

Proceed. Washington Academy Science, vol. 2, pp. 13-30.

1902a. Two new bears from the Alaska Peninsula. Proceed. Biological

Society Washington, vol. $15, \mathrm{p} .78$.

1902b. Four new Arctic foxes. Proceed. Biological Society Washington, vol. 15, p. 168 .

1918. Review of the grizzly and big brown bears of North America.

North American Fauna No. 41. U. S. Biological Survey, Washington, D. C.

Mertens, Robert.

1935. Aus dem leben des seeotters. Natur und Volk, jahrg. 65, heft 9, 401-407.

MidDENDORFF, A. T. von.

1853. Reise in den äussersten Norden und Osten Siberiens während. .

1843 und 1844. . . St. Petersburg, 1847-1875. Vol. 2, tl. 2. Zoologie.

Wirbelthiere. Säugethiere, Vögel und Amphibien. $256 \mathrm{pp}$. 
IIILLER, Alinen H.

1941. Speciation in the avian genus Junco. University California Pirbl. Zoology, vol. 44, No. 3, pp. 173-434.

1949. Some concepts of hybridization and intergradation in wild populations of birds. Auk, vol. 66, No. 4, pp. 338-342.

MILLER, GERRIT S., JR.

18.99. Description of a new vole from eastern Siberia. Proceed. Biological Society Washington, vol. 13, p. 11.

1923. List of North American Recent mammals. U. S. National Museum Bull. 128.

1929. The gums of the porpoise Phocoenoides dalli (True). Proceed. U. S. National Museum. vol. 74, p. 1.

1930. A note on the skeletons of two Alaskan porpoises. Smithsonian Misc. Collections, vol. 82 , No. 13, 2pp.

Miller, Gerrit S., Jr., and Remingtun KellogG.

1955. List of North American recent mammals. U. S. National Museum, Bulletin 205. Washington.

Mililer, Loye.

1940. Observations on the black-footed albatross. Condor, vol. 42, No. 5, pp. 229-238.

1942. Some tagging experiments with black-footed albatrosses. Condor, vol. 44 , No. 1 , pp. $3-9$.

Miller, MaX.

1936. Fog and men on Bering Sea. E. P. Dutton \& Co. Inc., New York, N. Y.

Murie, Olaus J.

1930. A new Alaskan Microtus. Jour. Mammalogy, vol. 11, No. 1, pp. $74-75$.

1935. The Alaska-Yukon caribou. North American Fauna No. 54.

1936. The birds of St. Lawrence Island, Alaska. Appendix V, In Archeological excavations at Kukulik, St. Lawrence Island, Alaska. Misc. Pubs. 2, University Alaska. Washington, D. C.

1940a. Notes on the sea otter. Jour. Mammalogy, vol. 21, No. 2, pp. 119-131.

1940b. Food habits of the northern bald eagle in the Aleutian Islands, Alaska. Condor, vol. 42, No. 4, pp. 198-202.

1944. Two new subspecies of birds from Alaska. Condor, vol. 46, No. 3 , pp. 121-123.

1945. Larus ridibundus sibiricus from the Aleutian Islands. Auk, vol. 62 , No. 2, p. 313.

1952. Additional records of Cuculus in North America. Condor, vol. 54 , No. 2, p. 114.

MURPhy, Robert Cushman.

1936. Oceanic birds of South Anerica. American Museum Natural History, vols. 1 and 2.

NELSON, EDWARD W.

1878. The rock ptarmigan (Lagopus rupestris) in the Aleutian Islands. Bull. Nuttall Ornithological Club, vol. 2, No. 1, p. 38.

1883. Birds of Bering Sea and the Arctic Ocean. In Cruise of the revenue steamer Corwin in Alaska and the N.W. Arctic Ocean in 1881. U. S. Revenue Cutter Service. Washington. 
1887. Report upon natural history collections made in Alaska between the years 1877 and 1881. Arctic Ser. Pub. No. 3, issued in connection with the Signal Service, U. S. Army. Washington, D. C.

1893a. Description of a new species of Lagomys from Alaska. Proceed. Biological Society Washington, vol. 8, pp. 117-120.

1893b. Description of a new species of Aricola of the Mynomes group, from Alaska. Proceed. Biological Society Washington, vol. 8, pp. 139-142.

1898. Notes on the wild fowl and game animals of Alaska. National Geographic Magazine, vol. 9, pp. 121-132, April.

1909. The rabbits of North America. North American Fauna No. 29. U. S. Biological Survey, Washington, D. C.

1929. Description of a new lemming from Alaska. Proceed. Biological Society Washington, vol. 42, pp. 143-146.

1931. A new vole of the subgenus stenocranius from Alaska. Jour. Mammalogy, vol. 12, No. 3.

Nichols, JOHN TREADWELL.

1927. Tubinares off the Northwest coast. Auk, vol. 44, No. 3, pp. $326-328$.

NORDENSKIOLD, A. E.

1885. Reply to criticisms upon "The voyage of the Vega, around Asia and Europe." Bull. American Geographic Society, vol. 17, pp. 267-298.

OBERHOLSER, HARRY C.

1900. A new wren from Alaska. Auk, vol. 17, No. 1, pp. 25-26.

1905. The forms of Vermivora celata (Say). Auk, vol. 22, No. 3, pp 242-247.

1918. The subspecies of Larus hyperboreus Gunnerus. Auk, vol. 35, No. 4, pp. 467-474.

1919a. Notes on North American birds, VII. Auk, vol. 36, No. 1, pp. 81-85.

1919b. The status of Lams hyperboreus barrovianus Ridgway. Proceed. Biological Society Washington, vol. 32, pp. 173-176.

1919c. Notes on North American birds, IX. Auk, vol. 36, No. 4, pp. $556-559$.

1919d. Notes on the wrens of the genus Nanmus Billberg. Proceed. U. S. National Museum, vol. 55, pp. 223-236.

1930. Another new subspecies of Nannus troglodytes from Alaska. Proc. Biological Society Washington, vol. 43, pp. 151-152.

ORR, ROBERT T.

1939. Extension of the range of Sorex tundrensis. Jour. Mammalogy, vol. 20 , No. 2, p. 251.

1945. A study of the Clethrionomys lawsoni group of red-backed mice. Jour. Mammalogy, vol. 26, No. 1, pp. 67-74.

OSGOOD, WILFRED H.

1901. Natural history of the Queen Charlotte Islands, British Columbia. Natural history of the Cook Inlet Region, Alaska. North American Fauna No. 21, U. S. Biological Survey, Washington, D. C.

1904a. A biological reconnaissance of the base of the Alaska Peninsula. North American Fauna No. 24. U. S. Biological Survey.

1904b. Lake Clark, a little-known Alaskan lake. National Geographic Magazine, vol. 15, No. 8, pp. 326-331. 
1909. The big game of Alaska. National Geographic Magazine, vol. 20,

No. 7, pp. $624-636$.

PILIIER, WILLIAM.

1894. An Asiatic cuckoo on the Pribilof Islands, Alaska. Auk, vol. 11, No. 4 , p. 325 .

1899. The avifauna of the Pribilof Islands. In The fur seals and furseal islands of the North Pacific Ocean, part 3, pp. 355-431. U. S.

Treasury Dept., Conmission on Fur-Seal Investigations. Washington.

Parkes, Kenneth C., and Dean Amadon.

1948. The winter range of the Kennicott willow warbler. Condor, vol. 50, No. 2, pp. 86-87.

Pechuel-Loesche, M. E.

1871. Wale und Walfang. Ausland, 44.

Peters, James L.

1931. Check-list of birds of the world. Vol. 1.; Harvard University Press, Cambridge, Mass.

Peters, James L., and Ludlow Griscom.

1938. Geographical variation in the Savannah sparrow. Bull. Museum

Comparative Zoology, vol. 80, No. 13, pp. 445-448. Harvard University.

Petroff, Ivan.

1882. The limit of the Innuit tribes on the Alaskan coast. American

Naturalist, vol. 16.

1884. Report on the population, industries, and resources of Alaska.

In Tenth census of the United States, 1880, vol. VIII, $177 \mathrm{pp}$.

Pitelka, Frank A.

1948. The problematical relationship of the Asiatic shorebird Limnodromus semipalmatus. Condor, vol. 50, No. 6, pp. 259-269.

1950. Geographic variation and the species problem in the shorebird genus Limnodromus. University California Publ. Zoology, vol. 50, No. 1, pp. 1-100.

Pleske, THEODORE.

1928. Birds of the Eurasian tundra. Memoirs Boston Society Natural

History, vol. 6, No. 3, pp. 111-485.

Preble, Edward A., and W. L. McAtee.

1923. A biological survey of the Pribilof Islands, Alaska. North American Fauna No. 46, U. S. Biological Survey, Washington, D. C.

RADCLIFFE, LEWIS.

1932. Status of international convention for protection of whales. Jour. Mammalogy, vol. 13, No. 3.

Rainey, Froelich.

1940. Eskimo methods of capturing bowhead whales. Jour. Mammalogy, vol. 21, No. 3 .

RAND, A. L.

1950. Critical notes on Limnodromus semipalmatus. Condor, vol. 52, No. 5, pp. 228-231.

RaUsch, ROBERT.

1953. On the status of some arctic mammals. Arctic, vol. 6, No. 2, pp. 91-148.

ReIMANn, EDWARd J.

1938. Bald eagle takes live fish. Auk, vol. 55, No. 3, pp. 524-525. 


\section{Rhoads, Samuel N.}

1893. The Hudsonian chickadee and its allies, with remarks on the geographic distribution of bird races in boreal America. Auk, vol. 10, No. 4, pp. 321-333.

1902. Synopsis of the American marten. Proceed. Academy Natural Science Philadelphia.

\section{RICHMOND, ChaRLES W.}

1895. On the status of Bischoff's song sparrow (Melospiza insignis Baird). Auk, vol. 12, No. 2, pp. 144-150.

RIDGWAY, ROBERT.

1880. On a new Alaskan sandpiper. Bull. Nuttall Ornithological Club, vol. 5 , No. 3 , pp. $160-163$.

1883. Description of a new petrel from Alaska. Proceed. U. S. National Museum (1882), pp. 656-658.

1886. On the glaucous gull of Bering's Sea and contiguous waters. Auk, vol. 3, No. 3, pp. 330-331.

1887. Clarke's nutcracker (Picicorvus columbianus) in the Bristol Bay region, Alaska. Auk, vol. 4, No. 3, p. 255.

1895. On Fisher's petrel (Aestrelata fisheri). Auk, vol. 12, No. 4, pp. 319-322.

1898. Descriptions of supposed new genera, species, and subspecies of American birds. I. Fringillidae. Auk, vol. 15, No. 3-4, pp. 223-230, 319-324.

1900. Descriptions of supposed new genera, species, and subspecies of American birds, VI. Fringillidae. Auk, vol. 17, No. 1, pp. 29-30.

\section{RigGs, Thomas.}

1919. Annual report of the Governor to the Secretary of the Interior, Alaska Game Law.

RoBinson, G. D., and others.

1947. Alaskan volcano investigations: Report No. 2, Progress of investigations in 1946. U. S. Geol. Survey Preliminary Report.

\section{ROWAN, WilLIAM.}

1932. The status of the dowitchers with a description of a new subspecies from Alberta and Manitoba. Auk, vol. 49, No. 1, pp. 14-35.

KOWLEY, JOHN.

1929. Life history of the sea-lions on the California coast. Jour. Mammalogy, vol. 10, No. 1.

SALOMONSEN, FinN.

1931. On the geographical variation of the snow bunting (Plectrophenax nivalis). Ibis (ser. 13), vol. 1, pp. 57-70, pls. 1-11.

1932. Description of three new guillemots (Uria alge). Ibis (ser. 13), vol. 2, pp. 128-132.

1939. Moults and sequences of plumages in the rock ptarmigan (Lagopus mutus (Moutin)). Videnskabelige Meddelelser fra Danske Naturhist. Forening, vol. 103, 491 pp. Copenhagen, Denmark.

ScAMMON, C. M.

1869. On the cetaceans of the western coast of the North America. Proceed. Academy Science Philadelphia, ser. 2, vol. 21, pp. 13-62.

1874. The marine mammals of the northwestern coast of North America. J. H. Carmany and Co., San Francisco; Putnam and Sons, New York. 
Schalow, Herman.

1891. J. F. von Brandt: Ueber die Vogelfauna der Aleuten. Jour. für

Ornithologie, vol. 39, pp. 235-271.

SCHEFFER, ViCTOR B.

1939. Organisms collected from whales in the Aleutian Islands. Murrelet, vol. 20 , No. 3, pp. 67-69.

1940. The sea otter on the Washington coast. Pacific Northwest Quarterly, pp. 370-388, October.

1942a. A list of the marine mammals of the west coast of North America. Murrelet, vol. 23, No. 2, pp. 42-47.

1942b. Further records of the Dall porpoise in California. Jour. Mammalogy, vol. 23, No. 2.

1943. Fish bites bird. Nature Magazine, vol. 36, No. 1, pp. 41-42.

1949. The Dall porpoise, Phocoenoides dalli, in Alaska. Jour. Mammalogy, vol. 30, No. 2, pp. 116-121.

1958. Seals, Sea Lions and Walruses-A review of the Pinnipedia. Stanford Univ. Press. 179 pp.

SCHWARTZ, ERNST.

1942. The harbor seal of the Western Pacific. Jour. Mammalogy, vol. 23 , No. 2.

Schwartz, Ernst, and Henrietra K. Schwartz.

1943. The wild and commensal stocks of the house mouse, Mus musculus

Linnaeus. Jour. Mammalogy, vol. 24, No. 1, pp. 59-72.

SEALE, Alvin.

1898. Notes on Alaskan water birds. Proceed. Academy Science Philadelphia, vol. 50, pp. 126-140.

SEFToN, Joseph W., JR.

1926. Exhaustion of migrating sea birds. Condor, vol. 28, No. 5, p. 244. SETCHELL, W. A.

1912. Kelps of the United States and Alaska. In Fertilizer resources of the United States. Senate Doc. 190, 62nd Cong., 2nd sess., pp. $130-178$.

SHELFORD, VICTOR E., and others.

1935. Some marine biotic communities of the Pacific Coast of North

America. Ecological Monographs, vol. 5, pp. 249-354.

SHORTT, T. M.

1939. The summer birds of Yakutat Bay, Alaska. Contrib. Royal Ontario Museum Zoology, vol. 17. $30 \mathrm{pp}$.

1940. Eared grebe at Yakutat, Alaska-a correction. Condor, vol. 42, No. 3, p. 170.

Simpson, George GAYlord.

1940. Mammals and land bridges. Jour. Washington Academy Science, vol. 30, No. 4, pp. 137-163.

SMith, Philip S.

1927. Some post-Tertiary changes in Alaska of climatic significance.

National Research Council Bull. 61, pp. 35-39.

STEJ NEGER, LEONHARD.

1883. Contributions to the history of the Commander Islands. No. 1Notes on the natural history, including descriptions of new cetaceans. Proceed. U. S. National Museum, vol. 6, No. 4, pp. 58-59.

1884a. A brief review of the Lagopodes belonging to the group Attagen

Kaup. Zeitschrift für die gesammte Ornithologie, pp. 86-92. 
1884b. Die wichtigsten ornithologischen publicationen aus den vereinigten staaten. Vom. 1. Januar 1883 bis 1. Mai 1884. Zeitschrift für die Gesammte Ornithologie, pp. 179-189.

1885a. Results of ornithological explorations in the Commander Islands and in Kamtschatka. U. S. National Museum Bull. 29, 382 pp.

1885b. Notes on some apparently preoccupied ornithological generic names. Proceed. U. S. National Museum, vol. 8, No. 26, pp. 409-410.

1886a. Fra det yderste östen. Rejsebreve af Leonhard Stejneger. Reprint from Naturen, 1885-86, pp. 1-56. Kristiania, Norway.

1886b. On Brachyrhamphus perdix (Pall) and its nearest allies. Zeitschrift f. ges. Ornith., pp. 210-219, 1 pl.

1886c. On the status of Synthliboramphus wumizusume as a North American bird. Proceed. U. S. National Museum, vol. 9, p. 524.

1887a. Notes on the northern palaearctic bullfinches. Proceed. U. S. National Museum, vol. 10, pp. 103-110.

$1887 \mathrm{~b}$. Contributions to the natural history of the Commander Islands, No. 7, Revised and annotated catalogue of the birds inhabiting the Commander Islands. Proceed. U. S. National Museum, vol. 10, pp. $117-145$.

$1887 \mathrm{c}$. How the great northern sea-cow (Rytina) became exterminated. American Naturalist, vol. 21, pp. 1047-1054.

1889. Contributions to the history of Pallas cormorant. Proceed. U. S. National Museum, vol. 12, pp. 83-94.

1895. Arctic notes on the habits of certain rare northern birds in Commander Islands and Kamtchatka. Museum, Albany, N. Y., vol. 1, pp. 53-58, 85, 87, 101-102.

1896. The Russian fur-seal islands. Bull. U. S. Fish Commission. (1896), vol. 16, pp. 1-148.

1898. Ross's gull (Rhodostethia rosea) on Bering Island. Auk, vol. 15, No. 2, p. 183.

1906. Isolation versus natural selection. Auk, vol. 23, No. 3, pp. 265270 .

1928. Unsolved problems in arctic zoogeography. Special Publ. American Geographic Society, vol. 7, pp. 155-165.

Stevenson, Charles H.

1902. Utilization of the shins of aquatic mammals. In Rept. of Commissioner, U. S. Commission Fish and Fisheries, Part 28, pp. 281-352.

STONE, ANDREW J.

1900. Some results of a natural history journey to northern British Columbia, Alaska, and the Northwest Territory, in the interests of the American Museum of Natural History. Bull. American Museum Natural History, vol. 13, p. 60.

Stone, WitMer.

1900. Report on the birds and mammals collected by the McIlhenny Expedition to Point Barrow, Alaska. Proceed. Academy Natural Sciences Philadelphia, pp. 4-49.

StORER, ROBERT W.

1950. Geographic variation in the pigeon guillemots of North America. Condor, vol. 52, No. 1, pp. 28-31.

Sutton, George Miksch, and Rowland S. Wilson.

1946. Notes on the winter birds of Attu. Condor, vol. 48, No. 2, pp. 83-91. 
SWALES, BRADSHAW H.

1926. Ruby-throated hummingbird near St. Michael, Alaska. Condor, vol. 28, No. 3, p. 128.

SWARTH, HARRY S.

1909. Birds and mammals of the 1909 Alexander Expedition. University California Publ. Zoology, vol. 7, No. 2.

1920. Revision of the avian genus Prsserella, with special reference to the distribution and migration of the races in California. University California Publ. Zoology, vol. 21, No. 4, pp. 75-224.

1926. Birds of the Atlin district, British Columbia. University California Publ. Zoology, vol. 30, No. 4.

1928. Occurrence of some Asiatic birds in Alaska. Proceed. California Academy Science, vol. 17, No. 8, pp. 247-251.

1931. The tyranny of the trinomial. Condor, vol. 33 , No. 4, pp. 160162.

1933. The savannah sparrows of northwestern North America. Condor, vol. 35 , No. 6 , pp. $243-245$.

1934. Birds of Nunivak Island, Alaska. Pacific Coast Avifauna No. 22, pp. 1-64. Cooper Ornithological Club.

1935. Systematic status of some northwestern birds. Condor, vol. 37, No. 4, pp. 199-204.

1936. Savannah sparrow migration routes in the Northwest. Condor, vol. 38 , No. 1, pp. 30-32.

Sykes, C. E.

1923. Sn the Alaska Peninsula for brown bear. Outdoor Life, vol. 51, pp. 77-81, 157-162, 237-242.

TABER, RICHARD D.

1946. The winter birds of Adak, Alaska. Condor, vol. 48, No. 6, pp. 272-277.

TAVERNER, P. A.

1929. A study of the Canadian races of rock ptarmigan. Bull. No. 62, National Museum Canada, pp. 28-37.

1931. A study of Branta canadensis (Linnaeus), the Canada goose. Annual Rept. National Museum Canada for 1929, pp. 28-40.

1935. Continental land masses and their effect upon bird life. Condor, vol. 37, No. 3, pp. 160-162.

1936. Taxonomic comments on red-tailed hawks. Condor, vol. 38, No. 2, pp. 66-71.

TAYLOR, WALTER P.

1914. The problem of aquatic adaptation in the Carnivora, as illustrated in the osteology and evolution of the sea otter. Bull. University California, vol. 7, p. 472.

THAYER, JOHN E.

1914. Nesting of the Kittlitz murrelet. Condor, vol. 16, No. 3, pp. $117-118$.

ThAYER, JoHn E., and OUTrAM BANGS.

1921. The black-backed Kamchatkan wagtail, Motacilla lugens Kittlitz, in Alaska. Auk, vol. 38, No. 3, p. 460.

THONE, Frank.

1942. Aleutian weather. Science-Supplement, vol. 96. 
Todd, W. E. CLyde.

1935. Geographical variation in the American titlark. Proceed. Biological Society Washington, vol. 48, pp. 63-66.

Townsend, Charles H.

1887. Notes on the natural history and etınology of northern Alaska. In Report of the Cruise of the Revenue Steamer "Corwin" in the Arctic Ocean in the year 1885, by Captain M. A. Healy; pp. 81-102. U. S. Government Printing Office, Washington, D. C.

1913. The crested auklet. National Association Audubon Societies, Bird Lore, vol. 15, p. 133.

TRUE, FREDERICK W.

1884. The manatees and the Arctic sea cow, pp. 114-136. In Fisheries and Fishing Industries of the United States, by George Brown Goode. U. S. Government Printing Office, Washington, D. C.

1885. On a new species of porpoise, Phocaena dalli, from Alaska. Proceed. U. S. National Museum, vol. 8, No. 7, p. 95.

1886. An annotated list of the mammals collected by the late Charles L. McKay in the vicinity of Bristol Bay, Alaska. Proceed. U. S. National Museum, vol. 9, pp. 221-224.

1904a. The whalebone whales of the western North Atlantic compared with those occurring in European waters with some observations on the species of the North Pacific. Smithsonian Institute, Washington, D. C. (Smithsonian contributions to knuwledge, vol. 33.)

1904b. Note on three very large beaked whales from the North Pacific. Science (new ser.), vol. 20, No. 521, pp. 888-889.

1910. An account of the beaked whales of the family Ziphiidae in the collection of the United States National Museum, with remarks on some specimens in other American Museums. Bull. U. S. National Museum, vol. 73.

TURNER, LUCIEN M.

1885. Notes on the birds of the Nearer Islands, Alaska. Auk, vol. 2, No. 2, pp. 154-159.

1886. Contributions to the natural history of Alaska. Arctic series of publications in connection with the Signal Service, U. S. Army, No. 2. Washington, D. C.

VAN KaMMEN, I. J.

1916. Relative to the bald eagle in Alaska. Oölogist, vol. 33, pp. 156158.

Veniaminof, I. E. P.

1840. Zapiski ob ostrovakh Unalashkinskago. 3 vols. in 2 . St. Petersburg.

WaLES, JOSEPH H.

1927. Fearlessness of shearwaters. Condor, vol. 29, No. 2, pp. 119120.

WALKER, ERNEST P.

1920. Probable breeding of the Aleutian tern in southeastern Alaska. Condor, vol. 32, No. 3, pp. 111-112.

1923. Definite breeding record for the Aleutian tern in southern Alaska. Condor, vol. 25, No. 4, pp. 113-117.

Wallace, George J.

1939. Bicknell's thrush, its taxonomy, distribution, and life history. Proceed. Boston Society Natural History, vol. 41, No. 6, pp. 211-402. 
WetMoRe, AlexANDER, and others.

1944. Nineteenth supplement to the American Ornithologists' Union Checklist of North American Birds. Auk, vol. 61, No. 3, pp. 441-464.

1945. Twentieth supplement to the American Ornithologists' Union Checklist of North American Birds. Auk, vol. 62, No. 3, pp. 436-449.

WEYER, EDWARD M.

1929. An Aleutian burial. American Museum Natural History Anthropological Papers XXXI, Part III, pp. 219-238.

WIIELEN, TOWNSEND.

1946. Hunting big game, The Americas. Vol. II. Military Service Publ. Co., Harrisburg, Pa.

Willett, George.

1915. Summer birds of Forrester Island, Alaska. Auk, vol. 32, No. 3, pp. 295-305.

1920. Comments upon the safety of seabirds and upon the "probable" occurrence of the northern bald eagle in California. Condor, vol. 22, No. 6, pp. 204-205.

1921. Bird notes from southeastern Alaska. Condor, vol. 23, No. 5, pp. 156-159.

1927. Notes on the occurrence and distribution of some southeastern Alaskan birds. Condor, vol. 29, No. 1, pp. 58-60.

1928. Notes on some birds of southeastern Alaska. Auk, vol. 45, No. 4, pp. $445-449$.

1939. Remarks on Alaska Savannah sparrows. Condor, vol. 41, No. 2, p. 86.

Williams, CECil S.

1938. Notes on food of the sea otter. Jour. Mammalogy, vol. 19, No. 1, pp. 105-107.

Wilson, Rowland Sterle.

1948. The summer bird life of Attu. Condor, vol. 50, No. 3, pp. 124-129.

Wismer, N. M., and J. H. SWAinson.

1935. Some marine biotic communities of the Pacific coast of North America. Part 2. A study of the communities of a restricted area of soft bottom in San Juan channel. Ecological Monographs, vol 5, pp. 333-354.

ZANDER, H.

1853. Kurze Uebersicht der europaischen Peiper, Anthus Bechst. Jour. für Ornithologie, vol. 1, pp. 60-65. 


\title{
INVERTEBRATES AND FISHES COLLECTED IN THE ALEUTIANS, 1936-38
}

\author{
By Victor B. Scheffer, Biologist
}

\section{Introduction}

In the expeditions to the Aleutian Islands conducted by the Fish and Wildlife Service from 1936 to 1938, chief emphasis was placed on investigations of birds and mammals. Limited studies were made of the lesser forms of animal life that inhabit the subarctic waters of the Northeast Pacific and the Bering Sea and that live on the shores and slopes of the islands. With relation to the birds and the mammals, the myriad lesser organisms may collectively be termed the "supporting fauna."

One must actually visit the northern seas to realize the abundance of small animal life in the water and along the shoreabundance not of kinds but of numbers. From the deck of a ship, it is often possible to see swarms of reddish microcrustaceans drifting along on the surface of the water in such profusion that they impart a reddish cast to the water. At night, the churn of the ship's propeller sometimes turns up a glowing wake as it brings countless bodies of luminescent organisms to the surface. These organisms are recorered in the stomachs and crops of auklets and petrels. Where the ocean currents cause an upwelling of water rich in plankton, shearwaters and fulmars flock to the scene and baleen whales soon appear. On one occasion, at Unimak Pass, it was estimated that the surface of the ocean for 15 square miles was covered with feeding shearwaters, each separated from its neighbor by 10 or 20 feet. If the carcass of a bird or fish, weighing about 5 pounds, is lowered to the bottom of the sea and hauled up on the following day, the bones usually will have been picked clean by small amphipod crustaceans.

On certain of the Aleutian beaches that are corered with flat, shingly rocks the size of a man's hand, it is possible to uncover as much as a half pint of amphipod crustaceans or sand fleas hiding beneath a single rock. Such organisms, on islands with ex- 
tonsive beaches, are often the main source of food of the blue fox. In certain quiet waters it is possible to look down from a row boat and see a green carpet of sea urchins covering the floor of the occan. These animals make up the largest single item in the diet of the sea otter. More specific information on the food relations of Aleutian organisms will be presented, but some indication has here been given of the importance of the invertebrates and fishes in the teeming, complex fauna of the northern seas.

Specimens of invertebrates and fishes were collected at every opportunity, but the time made available for this phase of the work was very limited, therefore the collection is not complete. In includes, however, 255 species, or subspecies, of invertebrates and 18 species, or subspecies, of fishes, representing many of the forms that are encountered in the Aleutian area. Two new genera and six new species have been described to date on the basis of material in the collection, and many other species have had their langes extended.

With the exceptions noted, all of the specimens collected by members of the Aleutian expeditions have been identified by staff members of the United States National Museum or by collaborating agencies. The indispensable help of the following persons is gratefully acknowledged: Paul Bartsch, S. S. Berry, H. B. Bigelow, Austin H. Clark, Wesley R. Coe, J. E. Cornwall, Irving Fox, Theodore C. Frye, C. T. Greene, David G. Hall, Melville H. Hatch, Trevor Kincaid, J. T, Lucker, J. O. Maloney, J. Percy Moore, E. W. Price, Harald A. Rehder, Clarence Shoemaker, Walclo L. Schmitt, Leonard P. Schultz, Alan Stone, William Randolph Taylor, Margaret E. Van Winkle, Arthur Welander, and C. B. Wilson.

In the following pages, notes are presented on the invertebrates and fishes that were most commonly observed or, because of some special relationship to the birds and mammals, attracted the attention of members of the 1936-38 party. Some of the conspicucus marine algae are also discussed briefly. There is no attempt in this report to list all of the species of organisms collected, because, in the first place, such an array would be only an approach to a complete check list of the organisms of the Aleutian Islands. In the second place, a complete list of the species collected in 1936-38 would selve no useful purpose, because the specimen records, field data, and (in most cases) the specimens are already in the hands of specialists who have published, or will publish, on any material of outstanding value. It is hoped that the present report will be of interest to future workers in the Aleutian Islands National Wildlife Refuge. 


\section{Marine Algae}

Samples of the commoner seaweeds found in the Aleutian Islands were identified by T. C. Frye. The genus Alaria (the most abundant) is found in shoal water along the entire archipelago.

Its long, brown, leathery fronds are a nuisance in small-boat navigation. The thallus is 4 to 8 inches wide with a bladderlike midrib that is $1 / 2$ to 1 inch wide. This midrib remains floating after the sicles of the thallus have decomposed and washed away. Masses of Alaria are seen floating detached at sea and piled on the beaches after the first of August.

Laminaria has a similar structure, but the fronds are wider (as much as 2 feet) and the plant has the general appearance of a slick leather apron.

Nereocystis, the common bull-whip kelp of the Pacific Coast, has a long, hollow, floating stem increasing in diameter to a bulb at the free end. Very common along the mainland, this plant is observed only rarely west of the Alaska Peninsula. At King Cove, east end of the Peninsula, Nereocystis is definitely the dominant kelp as compared with Alaria to the westward. Nereocystis, in all cases a single plant drifting at sea or washed up dead on the beach, was seen on the following Islands: Unalaska, East Semichi, Atka, Ogliuga, and Amchitka.

Fucus is common along the beach; locally it is called "popweed" from the sound made by the bursting of the bladders when they are trod upon (fig. 1).

The bright-green sheets of sea lettuce, Ulva, are on every beach.

Spongomorpha has the texture and appearance of coarse green moss and grows attached to rocks. On spray-covered rocks, the cylindrical floats of Halosaccion occur in clumps suggestive of the local name "dead man's finger's".

Cystophyllum is a brown seaweed that occasionally washes up on the beach. It has a mass of fine branches covered with small brown bladder's, each of which is the size and shape of a grain of wheat.

Thallasiophyllum is easily distinguished by its wide brown fronds covered with holes like a colander.

A number of lime-secreting marine algae, locally called corals, 


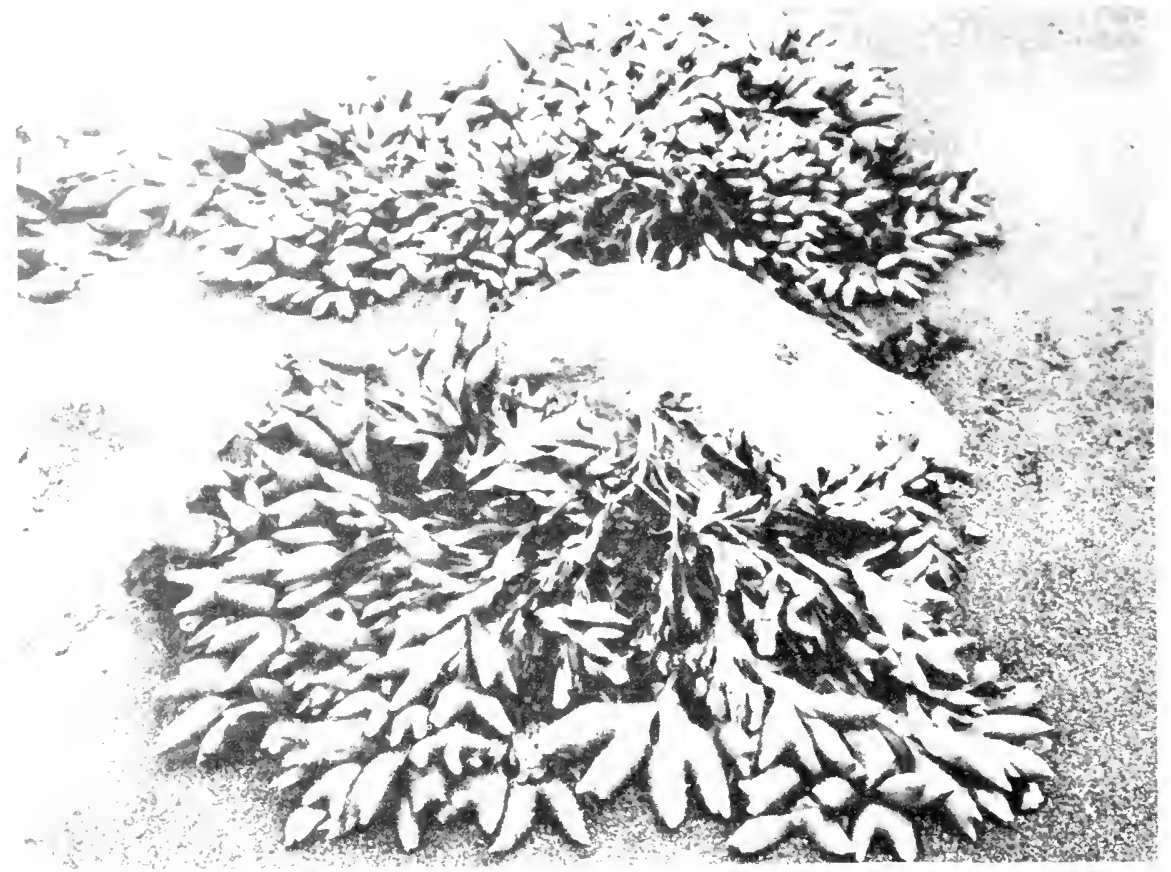

Figure 1.-Fucus, a brown seaweed common along the beaches of the Aleutian Islands. Rat Island, June 29, 1937.

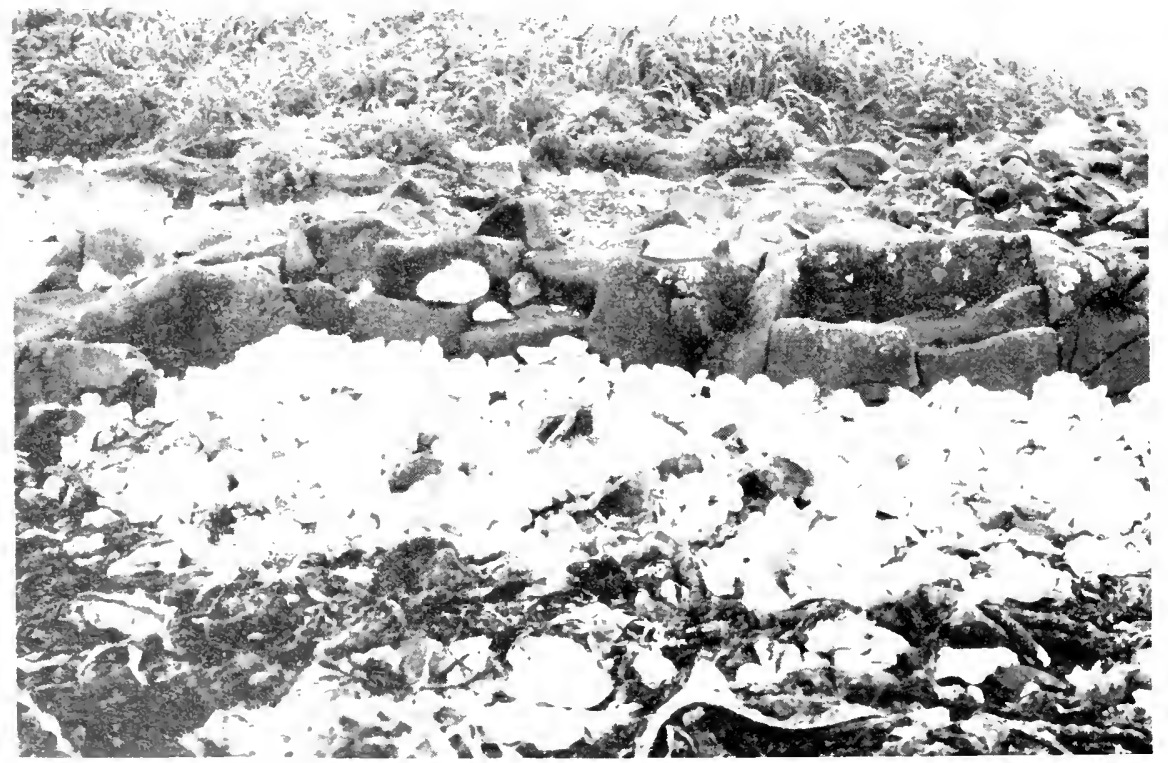

FrguRE 2.-Calcareous algae of the Lithothamion group commonly attach to the holdfasts of kelp and are stranded during storms. Ogliuga Island, August 4, 1937. 
are conspicuous on the Aleutian beaches (fig. 2). Members of the Lithothamnion group form chalk-white crusts around the rhizoids of kelps, these crusts being later washed up on the beach in windrows. Corallina grows in branched tufts on the rocks, looks like an ornamental coral, and is wine colored to dirty white. Its stalks are commonly found attached to pebbles brought up by dredging.

A list, accompanied by brief field notes, of 40 species of marine algae collected in the Aleutian Islands has been published by Okamura (1933), who stated that "the Aleutian algae are almost equally dispersed westward to Japan, and eastward to California."

(The vascular plant Zostera, or eel grass, an important waterfowl food, was observed growing in a lagoon on Vsevidof Island, near Umnak Island, but it was not seen farther west.) 


\section{Marine Invertebrates}

\section{SPONGES}

The vase sponge, Esperiopsis quatsinoensis, is common throughout the islands. It washes up on the beach and eventually bleaches out to a creamy-white color. In size and general shape, it resembles a flattened ice cream cone. A large specimen from Aiktak Island measured 28 centimeters from base to lip and was 30 centimeters wide.

\section{COELENTERATES}

\section{HYDROIDS}

Abietinaria filicula is a small hydroid about 5 centimeters long, resembling a feather. It is often washed up in tangles of seaweed.

Another hydroid, Thuaria robusta, has been collected in sea otter scats.

\section{JELLYFISHES}

The common crystal jellyfish of the West Coast (Aequorea aequorea) is observed almost daily after the first of July in the Aleutian Islands. It is a transparent, lens-shaped medusa that, at first glance, appears to have no organized structure, but closer scrutiny will show a delicate central manubrium and a fringe of fine tentacles. The body mass is firmer than that of the large red jellyfishes and may be turned over readily in the hand. A few specimens reach a diameter of 150 millimeters.

Aurelic aurita is transparent, but it has a conspicuous structure in the center-a set of four yellowish-brown gonads arranged like the leaves of a four-leafed clover. Of the two species, Aequorea appear's much more frequently 'during the summer.

Cyanea capillata is one of the large, trailing, red jellyfishes frequently seen from July to September, especially in the calmer bays. The rim of the medusa is divided into eight pairs of short lobes, or a total of 16 lobes. Each lobe has a medial notch about 
3 centimeters deep. Muscle fibrils can be seen extending into these lobes in bundles of 12 or more.

A number of small medusae were collected in plankton hauls, including Aegina, Hybocodon, Mitrocoma?, Rathkea, Sarsia, and Stomotoca.

\section{FLATWORMS}

A monogenetic fiuke, Entobdella hippoglossi, was collected from the skin of a halibut (Hippoglossus stenolepis) off Nikolski, Umnak Island, on August 30, 1938. (See also Annelid Worms.)

\section{ROUNDWORMS}

Sperm whales (Physeter catodon) brought to the Akutan whaling station are, without exception, infested with intestinal worms. According to Coast Guard Inspector A. Van De Venter the baleen whales are commonly infested as well. Anisakis physeteris was collected from the intestine of sperm whales here (Scheffer 1939).

Contracaecum clavatum is a thready white worm found in masses in the stomach of nearly every cod (Gadus macrocephalus) examined in Aleutian waters. A single specimen of Cystidicola sp. was also collected in the cod. Porrocaceum decipiens was found encysted in larral stage in the mesenteries of the cod.

An undetermined species (larval) of Porrocaccum was taken from the stomach of a sea otter.

\section{NEMERTEAN WORMS}

Paranemertes peregrina is a long, thready worm found in the tidal zone under rocks; it is colored dark brown to purple above and white to yellow below.

\section{BRACHIOPODS}

Three specimens of a single species, Diestothyris frontalis, were collected.

\section{ANNELID WORMS}

Two leeches from the skin of fishes were collected: Ottoniobdella scorpii is a cream-colored worm, 25-50 millimeter's long, commonly found attached to the dorsal surface of the sculpin (Hemilepidotus). Platybdella quadrioculata was collected once, in the operculum of a cod (Gadus macrocephalus).

Many free-living worms doubtless are present in the sand and among the tide-pool rocks of the Aleutian beaches, but the collections of the present expedition have not been studied. A species 
of Nereis was found in small numbers in blue-fox droppings on Attu Island.

A small, tan-colored earthworm was noticed on several occasions, well up in the grass of the islands.

\section{ECHINODERMS}

\section{BRITTLE STARS}

Gorgonocephala eucnemis var. caryi, the basket star, has five arms which branch and rebranch profusely toward the periphery into a tangled mass of tendrils. The terminal branches writhe slowly in the living specimen and are tan in color. Specimens were snagged occasionally on codfish hooks.

Ophiopholis aculeata is a small reddish species often streaked or mottled with lighter colors. It was collected on three islands.

Ophiura sarsii is grayish or tan. It was collected on three islands.

\section{STARFISHES}

Two specimens of Aleutiaster schefferi, a small stubby sixrayed starfish were taken; 1 on Attu Island and 1 on Amchitka, in both cases by dredging. They formed the basis of a new genus and species (Clark 1939). The family Ganeriidae, to which Aleutiaster was assigned, hitherto included 4 genera in the Antarctic and 2 in the West Indies. "It is especially interesting, therefore, to find a member of this family in the North Pacific." The topotype has a radius of only 5 millimeters.

Two species of Henricia were collected. H. leviuscula, taken only once, was noted 'as purple above and tan beneath. $H$. sanguinolenta form tumida, taken on five islands was noted as red. The latter is a slender, five-rayed "blood star" with a radius of about 20-30 millimeters. In a tide pool on Umnak Island it was associated with other starfishes of the same size, but with six-rays (Leptasterias).

The only large species of starfish in the Aleutian Islands, according to A. H. Clark, is Asterias remurensis (fig. 3). A specimen taken at Unalaska was wine-colored above, crossed by white channels and spots, and was light tan below. A pronounced light radial streak on the dorsal surface of each ray extended from a pentagonal hub at the center. The limp, fioppy attitude of this starfish is quite different from the rigidness of the common mainland Pisaster.

Four species of Leptasterias were collected, L. alaskensis most 


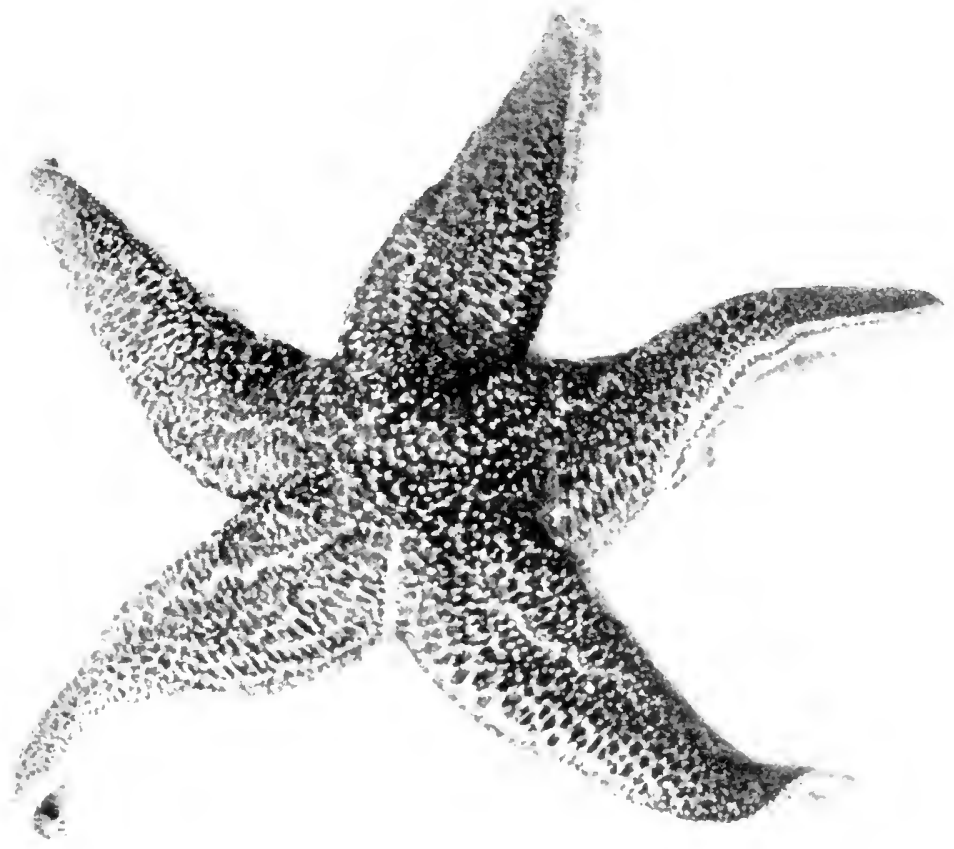

Figure 3.- The only large 5-rayed starfish of the Aleutian Islands, Asterias amurensis. This species is about 1 foot in diameter. Unalaska, August 18, 1937.

frequently (on six islands). These are slender, six-rayed starfishes, noted as dark green, gray, tan, or purplish red.

No other Pacific Coast form resembles the 20-rayed starfish, Pycnopodia helianthoides (fig. 4). Specimens were taken at King Cove, 35 miles east of Unimak Island, but not in the Aleutian Islands proper. No doubt it occur's at the east end, at least, of the chain.

\section{SEA URCHINS}

Strongylocentrotus dröbachiensis, the green sea urchin, is one of the most common inshore animals of the Aleutian Islands (fig. 5). In many places it is possible to look down from a boat through the clear water and see thousands of individuals side by side in a submarine garden of green. It occurs on rocky bottoms more frequently than on sand. Several specimens dredged from deep water ( 30 fathoms) off Sanak Island were a faded brown in color. Sea urchin spines are so predominant in the refuse heaps 
ol ancient Aleut villages that the middens are grayish in color. Sea urchins are eaten by the present-day natives. A small child was seen sucking the brown contents of one at Nikolski. The shell was cracked open and the orange part (gonad and liver) was caten with the fingers. Sea urchins do not seem to be particularly palatable to fish. For example, in 20 cor? stomachs examined at Chuginadak Island, only 1 small urchin was found. The occurrence of sea urchin remains in sea-otter, blue-fox, and sea-gull droppings has been mentioned elsewhere.

According to Clark, no other species of Strongylocentrotus occur in the Aleutians. A fisherman stated that he had seen the large purple S. franciscanus at Sitka, Alaska, but he had not seen it in the Aleutians.

The sand dollar, or sea biscuit, Echinarachnius parma, is thinly siattered along the Aleutians. Dead shells were seen or collected on the beaches of seven islands. Clark says that this is the only species of sand dollar in the Aleutians.

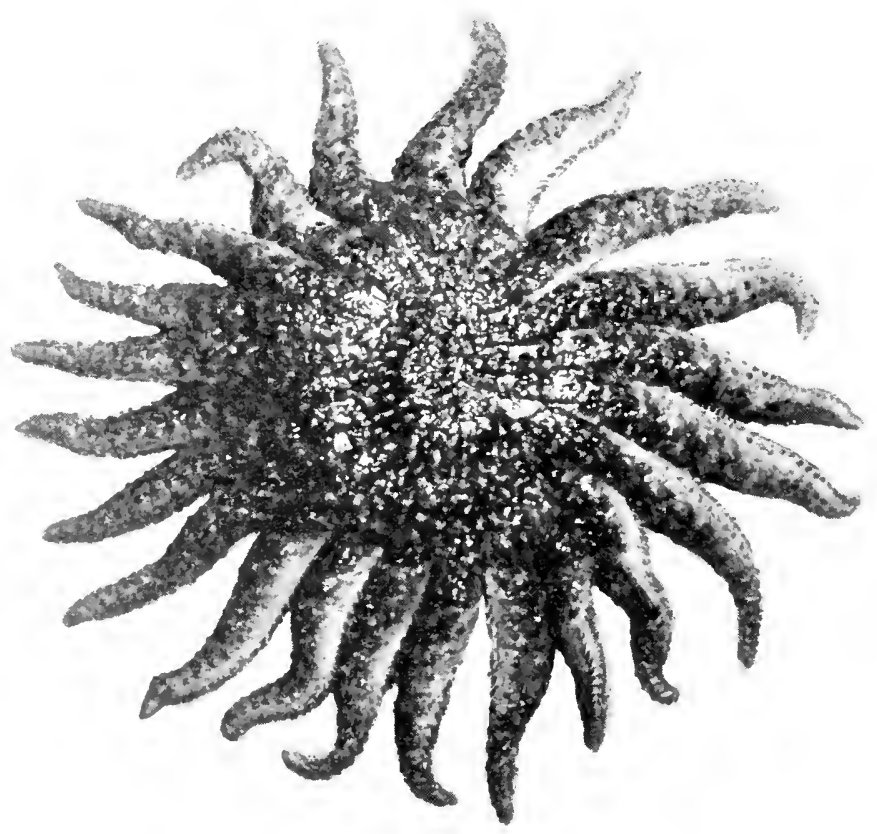

Figure 4.-Twenty-rayed starfish, Pycnopodia helianthoides. King Cove, September 9, 1938. 


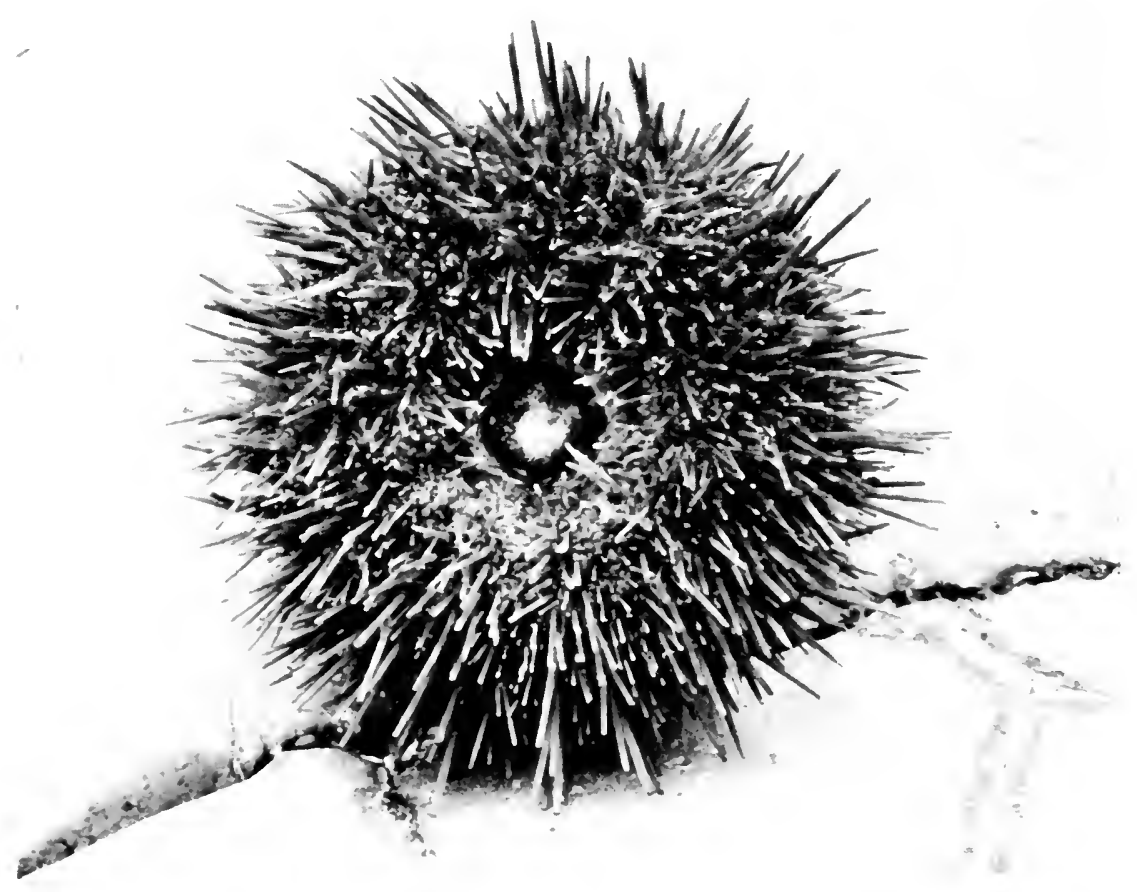

Figure 5.-Green sea urchin, Strongylocentrotus dröbachicnsis, ventral or oral view. Rat Island, June 30, 1937.

\section{SEA CUCUMBERS}

The sea cucumber, Cucumaria populifer, was collected at Kiska Island and was observed at other places in the archipelago.

\section{CRUSTACEANS}

\section{COPEPODS}

Eighteen species of copepods were irlentified in marine-plankton collections. Concerning Acartia pacifica, Dr. Wilson states (in correspondence), that-

This species was established by Steuer in 1915 with figures of the fifth legs of the two sexes and a statement of the size but with no description. These are the first to be reported since that date and the species is much in need of a detailed description.

The predominant species, judging from the number of collections in which it appears, is Eucalanus clongatus.

Several parasitic copepods were collected, Lepeophtheirus 
purimentis, on a cod at Tanaga Island, and L. salmonis, on a humploack salmon (Oncorhynchus gorbuscha), also at Tanaga Island.

A species of Pennclu uccasionally is recovered from whales at Akutan Island. Inspector Van De Venter at the whaling station said that no specimens were seen in 1938 and only one was seen in 1987.

\section{BARNACLES}

Ordinary rock barnacles are common throughout the Aleutians (fig. 6). Balanus crenatus was collected by dredge at Atka Island.

Two interesting species of barnacles attach to the skin of the humplack whale (Megaptera novacangliae) in the North Pacific (Scheffer, 1339). Coromula diadema is a white, hard barnacle that attaches to the skin, and Conchoderma auritum is a fleshy, elongated species that attaches, in turn, to Coronula (fig. 7). A fisherman said that Coronula is also found, though rarely, on the lower jaw of the sperm whale (Physcter catodon) just below the teeth. Two employees of the whaling station said that they had seen barnacles only on the humpback.
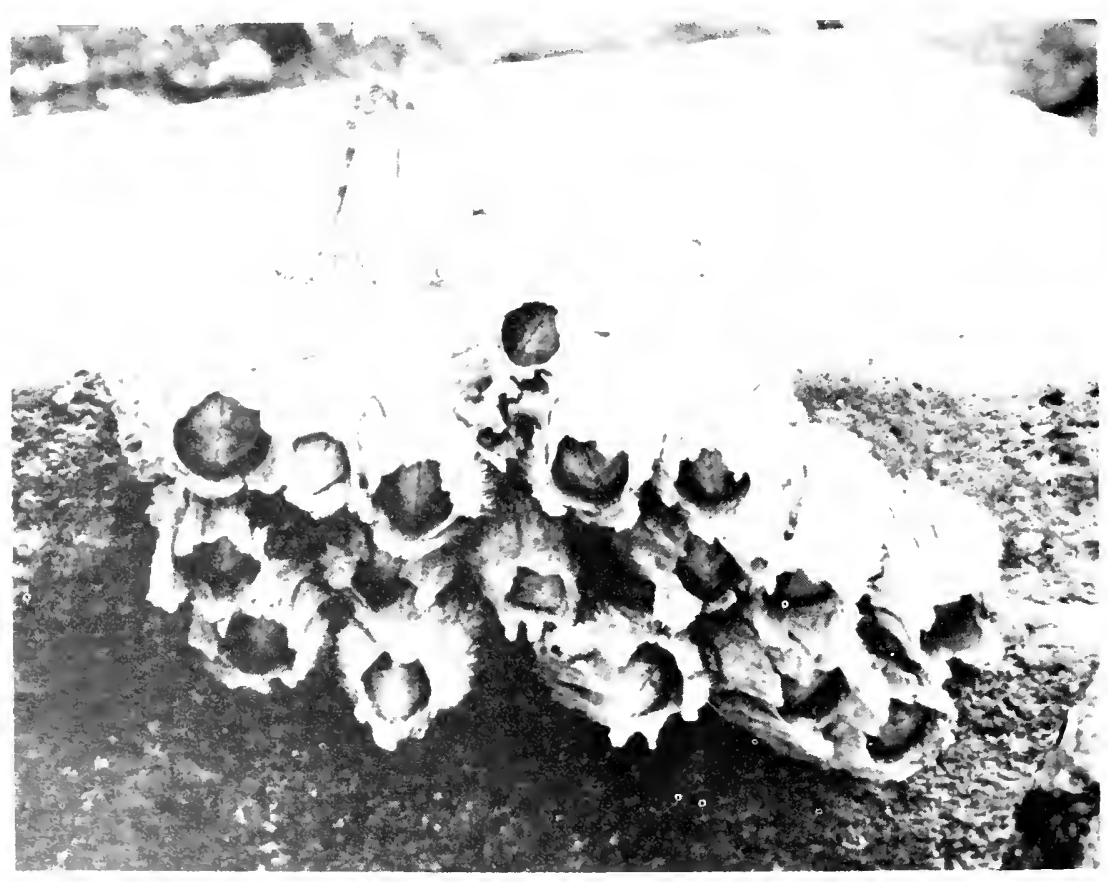

Figure 6.--Rock barnacles, Balanus sp., in tidal zone. Unalaska Island, July 10, 1937. 

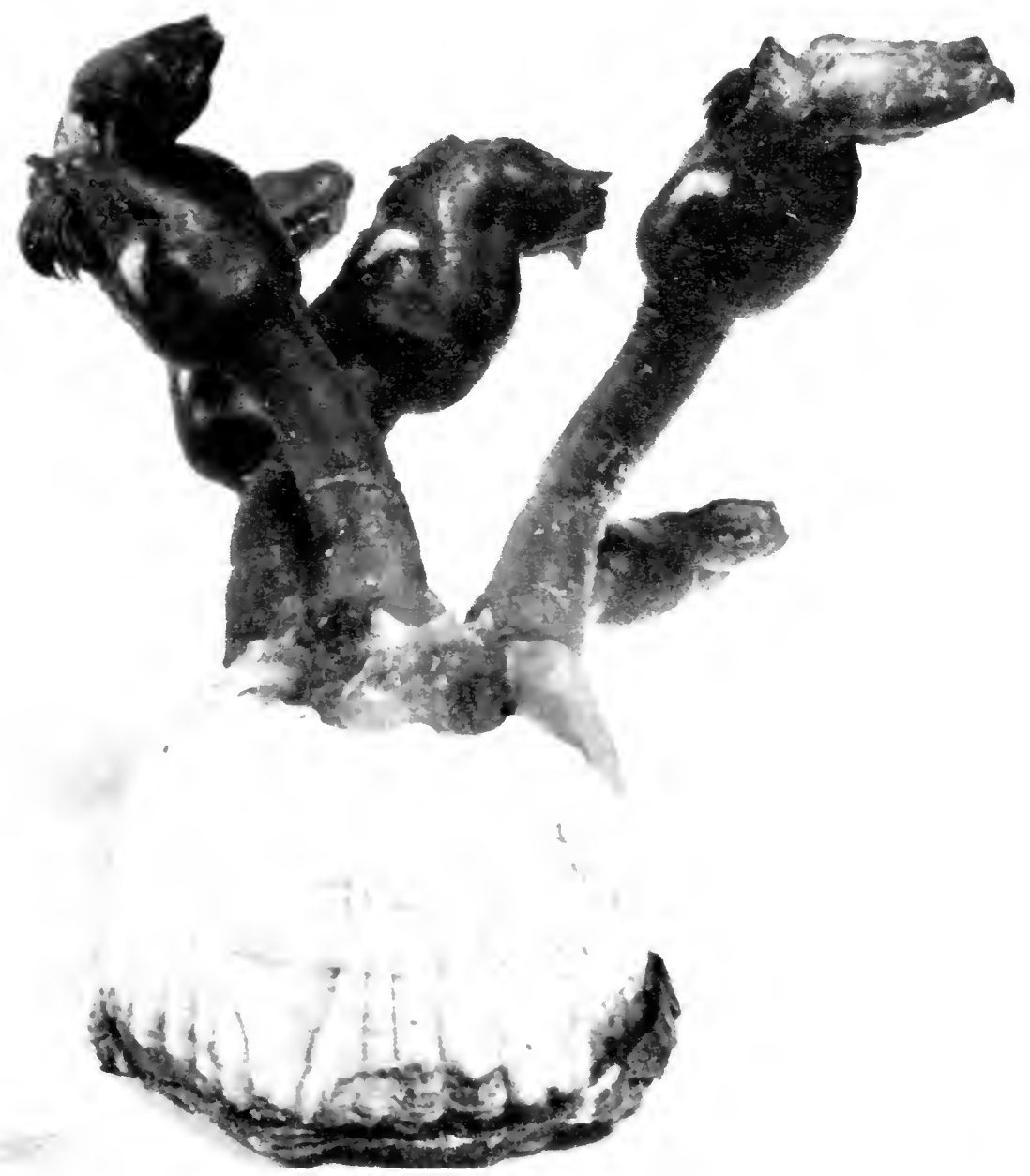

Figure 7.-Two species of barnacles collected from the skin of a humpback whale. The dark stalks of Conchoderma auritum attach to the white plates of Coronula diadema. Akutan Island, August 6, 1938.

Lepas, the goose barnacle, was collected at Otter Cove, Unimak Island, after a serere storm in September, 1937. Nany tons of seaweeds were washed up on the beach, and Lepas was observed attached near the rhizoids of the brown kelp, Nereocystis. Lepas was not seen west of Unimak Island.

\section{AMPHIPODS}

Several genera of marine amphipods were collected: Gammarus, Odius, Opisa, Orchestia, Orchestoidea, and Melita. 
Orrhistiu trustitum was the most commonly observed species living under the shelter of stranded seaweed or rocks throughcut the Aleutians. The principal food of this crustacean scoms to be rlecaying seaweed, of which there is a limitless supply; it also eats decaying fish, shellfish, sea birds, and mammals cast up from the sea. Orchestia is often found associated with the isoporl Lygra pallasi and carabid beetles.

Beach fleas are of more than passing interest for, in spite of their small size, they may form the major item of food for the blue fox. As a general r'ule, on islands where sea birds are plentiful the fox droppings contain mostly feathers and few or no beach fleas. Where birds are not available, however, the droppings are characteristically whitish in color and are composed of the chitinous exoskeletons of beach fleas and isopods, together with traces of other beach organisms.

Paracyamus boopis (fig. 8) occurs on the skin of the humpback

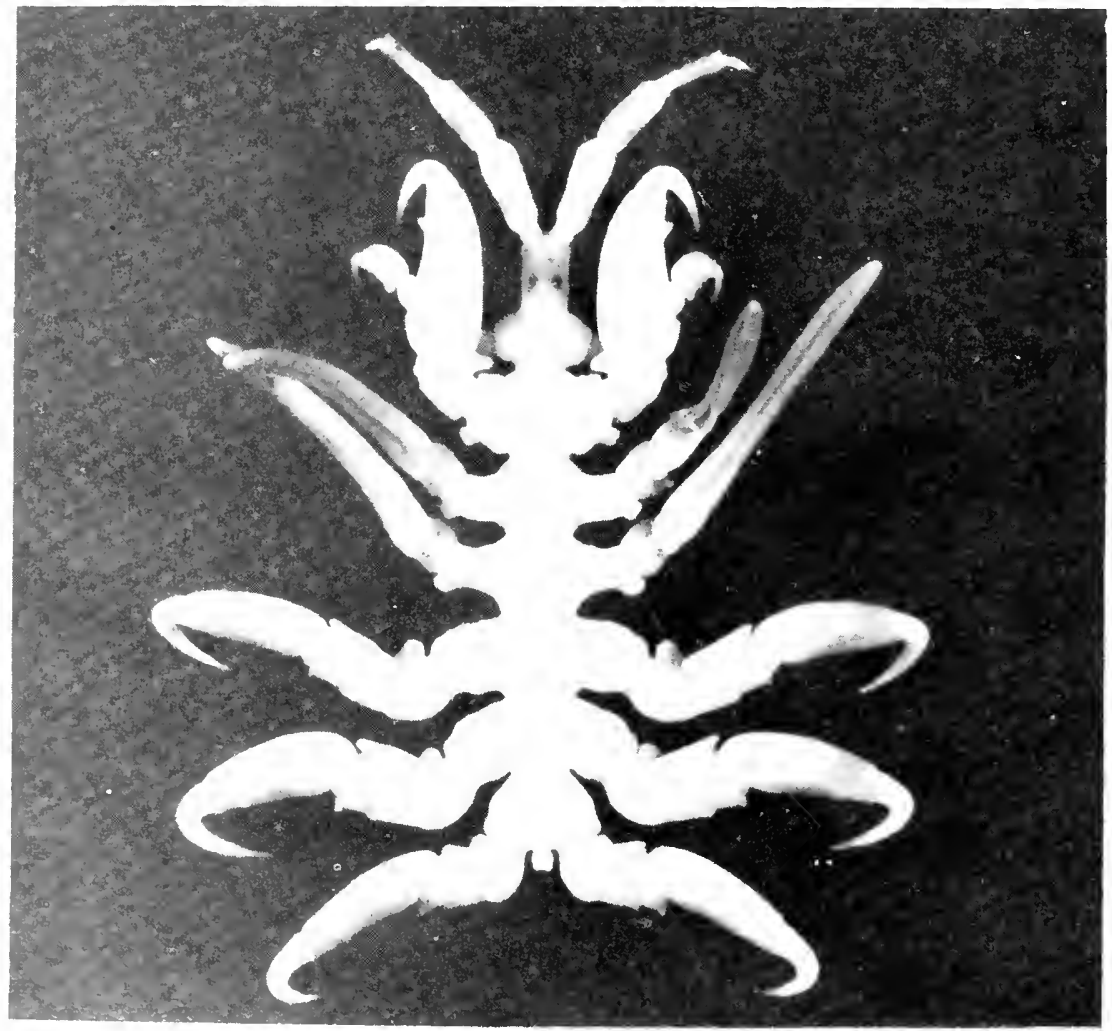

Figure 8.-Parasitic amphipod, Paracyamus boopis, from skin of humpback whale. Akutan Island, August 6, 1938. 
whale (Scheffer 1939). Known at the Akutan whaling station as a "whale louse," this amphipod clings tenaciously to the skin of the whale around the genital opening and, to a certain extent, over the entire body. When pried loose, it immediately seizes the collector's fingers with sickle-shaped clarvs.

\section{ISOPODS}

The isopods or sea slaters commonly are found clinging to damp rocks in the tidal zone. A few species are parasitic on fish.

Exosphaeroma oregonensis is common throughout the islands, not only in the tidal zone but also in brackish pools some distance from the sea. In Nikolski Lake, on Ummak Island, this isopod was living in water that harl, to the taste, no perceptible salt content. The animal curls up into a round ball when disturbed.

Idothea ochotensis, a large, dark species, was taken only once. in Chichagof Harbor, Attu Island.

Lygia palkesi is 1 of the 2 most common isoporls; it is flat, leadgray or blackish brown, with a broarlly oval outline. It is found on, or under, damp stones, and it was found from the mainland to Attu Island. It has been taken from fox droppings.

Idothea wosnessenskiit also is abundant. It is somewhat more slender than Lygin and occupies a similar habitat.

Mesidotea. Munna, and Synidoted were each collected once.

Rocinela belliceps is a flesh-colored isopod about 25 millimeters long, with a suffusion of reddish and brown, paler on the ventral side; eyes are black. It attaches to the body, fins, or operculum of the cod throughout the Aleutian Islands.

\section{SHRIMPS}

Shrimps of many species are found in dredge hauls or are recovered from the stomachs of corl, sculpins, and halibut. In the 1936-38 collections, Argis, Crago, Pandalus, Spirontocaris, Lebbeus, Eualus, and Heptacarpus are represented. Crago alastiensis and Spirontocaris dalli are represented from more collecting stations than any other species.

\section{HERMIT CRABS}

Six species of Pagurus are represented in the collections, of which $P$. hirsutiusculus is by far the most common. Hermit crabs are found everywhere along the beaches, in shells of periwinkles or larger molluses. 
n80) NORTH AMERICAN FAUNA 61, FISH AND WILDLIFE SERVICE

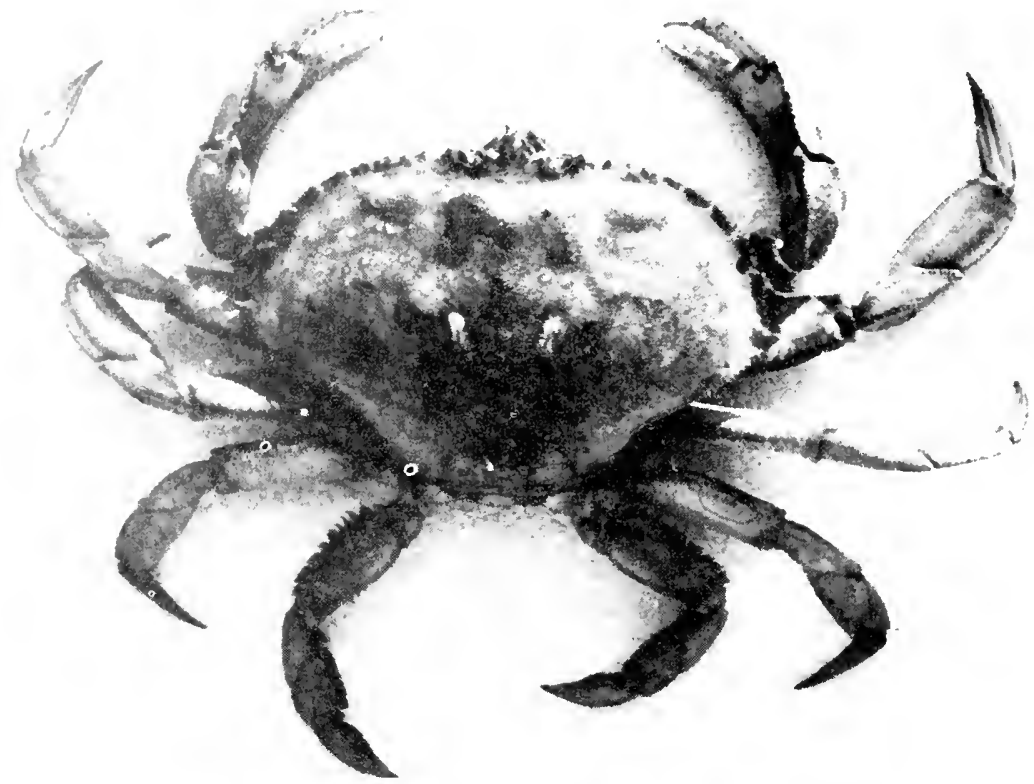

Figure 9.-Common crab, Cancer magister, taken by trawling at a depth of 15-20 fathoms. Petersburg, Alaska, September 17, 1937.

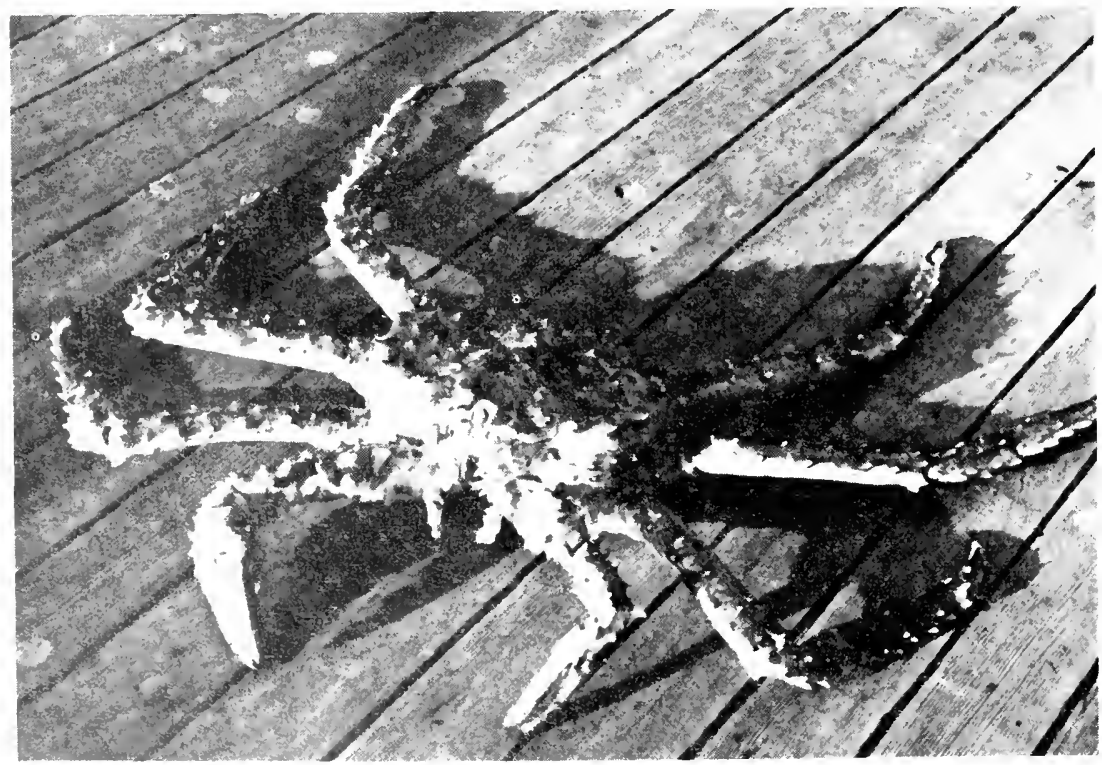

Figure 10, - King crab, Paralithodes sp., taken by trawling at a depth of 15-20 fathoms. Petersburg, Alaska, September 17, 1937. 


\section{ANOMURAN CRABS}

Dermaturus mandti was taken at three localities, and Oedignathus inermis and Placentron wosnessenskii each at one locality.

\section{OTHER CRABS}

Cancer magister, the large edible crab of commercial importance on the Pacific coast, was taken as far west as Tanaga Island, and it probably occurs still farther west (fig. 9). Cancer oregonensis is distinguished from the preceding species by its hairy walking legs. Chionoecetes, Erimacrus, Hyas, Oregonia, Paralithodes, Pugettia, and Telmessus are also represented in the 1936-38 collection. Paralithodes camtschatica was taken for food in the Bay of Islands by the ship's crew (fig. 10). It is one of the huge king crabs for which the Japanese have fished in recent years in Aleutian waters. It seems to be restricted to certain localities or to certain water conditions, for it was not found in dredge hauls made at other stations along the islands.

\section{MOLLUSKS}

\section{BIVALVES}

The species of marine mollusks in the North Pacific are numbered by the hundreds. Only a few of the more conspicuous and more readily obtainable species are represented in the 1936-38 collections.

Bankia setacea, one of the shipworms or teredos, possibly may be present, although only the calcareous tubes in driftrood were collected (Unimak Island).

Three members of the family Cardiidae were collected. Clinocardium nuttalli, the giant cockle, is rather common and is used for food by the natives. In digging the mollusk, a two-tined potato fork bent like a hoe is raked through sand until it strikes a solid object. It is said that the flesh makes good chowder, comparable in sweetness to that of the razor clam.

Chlamys islandica, the scallop or pecten, was found in sea-otter droppings and on the beaches of Ogliuga and Vseridof islands. Some shells are white, others are pinkish both inside and out.

Two species of Liocyma were collected, one of which was hitherto undescribed (Bartsch and Rehder 1939). Liocyma is a common small white clam about 25 millimeters long; oval with fine concentric rings; occasionally greenish when living. It was noted also on tideflats of the Alaska mainland. 
Five species of Macoma were collected.

Two small mussels, Musculus discors and $M$. vernicosus, were collected. Each is about 10 to 15 millimeters long, and is reddish brown or tan. The latter has a shining, varnished surface.

The mud clam or gaper, Mya truncata, was collected once, at Unalaska.

The larger, abundant mussels are of two kinds. Mytilus edulis, the edibie or blue mussel, is smooth and regular and is purplish blue to black in color with a bluish nacre (fig. 11). The umbo is apical, unlike that of the horse mussel. The edible mussel is used for food by the natives and is said to be best when there is a roll of snow-white fat on either sicle of the body. When yellow and lean, the flesh is umpalatable. Volsella modiolus, the horse mussel, can be distinguished from the former by its larger, thicker shell and by the presence of a brown periostracum. The umbo is never at the apex, and the nacre is gray. The horse mussel usually grows solitary or in clusters of a few, while the edible mussel may cover the rocks in an area many feet in diameter. Both attach to rocks by a thready byssus, but the horse mussel usually is partly buried in sand. (A third large mussel, Mytilus californicus, was collected only once-at a depth of 30 fathoms off Sanak Island.)

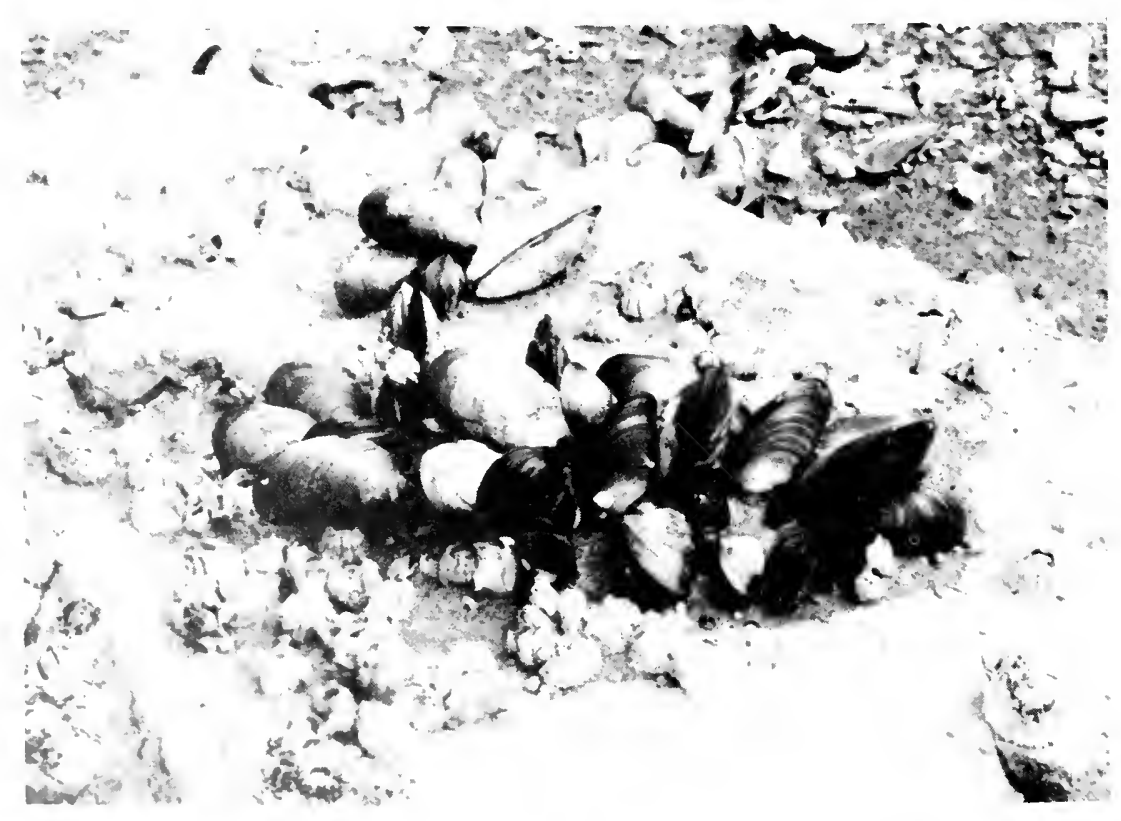

FIGURE 11,-Edible or blue mussels, Mytilus edulis, in tidal zone. Unalaska Island, July 10, 1937. 
The rock oyster, or jingle, Pododesmus macrochisma, is fairly common throughout the Aleutian chain. It is especially abundant near the Peninsula. The rock oyster can not usually be collected between tide lines, but its empty shells are strewn along the beach where they have been cast up from shallow water. The oysters grow solitary or in clusters (seldom more than four), on rocks just below low tide and never are buried in the sand. The attached valve is perforated by a conspicuous hole. The oysters are eaten by natives who fry the reddish flesh in butter.

Protothaca staminea is a small cocklelike clam with concentric ridges more conspicuous than the radiating lines.

The butter clam, Saxidomus giganters, has a thick white shell, glossy within and chalky outside, with the growth lines not pronounced. It is used as food by whites and natives.

The razor clam, Siliqua patula, was collected only at Atka and Unimak islands. The flesh is considered by local natives to have a finer taste than that of any other mollusk. It is difficult to gather any number of the clams, horiever, because they grow in fairly deep water, and the tides in the Aleutians do not fall low enough to expose the beds. It is possible to dig these light-shelled clams by backing a power boat up to the beach, throwing out two anchors astern, and letting the wash of the propeller lift the clams out of the sand. A native of Unalaska stated that they used to be abundant in front of the village.

Spisula polynyma is widespread among the islands. It is a rather large bivalve with brown periostracum and acute dorsal angle.

\section{SNAILS AND SEA SLUGS}

Five species of limpets, Acmaea, were collected (fig. 12). Limpets are very common throughout the Aleutian Islands, in pools or clinging to wet rocks above low tide. The only species found in sea-otter and blue-fox droppings was $A$. digitalis. A. pelta was collected most often (at 10 stations) and is the largest of the Aleutian limpets, reaching a diameter of 5 centimeters. A. mitra is a strongly peaked species. A. scutum was collected at seven stations.

An odd, tiny snail Anabathron muriei was described from specimens found in sea-otter droppings (Bartsch and Rehder, 1939).

Eight species of Buccinum were collected.

Fusitriton oregonensis was the only large, cornucopialike snail that was collected; it has a length of about 5 centimeters, and is 
olive colored and hairy. Beringius hennicotti is similar in shape but is slightly smaller and is not hairy.

Three species of periwinkles, Littorina, were collected (fig. 13). The periwinkles are characteristic animals of the tidal zone. They are able to withstand drying for a long time, and they crawl well above the watelline to rocks and seaweed where they cling in cluster's that often number in the hundreds. The periwinkle is edible, but the flesh is not particularly tasty. Picking out the small fragments of meat becomes tiresome, like eating sunflower seeds. $L$. sithana was by far the most abundant species (at nine stations). On Amlia Island the empty shells of this species served as homes for small hermit crabs (Pagurus hirsutiusculus). The species was also found in sea-otter scats.

Five species of Margarites were collected, most of them smooth, globular, white snails.

Four species of Nucella were collected. Nucella lamellosa forms collarlike egg cases of cemented sand, often washed up on the beach.

A single sea slug, or nudibranch, Diaulula sandiegensis, was collected. Other species are reported from the Aleutians. Diaulula was taken by dredge from sandy bottoms at Attu and Tanaga.

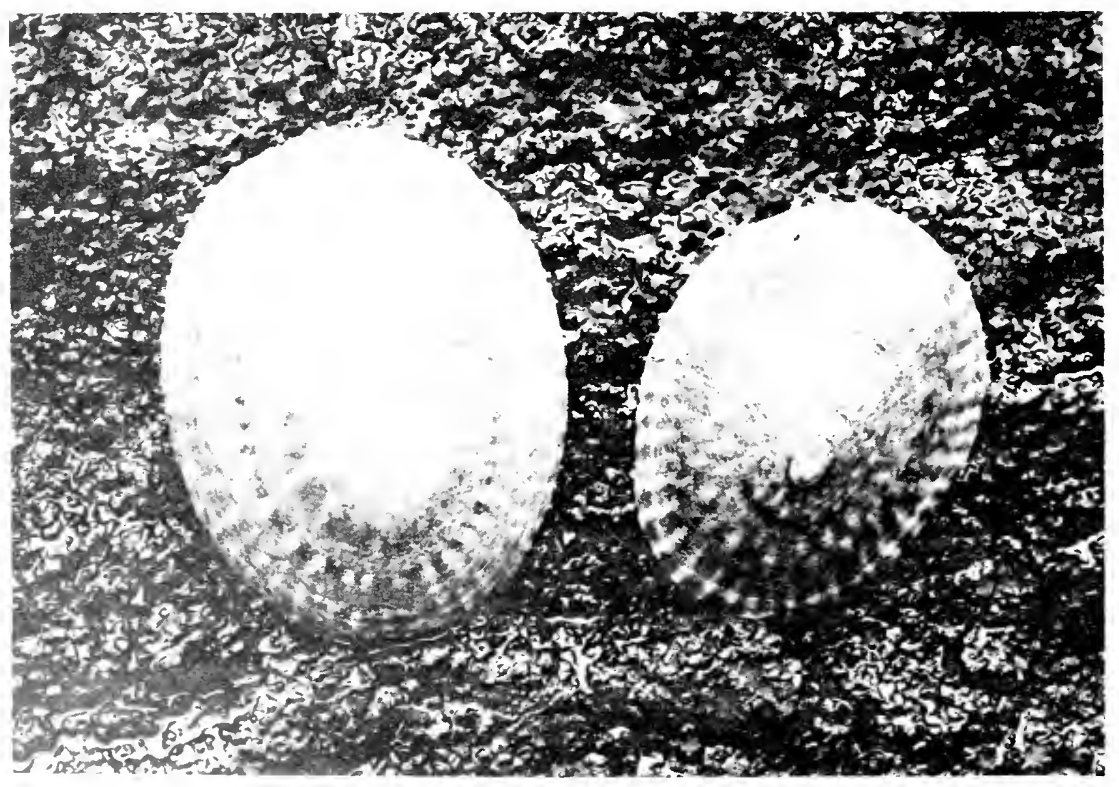

Figure 12.-Limpets, Acmaea sp., clinging to rocks in the tidal zone. Unalaska, July 10, 1937. 


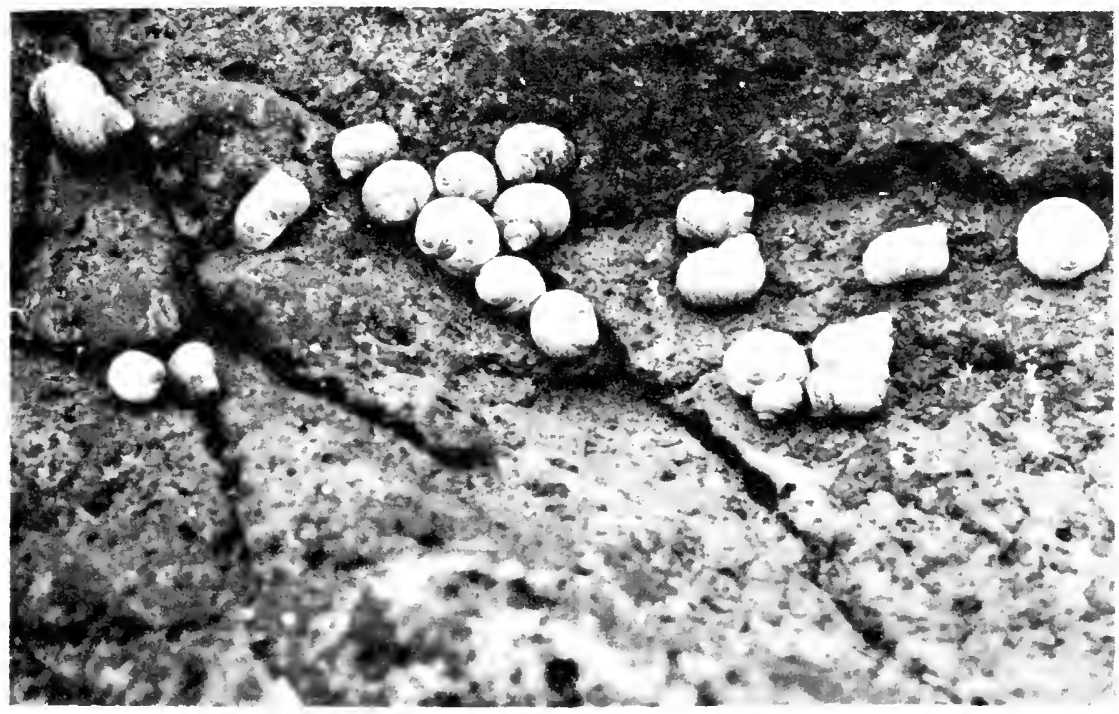

Figure 13.-Periwinkles, Littorina sp., clinging to rocks in the tidal zone.

Unalaska, July 27, 1937.

\section{CHITONS}

Nurie picked up a fragment of the giant chiton, Amicula stelleri on Amchitka Island. The species is brick red, as large as 10 by 20 centimeters, and has a leathery girdle completely covering the eight dorsal plates.

Katharina tunicata is fairly common. Many individuals were noted at Umnak Island in shallow tidal pools and at Amlia Island on a rocky, kelp-covered ledge. The body is black and leathery, with a row of eight plates down the back. Its local name "bidarka" is also applied to the skin boat of the Aleuts. The natives prepare the chiton for eating by boiling it in sea water for 10 minutes, then peeling off the skin, scales, and viscera and soaking in fresh water. The general color of the live chiton is dark brown with brown and tan plates.

Mopalia ciliata wosnessenstii is a small chiton about 25 millimeters long that is pink on the dorsal surface. Its fringed edges have given it the name of mossy or hairy chiton. It was collected at three stations.

Schizoplax brandti and Tonicella mber were collected in seaotter droppings, and, in addition, 24 specimens of Schizoplax brandt $i$ were collected on the rocks of Herbert Island. 


\section{DEVILFISHES}

Two cephalopors were observed. A- large devilfish, Octopus apollyon, was taken at Nikolski Village, Umnak Island, in a beachseine drag for salmon. The water here was not more than 10 feet deep at the mouth of a small stream. The ship's cook fried a steak of white meat from the dome of the devilfish and we found it more tender than we anticipated. The natives usually boil the head steaks before frying, and they boil the tentacles before eating. S. Halvorsen, Coast Guard inspector at the Akutan whaling station, stated that the stomach of a sperm whale killed in 1937 contained 16 devilfish, presumably of this species. The natives are said to take good-sized specimens in Nazan Bay, Atka Island, although we were able to get only two small ones here.

A squid, Rossia pacifica, was found on the beach at Unimak Island after a storm in September. The color of the dead specimen was white, peppered with fine brown spots. Kenneth Newell, who is familiar with the "ink-fish" of Puget Sound said that he had never seen one in the Aleutian Islands. S. Halvorsen, however, reported that they were common in the stomachs of sperm whales brought into the Akutan whaling station. Possibly the species does not range much farther west than the Alaska Peninsula. 


\section{Fresh-Water Invertebrates}

The Aleutian Islands are dotted with shallow pools. In only a few cases are the pools larger than 5 or 10 acres, and most of them are depressions only a few feet across. Standing on a hillside on Agattu Island, and looking over an expanse of about 2 by 5 miles, we estimated that there were 200 pools in sight.

In 1937, collections of fresh-water organisms were made in 24 lakes scattered along the Aleutian chain. Crustaceans were collected with a plankton net; mollusks and aquatic insects were collected by hand. (A discussion of the insects is presented later in the section devoted to land invertebrates.)

The pools and lakes may be classed loosely in three groups, according to their size and the amount of vascular plant life present, as follows:

Type 1: Small, clear pools (fig. 14). Shallow; vegetation absent

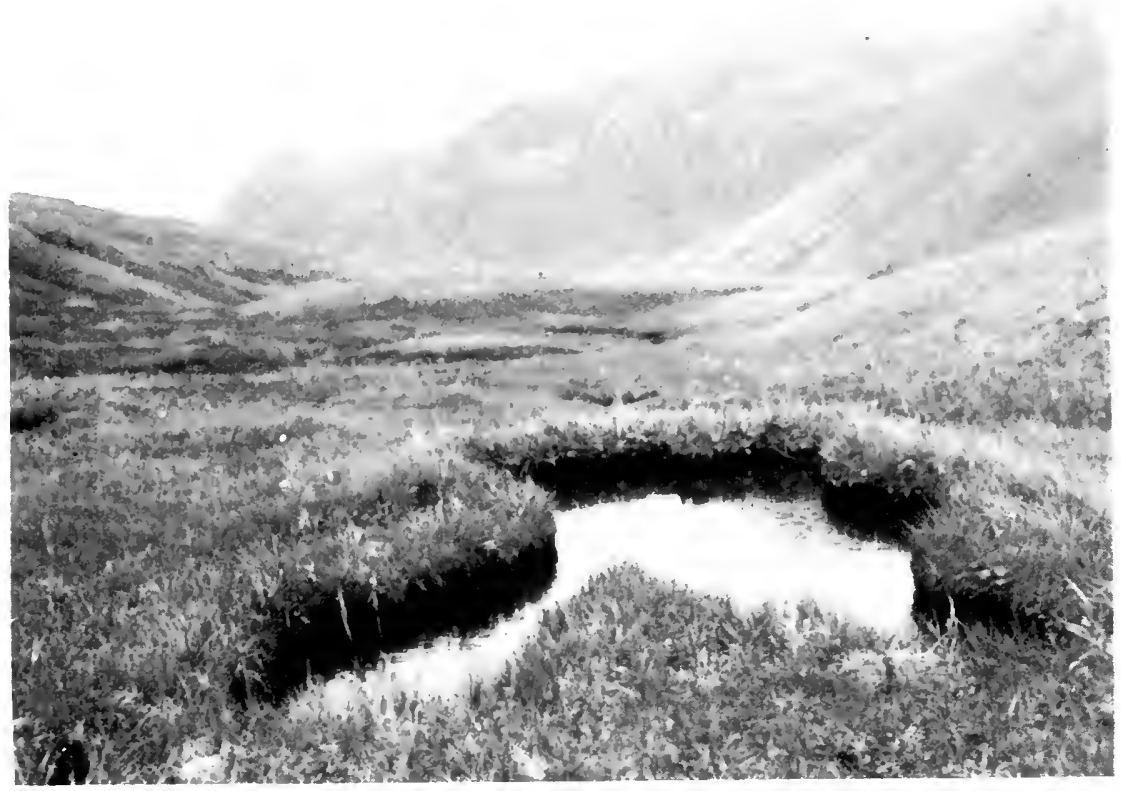

Figure 14.-A fresh-water pool of type 1 (small and clear). Attu Island, August 17, 1938. 
or, if plesent, consisting of sparse patches of emergent Hippuris and Cerex; bottom consisting of clean volcanic sand or occasional silt. This type is by far the most abundant. Many of the clean pools do not support plankton because they overflow and are flushed out by each rain. The water in type 1 pools usually is slightly tea-colored, like that of sphagnum bog pools on the mainland. We discovered that it was possible to determine whether a pool contained enough plankton to warrant taking a haul by looking for aquatic bugs and beetles. A pool highly productive of plankton is generally well populated with aquatic insects. The clear pools are characterized by the presence of Diaptomus, often in such numbers that a tow over a course of 300 feet may net a haul of 50 cubic centimeters of these red-bodied crustaceans. One such haul on Sanak Island consisted almost entirely of Diaptomus shoshone var. uardi, D. ashlandi, and D. eiseni. Cyclops serrulatus is also commonly present in type 1 pools.

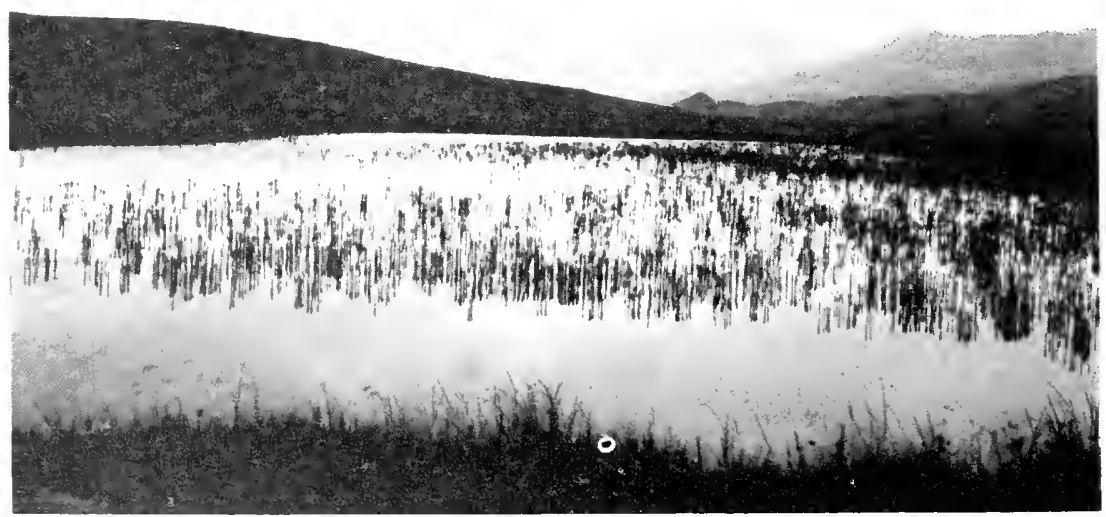

Figure 15.-A fresh-water pool of type 2 (small and weedy). Atka Island, August 13, 1937.

Type 2: Small, weedy pools (fig. 15). Shallow depressions in the tundra, 50-100 feet in diameter, with oozy silt bottoms. This type is not common. Hultén (1937) concludes that the vegetation in Aleutian lakes is so sparse that real associations are hardly 
formed: "The few aquatic plants, such as Potamogeton perfoliatum, Myriophyllum spicatum. Sparganium hyperboreum, and Ranunculus tricopingllus, Hippuris vulgaris and Isoetes Braunii maritima, usually occur single or in patches." We found that the dominant organism in plankton of type 2 pools is Chydorus sphaericus. Amphipods are usually present in the weeds.

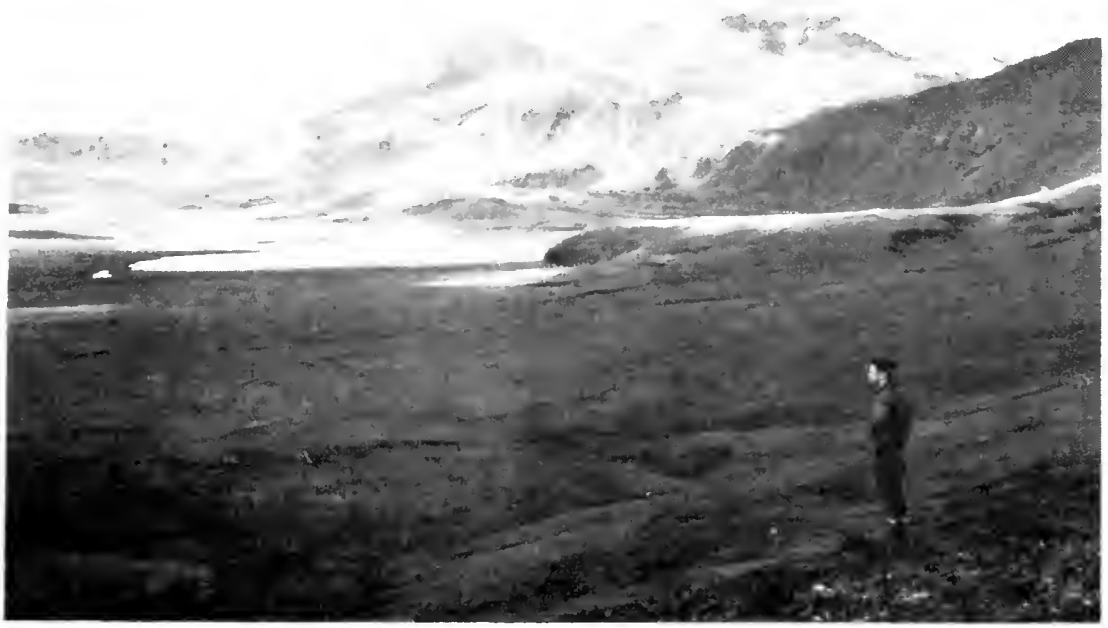

Figure 16.-A fresh-water pool of type 3 (large and barren), about $0.2 \times 1.5$ miles. Semisopochnoi Island, August 23, 1938.

Type 3: Large, barren lakes (fig. 16). Scant vegetation around shore; clean sand and rubble bottom; windswept. The largest examples are about 2 miles long. Only about 10 of the 75 islands have lakes of this type. The temperature of the water in three lakes at least 1 mile long was measured in August and was found to be $56^{\circ}$ F., $57^{\circ}$ F., and $58^{\circ}$ F. respectively. The plankton is uniformly sparse: in fact, hauls made in the lake at Unalaska Village in June and July were discarded for lack of a discernible catch. Again, in a lake measuring 1 by 2 miles, on Unimak Island, a haul was made in late August with negative results.

The surface temperature of fresh-water bodies in the Aleutian Islands fluctuates greatly from day to day because of the shallowness of the water and the open surroundings (see table, p. 390). The lowest temperature recorded was $44^{\circ} \mathrm{F}$. on September 10 ; 
cold wind was blowing at the time. The highest temperature recolded was $66^{\circ} \mathrm{F}$. on July 22 , after one of the rare days of full sunshine.

Mean surface temperature of the water of Aleutian Island pools and lakes, 1937-38

\begin{tabular}{|c|c|c|}
\hline Month & Number of observations & Mean temperature $\left({ }^{\circ} \mathbf{F}\right.$.) \\
\hline $\begin{array}{l}\text { June- } \\
\text { July } \\
\text { August } \\
\text { September-... }\end{array}$ & $\begin{array}{r}2 \\
6 \\
33 \\
4\end{array}$ & $\begin{array}{l}56.5 \\
58.6 \\
55.8 \\
51.2\end{array}$ \\
\hline Mean & 45 & 55.8 \\
\hline
\end{tabular}

The fresh-water plankton crustaceans have been identified by Trevor Kincaid, of the University of Washington. His remarks on the material are as follows:

Very little is known regarding the fresh-water plankton of Alaska, and this is particularly true of the region including the Aleutian Islands which is practically a blank in so far as records are concerned.

The writer has been assembling plankton from various parts of Alaska with a view to determining the geographic distribution of the species occurring in the fresh water bodies in that territory, and to discovering what relation exists between the fauna of Asia and that of Alaska and of North America in general. It is becoming clear that this relationship is much closer than has been suspected.

In the genus of fresh-water copepods Diaptomus it has been supposed that no species was common to both continents, but we now find several species of this group ranging across Europe and Asia into Alaska, while at least one species having a wide range over western North America has been reported from a lake in Siberia.

The series of tows brought back by the expedition from the Aleutian Islands was regarded as particularly important since the archipelago forms a series of natural stepping stones extending from the Siberian region to the Alaskan Peninsula and southward, and as one might expect to find here the collection extends the known westerly range of several American species, and expands the easterly range of at least one Asiatic form.

Diaptomus ashlandi was originally described from Wisconsin and is known to be widely distributed over the northern portion of the Pacific Coast. It appears in tows taken on the islands of Sanak and Unalaska. Diaptomus shoshone var. warli was first reported from Spokane, Washington and has since been reported from the Island of St. Paul in the Pribilofs. It appears in a tow taken on Sanak Island. Diaptomus eiseni was described from California, but has since appeared in collections taken at widely separated localities of the Pacific Coast. It has been reported from a lake in Siberia. A single specimen was found in a tow taken on Sanak Island. Arctodiaptomus kurilensis was recently described from the Kurile Islands by Kiefer. It appear's in a tow taken on the islands Kanaga, Tanaga and Atka which lie near the middle of the Aleutian chain.

The cyclopoid copepods found in the collection are, as might be expected, species already known to be common to both continents, or as in the case of 
Cyclops serrulatus, with a cosmopolitan distribution. The same is true of most of the Cladocera, the majority of which are common to Europe, Asia and America. However, even in the case of widely distributed forms it is interesting to determine their existence as part of the local fresh-water fauna."

Trevor Kincaid has recently (1953) published a report which mentions the 1937-38 Aleutian collection of plankton crustaceans.

\section{CRUSTACEANS}

\section{CLADOCERANS}

Daphnia pulex (de Geer)

Daphnia longispina (O. F. Müller)

Bosmina obtusirostris Sars

Macrothrix hirsuticornis Norman and Brady

Alona rectangula Sars

Pleuroxus denticulatus Birge

Chydorus sphaericus (O. F. Müller)

Chydorus latus Sars

Alonella nana (Baird)

\section{COPEPODS}

Eurytemora affinis Poppe

Arctodiaptomus kurilensis Kiefer

Diaptomus ashlandi Marsh

Diaptomus shoshone var. wardi Pearse

Diaptomus eiseni Lilljeborg

Cyclops (Acanthocyclops) viridis Jurine

Cyclops (Cyclops) strenus Fischer

Cyclops (Eucyclops) sermulatus Fischer

\section{OSTRACODS}

Cyclocypris sp.

\section{MOLLUSKS}

Eleven species of mollusks were collected from fresh-water pools and lakes. All of them were small bivalves or snails found clinging to submerged regetation or in the bottom mud; none were as large as the fresh-water mussels of the mainland. A full list of the species collected is as follows:

Fossaria truncatula. Gyraulus deflectus, Menctus opercularius planulatus. Pisidium abditum?, Pisidium liljeborgi, Pisidium ovum?, Retinella binneyana pellucida. Sphaerium tenue, Stagnicola atkaensis (9 out of 12 were infested with trematode rediae), Stagnicola randolphi, Stagnicola yukonensis atlinensis. 


\section{Land Invertebrates}

\section{MOLLUSKS}

Two land snails and one slug were collected in the Aleutian Islands, all of them at Unalaska. Haplotrema sportella is a dark greenish-yellow snail collected in clamp grass on a hillside, September 6,1938 . Trespericola columbiana, collected at the same time and place, is light horn-colored and is slightly more globular than Haplotrema. Prophysaon andersoni is a common slug around Unalaska Village.

\section{BEETLES}

As might be anticipated in a treeless, windblown region, the insect fauna is poor. The most commonly observed insects are small flies breeding under decaying seaweed along the beach, under damp stones, and in shallow pools. Pools also may contain bugs, carldisflies, true flies, and collembola. No butterflies were observed though a tan moth was not uncommon. Bumblebees were occasionally seen in the flower fields. No grasshoppers or crickets were noted.

Hatch (1938) has previously reported on a collection of 27 species of beetles taken on the islands in 1937. Of these 27 species, 8 had not apparently been recorded previously from the Aleutian Islands, and 11 had their distribution extended westward by the 1937 records. A discussion of the importance and habitat relations of certain of the species listed by Hatch follows.

Scaphionotus marginatus is a large, iridescent ground beetle that is known (elsewhere) to feed on snails. (Snails and slugs were collected on Unalaska Island.) Several species of Nebria were collected on the mouldering debris of Aleut middens.

Three species of Hydroporus, minute beetles about 3 millimeters long, are common in fresh-water pools. Agabus is an aquatic beetle about 6 millimeters long. Ilybius is an aquatic form about 8 millimeters long, dark in color, with four small orange spots on the wing cover's. Colymbetes is the commonest large beetle (about 12 millimeters long) observed in fresh-water pools. A single specimen of a very large beetle, 30 millimeters long, was taken on Sanak Island, the first record of this Dytiscus from the islands. Gyrinus, 
the whirligig beetle, apparently is present on all of the islands.

Of the carrion-feeding beetles, Nebria, a small brown form, is fairly common in rotting kelp. Catops is the smallest beetle (about 3 millimeters long) observed on the islands. Specimens of a large ( 25 millimeters) black staphylinid were collected under a decomposing sea lion at Attu Village.

Eurystethes, whose habitat is on rocks by the sea, was collected once on Amchitka Island and once on Ogliuga Island, both times in sea-otter droppings.

Several click beetles, Ludius, and weevils, Lophalophus, were collected. A click beetle, Cryptohypnus littoralis (not reported by Hatch), was found by Cecil Williams in droppings of a blue fox on Attu Island.

\section{BIRD LICE}

A small series of biting bird lice (Mallophaga) was collected from the slender-billed shearwater, Puffinus tenuirostris, at Rat Island and at Unimak Island. The following determinations were made by the Bureau of Entomology and Plant Quarantine, U. S. Department of Agriculture:

Esthiopterum diversum, Gicbelia mirabilis, Ancistrona sp., Menopon. sp., and species of Analgesidae.

\section{DIPTERA}

The following species of true flies were identified in the 193638 collections :

Bibio variabilis, Calliphora vomitoria, Chironomus hyperboreus, Cynomia hirta, Dilophus tibialis, Empis sp., Platychims sp., Protophormis terranovae, Scatophaga sp., Syrphus sp.

\section{SPIDERS}

Only two kinds were commonly observed, Pardosa and Cybacus, both of which were medium-sized, dark-bodied spiders collected on mats of damp lichens and low vegetation. A single specimen (female) of a huge, milk-white Aranca sp. was collected near its orb web on a low bush at Unalaska.

Cybacus reticulatus was collected on eight islands. Members of this family (Agelenidae) spin sheet-like webs, usually in the form of a funnel with a tubular retreat.

Four wolf spiders (family Lycosidae) were collected. Members of this group do not spin webs and are commonly found running over damp fields. Lycosa sp. was taken once. Pardosa tursalis was taken on six islands. Pirata piratica was taken once. The 
latter species is said to live in the vicinity of water, upon which it luns freely, and beneath which it dives when alarmed. Tarentula aquilonaris was newly described by Fox (1940) from specimens taken on Attu Island.

A tick, whose identity is not known to us, apparently is abundant on Bogoslof Island at certain seasons. According to Morris (1937, p. 952),

The murres were pestered with a tick about the size and appearance of a small wood tick. These became especially numerous on the second week in August. As many as 100 were picked off the inner walls of the tent each day for a week. Several got on members of the party but only one tick drew blood.

We recall picking lead-gray ticks from the body of a bird killed somewhere at sea in the Aleutian Islands, but the specimens have been mislaid. 


\section{Fishes}

Forty-eight species of fish were collected in the Aleutian Islands proper. These were identified by Dr. Leonard P. Schultz, and two of them were described by him as being new (1939). The following list, alphabetically arranged, includes remarks on the noteworthy species only. A few descriptive notes in quotation marks from Evermann and Goldsborough (1907) are included.

Alepisaurus ferox, the lancet fish, is a fearsome species with large, glassy eyes and an array of needle-sharp teeth. The only specimen taken was one that had been caught in a crevice of rock between tide levels on Amchitka Island, where it had been badly eroded. (Murie also saw a beach-worn specimen in 1936.) The body was about 2 feet long and scarcely larger in diameter than a broom handle. Schultz says that there is only one species of Alepisaurus in the North Pacific and that the usual length is 4 to 5 feet.

Ammodytes tobianus personatus is very common along the beaches and was often taken in large numbers with the seine; it is a bright silvery little fish that is called locally "needlefish". Evermann and Goldsborough (1907) say, "they quickly bury themselves in the sand when disturbed. . . more delicious little fish probably do not exist. They are usually prepared by rolling in fine cornmeal or cracker crumbs and frying in butter."

Aspicottus bison is one of the smaller sculpins reaching a length of about 10 inches. (See Hemilepidotus.)

Atheresthes stomias, one of the flounders, is called locally "turbot." It swims with its right side up.

Bathymaster signatus, a beautiful little fish, was taken once in the Bay of Waterfalls, Adak Island. It is reddish-brown with blue-green spots; also it has a blue line along base of ventral fin, a reddish line adjoining, and then another blue line near tips of fin rays.

Chiropsis decagrammus. Only small specimens of this greenling, or rock trout, were taken, at Unimak Island.

Clupea pallasi. Pedler, agent of the Alaska Commercial Co. at Unalaska, told us of the herring industry near Unlaska and Dutch Harbor. In 1938, the first run was from June 26 to July 27, 
and the second run, much smaller, was from August 26 to September 6 . The run varies greatly in size from year to year. In 1938, there were 165 tons of bloater's and 2,000 barrels ( 250 pounds to a barrel) of gibbed herring prepared at Dutch Harbor. The gibbed, or Scotch-cured, herring are cleaned and are salted only once. All herring are taken by gill nets near Dutch Harbor. Gibbed herring sold in Seattle for about $\$ 15$ a barrel.

Cycloptericlae, the member's of which family are commonly known as lumpsuckers, are characterized by a round sucking disk on the ventral surface of the body. By this means they attach to rocks and sometimes to kelp in the region of wave action alongshore. They are able to attach or release themselves almost instantly. The only adult taken was found on the beach in poor condition. The larvae of Elephantichthys copeianus? were taken at two dredge stations. These were handsome little fish about 25 millimeters long, tan colored with pale-blue "spectacles" between the eyes.

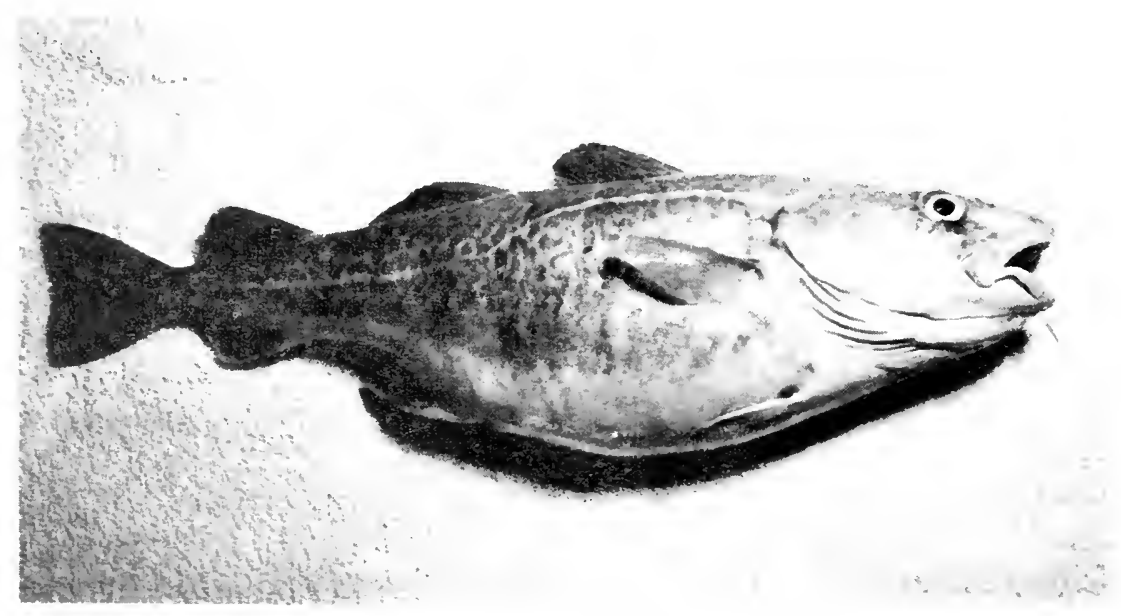

Figure 17.-Alaska cod, Gadus macrocephalus, False Pass, August 5, 1938.

Gadus macrocephalus, the common Alaska cod, was taken with hook and line at nearly every anchorage (fig. 17). In deep water near Atka Island on August 10 the ship's crew caught more than 80 fish in half a day. Most of them were later salted down. All specimens taken during the summer were wormy, although not unfit for eating. Stomach contents from three localities contained masses of the nematode Contracaecum clavatum. In one stomach, a female Cystidicola sp. was found. The mesenteries of the cod were usually knotted with masses of cysts of the nematode Porro- 
caecum decipiens - this worm also was taken from the stomach of an adult hair seal on Khwostof Island. External parasites of the cod included a copepod, Lepeophtheirus parviventris, an isopod, Rocinela belliceps, and a leech, Platybdella quadrioculati.

Stomach contents of cod were examined from time to time, partly out of curiosity and partly to recover specimens of invertebrates for the general collection. Common items in the diet included large amphipods (often half a pint or more in a single stomach), shrimp, octopus or squid beaks, sea urchins, snails, clams, crabs, and many small fishes. Near Chuginadak Island, on August 21, the head of an adult cormorant Phlacrocorax sp. was found in a cod stomach. Off Ogliuga Island, on August 12, the entire body, considerably softened, of a parakeet auklet ( $C y$ clorrhynchus psittacula) was recovered (Scheffer 1943).

Gasterosteus aculeatus aculeatus, the three-spined stickleback, was taken on three islands in fresh-water pools. G.a.microcephalus was taken on four islands, also in fresh-water pools or streams. Both races of aculeatus may be found in both salt and fresh water, but the resident salt-water form is more heavily plated and is given the subspecific name aculcatus, while the resident freshwater form is given the name microcephalus. In fresh water, all but four or five plates near the head are eventually lost.

In some places, as on Kavalga Island, sticklebacks occur in ponds on plateaus isolated from the sea and now inaccessible to fish. It is our opinion that the fish gained access to such ponds before the outlet streams became steep.

In several cases, sticklebacks were noted heavily infested with

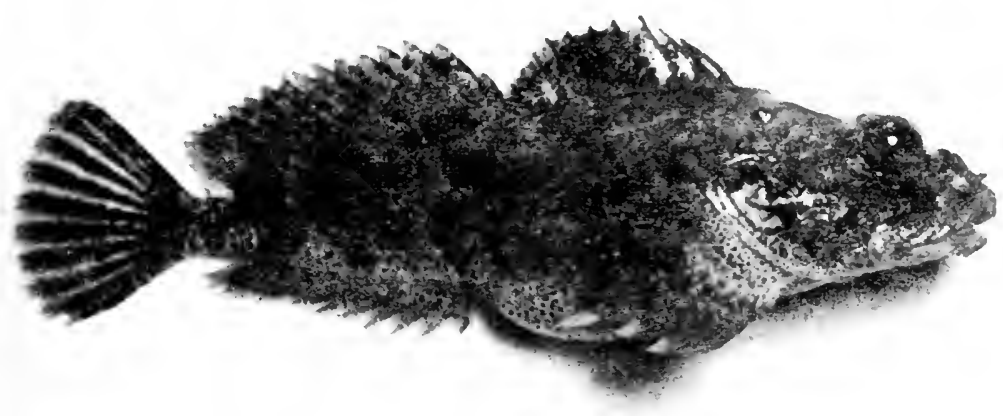

FIgURE 18.--Red sculpin, Hemilepidotus hemilepidotus; color: red and brown. Kagamil Island, August 29, 1938. 
tapeworms, which filled the body cavity to the extent that the fish had a pot-bellied appearance. (See also Pungitius, the manyspined stickleback.)

Gymnocanthus pistillyger is a bullhead, or cottoid, of interest because it was found in a sea-otter scat on Ogliuga Island. There are many species of cottoids in the shoal water and tide pools of the Aleutian Islands.

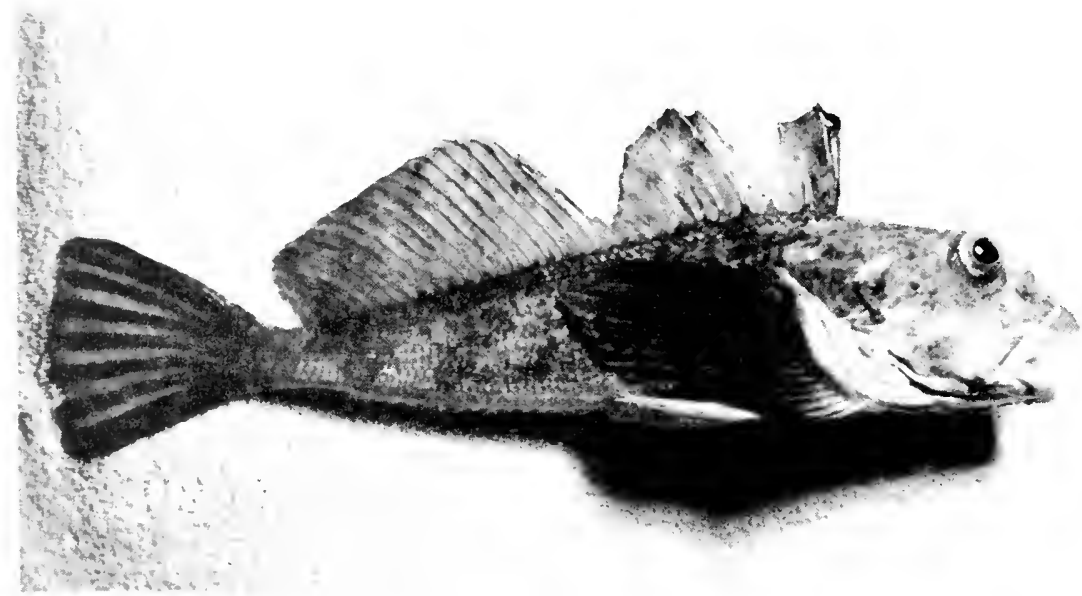

Figure 19.-Irish lord, Hemilepidotus jordani; color: dirty olive and black. Kiska Island, August 19, 1938.

Two species of Hemilepidotus are very common in the islands. $H$. hemilepidotus, the red sculpin, is brick red to brown in color (fig. 18) ; H. jordani, the Irish Lord, is a dirty, olivaceous brown with irregular dark bars (fig. 19). Sculpins are bottom feeders with an amazing capacity to swallow large objects. When caught with hook and line, it is often necessary to dissect the fish to recover the hook. When the boat was at anchor, sculpins were soon attracted to the spot by garbage thrown overboard from the galley. Among other items found in sculpin stomachs, we have noted a match box, a boiled potato, a good-sized chicken leg, and the entire carcass of small bird specimens discarded from the skinning room. Invertebrates seem to make up most of the natural diet: brittle stars, snails, clams, crabs, shrimps, amphipods, and many others.

Color notes were taken of a specimen of $H$. hemilepidotus from Kagamil Island: red, mottled with brown, belly is white with chocolate spots; color fades rapidly. A specimen from Vsevidof Island: head appears as though bright-red paint had been poured 
over it; a few red splotches on body; general body color is light brown and red; belly is light with small chocolate specks; a darkcolored stripe runs along each side near dorsal line, and a dark horizontal stripe runs across each eyeball.

Color of a specimen of $H$. jordani from Kiska Island: dirty olive with several short, vertical, irregular dark bars near the dorsal line; lips are yellow; belly is light.

Hippoglossus stenolepis, the halibut, is fished on certain banks, but it may be encountered anywhere among the islands (fig. 20). It is the largest of the flounders and is said to reach a weight of almost 400 pounds. We took a 100-pound fish off Bogoslof Island in the deeper waters that it frequents. The halibut swims with its light side up.

Lebius superciliosus, the pogie, greenfish, or red rock trout, was taken on seven islands (fig. 21). Color notes on one specimen: general ground color of skin is black with greenish cast, covered

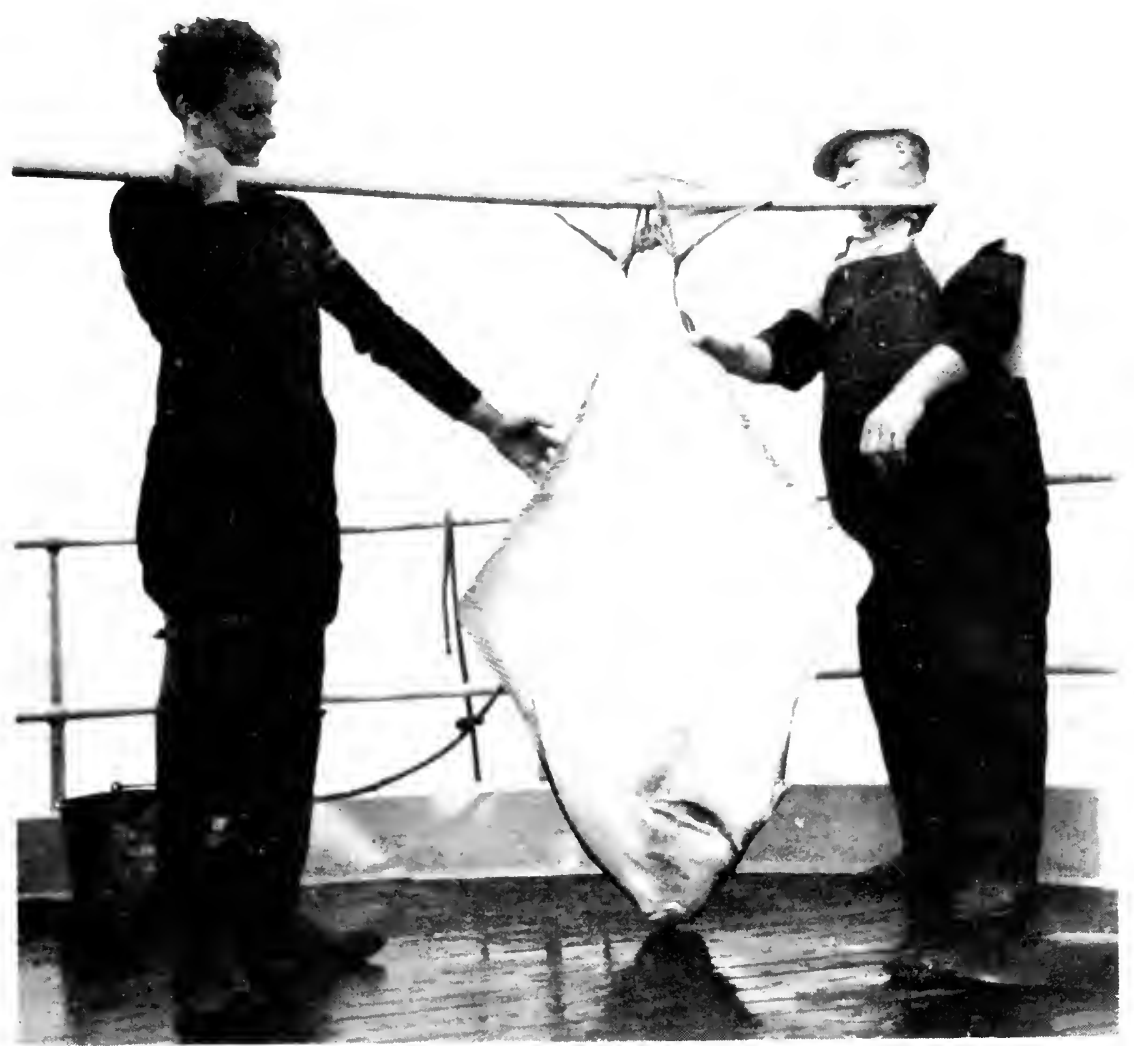

Figure 20.-Halibut, Hippoglossus stenolepis, weighing approximately 100 pounds. Bogoslof Island, August 31, 1938. 


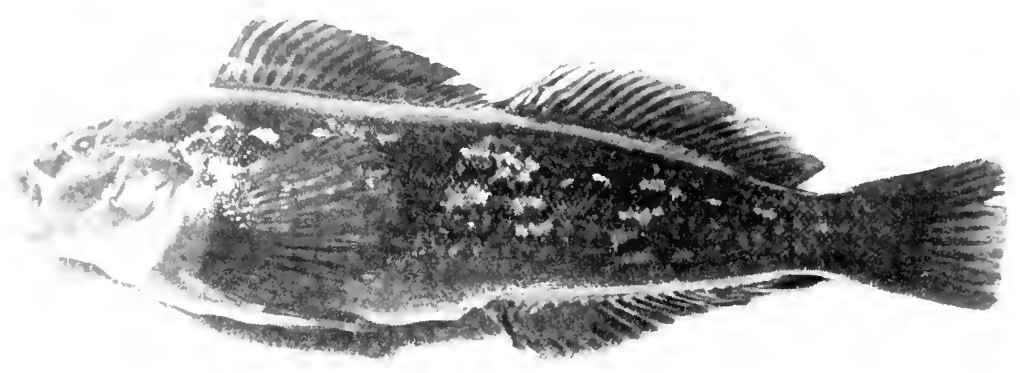

Figure 21.-Pogie, Lebius superciliosus. The flesh may be vivid green or white. Attu Island, August 16, 1938.

with irregular spots of light tan. Inside of mouth and under jaw is light green; flesh and viscera are green. Another specimen: back and sides are brownish olive mottled with black, and are spotted with bluish green; under-parts are yellowish; flesh is white. On many specimens, the skin is a rich dark red, almost matching the froncls of kelp, among which the fish swim. The vivid green flesh of the majority of specimens is a startling sight to a per'son seeing it for the first time. Dr. L. P. Schultz says that the presence, or absence, of green color throughout the flesh is not, to the best of his knowledge, a sex character. The flesh color is sometimes more of a blue than a green. O. J. Murie reports that the fish comes up to the shallow water along the beach at night and makes a popping noise like kelp bladders exploding. The fish was found in nests of the bald eagle on several occasions, suggesting that it is a shoal-water species.

Lepidopsetta bilineata, was called "flounder" on one occasion and "sole" on another, by the same fisherman. It swims with its right sicle up. Evermann and Goldsborough (1907) state that the flounder is widely distributed and that it takes the hook readily.

Myorocephalus polyacanthocephalus was taken on four islands. This is said to be a large sculpin, but we have no field notes on it.

All five species of Northeast Pacific salmon were collected in the Aleutians, the humpback and the silver salmon were found most frequently : 


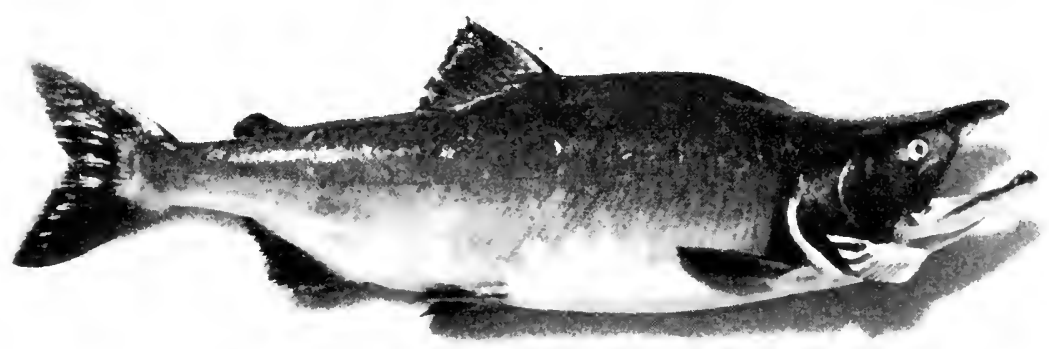

FIGURE 22.-Pink or humpback salmon, Oncorhynchus gorbuscha, breeding male. Amchitka Island, August 22, 1938.

Oncorhynchus gorbuscha, the humpback, or pink salmon is said by Evermann and Goldsborough to be the most common species in Alaska (fig. 22). Some of our specimens were adults, and others were fingerlings caught on hook and line in streams. A parasitic copepod, Lepeophthcirus salmonis, was collected from the back of a humpback salmon on Tanaga Island.

Oncorhynchus keta, the dog, or chum salmon, was collected only once-on Atka Island. The natives had constructed a crude fish trap at the outlet to Korovin Lake. On August 13, the silver salmon were running and there were also a few dog salmon in the trap. These were not recognized by the natives as dog salmon, but were termed "winter salmon" and were given an Aleut name slightly different from that of the silver. Four specimens examined were males with apparently mature testes but without the external hump that is characteristic of the breeding fish.

Oncorhynchus kisutch, the silver salmon, was collected on five islands.

Oncorhynchus nerka, the sockeye, or red salmon, was running into a lake on Attu Island in early June 1937 (figs. 23 and 24). The species runs only into streams that have lakes somewhere in the headwaters.

Oncorhynchus tschauytscha, known as the king, spring, or chinook salmon, was collected only in the fingerling stage. The adults frequent deep, or offshore waters, occasionally reaching a size of 100 pounds. They are taken by trolling.

Oxycottus acuticeps is of the many species of tide-pool bullheads. 


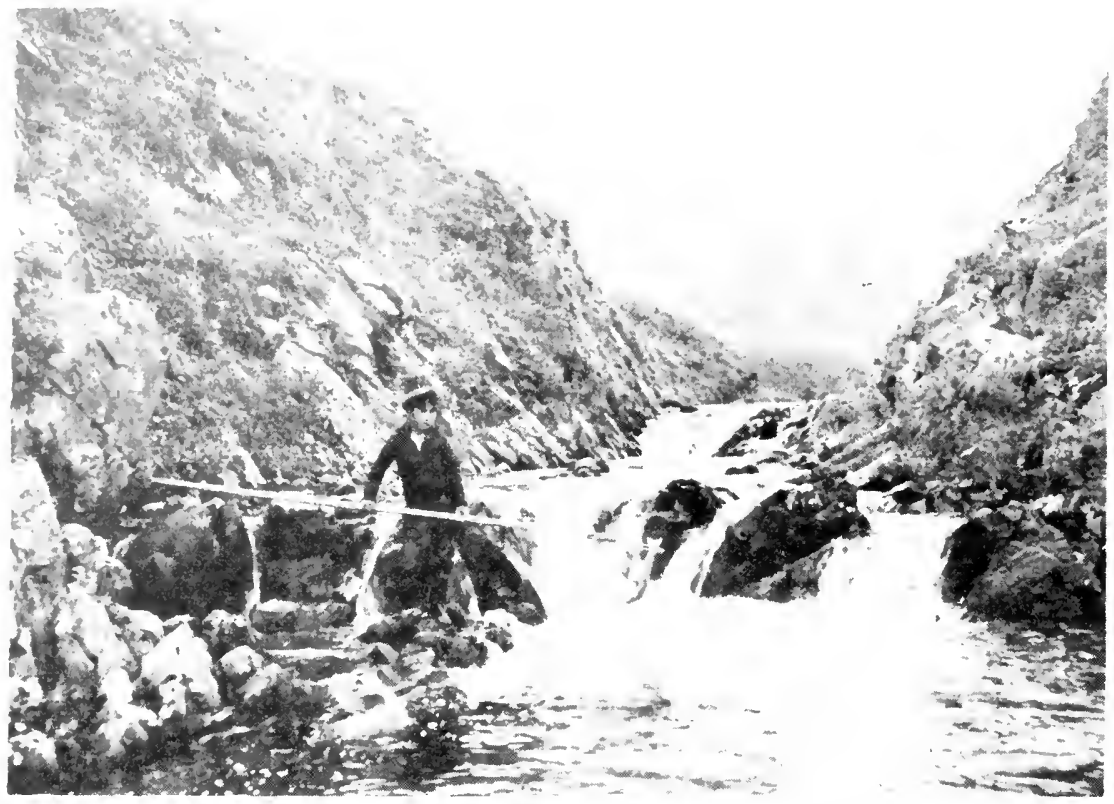

Figure 23.-Native boy netting sockeye salmon, Oncorhynchus nerka. Attu Island, August 17, 1938.

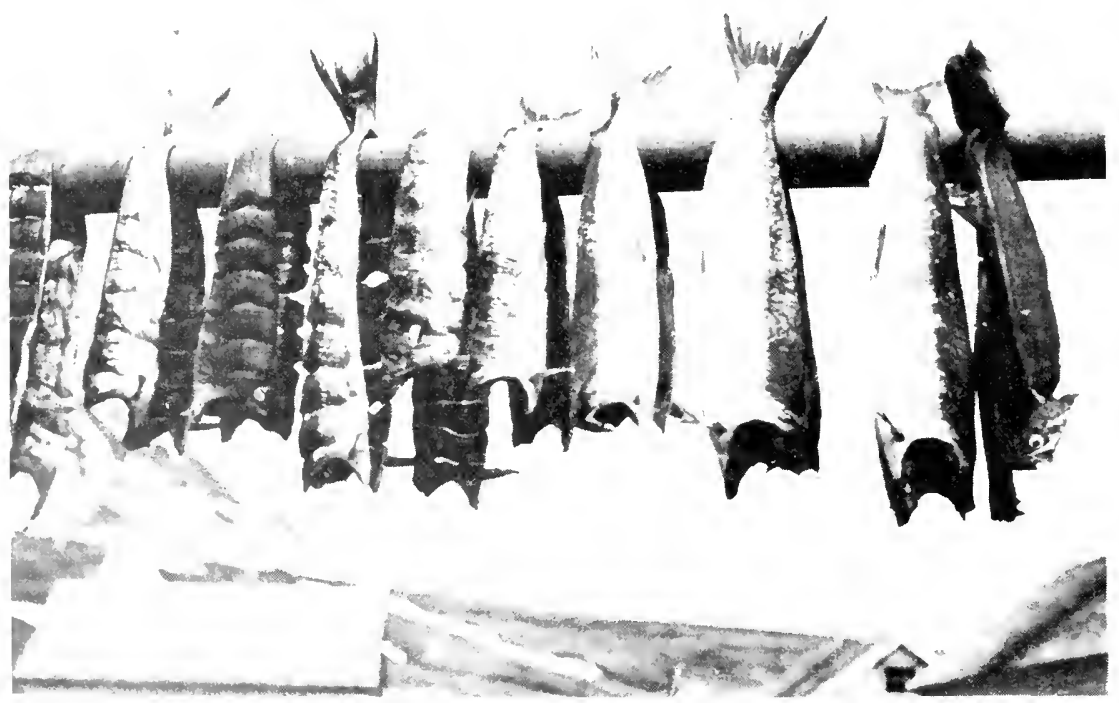

Figure 24,--Red or sockeye salmon, Oncorhynchus nerka, taken in gill nets by Attu Island natives and dried for winter food. June 8, 1937. 
It is a bizarre little fish, colored bright grass green over the entire body, matching the sea lettuce (Ulva) among which it lives. The webs of the fins are transparent, with yellow at the base. There is a little silver color on the jaws; otherwise, the body is uniformly green. Another bullhead, Oligocottus, is also commonly green.

Phallocottus obtusus, a cottoid taken on Igitkin Island, was the basis for the description of a new species and genus by Schultz (1939).

Pallasina barbata, a sea poacher, is a very slender fish with a long sturgeon-like snout. Specimens about 5 inches long were taken in a seine haul in the surf at Umnak Island.

Pholis laetus is one of the many blennies that inhabit the tide pools. It is a small, smooth fish, shaped like a slender cigar; it is yellowish with a series of paired transverse black bands on the dorsal surface.

Platichthys stellatus was taken only at Unimak Island. The starry flounder is said by Evermann and Goldsborough (1907) to be the most abundant and most widely-distributed flounder in Alaska. It has black spots along both dorsal and ventral fins, and is unlike other species in the North Pacific. It swims with its left side up.

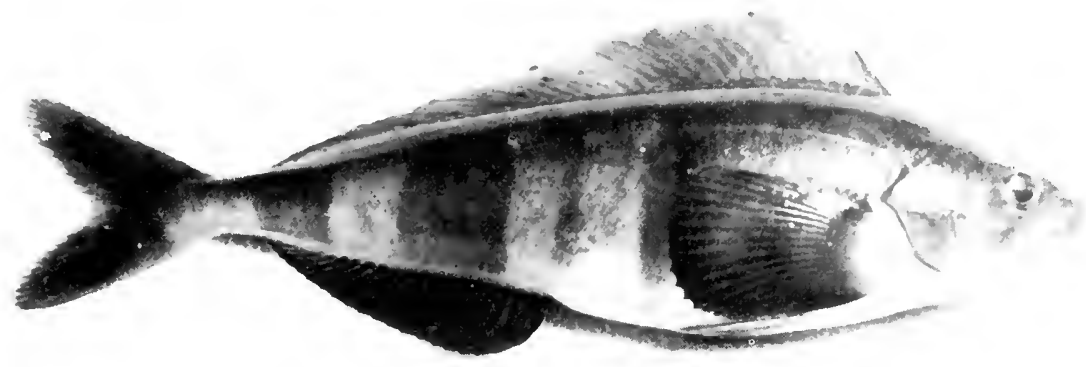

Figure 25.-Atka mackerel, Pleurogrammus monopterygius. Attu Island, August 16, 1938.

Pleurogrammus monopterygius, the Atka or Attu mackerel, occur's along the Aleutian chain, but apparently it is most abundant near the west end (fig. 25). At the mouth of Chichagof Harbor, Attu Island, we were able to look down into the clear water and see dozens of Atka mackerel swimming among the kelp fronds. 
The borly is strikingly marked with broad bands of black and yellow. A number of specimens were taken by the crew by "jigging" (jerking a hook with an artificial lure up and down in the water). Specimens were also found in nests of the bald eagle.

Pungitius pungitius, the many-spined stickleback, was taken in fresh water pools on Afognak Island and the Semichi Islands, both localities east of the Aleutian Islands proper.

Salmo? William Gardner, employee at the salmon cannery at False Pass, told us that there are at least four streams on Umnak Island where steelhead trout run. No species of Salmo were collected in the Aleutian Islands by our party, and it is unlikely that any occur far from the Alaska mainland. Evermann and Goldsborough state that there are no records for rainbow trout (S. gairdneri) in any waters off, or north of, the Alaska Peninsula, and that there are no records for cutthroat trout (S. clarki) beyond Kodiak Island. However, there may be more recent records extending the range of these species. Salmonoid fingerlings collected along the Aleutians by our party invariably were young salmon or Dolly Varden trout.

Salvelinus malma spectabilis, the Dolly Varden trout, is abundant throughout the islands, both in fresh-water streams and in salt water near the mouths of the streams. Locally, it is regarded as an important predator on salmon eggs, but there is no conclusive evidence to this effect. We found the flesh of the Dolly Varden to be quite tasty, although it was scorned by some members of the party. On Amchitka Island, July 19, 52 specimens were taken with a single haul of a small beach seine. An interesting landlocked form of Dolly Varden was observed at Unalaska. On August 17, Captain H. A. Searles presented us with six specimens taken with hook and line in Pyramid Creek above an impassable falls. This form is much smaller and less silvery than the sea-run form, but the body colors are more brilliant. The belly is bright orange, back of the ventral and anal fins it is scarlet, and the body spots are bright orange.

On Attu Island, on August 17, the natives were removing dozens of large Dolly Vardens from gill nets set for red salmon, leaving them to rot on the lakeshore. Several odd-looking trout, said by the natives to be different "kinds" of trout, proved to be spectabitis.

Sebastodes ciliatus. A few sea bass were taken with hook and line orer the rail of the ship. The fish is not particularly common in the Aleutians. 
Sigmistes smithi, a small cottoid, was described by Schultz (1939) from a collection made on Igitkin Island.

Theragra chalcogramma chalcogramma, the Alaska pollack, or silver hake, was not observed in the islands, although it was discovered that a young specimen had been taken in a beach haul made on Igitkin Island (fig. 26). Adults were taken readily at Seward and Petersburg, on the mainland.

Trichodon trichodon was taken several times among kelp. It is a small sand fish with an undershot jaw studded with fine, sharp teeth. Its odd appearance attracts immediate attention.

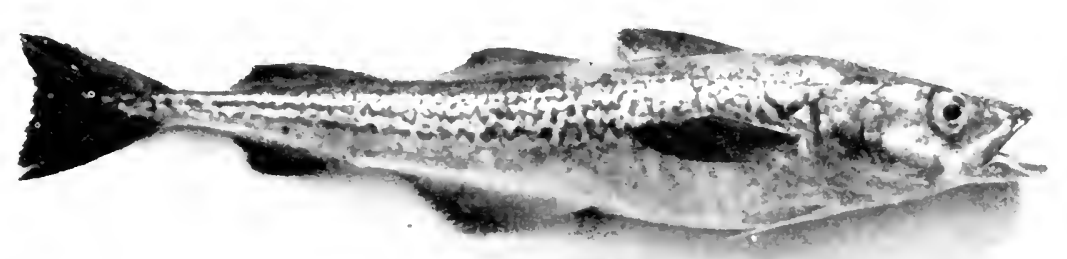

Figure 26.- Silver hake or Alaska pollack, Theragra chalcogramma. Chignik, Alaska, September 14, 1938.

Zaprora silcnus. A specimen was taken by one of the ship's crew while he was fishing for Atka mackerel from a dory. The ungainly borly so startlect the man that his first impulse was to drop it back into the ocean. Another specimen, not recognized at the time, was observed off Unmak Island, hovering under a large orange jellyfish (Cyanea) at a depth of about 1 foot. It followed the shelter of the umbrella and the hanging tentacles. When the jellyfish was netted, the fish darted into the bell and was later found in the certer. Color: belly is white, sides and back are olive gray; from above, it appeared orange because of the reflected light from the Cyanea. The jellyfish was taken about 1/1. mile off shore (Scheffer 1940). 


\section{Literature Cited}

Bartsch, Paul, and H. A. Rehder.

1939. Two new marine shells from the Aleutian Islands. Nautilus, vol.

52 , No. 4, pp. 110-112, pl. 8.

Clark, Austin H.

1939. A new genus of starfishes from the Aleutian Islands. Proceed.

U. S. National Museum, vol. 86, No. 3061, pp. 597-600, pl. 57, figs. 1-4.

Evermann, B. W., and E. L. Goldsborough.

1907. The fishes of Alaska. U. S. Bur. Fisheries Doc. 624, vol. 26, pp. 221-376, pls. 16-32.

FOX, IRVING.

1940. Notes on Nearctic spiders chiefly on the family Theridiidae.

Proceed. Biological Society Washington, vol. 53, pp. 39-46, figs. 1-3.

Hatch, Melville H.

1938. Report on the Coleoptera collected by Victor B. Scheffer on the

Aleutian Islands in 1937. Pan-Pacific Entonıology, vol. 14, No. 4, pp. 145-149.

Hultén, ERIC.

1937. Flora of the Aleutian Islands. Bökforlags Aktiebolaget Thule.

Stockholm, Sweden, $397 \mathrm{pp}$.

KinCAID, TREvOR.

1953. A contribution to the taxonomy and distribution of the American fresh-water calanoid crustacea. 73 pp., 5 pls. The Calliostoma Co., Seattle, Wash.

Morris, George E.

1937. Bogoslof Island. Proceed. U. S. Naval Institute, vol. 63, No. 413, pp. 950-952.

OKAMURA, K.

1933. On the algae from Alaska collected by Y. Kobayashi. Records of Oceanographic Works in Japan, vol. 5, No. 1, pp. 85-98, pls. 4-5. SCHEFFER, VICTOR B.

1939. Organisms collected from whales in the Aleutian Islands. Murrelet, vol. 20 , No. 3 , pp. $67-69$, figs. $1-5$.

1940. Two recent records of Zaprora silenus Jordan from the Aleutian Islands. Copeia, No. 3, p. 203.

1943. Fish bites bird. Nature Magazine, vol. 36, No. 1, pp. 41-42, 4 figs.

SCHULTZ, LEONARD P.

1939. A new genus and two new species of cottoid fishes from the Aleutian Islands. Proceed. U. S. National Museum, vol. 85, No. 3038, pp. 187-191. 


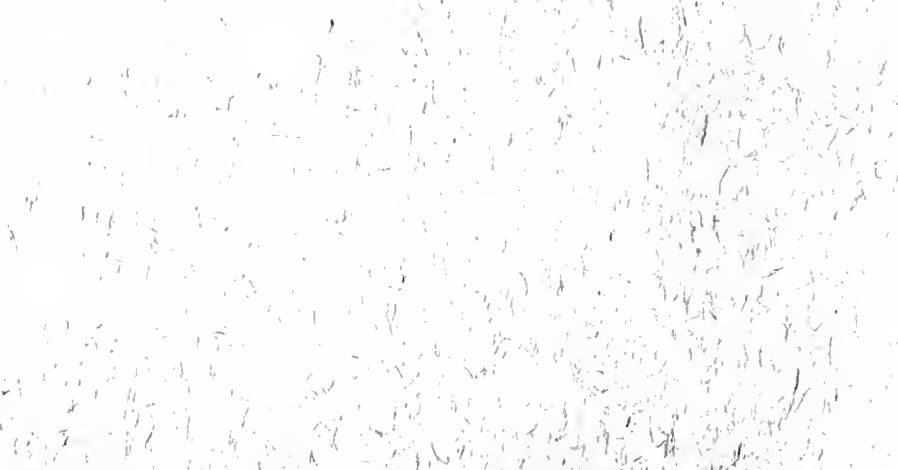

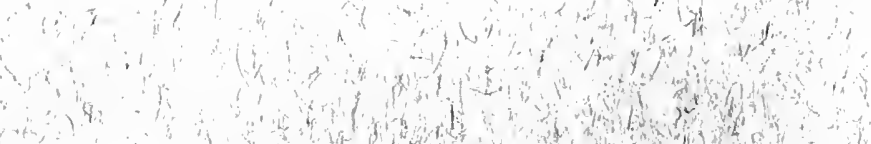

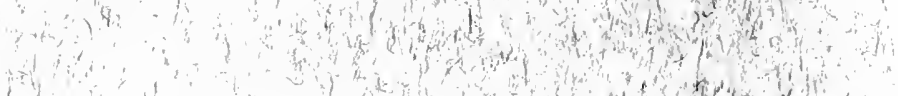
$\left\{\begin{array}{l}1 \\ 3\end{array}\right.$

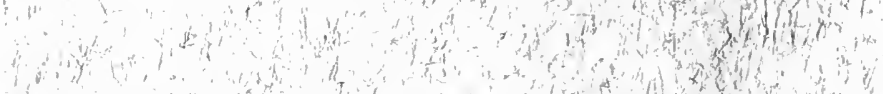
${ }_{1}^{4} y_{1}$ \{\}$_{0}^{1}$

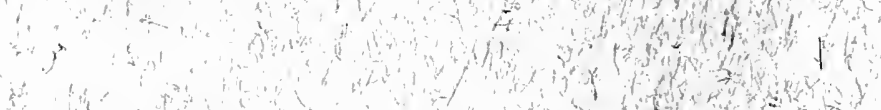
10

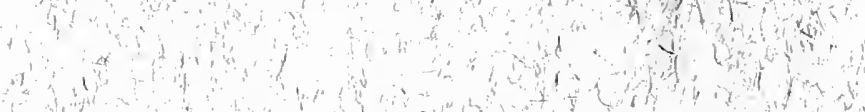
16

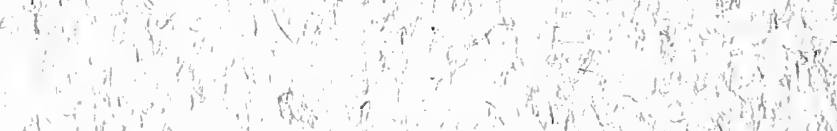
(1) (1)

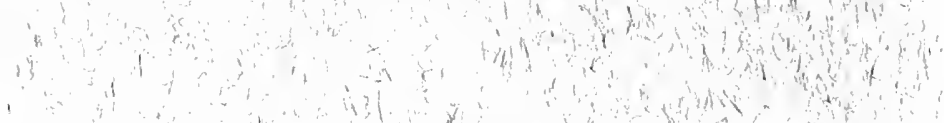
(1) a a 